\title{
Good Governance in the Era of Global Neoliberalism
}

Good Governance has become the major buzzword in aid policy and development thinking today. The concept is often defined as a political regime based on the model of a liberal democratic polity, which protects human and civil rights, combined with a competent, non-corrupt and accountable public administration.

As this book will show, however, Good Governance is not just 'good'. The concept, as advocated by the donor community, often represents an instrumentalist, managerial and technocratic approach to development, aiming at the creation of an environment favourable to the implementation of prescribed economic reforms.

By making use of a wide range of in-depth case studies from various developing countries and post-communist states, this book analyses the causes and effects of neoliberal restructuring and the process of depolitisation and conflict that went with it. The contributors critically examine the contradictory nature of the concept of good governance and the consequences that have been seen to go with it.

This important book provides a refreshing contribution to the literature on good governance. It will provide an interesting read for those with an interest in economics and development studies as well as being useful to policy makers and non-governmental organizations.

Jolle Demmers is researcher and lecturer at the Centre for Conflict Studies at Utrecht University, The Netherlands.

Alex E. Fernández Jilberto is senior lecturer in International Relations at the University of Amsterdam, The Netherlands. Another of his books, Labour Relations in Development, is also available from Routledge.

Barbara Hogenboom is researcher and lecturer at the Centre for Latin American Research and Documentation (CEDLA), Amsterdam, The Netherlands. 


\section{Routledge Studies in the Modern World Economy}

1 Interest Rates and Budget Deficits A study of the advanced economies Kanhaya L. Gupta and Bakhtiar Moazzami

\section{World Trade after the Uruguay} Round

Prospects and policy options for the twenty-first century

Edited by Harald Sander and András Inotai

\section{The Flow Analysis of Labour} Markets

Edited by Ronald Schettkat

\section{Inflation and Unemployment} Contributions to a new macroeconomic approach Edited by Alvaro Cencini and Mauro Baranzini

\section{Macroeconomic Dimensions of} Public Finance

Essays in honour of Vito Tanzi Edited by Mario I. Blejer and Teresa M. Ter-Minassian

6 Fiscal Policy and Economic Reforms

Essays in honour of Vito Tanzi Edited by Mario I. Blejer and Teresa M. Ter-Minassian
7 Competition Policy in the Global Economy

Modalities for co-operation Edited by Leonard Waverman, William S. Comanor and Akira Goto

8 Working in the Macro Economy A study of the US labor market Martin F.J. Prachowny

9 How Does Privatization Work? Edited by Anthony Bennett

10 The Economics and Politics of International Trade Freedom and trade: Volume II Edited by Gary Cook

11 The Legal and Moral Aspects of International Trade Freedom and trade: Volume III Edited by Asif Qureshi, Hillel Steiner and Geraint Parry

12 Capital Markets and Corporate Governance in Japan, Germany and the United States Organizational response to market inefficiencies Helmut M. Dietl

13 Competition and Trade Policies Coherence or conflict Edited by Einar Hope 


\section{Rice}

The primary commodity

A.J.H. Latham

15 Trade, Theory and Econometrics Essays in honour of John S.

Chipman

Edited by James C. Moore,

Raymond Riezman and James $R$.

Melvin

16 Who benefits from Privatisation? Edited by Moazzem Hossain and Justin Malbon

17 Towards a Fair Global Labour Market

Avoiding the new slave trade Ozay Mehmet, Errol Mendes and Robert Sinding

18 Models of Futures Markets Edited by Barry Goss

19 Venture Capital Investment An agency analysis of UK practice

Gavin C. Reid

20 Macroeconomic Forecasting A sociological appraisal

Robert Evans

21 Multimedia and Regional Economic Restructuring Edited by Hans-Joachim Braczyk, Gerhard Fuchs and Hans-Georg Wolf

22 The New Industrial Geography Regions, regulation and institutions

Edited by Trevor J. Barnes and Meric S. Gertler
23 The Employment Impact of Innovation

Evidence and policy

Edited by Marco Vivarelli and

Mario Pianta

24 International Health Care

Reform

A legal, economic and political analysis

Colleen Flood

25 Competition Policy Analysis Edited by Einar Hope

26 Culture and Enterprise The development, representation and morality of business Don Lavoie and Emily ChamleeWright

27 Global Financial Crises and Reforms

Cases and caveats

B.N. Ghosh

28 Geography of Production and Economic Integration

Miroslav N. Jovanovic

29 Technology, Trade and Growth in OECD Countries

Does specialisation matter?

Valentina Meliciani

30 Post-Industrial Labour Markets

Profiles of North America and

Scandinavia

Edited by Thomas P. Boje and

Bengt Furaker

31 Capital Flows without Crisis

Reconciling capital mobility and economic stability

Edited by Dipak Dasgupta, Marc

Uzan and Dominic Wilson 
32 International Trade and National Welfare

Murray C. Kemp

33 Global Trading Systems at Crossroads

A post-Seattle perspective Dilip K. Das

34 The Economics and Management of Technological Diversification Edited by John Cantwell, Alfonso Gambardella and Ove Granstrand

35 Before and Beyond EMU

Historical lessons and future prospects

Edited by Patrick Crowley

36 Fiscal Decentralization Ehtisham Ahmad and Vito Tanzi

37 Regionalisation of Globalised Innovation

Locations for advanced industrial development and disparities in participation Edited by Ulrich Hilpert

38 Gold and the Modern World Economy

Edited by Moon Joong Tcha

39 Global Economic Institutions Willem Molle
40 Global Governance and Financial Crises

Edited by Meghnad Desai and Yahia Said

41 Linking Local and Global Economies

The ties that bind

Edited by Carlo Pietrobelli and

Arni Sverrisson

42 Tax Systems and Tax Reforms in Europe

Edited by Luigi Bernardi and

Paola Profeta

43 Trade Liberalization and APEC Edited by Jiro Okamoto

44 Fiscal Deficit in the Pacific Region

Edited by Akira Kohsaka

45 Financial Globalization and the Emerging Market Economies Dilip K. Das

46 International Labor Mobility Unemployment and increasing returns to scale Bharati Basu 


\section{Good Governance in the Era of Global Neoliberalism \\ Conflict and depolitisation in Latin America, Eastern Europe, Asia and Africa}

Edited by Jolle Demmers, Alex E. Fernández Jilberto and Barbara Hogenboom 
First published 2004

by Routledge

Published 2017 by Routledge

2 Park Square, Milton Park, Abingdon, Oxon OX14 4RN

711 Third Avenue, New York, NY 10017, USA

Routledge is an imprint of the Taylor \& Francis Group, an informa business

Copyright (C) 2004 Jolle Demmers, Alex E. Fernández Jilberto and Barbara Hogenboom, selection and editorial matter; individual chapters, the contributors

Typeset in Times by

Taylor \& Francis Books Ltd

The Open Access version of this book, available at www.tandfebooks.com, has been made available under a Creative Commons Attribution-Non Commercial-No Derivatives 4.0 license.

British Library Cataloguing in Publication Data A catalogue record for this book is available from the British Library

Library of Congress Cataloging-in-Publication Data

A catalog record for this book has been requested

ISBN 978-0-415-34116-5 (hbk) 
In loving memory of Jean Carrière 



\section{Contents}

List of illustrations $\quad$ xi

Notes on Contributors xiii

Preface

xvii

JOLLE DEMMERS, ALEX E. FERNÁNDEZ JILBERTO

AND BARBARA HOGENBOOM

1 Good governance and democracy in a world of neoliberal regimes

JOLLE DEMMERS, ALEX E. FERNÁNDEZ JILBERTO

AND BARBARA HOGENBOOM

2 The political economy of neoliberal governance

in Latin America: The case of Chile

ALEX E. FERNÁNDEZ JILBERTO

3 'Que se vayan todos': Neoliberal collapse and social protest in Argentina

NORMA GIARRACCA AND MIGUEL TEUBAL

4 Governing Mexico's market democracy

BARBARA HOGENBOOM

5 Triple transition and governance in El Salvador

116 CHRIS VAN DER BORGH

6 Playing Russian roulette: Putin in search of good governance 
$\mathrm{x}$ Contents

7 'Good governance' can make bad government: A study of international anti-corruption initiatives in Bosnia-Herzegovina DAVID CHANDLER

8 Clanism and predatory capitalism: The rise of a neoliberal nomenklatura in Ukraine

HANS VAN ZON

9 Between globalisation and sub-national politics: Russian think tanks and liberalism

ANDREY S. MAKARYCHEV

10 'Bad governance' under democratic rule in Taiwan TAK-WING NGO

11 The political economy of recovery in Indonesia

J. THOMAS LINDBLAD

12 China's transition to industrial capitalism:

Tracking institutional reform

HENK HOUWELING

13 From new order to new world order: Good governance and violence in Indonesia

JUDITH LARGE AND NICK MAWDSLEY

14 Good governance, privatisation and ethno-regional conflict in Cameroon PIET KONINGS

15 Global neoliberalisation and violent conflict:

Some concluding thoughts

JOLLE DEMMERS 


\section{Illustrations}

\section{Figures}

3.1 Argentina: Percentage variation of the GDP, 1987-2002 74

3.2 Argentina: Bank deposits, 1994-2002 75

3.3 Argentina: Unemployment and underemployment, 1982-2002 76

3.4 Argentina: Poverty and indigence rates, 1988-2002 77

3.5 Argentina: Total number of conflicts during the

Convertibility Plan, 1991-2001

80

3.6 Argentina: Causes of conflicts, 1993-2000 81

3.7 Argentina: Causes of conflicts, 1997-2000 82

\section{Tables}

2.1 Ecuador, Peru and Argentina: Major economic indicators, 1999-2001

2.2 Latin America and the Caribbean: Development of some economic indicators, 1982-2001

2.3 Latin America: Poor and indigent population, 1980-1999 50

2.4 Chile: GDP and total foreign debt, 1986-2001 53

2.5 Chile: Socio-economic indicators of distribution and the concentration of income, 1990-2000 60

9.1 Russia: The roles and functions of Russian think tanks 218 



\section{Contributors}

Chris van der Borgh is lecturer and researcher at the Centre for Conflict Studies, Utrecht University (The Netherlands). He wrote his PhD thesis on post-war El Salvador and specializes in issues of conflict transformation, political reform and development interventions. His recent publications include 'Political violence, intrastate conflict and peace processes in Latin America' (European Review of Latin American and the Caribbean Studies, no. 70, 2001) and 'The Politics of Neoliberalism in Post-War El Salvador' (The International Journal of Political Economy, vol. 30, no. 1, 2001).

David Chandler is senior lecturer in International Relations at the Centre for the Study of Democracy, University of Westminster. He has written widely on democracy, human rights and international relations. His most recent publications include Bosnia: Faking Democracy After Dayton (London: Pluto Press, 1999) and From Kosovo to Kabul: Human Rights and International Intervention (London: Pluto Press, 2002), and he edited Rethinking Human Rights: Critical Approaches to International Politics (New York: Palgrave, 2002).

Jolle Demmers is researcher and lecturer at the Centre for Conflict Studies at Utrecht University (The Netherlands). She works on (long-distance) nationalism and violent conflict, and neoliberal restructuring and conflict. Her recent publications include Friends and Bitter Enemies: Politics and Neoliberal Reform in Yucatán, Mexico (Amsterdam: Thela Thesis, 1998), Miraculous Metamorphoses: The Neoliberalization of Latin American Populism (edited with Alex E. Fernández Jilberto and Barbara Hogenboom, London: Zed Books, 2001) and 'Diaspora and Conflict: long-distance nationalism, locality and the delocalisation of conflict dynamics' (Javnost/The Public: Journal of the European Institute for Communication and Culture, vol. 9, no. 1, 2002).

Alex E. Fernández Jilberto is senior lecturer in International Relations at the University of Amsterdam. He has published various books and articles on the political economy of Latin America and developing countries in 


\section{xiv Contributors}

general. His most recent publications include Regionalization and Globalization in the Modern World Economy: Perspectives on the Third World and Transitional Economies (edited with André Mommen, London: Routledge, 1998), Miraculous Metamorphoses: The Neoliberalization of Latin American Populism (edited with Jolle Demmers and Barbara Hogenboom, London: Zed Books, 2001) and Labour Relations in Development (edited with Marieke Riethof, London: Routledge, 2002).

Norma Giarracea is a sociologist teaching at the University of Buenos Aires and researching at the Instituto Gino Germani (University of Buenos Aires) where she coordinates the Grupo de Estudios Rurales. She has written and edited numerous books, most recently La Protesta Social en la Argentina. Transformaciones económicas y crisis social en el interior del pais (Buenos Aires: Alianza Editorial, 2001), ¿Una nueva ruralidad en América Latina? (Buenos Aires: CLACSO, 2001) and 'Crisis and Agrarian Protest in Argentina. The Mujeres Agropecuarias en Lucha' (Latin American Perspectives, 2001).

Barbara Hogenboom is researcher and lecturer at the Centre for Latin American Research and Documentation (CEDLA) in Amsterdam. She writes on national and transnational politics and neoliberal restructuring in Latin America. Among her recent publications are Mexico and the NAFTA Environment Debate: The Transnational Politics of Economic Integration (Utrecht: International Books, 1998), Miraculous Metamorphoses: The Neoliberalization of Latin American Populism (edited with Jolle Demmers and Alex E. Fernández Jilberto, London: Zed Books, 2001) and 'Awakening from the dream of global civil society: the NAFTA experience' (in B. Hogenboom et al., Cross-border activism and its limits: Mexican environmental organizations and the United States, Amsterdam: CEDLA, 2003).

Henk Houweling is associate professor of International Relations at the Department of Political Science, University of Amsterdam. His research field is peace and war in relation to problems of industrialization, development and underdevelopment. Among his recent publications are 'Destabilizing consequences of sequential development' (in L. van de Goor, K. Rupesinghe and P. Sciarone (eds), Between development and destruction. An enquiry into the causes of conflict in post-colonial states, London: Macmillan, 1996) and 'Industrialization in East Asia' (in H. Henke and I. Boxill (eds), The end of the Asian model? Amsterdam: John Benjamins, 1999).

Piet Konings is senior researcher at the African Studies Centre, University of Leiden (The Netherlands). He has published widely on the political economy and labour in Africa, especially in Ghana and Cameroon. His most recent publications include Unilever Estates in Crisis and the Power of Organizations in Cameroon (Hamburg: LIT Verlag, 1998), Trajectoires 
de Libération en Afrique Contemporaine (Paris: Karthala, 2000), and Negotiating Anglophone Identity: A Study in the Politics of Recognition and Representation in Cameroon (forthcoming).

Judith Large is a research fellow of the Department of Politics and International Relations at the University of Kent, Canterbury, and an independent practitioner/consultant in conflict analysis and strategic planning. Her work in Indonesia has included practical experience in Maluku, Aceh, Kalimantan and Sulawesi. From September 2000 to March 2001 she was visiting lecturer at the Centre for Conflict Studies, University of Utrecht (The Netherlands).

J. Thomas Lindblad is an associate professor at the departments of Southeast Asian Studies and History of the University of Leiden. He specializes in the modern economic history of Southeast Asia, in particular Indonesia. Recent publications include Foreign Investment in Southeast Asia in the Twentieth Century (London: Macmillan, 1998), Coolie Labour in Late Colonial Indonesia (with Vincent Houben and others, Wiesbaden: Harrassowitz, 1999) and The Emergence of a National Economy. An Economic History of Indonesia, 1800-2000 (with Howard Dick, Vincent Houben and Thee Kian Wie, Crows Nest, NSW: Allen \& Unwin, 2002).

Andrey S. Makarychev is professor at the Department of International Relations and Political Science, Nizhny Novgorod Linguistic University, Russia. His fields of research are comparative regionalism and federalism, security studies, and the international relations of Russia's subnational units. From 2000 to 2003 he was International Policy Fellow at the Open Society Institute, Budapest. Recent publications include 'Economic reforms and new patterns of post-Soviet regionalism' (in A.E. Fernández Jilberto and $\mathrm{A}$. Mommen (eds), Regionalization and Globalization in the Modern World Economy: Perspectives on the Third World and Transitional Economies, London: Routledge, 1998), and 'Russia's regional labours markets: coping with the pressures of globalization' (in A.E. Fernández Jilberto and M. Riethof, Labour Relations in Development, London: Routledge, 2002).

Nick Mawdsley has worked and lived in Indonesia for six years, initially as a researcher in the forestry sector. At the British Council he was the manager of the Governance and Society programme, where he worked on issues of governance reform, conflict management and the social safety net. He is currently working on short-term assignments on these issues.

André Mommen works for the Department of Political Science, University of Amsterdam. In the past, his research has focused on neo-liberal reforms in developing and transitional countries. He has written on the effects of reforms in both developed and developing countries on the position of 


\section{xvi Contributors}

trade unions. Among his most recent publications is Regionalization and Globalization in the Modern World Economy: Perspectives on the Third World and Transitional Economies (edited with Alex Fernández Jilberto; London: Routledge 1998).

Tak-Wing Ngo is lecturer in Chinese Politics at Leiden University (The Netherlands) and has been a Fellow of The Netherlands Institute for Advanced Study (NIAS). He is currently the editor of China Information - a major journal in the China field, and the editor of the NIAS Press (formerly Curzon Press) series of books on Democracy in Asia. Among his recent publications are the edited volumes The Cultural Construction of Politics in Asia (Richmond: Curzon, 2000) and Hong Kong's History: State and Society under Colonial Rule (London: Routledge, 1999).

Miguel Teubal is professor of economics at the University of Buenos Aires and researcher for the National Council for Scientific and Technological Research (CONICET) at the Centre for Advanced Studies of the same university. He has published widely on the political economy of food, agriculture and poverty in Latin America and Argentina. Recent books include Agro y alimentos en la Globalización: una perspectiva crítica (Buenos Aires: La Colmena, 2002), Globalización y expansión agroindustrial. Superación de la pobreza en América Latina? (Buenos Aires: Ediciones Corregidor, 1995), and Teoria, estructuras y procesos económicos, a collection of essays in honor of Dr. Julio H.G. Olivera (Buenos Aires: Eudeba, 1998).

Hans van Zon is research professor in Central and East-European Studies, University of Sunderland (UK). He worked as research coordinator for the European Commission (DG XII). His recent publications include The Political Economy of Independent Ukraine (London: Macmillan, 2000), Central European Industry in the Information Age (Aldershot: Ashgate, 2000) and 'Central and Eastern Europe: Catching Up or Marginalization in the European Free Trade Zone' (in A.E. Fernández Jilberto and A. Mommen (eds), Regionalization and Globalization in the Modern World Economy, London: Routledge, 1998). 


\section{Preface}

At the dawn of the twenty-first century world politics is (once again) framed in terms of Good and Evil. The Forces of Freedom are fighting the Axes of Evil, while Civilization and Enlightenment are placed opposite Fundamentalism, Darkness and Barbarism.

As is often the case, these words hide complex and ambiguous realities. The recipe for 'freedom', for instance, as proclaimed by Western powers and International Financial Institutions (IFIs) based on globalisation and market deregulation, is often seen as 'market fundamentalism' by developing countries. This is perhaps the greatest paradox of our times: the implementation of liberalism by force.

This volume deals with the complexities and paradoxes surrounding one of the 'Goods' in contemporary development discourse: Good Governance. During the 1990s, the IFIs refashioned their somewhat worn-out discourse on the salutary effects of the free market by a strong emphasis on poverty reduction, transparent governance, human rights and democracy. Put under one heading, this new discourse was called Good Governance. And indeed, it seemed to proclaim only 'the good'. It aimed to help countries reach economic prosperity, ensure the rule of law, improve the efficiency and accountability of their public sectors and tackle corruption. Good Governance was to confront the Bad Governance of many developing countries' administrations. It was this Bad Governance that was held responsible for the disappointing results of the structural adjustment programmes of the 1980 s and the rise of the parallel economy, poverty and income disparities in recently 'neoliberalised' countries.

However, this book tells a different story. By making use of a wide variety of case-studies from various developing countries and post-communist states, this edited collection critically analyses the causes and effects of neoliberal restructuring and the policy of Good Governance that went with it. It shows how, in the encounter with national and local contexts, the recipe of Good Governance produced unexpected and often unwanted outcomes. The Good Governance approach entails an essentially depoliticised notion of governance, insulating governance from the actual political process: the struggles for power, control over resources, as well as access to the decision- 


\section{xviii Preface}

making process. Apart from many differences and specificities, the case studies in this book show how the neoliberal recipe encouraged new forms of division, inequality and instability. In addition, the book unmasks the Good Governance solution embraced by the IFIs and many donor countries and lays bare its essentially neoliberal agenda.

This book started from the fascination of our co-authors and ourselves with the uncontested popularity of Good Governance in policy circles and the adverse effects of global neoliberalisation in many developing countries. Building on previous research projects on issues such as market reforms in developing countries and the rise of neoliberal populism, we were happy to have a very diverse group of academics willing to participate in this project on the connection between neoliberalism, Good Governance, depolitisation and conflict. Without the authors' in-depth knowledge of their regions, their critical analysis and intellectual dedication, this book would not have been possible. We are very sad, however, that our dear friend and political scientist Jean Carrière no longer forms part of this group of critical thinkers. It is to him we dedicate this book.

Jolle Demmers, Alex E. Fernández Jilberto and Barbara Hogenboom 


\title{
1 Good Governance and democracy in a world of neoliberal regimes
}

\author{
Jolle Demmers, Alex E. Fernández \\ Jilberto and Barbara Hogenboom
}

Good Governance has become the major buzzword in aid policy and development thinking today. It even seems to have dethroned Sustainable Development as the international policymakers' mantra. Conceived within the World Bank, the concept has been embraced by the governments of Western countries and by the IMF as both a goal and a condition of official (development) assistance. To lending countries, Good Governance is first of all yet another element of conditionality for indispensable loans, and ultimately for their acceptance as equal participants in the global economy. The transformation of Good Governance from simply a goal to also a condition for development assistance, emergency credits and debt relief coincided with the substantial decrease of North-South redistribution by means of official development funding. It coincided as well with the international compliance of the left with the position that free markets are the primary tool for the development of what were once known as the Second and Third Worlds.

In the early years of neoliberal globalisation, neoliberalism was primarily an economic agenda that included a negative connotation of the state and the public sector. 'More market and less state' was in fact the prime objective of both the stabilisation programmes that started in the late 1970s, and the Structural Adjustment Programmes (SAPs) that were vigorously enhanced and extended in the 1980s. The early global neoliberal agenda hardly cared about a country's political system, its type of government or the participation of its citizens. The Bretton Woods institutions' main concern was the implementation of economic restructuring, and if necessary the suppression of socialist tendencies - a task that authoritarian regimes and autocratic leaders had generally less trouble with than democratic governments.

However, with the ending of the Cold War a new discourse on governance and the political system arose. Unemployment, poverty, income disparities and the sudden rise of the parallel economy, black marketeers and criminal networks in recently 'neoliberalised' countries (particularly the former Soviet Union and large parts of Africa) prompted the idea that global neoliberalism could only successfully proceed in a 'sound' governance environment. It was not the neoliberal model that was to blame for the lack of progress, but rather the immature, corrupt and inefficient state administrations. From the 


\section{Jolle Demmers, Alex E. Fernández Jilberto and Barbara Hogenboom}

early 1990 s onwards, the call for less state has gradually been substituted by a call for a better state. This new approach should not be confused with a plea for a return to the strong (Keynesian or socialist) state. Rather it implies better and transparent governance of what is left of the state after neoliberal restructuring has been implemented. Often, the emphasis on 'good' governance was combined with a call for democratisation. As with Sustainable Development, the global fashion of Good Governance has proven hard to resist. In both political and academic circles the concept has easily spread and, apart from irritating some sensitivities in developing countries about new mechanisms of imperialist interference, it has largely been well received. But then, who would be against a rather broad and vague concept with the adjective 'good' attached to it?

In this introductory chapter we will critically analyse the emergence of Good Governance and democratisation as prioritised issues of the international development agenda, within the context of worldwide neoliberalisation. Apart from the causes, we will consider the political, economic and social consequences of this triad-like political project for free markets, Good Governance and democratisation. Instead of understanding its emergence as a genuine medicine against the illnesses caused by the free market agenda, we see the introduction of the good governance project as a placebo with possibly lethal consequences. Of course, in itself there is nothing wrong with the idea of 'good governance'. However, as this chapter shows, whereas the concept is explicitly presented as non-political and nonideological, it strongly favours economic liberalisation. The attractiveness of the concept of Good Governance lies in its capacity to make complex issues seem manageable, to hide disagreement and to provide a practical answer to the disappointing results of the Structural Adjustment Programmes of the 1980s.

\section{Good Governance and the effective state}

By the year 2000 Good Governance had been globally accepted as a crucial means to achieve both development and poverty reduction, as is shown by the world leaders' adoption of the United Nations Millennium Declaration. However, Good Governance is by no means an univocal concept. The foggy and positive aura surrounding Good Governance often blurs the fact that the concept includes at least three different views on development (Leftwich 1993; WRR 2001).

The first and dominant approach is managerial or technocratic. Its main elements are efficiency, authority and accountability of the state. In order to achieve this goal, enhancing a sound economic climate, transparency and the rule of law, and tackling corruption are considered the most important mechanisms. Public institutions and officials should therefore be controlled and held responsible for their functioning. This strictly qualitative improvement of the (small) state is expected to considerably contribute to 
development, understood as economic growth. The main link between these two is the private sector, as both local and foreign companies are expected to invest more in a country when they have more confidence in its institutions, regulations and officials. The state should therefore ensure market stability, sound monetary and fiscal policies and secure competition.

Compared to this merely economic instrumentality of Good Governance, the other views hold a broader perspective. A second approach considers poverty alleviation as the major goal, and Good Governance as a means to achieve it. Consequently, it stresses the role of effective public institutions dealing with the poor and poverty, and the importance of the poor participating in (the policy of) these institutions. This more socio-economic approach nevertheless remains within the boundaries of the given situation of a small state apparatus and its neoliberal policies while precluding alternatives (e.g. land reform or subsidising or protecting vulnerable producers, sectors or regions).

Third, Good Governance is sometimes used to refer to governance issues from the angle of human rights and democracy. From this perspective, Good Governance is a combination of a separation of powers, an independent judicial system, freedom of organisation, speech and press, free elections and a multi-party political system. The role of civil society is considered to be of great importance, not only through participation but also as the driving force behind equitable development. In this approach development is understood as encompassing economic, socio-economic and political processes, taking place simultaneously. Nevertheless, usually only the basic human and political rights are referred to, while economic, social and cultural rights are left out.

Finally, in some instances, elements of the abovementioned technocratic, poverty alleviation and political approaches are melded together into a broader systemic point of view that encompasses political and economic relations and power. This wider approach acknowledges that governance is about more than formal institutional structures and state authority. Nevertheless, like in each of the three other approaches, open markets and maximum freedom of market actors are the premises. As Leftwich already noted in 1993 (p. 611), even from this systemic perspective 'good governance means a democratic capitalist regime, presided over by a minimal state which is also part of the wider governance of the New World Order'.

Since Good Governance encompasses three perspectives on the link between governance and development, different actors have adopted the concept and they have been prescribing it for various problems. While multilateral institutions and governments of industrialised countries tend to favour and stress one of these three approaches, when opportune they 'borrow' another approach or elements of it. We will later on discuss the downsides of the concept's flexibility and elasticity, but let us start by shortly reviewing how Good Governance globally sprouted, grew and has come to bloom. 


\section{Jolle Demmers, Alex E. Fernández Jilberto and Barbara Hogenboom}

\section{The historical and doctrinal roots of Good Governance}

Contrary to the idea of Sustainable Development, which arose in environmentalist circles and was later co-opted and remoulded into sustainable growth by mainstream policymakers and theorists as well as major corporate interests, the notion of Good Governance came from the World Bank itself. The first World Bank publication in which the concept was discussed was a 1989 report on Sub-Saharan Africa. The conclusion of this evaluation of Structural Adjustment Programmes (SAPs) was that a lack of Good Governance explained their disappointing results. This was by no means a repudiation of the Bank's policy of decreasing the role and size of the state; the report concluded that Africa needed not just less government but better government. The focus on the need for more efficient and professional institutions and bureaucrats hid the more political issue that was involved, that is, the struggle within African countries between those who benefited from and those who suffered from the SAPs. Those who stood to lose and were located in and around the state apparatus formed a serious obstacle for the restructuring process envisioned by the World Bank and other funding agencies and governments. Thus it became clear that the state, paradoxically, had to be both strong and relatively autonomous in order to achieve effective adjustment. Since its Articles of Agreement do not allow for explicitly political lending criteria, the Bank could not but respond in a managerial mode, as it did with the introduction and managerial approach of Good Governance (Leftwich 1993).

It needs to be stressed that the notion of Good Governance was conceived in an evaluating study of the region that not only was facing the most extensive problems with development and governance, but that had also experienced the most destructive effects of the SAPs and declining development support. Rather than critically evaluating all structural causes of Africa's misery, the report took neoliberal restructuring for an indisputable policy goal. In other words, the real question that was to be answered was how to develop Africa within the limits set by Structural Adjustment; or, what were the main obstacles for the SAPs to be successful? Good Governance was the answer. Only a few years later, the concept was completely integrated into the general (development) policies of the major multilateral organisations (particularly the IMF, but also the OECD through its Development Assistance Committee) and Western governments (cf. Leftwich 1993; Patomaki 1999; Weiss 2000; Woods 2000; WRR 2001). Unlike the Bretton Woods institutions, the latter were not restrained from dealing with more political affairs.

Whereas the definitions differed somewhat, for each of the institutions and countries promoting Good Governance, it had clearly to do with the use of control, authority and power (cf. Weiss 2000). Initially, the World Bank used a technocratic approach that equated Good Governance with sound development management (World Bank 1992), and also France has 
primarily stressed a technocratic version of the concept. The poverty alleviation approach was represented in the development policy of the English government, with the World Bank partly absorbing this issue later on. The third and more political approach found adherents among the Nordic countries and some of the European development assistance NGOs, while it was also supported by some of the UN institutions, in particular the UNDP. ${ }^{1}$ In line with its intention to promote human development the UNDP also stressed the intrinsic value of Good Governance. In addition, it stressed the importance of domestic policies and the empowerment of the powerless (Weiss 2000: 802). ${ }^{2}$

The shift in the World Bank with respect to Good Governance took place in the mid-1990s. A 1994 evaluation shows that in the previous years Good Governance lending and research had expanded enormously, concentrated in economic and social dimensions and in Latin American and African countries. The Bank had focused on four areas: public sector management, accountability, the legal framework for development, and transparency and information (World Bank 1994). The fact that participatory approaches and human rights were labelled as 'linked issues' indicates that, apart from developing attention for the social side of Good Governance, even some elements of the political approach were used, at least in the Bank's discourse. This shift became more finely tuned in the World Bank's World Development Report 1997 that bears the subtitle The State in a Changing World (which will be analysed in the second section of this introduction).

At the time of the gradual shift of the Bank's Good Governance policies, the IMF adopted the technocratic version of Good Governance. In September 1996, the Interim Committee of the Fund adopted the Partnership for Sustainable Global Growth, which stated that good governance in all its aspects is an essential element for economic growth. These aspects include the rule of law, efficiency and accountability of the public sector, and tackling corruption were to be guiding lines of its policy (IMF 1997: v). This involvement of the IMF focused on transparency of government accounts, effectiveness of public resource management, and stability and transparency (of the economic and regulatory environment for private sector activity). In the late 1990s the IMF and the World Bank joined forces to work on the highly indebted poor countries (the HIPC initiative). After extensive efforts and actions of NGOs and churches for debt relief, the Bretton Woods institutions agreed to write off some of the debts of these countries. In order to apply for this, the governments of these countries first had to have a Poverty Reduction Strategy Paper (PRSP) approved, which - apart from the new principles of 'ownership' (i.e. the government has to demonstrate its sense of responsibility for diminishing poverty) and 'local participation' in poverty reduction programmes - should include strategies with respect to Good Governance. $^{3}$ 
6 Jolle Demmers, Alex E. Fernández Jilberto and Barbara Hogenboom

The three 'attractions' of Good Governance

Apart from its nice, alliterating sound, there are several reasons for the rapid and wide spreading of Good Governance discourses in the context of neoliberal globalisation. First, it filled a conceptual and policy gap that became apparent after the Structural Adjustment Programmes were implemented. It was clear what the state had to do in terms of allowing, enabling and supporting the private sector's economic role while strictly limiting its own, but there was not a clear vision on how it had to operate. Good Governance thus came as a practical solution to a pressing problem.

Second, part of the attraction of the idea lies in its tendency to translate complex and sometimes conflicting economic, social, political and cultural processes into manageable issues of governance and policy. By largely restating some sensible, old principles of administration and organisation, and subsequently subscribing them to developing countries, Good Governance may be confused for merely a modern jacket clothing nothing new. However, this redressing involves a major simplification of the understanding of development and even of the technocratic understanding of governance. What is lacking is the recognition that development - as any type of change - can cause new tensions between competing agendas for development. Such a focus on a non-conflict vision is at best naive. This was also true for the Bank's early analysis of governance, 'because it entirely ignores that good governance is not simply available on order, but requires a particular kind of politics to institute and sustain it' (Leftwich 1993: 612). Despite some broadening and refinement of the ideas of the Bank and other important multilateral and national institutions, part of this criticism still holds. While this explains some of the concept's attractiveness, it is not without risk. That is to say that simplistic assumptions of the time scale and support that are needed to build the institutions and knowledge to achieve Good Governance may after some time cause serious problems and opposition.

Third, Good Governance is a notion that hides important disagreement about the concept and processes of development. While under the umbrella of Good Governance these three views seem to fit together, in reality they may strongly clash. The technocratic call for a minimal state and opening up for the world market often counters demands for socio-economic protection and public investment in health, education and safety. Also the proposals for poverty alleviation and those for neoliberal restructuring tend to be opposite, particularly when it comes to (re)distribution of wealth. As these different views all join the banner of Good Governance, not only this concept but also even the debate on how to achieve just, sustainable and human development is blurred.

Generally presented as a non-political and non-ideological programme, these three attractions of the concept of Good Governance - filling gaps, simplifying complex issues, hiding disagreement - tend to work in favour of 
economic liberalisation, both by strengthening its supporters and by disarming its critics. Although from the perspective of the political approach of Good Governance there is a clear need and use for democratic decisionmaking and active citizen involvement in policy-making, in practice the managerial or technocratic approach dominates in multilateral and bilateral relations. And even advocates of this political approach generally eschew calls for economic and social rights, just like the advocates of the poverty alleviation approach stayed away from ideas of redistribution. This more or less implicit defence of the status quo is not only visible in the major multilateral institutions and industrialised governments, but also in most of the developing countries' governments, in the major political parties around the world and also in many NGOs. Let us move on to consider the contribution of Good Governance policies to national processes of depolitisation around the globe.

\section{Depolitisation with a neo-imperialist touch}

The discourse of Good Governance emerged at the time that the promotion of democratisation had already become an important element of the dominant international agenda for development. The emphasis on democracy was triggered by the shift of US foreign policy in the mid-1980s. As soon as the international Communist threat faded, and the risk that the democratisation of non-industrialised countries would be at odds with American economic interests and convictions was strongly diminished, pro-democracy policies and participatory development replaced the anti-communist and therefore frequently pro-authoritarianism policies of the US and the Bretton Woods institutions. Next to the United States Agency for International Development (USAID), the National Endowment for Democracy (NED), which started to operate in 1984, has served as an important channel of democracy promotion. ${ }^{4}$ Although the mandates of the IMF and the World Bank do not allow for 'political' interference in a lending nation, particularly the Bank has been increasingly referring to the importance of participatory development and 'the voice of citizens'. As a result of the change of the US position, European governments and NGOs, who had previously disguised their support for democratisation in developing countries, could also be more openly active on political issues (cf. Biekart 1999). Over 100 developing and transition countries ended military or one-party rule during the 1990s, and in 1998 more than 60 per cent of the countries had multiparty elections, compared to less than 30 per cent in 1974 (UNDP 2001: 10-11).

The limitations of the new dominant democratisation and participation agenda are reflected in the Bretton Woods and US approach to democracy. In US foreign policy, for instance, democracy is restricted to the political sphere and it is not recognised that political power is also a means to transform unjust socio-economic structures, nor that the social and cultural spheres may also have to be democratised. Democracy has been mainly 


\section{Jolle Demmers, Alex E. Fernández Jilberto and Barbara Hogenboom}

understood as polyarchy, in the sense of 'a system in which a small group actually rules, and mass participation in decision making is confined to choosing leaders in elections that are carefully managed by competing elites' (Robinson 2000: 43). Political, human and social rights are hardly valued beyond their instrumental role in economic and socio-economic development, which is expected to be furthered by open markets and a subsidiary state. This approach fits well into the dominant perspective on Good Governance, with its minimalist view on the question of governing a (developing or industrialising) country, which is technocratic, non-political, and merely a rationalisation of the remnants of the state. Moreover, this approach of democracy fits well into the functional neoliberal theory of politics, which holds that democratic politics needs a thriving free market economy and vice versa (Leftwich 1993).

The new international discourse on democratisation has in general been accepted, applauded and put into practice, but - as we have already seen such seemingly unanimous support may hide conflicting views and (latent) tensions. Developing countries do have a point when they label the prodemocracy development agenda as 'market fundamentalism' and a projection of the Western model of development. The 'package' of economic and political reform reflects the post-Cold War consensus that neoliberal policies are more successful and more legitimate in the context of a liberal-democratic regime than in the context of an authoritarian regime (Patomaki 1999). Due to this consensus, the international programmes and conditions for developing and post-communist countries were extended from the economic to the political terrain, and to governance issues.

Let us look a little deeper into this programmatic coupling of institutional, political and economic objectives by studying the input of the leading international institution for development: the World Bank.

\section{The World Bank view}

After an early technocratic approach, from the mid-1990s onwards, the World Bank's vision on Good Governance has been a mix of the abovementioned three approaches, including the political approach with notions of democracy. Coinciding with the entry of James D. Wolfensohn as its president, the Bank became more ready to acknowledge the importance of the state, as demonstrated by at least three issues of its World Development Reports: The State in a Changing World (1997), Attacking Poverty (2000a) and Building Institutions for Markets (2002). ${ }^{5}$

All three reports show that the World Bank promotes democracy, but largely in ways serving development in economic terms. On the one hand, democratisation and decentralisation are presented as positive processes, and the Bank frequently stresses the need for the state to be responsive to citizens. 'Building a more responsive state requires working on mechanisms that increase openness and transparency, increase incentives for participa- 
tion in public affairs, and where appropriate, lessen the distance between government and the citizens and communities it is intended to serve' (1997: 11 , italics added). On the other hand, the Bank's concern with participation actually seems to stem more from its concern with the eventual success of state reform than with this being a fundamental citizen's right. ${ }^{6}$ 'Governments are more effective when they listen to businesses and citizens', is the reasoning in WDR 1997 (p. 10). In WDR 2002, the chapter on political institutions and governance discusses 'how political institutions shape governance around the world by setting limits on the ability of the state to exercise its power arbitrarily' (p. 97). While few would argue otherwise, it is exemplary of the Bank's narrow approach.

Another case of democracy's instrumentality can be seen in the Poverty Reduction Strategy Papers (part of the programme for debt reduction of highly indebted poor countries) that were required by the Bank and the IMF from 1999 onwards. In these papers a government is obliged to address issues of 'participation' as well as 'ownership', which stemmed from evaluations that demonstrated the benefit of these principles for the effectiveness of the institutions' funding. Woods (2000: 824) claims that the institutions recognise the usefulness of democratisation and political accountability beyond these principles, but that their mandates prevented them from turning this into policy guiding lines. Although this is probably true for many of the institutions' staff, in the policies and publications of the institutions there is little that supports this view.

More than democracy, the Bank is concerned with the state's effectiveness. 'An effective state is vital for the provision of the goods and services - and the rules and institutions - that allow markets to flourish and people to lead healthier, happier lives' (World Bank 1997: 1). According to the Bank, this is particularly important for the poor, because they are the ones that suffer most from poor governance, in the form of corruption and high inflation. As in orthodox economic theory, the World Development Reports underline that the state can become more effective by, among other things, subjecting its institutions to more competition. Next to this, 'voice' and 'participation' are perceived as important tools to improve the state's relations with citizens and businesses, and thereby improve the former's effectiveness. Apart from a free press and the state adequately providing information to the citizens, open elections are presented as an important means to achieve this, but the Bank acknowledges that elections do not necessarily mean that the state is more responsive. The four other imperatives the Bank therefore suggests are: consultation of affected groups; direct participation of users in designing, implementing and monitoring public goods and services; monitored decentralisation; and developing local mechanisms for accountability and competition.

The bottom line of the three reports is that open markets give way to development, in the process of which good governance and democracy serve as preconditions. This explains the Bank's ambiguous position on democracy: citizen participation is welcomed as a tool to achieve a more effective 
state and subsequently more growth - not as a right in itself. Accordingly, free markets and a responsive and well-organised state are presented as a win-win situation for the poor and businesses. ${ }^{7}$ This linear approach is sustained despite the evidence of growing national and international inequalities as well as economic volatility since the introduction (by the Bank and other actors) of the agenda for global free markets (cf. UNDP 2001). While there are of course numerous cases in which the interests of civil society and the private sector can converge, provided that there is an adequate political and governance system, the Bank neglects the many tensions between the two to an extent that is at best naive, or at worst cor-porately biased. In the discussion about tax collection, for instance, the World Bank 2001 is concerned that due to institutional weaknesses in developing countries, 'governments tend to focus their energies on easily collected taxes, which are often the most distortionary' (p. 110): taxes on international trade and taxes on large firms. In its focus on the negative effects of this taxation for competition (through sheltering inefficient domestic producers) and economic dynamism (through discouraging large companies, which the Bank perceives as the most dynamic), it does not recognise reforms to change this, apart from rationalising collection operations through rising taxes on consumption (value added tax) and higher contributions for public services, something which largely comes at a cost to citizens.

Whereas the World Development Reports dealing with state institutions and citizen participation are more of a refinement than a reform of its promarket policies, the World Bank might be making a shift in allowing for more diversity. The WDR 2000/2001 and 2002 emphasise that there are no blueprints for Good Governance. 'Clearly, there is no unique path to growth and poverty reduction' (2001: 4) is one of the many references at this point. This attempt to no longer be labelled as an institution of one-size-fits-all policies must be seen in the light of the comments on previous Bretton Woods policies by such well-known scholars as Paul Krugman and Dani Rodrik. These critiques became particularly fierce when the Asian crisis showed that worldwide blueprints for free markets could destabilise 'miracle economies' to an extent that the global economy was threatened, and that standard IMF emergency lending made things only worse. The sensitivity of the Bank to this criticism is also shown by the theme that was selected for the WDR 2003: social cohesion. Earlier, John Gray (1998: 203) expressed strong comments on this, saying that 'What is lacking in the World Bank's account is recognition of the state's economic role in preserving and fostering cohesion in society'. Although it is still too early for a proper evaluation, the start with the Poverty Reduction Strategy Papers indicates that the new, more diverse approach is also actually implemented. Nevertheless, it is clear that this diversity has its clear limits with the institutions' continued neoliberal agenda.

What has been labelled as an agenda of Good Governance and democratisation, in many instances turns out to involve the enhancement of 
so-called market democracies or capitalist democracy. This has given way to economisation and depolitisation, as the main task of restructured states and (new) democracies is to generate attractive and open markets for capital. In this respect a special role is played by the increasingly integrating capital markets, which give way to an adverse form of political globalisation. As Phil Cerny (1997: 178) has emphasised, the financial market constitutes the link between all other market processes, and through financial globalisation national governments end up with increasingly less control over their economic policy. And Gray (1998: 9) points out that '[t]he late-twentiethcentury free market experiment is an attempt to legitimate through democratic institutions severe limits on the scope and content of democratic control over economic life'.

While financial and economic liberalisation has contributed to an overall loss of state power, in the process some institutions have gained influence, particularly national banks and ministries of finance. Saskia Sassen (1999) has noted that it is these state institutions that have become the linkages between societies and globalising forces. In addition, neoliberal restructuring implied not so much an abolishment but rather the change of a range of policies, including investment rules, property rights and trade standards. Simultaneously, technocrats have taken the lead in the liberalised state, and in its transnational activities of policy coordination (cf. Slaughter 2000) ${ }^{8}$ So while the state is far from dissolved, its functioning has been restricted in scope as it is becoming increasingly difficult to legitimately incorporate other values, interests and goals in the policy-making process than those fitting within neoliberal parameters.

\section{The national arena}

The national political arena is equally infected by the economising and depoliticising tendencies that restrict policy-making and thereby political processes, and ultimately citizenship. If we take the case of local politics, it is exemplary that the dominant development agenda is strongly prodecentralisation (for limiting central state power and furthering participation) yet opposing calls for self-determination, particularly those running against the rules and interests of the liberalised economy, such as those of the Zapatistas in Chiapas, Mexico and, as discussed in Chapters 13 and 14 of this volume, groups in Aceh, Maluku and Anglophone Cameroon. Another issue has to do with the tensions between democracy, on the one hand, and large inequalities and a major concentration of power, on the other hand. In theory, liberal democracy is for freedom and against the concentration of power in just a few hands, whether political (strong state) or economical (monopolies, cartels). In practice, however, due to policies for open markets, market players have gained freedom at the cost of citizens' political influence, while economic inequalities have expanded internationally and nationally. States have largely been unsuccessful in 


\section{Jolle Demmers, Alex E. Fernández Jilberto and Barbara Hogenboom}

limiting the ongoing concentration of corporate power, whereas people are increasingly identified as consumers instead of citizens. It is in this respect significant that instead of national legislation or international agreements, transnational companies have among themselves started to 'borrow' public legislation to develop their own corporate quasi-legal regimes for conflict resolution (Sassen 1999). Another form of self-regulation is expected with respect to these companies' 'responsible' and 'ethical' behaviour, with global consumers as their monitoring agents.

The political outcome of the international democracy agenda is thus very problematic. For people living in countries that were previously ruled by an authoritarian regime, democratisation is a major step forward, although for those striving for more equal social and economic relations the new democracies can still be rather restrictive. In addition, from a global point of view, the neoliberal promotion of democracy has reduced (both theoretically and practically) the roles of the main intermediaries of political representation, political struggle and true consensus building. All in all, however, as Richard Falk also notes, globalisation so far has contributed to the decline in the quality as well as the significance of citizenship. 'The options offered to the citizen are becoming far less meaningful, especially for that bottom 80 per cent of the citizenry that appears to be losing out as a consequence of economic globalisation' (Falk 1999: 159). Combined with the increasing international and national inequalities, this has produced a growing disinterest and distrust of formal political intermediaries The seemingly paradoxical coincidence of this type of democratisation with nothing less than a depolitisation of democracy, the state, and politics itself has disarmed, paralysed or even brain-washed most of capitalism's previous critics and reformers, such as socialists, social-democrats, nationalists and communists. ${ }^{9}$

Good Governance policies have added to this depolitisation. Both uncompleted neoliberal restructuring and the negative effects of neoliberal policies are explained as caused by bad governance - as if to say, 'there's nothing wrong with the neoliberal model, it just hasn't been done well' and 'they don't know yet how to govern properly'. In this view Good Governance is the necessary ingredient to complete neoliberal policies and turn them into successes. While at first glance being little more than some basic guidelines to achieve a 'civilised' state, in reality Good Governance often serves as a sub-ideology to further enhance the neoliberal agenda. As Patomaki writes:

From a cosmopolitan democratic perspective, it is clear that slogans such as 'participatory development and good governance' should not be ways to impose, in an undemocratic way, particular, Western visions of organizing society upon the dependent countries of Latin America, Africa and Asia. It is even worse when this paternalistic - and often straightforwardly imperialistic - attitude is coupled with de facto 
furthering of profit-seeking corporate interests of those actors who seem to be beyond all measures of transparency, good governance, and democratic accountability, in particular Bretton Woods institutions and the transnational corporations.

(Patomaki 1999: 133)

The threefold development agenda on economics, governance and politics has indeed been far from unbiased or 'interest-free', since Good Governance and democratisation have been moulded into concepts and policies that are supportive of neoliberalism and vested global economic interests. The strategy to further democracy was not only motivated by the long-standing needs of the people living under undemocratic regimes, nor by genuine international concern and solidarity alone. Robinson (2000: 43) claims that the 'free markets and democracy' agenda is rather intended 'to make the world both available and safe for global capitalism by creating the best conditions around the world for the unfettered operation of the new global production system'. This is also clear in the discourse of the OECD's Development Assistance Committee on Participatory Development and Good Governance (PDGG). It does compromise between partly contradictory elements of traditional Western liberal modernisation theory and more critical thinking on empowerment through participation, but with economic and political liberalism dominating the policy agenda. Thus, even within this PDGG discourse, the OECD refuses to take seriously the indigenous cultures and identities of particular peoples or countries, except explicitly at the local level (Patomaki 1999). To some of the participants in this disguised battle over the meaning of democracy - particularly those that previously were in support of autocratic leaders and authoritarian regimes - promoting democracy is in the first place a means to co-opt the agenda of its (potential) opponents.

\section{The role of the United States}

Although deterritorialisation has been one of the major characteristics of recent globalisation (cf. Held et al. 1999, Scholte 2000), the just-mentioned vested interests are (still) far from non-territorial in nature. Either in the G7, the OECD, the Bretton Woods institutions, or in the less institutionalised arenas of global economic politics, the United States seems to have gained rather than lost hegemonic power since the end of the bipolar system. This crucial trend has largely remained hidden behind the absence of coercive institutions of empire. For our analysis of global processes of polarisation and depolitisation, however, this is an important notion: '[T]he United States has abandoned any pretensions to global empire or overt hegemony since its enormous structural power has remained deeply inscribed into the nature and functioning of the present world order' (Held et al. 1999: 425). And this power is applied for something even greater than the enhancement 


\section{Jolle Demmers, Alex E. Fernández Jilberto and Barbara Hogenboom}

of its immediate economic and geopolitical interests. As Gray (1998: 101) points out, it is the utopia of global laissez faire that is the ultimate goal of the US. 'Only in the United States is the Enlightenment project of a global civilization still a living political faith. During the Cold War this Enlightenment was embodied in American anti-communism. In the postcommunist era it animates the American project of a universal free market.' And since 11 September, 2001 the US government has come to label most forms of opposition to this Enlightenment project as 'terrorist' and 'evil'.

The American bias of globalisation can be viewed, among other places, in the policy-making processes of the World Bank and the IMF. In a reaction to Anthony Giddens's remark that the US 'doesn't control financial markets any more than any other country or agency does', Will Hutton points out that financial markets 'are also transmission mechanisms of very particular economic ideas and of very particular economic interests, which are overwhelmingly if not exclusively American', adding that Americans benefited hugely from the East Asia crisis as the IMF emergency programmes cemented the commitment to liberalisation, opening to US markets and stimulating sales of Asian companies to US investors (Giddens and Hutton 2000: 59). Similarly, World Bank policies are disproportionately influenced by the US, and not only by its major voting rights on the board of directors, its right to deliver the Bank's president, and the Bank's location - as the IMF in Washington DC. There is a list of documented cases in which the US influenced World Bank policy via unofficial avenues: to not divert from the track of presenting economic growth through open markets as the medicine to every illness of underdevelopment (e.g. the conflict over the question of empowerment in the World Development Report 2000/2001, cf. The Economist of 24 June 2000: p. 11); to silence internal dissident voices (e.g. the Bank's chief economist Joseph Stiglitz, cf. Wade 2001); ${ }^{10}$ and to provide or change loans because of US foreign policy (e.g. the major loan to Mexico for environmental protection in the border zone with the US on the eve of the US Congress voting over the ratification of NAFTA, cf. Hogenboom 1998: 222).

Clearly, the global influence of the US is one of relative, not absolute, power, but it has survived the last decade of the twentieth century remarkably well. 'The US does not have the hegemonic power needed to make a universal free market a reality, even for a short time. But it certainly has the power to veto reform of the world economy. So long as the US remains wedded to "the Washington consensus" on global laissez-faire there can be no reform of world markets', Gray (1998: 218) explains. At the time of the Asia crisis, in 1997 and 1998, many were convinced that the end of the Washington Consensus was near. The ILO, for instance, hoped that the crisis would be the starting-point of a more socially oriented global development model, just as the Great Depression had given way to the new social contract in industrialised countries (ILO 1998). Earlier on, in 1995, Paul Krugman had already predicted that the crisis of the Mexican peso would open the eyes of policymakers and (official and private) crediting agencies alike to the fact that the 
promotion of 'free markets and sound money' by the US government, the IMF, the World Bank and other leading institutions that collectively define the conventional wisdom, had raised the expectations of this agenda to such unrealistic heights that it had produced nothing less than a global speculative bubble. This 'first financial crisis of the 21st century' (according to IMF's director Michel Camdessus) shed another light on the alleged advantages of financial integration, demonstrating more clearly some of its disadvantages such as financial volatility (Eatwell 1997). After the earlier financial crises of the 1990s in Europe (1992/93) and Mexico (1994/95), and the jitters caused in East Asian affected countries as large and far away as Russia (1998) and Brazil (1999), the agenda of deep and broad liberalisation of capital markets was indeed very weak. After some time, however, general perceptions shifted, and apart from the Euro crisis, the blame of these crises was successfully put on so-called crony capitalism.

Arguments that the volatile nature of the global financial markets and the irresponsible financial liberalisation policies that were pushed by the US, the IMF and the World Bank had been the major cause of the financial crises around the world gradually faded, especially when it turned out that the economies of the industrialised countries would only be slightly harmed by the crisis that ruined the jobs of millions in the South. Although the World Bank became somewhat more receptive to the (temporary) use of capital controls, financial liberalisation has remained on the agendas of both the IMF ('as soon as possible') and the Bank (in the medium term), reflecting only a slight divergence with the agenda for rapid capital market liberalisation of the US government and corporate financial institutions (read: opening national financial systems to US banks and institutions while pegging currencies to the dollar). These actors behind the Washington Consensus claim that financial crises can be prevented when capital flows are monitored by transparent, independent and capable national institutions.

Instead of allowing for regional, national and international restrictions to capital flows, Good Governance was thus reinforced, as it became the main prerequisite for liberalising financial markets. The Asian crisis could implicitly be presented by the Bretton Woods institutions as proving their governance agenda right. In other words, Good Governance saved the 'Washington Consensus' and the institutions and interests behind it, at least for some time. Looking back at the Asia crisis and the global response, there has been but a slight reform. International financial regulations have been specified at some points, and flows of information have been improved. The division of benefits and responsibilities between public and private players has none the less remained unchanged, as plans for burden sharing at times of crisis have not been implemented. The criticism that the Bretton Woods agencies operated with global blueprints for national problems brought about a considerable change of World Bank policies; at least in words it reacted with a repeated stress on the need to take the national situation into 
account (cf. World Development Report 2000/2001 and 2002). On the other hand, the dominant international agenda for development was now more structurally extended from economic thinking to governance issues. All in all, instead of threatening the global spread of the free markets project, and with the help of Good Governance discourse, the financial crises of the 1990s turned out to add to neoliberal thinking and policies, reinforcing the processes of depolitisation around the globe.

\section{A world of neoliberal regimes}

As the studies of individual countries in this book show, the global spread of neoliberal ideology and policies during the last two decades of the twentieth century gave way to fundamental changes of national economies, governance and politics around the world. The triumph of capitalism that went with the end of the Cold War was largely captured by the neoliberal current, resulting in the reform of various capitalist models. This does not imply that the diversity of regional and national economic models has been fully erased, since national programmes of neoliberal restructuring have been partly shaped by historical circumstances (economic, political, social) and existing policies. Yet, imbued with neoliberal thought, capitalist and socialist regimes have gradually taken the shape of neoliberal regimes, largely irrespective of the type of party or coalition in government.

A shift of regime is more than a new economic model: it also encompasses a change in government. It implies the use of a different set of rules and practices regulating the access to power and the making of authoritative decisions, thereby affecting the social welfare and economic security of citizens. Interestingly, many of the dramatic transitions from communism or authoritarian populism were caused by rising popular discontent and the former rulers' inability to make their economies competitive with those of Western Europe, the United States and East Asia. These industrialised countries were simultaneously compelled to make new institutional arrangements to accompany the growing openness of their economies to foreign competition.

It was the debt crisis of the early 1980s that drew a watershed between the era that combined capitalist models inspired by Keynes and socialist models inspired by Marx, Lenin and Mao, and the subsequent neoliberal revolution. Starting with Mexico's moratorium on its debt payments in August 1982, the crisis rapidly spread through Latin America and then through the rest of the world. As a result, the cracks that had appeared in international Keynesianism during the 1970 s, caused by the end of the system of fixed exchange rates, the first oil crisis, stagnating growth, mounting inflation rates and public budget deficits, could no longer be mended. The belief that the nation-state could operate as the determining force for balancing economic growth with the help of interest rates, public investment, stateowned companies and cheap state credit disappeared. In this context, and 
under the direction of Ronald Reagan and Margaret Thatcher, renewed (economic) liberal thought gained support. The fact that the New Right had gained control in the United States and the United Kingdom contributed to the 'radiating' power of neoliberalism to the rest of the world.

A free market for capital, goods and services, with the state's role being largely limited to facilitating this market, was successfully declared the sole and indivisible solution to economic stagnation and budget deficits. But this was far from a voluntary process. The governments of developing countries had no other option than going along with this current if they were to be accepted for new foreign loans and the renegotiation of debt payments, which were both indispensable for economic stabilisation and recovery. After years of (too)-easy lending on the global capital markets the debt crisis forced developing countries de facto to hand over their sovereignty in defining national economic policies to the international financial organisations, particularly to the IMF and the World Bank, which also happen to be the gateways to the private capital markets. And at the time that countries came knocking on the doors of the Bretton Woods institutions, they had passed through a process of ideological reorientation that resulted in the policy of structural adjustment. Latin America's early experience with (authoritarian) liberalisation following the Chicago Boys' recipe was posed as an example to the new market democracies of Africa, Asia and later on also Eastern Europe. The major influence of the US, and to a lesser extent the UK, in the IMF and the World Bank was crucial to the global spread of the new neoliberal orientation. Around the globe, the economic policies of developing and post-socialist countries came to be heavily influenced by the transnational bureaucracies of the World Bank, the IMF and transnational fora such as the Group of 7, the World Economic Forum (Davos), and the Trilateral Commission.

Apart from the general condition of sound macro-economic policy, the Bretton Woods institutions demanded many specific reforms directed at opening up the economies that were previously for some part sheltered against fierce foreign competition. Two main elements were the privatisation of state enterprises and the liberalisation of flows of goods, services and capital. In the 1990s, the countries in Eastern Europe went through an accelerated process of liberalisation, while developing countries continued their programmes for liberalising their national markets. In the case of deregulating the financial markets, again the Bretton Woods institutions, and particularly the IMF, advocated rapid restructuring. Financial liberalisation in the Western economies and technological modernisation had already allowed for major expansion of global financial markets. Developing and transition countries were told that opening up for transnational capital would be beneficial for economic growth, for among other things it would generate access to sources of cheaper private credit. Together these trends caused the mobility of capital to increase to a rate unprecedented in the history of global capitalism (Eatwell 1997). 


\section{Jolle Demmers, Alex E. Fernández Jilberto and Barbara Hogenboom}

To the state, liberalisation and privatisation implied the loss of much of its previous economic steering capacity, either to the corporate sector or to international institutions. Partly as a result of this development, the deregulation of national economies went hand in hand with new initiatives for regional economic cooperation, that is, integration in the global market via regionalisation (MERCOSUR, NAFTA, ASEAN, etc.). 'Regionalization can be defined as an integration process on the regional level with the help of governments. Regionalization appears here as an aspect of a process towards the liberalization of markets and FDI regulations. These regional arrangements appear to be the direct result of governmental actions instituting regional trade regimes and creating deeper integration of separate economies at the regional level' (Fernández Jilberto and Mommen 1998: 7-8).

Socially and politically the rise and spread of neoliberal regimes have been very important too. From a historical perspective the old bipolar world was a relatively stabilised system with steadily growing material wealth, particularly in the developed capitalist world, and manageable crises in both camps. In the developed capitalist countries parliamentary democracy was the rule, while in Second and Third World countries generally some form of (semi-)authoritarian or populist rule was applied. Economic growth was the key for political and military success for all regimes. The breakdown of communism eliminated a competing model, which had obliged most Western leaders to respect some kind of equilibrium between the worlds of capital and labour. In addition, the fall of the Soviet Union gave way to rapid impoverishment of the countries of the former socialist bloc, and to disarray in most of the Third World. The end of the Eastern bloc and the rapid liberalisation of certain parts of the Chinese economy in the early 1990s, further consolidated the globalisation of neoliberalism. As we have discussed, the decrease of the communist threat had already cleared the way for including a political component to the neoliberal agenda, resulting in the powerful motto of free markets and democracy. Yet this agenda's consolidation came only after the (harshly suppressed) student protests in Beijing's Tiananmen Square and especially after the fall of the Berlin Wall in 1989, which was followed by fundamental political and economic change in Eastern Europe and the Soviet Union. Since the mid-1990s, one can no longer deny the victory of the neoliberal ideology over the socialisms of Eastern Europe, the populism and nationalism of the Keynesian-style economies of the Third World, and the Western European welfare state.

The end of regimes based on welfare and import-substitution policies that embraced large parts of the working classes has given way to further integration in the capitalist world system of practically all countries, thereby contributing to a gradual denationalisation of politics. The role and the functions of the state have become increasingly focused on functionality to the global market and capital. Simultaneously, democratisation took place 
as authoritarian regimes of the right and the left were defeated. Around the world, these developments had a similar impact on different accumulation regimes and political systems, ranging from the Central Planning economies of Eastern Europe to the import-substitution industrialisation (ISI) models of Latin America, and from conservative dictatorships in southern Europe to the so-called Marxist military regimes in Africa. Economic liberalisation, denationalisation of policy-making, and formal democratisation became the common features of regime changes in Eastern and Southern Europe, Latin America, Africa and also Asia, with the Arab world as a notable exception.

Under these specific historical circumstances, neoliberalism and globalisation have been reinforcing each other. Until then, economic globalisation was largely the result of technological progress in communication and transport, which increasingly allowed and even forced companies to search for markets beyond the national or regional frontiers. In the 1990s, thinking and acting in terms of economic globality was strongly fed by the open market policies put in place in most countries, while in the opposite direction globalisation strongly enhanced neoliberal restructuring. As we will further analyse in this chapter and throughout this book, neoliberal globalisation is affecting a wide range of major issues for current and future development: economics, politics, social change, security and the environment, to name the most prioritised ones. Power, and control over power, seem to be central to any of these issues.

As the in-depth contributions to this volume show, the global process of neoliberalisation has not produced a uniform output, but various neoliberal regimes, depending on the national economic model and the political circumstances. National political elites played an important role: their views and interests, their relative autonomy in national politics, and their relations with international actors (states, multilateral organisations and transnational banks and companies) substantially affected the specific contents and exceptions of neoliberal policies. Despite converging tendencies, then, the outcome of economic restructuring has not been one model, let alone one global free market. Instead, we can discern various neoliberal models, with crucial differences between regions, and between countries within a region. In the next sections we briefly review some interesting cases from around the world.

\section{The United States and Western Europe}

By the early 1990s, the European Left and the Democratic Party in the United States understood that the world order had fundamentally changed and that they could no longer rely on the theoretical fundamentals of Keynes. When redefining their electoral platforms, both Bill Clinton and Tony Blair adopted a neoliberal stance in order to prevent further electoral defeat. Clinton moved away from the traditional great coalition of ethnic minorities, urban poor, industrial workers and white-collar workers and 
reconstituted a middle-class alliance including the emerging professional classes and the better educated. Blair marginalised Old Labour and conquered the middle class with a programme that rejected any reference to renationalisation, high taxes and increased state spending. In Blair's view, economic growth could be fostered by giving incentives to investors and further deregulating the labour market, while the Left could guarantee higher qualification of the labour force by improving the quality of schooling and health services. Clinton strongly advocated free trade, thereby alienating organised labour from his party. By proposing supplemental agreements on the protection of labour rights and the environment to the NAFTA, he did give in to some of the objections of the AFL-CIO and other critics, but more importantly he created the basis for (tight) Congressional approval for regional free trade.

Although Blair and his Third Way discourse did not charm all social democratic parties of Europe, they had been similarly affected by the crisis of the economy and the welfare state, and by the collapse of the Soviet Union. The Third Way appeared as an alternative to the alternative, that is, to the traditional alternation between Left and Right. While praising the social democracy of the second half of the twentieth century for its major social achievements through the constitution of the welfare state, Third Way proponents point out that this model had been exhausted because of the combination of monetary policies with social benefits, the redistribution of wealth via fiscal means, etc. In addition, they refer to the perverse effects of these policies, such as the diminution of citizen's responsibility, subsidised social exclusion, major unemployment, the bureaucratisation of public service policies, and the failing answer to criminality and insecurity (cf. Giddens 1998).

The Third Way legitimised European centre-left parties to adopt a centreright programme of neoliberal restructuring. This was done by means of combining welfare based on deregulation and lower public expenditures, with solidarity considered as a mechanism of destatalised social cohesion, and democracy in a fragmented form, through improving supranational institutions and politics that can guarantee the effectiveness of citizens' rights. At an ideological and political level, the social democratic support for the economic agenda of the right strengthened the idea that there is only one way to global capitalism. In practice, however, liberalisation and privatisation hardly solved pressing social problems in Europe. Overall, European unemployment rates remained rather high, with an average rate of 9.1 per cent in 1999 (European Commission 2001: 110), while income inequality increased, which in several countries added to xenophobic sentiments and the increasing (local) political presence of the extreme right. While in the past the First World's welfare state used to be depicted as a shining example for the Third World, nowadays citizens of industrialised countries are gradually becoming used to the idea that their societies are going to look more like those of Brazil or Thailand. 


\section{Eastern Europe}

An interesting effect of the fall of the Berlin Wall was the waning of the difference between socialist and social democratic parties in Europe. Like most of the social democrats in Western Europe, the Eastern and Central European socialist parties that since then have had electoral success were the ones that adopted a pro-capitalist and modernising stance. This has turned them into acceptable coalition partners of the liberals. While the drive to neoliberal convergence has to be understood as a response to various changes, more than in any other region, Eastern Europe's economic liberalisation cannot be alienated from the end of the Cold War (see Chapters 6, 7, 8 and 9 of this volume).

The context of the democratisation processes of the former socialist countries have been far from ideal. After decades of a state-controlled model, the impact of economic liberalisation was profound, affecting practically all economic, social and political processes and relations. The social situation in the former socialist countries, including income, life expectancy and school enrolment, deteriorated at a dramatic rate. ${ }^{11}$ Mihály Simai (1998: 131) states that "ii]f the first experiments with democracy result in inflation, unemployment, increasing inequalities, and a declining standard of living for the "silent majority" of the population, the result will be fear, alienation, and distrust'. These problems added to historical legacies, such as a relatively small middle class, and weak political party structures, which are two important elements for constituting a democracy. While in Central Europe (Hungary, Poland and the Czech Republic) and the Baltic countries with some pre-communist democratic experience democratisation has progressed substantively, in Eastern Europe and the Balkans post-Soviet political development has been most difficult and conflictive, with serious risks of extremist 'solutions' and the rise of identity politics.

When the Soviet 'empire' collapsed, it fell into its constituent parts. Some national elites, such as those in the Central Asian republics, inherited the state even though they had been beneficiaries of the old order. In Central Europe, nationalists or post-communist social democrats came to power. Twenty new states were rapidly created but most of them remained dependent on trade with Russia. Because of the insolvency of the Soviet Union and its successor states, for the Eastern European ex-communist countries the important potential trading partners were the countries of the EU and the EFTA (European Free Trade Area). However, free access to these markets was denied and the eastward enlargement of the EU slowed down considerably when it became clear that the liberalisation and integration policies of the EU did not generate the anticipated prosperity and stability. And while the governments of Eastern European countries are at the mercy of the EU for the timing and conditions of entry, many of their citizens have given up hope of a rapid improvement of their situation.

Although bringing about many structural changes, the disappearance of the Iron Curtain did not bring about the anticipated economic growth. 


\section{Jolle Demmers, Alex E. Fernández Jilberto and Barbara Hogenboom}

While some of the Eastern European economies are highly industrialised (e.g. Russia, Poland, the Czech Republic and Hungary), their industries were very differently organised than those in capitalist economies. The existence of large industrial sectors and a skilled labour force would seem to preclude 'starting from scratch', but so far the transitional economies have had serious difficulties attracting sufficient foreign capital to modernise their industry. Meanwhile, the position of Russia remains problematic as liberal reformers in Moscow are countered by groupings of 'raw materials lobbies' and 'comprador elites' interested in trading commodities with the West, while 'industrialists' are stressing the necessity of reconstructing a regional market of a Soviet type. Russia is still struggling with the loss of its superpower status, while the country shows a strong tendency to divide itself up into semi-independent regions. Market forces have been hampered by inconsistent shock therapies failing to achieve macroeconomic stabilisation and imposing greater costs than in the Baltic or Central European states. Moreover, as Mommen (Chapter 6 of this volume) points out, deregulation and privatisation helped the Mafia to penetrate the economy massively, contributing to the expansion of the transnational Mafia networks in the former Soviet block. Yet possibly even more important is the Mafia's penetration and control of the decomposing Russian state, which is seriously hampering arenas of democratic decision-making. The question thus remains what the outcome of the Russian road to market capitalism and democracy will be.

\section{Latin America}

Neoliberal regimes made an early appearance in Latin America, especially in countries such as Chile and Argentina where the neoliberal restructuring process was already initiated by military dictatorships of the 1970s and 1980 s, and was later adopted by populist parties in the 1990s (e.g. Chile's Socialist Party). These early cases received major US-based support, ideologically (by the 'Chicago Boys'), strategically (military) and economically. Nevertheless, the initiative and continuity of neoliberal policies were largely 'home-grown', both in national economic crises and in a national political response. This early neoliberalism was introduced by violent and anticommunist military dictatorships (Chile 1973, Argentina 1976, Bolivia 1982). With neoliberalism, the ISI idea that development was equivalent to industrialisation was replaced by a concept of development being equivalent to economic growth, thereby ending the protagonist position of the working class. And with the ideological synthesis of the doctrine of

National Security and neoliberalism the juntas had found an effective instrument for the physical elimination of the intellectual inheritors of Keynesianism and socialism.

Other Latin American countries experienced internal shifts within the ruling (populist) party during the 1980 s, which resulted in the weakening of 
the Keynesian faction and the rise of a neoliberal, technocratic rule. This form of neoliberalisation of the political and economic regime had its starting-point more dominantly in the international arena, with the rapid spreading of the debt and economic crisis in the 1980s. The global environment fed internal struggles and the reshuffling of the balance of power between adherents of state-led growth and market-led growth. As Hogenboom (Chapter 4 of this volume) shows in the case of Mexico, the national and international crisis resulted in the neoliberalisation of the de facto state party, the PRI, which allowed for the creation of the NAFTA. In Brazil, the programme of neoliberal restructuring was initiated under the presidency of Fernando Collor de Melo (1990-92), five years after the end of military rule and subsequent fruitless intents to terminate the crisis. President Fernando Henrique Cardoso (since 1994) deepened these reforms and his Plano Real - formulated during the presidency of Itamar Franco linked financial stability to neoliberal policies as the only way to end hyperinflation. Finally, some Latin America countries passed through a different process of regime change, such as a shift away from the former ruling parties and elites towards a modern civilian caudillo. One example is the neoliberal authoritarian populism of President Fujimori in Peru (1990-2000), another is the strong presidentialism of Venezuela's Hugo Chávez (elected in 1998), who has matched economic restructuring with a foreign policy of explicit anti-Americanism. In each of the abovementioned Latin American cases, the new economic model implied a toning down of labour protection while the economic crisis forced governments to cut social expenditure. Despite the democratisation processes that occurred in most countries, the lack of transparency and accountability remained a pressing problem as various corruption scandals have shown.

The first four chapters of this book show in detail how neoliberal restructuring brought about radical changes in state-society relations in Latin America. In the era of 'classic' populism, government policies facilitated rapid industrialisation as well as income distribution, which mostly benefited the urban popular sector. The stability of the political regime was considered to depend directly on the continuity of this distribution. State companies indirectly supported and subsidised the development of the private industrial sector, while generating public resources for social policy (such as health care and education). The privatisation of the parastatal sector thus had a profound political impact as it brought an end to this type of state-society relations. In addition, the leaders of the democratic opposition had to abandon any political radicalism if they were to be considered a viable 'alternative'. Under the condition where political stability depends on the continuity of liberalisation policies and state deregulation, the (re)construction of a civil society takes place largely separate from the state. Similarly, the political role of parties has changed considerably. At the time of classic populism, the electoral strength of populist parties was for a large part based on their successful channelling of social demands to the state. 


\section{Jolle Demmers, Alex E. Fernández Jilberto and Barbara Hogenboom}

Central elements of the populist political model were the state, as the centre of social and political conflict, and (either authoritarian or democratic) charismatic leadership. In the neoliberal era, the state transferred both its functions as economic agent and regulator of social inequality to the market, thereby undermining much of the historical political task of the populist parties.

The survival of populism in times of neoliberalism is one of the remarkable phenomena of Latin American politics in the late twentieth century (Demmers, Fernández Jilberto and Hogenboom 2001). The socio-economic characteristics associated with populism (state intervention, Keynesian policies) have largely been pushed aside by the 'neoliberal populist' parties of the 1990s. What has remained, apart from the parties themselves, is a continued need for mass support, and a stress on (charismatic) personal leadership. In many countries the heritage of military dictatorship or oneparty rule had created a situation in which interest associations, political opposition and organisational networks remained weak. In addition, partly as a result of the economic crisis and neoliberal restructuring, Latin America's informal sector increased rapidly, sometimes comprising half of the population. As democracy (re)emerged, large numbers of politically uncommitted people gained full access to the ballot box, and it was to these groups that the neopopulist leaders appealed. They thus differed substantially from 'classic' populists in that they appealed directly to the huge informal sector and unorganised urban and rural poor, instead of to the 'traditional' populist sectors such as urban workers and the provincial lower middle classes. By adapting populism to the severe economic constraints of the late 1980s and 1990s, neopopulists such as Menem, Collor, Fujimori and Salinas showed that neoliberal policies did not preclude continued populist policies. Conversely, as Weyland (1996: 9) stipulates, '[t]hey used political populism to impose economic liberalism, and in turn used economic liberalism to strengthen their populist leadership'.

\section{Africa}

In Africa, too, it was the debt crisis of the 1980s that gave occasion to profound policy changes, but to some extent the crisis was the excuse external actors had been waiting for to become involved in 'solving' Africa's problems. After independence, African regimes had failed to modernise their economies and, almost without exception, relied for their foreign exchange on the export of just one or two primary products, suffering from falling world prices. While the post-independence states aimed to develop import-substituting manufacturing, state institutions served to sustain the state rather than to achieve this goal. Moreover, the abuse of power and rent-seeking activities of the ruling class led to the failure of industrialisation. Simultaneously, the largest economic sector of Africa, agriculture, suffered from heavy export taxation and poor manage- 
ment. As a result of these poor economic prospects, domestic investment and savings were low and capital flight was high, whereas foreign investment remained limited to a few lucrative sectors (primarily mining and fossil fuels). The World Bank's early Structural Adjustment Policy for SubSaharan Africa focused on promoting the export of traditional primary products. However, it turned out that currency devaluations increased prices for imported food and equipment, which seriously hurt urban consumers and local industry, while agricultural production was hindered by declining national income and falling world prices. Privatisation of parastatal companies led to bankruptcies or takeovers of strategic enterprises by foreign capital without boosting investment.

These troublesome experiences made the World Bank shift its programmes to export diversification. In order to succeed, substantial new foreign investment was needed, and the Bank and other credit agencies attempted to convince African governments of the importance of open markets and a reliable investment climate. Many African countries liberalised their financial sector in order to stimulate more and cheaper flows of financial capital. As a result, foreign direct investment and short-term capital flows have been stepped up and have spread to a broader group of African countries and sectors, although capital flows remain concentrated in the hands of a few multinational corporations and banks. Unfortunately, financial liberalisation coincided with the weakening of financial monitoring systems of the state, thus leaving the growing financial sector with less of the much-needed overview (Bhinda et al. 1999). With respect to trade, African countries have to a greater or lesser extent liberalised their policies, but overall Africa's trade liberalisation has not advanced as far as in other developing regions. Apart from political and social reasons, the region's economic protection has to do with its continuing vulnerability to the world market, particularly to the low and falling world market prices for export commodities. ${ }^{12}$ After the painful first half of the $1990 \mathrm{~s}$, with an average negative growth per head, in the second half of the 1990s growth improved, particularly in Mozambique, Mauritius and Uganda, as well as in the major economies of South Africa and Nigeria. Between 1996 and 1998, average growth in Sub-Saharan Africa was 5 per cent, but also the least developed countries achieved an average growth of 4.1 per cent in 1998. Since then, however, average economic growth has diminished and in some countries income per head has been negative again (ECA 2000). Africa's neoliberal regimes thus have not succeeded in stimulating the much-needed economic growth, in either quantative or qualitative terms.

However, even high growth rates are unlikely to contribute substantially to human and sustainable development unless there is certain continuity in governance matched with sufficient control by (organised) citizens. Unfortunately, the optimism of the early 1990s about democratisation of the African continent did not live long. Nelson Mandela's becoming president of South Africa and Kabila's victory over Congo's dictator Mobuto were 


\section{Jolle Demmers, Alex E. Fernández Jilberto and Barbara Hogenboom}

promising, but the genocide of Rwanda and the bloody civil wars in countries such as Congo and Sierra Leone also killed many of these high hopes. Only in a few countries did the recipe of free markets and liberal democracies seem to have positive effects. In the majority of cases, liberalisation damaged the vulnerable post-colonial state and fed the parasitic conduct of national elites benefiting from the intensified private cooperation with foreign capital. In Chapter 14 of this volume, this process is described in detail for the case of Cameroon. Despite the lack of clear figures, it is evident that due to open markets Africa's share in transnational criminal activity has expanded rapidly and that the growth of Africa's illegal trade (smuggling of weapons, drugs, people for prostitution, etc.) has been higher than the growth of legal trade. The connection between neoliberalisation and the rise of local economies of war is further explored in the final chapter of this volume. Meanwhile, the official share of Sub-Sahara Africa remains limited to about 1.5 per cent of total global trade, of which South Africa and Nigeria make up 35 per cent and 14 per cent respectively (World Bank 2000b).

Africa's ongoing vulnerability and suffering is increasingly less recognised and cushioned by the international community, in which Africa is consistently pushed towards further liberalisation. Also the European Union redirected its policy towards Africa, as the Agreement of Cotonou signed in 2000 demonstrates. Along the lines of WTO policy, the EU decided that this follow-up of the Lomé Agreement (for trade and aid relations with former European colonies in Africa, the Caribbean and the Pacific) had to do away with previous preferential trade. Trade preferences will stay in place for the Least Developed Countries (LDCs), but for the other developing countries they were partly suspended immediately, and the rest will end in 2008. The other way around, Europe has done little to give Africa a fair chance. Despite many promises, the 33 LDCs in Sub-Sahara Africa are still denied free access to the EU market. In addition, while the World Bank calculated that an end to export subsidies in industrialised countries would speed up Sub-Saharan growth to 14 per cent, EU subsidies for agriculture continue to hamper the perspectives of agriculture-based economies. Another major obstacle for future development is the high foreign indebtedness of Africa's governments, which has in general declined too little to bring about serious positive change.

Because of this most difficult situation, in 2001 the presidents of South Africa, Algeria and Nigeria launched the Millennium Partnership for the African Recovery Programme (a sort of African Marshall Plan) at the World Economic Forum in Davos. The programme aims to stimulate the region's economic development, which is most likely to happen in countries with the conditions best fit for rapid growth: Mozambique, Guinea Equatorial, Uganda, Mauritius and Senegal, which also have proceeded the fastest with structural liberalisation reforms. However, it should also benefit the countries with slower reforms and those on the edge of civil war (South Africa and Tanzania). Although including a wide ranch of themes, such as debt 
alleviation, stimulating investment, human development and infrastructure, the programme has also been criticised for being the Trojan horse of the Washington Consensus and an initiative for regional neoliberalisation.

Asia

Contrary to African and Latin American crisis-struck countries, in the 1980s the Asian NICs (Newly Industrialising Countries) did not seem to be in need of a different model of integration in the world market. Since the 1960s, these Asian economies had experienced sustained high growth, together with a reduction of poverty and of income inequality. Although using very different combinations of economic policies, from hands-off to highly interventionalist development policies, these countries shared the combination of macroeconomic stability and investment in human capital. The 'Asian miracle' consisted of very rapid export growth of manufactured exports, and industrialisation faster than all other regions in the world. These achievements were supported by high rates of domestic savings and a rapid output and productivity growth in agriculture. In South Korea, Taiwan, Indonesia, Thailand, Singapore, Hong Kong, Malaysia and Japan private investment was high, but public investment remained important and was counter-cyclical to the reduction in private investment in periods of economic contraction. In other economies the fiscal contraction of macroeconomic adjustment was reflected in lower public investment rates. Furthermore, the Asian NICs invested in education and were well ahead of other developing countries (Haggard 1990: 191-271).

However, the East Asian financial crisis shed a very different light on the region's development model. Suddenly, the close ties between the political and economic elite that were previously viewed as an important basis for the success of the Asian mix of sustained public and private economic investment, now became labelled as 'crony capitalism' and were perceived as a source of instability. As Chapters 11 and 13 of this volume illustrate, in Indonesia, Thailand, and South Korea the currency crisis of 1997/1998, with an average 40 per cent loss of value, turned into a major financial, economic and social crisis, due to a combination of problems with the exchange rate, the banking sector and the stock exchange. In previous years, IMF and World Bank sponsored policies of rapid financial liberalisation had caused a massive inflow of foreign capital to Asian corporations, largely via banks. And when the financial storm hit the region, the standard IMF measures for a traditional balance of payments crisis, namely stringent monetary policy and high interest rates, contributed to uninformed fear of foreign investors that the Asia crisis was just another emerging market crisis caused by an overvalued currency and an overspending government. Western prejudices and a lack of understanding of the Asian model (both before and during the currency crisis) thus added to the panic at the capital markets and to the subsequent crisis. Rather than reconsidering the region's need for and risks 


\section{Jolle Demmers, Alex E. Fernández Jilberto and Barbara Hogenboom}

of opening its financial markets, the IMF pushed the governments towards further liberalisation. After Asian emerging markets had to abandon fixed exchange rates, the investment climate became more volatile, and foreign investors became reluctant to pour money into Asian mutual funds. Ironically, this is the market's 'reward' for Asia's economic and (partial) financial acceptance of neoliberalisation (cf. Jomo 1998).

Apart from the damage to the affected countries, the Asian financial crisis and its aftermath also severely slowed down the economic recovery of one of the larger national economies of the world-Japan. The problem is that the Asian economies are competing with one another, and that competing devaluations are useless. In addition, China's low wages will make of this country a dangerous competitor on the important US market. The Asian Tigers seem to have only lately become aware of the switch, as China and India were competing for Western consumer markets with cheaper labour and currencies not so tightly linked to the strengthening US dollar.

As is outlined in Chapter 12 of this volume, somewhat similar to the Asian NICs, communist China has developed a rather successful model of mixing public and private roles and investment in order to achieve growth through economic integration in the world market. Between 1980 and 2000, China's recorded average annual GDP growth was around 10 per cent! This rapid growth was based on reforms giving farmers more possibilities to increase their productivity to market their crops, and on a governmentfostered industrial export policies, including tax reforms, currency devaluations and duty-free imports. Productivity gains have been highest in the export-oriented regions in the southern provinces that could attract heavy investment flows from Hong Kong and Taiwan. After long negotiations, often bilaterally with the United States, in 2001 China was finally accepted as a member of the WTO, which implies a commitment by Peking to further economic liberalisation. China's (fragmented) economic liberalisation, however, seems to have brought little change in its political system.

\section{Worldwide responses}

Recent globalisation has been accompanied by social fragmentation, growing economic inequalities and depolitisation. Despite economic growth and development progress on many levels (access to safe water, children attending school, etc.), increasing economic and income inequality is both an international and a national trend, affecting the societies of so-called least developed countries, transition economies, emerging markets as well as industrialised countries (cf. UNDP 2001). Among other things, neoliberal economic rules and practices tend to partly reproduce existing inequalities while also producing new ones. Increasingly, indications of neoliberalism's detrimental social, economic and political effects have fed scholarly criticism. Falk (1999: 159) states that the political options 'offered to citizens are 
becoming far less meaningful, especially for that bottom 80 per cent of the citizenry that appears to be losing out as a consequence of economic globalisation'. According to John Gray, '[a]t the global level, as at the nation-state, the free market does not promote stability or democracy'. 'A reform of the world economy is needed that accepts a diversity of cultures, regimes and market economies as a permanent reality', and '[i]f they do not begin to reflect the diversity of a more plural world, the transnational institutions that embody global laissez-faire will lose their remaining authority' (Gray 1998: 21, 19, 199). And in a vivid debate on globalisation, Americanisation and world problems between Anthony Giddens and Will Hutton (2000: 61), the latter tells the first: 'you can't have it both ways; the injustices you want to correct are not independent of the capitalism you admire - they result directly from its operation'.

As Demmers explores in the final chapter of this volume, the combination of neoliberal restructuring, market democracies and good governance policies is harmful to the prospects of peaceful coexistence and sustainable development in an increasingly 'smaller' and 'fuller' world. Tensions and conflicts linked to neoliberal globalisation add up to numerous 'old' problems of poverty, political inequality, ethnicity, limited and badly distributed natural resources, etc. Unfortunately, as we have described with respect to the depolitisation of traditional political avenues, national politics and the state can in general offer only less keys for decision-making and solutions that settle conflicts and satisfy people's current and future needs. With modern globalisation, a growing share of far-reaching decisions is made at a great distance from the affected people, without them having much of a say, either directly through international institutions or indirectly through their national government. International and transnational organisations such as the WTO, the IMF and the World Bank can not only be blamed for a lack of internal good governance (cf. Woods 2000), they are increasingly encroaching on crucial domestic policies and national sovereignty, while having repercussions on international law too (Gill 2000: 132). Moreover, no new (compensating) mechanisms for regional and global democracy have been developed and installed, thereby giving way to a net loss of citizens' influence. Another important democratic void lies in the ongoing story of poor countries and citizens having little or no means to fight unfairness, such as EU subsidies for agricultural production or US protectionism against textiles.

Although this growing gap between citizens and the centres of actual political power could also take place with globalisation under another ideological flag, the neoliberal prioritisation of the market does add to 'de-democratising' trends. While 'the global' increasingly penetrates 'the national', affecting economic, social, political and cultural relations and practices, the promotion of Good Governance and market democracy has left the (causes of) international political inequalities largely untouched. This is clearly demonstrated by the denial of important citizens' rights, such 


\section{Jolle Demmers, Alex E. Fernández Jilberto and Barbara Hogenboom}

as economic and cultural rights, and the right of resistance. Neither democratisation nor good governance have provided for empowerment of the powerless outside the neoliberal framework.

As old and new grievances of groups of citizens find increasingly less response in state agencies and national intermediaries such as political parties and labour unions, since the 1990s the world has witnessed the rise of three expressions of grievance at the national and transnational level: attempts for peaceful opposition, violent conflicts and terrorism. Many of the chapters in this volume touch upon national and/or local cases of conflict and opposition, either by new and/or old social movements and organisations, or by political parties. Particularly in Argentina, El Salvador, Indonesia, Cameroon and Taiwan, free market reforms coincided with the rise of ('new') violence and conflict. In Chapter 15, by way of a conclusion, Demmers signals how neoliberalisation went with the rise of identity conflicts and 'post-nation-state conflicts'.

We will conclude this introductory chapter by discussing some interesting elements of the emerging transnational movement against neoliberal globalisation, which is often - somewhat erroneously - labelled as the 'anti-globalisation' movement.

\section{The 'anti-globalisation' movement}

The official entrance of anti-globalists in the international political arena took place in November 1999 at the WTO summit in Seattle, where the terms for a new world trade round were to be agreed upon. The protests of almost forty thousand people impeded the usual course of these kinds of international summits, in which the citizenry's role is limited to being informed via the media of the outcome of the decision-making process. In Seattle, the demonstrators against the global order seriously hampered the meetings of state officials - in a literal as well as in a figurative sense. The (symbolic) representation of the interests of civil society was no longer left to the governments, but was captured by all of the participating NGOs. Since then, we have witnessed this type of protest at the (semi-) annual meetings of the IMF and the World Bank (in Washington and Prague), at summits of the G7 (in Genoa) and the EU (in Gothenburg), and at the Global Economic Forum (in Davos). Many have been surprised over the ideological and political nature of this new global movement. Is it the start of a new type of global democracy (Clark 1999), at the time of the 'debordering' of the Westphalian-style nation-state, which was based on the principles of territoriality, sovereignty, autonomy and citizenship? ${ }^{13}$

The new global movement is difficult to conceptualise, not only because of the diversity of its composing groups but also because of their partly contradictory objectives. The groups' common point of departure is their conviction that the dominant form of globalisation is the driving force behind the world's major problems and risks: increasing inequalities, envi- 
ronmental degradation, the ongoing exploitation of workers (particularly child labour), genetic modification, cultural imperialism (Americanisation), and the continuity of authoritarian regimes. They identify transnational corporations and transnational and international organisations (particularly the IMF, World Bank and WTO) as the main motors behind destructive forms of globalisation. Rather than a hierarchically organised whole, the movement consists of a broad coalition of often small groups such as Mexican Zapatistas, ecologists, students for Tibet's liberation, feminists, Christian organisations, militant anarchists, groups protecting their cultural identity, etc. They are supported by internationally known - 'old' and 'new' - individuals, such as Noam Chomsky, Ralph Nader, Naomi Klein, Vandana Shiva and José Bové, who despite their charisma do not act as the movement's actual leaders. Enabled by the Internet, this diversity of more or less organised groups and individuals has formed a vivid transnational network. Although there are several organisations that function as spiders in the web, the movement lacks a single and clear core.

The contradictions between the anti-globalists' objectives was already visible in the participation in Seattle, where US unionists who opposed further trade liberalisation in order to prevent a loss of US jobs and a lowering of US salaries were marching with (a much smaller representation of) Third World activists against the protectionism of industrialised countries against cheap products from developing countries. Another example concerns the attitude towards the major international organisations, ranging from the anarchists' agenda of eradication to more moderate and cooperative proposals for building a consensus by groups such as Global Trade Watch. Yet the movement's diversity and broad agenda are also part of its strength, and probably also of its durability. In particular, the movement's nature has underlined the indivisibility of human, political and economic rights. This has motivated already strong and established NGOs, such as Amnesty International, to support the anti-globalists' struggle. In Amnesty International's Annual Report 2001 its Secretary General Pierre Sané refers positively to 'the emergence of a new network of protest movements', concluding that a 'global solidarity network to address the negative consequences of globalisation is in the making', and that Amnesty International 'will bring its unique contribution to this endeavour'.

The anti-globalist movement highlights the increasing relevance of NGOs, both in political debates and in the development of civil society, and both within and beyond national borders. Among other things, they have assumed the critical attitude towards international economic inequality and the dominant economic model that was previously expressed by the governments of poor countries. ${ }^{14}$ In addition, their ability to establish transnational alliances permits them to contribute to the (re)construction of national civil societies, as in the democratisation processes of Latin America and Eastern Europe. As Stephen Gill (2000: 138) observes, many of the forces that are entailed by this new movement 


\section{Jolle Demmers, Alex E. Fernández Jilberto and Barbara Hogenboom}

'are linked to democratisation and a search for collective solutions to common problems. It seeks to combine diversity with new forms of collective identity and solidarity in and across civil societies'. This is not to say that the international role of NGOs dates from the twentieth century's last decade; both the League of Nations (1919) and the United Nations (1945) already incorporated certain limited forms of consulting non-governmental organisations. Yet only in the early 1970s NGOs gained a position in international politics that was recognised by scholars as being of influence. Nye and Keohane (1971) were probably the first to include NGOs, together with transnational corporations and intergovernmental organisations, in a renewed and broader concept of International Relations, thereby recognising their international transformative role.

Over the past few years a debate has been going on about the need to fundamentally democratise the international system. David Held's concept of a cosmopolitan democracy (1995) has been one of the points of departure for discussions on the importance of guaranteeing citizens' rights, including an international structure of citizens' control over 'national' systems of political and economic power. Among the various proposals is the creation of an actual transnational parliament within the UN structure that would have to ensure that economic globalisation is matched with global democratisation as well as social actors' influence on global corporate activities. Some of the proposals for institutionalised international democracy are motivated by the limitations of NGOs. While having been crucial in demonstrating the democratic void of the international system, NGOs themselves have also been criticised for being undemocratic in the sense of their (internal) decision-making processes and their inability to substantiate their position as representing (parts of) civil society. In particular the relations that emerge among transnational NGO networks are problematic from the perspective of representation and accountability (Jordan and Van Tuijl 2000). A specific critique on anti-globalist organisations is that they use anti-democratic means to achieve internationally what they were unable to achieve in their national parliaments, but such an argument ignores the fact that parliaments have lost part of their authority and meaning in the recent process of globalisation. Another issue is the still weak representation of organisations from 'the South'.

A more positive characterisation of the transnational political role of NGOs comes from Richard Falk, whose scholarly analysis is meant to 'encourage a mobilization of the now disparate forces of globalisation-frombelow in the direction of greater solidity and political weight'. In his view, citizen mobilisation against what he calls 'globalisation-from-above' is most likely to occur under the banner of democracy, 'but democracy reformulated to the basic aspiration of peoples everywhere to participate in the processes that shape their lives' (Falk 1999: 146). The definition of democracy is crucial, for we have seen that in many recent cases political liberalisation was applauded as a democratising event, while in reality the influence of citizens 
hardly improved. Still, democracy is key to progressive change; a change that could allow globalisation processes to be redirected in ways that ensure that it will be beneficial to more people, in particular those needing it most, while taking better account of the needs of future generations too. In such a process of citizens' empowerment, social and economic rights are taken as seriously as human and political rights.

Completely in contrast with current trends, Falk presents the survival of the compassionate state as one of the major challenges of today's democratic politics. Indeed, it is hard to imagine a revitalisation of democracy without a revitalisation of the state. Although there have been important cases of civil society organisations making a change by directly 'attacking' TNCs, or by raising transnational awareness, the state will remain the main link between the local and the global level. Yet in order for the state to survive or simply to be created, it requires fundamental reinvention and (re-) instrumentalisation. This does not mean a return to an old model of the state, nor does it imply that democratisation of local, global and non-state (political) arenas are futile. However, democratic decision-making has so far been practically non-existent at the regional and global level, adding to the insulation of globalising elites. It will take much time and major efforts to change this. Moreover, the national state can be an effective and suitable level for really empowering the powerless, where the right to a voice and resistance can have an immediate impact. As a consequence, the state will remain an important focus of the struggle for democracy.

\section{Notes}

1 The UNDP has already for quite some time pleaded that 'stronger governance [is] necessary to pick the fruits of globalization' (UNDP 1999: 8). Based on its extensive research on global human development, presented annually in the Human Development Report, it has also supported calls for international redistribution. More than most other multilateral organisations, the UNDP uses an 'inclusive' approach to development, for instance linking the discussion on regulating financial markets to the question of international inequalities.

2 Despite certain differences between the governments of major Western countries, the Development Assistance Committee (DAC) of the OECD reached a consensus on Good Governance in 1995. As a guideline for development cooperation, good governance was linked with participatory development. However, the discourse is dominated by economic liberalism, including primacy to the capitalist market economy in all social spheres, privatisation and economic decentralisation. The DAC's political agenda with respect to Good Governance is also mainly liberal, in the sense that human rights are interpreted as civil rights of property and 'negative' freedom from state interference (Patomaki 1999).

3 The European Union, on the other hand, included political issues more openly into its Good Governance agenda. In the Cotonou Treaty that was signed in 2000 with former European colonies, for example, against the wish of the developing countries the EU strongly pressed for reference to respect for human rights and democratic principles.

4 Although officially an NGO, the NED has been financed by the US government and has been subject to congressional oversight. According to its website 


\section{Jolle Demmers, Alex E. Fernández Jilberto and Barbara Hogenboom}

(www.ned.org), the NED plays a critical, complementary role to US government promotion of democracy: 'NED's NGO status allows it to work where there are no government to government relations and in other environments where it would be too complicated for the U.S. Government to work. (...) NED's independence from the U.S. Government also allows it to work with many groups abroad who would hesitate to take funds from the U.S. Government'. Its approach to democracy is clearly pro-free markets ('political and economic freedom').

5 According to members of the World Bank staff, this attention of the Bank and the shift away from 'the rather narrow and "technocratic" view' were partly motivated by the 'weak performance' of its projects in public sector management and in institution building in other sectors (World Bank 2000c: xiii, xi).

6 The report carries a mix of progressive political statements ('Partnership involves bringing the voice of the poor and of marginalized groups into the very centre of the policymaking process', World Bank 1997: 10) and passages that seem to proclaim only superficial participations ('Effective leaders give their people $a$ sense of owning the reforms - a sense that reform is not imposed from without', World Bank 1997: 14, italics added).

7 Burnside and Dollar wrote an influential World Bank report in this respect in 1997. These authors found that Good Governance in the technocratic sense (e.g. institutions supporting the market and good fiscal, monetary and trade policy) contributes to development understood as growth of GDP.

8 Anne-Marie Slaughter (2000) has done research on the increasing importance of international government networks among financial regulators: agreements between national regulatory agencies, and transgovernmental regulatory organisations, such as the Bank for International Settlements (BIS), the International Organisation of Securities Commissioners (IOSCO), and the International Association of Insurance Supervisors (IAIS). While providing much-needed insight in the rise of the new transnational elite, Slaughter erroneously discharges most of the criticism with respect to the lack of their accountability, labelling their operation as 'soft power'.

9 Falk (1999: 131) correctly analyses: 'there is the virtual futility of concentrating upon conventional electoral politics, given the extent to which principal political parties in constitutional democracies have subscribed to a program and orientation that accept the essential features of the discipline of global capital'.

10 As experienced by the Bank's (then) chief economist Joseph Stiglitz, who argued for a strong state matching and if necessary limiting free market forces, the future of the state in developing countries could be discussed (again) by the World Bank, but only within the limits of the open markets ideology, in which the free flow of goods and particularly capital have top priority, and in which the state is to perform a functional, subsidiary role.

11 For post-communist countries, the human development index (HDI) of 1999 was lower than that of 1980 (e.g. in the Russian Federation and Romania), 1985 (e.g. in Bulgaria and Latvia) and 1990 (e.g. in Ukraine and Lithuania). Eastern Europe was in fact the only region in the world that had a lower life expectancy at birth in the period 1995-2000 than in 1970-1975 (UNDP 2001: 10, 12).

12 For example, the price of coffee, the principal export product of Uganda, Kenya and Ethiopia, fell sharply in the late 1990s, to the extent that between 1996 and 2000 Uganda lost more than half the value of its cancellation of external debt.

13 Apart from the impact of technological and economic change, the erosion of the traditional nation-state has also been enhanced by the politics of human rights issues and environmental protection, in which NGOs have been transnational influential players since the 1980s (Evans 1997; Scholte 1997). 
14 The last remaining sources of governmental resistance against neoliberal globalisation are a small number of autocratic leaders (e.g. Khadafi in Liberia and Fidel Castro in Cuba) and a few anti-Western authoritarian regimes (e.g. in the Middle and Far East). They are internationally hardly influential, and moreover, they are far from enlightening sparks for the progressive agenda.

\section{Bibliography}

Amnesty International (2001) Annual Report 2001, http://web.amnesty.org/web/ ar2001.nsf.

Biekart, Kees (1999) The Politics of Civil Society Building. European Private Aid Agencies and Democratic Transitions in Central America. Utrecht/Amsterdam: International Books/The Transnational Institute.

Bhinda, Nils et al. (1999) Private Capital Flows to Africa-Perception and Reality, Den Haag: FONDAD.

Burnside, Craig and David Dollar (1997) Aid, Policies, and Growth, Policy Research Working Paper, no. WPS 1777, World Bank.

Cerny, Philip G. (1997) 'International finance and the erosion of capital diversity', in Colin Crouch and Wolfgang Streeck (eds), Political Economy of Modern Capitalism, London: Sage.

Clark, Ian (1999) Globalisation and International Relations Theory, Oxford: Oxford University Press.

Demmers, Jolle, Alex E. Fernández Jilberto and Barbara Hogenboom (eds) (2001) Miraculous Metamorphoses. The Neoliberalisation of Latin American Populism, London: Zed Books.

Eatwell, John (1997) International Financial Liberalisation: The Impact on World Development, UNDP, ODS Discussion Paper 12.

ECA (United Nations Economic Commission on Africa) (2000) Economic Report on Africa 1999, The Challenges of Poverty Reduction and Sustainablity, http:// www.uneca.org/eca_resources/publications/ESPD/economic_report_1999.htm.

European Commission (2001) Employment in Europe 2001. Recent Trends and Prospects, http://europa.eu.int/comm/employment_social/empl\&esf/docs/empleurope2001_en.pdf

Evans, Peter (1997) 'The Eclipse of the State? Reflections on Stateness in an Era of Globalisation', World Politics 50: 62-87.

Falk, Richard (1999) Predatory Globalization. A Critique, London: Polity Press.

Fernández Jilberto, Alex E. and André Mommen (1998), 'Globalization versus regionalization', in: Alex E. Fernández Jilberto and André Mommen (eds), Regionalization and Globalization in the Modern World Economy. Perspectives on the Third World and transnational economies, London and New York: Routledge.

Giddens, Anthony (1998) The Third Way, Cambridge: Polity Press.

Giddens, Anthony and Will Hutton (2000) 'Is Globalization Americanization?', Dissent, Summer, pp. 58-63.

Gill, Stephen (2000) 'Toward a Postmodern Prince? The Battle in Seattle as a Moment in the New Politics of Globalisation', Millennium: Journal of International Studies, vol. 29, no. 1, pp. 131-40.

Gray, John (1998) False Dawn, New York: The New Press.

Haggard, Stephan (1990) Pathways from the Periphery: The Politics of Growth in the Newly Industrializing Countries, Ithaca: Cornell University Press. 


\section{Jolle Demmers, Alex E. Fernández Jilberto and Barbara Hogenboom}

Held, David (1995) Democracy and the Global Order. From the Modern State to Cosmopolitan Governance, London: Polity Press.

Held, David et al. (1999) Global Transformations. Politics, Economis and Culture, Stanford, CA: Stanford University Press.

Hogenboom, Barbara (1998) Mexico and the NAFTA Environment Debate. The Transnational Politics of Economic Integration, Utrecht: International Books.

ILO (1998) 'ILO Governing Body to examine response to Asia crisis', press release, 16 March.

IMF (1997) Partnership for Sustainable Global Growth.

Jomo, K.S. (1998) Tigers in Trouble: Financial Governance, Liberalisation and Crises in East Asia, London: Zed Books.

Jordan, Lisa and Peter van Tuijl (2000), 'Political responsibility in transnational NGO advocacy', World Development, 28 (12): 2051-65.

Leftwich, Adrian (1993) 'Governance, democracy and development in the Third World', Third World Quarterly, 14 (3): 605-26.

Krugman, Paul (1995) 'Dutch Tulips and Emerging Markets', Foreign Affairs, July/August: $28-44$.

Nye, Joseph S. and Robert O. Keohane (1971) 'Transnational Relations and World Politics', International Organization, 25 (3): 329-49.

Patomaki, Heikki (1999) 'Good Governance of the World Economy?', Alternatives: Social Transformation and Humane Governance, Jan-Mar, 24 (1): 119-43.

Robinson, William I. (2000) 'Polyarchy: Coercion's New Face in Latin America', NACLA Report on the Americas, 34 (3), November-December: 42-8.

Sassen, Saskia (1999) 'La nueva geografía de la poder', speech at the CISANUNAM conference Globalización y sus manifestaciones en América del Norte, Mexico City, 3 November.

Scholte, Jan Aart (1997) 'Global capitalism and the state', International Affairs, July: 427-52.

(2000) Globalization. A critical introduction, Basingstoke: Macmillan.

Simai, Mihály (1998) 'The democratization process and the market', in Takashi Inoguchi, Edward Newman and John Keane (eds), The Changing Nature of Democracy, Tokyo: United Nations University Press.

Slaughter, Anne-Marie (2000) 'Governing the Global Economy through Government Networks', in Michael Byers (ed.), The Role of Law in International Politics. Essays in International Relations and International Law, Oxford: Oxford University Press.

UNDP (1999) Human Development Report 1999, New York/Oxford: Oxford University Press.

— (2001) Human Development Report. Making new technologies work for human development, http://www.undp.org/hdr2001.

Wade, Robert (2001) 'Showdown at the World Bank', New Left Review 7, Jan-Feb: 124-37.

Weiss, Thomas G. (2000) 'Governance, good governance and global governance: conceptual and actual challenges', Third World Quarterly, 21 (5): 795-814.

Weyland, Kurt (1996) 'Neopopulism and Neoliberalism in Latin America: Unexpected Affinities', Studies In Comparative International Development, 31 (3): 3-31.

Woods, Ngaire (2000) 'The Challenge of Good Governance for the IMF and the World Bank Themselves', World Development, 28 (5): 823-41.

World Bank (1992) Governance and development, Washington, DC: World Bank. 
(1994) Development in practice: governance - the World Bank's experience, Washington, DC: World Bank.

- (1997) World Development Report 1997. The State in a Changing World, Washington, DC: World Bank.

(2000a) World Development Report 2000-2001. Attacking Poverty (2000-2001), Washington, DC: World Bank.

(2000b) Can Africa Claim the 21st Century?, Washington, DC: World Bank.

- (2000c) Reforming Public Institutions and Strengthening Governance. A World Bank Strategy, Public Sector Group (November), Washington, DC: World Bank.

(2001) World Development Report 2002. Building Institutions for Markets, Washington, DC: World Bank.

WRR (2001) Development Policy and Good Governance, Reports to the government, no. 58, http://www.wrr.nl/HTML-EN/BasisPU-EN.html. 


\title{
2 The political economy of neoliberal governance in Latin America
}

\section{The case of Chile}

\author{
Alex E. Fernández Jilberto
}

In response to the debt crisis of the 1980s, the collective of Latin American countries under pressure from international financial institutions like the IMF experienced rough and profound programmes of economic reform. Almost half a century of Keynesian economic policies, which implemented a scheme of self-sustained and state sponsored industrial development, was replaced by neo-liberalism - an open economic model that reintegrated the region into the global market on the basis of comparative advantage. The programmes of stabilisation and structural adjustments ended up disarticulating and dismantling the system of relations between the state, the economy and the global market, established during the post-war era. Latin America's insertion into the process of globalisation meant a return to regional capitalism and the elimination of the populist state as the basis of relations between the economy and social actors.

Originating in the international crisis of the 1930s, the populist state had constituted an axis of Keynesian governance in Latin America. It was based on a system of compromise between capital and labour, mediated and regulated by the state; a model of inward industrialisation; and a process of the gradual incorporation of marginalised social groups into the collective life of the nation for the benefit of development. It was often accompanied by a political regime that might not have always been democratic, but at least continued to expand the inclusion of more social groups. In populist governance the political system was considered to be the most effective place to resolve and regulate class conflict. In this sense the populist state was always one of compromise and negotiation.

Until its crisis, which began in the mid-1970s, three types of conflict characterised populist governance: those stemming from confrontation between the popular and the leading classes; conflicts between those groups participating in ISI development and those being excluded; and conflicts derived from competing interests between national capital and imperialism. Nevertheless, the populist state was defined as being an agent of the economic transformation of society, as well as an agent of legitimacy and cohesion by way of implementing policies of income distribution. These characteristics were incompatible with the needs of accelerating the process 
of capital accumulation deemed necessary to diversify the industrial sector. As a result of the dilemma (more accumulation versus more income distribution), most of the populist regimes of Latin America, based on models of class compromise and Keynesian governance, fell apart.

After the economic downturn of the 1980s - known as the Lost Decade because of its high social costs - neoliberal restructuring (privatisation and deregulation) started to register evidence of economic growth. This provoked an ideological euphoria based on the idea that a model of corporate society constructed by neoliberalism would give course to a scenario where the market can regulate itself and solve significant social conflicts. In turn, the hope for eliminating social conflicts was considered to be the logical result of the end of the Cold War and the rise of the neoliberal state, which would transfer the task of regulating social inequalities to the market. Nevertheless, the neoliberal optimism saw its end with the fall of Andean Thatcherism: in Ecuador in December 1999, the fall of the autocratic regime of Fujimori in Peru in November 2000, and the collapse of neoliberal governance in Argentina in December of 2001. The first part of this article will look at these cases separately. The second part will look into the case of neoliberal governance in Chile, in order to explain the high rates of economic growth and political stability after the electoral defeat of the Pinochet dictatorship in 1988. Although Chile is one of the countries of Latin America - and the world - with the worst rate of income inequality, throughout the 1990s it has been considered to be a paradigm model of neoliberalism for other developing countries. The economic growth rate between 1985 and the Asian crisis (1997) averaged 7 per cent annually, with low rates of inflation and significant reductions of the poverty and (low) unemployment rates. These facts form the empirical basis for successful neoliberal governance. But an even greater part of this economic stability is due to a political system of restricted democracy, where the military and corporate powers controlled the framework of economic management and civil society.

\section{Latin America: democratisation and neoliberal governance}

In Latin America the debate on governance has followed a different course than that of the Euro-American experience. Since the 1980s, the debate about good governance has partly been replaced by and/or subordinated to the concerns of revaluating the role of civil society during the resistance against the oligarchic-neoliberal military dictatorships in Central and South America. On the other hand, there has been much discussion concerning the compatibility between the process of democratisation since the mid-1980s and the neoliberal economic policies which have been harshly criticised by democratic opposition forces given the factors of social exclusion, misery, poverty and the high concentration of income that they generated. It suffices to say that toward the end of the $1990 \mathrm{~s}$, large inequalities in income distribution continued to be characteristic of the social economic structure in 
neoliberal Latin America. The region has become the world's most unequal: 30 per cent (and in extreme cases like Brazil 45 per cent) of national incomes are concentrated in the hands of the top 10 per cent of high income earning households (Cepal 2001b: 67). Without doubt opposition to the dictatorships aspired to restore the Keynesian model of social democracy, where economic policy and the relationship between state and civil society were based primarily on the intervention of the populist or compromising state.

There are different explanations for why Latin American democratisation finally assumed the character of a neoliberal democracy that aimed at reconciling state and civil society mediated through the market. A first reason refers to the transference of economic power and sovereignty from the state and the national political regime to the global institutions of neoliberal governance such as the IMF and the World Bank. This represented the consolidation of the processes of neoliberal reconstruction that was generalised in Latin America at least since the debt crisis and the emblematic example of the Mexican crisis of 1982. The process of transferring sovereignty came along with substituting the populist state with the neoliberal state, which stimulated the transnationalisation of the economy by means of privatising public corporations and opening up the national economies to external forces. Parallel to this was the modernisation of a highly concentrated and centralised corporate base, which was associated with multinational capital in the conglomerate form of large corporations (Cepal 2001a; Peres 1998). This corporate base became the key actor in a new economic system and a development model that aspires to spread the enterprise spirit within civil society. The modern entrepreneur leaves behind its clientelistic and corporatist dependency on the state and the political regime.

A second reason for the rise of neoliberal democracies in Latin America was the installation of the neoliberal state. This lead to the substitution of the social-political matrix and political regime of the Keynesian period, where the demands of civil society including the distribution of resources were canalised by the state through the system of political parties. Previously, the state and the political regime played a direct role in managing the economy, allowing room for workers to increase salaries by means of political pressures (Montero 2000: 81). The neoliberal state put an end to this economic model that worked with a system of distorted prices, as a result of corporate pressures, and where the allocation of resources was executed by means of the political route. During the populist era the regime of political parties worked as an intermediary before the state, having centralised many of the workers' demands through the centre-left as well as the interests of entrepreneurs through the parties of the right (Moulián 1997). This system of relations between private and public actors was functional to the model of ISI accumulation of capital and guaranteed a governance model that facilitated the compromise between capital and labour. 
A third reason explaining Latin American neoliberal democracies is the substitution of the party system as a channel for social demands towards the state by the market, which created a need for repositioning the role of political parties. The resetting of a democratic political class that survived the authoritarian regimes facilitated this imperative. Additionally, the civil heirs of the dictatorships and their predecessors negotiated a continuity of the economic policy. On the other hand, the pressures of the IMF and the economic conglomerates forced and/or facilitated the rapid neoliberalisation of the old populist parties, which took on an important role in the democratisation process. A significant example of this is Argentina's Peronism and the Chilean Socialist Party (Teubal 2001; Fernández Jilberto 2001).

\section{Financial crises, poverty and cleptocracy}

In Latin America, the 1980s is called the lost decade. This illustrates the backward movement of development in the region due to the implemented process of neoliberal reconstruction as a solution to the crisis of foreign debt. The policies of structural adjustment, which had been initiated during the 1970 s by the dictatorial regimes of Pinochet in Chile and Videla in Argentina combining neoliberal reforms with national security doctrines inspired by the ideology of the Cold War, became generally accepted throughout the region during the 1980s. Despite the evident developmental needs of most Latin Americans, according to the UN Economic Commission for Latin America, by the end of 1989 the GDP per inhabitant was equivalent to that registered ten years earlier (Cepal 1990: 11).

The countries of Latin America started the 1990s off with a large foreign debt and an inadequate line-up of exports for international demand. On top of this, there were still unresolved macroeconomic problems, a lack of infrastructure, insufficient technological development, financial incapacity, inability to manage national state matters, massive unemployment, the alarming concentration of income and the depletion of natural and environmental resources. These problems were supposed to be corrected by the increase of privatisation policies, the further opening of the economy, deregulation, the elimination of tripartism that had previously characterised the relations between the state, capital and labour, and finally by flexibility in the labour market. The new populist parties that assumed the leadership in re-establishing democracy continued to deepen the depoliticising of the economic debate that was imposed by the authoritarian regimes and neoliberal technocracy of the military.

The neoliberal euphoria of the 1990s, which was based on the experience of fast economic growth, the stability of the macroeconomic variables and on the successful control of the inflation, in many cases due to dollarisation or programmes of convertibility establishing the parity of the local currency with the dollar, saw its end in 1999. This was manifested in the crisis and 
collapse of Andean Thatcherism in Ecuador in December 1999, the collapse of the Fujimori regime in Peru in November 2000, and the fall of populist neoliberalism in Argentina in December of 2001 (see Table 2.1).

\section{Andean Thatcherism}

In January 2000, Ecuadorian President Jamil Mahuad (1998-2000) announced the implementation of a dollarisation programme to control the inflation, which by that time had reached 300 per cent. Both dollarisation and the neoliberal programme of economic austerity were rejected by means of violent social protests that had been taking place in Quito, Guayaquil, Cuenca and other large urban centres of the country since 1997. These protests culminated on 21 January 2000 with the occupation of Quito by the Confederation of Indigenous Nationalities of Ecuador, which in alliance with young army colonels took the presidential palace, forcing the flight of President Mahuad. It was only by pressure from the United States and the direct intervention of the Clinton administration that a constitutionalist solution' managed to eliminate the alliance between the indigenes and the colonels and designate, on behalf of the National Congress, Gustavo Noboa as the new president. With this measure, the cycle of neoliberal populism in Ecuador which began with President Febres Cordero (1984-1988) came to a close (Carrière 2001: 141). Febres Cordero was a visceral partisan of neoliberalism whose economic vision has been described as Andean Thatcherism. He arrived to power with the slogan 'Shelter, food and work', and applied drastic measures that led to the de-industrialisation and liberalisation of the national economy. He did this by implementing constitutional reforms that

eliminated the legal stumbling blocks which prevented the privatisation of public companies. This approach reached its extreme in 1986, when the policies of structural adjustment and reduction of the public spending drastically lowered the standard of living of the popular classes. The result of Cordero's economic policy was the return to dependency on the world market through the sale and export of primary resources and a low degree of diversification.

The two governments that exerted power in Ecuador between 1988 and 1996 differed only rhetorically. President Rodrigo Borja represented a social democratic accent in favour of the neoliberal cause, in order to win over the popular sectors of society, arguing that after the hard neoliberal reforms were implemented better times would come to the poor. His successor, president Sixto Duran-Ballen, argued that poverty and misery were the result of the inconsistent application of the economic reforms and that a greater coherence of neoliberal policies could facilitate elimination of economicsocial inequalities. Nevertheless, in the presidential elections of 1996 Sixto Duran-Ballen was replaced by the populist leader from Guayaquil, Abdala Bucaram, whose electoral victory rested on criticising the economic groups and elite that controlled the nation. A populist in the truest sense of the 
Table 2.1 Ecuador, Peru and Argentina: Major economic indicators, 1999-2001

\begin{tabular}{|c|c|c|c|c|c|c|c|c|c|}
\hline & \multicolumn{3}{|c|}{ Ecuador } & \multicolumn{3}{|c|}{ Peru } & \multicolumn{3}{|c|}{ Argentina } \\
\hline & 1999 & 2000 & 2001 & 1999 & 2000 & 2001 & 1999 & 2000 & 2001 \\
\hline GDP growth (\%) & -9.5 & 2.8 & 5.0 & 0.9 & 3.0 & -0.5 & -3.4 & -0.6 & -3.8 \\
\hline Inflation (\%) & 60.7 & 91.0 & 24.6 & 3.7 & 3.7 & 0.1 & -1.8 & -0.7 & -1.6 \\
\hline $\begin{array}{l}\text { Real wages - } \\
\text { minimum (\%) }\end{array}$ & -10.7 & -3.5 & 11.7 & -2.2 & 1.2 & -2.0 & 1.1 & 1.5 & 0.0 \\
\hline $\begin{array}{l}\text { Urban } \\
\text { unemployment } \\
\text { rate }(\%)\end{array}$ & 14.4 & 14.1 & 10.9 & 9.2 & 8.5 & 9.5 & 14.3 & 15.1 & 17.4 \\
\hline $\begin{array}{l}\text { Current account } \\
\text { balance in } \\
\text { millons of dollars }\end{array}$ & 955 & 1383 & -823 & -1817 & -1645 & -1120 & -12038 & -8973 & -5301 \\
\hline
\end{tabular}

Source: Cepal (2001a). 


\section{4}

Alex E. Fernández Jilberto

word, this character promised to increase food and fuel subsidies, and extended health and education services to the urban and rural poor. By his fifth month in office he applied the most drastic package of neoliberal economic measures since 1984 . The government fell steeply with a destitute creed made by the National Congress, referring to his Excellency's mental incapacity (Corkhill \& Cubitt 1998; De la Torre 1997).

\section{Fujimorismo}

In Peru, Andean Thatcherism arrived with President Alberto Fujimori (1990-2000) and its demise concluded with his flight to Japan in November 2000, when after attending the Asia Pacific Summit of Economic Cooperation he obtained a peculiar kind of political asylum. This particular experience put an end to other Latin American regimes that have tried to impose economic reconstruction and neoliberal governance through the autocratic and dictatorial route. From the beginnings Fujimori's government depended on the coexistence of both democratic and authoritarian structures, which allowed him to exert control over popular protests and the parliamentary opposition to the policies of structural adjustment, liberalisation, privatisation and economic deregulation (Gonzales de Olarte 1998). This strategy culminated with the self-coup of 5 April 1992 when Fujimori decided to eradicate the parliamentary opposition to the drastic policy of structural adjustment initiated in August of 1990. He then created the bases for the constitutional reforms necessary to guarantee his permanence in power, via re-election every five years, until 2005.

'Fujimorismo' constituted the political expression of a repressive state destined to force the implementation of neoliberal restructuring, combining autocracy, dictatorship and corrupt political methods (Crabtree 2001). This task was assumed by the National Intelligence Service (SIN) under the direction of Vladimiro Montesinos, who during the 1990 presidential elections had been in charge of eliminating documents that accused Fujimori of fiscal crimes during his real-estate entrepreneurship. The finance of corruption gradually turned Peru into a narcotic state, as it was developed directly by the services of national security that depended on the one hand on quotas paid by Colombian narco-traffickers who financed FARC guerrilla forces, and on the other hand received illegal commissions from the purchase of fighter jets from Belarus in 1996 and the Russian Republic in 1998. It suffices to mention that during the presidential elections of April 2000 Fujimori obtained only 52 of the 120 parliamentary positions; he lacked the necessary parliamentary majority, managing eventually to obtain 64 seats by bribing another twelve to the tune of $\$ 15,000$ dollars (Puertas 2000). ${ }^{1}$

The significant popular support which the Fujimori government enjoyed was to a large extent due to the political collapse of the left during the elections of 1990 , to the fast reduction of the hyperinflation to 18 per 
cent in 1991, and to the dismantling of the Maoist guerrilla group the Shining Path and the capture of its leader Abimael Guzman in 1992. With all this, Fujimori put an end to the general sensation of social crisis and political disarticulation that resulted in recession and guerrilla warfare during the final days of the president Alan Garcia of the centre-left party APRA (1985-1990). It is necessary to remember that the presidential election of 1990 took place in the context of an acute economic crisis caused by a 10.4 per cent fall in GDP in 1989 , inflation equivalent to 2,775 per cent and a foreign debt reaching $\$ 1.9$ billion. The positive results of the volatile shock therapy were manifested in a GDP growth rate of 4.9 per cent in the second semester of 1991, arriving at 14 per cent in 1996 (Cotler 1998). These facts helped Fujimori to be re-elected in 1995, but only after the self-coup of 1992 and the elimination of the constitutional obstacles that prevented re-election.

Fujimori's 1990 electoral promises were remarkably different from the radical neoliberal policies he implemented. His strategy was based on seeking political support of the low popular and middle class sectors, which were seriously affected by hyperinflation, recession and unemployment (Roberts 1998). In order to obtain support, he verbally opposed all policies of shock therapy and draconian forms of structural adjustment. As a candidate, Fujimori argued that these could be avoided by means of a coherent structure policy and by increasing the prices of public services, elimination of state subsidies to basic products, and by competitive monetary devaluations. According to his advisers Santiago Roca and Adolph Figueroa, these measures would call a halt to the growing gap between rich and poor. Additionally, they believed that it was possible to obtain economic stability by means of negotiations on the control of prices between the government, the industrialists and the unions. Fujimori appeared to be the anti-shock candidate and summarised his electoral strategy with the words 'stabilization without recession'. ${ }^{2}$ However, on 7 August 1990, only ten days after his rise to the presidential office, Alberto Fujimori ordered the military to occupy the city of Lima as a precaution in case of the disturbance and social rebellion that could be caused by the brutal increases of prices: petrol prices soared 3,140 per cent, paraffin (used by the poor to cook) rose 6,964 per cent, bread 1,567 per cent, cooking oil 639 per cent, and sugar 522 per cent (Stokes 2002). At this point Fujimori's shock therapy began to take its course.

\section{Argentine neoliberalism}

The fall of neoliberal governance in Argentina took place in December of 2001. It was the direct result of the impact of global financial crises on an economy whose burden was the inheritance of an economic system of a military dictatorship (foreign debt), a decade of the so-called Convertibility Plan that established the parity between the peso and the dollar, a cleptocracy that 
was established with the government of President Carlos Menem (1989-1999), and the inoperative government of President de la Rúa (1999-2001). It ended with the resignation of Fernando de la Rúa, who came to power in 1999 with the support of FREPASO (Solidary Country Front), which represented an alliance of the Radical Civic Union Party with the progressive forces of Argentine politics. De la Rúa's electoral victory, with 48 per cent of the votes, against the Peronist candidate Eduardo Duhalde, was based on promises to put an end to the domination of the corrupt political class and to cure the economic recession. It was to give course to the implementation of an alternative economic policy, different to that of the decade-long ultra-neoliberal Menem government. De la Rúa's incapacity to establish an economic policy that allowed the materialisation of his objectives ended in the erosion of his political alliance. This eventually provoked de la Rúa to voluntarily depend on Peronist support, leading him to name Domingo Cavallo Minister of Economy in April of 2001. Cavallo was the Peronist author of the Convertibility Plan under Menem.

While poverty continued to grow to a dramatic number of 14 million people, and the cleptocratic political class remained free, Cavallo attempted at all costs to save his masterpiece, the Convertibility Plan. He avoided a devaluation of the peso and hoped for the unblocking of an IMF loan of $\$ 1.264$ billion that would allow Argentina to continue its payments of foreign debts and enable the payments of wages for public employees and pensions, etc. The slowness with which measures were taken, together with the establishment of the financial 'corral' to halt the flight of capital, was the straw that broke the camel's back, causing the popular rebellion and the fall of president de la Rúa. With this crisis, and after four presidents in a period of two weeks, Eduardo Duhalde made himself president and restored Peronist rule during the worst crisis Argentina had experienced in over a hundred years. Caught between the dilemmas of international pressure - the United States was in favour of the absolute dollarisation of the economy (substitution of the peso by the dollar), and Spain's president Aznar was in opposition to any devaluation as it would put the investments of Spanish corporations (Telefónica, REPSOL, BNVA, Gas Natural, Dragados, etc.) into danger - Duhalde inevitably chose the return to and devaluation of the Argentinean peso.

This crisis had been preceded by three years of consecutive recession, which had its origins in General Jorge Videla's dictatorial regime (1976-1981). During Videla's time, foreign debt went up from $\$ 7.280$ billion in 1975 to $\$ 35.671$ billion in 1981. And in 2001, Argentina's foreign debt reached \$169 billion (OECD 2001: 20). Between 1976 and 2000, Argentina's debt payments were the equivalent of $\$ 212$ billion. The one responsible for these foreign debts was Martínez de Hoz, Minister of Economy during the dictatorship, who with the IMF justified borrowing as the only way possible to increase the foreign currency reserves that were necessary to establish an open economic policy. After the fall of the military dictatorship and during 
the first civil government of President Raul Alfonsin (1983-1989), the Argentine Central Bank declared that it had no public record of the foreign debt so that the state was forced to accept the declarations of its foreign creditors (Toussaint 2002). Finally, the Argentine state under the presidency of Alfonsin had to assume the whole of the public and private foreign debt. The private debt stood at $\$ 14$ billion, including the debts of multinational companies whose Argentine branches were Renault Argentina, Motor Ford Argentina, Mercedes-Benz Argentina, IBM Argentina, City Bank, Chase Manhattan Bank, Bank of America, First National Bank of Boston, Deutsche Bank and Société Générale.

Alfonsin's decision to assume the whole debt was based, on the one hand, on his need to prevent the destabilisation of new democratic governance, which could be caused by the economic conglomerates that had already profited from the neoliberal policies of the dictatorship; and on the other hand, the necessity to maintain economic stability by continuing with the neoliberal policies initiated by Martínez de Hoz. Nevertheless, in spite of this decision, Alfonsin could not calm the ambitions of the economic giants that cried for deepening neoliberal measures. This finally forced Alfosin to his 'legal fall' from power through the 1989 economic coup, handing over the presidency to Carlos Menem a year before his term was over. This coup was sponsored by the economic forces, which consciously used the flight of capital of February 1989. This was done in order to devalue the peso, causing hyperinflation (5,000 per cent in 1989). Carlos Menem came to power on a typically Peronist electoral campaign that included a series of interventionist and nationalistic economic measures destined to fortify the social alliance among the working and middle classes and the industrial bourgeoisie. This programme, used as an electoral strategy, included introducing the 'salariazo' (large wage increase) and privatisations, which together would facilitate shock-therapy treatment, in order to deepen the neoliberal policies (Teubal 1996: 205).

In April of 1991 minister Domingo Cavallo introduced the Convertibility Plan. This was made possible thanks to the confident resumption of capital flows towards Latin America of \$24.2 billion between 1992 and 1998 (Cepal 2000). This foreign capital satisfied the demand for high consumption rates with hard currencies. Imports increased more rapidly than exports, pushing the trade surplus from $\$ 8$ billion in 1990 to a deficit of $\$ 7$ billion in 1994 (Calcagno and Manuelito 2001: 12). Added to this were the payments of interest on foreign debt and utilities of foreign direct investment, arriving at an imbalance between 1997 and 2000 which oscillated between $\$ 10$ and $\$ 15$ billion, equalling 35 to 50 per cent of the exports of goods and services. It demonstrated that the Convertibility Plan depended on various external resources. Between 1992 and 1999, Argentina needed $\$ 90$ billion to manage the increasing account deficit and to accumulate the reserves necessary to endorse the parity of the peso with the dollar. Due to the Mexican peso crisis, the Asian crisis and the Russian moratorium, and the low gains from 
the privatisation programmes, the Argentine state had to assume 68 per cent of the financing that originally had come from abroad.

\section{Neoliberal crises and social exclusion}

The international recession affected Latin America in 2001 unlike any other financial crisis of the 1990s, and spread throughout the entire region. The worldwide recessive tendencies produced and accelerated a contraction in the value of the region's external commerce, to a point not seen since the debt crisis of 1982. The abrupt reduction of US demand for Latin American products and the fall in prices of exportable raw materials were the material effects of the crisis of 2001. Previously, the cycles of expansion as well as contraction of the Latin American economy during the 1990s had resulted in volatile rates of growth, insufficient to substantially reduce unemployment and cure the precarious socio-economic situation of the 44 per cent of the population living in conditions of poverty and indigence. The crisis starting in 2001 is the third in less than a decade. The Latin American financial crises of 1995, 1998 and 1999 originated externally and reopened the debate concerning the extreme degree to which the region must be protected from global financial crises. ${ }^{3}$

The devaluation of the Mexican peso in December 1994 caused a massive flight of capital in several countries in the region and generated a virtual suspension of external financing. Argentina was the most affected country after Mexico. The massive financial aid packages from the IMF, the World Bank and the United States managed to limit the effects for only three trimesters. The Asian crisis of 1997 expanded towards Latin America through commerce, and particularly finance. It was expressed in a fall of prices in raw material exports and (diverse) non-traditional agricultural products. The Russian Federation's moratorium of August 1998 and the rouble devaluation decrees exacerbated the impact of the Asian crisis even further, and the effects of these were felt throughout all of Latin America (see Tables 2.2 and 2.3).

The vulnerability of the Latin American neoliberal economies in the face of international crises and financial instability has led to little progress in terms of social equality. This leads to questioning the principle that - by definition - economic growth is good for the poor (La Fuente and Saínz 2001). Furthermore, the debate concerning the inability of neoliberal governance to achieve favourable results is reopened; there is now a need to reflect on some crucial themes that should be placed on Latin America's social agenda. During the 1980 s, the neoliberal regimes thought that - in the long run - they could resolve the problems of poverty, social inequality and inflation by stabilising macroeconomic variables and reducing the state sector in favour of the private sector. They believed that the 'trickle-down effect' would be an effective instrument in poverty reduction. Latin American neoliberalism discarded all policies of state intervention destined to force a 
Table 2.2 Latin America and the Caribbean: Development of some economic indicators, 1982-2001

\begin{tabular}{|c|c|c|c|c|c|c|c|c|c|c|c|}
\hline & $1982 / 89$ & 1992 & 1993 & 1994 & 1995 & 1996 & 1997 & 1998 & 1999 & 2000 & 2001 \\
\hline GDP & 1.1 & 3.0 & 3.5 & 5.2 & 1.1 & 3.7 & 5.2 & 2.2 & 0.4 & 4.1 & 0.5 \\
\hline $\begin{array}{l}\text { GDP per } \\
\text { inhabitant }\end{array}$ & -8.3 & 1.2 & 1.8 & 3.5 & -0.6 & 2.0 & 3.5 & 0.6 & -1.2 & 2.5 & -1.0 \\
\hline $\begin{array}{l}\text { Bruto } \\
\text { formation of } \\
\text { stable capital }\end{array}$ & & 6.1 & 5.1 & 10.6 & -4.7 & 5.0 & 13.3 & 3.0 & -5.4 & 2.9 & -1.0 \\
\hline $\begin{array}{l}\text { Consumer } \\
\text { price rates }\end{array}$ & 2793.2 & 414.4 & 876.6 & 333.1 & 25.8 & 18.4 & 10.4 & 10.3 & 9.5 & 8.7 & 7.0 \\
\hline $\begin{array}{l}\text { Urban } \\
\text { unemployment }\end{array}$ & & 6.1 & 6.2 & 6.3 & 7.2 & 7.7 & 7.2 & 7.9 & 8.8 & 8.4 & 8.4 \\
\hline
\end{tabular}

Source: Cepal (2001b). 
Table 2.3 Latin America: poor and indigent Population, 1980-1999

\begin{tabular}{|c|c|c|c|c|c|c|c|c|c|c|c|c|}
\hline & \multicolumn{8}{|c|}{ Poor } & \multicolumn{4}{|c|}{ Indigents } \\
\hline & \multicolumn{2}{|c|}{ Total } & \multicolumn{2}{|c|}{ Urban poverty } & \multicolumn{2}{|c|}{ Rural poverty } & \multicolumn{2}{|c|}{ Total } & \multicolumn{2}{|c|}{$\begin{array}{c}\text { Urban } \\
\text { indigency }\end{array}$} & \multicolumn{2}{|c|}{ Rural indigency } \\
\hline & millions & $\%$ & millions & $\%$ & millions & $\%$ & millions & $\%$ & millions & $\%$ & millions & $\%$ \\
\hline 1980 & 135.9 & 40.5 & 62.9 & 29.8 & 73.0 & 59.9 & 62.4 & 18.6 & 22.5 & 0.6 & 39.9 & 32.7 \\
\hline 1990 & 200.2 & 48.3 & 121.7 & 41.4 & 78.5 & 65.4 & 93.4 & 22.5 & 45.0 & 15.3 & 48.4 & 40.4 \\
\hline 1994 & 201.5 & 45.7 & 125.9 & 38.7 & 75.6 & 65.1 & 91.6 & 20.8 & 44.3 & 13.6 & 47.4 & 40.8 \\
\hline 1997 & 203.8 & 43.5 & 125.7 & 36.5 & 78.2 & 63.0 & 88.8 & 19.0 & 42.2 & 12.3 & 46.6 & 37.6 \\
\hline 1999 & 211.4 & 43.8 & 134.2 & 37.1 & 77.2 & 63.7 & 89.4 & 18.5 & 43.0 & 11.9 & 46.4 & 38.3 \\
\hline
\end{tabular}

Source: Cepal (2001b). 
change in the distribution of income, as state intervention was thought to have affected economic growth negatively.

It was the dramatic case of Argentina that has again brought to the fore the need to implement a policy of income distribution; equal development is more than just a question of structural adjustment. Alternative views on income distribution can be found in three different analytical perspectives (Franco and Sainz 2001: 58). The first perspective questions the idea that a high concentration of wealth, savings and investment is a prerequisite for the long-term reduction of poverty; it asserts that a policy of equal income distribution can actually be an economic growth stimulant. The second perspective links income distribution to poverty and states that existing poverty is not necessary. If the state had been more active in pushing policies that would maintain wages at the same level they were at the beginning of the 1980s, the increase in poverty as a result of the financial crises would have been 50 per cent lower than it is now. Finally, the third point of view sustains that a reduction in social inequality is necessary in order to guarantee stability in democratic regimes; supposedly, economic growth favours an increase in public spending which in return should increase equality and limit the social exclusion that threatens democracy with violence and the insecurity of its citizens.

The globalisation of Latin America, and its participation in the global information society, forces us to reconsider the relationship between social exclusion and citizenship. It has directly affected the egalitarian exercise of citizens' rights. How can we still speak of citizenship and representative democracy when the elected look towards the global market and the voters towards their own private lives (Touraine 1997)? And how can we extend economic and social rights to the excluded, if politics continues to be kidnapped by the economy? On the other hand, the poor see their social exclusion being deepened as result of the emergence of new forms of citizenship that are found in information technology, management and computerisation. The practice of citizenship in Latin America is no longer limited to the disposition of political, civil and social rights, but also includes the right to equally participate in information exchange. This is the result of the radical change in the material and symbolic basis of Latin American democracy, which rests upon an economy of permanent crisis, but also on the extended use of information technologies (Cepal 2001d: 305).

\section{Chile: neoliberal governance and incomplete democratisation}

If one compares Chile with the rest of Latin America, especially with the crisis of neoliberal governance in Ecuador, Peru and Argentina, one might conclude that this country constitutes a paradigm of neoliberal success. The Chilean success, defined in terms of economic growth and stability during the 1990 s, has been interpreted as the result of early capitalist reform during the dictatorship of Pinochet (1973-1990), and the maintenance of the so-called 


\section{Alex E. Fernández Jilberto}

authoritarian enclaves preserved by the current democratic structures. The authoritarian enclaves are composed of the existence of designated senators, not chosen in the National Congress; electoral rules that facilitate the overrepresentation of conservative minorities; and the majority military representation in the National Security Council, which has ample powers of control over civilian authorities. On top of that, there was the establishment of the Concertación de Partidos por la Democracia (Agreement of Parties for Democracy, CPD), which led to the restoration of democracy in 1989 and the continuity of the neoliberal policies of the dictatorship. The continuity of the dictatorship's economic model, as well as the unfruitful search to manage a consensus where the right has to eliminate the authoritarian enclaves, were based on the idea that it is necessary to gain the support of industrialists and the military for the stability of the transition to the democracy.

The reconciliation of democracy with neoliberalism and the undesired maintenance of the authoritarian enclaves are the key to the stability of neoliberal governance in Chile (Silva 1996; Korzeniewicz and Smith 2000). The system must also include a type of political party that uses the mechanisms of neoliberal corporatism which defends the interests of private enterprise interests on the one hand, and on the other favours policies of poverty reduction in order to neutralise a possible radicalism of social demands (Weyland 1998). The reduction of extreme poverty has become the great argument of the success of Chilean neoliberalism compared to other cases in Latin America; it is presented as an example showing that it is possible to have progressive neoliberalism. It suffices to say that, until recently, Chile under the government of Lagos, Argentina under de la Rúa and Brazil under Cardoso were considered to be prototypes of Third World social democracy. Besides de la Rúa, it was Fernando H. Cardoso who declared himself a fervent supporter of the Third Way social democracy in Latin America. Nevertheless, his success in the fight against social inequalities is far from the results seen in Chile (Smith and Messari 2000).

\section{Asian crisis, the arrest of Pinochet and human rights}

The economic growth that has characterised the Chilean miracle, which managed to survive the crisis of the Mexican peso of 1995 and the devaluation of the Real in Brazil in 1998 without great difficulties, has not managed to avoid the prolonged negative effects of the Asian crisis. Together with a systematically growing external debt, the Asian crisis has caused a significant reduction of economic growth. The effects of this crisis dropped the curtain on the 1999-2000 presidential elections. The abrupt interruption of fifteen years of sustained development saw a reduction in 1997 when the GDP registered 7.4 per cent and fell to 3.9 per cent in 1998 and then to 1.1 per cent in 1999. This created a panic among Chile's highly consumeroriented civil society and its entrepreneurial class, who compared the first negative symptoms of the Asian crisis with the gigantic recession of 1982 
Table 2.4 Chile: GDP and total foreign debt, 1986-2001

\begin{tabular}{lrl}
\hline Year & GDP growth (\%) & Foreign debt (Smillions) \\
\hline 1986 & 5.6 & 19.501 \\
1987 & 6.6 & 19.208 \\
1988 & 7.3 & 17.638 \\
1989 & 10.6 & 16.252 \\
1990 & 3.7 & 17.425 \\
1991 & 8.0 & 16.364 \\
1992 & 12.3 & 18.242 \\
1993 & 7.0 & 19.186 \\
1994 & 5.7 & 21.478 \\
1995 & 10.6 & 21.736 \\
1996 & 7.4 & 22.979 \\
1997 & 7.4 & 26.701 \\
1998 & 3.9 & 31.691 \\
1999 & 1.1 & 34.167 \\
2000 & 5.4 & 36.849 \\
2001 & 3.0 & 37.790 \\
& & \\
\hline
\end{tabular}

Source: Banco Central de Chile (2002).

and 1983, when the GDP fell by 15 per cent and generated an unemployment rate of 25 per cent (see Table 2.4). In 1999, when the GDP fell 1.1 per cent, unemployment rose 13 per cent (Maira 2000). The election of Ricardo Lagos as president was strongly influenced by the results of his predecessor Eduardo Frei Ruiz-Tagle (1994-2000).

The second government of 'Concertación' under Frei was characterised by four successful years, then by the acute economic crisis caused by the Asian flu and finally by the political disillusion produced among important sectors of the civil society after Frei's unrestricted defence of Augusto Pinochet during the ex-dictator's detention in London in October of 1998. In 1994 the GDP had grown 5.7 per cent, in 199510.6 per cent, and in 1996 


\section{Alex E. Fernández Jilberto}

and 19977.4 per cent. Nevertheless, in 1998, Chile began to feel the effects of the fall of the Asian stock exchanges and the sealing off of the markets for Chilean exports. The fall in economic growth was the first in Chile since the crisis of the 1980s. Frei Ruiz-Tagle's government initially thought that the effects of crisis were temporary matters of some economic adjustment resulting from the slowdown of exports to Asian markets, and only recognised the calibre of the crisis when the recession hit during the first half of 1999. Right-wing and corporate criticism of the government's macroeconomic policies concentrated on the errors of monetary policy committed in 1997, which in the heat of the Asian crisis led to a drop in interest rates (Muñoz Gomá 2000). The right also formulated criticism against the government's fiscal policy that had contributed to an excessive demand.

The arrest of ex-dictator Augusto Pinochet in London on 16 October 1998 (demanded by the Spanish judge Baltazar Garzón) was the other factor that decisively influenced the political profile of the last two years of the Frei Ruiz-Tagle government. The arrest created a climate of political polarisation, where the civil heirs of the military bureaucracy encircled the government, forcing it to validate the political rhetoric of the pinochetismo. For the right, the arrest was considered to be an attempt at political murder, destined to deprive the dictator of his senator-for-life status. It was also associated with the failed assassination attempt conducted by the Manuel Rodriguez Patriotic Front in $1986 .{ }^{4}$ On the other hand, the Frei government assumed an unrestricted defence in favour of the ex-dictator and committed innumerable errors, such as granting the tardy status of special mission to Pinochet's visit to London. The government initially affirmed that his detention was not a state affair but argued later that it was an attack on the country's sovereignty, and that Chile had to organise the coarsest diplomatic-political operation of the nation's history in order to achieve the dictator's repatriation. After a series of diverse and failing resolutions brought about by English as well as Spanish justice systems, the Chilean armed forces pressured the president of the republic to put in place one of the authoritarian enclaves: the National Security Council, where the armed forces hold 50 per cent of the voting rights. This created a situation of virtual co-governance between Frei Ruiz-Tagle and the military. In turn, it allowed political space for the right-wing candidate of the December 1999 presidential elections to increase his electoral volume, by proclaiming his independence from the political and human rights situation inherited from the dictatorship.

Many sectors of civil society, human rights organisations and the relatives of victims and the 'disappeared' considered the arrest of Pinochet in London to be the first possibility of putting an end to impunity that was applied de facto to the crimes against human rights committed by the junta. Together with the arrest, these sectors of society unveiled the incapacity of the 'Concertación' governments (since 1990) to carry out legal sanctions and procedure against the military bureaucracy, which some have critically called 
moral cleansing (Moulián 1997). Since 1973 the executions of citizens without due process of law, the complicity of courts and judges in Chile, together with Pinochet's state terrorism created a political regime that based its existence on the systematic violation of human rights (Matus 1999). ${ }^{5}$ After the defeat of Pinochet in the plebiscite of 1988 and the first democratic presidential elections of 1989 , there was ample consensus in Chile to punish and sanction the military for its violations against human rights during the dictatorship. These sanctions should have been the basis of national reconciliation that would derogate, on behalf of the first democratic government, the 1978 Law of Amnesty declared by Pinochet himself in order to protect the military against future accusations of crimes against humanity.

President Patricio Aylwin (1990-1994) played an important part in making sure that the state would assume responsibility for human rights violations during the military government. Additionally, he created the Truth and Reconciliation Commission destined to investigate the case of the detained and the disappeared, and promoted reparation for damages by laws to serve victims of the military regime. Aylwin, who considered himself to be the President of the Reconciliation, thought that this set of measures would manage to finalise the transition to democracy and solve the problems of human rights violations, which were seen as the biggest threat to political stability. Despite being successful in some areas, Aylwin failed in his attempt to obtain national reconciliation. The measures actually taken were insufficient, it was impossible to countermand the 1978 Law of Amnesty, the armed forces refused to assume responsibility for their crimes, victims' relatives persisted in demanding that justice be served, and Pinochet remained in his position as Commander-in-Chief.

The government of Eduardo Frei Ruiz-Tagle (1994-2000) also tried to complete the transition to democracy by solving the problems of reconciliation and heeding the demands of justice for victims. But Frei failed in almost all of his attempts to make consensual agreements among the military, the government and human rights organisations, which aimed at reducing the significance of the problem (Loveman 2000). The failure can be explained partly as the result of the opposition of human rights organisations and the groupings of victims' relatives who all stood against impunity. The armed forces insisted that they had fulfilled the task of saving Chile from international communism and that all conflicts have their casualties. The last attempt made by the Frei government to resolve the conflicts was the creation of the Dialogue Round on Human Rights. This initiative aimed at uniting victims with the perpetrators in the search for a consensual agreement on solving the problems of retroactive justice. In this sense, it is easy to understand the sense of faith that the human rights organisations had in Frei's government to punish the military bureaucracy. This also explains civil society's indignation after Frei unconditionally defended Pinochet against the arrest in London. 


\section{The third government of 'Concertación'}

In the presidential elections of December 1999 the candidate for the Agreement of Parties for Democracy (CPD), Ricardo Lagos, won over 7 million votes, a relative majority of 47.9 per cent against the 47.7 per cent gained by the candidate of the right, Joaquin Lavín. Therefore, it was necessary to conduct a second round of votes in January 2000. After a decade in power, the CPD started a third presidential period with only 51 per cent of the votes and less than three points of difference over Joaquin Lavín. Remember that in the presidential elections of 1989, Patricio Aylwin obtained 55 per cent of the votes, and that in 1993 Eduardo Frei Ruiz-Tagle had 58 per cent of the votes. Diverse new political factors gave a special character to the elections of 1999/2000. For the first time, the right-wing movement for the dictatorship's neoliberal reconstruction presented one candidate. For the first time, and after his detention in London in 1998, Pinochet was not considered to be an extra-electoral political factor. For the first time after the restoration of democracy in Chile, a second round of votes was conducted between the two highest candidates. And finally, for the first time, the candidate of the right used a successful electoral strategy based on depolitisation of the elections and his disassociation from Pinochet, particularly of the theme of human rights.

The presidential elections were dominated by a number of ideological contradictions and discrepancies, especially in reference to the neoliberal legitimacy, among the parties of 'Concertación' (Garretón 2000). For the right and the industrialists, Chile was already modernised in that a democratic regime had been installed together with an open-market economy that facilitated its deep international integration. For the right the compatibility established in ten years of the CPD between neoliberalism and democracy tended to slow down the dynamics of the free market as it took some time to eliminate state intervention. In this view, policies should remain subordinated to the needs of the economy and globalisation, and therefore the presidential elections should not end up promoting social reforms or displace the foundations of neoliberalism.

The electoral campaign of the right, led by the staunch bastion of civilpinochetismo in the Independent Democratic Union, maintained its strategy of de-politicisation of the elections and the separation of the political image of its candidate Joaquin Lavín from the political influence of Pinochet. In order to accomplish this, it accentuated the need for political change that would put an end to the continuity of 'Concertación' governments, rather than question the role of the military. It criticised government sponsored state intervention (increases in social spending) and emphasised the need to open the market economy even further in order to solve people's problems. The number of votes won by the Chilean right during the presidential elections of 1999-2000 was the highest since 1938, and three times higher than in 1993 (Garretón 2000). The success of the right in its aim to devalue poli- 
tics consisted of individualising social demands (people's problems) that normally are satisfied by the state, and by avoiding all debate about the legitimacy and the political and social consequences of neoliberal governance. This approach, together with the fact that - for the first time - the presidential election was not accompanied by parliamentary elections, helped the right to move to the centre and challenge the dominance of the Christian Democrats and the CPD.

It needs mentioning that part of the left has not participated in the CPD governments. This part, which proposed three candidates for the first round of elections in December 1999, is composed of human rights groups, the Greens and the Communist Party. For them, the ten years of democratic government have been dedicated to administer the economy inherited from the Pinochet dictatorship. The elections were considered to be an important opportunity to denounce the neoliberal model and conservative politics, particularly with reference to the issue of human rights. In their view, Chile today is the result of a neoliberal ménage a trois that is expressed in the relationship between the military, intellectuals and industrialists (national or transnational). These three actors have constructed a society where social relations are considered to be a natural order based on the laws of the market and where politics is a space reserved only for cosmetic adjustments. Accordingly, the parties of 'Concertación' and the competing right generate simple instruments of power for those aspiring to rule in an overwhelming shortage of opportunities (Moulián 1997: 62) The anti-CPD left has emphasised the primacy of principles and politics that place the importance of social democracy over the market.

During the period prior to the 1999-2000 elections, there were two diverging tendencies among the 'Concertación' parties. On the one hand, there were the left groups of the CPD, represented by the Socialist Party and the Party for Democracy, which argued for combining the continuity of the neoliberal economic policy with the programme to eradicate the political institutions inherited from the dictatorship (bi-partisan system, designated senators, etc.). On the other hand, there were the anti-mobilisation groups that rejected all attempts to radicalise the government programme. They believed that all forms of political radicalisation could lead to economic collapse and alter the balance of power among industrialists, government and military. The economic success and political moderation had to be guarded at all costs. In this line of thought, the 'Concertación' committed two mistakes: the arrest of Pinochet in London in 1998, and the end of the Christian Democrats' hegemony within the CPD, which resulted in the naming of a socialist candidate after two Christian Democratic presidents. ${ }^{6}$

\section{Neoliberal governance and incomplete democratisation}

The stability demonstrated by neoliberal governance in Chile has been based not only on the involuntary conservation of authoritarian enclaves but also 


\section{Alex E. Fernández Jilberto}

on the depolitisation of the economy. Various authors have shown that the successful processes of democratisation have almost always given rise to conservative democratic regimes (Przeworski 1992) and that the return to democracy in Chile has not been the equivalent of the return to politics (Causiño and Valenzuela 1994). The democratisation of Chile has not meant the restoration of the democratic regime prior to 1973, which since the 1930s was characterised by the existence of a compromise state. The previous democratic regime was not only based upon Keynesian industrialisation. Rather, it also regulated the relations between capital and labour and had played an active role in the regulation of inherent social inequalities. In contrast, the installation of democracy in 1990 was built within the framework of protected democracy originating in the new Constitution promulgated by Pinochet in 1980 . This means that every single constitutional change was possible only by consensus among the right-wing civil heirs of pinochetismo. It implies the acceptance of a neoliberal state whose function is the creation of favourable conditions for the private sector, within a framework of a radically globalised economy. With this, the Chilean state abandoned all its functions in regulating the market with respect to problems of social inequality.

The relations between the state and civil society are now mediated by the market, which rejects policies of social integration. This phenomenon is considered to be the depolitisation of the economy (Cuevas Valenzuela 2001) and it is expressed in the weak capacity of Chilean political parties to change the course of economic development. This condition favours the existence of a politically demobilised society that operates on privatised social relations and considers the negotiations that take place among the elite to be a natural phenomenon. In its entirety, the model of protected democracy and the political system establishing all types of limitations to popular sovereignty is destined to guarantee the immunity of the market against political pressures. The structural implementation of neoliberal policies favoured the restrictions on political action and consolidated the automatisation of the economy, limiting all forms of political intervention geared towards strengthening democracy. The Agreement of Parties for Democracy that led the transition to democracy and governed Chile for almost a decade and a half was responsible for this type of transition based on a permanent agreement with the parties of the right, political restrictions and the autonomy of the economy.

This model of democratic transition saw its first symptom of exhaustion in the debate concerning what is called democratic consolidation. The debate is about conditions that prevent authoritarian regression, the domination of 'factual power' (the military bureaucracy and industrialists) or the breakdown of the entire regime (Garretón 2001). Factual powers in Chilean democracy are represented by entrepreneurs, who argue for a continuity in neoliberal politics, and by the military, threatening to regress from the democratic regime in order to avoid a reform of the 'protected democracy' 
implemented in the Constitution of 1980 . In Chile, the factual powers can be understood as those with the capacity to impose the will of corporations and the military. On the other hand, the process of permanent renovation of democracy, aimed at accommodating relations between civil society, the main political parties and the state, is stuck in the face of market primacy over politics. This proves that a great part of institutionalised democracy heavily depends on the legacies of the old regime which are expressed as the submission of the majority to the veto of the minority, or at least in perpetual compromises. The consolidation of the Chilean democracy consecrated an incomplete form of representative democracy in which the industrialists and the military operate like forces of containment against institutional change or economic radicalism, whereas a moderating mechanism of the civil regime (the CPD) accepts this situation as the only option for re-establishing democracy. The Socialist Party, representing the left wing of the 'Concertación', has played a significant role in accepting this 'protected democracy' and in legitimising neoliberal democracy. Moreover, this party has served as a social pacifier of the demands of the labour movement and civil society organisations (Moulián 1994).

\section{Poverty and social agreement}

The success of the CPD governments in reducing poverty has been the best argument to legitimise the participation of the Socialist Party in the governmental alliance. Between 1987 and 1998 poverty was reduced from 45.1 per cent to 21.7 per cent of the population. In numbers this means that, while in 1987 there were 5.7 million people living in poverty in Chile, this dropped to 3.3 million in 1997 (Ministerio Secretaría General de Gobierno 1999). However, Chile has one of the worst rates of income disparity in Latin America (see Table 2.5). The 'Concertación' governments have always had the objective to make neoliberalism and sustained long-term economic growth compatible with the reduction of poverty, better income distribution and the strengthening of democracy. Up until now, they have failed in this objective. The CPD started off from the premise that macroeconomic stability and economic growth were indispensable conditions to obtain these social goals; but they were not sufficient to reduce inequality.

While the reduction of poverty required active public policies, the neoliberal policies inherited from the dictatorship allowed only for gradual changes in social policies and the process of decision-making. These changes were possible only by ample consensus among industrialists, workers and non-governmental organisations. This was all about formulating a social policy that made social demands compatible with the national macroeconomic and international economic restrictions. In order to accomplish this, three instruments were created: first, the Framework Accord between the trade unions, the industrialists and the state, which aimed at creating a consensus on wage policies in the public and private sectors independent of 
Table 2.5 Chile: Socio-economic indicators of distribution and the concentration of income, 1990-2000

\begin{tabular}{|c|c|c|c|c|c|c|c|c|}
\hline \multirow[t]{2}{*}{ Year } & \multirow{2}{*}{$\begin{array}{l}\text { GDP per } \\
\text { inhabitant } \\
\text { in } 1995(\$)\end{array}$} & \multirow{2}{*}{$\begin{array}{l}\text { Income per } \\
\text { inhabitant } \\
\text { in } 1995 \text { (\$) }\end{array}$} & \multirow{2}{*}{$\begin{array}{l}\text { Urban } \\
\text { unemployment } \\
(\%)\end{array}$} & \multirow{2}{*}{$\begin{array}{l}\text { Average } \\
\text { income } \\
(\%)\end{array}$} & \multicolumn{4}{|c|}{$\begin{array}{l}\text { Participation in total national income (urban areas) } \\
\text { of }\end{array}$} \\
\hline & & & & & $\begin{array}{l}40 \\
\text { most } \\
\text { poor }\end{array}$ & $\begin{array}{l}30 \text { middle } \\
\text { poor }\end{array}$ & $\begin{array}{l}20 \text { before the } \\
\text { richest } 10\end{array}$ & 10 richest \\
\hline 1990 & 3425 & 3164 & 7.8 & 9.4 & 13.4 & 21.2 & 26.2 & 39.2 \\
\hline 1996 & 4834 & 4433 & 6.4 & 13.5 & 13.4 & 20.9 & 26.4 & 39.4 \\
\hline 2000 & 5309 & 4705 & 9.2 & 14.1 & 14.0 & 20.9 & 25.4 & 39.7 \\
\hline
\end{tabular}

Source: Cepal (2001a). 
the resources invested into other social policies; second, the Labour Reform, which tried to put an end to the restrictions established by the dictatorship, in order to gain social pacification and economic stability; third, the Tributary Reform, which aimed at increasing taxes in order to provide the state with the minimum financial resources for social programmes (Chilean income tax is only just below 20 per cent). The reduction of social spending constituted a permanent objective of the military regime; for the CPD governments, the objective was to quickly increase social spending without negative repercussions on the stable economic growth.

The social policies of the 'Concertación' governments have been based on two objectives. On the one hand, it was necessary to fortify public political support directly by providing the population with services such as housing, education, health, social security and justice. The other was the implementation of programmes aimed at improving living conditions for the poor and the more vulnerable sectors of society. For the CPD governments, an increase in social spending was a political decision that required national consensus. At times this meant a direct confrontation with the civil heirs of the dictatorship that saw social spending as a threat, especially at a moment of economic crisis. But these social policies never meant the restoration of the system of compromise and social intervention that reigned in Chile between the 1930s and 1973. This state, which was associated with the Latin American version of international Keynesianism, played an ever-increasing roll in finance, production and the direct management of social services. It had created a basic infrastructure of services and stimulated demand (Raczinski 1999). The totality of this system was eradicated by the neoliberal reconstruction implemented by the military government, including the privatisation of the health system, public education and pension funds. Next to the privatisation of public services, the most important characteristics of Chile's neoliberal governments have been the reduction of social spending, the limitations placed upon policies for the extreme poor; the decentralisation of the social and public policies; and the incorporation of market mechanisms in subsidising the demand of social services. The reduction of social spending was considered to be a permanent anti-inflationary measure that was to stimulate economic growth. Together, under the political philosophy of neoliberalism, the Subsidiary State replaced the State of Commitment in social policies definitively.

\section{Conclusions}

The success of neoliberal governance in Chile, in comparison with most other Latin American countries, can be explained in many ways. First, neoliberal restructuring implemented by the military dictatorship (1973-1990) was accomplished much earlier than in other countries in the region. This granted the country a comparative advantage in the availability of investments at the international financial market, which was fortified by a 


\section{Alex E. Fernández Jilberto}

type of state that - for the first time in its history - established an unconditional openness to foreign investment. On the other hand, the process of democratisation and the continuity of the neoliberal policies of the Pinochet government guaranteed a political stability that was preferred by both internal investors and multinational corporations.

The existence of a stable democratic regime in Chile since 1990 is due not only to sustained economic growth. It has also depended on the capacity of industrialists and the military, which operate as factual powers, to limit the civil government's aspirations of political and economic transformations. Additionally, the constitution of the ideologically neo-liberalised and modern political class has led to political 'do-nothing' policies that punish attempts to radically change economic policy. In the face of international financial crises, the first reaction has always been the protection of the economic model at all costs and the instinctive rejection of reform. The Agreement of Parties for Democracy has managed to marginalise all dissidence of neoliberal economic policy while neutralising the criticism coming from the non-CPD left.

The bi-partisan electoral regime, consecrated in the Constitution of 1980 , which formed the basis of protected democracy, has favoured the formation of large coalitions that force the principle of negotiations as the instrument to exercise power. Through this, it has kept all attempts at politicising the debate on the extreme concentration of wealth under control. The primordial task of the civil political class has not been to emphasise or re-assert civil society; rather its objective is to guarantee the stability of economic variables and the maintenance of the neoliberal model. The depolitisation of the economic debate is perhaps one of the principal achievements of neoliberalism in Chile. Politics have thus not been restored with democracy. The Lagos government's success in doing away with authoritarian enclaves, confronting the prolonged recession initiated by the Asian crisis, and its capacity to modify the unequal distribution of income, will all depend on the future electoral endorsement of the 'Concertación'. Meanwhile, and in contrast to Chile, the collapse of neoliberal governance in Argentina has transformed this empire of misery into a great laboratory of civil society resistance against neoliberalism.

\section{Notes}

1 Even Spanish multinational companies, such as Telefónica and ENDESA (the electric monopoly giant), benefitted from the regime's privatisation programmes. They are not only accused of benefitting from the regime but also of having collaborated voluntarily or involuntarily with repressive policies. Telefónica was investigated after the fall of Fujimori for alleged complicity and tolerance of illegal telephone monitoring operations between 1992 and 2000 (YáñezBarnuevo 2001).

2 After the APRA's loss of face during the Alan Garcia government and the fracturing of the left, Fujimori's only serious opponent was Mario Vargas Llosa. Vargas Llosa's proposed programme was to solve the crisis by implementing a 
radical neoliberal revolution that included a direct attack on hyperinflation and the fiscal deficit (shock therapy), which would require reducing the influence of the unions (Vargas Llosa 1993). APRA voters, as well as those from the left, ended up supporting Fujimori in the second round of elections, as he was considered to be non-representative of the traditional social elite.

3 The 1995 crisis was the only one that was not related to globalisation; it originated in one country (Mexico) and the effects on the rest of Latin America were felt not in trade but in finance.

4 This association was mystified by the dictator who said that the impact of the bullet in the windshield of his armoured car had the image of his protector, the Virgin of Perpetual Help (Torres and Sepúlveda 1998).

5 The great majority of the regime's victims were executed and/or condemned for Treason to the Fatherland, Illicit Association and Flight from Law. Torture, under the 'missing detainee' formula, was the normal mechanism used to physically eliminate all opposition, and the application of exile and prison sentences was a daily occurrence of political life in a civil society terrorised by institutionalised violence. Other citizens were victims of Operation Condor that was coordinated by security services of the dictatorships of Brazil, Argentina, Uruguay, Paraguay and Chile.

6 For the selection of presidential candidates, the CPD, just like the PRI in Mexico, had introduced the US system of primary elections. In them Ricardo Lakes obtained 71 per cent of the votes, defeating the Christian Democratic candidate Andrés Zaldivar who got only 29 per cent of the CPD votes (Maira 2000). This generated a political crisis within the Christian Democratic Party, which threatened the stability of the 'Concertación' and created a degree of uncertainty between industrialists and the military in endorsing President Lagos.

\section{Bibliography}

Banco Central de Chile (2002) Series Estadísticas, Santiago: Banco Central.

Calcagno, A. and S. Manuelito (2001) La convertibilidad argentina: un antecedente relevante para la dolarización de Ecuador? Santiago: Cepal/Naciones Unidas.

Carrière, J. (2001) 'Neoliberalism, Economic Crisis and Popular Mobilization in Ecuador', in J. Demmers, A.E. Fernández Jilberto and B. Hogenboom (eds) Miraculous Metamorphoses. The Neoliberalization of Latin American Populism, London: Zed Books.

Causiño, C. and E. Valenzuela (1994) Politización y Monetarización en América Latina, Santiago: Pontificia Universidad Católica de Chile.

Cepal (1990) Transformación Productiva con Equidad. La tarea prioritaria del desarrollo de América Latina y el Caribe en los años noventa, Santiago: Cepal/Naciones Unidas.

-- (2000) Balance preliminar de las economías de América Latina y el Caribe 2000, Santiago: Cepal/Naciones Unidas.

- (2001a) Balance Preliminar de las Economias de América Latina y el Caribe, Santiago: Cepal/Naciones Unidas.

\footnotetext{
- (2001b) Panorama Social de América Latina 2000-2001, Santiago: Cepal/Naciones Unidas.

- (2001c) La Inversión Extrajera en América Latina. Informe 2000, Santiago: Cepal/Naciones Unidas

- (2001d) Equidad, desarrollo y ciudadania, Santiago: Cepal/Naciones Unidas.

Corkhill, D. and D. Cubitt (1998) Ecuador: Fragile Democracy, London: Latin American Bureau.
} 
Cotler, J. (1998) Los Empresarios y las Reformas Económicas en el Perú, Lima: IEP.

Crabtree, J. (2001) 'The Collapse of Fujimorismo: Authoritarianism and its Limits', Bulletin of Latin American Research, 20 (3): 287-303.

Cuevas Valenzuela, H. (2001) 'La Nueva Democracia en Chile', in P. Milet (ed.), Estabilidad, Crisis y organización de la Política. Lecciones de Medio Siglo de História Chilena, Santiago: Flacso.

De la Torre, C. (1997) 'Populism and democracy: political discourses and cultures in contemporary Ecuador', Latin American Perspectives, 14 (3): 12-24.

Fernández Jilberto, A.E. (2001) 'The Neoliberal Transformation of Chilean Populism: The Case of the Socialist Party', in J. Demmers, A.E. Fernández Jilberto and B. Hogenboom (eds) (2001) Miraculous Metamorphoses. The Neoliberalization of Latin American Populism, London: Zed Books.

Fernández Jilberto, A.E. and A. Mommen (1996) 'Setting the Neoliberal Development Agenda. Structural adjustment and export-led industrialization', in A.E. Fernández Jilberto and A. Mommen (eds), Liberalization in the Developing World. Institutional and economic changes in Latin America, Africa and Asia, London: Routledge.

- (eds) (1998) Regionalization and Globalization in the Modern World Economy. Perspectives on the Third World and Transitional Economies, London: Routledge.

Flacso (2000) Chile Nuevo Gobierno: desafios de la reconciliación (1999-2000), Santiago: Flacso.

Franco, R. and P. Saínz (2001) 'La agenda social latinoamericana del año 2000', Revista de la Cepal, 73: 55-66.

Garretón, M.A. (2000) 'Cambio, Continuidad y proyecciones de las Elecciones Presidenciales de Fin de Siglo', in Flacso, Chile Nuevo Gobierno: desafios de la reconciliación (1999-2000), Santiago: Flacso.

- (2001) 'Balance y perspectivas de la democratización política chilena', in P. Milet (ed.), Estabilidad, Crisis y Organización de la Politica. Lecciones de Medio Siglo de História Chilena, Santiago: Flacso.

Gonzales de Olarte, E. (1998) El Neoliberalismo a la Peruana, Lima: IEP.

Korzeniewicz, R.P. and W.C. Smith (2000) 'Los Dos Ejes de la Tercera Vía en América Latina, in Flacso Chile Nuevo Gobierno: desafios de la reconciliación (1999-2000), Santiago: Flacso.

La Fuente, M. and P. Saínz (2001) 'Participación de los pobres en los frutos delo crecimiento', Revista de la Cepal, 75: 161-70.

Loveman, B. (2000) 'La Reconciliación Nacional en América Latina, Utopia y "Pomada" de los noventas', in Flacso, Chile Nuevo Gobierno: Desaíos de la reconciliación 1999-2000, Santiago: Flacso.

Maira, L. (2000) 'Chile bajo la Administración Lagos. El Difícil camino al Palacio de la Moneda', in Flacso, Chile Nuevo Gobierno: desafios de la reconciliación (1999-2000), Santiago: Flacso.

Matus, A. (1999) El Líbro Negro de la Justicia Chilena, Santiago: Editorial Planeta.

Ministerio Secretaría General de Gobierno (1999) El Tiempo de la Gente. Las cifras de una década de oportunidades y progreso, Santiago: Gobierno de Chile.

Montero, C. (2000) 'Las Relaciones Laborales: un asunto público?', in O. Muñoz Gomá, Estado y el Sector Privado, Santiago: Dolmen.

Moulián, T. (1994) 'Limitaciones de la Transición a la Democracia en Chile', Revista Proposiciones, 25: (34 45).

- (1997) Chile Actual, anatomía de un mito, Santiago: Lom. 
Muñoz Gomá, O. (ed.) (2000) El Estado y el Sector Privado, Santiago: Dolmen. OECD (2001) Statisques de la dette extérieure, Paris: OECD.

Peres, W. (1998) Grandes Empresas y Grupos Industriales Latinoamericanos, Mexico: Siglo XXI Editores/Cepal.

Puertas, L. (2000) 'Un Vídeo muestra cómo el "número dos" de Fujimori compra a un diputado de la oposición', Diario El País, September 16: 15.

Przeworski, A. (1992) 'The Games of Transition', in S. Mainwaring, G. O'Donnell and J. S. Valenzuela (eds), Issues in Democratic Consolidation, Indiana: University of Notre Dame Press.

Raczinski, D. (1999) 'Políticas Sociales en los años noventa en Chile. Balance y Desafios', in P. Drake and I. Jaksic (eds), El Modelo Chileno. Democracia y Desarrollo en los noventa, Santiago: Lom.

Roberts, K.M. (1998) Deepening Democracy. The Modern Left and Social Movements in Chile and Peru, Stanford: Stanford University Press.

Silva, E. (1996) The State and Capital in Chile. Business Elites, Technocrats, and Market Economics, Boulder: Westview Press.

Smith, W.C. and N. Messari (2000) 'Democracy and Reform in Cardoso's Brazil: Caught Between Clientelism and Global Markets?', in J. Stark (ed.), The Challenges of Change in Latin America and the Caribbean, Boulder: North-South Center Press/Lynne Rienner.

Stokes, C. (2002) Mandates and Democracy. Neoliberalism by surprise in Latin America, Cambridge: Cambridge University Press.

Teubal, M. (1996) 'Structural Adjustments, Democracy and the State in Argentina', in A.E. Fernández Jilberto and A. Mommen (eds), Liberalization in the Developing World. Institutional and Economic Change in Latin America, Africa and Asia, London: Routledge.

(2001) 'From Import Substitution Industrialization to the "Open" Economy in Argentina: The Role of Peronism', in J. Demmers, A.E. Fernández Jilberto and B. Hogenboom (eds) (2001) Miraculous Metamorphoses. The Neoliberalization of Latin American Populism, London: Zed Books.

Torres, M. and L. Sepúlveda (1998) Los Documentos del juez Garzón y la Audiencia Nacional. El Caso de España contra las dictaduras chilena y argentina, Barcelona: Editorial Planeta.

Touraine, A. (1997) Podemos vivir juntos? México: FCE.

Toussaint, E. (2002) Crisis Financiera en Argentina: el origen de la deuda, Paris: Observatorio de las Transnacionales.

Vargas Llosa, M. (1993) El Pez en el Agua: Memorias, Barcelona: Seix Barral.

Weyland, K. (1998) 'Economic Policy in Chile's New Democracy', Journal of Interamerican Studies and World Affairs 41 (3): 67-96.

(2000) 'Neopopulism and Market Reform in Argentina, Brazil, Peru, and Venezuela'. Paper for XXII International Congress Latin American Studies Association, Miami, 16-18 March.

Yáñez-Barnuevo, L. (2001) 'España en América’, Diario El País June 30: 3. 


\title{
3 'Que se vayan todos' Neoliberal collapse and social protest in Argentina
}

\author{
Norma Giarracca and Miguel Teubal
}

On 19 and 20 December 2001 a massive, spontaneous and essentially nonviolent popular uprising occurred in the streets of Argentina in defiance of the State of Siege proclaimed by the wholly discredited government of Fernando de la Rúa. These events were preceded by days in which social protests of different sorts had reached their peak with the looting of supermarkets and food shops. The police responded with repression that took the lives of more than 30 persons.

This was the culmination of a cycle of protest that began several years back (Giarracca et al. 2001). As will be discussed in this article, the Alianza voted into government in 1999 soon betrayed its electoral promises and deepened the severe structural adjustment programme implemented by the Menem administration in the 1990s (see Teubal 2000/2001; 2001b). The new government's electoral promises were soon transformed into new adjustments: wages of public employees were reduced 13 per cent in nominal terms, taxes were increased, and legislation furthering the flexibilisation of the labour market was passed by the legislature. Adjustments were thereby extended to health and education. These measures instituted by de la Rúa's first Minister of Economics José Luis Machinea, presumably a new convert to orthodoxy in economic affaires, contributed to increasing unemployment, lowering the wages and incomes of the poorest income groups. The government was soon to replace Machinea with Domingo Cavallo, Menem's wizard Minister of the Economy, the architect of the Convertibility Plan and the extreme Structural Adjustment programme of the previous decade. Cavallo proceeded to apply a series of package deals negotiated with the IMF for the purpose of avoiding a default on foreign debt servicing and the maintenance at all costs of the Convertibility Plan of 1991. His policies were soon to founder lamentably.

Unemployment increased exponentially, the recession was deepened since 1998 the economy had begun to stagnate and decline - and the living conditions of vast segments of the population continued to deteriorate drastically. In this context social protests of all sorts were on the rise. The drop that caused the cup to overflow was the creation of the so-called corralito measure on 3 December 2001 that impeded the public from withdrawing 
their savings and deposits from the banks. Devised to save the banks from the run of depositors as well as wholesale capital flight that had been proceeding throughout the year, this measure increased the band of protesters to a wide contingent of middle class savers.

The days prior to Wednesday December 19 had seen a variety of massive protests, but after the looting of supermarkets and food shops the government declared the state of siege, prohibiting meetings and reunions of all sorts. The people's response to the President's message transmitted by the national radio and television network was immediate. Throughout the city of Buenos Aires, from balconies and windows the sound of pans and pots being banged began to be heard. After media attention for these spontaneous events, people came out into the streets. Although it was already late at night, citizens armed with pans, sticks, spoons and drums noisily manifested their disapproval. From different parts of the city the chant that was to become a symbol of these days began to be heard: 'Que se vayan todos' (throw them all out).

Most politicians were rebuffed, in particular those that had passed through government office. The feeling of rejection extended not only to the government of the Alianza but to all politicians and to members of the Supreme Court as well. The police stood by that night but did not intervene. A point of gathering was the Plaza de Mayo, the square that had seen the essential events in the history of Argentina and that once again became the scenario of protest. Many protesters remained in the Plaza all night, as a peaceful manifestation of civic disobedience.

In the early hours of December 20 the Minister of Economics Cavallo and the other remaining ministers resigned, leaving de la Rúa free to negotiate a solution to the crisis with the opposition Justicialista Party. The next day the protesters were joined by office workers, many of whom were in suits and with briefcases, and by members of human rights organisations. Ordered by the government, at noon a ferocious repression began, first in and around the Plaza, thereafter throughout the centre of the city. The international media registered these events that were transmitted to the world. At least seven persons were killed point blank, and more than thirty died in the two days of repression. This was one of the worst repressions by a democratically elected government in the history of Argentina, and they led to de la Rúa's resignation. He was succeeded by Adolfo Rodríguez Saa (the Peronist governor of the Province of San Luis), who was to resign only a week later. After a few days in which a series of chiefs of state came and left, Eduardo Duhalde was voted to the presidency by the legislature, and he remained.

The experience of 19 and 20 December is considered a landmark in the recent history of Argentina, marking a before and an after in the socio-political development of Argentine society. On the one hand the events can be viewed as a reaction to the worst crisis in Argentine history, a profound economic, social, political and institutional crisis that has played havoc with 
the living conditions of the vast majority of the Argentine population. Some observers even consider this crisis as leading to 'a state of absolute disintegration' of Argentine society (Petras and Veltmeyer 2002). On the other hand, the events and the important social manifestations that preceded them, as well as those that have been developing since, have given way to important transformations in Argentine society. New social actors have been emerging and some of the old ones have consolidated their presence. While new forms of popular participation - for example the piqueteros - had already begun to manifest themselves previously, they acquired a new 'presence' thereafter. The asambleas populares have also emerged as important social actors in Argentine civil society.

The creation of new forms of popular participation have multiplied in the neighbourhoods, among the piqueteros, the asambleas populares and elsewhere. Since then no 'solution' to the crisis can legitimately be made without consideration of these new social actors of society. Thus, what may be emerging may well be a new form of participatory democracy, one that seeks to replace a regime that seems to have lost all legitimacy. Hence, we are confronted with a true crisis of representation, a crisis that manifests itself very clearly in the battle cry of the people, that has become the lemma of the rebellion: 'Que se vayan todos, que no quede ni uno solo' (throw them all out, leave no one).

What were the factors that determined the nature and characteristics of the crisis in Argentina, and what are its peculiarities? How do they relate to the social protest as it evolved throughout the 1990s? What are the characteristics of the social protest that manifests itself in the midst of this crisis? These are some of the questions we address in this article. In the first part we analyse the Argentine crisis as a crisis of neoliberalism, and describe the main measures adopted by the Menem and de la Rúa administrations as well as their consequences. Then we look into the several cycles of social protest that have emerged concurrently throughout the decade and that culminated in the rebellion of December of 2001. Finally we present a dense description of the new forms of economic and political organisation that are emerging in Argentina.

\section{A crisis of neoliberalism}

After more than a quarter of a century of neoliberalism, over a decade since the application of a severe structural adjustment programme, and after several years of recession leading to a full-fledged crisis, the living conditions of the vast majority of the Argentine population are critical. Although it is unknown if the Argentine economy has reached the bottom of the crisis or if disintegration is yet to continue, this crisis - economic, social, political, institutional, or if you wish 'organic' - is clearly a completely new experience that could be leading to profound transformations of Argentine society. The role of the Argentine government, subservient to the IMF and international 
financial interests, was quite evident in determining the collapse of the Argentine economy. We intend to show here that the structural adjustments of the 1990s led to this crisis, and that the more recent adjustments and liberalising measures in the midst of the recession adopted by government under pressure from the IMF, the United States and the international financial community (including the European Union) only contributed to the debacle. Not only were no anti-cyclical measures adopted, but the adjustments that were made time and again, only contributed to a deepening of the crisis, and so did the attitude of the banks. Thus, the main causes for the present crisis must be sought in the institutions and policies adopted since the 1990s, the Convertibility Plan, and the consequent measures contributing to enormous regressive transfers of income and wealth. This went along with wholesale corruption and impunity, with regards to government measures, all of which are now being put in question. In this respect the Argentine crisis is probably much more a crisis of neoliberalism than other crises, for example the Asian crisis of 1997 or the Russian crisis of 1998, simply because Argentina had already embarked upon a full-fledged structural adjustment programme in the 1990s and was even considered in international financial circles a model case study in the application of these programmes.

\section{Convertibility and structural adjustment}

The severe Structural Adjustment (SA) programme applied in Argentina in the 1990s closely followed the main tenets of neoliberalism. This programme was preceded by the so-called Convertibility Plan of April 1991, whereby a 'currency board'-type of foreign exchange regime was established. A new peso was fixed to the dollar on a one-to-one basis and the full liberalisation of financial transactions to and from abroad was established. Since then even exporters had no obligation to sell their earned foreign exchange to the Central Bank.

While the fully convertible Argentine peso was pegged to the dollar on a one-to-one basis, all money creation not backed by foreign exchange reserves of the Central Bank, by the inflow of foreign capital from abroad, or by new indebtedness, was also prohibited. This had the ostensible purpose of eliminating all government discretionality with regard to monetary and foreign exchange policies. Its effect was equivalent to putting Argentina on a sort of Gold or Dollar Standard, limiting the functions of the Central Bank to that of an exchange broker. Yet its main purpose, and the reasons for its temporary success, had to do with bringing down the inflation and hyperinflation that had beset Argentina in the 1989-1991 period, by drastically eliminating devaluation expectations and prohibiting by law price indexing (except when applied to certain public rates after the main public services were privatised, these being indexed to the wholesale price index of the US). Domingo Cavallo, the Minister of Economics who instituted this monetary regime, sought presumably to establish a new and 
enduring monetary and foreign exchange regime that would stabilise the economy and permit him to apply a drastic SA programme that was to include a wholesale privatisation programme, a drastic open-door policy vis $\grave{a}$ vis foreign trade and foreign investments, and strong deregulatory measures, in particular, concerning the flexibilisation of labour markets.

This SA programme was part of a 'shock' therapy strategy whose application was due in large part to political considerations: Menem needed to let it be known that he was not going to apply a typically Peronista (that is, nationalist and populist) economic strategy, despite his electoral promises. Nevertheless, this strategy would not have been as 'successful' as it apparently was - at least in the early 1990 s - were it not for the stability obtained by the Convertibility Plan of 1991. In 1989, wholesale capital flight had implied a sort of economic coup leading to the hyperinflationary spurts of 1989-1991 that were only successfully controlled by the Convertibility Plan: by tying the peso to the dollar exchange rate, 'inertial' inflationary expectations were eliminated. The plan also legalised contracts in dollars, including savings denominated in dollars and deposited in the banking system. Capital movements were more fully liberalised than, for example, in Chile. In essence, as we have mentioned elsewhere (Teubal 2000/2001) the convertibility plan constituted a straitjacket making any future devaluation extremely difficult.

With the Convertibility Plan in place Domingo Cavallo and Carlos Menem implemented their extreme SA programme (cf. Teubal 2001b; 2000/2001). All prior industrial, regional and export promotion regimes were suspended and the advantages local manufacturers had in providing for state purchases were eliminated. Government finances were initially controlled (though this was mainly due to lower inflation rates); indirect taxes on consumption were increased, affecting mostly the middle and working classes. A surplus of public finances was considered necessary to finance the external sector, which included the need to pay for foreign debt servicing. The international financial establishment was elated by the fact that the Argentine government entered the Brady Plan and regularised payments on its foreign debt. This was also made possible by the substantial resources earned by the privatisation programme. The overall economic expansion induced by increased consumption and the inflow of capital funds from abroad in the first years of the Menem administration also helped substantially to legitimise the overall programme.

The privatisation of the public sector was swift and exhaustive: in less than three years more than thirty state public enterprises, the bulk of the state enterprise system, were sold. Observers noted the swiftness and thoroughness with which the Argentine government carried out this programme. Privatisation reached such diverse areas as telephones and communications, airline companies, petrochemicals, petroleum, about 10,000 kilometres of highways, railways and other transport systems, natural gas distribution, electricity, water, iron and steel industries, coal, a series of firms in the area of defence, hydroelectric dams and other varied items such as television channels, 
hotels, ports, silos, and horse-racing stadiums. The privatisation programme, however, excluded the institutionalisation of regulatory boards, which in First World countries is part and parcel of most privatisation programmes. Many of the privatisations were considered questionable, either due to their weak legality, or to corruption charges concerning many of those functionaries involved in their implementation. Deregulation followed similar procedures.

Structural Adjustments and the Convertibility Plan were complemented by a drastic open-door policy and a series of deregulatory measures, many of which were implemented by decree. Almost all quantitative restrictions on imports were eliminated (except those concerning the automobile industry in relation to the MERCOSUR). A similar situation affected tariffs. In March 1991 a new tariff structure was set: raw materials were to have a nil tariff rate, inputs 11 per cent and final manufactured goods 22 per cent. The average tariff fell by 10 per cent. Likewise, measures and institutions related to the agricultural sector were also liberalised. The Agricultural Boards that had been created in the 1930s were now eliminated (Junta Nacional de Carnes, de Granos, del Azúcar, de la Yerba mate, etc.). But probably much more than other deregulatory measures the overall flexibilisation of labour markets constituted a distinctive feature of the new regime of accumulation, and has been put on a par with measures such as the privatisation of the bulk of state enterprises. Thus, a series of laws contributing to the precarisation of labour markets ensued. Apart from this the social security system was also partially privatised and deregulated.

The case of Argentina (at least up to Mexico's 'Tequila' crisis) was portrayed in international fora as a showcase worth considering together with that of Chile and (pre-Chiapas) Mexico. The Minister of the Economy, Domingo Cavallo, was seen as a wizard, having been well received in international financial circles. The measures implemented under the Menem administration had substantially changed the rules of the game of the Argentine economy. Nevertheless, they went along with corruption, impunity, and a Supreme Court that endorsed the questionable legality of the privatisations being carried out. A new regime of accumulation was put in place. In the 1970 s under the military dictatorship, import substitution industrialisation strategies that had prevailed previously were set aside. The hegemony of financial interests that had begun in the 1970s became clear in the 1990 s with the privatisations programme, the Brady plan and the new orientation that financial and speculative activities acquired thereafter. While this hegemony was established, productive activities were on the whole given much less importance. De-industrialisation would become one of the main consequences of these policies.

\section{Consequences of the structural adjustment programme}

What were the economic and social consequences of the SA programme? How and why did it finally evolve into the present crisis? What the main 


\section{Norma Giarracca and Miguel Teubal}

defenders of the SA policies do not say, is that the model implemented in Argentina was: (a) highly regressive, in terms of its consequences for income distribution and distribution of wealth; (b) did not lead to a sustained growth and development process; and (c) was highly vulnerable to external and domestic shocks, something that the events of the mid-and late 1990s brought to light forcefully. Needless to say, these characteristics are interrelated. It soon became evident that the Convertibility Plan, together with the privatisations and the associated measures related to the severe structural adjustment programme implemented in the 1990s, contributed to the increased regression in the distribution of wealth and income in numerous ways and that this can be considered a key factor leading to the present crisis.

While in the mid-1970s economic policy furthered the power of the large economic groups (Azpiazu, Basualdo and Khavisse 1986) the SA programme contributed to consolidating this power (cf. Basualdo 2000). The Convertibility Plan and the privatisation programme favoured the large local economic groups as well as assorted foreign transnational interests. Concentration and centralisation of capital was the mark of the day. This implied in part specially favouring local capital in the early 1990 s, while in the late 1990s the bulk of these interests were sold out to large transnational corporations. Towards the end of the decade the takeover by foreign capital became one of the marks of the neoliberal process transforming local economic groups into a sort of 'rentier' bourgeoisie. These processes were intensified due to the importance acquired by financial and service industries in the Argentine economy in relation to the deteriorating importance of the productive sectors.

De-industrialisation led to a changeover in the industrial structure of the economy. It was complemented by the increased control by foreign capital of certain key areas associated with banking and finances. While the banking and financial interests were favoured throughout the period, towards the end of the decade foreign banks acquired an increased significance. De-industrialisation and the change in industrial structure affected small business that lost out drastically. This factor together with the restructuring of the economy as a whole contributed to unemployment, a greater regression in income distribution, and increasing poverty. In other words, all the trends that appear magnified in a crisis situation were already present in the 1990s.

Apart from the structural changes to which we make reference, relative prices changed substantially, nominal wages were controlled and therefore fell in real terms, the domestic market was weakened and hence much small and medium-sized business found it difficult to survive due to reduced domestic demand. Public tariffs increased with the wholesale privatisation of utilities. Argentina emerged with the highest rates in the world that contributed to deteriorating living conditions. Nevertheless this permitted the privatised service companies to have the highest profit rates of the whole economy (Basualdo et al. 2002: 64). Furthermore these same companies did 
not always fulfil their contracts, and illegally increased their rates. This contributed to increased costs, to deteriorating living conditions and to increased outlay for small business. Interest rates were also maintained at high levels, much higher than international rates. To a large extent the whole economy pivoted around these interest rates, and the need to provide for new debt financing. All these measures combined with an overvalued exchange rate and low tariffs to de-industrialisation, and regression in income distribution, and to a lack of a viable industrial export strategy. In many cases specific rules were favouring large business, for example supermarkets vis $\dot{a}$ vis small shops. The instability of the system was reflected in the possibility for capital flight when 'confidence' was lost, for example during the Tequila crisis of 1995.

On the whole, convertibility and fully fledged openness to international financial capital contributed to instability. This was seen during the successive crises that followed the Tequila crisis: the Asian, Russian and Brazilian crises. The vulnerability of the Argentine economy to external shocks became evident, with capital outflows occurring at a moment's notice. Vulnerability was also great due to variability of export prices, in particular in the late 1990s. The expansion that had begun with Convertibility petered out in the mid-1990s. The lack of confidence created by the Tequila crisis in 1995 induced speculative capital to withdraw. Stock prices fell sharply on the Buenos Aires Bolsa. The economy fell into recession, unemployment soared from 12 to 18 per cent in less than six months. This also went along with a run on the banks. But at that juncture the government managed to sail through the turbulence.

The Tequila crisis reflected the increased vulnerability of the Argentine economy to speculative capital movements. After this crisis it appeared that the external shock had been absorbed in 1997 and 1998 and GDP resumed its increase somewhat (see Fig. 3.1). But stagnation set in once again in 1998. Demand and wages fell, while unemployment and poverty increased. The change of government in 1999 generated expectations that were rapidly betrayed due to the adjustments applied by the government of the Alianza: taxes were increased, nominal wages were reduced, and laws providing for increased flexibilisation of labour were controversially passed. For one, the threat of a default soon began to be put on the agenda. This latter aspect of the crisis situation was apparently what most worried the national and international establishment, given that it had direct relations with their financial interests. The need to acquire rollovers of foreign debt servicing elicited more and more adjustments which, however, only caused more and more recession without solving the presumed problem of the fiscal deficit.

Early in 1998 the Argentine economy veered inexorably towards recession, depression and finally crisis. At no time were measures of a counter-cyclical nature applied, only more and more adjustments, catering to the need to appear 'responsible' to international moneylenders. At a certain juncture Minister of Economics José Luis Machinea, a 


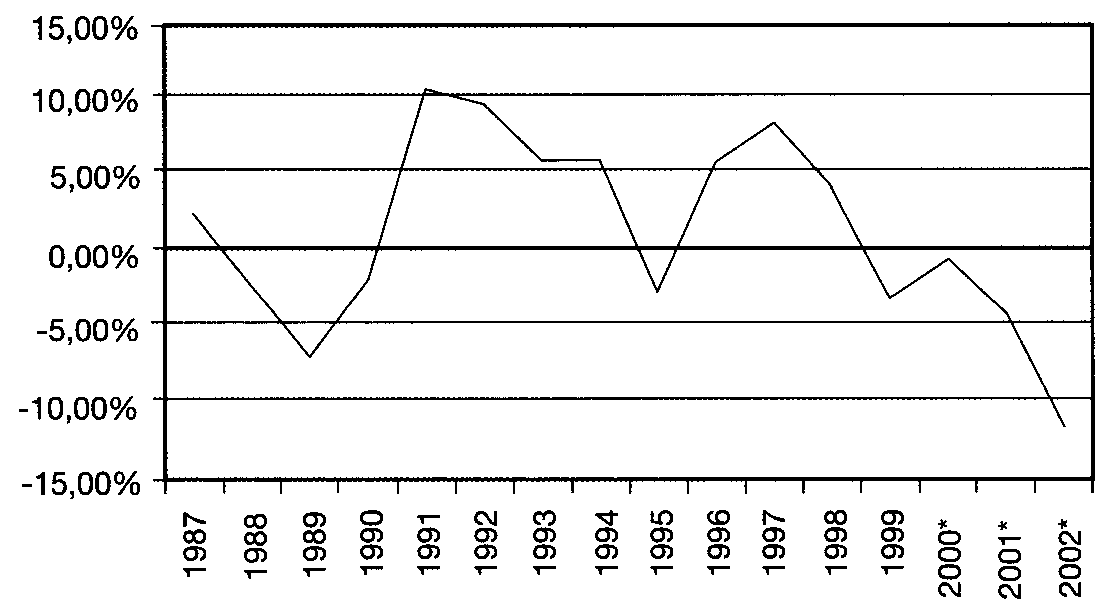

Source: Dirección de Cuentas Nacionales (2002)

Figure 3.1 Argentina: Percentage variation of the GDP, 1987-2002

structuralist turned orthodox, was substituted by Domingo Cavallo, the wizard of the Carlos Menem years. Some people thought that Cavallo was to apply a heterodox policy and maybe end the convertibility, thereby leading Argentina out of crisis. However, all he did was to concoct special package deals tending to roll over debt servicing, exchanging old foreign debt bonds for new ones at great cost (and with great profitability for his banking friends), but with a still greater increase in foreign debt; all this with the IMF concurring and providing the required additional funds. Cavallo's main objective was to save convertibility and to avoid default at all costs. ${ }^{1}$ Nevertheless, the country risk index skyrocketed and money became more and more expensive. Confidence was lost. The Argentine government was worried about this but the recession continued, leaving the government with less money to cope with the reductions in the fiscal deficits required by the IMF. In the meantime savers had been induced to place their savings in the banking system, mostly in foreign banks. Pedro Pou, the President of the Central Bank, proclaimed the solidity of the Argentine banking system: home offices would act as a lender of last resort in favour of depositors, he assured. Of course this did not occur when the crisis set in.

In 2001 the debacle was let loose. Bankers were responsible for capital flight, they sent their money to their home offices, presumably in payment of debts. The establishment also contributed to capital flight, not only a flight 


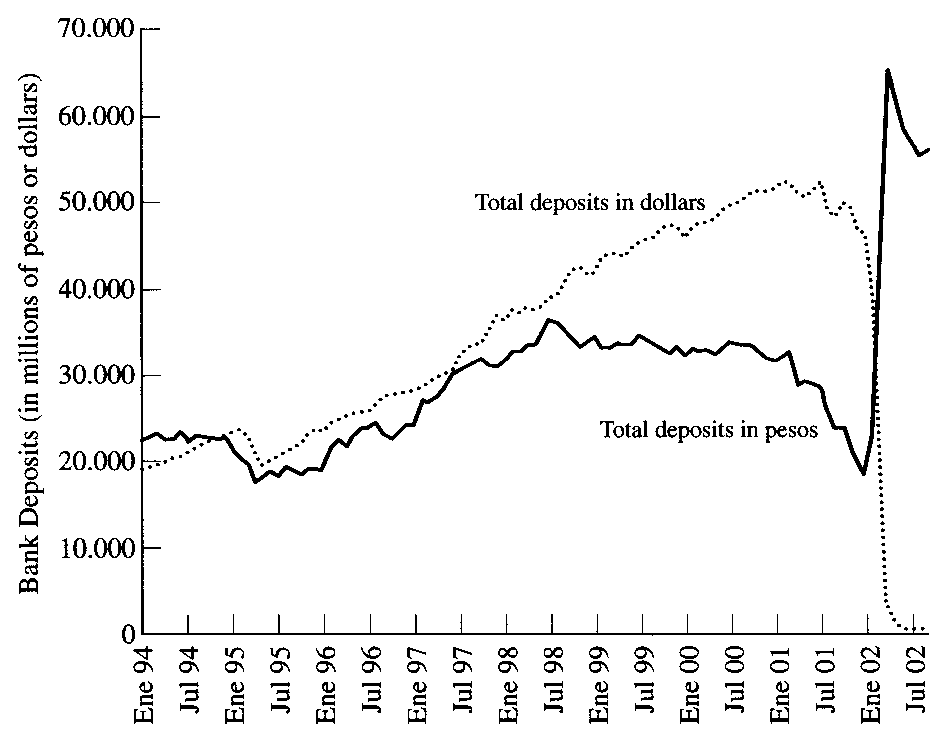

Source: Banco Central de la República Argentina (2002)

Figure 3.2: Argentina: Bank deposits, 1994-2002

from the banking system and into the dollar but also abroad. Large savers withdrew their deposits despite very high local interest rates. Exchange reserves fell drastically to the tune of $\$ 16$ billion and the banks were put on the spot (see Fig. 3.2). It was at this juncture that Cavallo created the corralito, the limitations on savers to withdraw their savings. At the beginning he permitted transfers within the banking system, but thereafter the corralito was established: savings were compulsorily 'pesified' (de-dollarised) and/or transformed into government bonds, payable in up to twelve years. To save some banks, the whole banking and financial system was put in question. Thereafter, convertibility was done away with, the peso was devalued, and due to the maintenance of the relatively free foreign exchange market devaluation skyrocketed to 360 per cent. This was followed by the biased pesification of debts and credits, and by pressures on behalf of petroleum companies, exporters, privatised services and supermarkets to increase prices. Inflation once again set in, reaching by mid-2002 about 40 per cent (by October 2000 wholesale prices in the year had increased 123.5 per cent), whereas inflation was directly related to the price of the dollar, since real wages, with inflation, fell drastically. 


\section{Norma Giarracca and Miguel Teubal}

\section{The crisis in 2001-2002}

Since 1998, Argentina's GDP has fallen systematically. In 2001 it fell 4.5 per cent, and in the first quarter of 2002 it was falling at a record 16.3 per cent (see Fig. 3.1). Based on official data it is estimated that by June 2002 the Argentine GDP was 25 per cent lower than what it was in 1974. In June 2002 unemployment reached over 23 per cent of the active labour force (in 2000 open unemployment had been 14.7 per cent) while another 22 per cent was 'underemployed' in part-time jobs. Diverse forms of unemployment and precarisation of employment had become endemic in the Argentina of the 1990s (see Fig. 3.3).

Real incomes worsened for the bulk of the population, except for those in the upper 10 per cent income strata. In 1974, the poorest 10 per cent income earners of the population received 2.3 per cent of GDP and the richest 10 per cent of the population received 28.2 per cent of GDP, which is 12.3 times what the poorer strata received. In 1990, the richest 10 per cent income earners absorbed 35.3 per cent of total national income, while the poorest 10 per cent income earners still received 2.3 per cent. And in 2002, the poorest 10 per cent income earners received only 1.1 per cent, while the upper 10 per cent received 37.6 per cent of GDP, which is 33.6 times more than the poorest income

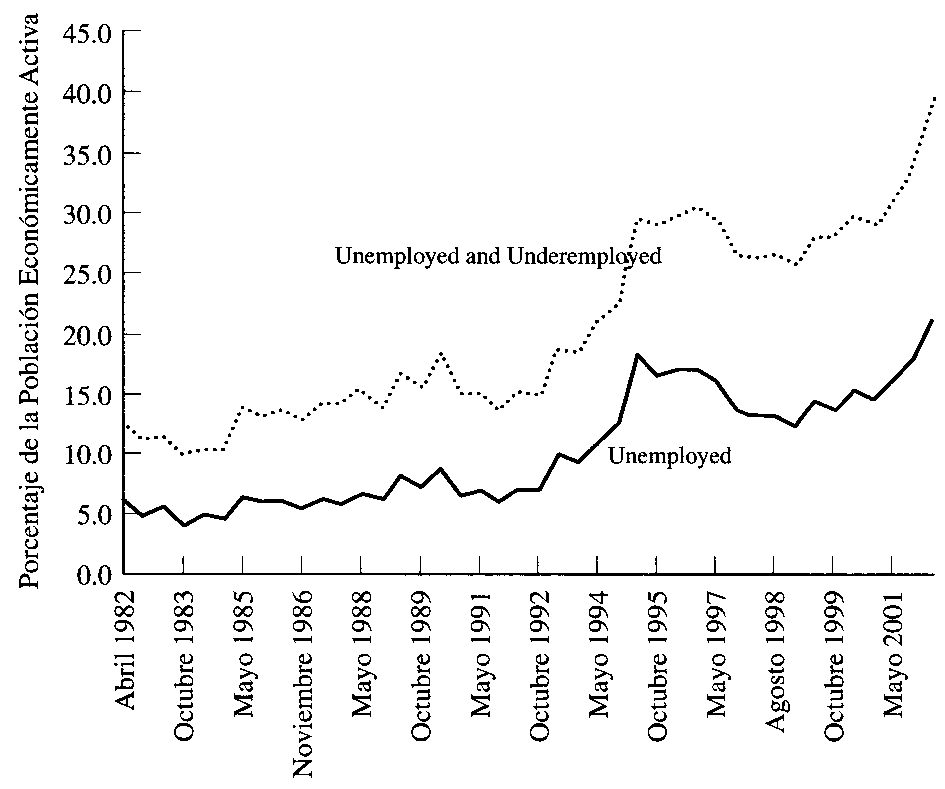

Source: INDEC (2002)

Figure 3.3 Argentina: Unemployment and underemployment, 1982-2002 
strata. In recent years, 90 per cent of the population has seen their incomes slashed and eroded drastically, and the transfer of income and wealth has been enormous. The development of the new bargaining markets may be a manifestation of this. The situation is particularly bad in the provinces.

The recent impoverishment in Argentina has been one of the greatest and fastest in the world. Poverty and hunger in Argentina in 2002 reached scandalous proportions. In the early 1990s only 15 per cent of the population had incomes below the poverty line, but in 2000 this proportion had reached 30 per cent, and between January and May of 2002 the number of poor grew by 3.8 million, that is 762,000 per month, 25,000 per day. By June 2002 more than half the population (about 18 million inhabitants) were poor, that is, living below the poverty line; and 22 per cent ( 7.7 million) were registered as living under the indigence line (see Fig. 3.4). In the country as a whole 58 per cent of the 9.8 million people younger than 14 years old are poor and 28 per cent are going hungry. As Claudio Lozano (2002) of the Central de Trabajadores Argentinos (CTA) puts it, "[Argentina] is a country in which the majority of poor are young, and the majority of the young are poor'. Simultaneously, a large proportion of the retired who depend upon their retirement pensions, which had already become very low, have fallen into the category of indigents. Many of them form part of the new poor, mostly middle class, that rapidly fell into poverty in recent years. In addition, most of the unemployed are indigent, but even so 1.8 million of the employed are also indigent. In the period May 1998-May 2002 'indigent employment'

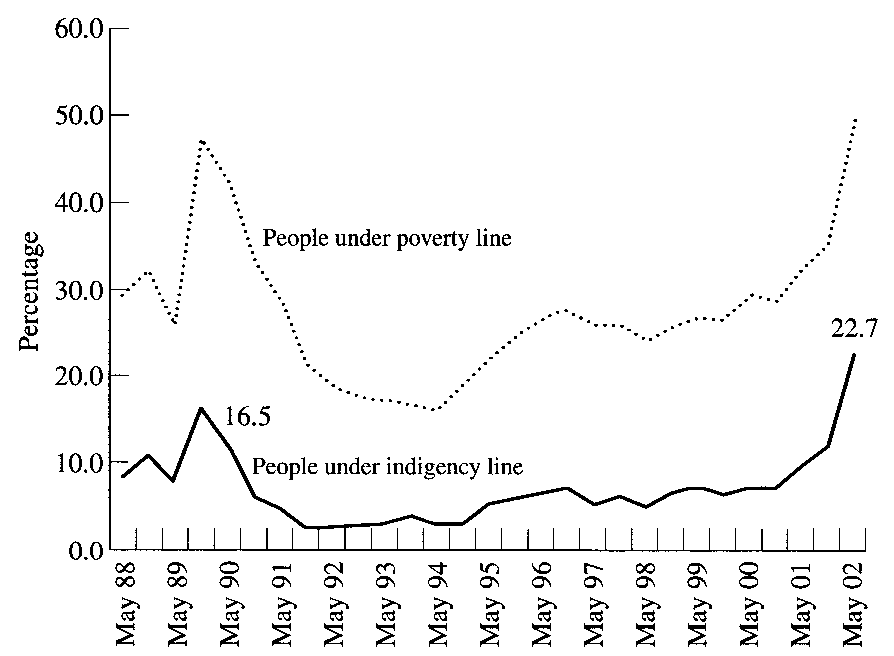

Source: Encuesta Permanente de Hogares (2002)

Figure 3.4 Argentina: Poverty and indigence rates, 1988-2002 
increased 70 per cent, representing 733,000 very low paid jobs (Página 12 Cash, 13 October 2002).

The scale of impoverishment is indicated in the increased indices of infant malnutrition. For instance, in 2002, in the district of Matanza pertaining to the greater Buenos Aires area, more than 58 per cent of children are malnourished, and more than 60 per cent of children in Misiones (in the north) have anaemia, due to cuts in Government provision of food to schools. This food situation is truly scandalous when it is considered that Argentina produces enough food to feed 300 million inhabitants adequately, eight times her present population of 36 million. Argentina produces among other things 70 million tons of cereals, 2 tons per person, one of the highest rates of cereal production per capita in the world. Yet millions of people have gone hungry, and the spectre of people seeking their food in the garbage is tremendous. In addition, health services have also deteriorated and medicine is lacking, whereas education is also having its funding reduced. In many provinces teachers, public employees and doctors have gone for months without receiving their salaries. As a result, Argentina is being transformed into a country of emigration, while historically it was one of immigration.

Evidently this dramatic social situation is related to the collapse of economic activity. In the first months of 2002 industrial activity fell more than 18 per cent, and as an example automobile production fell 55 per cent in the first ten months of 2002. In 2001 industrial production had already fallen 10 per cent, while the closure of factories had started in 1999. In 2002, industrial capacity was 50 per cent in the majority of industries.

A peculiarity of the Argentine case can be related to the near bankruptcy of the financial system, largely due to wholesale transfers made by foreign banks to their home offices. While structural adjustment policies contributed to the recession and the crisis, the massive withdrawal of funds by foreign and domestic elites - tolerated and induced by foreign banks contributed to the precarious financial situation. Between 1999 and 2001 IMF loans only served to pay the banks and international financial interests, and of course to service Argentina's ever-increasing foreign debt. But by creating the so-called corralito, the 'credibility' of the banking system as a whole was put in question. The IMF pressured the Argentine government to change the law of economic subversion, which could be used to prosecute foreign bankers implicated in illegal transfers of money to the tune of $\$ 50,000$ million in 2001-2002. Yet with a lack of funds and the refusal of the home offices to refurnish their local affiliates with the money that had been withdrawn, the IMF accused local savers of the crisis. The IMF and the World Bank also pressured the Argentine government to assume responsibility for the depositors' money by issuing a compulsory bond, payable in the future, thus divesting the banks of their responsibility with regard to their own depositors. In the absence of funds and given the refusal by the foreign banks' home offices to recapitalise their Argentine branches, banks declared themselves on the verge of bankruptcy. 
Together these measures contributed to the overall crisis. They froze the supply of credit, broke the chain of payments, thus contributing to a deepening of the recession, by now transformed into a full scale crisis. The only way the government saw as being viable to stop the collapse of some banks was via the corralito, but freezing the withdrawal of funds delegitimised completely the banking system. All in all, the crisis resulting from neoliberal policies impoverished over 80 per cent of the population, ruined industry, and robbed the savers of their money that had been invested in good faith. No wonder that almost all walks of life have gone to the streets, because of the massive nature of the damage being done. Not only the unemployed were robbed of their jobs, the workers of their wages, the middle classes and pensioners of their savings and pensions, but the very foundation of the capitalist system has been put in question. After all, what about the property rights of the people?

\section{A decade of protest}

The Convertibility Plan of 1991, applied by the government of Carlos Menem and his Justicialista Party that won the elections of 1989, marks not only the beginnings of a neoliberal programme that would end eleven years later with the events of 19 and 20 December 2001, but also the beginnings of a nationwide 'cycle of protest'. With the return to democracy in 1984, the CGT (General Confederation of Labour) and the large trade unions were the main organisations that confronted the adjustment policies of the Radical Party at the time in power, while the human rights movement made claims for justice and the punishment of those responsible for the repression during the Military Dictatorship.

Nevertheless, in the 1990s social protests were to a large extent of a different sort. First, they mostly originated in the interior of the country, though in many cases they rapidly extended themselves towards the centre and the city of Buenos Aires. This was the case for agrarian movements that were not related to the traditional corporate organisations of the agricultural sector, and for movements of consumers of newly privatised services (cf. Giarracca et al. 2001; Giarracca and Teubal 2001). Also the movement of the unemployed, known as the piqueteros, began in 1996 in Neuquén (in the south). This initiative has later on been replicated and expanded to many provinces, and in 2000 it reached Buenos Aires. Second, the number of social conflicts was high, as a report by the Consultora de Investigaciones Sociales Independientes (CISI 2000) shows. ${ }^{2}$ According to data presented in Fig. 3.5, throughout the 1990 s no less than 1000 conflicts per year took place; and 1995, the year of the presidential re-election of Menem (and of the Tequila crisis), represents a peak in this respect. Thereafter there was a reduction in the number of protests, but since 1997 these have once again been increasing. Third, in the 1990 s many protests were carried out by social actors other than trade unions and human rights movements, such as the groups of unemployed, neighbourhoods (barrios) and farmers. 
Period 1991-2001

and the most important economic and politic events

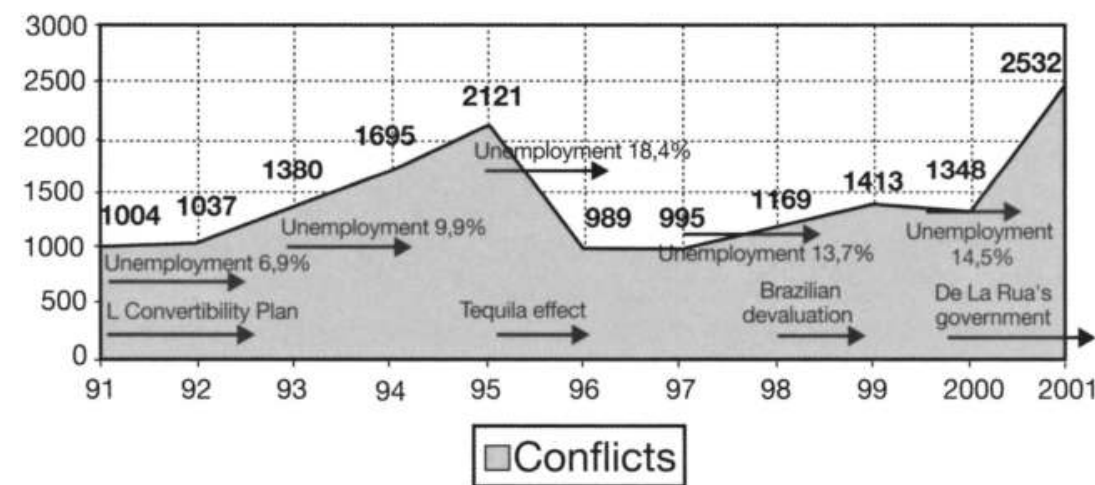

Source: CISI (2000: 6)

Figure 3.5 Argentina: Total number of conflicts during the Convertibility Plan, 1991-2001

The protests of organised labour also changed in the 1990s. Unemployment and the connections of traditional trade unionists with the governing Justicialista Party contributed to a reduction of the activities by these unions. There was a split in the powerful CGT and two new trade union organisations emerged: the Central de Trabajadores Argentinos (CTA), and the Movimiento de Trabajadores Argentinos (MTA). The CTA and the MTA were the main organisers of the trade union protests of the decade, such as marches, demonstrations and occupations, although strikes continued to be the main form of protest ( 35 per cent), followed by demonstrations (28 per cent) (CISI 2000). However, over 90 per cent of all of the decade's social protest was ignored by the power structure prevailing in the country, that is, either by the state or the private sector.

The 1990s was the decade of struggles for the maintenance of rights that had been acquired, and of patrimonies that had been accumulated - such as the land that family farmers maintained for generations - and struggles for the maintenance of social positions that had permitted access to health care, education and housing. Trade union actions changed and new unions especially were supported by other social movements. While unionism remained important in the new social protests, especially through the mobilisation of the new trade union organisations, protests by other types of organisation 


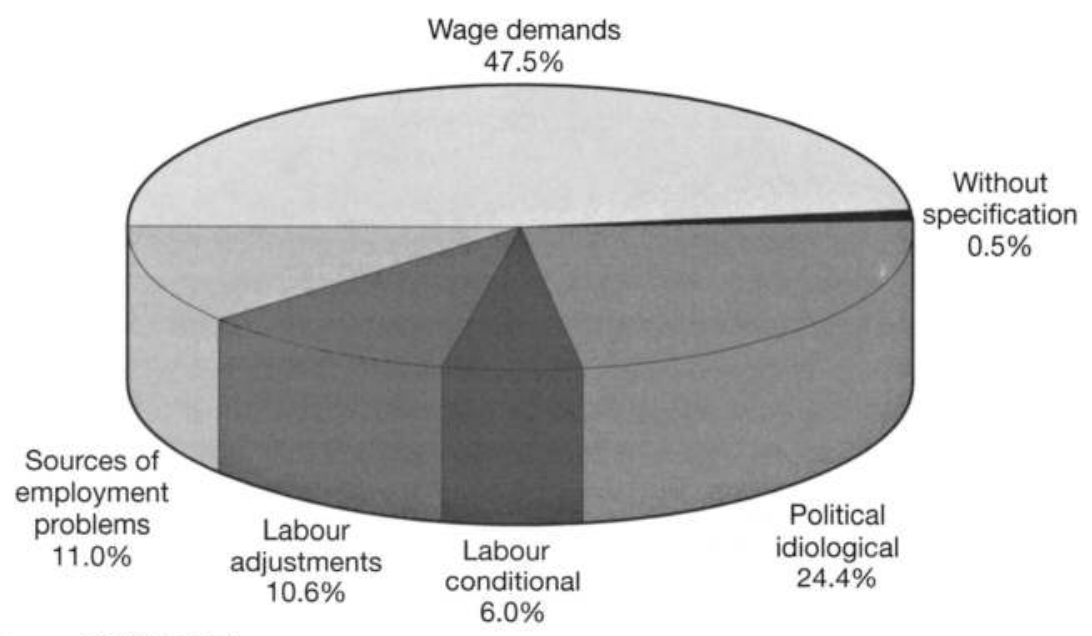

Source: $\mathrm{CISI}$ (2000: 60)

Figure 3.6: Argentina: Causes of conflicts, 1993-2000

grew more substantially. In conflicts with the private sector, workers' demands often had to do with the maintenance of sources of employment and deteriorating working conditions (see Fig. 3.6). However, the main reason for labour conflicts was wages, in particular in the cases when the employer was the state. Unions of teachers and public employees, pertaining to the CTA, led many of these protests. The struggle for the maintenance of public education was sustained by teachers, university students and parents. For more than two years, the protest by the primary teachers of CTA was important for representing the symbolic claim of many demands. After having started in Neuquén (like the piqueteros), teachers installed a large tent at the head of the National Congress where groups of teachers fasted (each group spending three or four weeks fasting together). The teachers received the support of other social actors, of international visitors, of musicians, artists, journalists, etc. Their carpa blanca (white tent) was only withdrawn when the government of the Alianza assumed power in 1999, for many of the new government authorities had been very committed to the teachers' struggles and had promised to seek increases in the budget for public education. This was probably the protest that showed most clearly how a trade union claim could be articulated with the newly emerging social movements.

Of the social protests that were not based on the trade union movement, many had to do with politics, especially with deregulation. Deregulatory measures of the government affected certain economic sectors and the social 


\section{Norma Giarracca and Miguel Teubal}

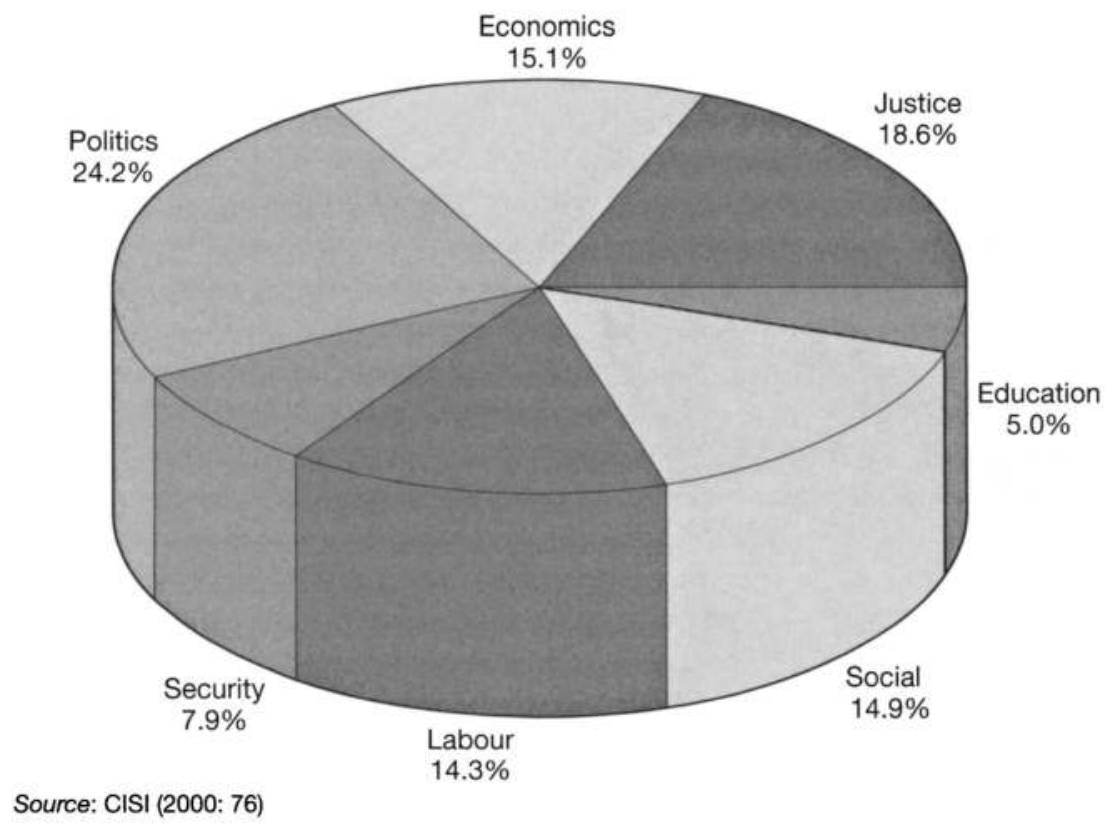

Figure 3.7: Argentina: Causes of conflicts, 1997-2000

security system, and undermined some of the institutions that had been created in the first decades of the twentieth century. As Figure 3.7 shows, other protests were related to the fact that the judiciary was strongly subordinated to the economic and political power structure ('justice'); protests against economic measures that reduced the budget for social spending ('economics'); employment and work programmes for the unemployed ('labour'); struggles for public education ('education'); and a series of civic claims associated with greater liberties, public security and rights ('social').

\section{Deepening protest and popular uprising}

The two years of the government of the Alianza (1999-2001) was a period of new adjustments, increased impoverishment of greater segments of the population, and an intensified struggle of the unemployed to obtain work programmes. It was within this context that the climate of a rejection of the political class was extended, especially after the corralito exasperated the savers. ${ }^{3}$ During the week beginning 16 December 2001 there were numerous protest actions of different sorts: protests in the provinces similar to those described above; new types of protest by savers and by owners of small 
companies in Buenos Aires against the corralito; rebellions against municipal authorities in many provinces; and numerous lootings of supermarkets and food shops around the country. Thus there were new and old forms of protest as well as looting on behalf of the more desperate segments of the population. Many of these were induced by the peronista 'caudillos' in order to destabilise the de la Rúa government.

What worried the government most was the nationwide looting that had been going on for several days. In some cases looting had started by groups of unemployed. The intervention of the national and provincial authorities that convinced shopowners to distribute sacks of food in many cases impeded more looting. Nevertheless, in all the provinces looting was severely repressed, and in many cases there were confrontations with the police. Seven dead were officially recognised, and there were 140 persons wounded and 551 detentions. In the afternoon of 19 December the national government decided belatedly to put into effect an emergency plan for the distribution of food. Together with this announcement it accused looters of being 'activists', thus preparing the way for the state of siege. When the president in effect signed a decree declaring the state of siege for 30 days, there was an immediate and massive response of civic disobedience.

In our view this moment marked an important break. First, it was a massive action of civic disobedience against something that in other periods may largely cause consternation: the declaration of the state of siege. Second, inhabitants of neighbourhoods of the city of Buenos Aires did not come out into the streets because of certain organised sectoral claims or social identities, but spontaneously, to spend the whole night in the streets, shouting what would become an expression of a new collective identity: 'que se vayan todos'. With this shout and the profoundly disruptive character of the massive demonstration, the crisis in the system of representation was visibly and dramatically shown. The following day showed the impotence of a government that had been disobeyed and delegitimised, and whose only reaction was to give leeway to an extreme violence that was to cause a substantial number of fatalities.

\section{New forms of political participation}

After 19 and 20 December there were other demonstrations, marches and cacerolazos (noisy protests with pots and pans). The first series took place after Carlos Grosso, the corrupt ex-mayor of the city of Buenos Aires, was incorporated in the national government. The porteños were outraged by his designation and also with the new government of Adolfo Rodriguez Saa. That same night Grosso resigned, and two days later Rodríguez Saa also resigned the presidency. These two moments of popular mobilisation - that caused the resignations of de la Rúa and Rodríguez Saa - strengthened the idea that the people in the streets could regain the power that had previously been transferred to their representatives, and that they could cause changes at 


\section{Norma Giarracca and Miguel Teubal}

the level of the state. By discovering their power to dismiss or remove their representatives from office, groups of citizens became aware of their capacity to 'institute'. How could this capacity be maintained by people mobilised in the streets? And what would be the reaction of the other state powers - the legislature and the judiciary - to this new political expression? These were questions that the new situation elicited at the beginning of January 2002, at the same time a new government was voted into office by the legislature.

Three new forms of action derived from the events of 19 and 20 December: the weekly demonstrations (every Thursday) demanding the resignation of the Supreme Court; those emerging from the constitution of the asambleas populares (popular assemblies), also known as asambleas barriales or asambleas vecinales (neighbourhood assemblies); and the weekly cacerolazo and demonstrations to the Plaza de Mayo. ${ }^{4}$ The protest against the Supreme Court was first waged by the Asociación de Abogados Laboralistas (Labour Lawyers' Association) and gave way to a demonstration that mobilised many people. They demanded the resignation of the nine members of the Supreme Court named by different democratic governments who had acted in a way subservient to the needs of the government, even in cases when charges of corruption were considered. This process led to a request for a juicio politico (political judgement), which was however rejected.

The formation of numerous Asambleas populares was one of the most interesting and permanent consequences of the events of December 2001. Inhabitants of neighbourhoods of the city of Buenos Aires and of some zones of Greater Buenos Aires constituted a series of Assemblies. These assemblies were on the whole formed spontaneously, as was a large Asamblea Interbarrial (Assembly of Assemblies) meeting every Sunday in Parque Centenario in the city of Buenos Aires. To Parque Centenario converged representatives of the asambleas barriales (most of the time on the basis of rotation) with a series of mandates that had been accorded in each of the neighbourhoods. At the end of each Sunday all proposals of the day were voted, and those that were passed constituted mandates for the whole of the participating assemblies. The asambleas were as varied as are the barrios of Buenos Aires and various topics were discussed. As the months passed by, many of the initial slogans were abandoned and other problems related to the crisis of state institutions were discussed. For example, in the first weeks certain proposals were made, such as 'no pagar la deuda externa' (no payment of the foreign debt), or 'que se vaya Duhalde' (out with Duhalde, the provisional president). Later on, each assembly or grouping of assemblies continued discussing these themes but also oriented themselves towards solving other down-to-earth issues such as health problems, food consumption, the payment of services, etc.

In our view one of the most interesting aspects of the assembly movement is the implementation of another way of thinking about the political process. Instead of delegating power to representatives during elections only, leaving the government to make decisions in the name of a 
'majority', a permanent participation of the citizenry has been arising. The public arena has thereby been transformed into a site of deliberation, of encounter, of debate and decision-making, and of rejection of government decisions. Contrary to traditional forms of representation, the assemblies are organised horizontally. In the assemblies, participation is established merely by one's presence, everyone speaks in turn, and identities that could establish any sort of hierarchy are rejected. Representation is only temporary or transitory for the purpose of the meetings of several assemblies, as the old idea of an organisation with a fixed or 'professional' leadership is done away with. Although participation decreased after a few months, the asambleas continued functioning. Most of them have oriented their activities towards solving the more crucial problems of their constituencies, such as integrating 'clubes de trueque' (exchange clubs), carrying out joint purchases of food, and supporting the hundred or so factories that have been 'taken over' by their workers, many of which have been transformed into cooperatives. However, many parties of the left consider the asambleas as a space for political militancy, and have tried to give them a certain 'direction'. In this respect the legislators of the left consider the slogan 'que se vayan todos' as not affecting them, and on several occasions tried (sometimes successfully) to put themselves at the helm of the demonstrations against the politicians in general. This has created tensions within the assemblies, as many asambleistas openly reject these attitudes while others are more tolerant. ${ }^{5}$

\section{The piquetero movement and the MTD}

As mentioned, the struggles of the unemployed piqueteros spread to the whole country by 1997, but beginning with the events of December 2001 they were transformed into a piquetero movement. Under this heading are a series of varied organisations that bring together a group of unemployed people demanding social plans from the government. Other social actors can also participate in this movement, such as teachers, workers and pensioners. The piquetero movement includes a long list of organisations. The oldest is the Unión de Trabajadores Desocupados of Salta, that was formed during the struggles of 1997. In that same year several organisations of unemployed were organised in the Province of Buenos Aires, but they only obtained a measure of visibility in 2000 and particularly in 2001 .

A division that can be made within the piquetero movement has to do with the degree of autonomy or dependence of each group in relation to traditional political parties or trade unions. For example, the Bloque Piquetero Nacional includes organisations associated to certain parties of the left, for example the Movimiento Territorial de Liberación that responds to the Communist Party, and the Polo Obrero responding to the (Trotskyite) Partido Obrero. Another grouping of organisations responds to the CTA, while a third grouping known as the Movimiento de Trabajadores Desocupados (MTD) declares itself to be 


\section{Norma Giarracca and Miguel Teubal}

autonomous and independent of the old forms of representation. In this respect the latter has strong similarities and connections with the asambleas and therefore can be considered another of the new forms of political organisation emerging at present.

The piqueteros of the MTD are reunited in the Coordinadora de Trabajadores Desocupados 'Aníbal Verón'. As is the case with the assemblies, these piqueteros propose new forms of political activity that would lead to ongoing power of grassroots organisations, without delegating it to other instances of representation. The organisation has no (formal) leaders, functions within the organisations are performed by rotation, and all decisions are taken in assemblies in which all can participate. As a piquetero mentions in an interview: 'All is decided in the asamblea, nothing outside of the asamblea. When we speak of horizontality we mean that nobody is above anybody. We do not recognise leaders. Our practice has shown us that we can construct without leadership. [...] All delegates are removable. What we call the general chair [mesa general] is formed by the delegates of the barrio, who do not have a decision-making capacity, only an executive capacity. The chair executes the assembly's mandate. On the other hand the barrio delegates also rotate' (Página 12 14 October 2002: 15).

The MTD was constructed horizontally by all its participants, and its three main priorities are 'work, dignity and social change'. Dealing with problems in a communitarian way, these priorities can be changed, since they are not fixed. As with the assemblies, the MTD develops on the basis of the presence and work of its members, that involves blocking main roads (their most important form of action) and taking part in various work projects. These activities generate piquetera identities no matter what are the origins of the persons involved. The organisation has a precarious division of labour: productive projects, health care, formation (education), politics, press, external relations, security, etc., but no coordination is permanent. While previous expertise is respected, all participants can be trained for any of the required tasks. The organisation brings together about 7,000 families from different barrios of Greater Buenos Aires, the majority receiving the government's social support. Part of this money is used for productive communitarian projects, which permits the 'material life' of these families to be reproduced and contributes to the generation of new social relations. This set of productive projects is called 'economia solidaria' (solidarity economy). The piquetero of MTD Solano, quoted in the previous paragraph, states: '[W]e believe that the only way of solving the social problems of present Latin America is by constructing a new society, on a daily basis, in our daily work, in the creation of new social relations between our compañeros' (Página 1214 October 2002). ${ }^{6}$ Some piqueteros find that they have learned to go along step by step. 'We advance very slowly, but we go along together. [...] Maybe we will take longer to arrive, but we will do so all together.' 


\section{Final reflections}

One of the matters that the crisis and popular explosions of 2001 have made clear is the power structure of Argentine society. The deteriorating living conditions of vast segments of the population have revealed the fact that 'the people' are located in one part of society - the unemployed (many by now submerged in misery and hunger), but also the vast middle class - while the government, the politicians and the diverse segments of the establishment that sustained them (including international financial interests) are located in another. Neoliberalism implied the extreme polarisation of Argentine society, the social outburst of December 2001 being to a large extent a protest against some of its main tenets. In this respect the Argentine protest movements tie up with the anti-globalisation movement, although they may be even more grassroots-based than in other countries.

The economic aspects of the crisis have not as yet been solved, if they really have a 'solution' at all. Despite the initial declarations of Duhalde when he assumed the presidency that policy was to change, events thereafter showed otherwise. Throughout 2002 GDP and wages continued falling, unemployment increasing and factories closing. The new Minister of the Economy, Roberto Lavagna, managed to stabilise the dollar, set in some exchange controls, sought exporters (e.g. of oil and grain) to provide foreign exchange, and did not immediately heed the IMF's most extreme liberalisation demands. Despite the default declared by the previous president Rodriguez Saa, however, the government continued paying much of the debt it owes to international organisations. And the economy has in some areas become 'competitive' due to devaluation. While all these factors and measures may have contributed to at least a levelling-out of the crisis situation, the economy remains highly vulnerable to foreign shocks, as well as to IMF pressures. What will happen if the world crisis finally sets in? What will happen now that Luiz Inácio (Lula) da Silva is at the helm of government in Brazil? These questions only set forth the complexity of the macroeconomic situation affecting the Argentine economy.

Apart from this the new government has to respond to the political crisis that remains unsolved. The Supreme Court was finally maintained despite Duhalde having initiated procedures in the legislature to have the judges removed. And the popular call for elections was translated into a promise for presidential elections, not for a renewal of legislators or governors. In other words, no institutional change is being accorded that could minimally legitimise or transform the present political system. More than half of Argentines have stated that they are not going to vote, or will not vote for any candidate or any of the present political parties. Many are claiming the need for an overall constitutional change, that would change all legislators at all levels, as well as changing the forms of representation. A lack of legitimacy of the political system and of government policies has led to increased insecurity and increased violence. The stalemate in legitimacy has also led to 


\section{Norma Giarracca and Miguel Teubal}

an increase in repression. But a lack of solution to the economic and institutional crisis is equally contributing to an increase in violence, such as kidnappings and robberies.

On the other hand, a new popular economy seems to be emerging, based on need and solidarity. This is occurring at different levels. The 'clubes de trueque' have been going on for quite some time. At the level of the asambleas the communitarian purchase of food (mainly fresh vegetables) has become important, connecting as well with small producers, many organic, of the Buenos Aires area. Some of the assemblies also have given impulse to the development of huertas populares (popular vegetable gardens). And the piquetero movements have also embarked on productive projects, for instance the MTD of Solano has organised a bakery, while more than a hundred factories have been taken over by their workers and have been transformed into work cooperatives, which receive support of the assemblies. Although this emerging new popular economy is still marginal, it caters, like no other sector of the economy, to the needs of the people.

Nestor Kirchner was voted to the presidency in April 2003. Upon assuming the presidency in May a new situation was opened which has created great expectations. The new president introduced a series of institutional changes and a new relationship with the IMF. The new political forms that have emerged after the crisis of 19/20 December - asambleas, piqueteros and worker-operated factories - are confronted with a new scenario. Nevertheless, despite fragmentations and a weakening of their strength, they continue to be important actors of the political scenario.

\section{Notes}

1 Investigations by the legislature have shown the role of foreign banks in this crisis when they divested themselves of their foreign debt bonds, transferring them to their local branches, that thereafter also got rid of them.

2 With information provided by national and provincial newspapers, the CISI has registered the number and characteristics of a series of conflicts. On the whole they registered 16,000 protests that were classified in accordance with the "type of struggle' independently of the social actor concerned. This implied that if a trade union went on strike and then organised a march, for the CISI these would be two expressions of social protest. This would thus imply a larger number of 'protests' than if the 'action subject' were considered. Nevertheless, what is important are the variations observed throughout the decade with the same methodology being used.

3 The corralito created a dramatic situation for numerous people, the majority of whom were trapped in the banking system with savings and deposits of up to $\$ 10,000$. Some needed their money to confront terminal sicknesses, some were elderly retired and pensioners who needed their savings to survive, etc.

4 These new protests combined traditional forms of protest in Argentina - demonstrations and a great concentration of people - with new aesthetic contributions of young artists, such as murgas (popular carnival rhythms and dances) and theatrical representations However, after some time these protest forms became 'routinised' and by the end of the summer of 2002 they tended to become exhausted. 
5 The tensions created by the parties of the left within the asambleas as well as the piquetero movement reflect the Argentine intellectual and political debate coinciding with overall anti-globalisation resistance. Part of the dispute has to do with the role of the state and political parties in the new forms of thinking about politics (cf. Hardt and Negri 2002).

6 The organization has strong connections with the Movimento Sem Terra of Brazil, and has great respect for the Zapatistas of Chiapas, Mexico.

\section{Bibliography}

Azpiazu, Daniel (1998) La concentración en la industria argentina a mediados de los noventa, Buenos Aires: Flacso-Eudeba.

Azpiazu, Daniel, Eduardo Basualdo and Miguel Khavisse (1986) El Nuevo Poder Económico en los Años 80, Buenos Aires: Legasa.

Basualdo, Eduardo (2000) Concentración y centralización del capital en la Argentina durante la década del noventa, Buenos Aires: Flacso, IDEP, Universidad Nacional de Quilmes Ediciones.

Basualdo, Eduardo et al. (2002) El Proceso de Privatización en Argentina. La renegociación con las empresas privatizadas, Buenos Aires: Página 12 and Universidad Nacional de Quilmes Ediciones.

Briones, C. et al. (2002) Ruidos que hablan broncas. El decir y el hacer de las cacerolas en Argentina, Tercer Encuentro Anual de 'Performance y Políticas en las Américas. Globalización, Migraciones y Espacio Público', Lima.

Cerdeiras, Raúl (2002) 'La política que viene', Acontecimiento, 23 (Edn La escuela porteña, Buenos Aires).

Cheresky, Isidoro (2002) 'Autoridad política debilitada y presencia ciudadana de rumbo incierto', Nueva Sociedad, 179: 112-29.

CISI (2000) El conflicto social dentro del plan de convertibilidad. Argentina 1991-2001, Consultora de Investigaciones Sociales Independientes (Alejandro Gonda).

Colectivo Situaciones (2002) 19 y 20 Apuntes para el nuevo pensamiento social, Buenos Aires: Ediciones de Mano en Mano.

Colombo, Ariel (2002) 'Estas rebeliones', http://www.forodesobedienciacivil.com.

Giarracca, Norma et al. (2001) La protesta social en la Argentina. Transformaciones económicas y crisis social en el interior del país, Buenos Airess: Alianza Editorial.

Giarracca, Norma and Miguel Teubal (2001) 'Crisis and Agrarian protest in Argentina. The Movimiento de Mujeres Agropecuarias en Lucha', Latin American Perspectives 28 (6): 38-53.

Hardt, M. and A. Negri (2002) Imperio, Buenos Aires: Paidós.

Hershberg, Eric (2002) 'Why Argentina crashed - and is still crashing', Nacla Report, XXXVI (1).

Lewkowicz, Ignacio et al. (2002) Sucesos Argentinos, Buenos Aires: Notas ad-hoc.

Lozano, Claudio (2002) Catástrofe Social en Argentina. La Situación a Junio del 2002, Buenos Aires: Instituto de Estudios y Formación de la CTA.

Petras, James and Henry Veltmeyer (2002) Argentina: entre la desintegración y la revolución, Buenos Aires: Ediciones La Maza.

Rock, David (2002) 'Racking Argentina', New Left Review, 17: 55-86.

Schuster, Federico et al. (2002) 'La Trama de la Crisis', Informe de Coyuntura, 3 (Instituto de Investigaciones 'Gino Germani', Universidad de Buenos Aires): $1-74$. 


\section{Norma Giarracca and Miguel Teubal}

Scribano, Adrián (1999) 'Argentina "cortada": cortes de ruta y visibilidad social en el contexto del ajuste', in M. López Maya, Lucha popular, democracia, neoliberalismo: protesta popular en América Latina en los años del ajuste, Caracas: Nueva Sociedad.

Teubal, Miguel (2000/2001) 'Structural Adjustment and Social Disarticulation: The Case of Argentina', Science \& Society, 64 (4): 460-88.

(2001b) 'From Import Substitution Industrialization to the "Open" Economy in Argentina: The Role of Peronism', in J. Demmers, A.E. Fernández Jilberto and B. Hogenboom (eds), Miraculous Metamorphoses. The Neoliberalization of Latin American Populism, London: Zed Books. 


\title{
4 Governing Mexico's market democracy
}

\author{
Barbara Hogenboom
}

As in many other Latin American countries, Mexico's processes of liberalisation and democratisation took place almost simultaneously. The economic restructuring policy that started in the mid-1980s under president de la Madrid was extended by president Salinas and locked in in 1994 with Mexico's entry into NAFTA, and in the following years fine-tuned by president Zedillo. Meanwhile, Mexico's de facto state party, the PRI, gradually allowed for more political competition at its right (the PAN) and left (the PRD). After a period of several electoral victories at the local and state level, in 2000 the PAN won the presidential elections with its candidate Vicente Fox, and the PRI faced the end of its traditional position as provider of the president and holder of a majority in the federal Congress.

Electoral freedom and competition have advanced considerably in Mexico, at the federal, state and local level, but there is still a range of problems, such as irregularities during elections, illegal financing of campaigns, and especially in local politics many cases of conflict, abuse of power, threats and violence. Equally mixed results have been witnessed with respect to other characteristics of formal democracy, in particular the separation of power between the executive, the legislator and the judiciary, as well as the decentralisation of the state. Meanwhile, little progress has been made at the more profound levels of democratisation: citizen participation; protection of human rights; poverty reduction; and reducing economic, social and ethnic inequalities. The official reaction to the Zapatistas has shown that alternative views on democracy and development are tolerated, but not adopted.

In the eyes of the World Bank, Mexico should continue in the direction taken, and complete and consolidate its structural reforms. The Bank's main advice for president Fox at the start of his sexenio (six-year term) was: consolidate macroeconomic gains; accelerate growth through enhanced competitiveness; reduce poverty through human capital development; and balance growth and poverty reduction with the protection of natural resources. And the Bank suggests that this should be achieved 'by means of an efficient, accountable, and transparent government', with decentralisation, the judicial system, and corruption as the prioritised areas (World Bank 2001: 2). This is a clear stimulus for good governance by the institution with 


\section{Barbara Hogenboom}

which Mexico has a standing credit exposure of US\$11 billion and a "project pipeline' of about US\$1.5 billion per year. However, the Bank's suggestions for better government are not aimed at stimulating democratisation in broad terms, but at further strengthening a market democracy in Mexico. For instance, the World Bank argues approvingly that commercial and financial integration 'made it all but impossible for Mexican governments to continue substituting for private market-based resource allocation'. And its states that due to globalisation and democratisation the 'business of government' (sic) in Mexico has become much more accountable 'to both markets and voters' (World Bank 2001: 18).

In this chapter I aim to analyse the origins and political implications of Mexico's market democracy, by looking into the ways in which liberalisation, democratisation and social development have been governed. I will argue that the introduction and consolidation of neoliberal policies in Mexico have diminished the 'returns' of the country's democratisation process for its citizens because market interests and economic actors have increasingly been steering political processes. The decreased space and relevance of democratic decision-making processes, however, have been partly hidden behind formal democratisation and decentralisation. An interesting case study for the analysis of the domination of economic over political objectives, and the effects of this priority-setting for Mexico's development policies, is the relatively recent Plan Puebla-Panama (PPP). This plan for the development of Mexico's South-Southeastern region, as well as for the seven countries of Central America, was launched by Fox at the start of his presidency. Apart from public funding by the eight governments and the Interamerican Development Bank, extensive private funding is indispensable to realise the Plan goals. Simultaneously, Fox's team stresses that it is important to involve citizens in the decision-making processes of the PPP. However, representatives in federal and state congresses have no formal vote on the plan, and the demands for self-determination of social movements such as the Zapatistas have not been met. The PPP case will be discussed in the assessment of governing social development, after the section on governing liberalisation and governing democratisation. We will start here with a short introduction to the historical and theoretical context of Mexico's model of neoliberal development and democratisation.

\section{Neoliberal policies, democratisation and development}

While much has been written in recent years about the importance of institutions for achieving development, the governance debate has been dominated by the narrow perspective of institutional transparency and efficiency being favourable for attracting investors (see also Chapter 1 of this volume). More profound analyses have also looked into the need and importance of public institutions performing social and political tasks. An interesting study by Dani Rodrik shows that institutional quality in the 
broad sense is a major explanatory factor when comparing the development results of various national experiences with economic liberalisation. Rodrik stresses that strategies of increased economic openness in developing countries will only deliver much-desired economic and social progress if they are combined with three forms of institutional reform: first, improvement of the credibility of state apparatus, particularly the quality of the judiciary and bureaucracy; second, improvement of mechanisms of 'voice' of non-elites, that is, allowing and fomenting strong trade unions, strong and disciplined political parties, and a strong executive that takes the initiative in bargains and alliances with the popular sector; third, improvement of social safety nets since economic openness entails greater vulnerability for external shocks (Rodrik 1999: 97-8). He stresses the importance of institutions to mediate conflict among social groups as cleavages along ethnic, income and regional lines may give way to a situation of policy paralysis in which labour, business and other social groups block economic policies. 'Evidence shows that participatory political institutions, civil and political liberties, high-quality bureaucracies, the rule of law, and mechanisms of social insurance such as social safety nets can bridge these cleavages' (Rodrik 1999: 3).

This useful contribution to the discussion on the role of political and social institutions in developing countries' involvement in globalisation, however, says little about the tensions between the dominant (neoliberal) pattern of economic openness and a strengthening of these institutions. In the volume Fault Lines of Democracy in Post-Transition Latin America, some of these political tensions are articulated and linked to the issue of democratisation when Jeffrey Stark (1998: 76) points at the schizophrenia of Latin American government officials who attempt to be accountable to voters and markets, for they "try to project an "everything's fine" image abroad, while demonstrating to their citizens an appreciation of the seriousness of their socioeconomic problems'. As Atilio Borón (1998: 54) explains, due to economic globalisation new Latin American democracies have surrendered to transnational corporations and international financial institutions 'important margins of national sovereignty and self-determination', resulting in an emptying-out of democracy. And Norbert Lechner uses the term 'decentering of politics' and argues that, while this process started prior to the 1980s, 'neoliberalism turns the decentering of politics into a deliberate strategy'. The outcome of this process is, on the one hand, a depolitisation of the economy, and on the other hand, a 'colonization of politics by the rationality of the market' (Lechner 1998: 27, 32).

Before analysing the rise of Mexico's market economy, let us look briefly into a few of Mexico's particularities that have had a major impact on the country's pattern of economic, political and social development. To start with, Mexico's authoritarianism differed from the rest of Latin America, particularly for its stability and durability. Apart from the bloody history of the Mexican Revolution itself, the long-livedness of semi-authoritarian rule in Mexico was based on the profound entanglement of the state and the 


\section{Barbara Hogenboom}

Partido Revolucionario Institucional (PRI - Institutional Revolutionary Party). From 1929 until the early 1980s the PRI succeeded in basing its dominant position on images of unity for national development, and used little repression when compared to other Latin American authoritarian regimes. While the revolutionary element was watered down over the years, the PRI's name fulfilled its promise at the point of institutionality. Through control over the presidency, the state bureaucracy, official unions, elections, and (during the years of import substitution) a large apparatus of stateowned companies, the PRI-state ensemble built an enormous institutional framework for structural domination. Presidential centralism was a key element of Mexico's system, allowing executive control over the legislative and judicial powers. Most legislation came from the president's office, and the majority of the PRI (and affiliated parties) in Congress rendered the legislative process a decorative act. The president also appointed officials and politicians at various levels, as well as the next presidential candidate for the PRI (read: the next president). The PRI's control over the three major official unions of workers, farmers and civil servants provided the party with a massive number of members and electoral supporters, and prevented antiregime mobilisation. As many other late-developing nations have experienced, the consequence of such an authoritarian and corporatist system is a weak civil society, in which 'the majority of civil organizations operate not so much as safeguards against state despotism, than as administrative extensions of the state's highly corrupt and particulistic apparatuses' (Mouzelis 1995: 232-3).

Another particularity of the Mexican case is its North-South divide and its border at the north with the United States. For a long time - after Mexico lost more than half of its national territory to its northern neighbour in 1848 - the proximity of the US had a largely economic impact, with more than three-quarters of Mexico's external economic and financial relations stemming from the United States. Economic integration was extended in 1965 with the creation of the maquiladora programme, which encouraged export manufacturing in the border region with the US by taxing only the value added in Mexico of the export of assembled imported parts. Entry into NAFTA has further increased the Mexican dependency on the US economy. However, Mexico's major North-South differences in development are only partly linked to the fact of the United States lying north of Mexico. While the maquiladoras and the NAFTA have added to the economic and social imbalance, there is more history to the growing split between the country's modernising North and Centre (including Mexico City), and its ongoing poor and traditional South. Governmental policies have played an important role in this polarisation since the start of Mexico's industrialisation. The motor behind Mexico's economic miracle (1940-1970) was the agricultural sector that produced the much-needed cheap basic goods for the national industries. The rapid increase in agricultural production was enhanced by extensive public investment in large-scale irrigation 
projects and a national road structure in the dry north of the country. There, irrigation allowed for the creation of new farmland, and large modernised agricultural firms that could produce much higher returns than the traditional farming of small private or collective plots in the rest of Mexico (Hansen 1971). The South, on the other hand, has hardly benefitted from being the naturally richest part of the country, with enormous reserves of fossil fuels and perfect conditions for producing great amounts of hydroelectricity. The activities to free these natural resources have created only a small number of jobs, whereas the prices of these products have been the same around the country, and southern states have received little in return (e.g. in terms of infrastructure). The southern states thus have further subsidised the already subsidised production in the rest of the country, and this subsidisation of the North deepened the 'internal colonization' of Mexico's South (Lastra Bastar 2000).

\section{Governing liberalisation}

Mexico's economic restructuring agenda was both designed and pushed by technocrats. These relatively young state officials criticised the previous model of development through import substitution and state companies, and saw liberalisation as the only option to overcome economic stagnation and the debt crisis of the early 1980s. Trained in US universities and Mexican private schools, especially in economics and administration, technocrats had been educated in the liberal and neo-classical traditions. This new political elite was concentrated in planning and banking agencies and the presidential office, from whose ranks the presidents de la Madrid (1982-1988), Salinas (1988-1994) and Zedillo (1994-2000) were drawn. These institutions increasingly dominated Mexico's policy at the cost of more pro-protectionist ministries of industry, agriculture and labour (Centeno 1994).

This institutional shift and the technocrats' rise were the outcome of a struggle within the PRI against the former dominant politicos who opposed neoliberal restructuring. In the course of this struggle the technocrats were helped by a strong external insistence by private banks and financial institutions on economic restructuring, especially by the World Bank. Interestingly, Judith Teichman (2001) finds that it was not so much the World Bank pushing the Mexican government towards neoliberal reforms, but rather Salinas and his team of radical reformers (including Zedillo) using their links with the Bank to push for reform within the state-party apparatus. Based on their same educational background (and sometimes even personal ties from having studied together), and fed by extensive dialogue and contacts, Mexican and World Bank officials established relations of trust. On various economic issues, Mexican technocrats used Bank studies as well as joint studies to back up their arguments for reforms in the national political arena, while they themselves had in fact contributed heavily to their 


\section{Barbara Hogenboom}

contents. ${ }^{1}$ Compared to Chile and Argentina, its geopolitical importance gave Mexico much more influence with the Bank. Moreover, 'Mexico's market reform process was the most technocratically driven' (Teichman 2001: 157-8).

Under de la Madrid, economic restructuring was gradually introduced. Although the debt crisis of 1982 is usually seen as the starting point of neoliberal policies in Mexico, the real policy shift came only after new economic problems hit Mexico in early 1985. The World Bank - like the IMF - started pushing Mexico, and posed trade liberalisation as a condition of a US $\$ 500$ million loan. President de la Madrid then announced an acceleration of structural change, including a significant liberalisation of trade regulations by replacing trade permits with tariffs, and by cancelling or lowering many direct export subsidies. In 1986, Mexico became a member of the GATT, and in a few years import was liberalised by an overall halving of tariff levels and reducing the maximum tariff from 100 per cent to 20 per cent. The privatisation executed by de la Madrid involved the sale of smaller enterprises, and the financial disentanglement of the rest (Lustig 1992: 177).

President Salinas aimed to complete the restructuring process. Privatisation and the liberalisation of trade, services and capital were widened and deepened, while fossil fuels and agriculture were no longer excluded. Salinas replaced de la Madrid's Pact of Economic Solidarity between the state, the business and agricultural sectors and labour by the Pact for Stability and Economic Growth, aimed at growth through private investment, export of manufactured goods, and public investment in infrastructure. Legislative reforms served to strengthen financial intermediaries: commercial banking was reprivatised in 1990; foreign investment in banks, production and portfolio was liberalised; a new act encouraged the integration of financial groups, predominantly by allowing the establishment of financial holding companies; and Salinas's modernisation programme included a repeal of regulations restricting private investment, and the abolition of most price controls. Simultaneously, Salinas successfully sought for better international relations with private and official creditors, large investors and governments. Besides closer ties with the US government, Mexico extended its international relations via new bi-lateral and regional trade agreements with Latin American partners (e.g. with Chile, Brazil, Mercosur and Central America), and membership of the OECD and the APEC (Asia Pacific Economic Cooperation).

The privatisation programme was another crucial element of the neoliberal agenda for economic restructuring. Under Salinas, major transfers of parastatals to the economic sector took place, with a value of about US $\$ 20$ billion. The companies were not sold on the open market but through a far-from-transparent state-controlled system of selection. For prices below (sometimes much below) their real value, 93 per cent of them were sold to large Mexican enterprises and economic groups (Guillen 1994: 32-3). Teléfonos de México (Telmex), for instance, was sold to the 
powerful Grupo Carso for US $\$ 443$ million, whereas its official value was estimated at over US\$700 million (Proceso 9964 October 1995: 19). By thus transferring a considerable share of the state's economic power to large private Mexican enterprises, the privatisation process strengthened them as the new pioneers of growth and development. However, these enterprises became increasingly less 'national' through their links with foreign capital. For the agricultural sector, a key measure was the reform in 1992 of Article 27 of the Mexican Constitution. Since the Mexican Revolution, the main contents of this law had been the promotion of land reforms, the protection of communal land ownership (ejidos), and a restriction of outside investments and a prohibition of foreign direct investment in the ejidos. With the constitutional reform, these regulations were abolished in order to liberalise agricultural production, thereby giving up an essential element of post-revolution Mexico.

The United States has been a source of support for Mexico's neoliberal policies as major US interests stood to gain from economic openness, growth and stability in Mexico. First, pressure by the US government on some of Mexico's major creditors, including the IMF and the World Bank, resulted in the renegotiation of Mexico's debt under the Brady Plan. Second, the free trade agreement between Mexico, the United States and Canada meant a watershed. Since a return to protectionist policy is impossible as long as Mexico participates in NAFTA, it has both strongly embedded Salinas's neoliberal policies and helped to showed the rest of the world the structural nature of Mexico's reform. Third, when the peso crisis began at the end of 1994, the United States provided the Mexican government with extensive emergency funding. When it became clear that there was insufficient Congressional support for a US $\$ 40$ billion financial injection, president Clinton arranged a US $\$ 20$ billion package of loans through an executive order.

Despite these and other efforts to contain the peso crisis as much as possible, it suddenly brought some of the weaknesses of Mexico's economic and political system into the open. The direct cause of the crisis was a combination of an overvalued peso and a balance of payments deficit, which rendered Mexico incapable of paying back its short-term public debt. This problem stemmed from an unresolved long-term tension between exchange rate policy and macro-economic policy. As president Salinas had attempted to have both low inflation rates and exchange rate stability, the overvaluation of the Mexican peso had increased, and as a consequence consumer imports were high, while the demand for domestic products and the options for expanding export were limited. This situation contributed to decreasing levels of economic growth, falling from 4.5 per cent in 1990 to 0.4 per cent in 1993 (Lustig 1995: 375). Meanwhile, 1994 had been a year of presidential elections and it had been characterised by various troubled events, especially the Zapatista uprising in the first days of January in the southern state of Chiapas, and the assassinations of the 


\section{Barbara Hogenboom}

PRI's presidential candidate and its secretary-general. The political meaning of these events will be discussed in the next section, but here they are important to help understand why the peso crisis was not prevented by a timely devaluation of the peso or a rise in the interest rate. As such unpopular solutions would severely harm the chances of the PRI in the elections, Salinas aimed instead at a sustained inflow of foreign investment and therefore he 'dollarised' the short-term public debt. ${ }^{2}$ After the elections, however, it turned out that, besides his concerns for the PRI, Salinas was also heavily motivated by a personal interest in maintaining his image as the successful economic reformer because of his prospect of becoming president of the World Trade Organisation (WTO). He broke with the Mexican tradition of devaluing before the new president comes into office so as to give the newcomer a clean start, while exceeding the Mexican tradition of illegal presidential self-enrichment to such an extent that ultimately he was expelled from the country.

Too late, then, incoming president Zedillo was left to deal with the financial legacy of the Salinas sexenio. Due to the crisis, the value of the peso was almost halved and the economic and social effects were devastating. Compared to Salinas, Zedillo turned out to be primarily a diligent caretaker, whose major successes were keeping Mexico's debt and budget deficit under control, decreasing the country's financial vulnerability, and saving the banks. The arrangement that was made to save Mexican banks serves as an illustration of the way in which the technocratic elite governed the new relationship between the state and the large companies, the envisioned motors of neoliberal growth. Via the FOBAPROA, ${ }^{3}$ the Banking Fund for Protection of Savings, Mexico's public sector has been providing unprecedented support to private banks, with a value rising from the equivalent of 5.5 per cent of GDP in 1995 to 14.3 per cent in 1999 (Guillén Romo 2002: 573). Even though Mexico's banking sector generally performs badly as a provider of capital for productive activities, between 1995 and 1998 the public resources spent had amounted to approximately US\$60 billion, five times the amount the government had previously earned by the privatisation of these banks (Székely 1999: 14). This public money was also used to bail out investors who in spite of being aware of the weak supervision of the privatised financial sector had willingly taken great financial risks. While most Mexican citizens suffered heavily from the crisis and received little governmental compensation, the saving operation of the banks took place behind closed doors, with little control by congress and only at the last stage its authorisation. As a result, there was great concern that new corrupt deals were made, possibly as a form of restitution to those bankers who had so generously - yet illegally - supported the PRI's election campaign in 1994 (Székely 1999).

Due to the extensive economic and social effects of the peso crisis, a precise assessment of the results of Mexico's economic restructuring has become difficult. Still, even though political and personal factors played a 
role in the crisis's occurrence and impact, it was neoliberal policies that had enhanced more freedom of capital flow without creating the indispensable strong and independent supervisory structures. A first long-term economic effect of neoliberal restructuring and entry into NAFTA is that Mexico's historical economic dependency on the United States has further increased. After the Mexican recession following the peso crisis, between 1997 and 2000 the Mexican economy started to profit again from the booming US economy, and had average growth results of 5 per cent. Between 1992 and 1999, the volume of trade between the two neighbours more than doubled, while between 1993 and 2002 the share of Mexican exports going to the United States increased from 83 per cent to 91 per cent (Latin American Weekly Report WR-2-40: 473). This ongoing integration has been most visible in manufacturing and services, such as food processing, chemicals, machinery and electrical, electronic and transportation equipment. The US dominance is linked to a second major feature of Mexico's economy: the growth of export and maquiladoras. These predominantly (about 60 per cent) US-owned factories of export-processing assembly production have experienced spectacular growth rates since the middle of the 1980 s, while Mexican exports tripled between 1991 and 1998 (Alba Vega 2000).

Although the growth of Mexico's maquiladoras and further economic integration with the United States have brought certain economic gains, overall liberalisation policies have not brought about sustained economic development, while they have also created new problems. The maquiladora sector is a substantial source of employment, but it can not - by far compensate for the loss of jobs in other sectors (agriculture!) and the yearly need of about 1 million extra jobs for Mexico's young population. In addition, while maquiladora salaries are higher than those in manufacturing for the domestic market, working conditions and workers' right are notoriously low in this sector. Moreover, the maquiladoras are extremely dependent on the ups and downs of the US economy. In 2001, some 240,000 maquiladora jobs were lost, representing 18 per cent of this sector's employment (Mexico \& NAFTA Report 16 April 2002: 4). Meanwhile, the domestic economy is not doing well, yet it represents about 70 per cent of total economic activity. Maquiladoras do not provide a solution to this problem: they are extremely import-depended and are hardly integrated in national economy as less than 2 per cent of the assembled parts come from local providers (Alba Vega 2000).

Together, these trends have contributed to economic polarisation, which has profound social implications. Due to a policy focus on the macro level, the micro level has been harmed. A small group of large and advanced industrial companies was encouraged by the state, but the majority of small and medium-sized industrial firms and service and agricultural companies stayed behind. This situation of a small group of winners versus a large group of firms that have either lost or made little progress is reflected in analyses of social conditions. The economic crises of the 1980s, and the peso crisis, 
caused severe hardship for the poor and middle-class citizens of Mexico, who have also been hurt by neoliberal reforms. Despite compensatory programmes and the fact that within these groups some have been doing better, we will see that poverty and income inequality have grown and geographical polarisation has increased.

\section{Governing democratisation}

The economic restructuring programme initiated under president de la Madrid contributed to decreasing levels of popular support for the PRI and the state-party system, and thereby to political change and state reform. In the presidential elections of 1988 Salinas officially won with only 50 per cent of the votes, the lowest victory so far in the history of the PRI. This occurred despite the ruling party's disproportionate resource base and media coverage, as well as various forms of fraud in favour of its candidate before, during and immediately after the elections. Salinas's competitor was Cuauthémoc Cárdenas, leader of the left-wing PRD (Partido de la Revolución Democrática, Party of the Democratic Revolution). With his criticism of the PRI's neoliberal programme and Mexico's democratic void, Cárdenas appealed successfully to the many Mexicans who suffered from the economic crisis of the 1980s and the adjustment policies of de la Madrid.

Apart from the economic circumstances and policies, by the end of the 1980s three major shifts heavily affected the PRI-based political system. First, internally the system ran into trouble as the new technocratic elite was involved in a struggle with the opponents of neoliberal reform within the PRI, particularly with the old elite of politicos involved in corporatist relations. The technocrats lacked such corporatist experience, had few links to the PRI patronage system, and little experience in (local) politics (Centeno and Maxfield 1992). Second, state-society relations came under pressure as corporatist relations could not cover the increasing number of citizens outside the formal structures for farmers, workers and civil servants: people earning their living in the informal sector; migrants living in illegal slums in vastly expanding cities; workers frequently crossing the border with the United States. The state-party system was not in contact with these citizens who had the right to vote, and who started to become well organised in popular movements. Third, Mexico's corporatist system ran into trouble as stabilisation and adjustment policies diminished the state's resources to sustain corporatist relations, whereas economic liberalisation harmed the political compromise between the state, business circles and the working class. While many workers, small farmers and owners of small companies opposed policies of a rapid opening of the Mexican market, the old system could not sufficiently perform the task of channelling and sustaining social discontent (Bizberg 1993).

Despite extensive resistance, president Salinas aimed to continue economic restructuring and the party-state system by a combined economic 
and political modernisation. And although an utter priista, Salinas was willing to give up some PRI privileges and sometimes even PRI control in order to create a modernised Mexico. Salinas thus changed many traditional political alliances in order to be able to achieve economic liberalisation. The consultation and participation of official unions in policy-making came to an end under Salinas. Consequently, these unions had less control over issues that had previously legitimated their prominent role: wage policy, minimum wage, subcontracting, social security, housing programmes and pensions. To resolve the tensions that arose as a result of this new situation Salinas offered some compromises - a give-and-take approach which proved successful in the sense that the weakened labour-government relation did not break altogether (De la Garza Toledo 1994: 203). Small farmers also saw their corporatist linkages relation with the government melt away, while Salinas's agricultural reforms (the constitutional reform, dismantling of government support, abolishment of price guarantees, reduction of subsidies) greatly harmed the interests of subsistence farmers, who had traditionally been the most loyal PRI voters.

Simultaneously, Salinas and his team of technocrats established close relations with the economic elite. During most of de la Madrid's sexenio prominent businessmen were critical of the incomplete privatisation and deregulation programme, as well as the lack of credits and the height of interest rates. The PRI subsequently strengthened the bond with the business elite through its Commission for Financing and Consolidation of Resources, which raised funds for the presidential campaign of Salinas and encouraged owners of major firms (including the new owners of privatised firms) to contribute millions of US dollars. Such an extensive involvement of the private sector in electoral politics was a new phenomenon, resulting also from the popularity of PRD candidate Cuauthémoc Cárdenas, which worried the private sector. When Salinas came to power, he quickly recovered part of the confidence in the state-party system lost by his predecessor (Teichman 1992; Valdés Ugalde 1994). ${ }^{4}$ Personal links were the most important channels between Salinas's technocrats and Mexican businessmen, while institutionalised relations improved primarily through the Mexican Council of Businessmen (the CMNH of the top businessmen) and the Coordinating Committee for Commercial Export Business Organisations (the COECE of the largest industrial conglomerates).

These new relations of Salinas and his team with the top of the corporate sector had profound effects on the outcome of economic restructuring. Apart from a preferential status in privatisation procedures, these close ties allowed for effective business pressure to delay and/or limit the creation of a free and open market with full competition. This was done by influencing policy-making processes with respect to (foreign) competition (in the financial sector, telecommunications and airlines), as well as through the conglomerates' capturing of the regulatory boards which are officially supposed to ensure fair competition. These practices demonstrate where the 


\section{Barbara Hogenboom}

views of technocrats and businessmen started to diverge: the first aimed for free, open markets, while the latter wanted privatisation and deregulated markets but also pushed for arrangements that would protect their powerful position (Teichman 2001). Since the technocrats lacked popular support for their programme of market reform, they became dependent on the political and financial support of 'big business', which forced them to water down their pro-market agenda into a pro-conglomerates programme. ${ }^{5}$

Evidently, regaining internal (PRI) and external (popular) legitimacy for his government and its neoliberal programme remained important for president Salinas. Therefore he sought new state-society linkages which were initiated by the Presidencia instead of the PRI. This was primarily done through a new system of extensive social funding directed at impoverished communities. This National Programme for Solidarity, PRONASOL, was meant as a compensation for the social costs of neoliberal policies, and it was largely paid for by the income generated by the privatisation of state companies. Requests for funding had to be directed to the presidential office instead of going through the usual local, state and federal bureaucracy. The programme bore a clear anti-opposition element since, despite formal regulations that Solidarity funding should not be linked to the PRI, in reality this was often the case at the local level. ${ }^{6}$ This neopopulist approach served to modernise - not end - clientelist practices. Still, more than a PRI project, Solidarity served presidentialism by increasing Salinas's popularity and strengthening his control over the party and its more traditional factions, both at the federal and the local level (Bailey 1994; Dresser 1991). Also in other policy areas, Salinas's team of technocrats further strengthened the president's power and weakened the PRI's role in the state-party partnership, resulting in a more autonomous state. This reform of the Mexican state was of such a profound nature that Centeno (1994: 3-4) describes the Salinas sexenio as a revolution.

To the increasingly louder calls for democratisation, Salinas responded with some electoral reforms. Building on the initiatives of de la Madrid, the thrust of these reforms was a set of changes enabling more electoral competition at the level of municipalities and states, including legislative changes and the creation of the Federal Institute for Elections, IFE. These changes created more political openness with more chances for opposition parties in local elections. The right-wing PAN (Partido de Acción Nacional - National Action Party), especially, picked the fruits of this openness, while it caused more uncertainty for the PRI as a whole. At the federal level, electoral reforms remained limited, although shortly before the presidential elections of 1994, reforms allowing for a greater role of observing and monitoring elections were introduced.

As already mentioned, in 1994 Mexico went through a succession of troubled political events. The date of commencement of NAFTA, 1 January of that year, coincided with the occupation of several towns in the state of Chiapas by the Zapatistas, who demanded democracy, greater local 
autonomy, and more federal support for the impoverished indigenous population. In March, Luis Donaldo Colosio, the PRI candidate for the presidential elections, was killed at an election meeting in Tijuana, Baja California. Only three months later the secretary-general of the PRI, José Francisco Ruiz Massieu, was murdered. Both assassinations were surrounded by many rumours and contrasting information, and were handled unprofessionally by the police and the federal institutions, while the official commissions that were to investigate the incidents only added to the confusion and uncertainty. More than anything else, the dealings of these commissions and the problematic succession of Colosio by Ernesto Zedillo de Ponce León demonstrated the existence of fundamental conflicts within the PRI. Zedillo was a weak presidential candidate and his victory should be attributed to the PRI's electoral machine, to a general fear for increasing instability, as well as to the (temporary) success of Salinas's modernisation agenda (especially the Solidarity Programme, local electoral reforms and the NAFTA).

While the peso crisis and the government's handling of this crisis greatly harmed the legitimacy of the PRI and the new president, Zedillo made some federal political and electoral reforms. His effort to reform the judiciary and the Supreme Court showed a concern for the division of powers and the institutional strengthening of the system. Another way in which he contributed to a weakening of presidentialism, and simultaneously to democratisation of the PRI itself, was by ending the PRI's tradition of the sitting president personally nominating the new PRI candidate for the presidential elections. By abandoning part of the traditional powers of the president, Zedillo forced other institutions to restructure too (Rubio 1998). New electoral reforms were made, such as allowing the IFE to become autonomous, fixed public resources for political parties (proportional to the votes received in previous elections), and letting citizens of Mexico City choose their mayor through direct elections. Voting irregularities indeed decreased, and PRD leader Cuauthémoc Cárdenas won the new mayoral election in Mexico City, while the PRI lost its majority in the Chamber of Deputies. The activities of the NGO Alianza Cívica for electoral reforms, which organised nationwide monitoring of elections, were crucial and showed that political society has an important role to play. As Leonardo Avritzer (2002) puts it, the development of the IFE is a good example of an institution that was not only established and strengthened, but also 'citizenized'. These democratising tendencies finally allowed for a more open and effective expression of popular discontent with Mexico's political system. After more than 70 years of PRI domination, in 2000 the PAN's candidate Vicente Fox won the presidential elections.

The PRI's gradual loss of support, votes and power has heavily affected Mexico's presidentialism. As Weldon (1997: 227) analyses, Mexico's typical presidencialismo was based on the combination of four factors: a constitutionally-based presidential system; unified government through PRI control 
over the presidency and congress; party discipline within the PRI; and a president who is also the PRI's leader. ${ }^{7}$ This situation existed from the 1930s onwards, but has gradually been changing: first slowly and controlled, with limited constitutional changes from the 1980s onwards, then more rapidly with the PRI's loss of seats in the Chamber of Representatives in the 1990s and the end of the PRI's majority in 1997; and finally with the loss of the presidency. Evidently, none of these new circumstances are necessarily going to stay, and many elements of Mexico's political culture have survived well in this new environment, but there have been some profound effects on the political system. Even in the event that the PRI won the presidential elections in 2006, recent experiences have changed parties, politicians and representatives to such an extent that a return to the old presidencialismo is most unlikely. However, in his first two years in office, Fox has demonstrated a notable lack of success in governing post-presidencialismo Mexico. He and his far-from-coherent team of ministers failed to convince a majority of Mexican legislators on two of the three key policy initiatives (liberalisation of electricity, and fiscal reform), and had to accept that the third initiative on indigenous rights was watered down substantially by several amendments.

The fact that political liberalisation does not necessarily bring about substantive democratisation is well shown by Mexico's experience with decentralisation. As Victoria Rodríguez (1997: 140) has analysed, the decentralisation policies of de la Madrid, Salinas and Zedillo served as a means to 'hold on to power to ensure the continuity of their political party, the powers accumulated by the federal executive, and many of the institutions and privileges that sustained the PRI's control of government'. The governments of de la Madrid and especially Salinas succeeded in centralising by decentralising: de la Madrid by means of partial devolution in the form of his Municipal Reform, which was only partially implemented and therefore only partially strengthened local government, in practice largely benefitting state governors; and Salinas through his electoral reforms and the Solidarity Programme. The process of political liberalisation was far from unbiased: the right-wing PAN was tolerated as an acceptable rival of the PRI, particularly at the local level, and won several state and municipal elections, while at the federal level the PAN became an acceptable ally in the Mexican Congress; the left, on the other hand, often experienced (local) repression, especially after the near victory of the PRD leader Cuauthémoc Cárdenas in 1988. The focus on vertical forms of decentralisation was somewhat weakened under Zedillo, whose New Federalism agenda also touched on horizontally distributing powers, which is particularly complex for Mexico's system as it 'comprises a sharing of powers rather than a separation of powers', at each of the vertical levels of governance. However, Zedillo's agenda stressed the strengthening of state governments instead of municipal governments, thereby falling in the tradition of neglecting small (rural) municipalities (Rodríguez 1997: 140-50). 
A most disturbing effect of many of these decentralisation policies in Mexico is that they have partly given way to a feudalisation of political power. '[I]n some regions (Yucatán, Tabasco, Capeche, among others) and organizations [...] political power is falling in the hands of the most traditional leadership, that have been active in resisting the process of democratization' (Bizberg 2001: 91). A somewhat similar trend can be observed in cases of state-level reregulation, described by Snyder (2001: 195) as 'a political process in which politicians and societal groups bargain over the rules of new institutions for market governance', which replace former federal institutions destroyed by neoliberal reforms. The most plausible patterns of reregulation are either mass-based, neocorporatist frameworks that distribute benefits to non-elite groups, or frameworks that further enhance hegemony by oligarchs. The possibilities for grassroots organisations to transform old-style exclusionary corporatist institutions into participatory frameworks, however, are limited and highly dependent on both a non-party framing of the issue and the willingness of politicians to construct new public institutions. Moreover, 'neoliberal reforms in places with powerful traditional elites may [...] result in reregulated markets that generate monopoly rents for oligarchs' (Snyder 2001: 205).

What can be concluded of the complex ways in which democratisation evolved in Mexico since the 1980s? With Fox's victory in 2000 Mexico said farewell to its political system based on the PRI as de facto state-party, implying more than one step away from Mexico's semi-authoritarian legacy. Democratisation, however, has progressed more in electoral affairs than in other political levels, and as Loaeza (1994: 106, 113) points out, electoral liberalisation is not an equivalent of democratisation as long as certain groups of people are still able to change outcomes by ignoring formal rule, and government authorities retain a considerable margin of arbitrariness. At the federal level, on the one hand, since the PRI's loss of a Congressional majority there has been more openness in privatisations, but on the other hand, clientelist and personalist relations between the public and the private sector continue (Teichman 2001: 154). A salient example of Mexico's corruption and crony capitalism was the double scandal of illegal funding for the campaigns for the 2000 presidential elections: the PRI received large sums from the state oil company Pemex, while for the campaign of Fox - known for his anti-corruption discourse - legal restrictions on financing were evaded so as to allow for extra support by wealthy Mexican businessmen. Simultaneously, we have seen that at the state and municipal level, particularly in the economically marginalised southern regions of Mexico, political reforms even give way to a feudalisation of power and changes in the direction of pre-PRI political circumstances. Such developments are clearly opposite to the democratic presumption that all people should have opportunities to change outcomes by using formal rule.

Generally, political opportunities are still very unequal in Mexico. For instance, the party system may appear pluralistic, but the absence of channels 
for indigenous peoples' representation is a serious limitation to the nature of democracy (Harvey 1998: 238). The lack of equal political opportunities and the lack of acceptance of these opportunities are made apparent by the ongoing high incidence of political violence, particularly the murders of activists, politicians and journalists. Under Salinas, political violence was severe and, among others, 250 local PRD activists were killed (Proceso 935, 3 October 1994). There is the problem of the impunity of paramilitary groups, such as the infamous Paz y Justicia in Chiapas, and particularly in the poor states of southern Mexico there have been numerous cases of local struggles over land and water rights, and ethnic, religious and political conflicts resulting in violence against individuals, families and communities. For instance, on 30 June 2002 twenty-six farmers were killed in a massacre in the village of Santiago Xochiltepec in Oaxaca. In addition, human rights are still not well protected in Mexico, as the murder in 2001 of the leading human rights lawyer Digna Ochoa showed. Amnesty International (2002) concludes that by the end of 2001 Fox's international commitments 'had not resulted in effective improvement in human rights protection and reports of human rights violations remained widespread'. Taken together, it does not come as a surprise that Mexican citizens still have little confidence in the whole political system, including political parties, politicians, officials, the police and the judiciary (cf. The Economist 15 August 2002).

\section{Governing social development}

While Mexico's economic and political structures have passed through a range of profound changes, few solutions have been found for the country's massive social problems and the number of poor has increased. Overall, the social impact of economic restructuring programmes can be characterised as polarisation: the economic elite grew richer while the living standards of both the poor and the middle-class decreased, despite calling a halt to inflation. A structural problem in estimating the nature and extent of poverty in Mexico, however, is the unreliability of official national statistics, particularly the figures for population and unemployment, which tend to under-represent the real problems. This evil has not disappeared with the end of the PRI's state-party system; also Fox's National Plan for Development (2001-2006) suffers from major informational inadequacy (Urquidi 2001). Evidently, such ongoing institutional fraud - 'intransparency' in Good Governance discourse - helps to protect the government from accurate evaluation.

Nevertheless, several researchers have documented the structural social drama in Mexico. While progress has been made in some important areas such as life expectancy, child mortality, and extreme poverty, various analyses - with somewhat varying figures - show that the number of poor Mexicans has grown and that income inequality has increased. Trejo and Jones (1998: 70) point out that between 1984 and 1992 there was 'a sharp 
decline in the income share of all deciles of the economic scale except for a substantial increase in that of the richest 10 percent'. According to Dussel Peters's calculations, the concentration of income in the richest 10 per cent of the population rose from 33 per cent of total income in 1984 to around 38 per cent from 1989 onwards (until 1996). Simultaneously, the poorest 50 per cent of Mexicans together decreased their share of total income from 21 per cent in 1984 to 19 per cent in 1996, and the number of persons living in poverty (that is, poverty and extreme poverty) increased from 63.3 to 67.8 million (Dussel Peters 2000: 154-7).

An important factor explaining these negative social trends is the dramatic fall of real wages and minimum wages, and the new economic model's failure to create sufficient new jobs for the growing population. Manufacturing is only a minor source of employment-generation, not even among the five most important branches in this respect. Moreover, in the neoliberal era employment generation is not associated with trade nor with exports (Dussel Peters 2000). This is related to the above-mentioned insulation of the export sector from the rest of the economy. Meanwhile, 25 million Mexicans depend on income from the agricultural sector, which only accounts for 4 per cent of GDP (Latin American Mexico \& NAFTA Report 26 November 2002: 3). And more and more Mexicans cross the border to find work in the United States. In fact, this export of human capital has become a major source of income: in 2001, Mexicans working abroad sent home close to US\$9 billion, which equalled 70 per cent of the income of oil exports (La Jornada 4 March 2002: 23). Regional inequality only increased due to liberalisation, as poverty in Mexico's northern states decreased while its southern states faced a sharp increase (Trejo and Jones 1998: 72). The inadequacy of Mexico's neoliberal model to achieve social development is even more striking if we consider the generally beneficial external circumstances: since 1994 Mexico has had almost free access to the world's largest national economy, and this economy had high growth levels until 2000.

The deepening social crisis of Mexico cannot be attributed to a lack of social policy and programmes for poverty alleviation. Since the start of the debt crisis in 1982, social development has been a spearhead of government policies, which implied major efforts and resources. With the vast and increasing problems of poverty, subsequent Mexican presidents combined their neoliberal economic programme with new policies for social protection and building human capital. The already-mentioned case of Salinas's Solidaridad programme was a form of compensatory funding, using a share of the federal state's earnings from privatisation while modernising the president's and the PRI's relation with civil society. Zedillo replaced this programme with Progresa, which was - like Solidaridad - led by the Presidencia. Instead of Solidaridad's approach of having communities apply for funding, Progresa took the initiative in analysing the needs of communities and subsequently giving support in the form of food supplies and educational and health services. Fox's government changed the name of 
Progresa into Oportunidades, but much of Progresa's approach was continued after a positive external evaluation.

The changes of governance in social policy show some mixed results. On the one hand, the experience with Progresa and Oportunidades gives some reason for optimism as it shows that public resources spent on Progresa have, at least partly, reached the poor and that those poor people actually benefitted from the programme. In addition, allowing for an external evaluation is a step forward in reaching more transparency - although a reliable evaluation of course requires reliable and adequate data. And the fact that Fox's team changed little more than Progresa's name gives hope for more institutional continuity and learning, and less personalisation and clientelism in this important policy area. On the other hand, there is a serious risk that, with the decentralisation of social policies, the problems of institutional weakness and political clientelism are decentralised too. This is particularly troublesome for the southern states: they are not only in greatest need of good social policies, but they also suffer much more from economic backwardness, local authoritarianism and ethnic tensions. 'In southern states, autocratic PRI governments have few incentives to respond [to pressures from the poor for social aid] ... [T]his reduces the options of the southern poor to three choices: continuous social deterioration, migration, or rebellion' (Trejo and Jones 1998: 96). While Chiapas is the most obvious example of this terrible choice, indeed the other southern states face the same situation. ${ }^{8}$ Still, even in an optimist scenario in which federal programmes would continue to improve and the problems in state governments would be solved, good social policy does not necessarily lead to social development, at least not as long as economic development and government policies fail to create sufficient jobs with reasonable wages and workers' rights.

With respect to the necessity of economic development to achieve social development, president Fox has claimed to have found a new way to fight the marginalisation of the southern states of Mexico: the Puebla-Panama Plan (PPP). ${ }^{9}$ With this plan he aims to substantially raise the level of both public and private investment in this part of Mexico in order to match economic and social goals in the neoliberal framework. ${ }^{10}$ An interesting aspect of the plan is its international approach, as next to Mexico it encompasses Guatemala, Belize, El Salvador, Honduras, Nicaragua, Costa Rica and Panama. Of Mexico, only the states in the South and the Southeast are incorporated in the Plan: Puebla, Oaxaca, Veracruz, Guerrero, Chiapas, Tabasco, Campeche, Yucatán and Quintana Roo. In many ways, in particular socio-economically, these Mexican states have (increasingly) more in common with the countries of the Isthmus of Central America than with northern Mexican states. The PPP's goal is to strongly boost regional development, and the Mexican government states that the plan is to prevent the gap between rich and poor states in Mexico from growing even further ( $\mathrm{La}$ Jornada 29 April 2001). Implicitly, the government thus acknowledges that 
neoliberal policies and the NAFTA so far have further increased Mexico's regional polarisation.

The integration and extension of highways and electricity networks are the prioritised elements of this plan for development of the so-called Mesoamerican region and its population of 64 million. In addition, alongside some environmental and social projects, it involves a range of projects to improve and expand the rest of the region's infrastructure (including railways, airports, harbours, bridges and the connection of electronic communication networks). Such projects fit in with long-standing efforts for Central American integration, and even more so with the recent free trade agreements between Mexico and the Central American countries. ${ }^{11}$ It can count on major support from the Interamerican Development Bank (IDB), as well as from other multilateral institutions.

How and by whom will this huge plan be governed, and what say do citizens have in this? Official presentations of the plan particularly stress its social and ecological objectives, as well as the participation of citizens and communities in the planning and decision-making processes. The PPP's website states that ' $[t]$ he Puebla-Panama Plan promotes regional development and represents the beginning of a new phase of dialogue and shared work in order to overcome poverty and increase the quality of life of the peoples of Mesoamerica'. ${ }^{12}$ Indeed, shortly after the official start of the Plan consultation meetings took place in the involved Mexican states, and an independent citizens' committee is supposed to give feedback to the federal PPP office. However, the role of these forms of 'popular participation' is questionable since there are so many institutional levels involved in the Plan: international/transnational (IDB and other multilateral creditors); regional (the eight governments); national (Mexico's government, its PPP office, various ministries); state (state governments and institutions); and municipal. Although the approach that all are involved and all can have a say may seem at face value to be modern and democratic, in practice it is largely confusing, especially since there is no clear division of tasks and, more importantly, of responsibilities. Moreover, since the PPP is a plan (consisting of various projects) and not an international agreement or a policy that requires new legislation, the federal Congress has no say over it. Furthermore, as expressed by the Zapatistas' Subcomandante Marcos and others, the PPP and particularly its aim to attract major corporate investment clash with pleas for self-determination of local communities and indigenous people. ${ }^{13}$

The concern for tensions between the state, civil society and the private sector is understandable, for the region is rich in cheap labour and natural resources, including oil and many species (biodiversity). The PPP may stimulate economic growth, but it is most doubtful whether new maquiladoras and further corporate exploitation of natural resources will provide sufficient jobs, particularly since the anticipated form of modernising the agricultural sector (selling the many small plots and communal lands to large companies) 


\section{Barbara Hogenboom}

implies that even more people will leave the rural areas. Evidently such an economic, geographical and social shift will cause extensive ecological damage, but it seems as if the Mexican government prefers this to the current situation of over-exploitation of resources (soil, forest, etc.) by poor people in the countryside. It has been clear from the start that extensive private investment is needed to cover the costs of all the anticipated PPP projects, and the indispensability of corporate funding usually lends much influence to the involved large companies. At the same time, in order to enhance corporate initiative and profits, the government is investing major public resources and initiating new projects for deregulation. Seen from the US dominance in foreign investment and trade in Mexico and Central America, an important share of PPP's foreign capital will have to come from the United States.

Various non-governmental organisations and opposition parties claim that the Plan mainly serves the interests of large (foreign) companies, or simply US capital, without truly respecting the existence and evolution of regional integration at other (ecological, cultural, social) terrains, and without advancing sustainable development. The Mexican Network Against Free Trade (RMALC) refers to the Plan as an initiative for 'dependent economic integration' (RMALC 2001). And the PRD claims that the interest of the Mexican government in the PPP is mainly to unconditionally serve the United States (La Jornada 26 August 2001: 8). It seems indeed unlikely that president Fox and his PPP will succeed in achieving social development in southern Mexico. While the plan is rightly motivated by the acknowledgement that social development requires economic development as much as social policies, there is a lack of understanding of the type of economic development that is needed. The neoliberal mindset dominates, despite the lessons that could have been learned from twenty years of economic restructuring and ten years of NAFTA. As long as policy-makers only allow for solving Mexico's development problems in neoliberal terms of open markets, attracting private capital and where necessary adding public capital, a real dialogue with civil society will not come about.

\section{Conclusions}

To the direction and course of Mexico's processes of liberalisation and democratisation, Salinas's presidency (1988-1994) was central. After some preparatory work by president de la Madrid, Salinas and his team of technocrats set in motion the economic and political modernisation of Mexico, which was aimed at a neoliberal development model and some political reforms to allow for continued dominance of the PRI. Although largely an exercise of dual modernisation, under Salinas and even more so under Zedillo the economic project was of somewhat greater priority than the political project. Democratising measures were allowed as long as they would not inhibit the plans for liberalisation, thereby creating a market democracy. As a result, the extent to which Mexican citizens and organised 
civil society can have political influence depends highly on the matter. Issues of major economic or private sector interest, such as the peso crisis measures, receive 'special treatment'. And although Mexico's current government has to acknowledge that neoliberal policies have failed to bring about the much-needed social development, there is little openness to examine development alternatives outside the neoliberal parameters. Discourses of social movements on issues such as popular participation, the rights of indigenous people and sustainable development have been strategically copied (and disarmed) by Mexican governmental agencies without much effect on actual policy. Profound democratic change has thus partly been inhibited by Mexico's neoliberal policies, while existing power relations and traditional political mechanisms play their part too.

Political and economic liberalisation has not remained under complete control of the governing technocratic elite. The democratisation process of the 1990s and the presidential elections of 2000 show that the modernisation of the PRI-state system could not prevent pressures for electoral democracy from increasing. However, the PRI only lost federal political control after the economic restructuring process had been largely completed - and even then only to a party that supported the neoliberal model. We have also seen that the economic liberalisation has partly gone beyond the governing elite's control. The prominent position of large companies in the new development model, and the close ties between technocrats and the corporate elite, have given way to an increasing political weight of the interests of economic conglomerates. Among other things, policy-makers have become more sensitive to the pressures of 'big business', and large companies have an undesirable influence on official bodies that are to supervise the deregulated markets.

An important result of the economic and political modernisation set in motion under technocratic governance is that of multiple polarisation: economically, socially and politically. While proximity and free trade with the world's largest national economy have allowed Mexico to have more extensive and prompt economic results from its liberalisation policies, this has only further intensified the divide between a (small) modernised part of the economy and the large marginalised and underdeveloped segments. This economic polarisation is reflected in social relations, contributing to social inequality and major flows of migrant workers. And the decentralisation policies that have brought about democratisation in some parts of Mexico have in many cases given occasion to the opposite in regions with high levels of poverty and strong authoritarian legacies. There is a clear geographic dimension in each of these levels of polarisation, which are also reinforcing one another. Mexico's North-South divide has further increased and is posing a serious threat to the country's future development. If Mexico is to achieve peaceful, democratic and sustainable development, this multiple polarisation needs to be reversed, but Mexico's current market democracy and its governing elite seem unfit for the task. 


\section{Barbara Hogenboom}

\section{Notes}

1 According to the World Bank (1994), after 1982 relations with the 'core of the country's intellectual/technocratic elite' have been positive, and the Bank estimates that through its analytical support it has 'at times influenced directly or indirectly the course of Mexican policymaking'.

2 The government greatly extended the availability of Tesobonos (short-term government bonds that are indexed to US dollars but paid off in pesos), as a result of which the value of capital invested in Tesobonos rose from US\$2 billion to US\$29 billion.

3 This fund was established in 1990 as a preparation to the (re)privatisation of Mexican banks so that, when in trouble, banks would go to this fund rather than using public resources. However, the fund was unable to solve the problems caused by the peso crisis, as devaluation and the strong rise of interest rates had left thousands of companies and individuals unable to pay their debts. Therefore the government decided to help them out.

4 In early 1993, twenty-five of the wealthiest businessmen were again approached by a PRI fund, now with a request to contribute US $\$ 25$ million each.

5 With the weakening of the PRI, and the rise of the right-wing PAN at the local and federal level, the relations between political parties and businessmen seem to become more flexible, but not necessarily less influential. While owners of large companies have traditionally tended to support the PRI, the PAN's success is partly linked to the support by owners of (relatively new) medium-sized companies largely located in the northern states of Mexico, who disputed the political domination of large enterprises, the tendency of the PRI to neglect their interests, and the PRI's political practices.

6 Molinar Horcasitas and Weldon (1994: 139) show that more Solidarity money was directed to regions where Cárdenas received strong support at the 1988 presidential elections. Their data indicate that, next to poverty alleviation, the programme also served a political agenda, and that part of the recovery of the PRI during state and local elections in 1991 can be explained by PRONASOL spending.

7 Since the 1917 constitution the Mexican president has extensive powers, including introducing bills and constitutional reforms, vetoing legislation, agenda-setting in the budget process, nomination of Supreme Court justices, and the naming of the members of the government. However, these powers have been weakened through reforms such as those allowing for greater influence of the Senate in the selection of Supreme Court justices (1994), and the election of the governor of the Federal District (1995). Various constitutional reforms also changed the systems for the election of deputies and senators, thereby giving more room to opposition parties (Weldon 1997).

8 The case of the Solidaridad programme in Chiapas illustrates the problems and risks. High levels of poverty and the increasing social unrest in the 1980 s turned this state into the largest benefittor from Solidaridad funding, but these resources were insufficient to cushion the major sources of social problems: landlessness and unemployment. Moreover, the Solidaridad funds were politically manipulated in favour of the PRI and against independent organisations, thereby adding to divisions and tensions within indigenous communities (Harvey 1998: 183-6).

9 The analysis of the PPP is partly based on a series of interviews with representatives of the federal government, non-governmental organisations, and scholars, held in Mexico in March 2001.

10 Although often presented as a project of Fox, the Plan is a follow-up of the Tuxtla Agreement of 1991 between Mexico and Central America, and there have been several previous Mexican plans for regional development of the South, such as the Plan del Sureste of 1983 (see also Barreda Marín 2001). The PPP builds 
strongly on ideas developed under Zedillo, by Santiago Levy (one of the few persons who stepped from the last PRI government into Fox's team). Shortly after Fox's election, Dávila, Kessel and Levy (2000) published a paper in which they state that for more than 50 years the federal government's public policies have repressed economic development in the southeast, and that social policies will only bring about social development if accurate economic policies and investment allow for the region's productive potential to be released.

11 Mexico has had a free trade agreement with Costa Rica since 1995, with Nicaragua since 1998, and with the Northern Triangle (Guatemala, El Salvador and Honduras) since 2001, and a partial-scope trade agreement with Panama since 1985.

12 See the PPP section at the IDB website: http://www.iadb.org/ppp/ background.asp (December 2002).

13 Although this right was written down in the San Andres Accords, signed between the Zapatistas and the Mexican government in 1996, the Congress did not approve of its incorporation in the law of indigenous rights in 2001. An important contested point involves giving communities the right to collectively decide over the use and benefits of the natural resources of their lands and territories, including fossil fuels reserves.

\section{Bibliography}

Alba Vega (2000) 'México después del TLCAN. El impacto económico y sus consecuencias políticas y sociales', in Barbara Klauke (coord.), México y sus perspectivas para el siglo XXI, Münster: Westfälische-Wilhelms-Universität Münster.

Amnesty International (2002) Mexico. www.amnesty.org (December 2002).

Avritzer, Leonardo (2002) Democracy and the Public Space in Latin America, Princeton: Princeton University Press.

Bailey, John (1994) 'Centralism and Political Change in Mexico: The Case of National Solidarity', in Wayne A. Cornelius, Ann L. Craig and Jonathan Fox (eds), Transforming State-Society Relations in Mexico. The National Solidarity Strategy, San Diego: Center for U.S.-Mexican Studies.

Barreda Marín, Andres (2001) 'Los Peligros del Plan Puebla Panamá', in Armando Bartra (coord.), Mesoamérica - Los Rios Profundos. Alternativas pleyebas al Plan Puebla-Panamá, Mexico, DF: Instituto 'Maya'.

Bizberg, Ilán (1993) 'Modernization and Corporatism in Government-Labour Relations', in Neil Harvey (ed.), Mexico: Dilemmas of Transition, London: British Academic Press.

- (2001) 'Behind the Scenes - Clientele and Citizens in the Mexican Political Transition', Iberoamericana 1 (2): 87-106.

Borón, Atilio A. (1998) 'Faulty Democracies? A Reflection on the Capitalist "Fault Lines" in Latin America', in Felipe Agüero and Jeffrey Stark (eds), Fault Lines of Democracy in Post-Transition Latin America, Coral Gables: North-South Center Press.

Centeno, Miguel Angel (1994) Democracy within Reason. Technocratic Revolution in Mexico, Pennsylvania: Pennsylvania State Press.

Centeno, Miguel Angel and Sylvia Maxfield (1992) 'The Marriage of Finance and Order: Changes in the Mexican Political Elite', Journal of Latin American Studies 24 (1): $57-85$ 


\section{Barbara Hogenboom}

Dávila, Enrique, Georgina Kessel and Santiago Levy (2000) 'El sur también existe: un ensayo sobre el desarrollo regional de México', México, DF: Subsecretaría de Egresos, Secretaría de Hacienda y Crédito Público.

De la Garza Toledo, Enrique (1994) 'The Restructuring of State-Labor Relations in Mexico', in Maria Lorena Cook, Kevin J. Middlebrook and Juan Molinar Horcasitas (eds), The Politics of Economic Restructuring. State-Society Relations and Regime Change in Mexico, San Diego: Center for U.S.-Mexican Studies.

Dresser, Denise (1991) Neopopulist Solutions to Neoliberal Problems. Mexico's National Solidarity Program, San Diego: Center for U.S.--Mexican Studies.

Dussel Peters, Enrique (2000) Polarizing Mexico. The Impact of Liberalization Strategy, Boulder: Lynne Rienner.

Guillen, Arturo (1994) 'El proceso de privatización en México', Mondes en Developpement 22 (87): 29-39.

Guillén Romo, Hector (2002) 'Evolución del regimen macrofinanciero mexicano', Comercio exterior, 52 (7): 564-74.

Hansen, Roger D. (1971) La Politica del desarrollo mexicano, Mexico, DF: Siglo veintiuno editores.

Harvey, Neil (1998) The Chiapas Rebellion. The Struggle for Land and Democracy, Durham and London: Duke University Press.

Hogenboom, Barbara (1998) Mexico and the NAFTA Environment Debate. The Transnational Politics of Economic Integration, Utrecht: International Books.

Lastra Bastar, Francisco (2000) El Sureste: una deude pendiente, Villahermosa: Tabasco.

Lechner, Norbert (1998) 'The Transformation of Politics', in Felipe Agüero and Jeffrey Stark (eds), Fault Lines of Democracy in Post-Transition Latin America, Coral Gables: North-South Center Press.

Loaeza, Soledad (1994) 'Political Liberalization and Undercertainty in Mexico', in Maria Lorena Cook, Kevin J. Middlebrook and Juan Molinar Horcasitas (eds), The Politics of Economic Restructuring State-Society Relations and Regime Change in Mexico, San Diego: Center for US-Mexican Studies, pp. 105-22.

Lustig, Nora (1992) Mexico. The Remaking of an Economy, Washington: The Brookings Institution.

_ (1995) 'México y la crisis del peso: lo previsible y la sorpresa', Comercio exterior, mayo: 374-82.

Molinar Horcasitas, Juan and Jeffrey A. Weldon (1994) 'Electoral Determinants and Consequences of National Solidarity', in Wayne A. Cornelius, Ann L. Craig and Jonathan Fox (eds), Transforming State-Society Relations in Mexico. The National Solidarity Strategy, San Diego: Center for U.S.-Mexican Studies.

Mouzelis, Nicos (1995) 'Modernity, Late Development and Civil Society', in John E. Hall (ed.), Civil Society. Theory, History, Comparison, Cambridge: Polity Press.

RMALC (2001) 'El Plan Puebla Panamá: extensión y profundización de la estrategia regional neoliberal, o nueva estrategia de desarrollo integral y sustentable desde las comunidades' (segunda versión, Alejandro Villamar). Available online at http://www.rmalc.org.mx/documentos/ppp_rmalc.pdf.

Rodríguez, Victoria E. (1997) Decentralization in Mexico. From Reforma Municipal to Solidaridad to Nuevo Federalismo, Boulder: Westview Press.

Rodrik, Dani (1999) The new global economy and developing countries: making openness work, Washington DC: Overseas Development Council, Policy essay no. 24.

Rubio, Luis (1998) 'Coping with Political Change', in Susan Kaufman Purcell and Luis Rubio (eds), Mexico under Zedillo, Boulder: Lynne Rienner 
Snyder, Richard (2001) Politics after Neoliberalism. Reregulation in Mexico, Cambridge: Cambridge University Press.

Stark, Jeffrey (1998) 'Globalization and Democracy in Latin America', in Felipe Agüero and Jeffrey Stark (eds), Fault Lines of Democracy in Post-Transition Latin America, Coral Gables: North-South Center Press.

Székely, Gabriel (1999) 'Presentación', in Gabriel Székely (coord.), FOBAPROA e IPAB: El acuerdo que no debio ser, Mexico, DF: Oceano.

Teichman, Judith A. (1992) 'The Mexican State and the Political Implications of Economic restructuring', Latin America Perspectives 19 (2): 88-104.

- (2001) The Politics of Freeing Markets in Latin America. Chile, Argentina and Mexico. Chapel Hill: The University of North Carolina Press.

Trejo, Guillermo and Claudio Jones (1998) 'Political Dilemmas of Welfare Reform: Poverty and Inequaliry in Mexico', in Susan Kaufman Purcell and Luis Rubio (eds), Mexico under Zedillo, Boulder: Lynne Rienner.

Urquidi, Victor L. (2001) 'Comentarios al Plan Nacional de Desarrollo, 2001-2006'. Paper, Semenario Interactivo sobre el Plan Nacional de Desarrollo 2001-2006, Asociación de Académicos 'Daniel Cosío Villegas', 26 June.

Valdés Ugalde, Francisco (1994) 'From Bank Nationalization to State Reform: Business and the New Mexican Order', in Maria Lorena Cook, Kevin J. Middlebrook and Juan Molinar Horcasitas (eds), The Politics of Economic Restructuring. State-Society Relations and Regime Change in Mexico, San Diego: Center for U.S.-Mexican Studies.

Weldon, Jeffrey (1997) 'The Political Sources of Presidencialismo in Mexico', in Scott Mainwaring and Soberg Shugart (eds), Presidentialism and Democracy in Latin America, Cambridge: Cambridge University Press.

World Bank (1994) OED Précis - World Bank Relations with Mexico no. 71, June.

- (2001) Mexico. A Comprehensive Development Agenda for the New Era (Marcel M. Giugale, Olivier Lafourcade and Vinh H. Nguyen, eds), Washington DC: World Bank. 


\title{
5 Triple transition and governance in El Salvador
}

\author{
Chris van der Borgh
}

In situations of post-settlement peace building it is often emphasised that, in order to create a self-sustaining peace, a triple transition is needed, combining economic reform and political democratisation with changes in the security regime. The idea of the triple transition can be seen as an international agenda of economic liberalisation and good governance that is adapted to war-torn societies by adding security issues. The three transitions are generally seen as complementary to each other, changes in the economic system, political regime and security situation being interdependent. However, a number of studies have mentioned that in practice the different parts of the triple transition can be at odds with each other and can even lead to new tensions or conflicts. This chapter will have a critical look at the triple transition in El Salvador, a country that is considered to be one of the success stories of post-settlement peace building.

Compared to much more problematic or failed cases of peace building like Angola, Bosnia or neighbouring Guatemala, in El Salvador the civil war was successfully brought to an end by peace accords signed in 1992 and followed by democratic reform, economic growth and poverty alleviation. However, the transition from war to peace in El Salvador has left a number of problems unresolved. Violence has all but disappeared from Salvadoran society, although the nature of this violence may have changed. The political violence of guerrilla armies and military has made way for 'everyday violence', like the emergence of youth gangs and violent crime. Furthermore, the persistence of (new forms) of social exclusion, combined with rising socio-economic inequality, points at difficulties in tackling one of the root causes of the conflict in El Salvador. And although there has been a widening of political space, and democratic reforms have been considerable, authoritarian structures and practices have persisted or taken new forms.

This chapter critically explores the achievements of the Salvadoran triple transition. It focuses on the ways in which the processes of pacification and political democratisation (the key issues in the peace accords of 1992) and the programme of economic adjustment and liberalisation (that took place simultaneously) influenced each other. The chapter begins with a discussion of the concept of the triple transition. Thereafter, the case of El Salvador 
will be discussed. It starts with a brief discussion of the backgrounds and the nature of the peace agreements that were signed in 1992 by the Salvadoran government and the guerrilla movement FMLN. It follows with a large section on the analysis of the changes in three important interrelated fields: security, political reform and economic reform respectively. Finally, it deals in the conclusion with the question to what extent the processes of pacification, democratisation and economic liberalisation influenced each other, in either a positive or harmful way.

\section{Triple transition and peace building}

Since the end of the Cold War the interest in post-war reconstruction and peace building has increased dramatically, as the absence of war (negative peace) is generally seen as an insufficient guarantee for sustainable peace and it is now widely recognised that, in order to avoid a relapse into war, some kind of structural or social change is needed (Miall et al. 1999: 189-91). In the contemporary literature on post-war or post-settlement peace building it is recognised that such a process will take time, making a distinction between a transitional phase of post-war peace building and a consolidation phase (Kumar 1997; Ball 2000).

In both the short and the long run, peace building is generally seen as a multi-dimensional process, including the security, political, socio-economic, relational and psychological aspects of peace building (cf. Goodhand and Hulme 1999; Kumar 1997). Miall et al. (1999: 191, 203) mention four deficits that may hamper the consolidation of peace: political or constitutional incapacity; socio-economic debilitation; psychological and social trauma; as well as problems related to security. Ball (2000: 615) distinguishes between three broad categories of peace-building activity: the strengthening of the institutional base; consolidating internal and external security; and promoting economic and social revitalisation. This author leaves aside the social-psychological deficit and focuses on what others would call the "triple transition'. In practice many authors and policy-makers equate the concept of peace building with the triple transition. For example, Forman and Patrick (2000: 5) state that "Although each post conflict situation has its unique attributes, successful recovery often involves a "triple transition": a security transition from war to peace, a democratic transition from authoritarianism (or totalitarianism) to a participatory form of government; and a socio-economic transition, including both the rebuilding of economic capacities and (frequently) the movement from a controlled to a market economy'.

The concept of a triple transition has found response in the international community and there now seems to be a consensus about the kind of changes needed in order to reach a 'peaceful society'. ${ }^{1}$ This 'integrated approach' of peace building is rather ambitious, as it states that change should take place in different fields simultaneously. Cousens (2001: 12-13) instead argues that activities of peace building should focus primarily on the 


\section{Chris van der Borgh}

construction of a 'self-enforcing peace' and that the most effective way to do so is 'to cultivate political processes and institutions that can manage group conflict without violence but with authority and, eventually, legitimacy [...]. Most important is that a commitment to resolving conflicts without violence has begun to emerge among an increasingly inclusive set of national actors at both state and society levels, with an increasing likelihood that mechanisms for conflict resolution will become institutionalised even in the face of continuing violence.'

Cousens does not deny the need to address other issues in a post-settlement setting, but she emphasises that there should be clear priorities and the core of peace building ought to be political and has to address a country's emerging capacity to manage conflict. Furthermore, an important difference in the idea of the triple transition is that 'peace building as politics' focuses primarily on authoritative political institutions that can manage group conflict without violence, while these institutions do not necessarily have to be democratic.

One of the most explicit critiques on the triple transition is that of Paris (2001), who questions the assumption of many agents in the international community that market democracy is the surest foundation for peace. The author states that political and economic liberalisation can spawn new forms of instability. Democratisation may reinforce societal differences, in particular in societies with ethnic or religious tensions, where citizens can 'foster parochial exclusiveness'. Economic liberalisation can - at least in the short run - create or enlarge inequalities that can in their turn fuel resentment and discontent. Paris (2001: 323) states that 'contemporary peace builders effectively reproduce the flawed logic of 1950s- and 1960s-era modernisation theory'.

The alternative, according to this author, could be a more carefully implemented and case-specific process of political and economic liberalisation, called 'strategic liberalisation'. In the political field, this includes, amongst other things, gradual and controlled democratisation that delays elections and starts with the promotion of moderation by supporting initiatives in civil society that cuts across cleavage lines as well as the building of social capital. Hence, unlike Cousens who states that the core of peace building is the creation of political authority, which is not necessarily democratic, Paris opts for a gradual process of democratisation. Particular attention should also be paid to the liberalisation of the media and electoral rules that reward political moderation. In the economic field, adjustment policies should be made more peace-oriented. For example, higher inflation should be permitted in exchange for economic growth, and social safety nets should alleviate the poverty of those hit hardest by adjustment programmes.

Although the article by Paris is about the limits of international liberalism, the central argument is that liberal internationalism should not be rejected, but adapted to the realities of war-torn societies. This implies an extended timeframe for peace building missions (in combination with improvement of coordination between international agencies), and a longer 
and more intensive involvement of international agents, as for example the support for political moderation before organising elections means increased 'social engineering'.

Paris lays open some important flaws of what may be called today's international article of faith: the idea that in the long run (only) economic and political liberalisation will bring prosperity and peace. Instead, he argues that modernisation itself is a conflict-ridden process. However, the author also assumes that a longer and more intense presence of international agents, using a more sensible approach, will be more successful in realising basically the same agenda. This assumption is increasingly questioned today, for several reasons. First, with the experience of the international community in Bosnia in mind - a case of virtually unlimited intervention - one should not think too lightly about the capacities of the international community to build a lasting peace, nor about the legitimacy to do so (cf. Cousens 2001). Second, 'democracy building' has proved to be extremely difficult in many countries. Writing about USAID, Carothers (2002: 9) has pointed out that many countries 'got stuck somewhere on the assumed democratization process'. ${ }^{2}$ Third, economic liberalisation has been questioned ever since it became the central tenet of the international financial institutions (IFIs). This is not only the case because of the rising inequalities that it may cause and the risks for renewed violence, but also because it can cause a (further) decline of (the legitimacy of) state power that results from cuts in government budgets.

Obviously, all forms of political and economic modernisation cause social tensions, and so too will political and economic liberalisation. The question, however, is to what extent these tensions can be managed, or to what extent tensions that are generated by social change can be dealt with by the political and economic structures that are created in this very process. In fact, the question is whether the triple transition can deal both with the tensions inherent in any post-war context and with the new tensions that modernisation creates. The case of El Salvador is particularly interesting to answer this question because the triple transition was successful in ending the political violence of the civil war and led to a serious political opening and economic growth. These transitions in their turn led to new tensions that appeared far more difficult to address.

\section{The peace process in El Salvador}

According to the former secretary-general of the United Nations, Boutros Boutros-Ghali, the UN mission in El Salvador (ONUSAL) was 'the first in the "second generation" of peacekeeping operations to emphasise post-conflict peace building' (UN 1995: 3). This mission went beyond the traditional peacekeeping missions and aimed to combine elements of peacekeeping, with peacemaking and peace building. According to Boutros Boutros-Ghali the success of ONUSAL pointed to the need for an integrated approach to human security, addressing political, economic, social and environmental problems. 
Despite this emphasis on the need for a holistic approach, the focus of the Salvadoran peace accords was first of all on political reform and security, emphasising the need for demilitarisation and democratisation. The most detailed paragraphs of the peace accords consisted of detailed agreements concerning the cease-fire (paragraph 7) and the reform of the military apparatus and the transition of the military police into a civilian police (paragraphs 1 and 2 respectively). In combination with further juridical and electoral reforms (paragraphs 3 and 4), this would eventually lead to the rule of law in El Salvador. Attention to socio-economic problems in the peace agreements was, however, rather limited (paragraph 5). There was some attention to a land-titling programme for combatants of both sides, as well as a socio-economic forum consisting of government officials, employers and employees that would seek national reconciliation. ${ }^{3}$ Furthermore, the Plan for National Reconstruction (PRN) was supposed to be based on the consensus of the government and the FMLN guerrilleros.

Hence, the Salvadoran peace accords primarily reflected a political solution to the conflict, and one can argue that it was a case of 'peace building as politics', or a 'double transition' that was directed at the demilitarisation of the political system. However, a 'third transition' did take place in El Salvador, but it was not agreed upon in the peace accords, as it had already started before they were signed. The ARENA government that took power in 1989 had started a far-reaching programme of macroeconomic stabilisation and structural adjustment. The programme was not discussed during the peace talks and the new economic policy was implemented without taking into account the specific needs of the peace process. De Soto and del Castillo (1994) compared this situation with two doctors operating on a patient with a curtain drawn across the middle of his body. Although at a later stage del Castillo (2001) stated that the coordination between 'the doctors' (UN and IMF) improved (referring to it as 'by all standards a success story'), the neo-liberal reform process was developed and implemented by the ARENA party that represents the Salvadoran economic elite. Historically, this elite had been extremely reluctant to commit to socioeconomic reform, and an important issue in the discussion about the Salvadoran process of reconstruction is the question whether the neoliberal reform process has provided a 'socio-economic basis' for peace. In other words, does the economic transition match with the other two transitions? This question will be discussed further. First I will briefly discuss the political and economic roots of the war, and the wartime strategy of both national and international actors to end the war.

\section{Background to the peace accord: failed modernisation}

The root cause of the Salvadoran civil war was an economic structure that had led to great socio-economic inequalities, and that was sustained by a militarised political system that mainly served the interests of a small 
oligarchy with interests in the agro-export sector. Despite some political and economic changes in the period after the Second World War, until 1979 the position of the oligarchy was never really challenged. Efforts at economic modernisation led to economic growth through industrialisation and some diversification of agricultural exports in the 1960s and 1970s, but it did not lead to a serious challenge of the position of the oligarchy that also acquired a position in these new sectors. Neither did it lead to further distribution of income and land, and large sectors of the population, particularly the rural poor, were further excluded economically. Political modernisation failed because of the strong position of the conservative military, that backed the interests of the oligarchy and twice overruled the electoral victories of Christian-Democrat-led alliances in the 1970s. Hence, the decades preceding the civil war can be characterised as a process of economic and political modernisation that failed to include the interests of the excluded sectors of the population.

Once the war had started, the United States recognised the need to change economic and political structures, and made it a core element of its counter-insurgency project. The United States not only supported the military in their struggle against the left-wing guerrilla movement FMLN, but also actively supported the economic and political reform programme that was implemented by a junta consisting of reformist military and ChristianDemocrats and later by the Christian-Democratic government of Napoleon Duarte. The economic reforms included a land reform, the nationalisation of the banks as well as the nationalisation of the export of cotton, sugar and coffee - the main export commodities of the country. At the political level, there was an 'electoral opening'. This gave rise to a number of new political parties, the most important being ARENA which represented the interests of the economic oligarchy and that came to be the largest party in the country by the end of the 1980s. These political reforms cannot be equated with democratisation, as the military had all but disappeared from the political scene and it was far from safe for left-wing parties to participate. One can argue that during the war years, the Salvadoran government and its main supporter - the United States - already supported a 'triple transition', although of a different nature; it sought to end the war militarily, by eliminating the guerrilla movement; to reform the political system through 'electoralism' (or limited democratic reform); and to reform the economy through, amongst others, land reform and nationalisation (giving an important role to the government).

This agenda changed in the course of time, due to political changes at both a national and an international level. A crucial change nationally was the victory of the right-wing ARENA party in the parliamentary elections of 1988 and the presidential elections of 1989. ARENA president Alfredo Cristiani drastically reduced the role of the government in the economy and implemented a neoliberal economic reform project that undid the nationalisation of the banks and the nationalisation of export products. The 


\section{Chris van der Borgh}

programme also sought to liberalise trade, to stabilise the economy and to strengthen the private sector. Although since its foundation ARENA had objected to land reform, the new government was not able to reverse the measures completely. It can be argued that even this was not their first priority, as the composition and interests of the economic elites had changed considerably. The rural elite had suffered during the war years, and there were new opportunities in sectors like finance, commerce and construction. In particular the elites with interests in these emerging sectors were more interested in negotiating a peaceful end to the war, instead of holding on to the military defeat of the FMLN. Combined with the changing position of the United States and the guerrilla movement, who both increasingly favoured peace talks, a new opportunity for peace arose. As already mentioned, these UN-led peace negotiations concentrated on demilitarisation and democratisation. The socio-economic aspects were only to a limited extent taken into account. Anyway, the economic reforms of the Cristiani government complemented the measures of the peace accords and made El Salvador a case of 'triple transition' as defined by Forman and Patrick (2000). The question, however, is whether this new form of modernisation was and will be capable of managing the tensions existent in Salvadoran society, as well as the ones that emerge from the very process of change. I will go into this by discussing the three transitions separately, and in conclusion assess the success of the triple transition in building peace.

\section{Security: from political violence to everyday violence}

The Salvadoran peace accords led to far-reaching reforms regarding the role of military actors in society: the guerrilla movement FMLN disarmed and transformed into a political party and the military disappeared from political life. This was complemented by the abolition of the former military police forces and the formation of a new civil police force (PNC). The 'demilitarisation of political life' definitely was a landmark in the Salvadoran peace process, as it led to the end of the civil war and deepened the electoral democratisation that had started during the war years. In the years following the civil war political violence was reduced to a minimum and the human rights situation improved substantially. If the peace accords were a 'negotiated revolution', as some observers stated, it was because of this achievement.

There were, however, numerous obstacles in this transitionary period of demobilisation and disarmament that could have derailed the peace process. The problems that emerged - such as acts of political violence and the discovery of supplies of arms - were solved, thanks to the presence and skills of the UN mission in El Salvador (ONUSAL) that had put the (sustainable) protection of human rights at the core of its mission and that had a decisive impact on the outcome of the peace negotiations and on the implementation of the peace accords (Burgerman 2000). Furthermore, the 
United States actively supported the peace process and proved to be willing to put political pressure on the Salvadoran military when necessary. ${ }^{4}$

However, the building of the PNC - considered fundamental for guaranteeing human rights in the longer run - has been the object of severe criticism. The detailed description in the peace accords of measures concerning the foundation of the PNC could not prevent its foundation and building being object of continuous renegotiation and struggle in which officials of the Salvadoran government, the United States and ONUSAL, as well as Salvadoran and international NGOs, have been involved. There is no doubt that a lot has been achieved, as the foundation of an entirely new civilian police force is an achievement in itself in a country where police functions had to be militarised up until the peace accords were signed. It is also clear that rising crime rates in the years after the war have complicated the building of the PNC, but on the other hand, the Salvadoran ARENA-led government can been blamed for at least part of the problems. Critics point among other things at weak government support, outright obstruction by government officials, and the (illegal) involvement in the PNC of former military police members with a questionable record and even entire sections of the intelligence services (Costa 1999; Spence, Lanchin and Thale 2001). If anything becomes clear from the experience of the PNC so far, it is that institution building is a political struggle in itself and that new institutions cannot be fully 'built' during the years of a peace-keeping operation. This does not mean that institutional reform should not be supported (the foundation of the PNC is in itself a landmark), but that there are limits to what one can realistically expect to achieve in 'building the rule of law' (see also the next section).

One of the specific problems with the reform of the security sector in El Salvador is the fact that, while political violence virtually disappeared, new or everyday violence reached extremely high levels. The average number of homicides resulting from violent crime clashes between youth gangs and violence in the private sphere even exceeded the average numbers of casualties in the war years. ${ }^{5}$ There are different explanations for this post-war violence. Most frequently mentioned is that there is a 'security vacuum', suggesting that crime has spread because of the deficiencies of the PNC and problems with the integration in society of former members of the armed forces and the guerrilla movement, who are allegedly responsible for the main part of this new violence. It is assumed that these problems will be of a temporary nature, as they will be dealt with by further institution building; i.e. by a better-trained police force and an improved judicial system. Others have emphasised the political nature of some of the violence. For example, the research of ONUSAL's Joint Group found that, in the years following the civil war, members of the former military were still using political violence with a view to destabilising the country. The Joint Group also reported that violence had become 'more complex', as there were links between some PNC officers, ARENA members and other government officials to criminals involved in the drug trade. ${ }^{6}$ 


\section{Chris van der Borgh}

Another line of argument states that the problem of protracted violence has social, economic and cultural causes. Bourgois mentions several factors that can explain the high levels of homicide in El Salvador. First, he points to the social processes in which repression and violence have become embedded in daily interactions and that political terror (by the state) has generated 'everyday violence through the systematic distortion of social relations and sensibilities' (Bourgois 2001: 19). In this view, contemporary violence should not just be explained by the failed integration of ex-combatants or by problems in building the police force, but also by the ways human relations in general have been affected by the civil war. Second, Bourgois (2001: 8) states that violence is also (re)produced by structural violence, which he defines as 'historically-entrenched politicaleconomic oppression and social inequality'. By pointing to the latter Bourgois also draws attention to neo-liberal policies and the negative consequences of social inequality on the excluded and marginalised sectors of society.

Binford (2002: 215, 230) has criticised the first part of Bourgois's explanation of the new violence, stating that the post-war violence cannot just be seen as 'the post-war fallout of wartime political violence', and emphasising that everyday violence in post-war El Salvador should be merely seen as 'a function of poverty and exploitation in the present [structural violence] resulting from Peace Accords that hardly touched the pre-conflict economic class structure'. Although Binford and Bourgois agree that there is a relationship between the political economy of El Salvador and forms of everyday and symbolic violence, they seem to disagree about its relative importance. In fact, the evidence about the connection between social and economic marginalisation and violence and our understanding of the multiple forms of violence and its interrelations in El Salvador after the peace accords is still limited (Binford 2002: 215).

It is fair to say that the transition from war to peace has led to paradoxical results: on the one hand political life has been demilitarised and political violence has been sharply reduced; on the other hand the measures described in the peace accords have not resulted in less homicides. For that reason it will be hard for many Salvadorans to talk about human security at all. If peace building is more than creating a 'negative peace', the new violence should be curtailed and our understanding of the emergence of new forms of violence ought to be at the top of the agenda. I would argue that it is realistic to conceive the contemporary violence in El Salvador as more than a temporary problem in a transition from war to peace and that there clearly is a need to look beyond explanations that focus on 'violent crime' or a weak police force. We probably need several kinds of explanation for contemporary violence in different settings (crime, private sphere, youth gangs) and focus on the relationships between weak institutions (police, judicial system), social and economic exclusion (neoliberal policies) and distorted social relations (both as a result of the war, and as a result of the 
massive migration of Salvadorans to the United States which was a consequence not only of the war, but also of the lack of economic opportunities).

\section{Democratisation: electoral democracy and its limits}

The process of demilitarisation, discussed above, made possible a further democratisation of the political process, leading to elections in which opposition parties could freely participate. The importance and success of this process should not be underestimated, as the former enemies now 'fight' their struggle in the political arena. The ARENA party was the victor in the first municipal, parliamentary and presidential elections after the signing of the peace accords in 1994, although the FMLN won 25 per cent of the seats in the Assembly. The FMLN (that as a political party had kept the same name) has done better since, becoming the largest party in the 2000 parliamentary elections and being very successful in municipal elections amongst them in a number of the largest municipalities, such as the capital San Salvador (in 1997 and 2000). However, ARENA won the presidential elections of 1999 for the third consecutive time.

The reforms of the political process did not, however, lead to institutionalised practices of consensus building or concerted action between the former opponents ARENA and the FMLN, and Salvadoran politics has remained extremely polarised. A case in point is the lack of concerted action after the January 2001 earthquakes, when president Flores was reluctant to cooperate with FMLN representatives, and in a number of affected municipalities FMLN and ARENA members founded separate emergency committees (Spence, Lanchin and Thale 2001: 35-7). Another example is the lack of political will of ARENA government officials to institutional cooperation with the FMLN mayor of San Salvador, leading to delay in several projects (Bourtel 2002). With regard to consensus building with groups from civil society, the short experience of the forum for concerted socio-economic action is not very promising. In the peace accords it was agreed that representatives of employees, employers and the government would discuss socio-economic matters. Although the accords were not very precise about the agenda and role of the forum, it only existed for a short period, with the government not being very committed and both employers and employees mainly seeing it as a way to solve specific labour conflicts (Zamora 2001: 15-16). ${ }^{7}$

The Salvadoran peace accords set out to go beyond electoral democracy and therefore included the reform of the judicial sector and the security regime, which should eventually lead to the rule of law in El Salvador. As was discussed above, the building of the new civil police force - a core element in this process - is an ongoing and unsettled struggle. So is the reform of the judicial sector, which appears far more difficult to reform than, for example, the military sector, for both political and practical reasons. The problems are manifold; amongst them the limited attention 
that was given to the issue during the peace talks, the opposition of the head of the judiciary, and more generally the 'institutional nature and history of the judiciary and the complex relation between other aspects of a society and its legal system' (Popkin 2000: 8). Furthermore, international donors amongst them USAID - see themselves confronted with limits as to what external pressure and foreign assistance can achieve.

Democratisation, or the political dimension of the triple transition, was at the heart of the Salvadoran peace accords and departed from the same kind of assumptions about the nature of democratic transitions that have been identified by Carothers (2002). These assumptions include, amongst others, the belief in the determinative importance of elections, as both a foundation stone and a generator of democratic reforms, as well as the idea that underlying conditions - such as economic structure and political history - do not matter. Carothers's conclusion that many regimes are not 'either dictatorial or clearly heading towards democracy' is valid for El Salvador as well. Despite the rather extraordinary achievements in terms of democratic transition in El Salvador, the country can be characterised as a 'semi-democracy'. It is far from clear whether the country is heading for further democratisation or whether it has become stuck somewhere in the process.

The fact that the Salvadoran democracy is 'unfinished' or incomplete may be partly due to the fact that it is not matching with the process of economic liberalisation. According to Zamora (2001), the processes of political and economic liberalisation do not complement each other, as the democratic transition is geared to the incorporation of the citizens into the political process, whereas the neoliberal reforms lead to economic concentration and social differentiation. In fact, he argues, this is the result of the main 'deal' made during the peace negotiations: the bourgeoisie allowing for democratisation and the guerrilla movements allowing for the neoliberal economic model. As the ARENA party has won the presidency during three consecutive elections - despite severe internal problems and losses in elections both for the Assembly and for municipalities - this has enabled them to further implement the economic reform programme. Moreover, ARENA has implemented these policies in a rather authoritarian way, without consultation or transparency, while in particular the economic elites that are represented by ARENA have benefitted from the programme. ${ }^{8}$ Hence, in this view the economic and the political transition are at odds with each other, an issue that will be further dealt with in the next section.

\section{Economic liberalisation and protracted social exclusion}

The ARENA government that came to power in 1989 initiated a neoliberal programme of macroeconomic stabilisation and structural adjustment, which was one of the most ambitious efforts of the century to redefine the Salvadoran development model (Rosa 1993). The central objectives of the new model were the stimulation of the export sector, which had weakened in 
the foregoing decades, especially during the war years, and the attraction of foreign investment (Zamora 2001: 8). Among the most important structural measures were the privatisation of the banks and the rapid reduction of tariff barriers. ${ }^{9}$ These measures were complemented by a policy of macroeconomic stabilisation focusing on a liberalisation of the exchange rate, a reduction of inflation, the elimination of the fiscal deficit and the stimulation of savings. From 1995 onwards the further reduction of tariff barriers and the stabilisation of the exchange rate (instead of its liberalisation) were central objectives. The former led to the gradual elimination of tariffs while the latter eventually led to the - highly contested - 'dollarisation' of the economy. The economic plan was complemented by a social plan, including compensation policies, modernisation and decentralisation, that were all directed at poverty alleviation (Rivera Campos 2000).

There is discussion whether the policies implemented by three consecutive ARENA governments have been supportive of the peace process. A first question is whether a programme of macroeconomic stabilisation, in particular the target of fiscal discipline and the reduction of inflation, can be combined with the governmental financing of peace accords, which requires investments that may go beyond the targets set by the government. Both may be necessary for peace building: on the one hand government investment in high-priority programmes of the peace accords, like the reintegration of ex-combatants, is important in the short run; on the other hand deficit financing may lead to macroeconomic instability, which may hamper economic growth and investments in the longer run. In the case of El Salvador, initially the IMF and World Bank did not take this dilemma into account and asked the government to finance peace-related expenditure with additional public savings (Boyce 1995: 2109; Del Castillo 2001: 1978). ${ }^{10}$ In particular the fact that there was no fine tuning between IFIs and the UN of the objectives laid down in the peace accords and in the economic programme led to severe criticism (De Soto and del Castillo 1994). However, somewhat later, in 1993, the IMF did take into account the costs that were related to the reconstruction programme, and worked more closely with the UN and the Salvadoran government. ${ }^{11}$ The fact that the Salvadoran government actually spent less than the IMF had allowed for on these peace-related issues was therefore not a result of IMF conditionality, but of the government's own political and economic choices. ${ }^{12}$

Apart from the question about the financing of the peace accords, there is the question whether the economic strategy of ARENA has laid the foundation for a sustainable peace. There is widespread consensus about the need for (renewed) economic growth in a period of post-war reconstruction in combination with poverty alleviation, or with equity. In the case of El Salvador this combination is of great importance, as one of the triggers of war in El Salvador was a period of economic growth in the decades preceding the civil war, in which the position of the oligarchy was hardly affected, while inequality increased. So the question is not only whether 
there is economic growth, but also what kind of growth it is and who benefits. The economic model of the ARENA government is under increasing criticism with regard to its achievements in this regard.

This is partly because economic growth rates have gone down. While between 1991 and 1995 the Salvadoran economy grew by 6.1 per cent annually, it declined between 1996 and 2000 to less than 3 per cent (Pleitez Rodríguez 2001: 89). Furthermore, the source of economic growth has not been a revival of the export sector, as was intended by the ARENA governments. In fact, export earnings as a percentage of GDP further declined during the 1990s (Rivera Campos 2000: 89). The only export sector that showed growth was the assembly sector, while industry and agriculture have lagged behind. Instead, the most dynamic sectors in the Salvadoran economy in the first of half of the 1990s were construction, finance and trade. Hence, the objective to stimulate the export sector - one of the pillars of the development model propagated by ARENA - has failed (Zamora 2001).

In terms of poverty alleviation one can argue that El Salvador has done pretty well, as UNDP data show that whereas in 1991/1992 nearly 60 per cent of all households were poor, this was reduced to a little over 40 per cent in 1999 (Pleitez Rodríguez 2001: 116). ${ }^{13}$ The validity of these data are, however, contested by Rivera Campos (2000: 216), who also points to the fact that in the long run poverty appears to be a much more structural phenomenon than is suggested by the UNDP data. Moreover, the figures presented use a narrow definition of poverty, as they focus on the price of a basket of food items while not including access to, for example, health care and drinking water - both services being inaccessible or insufficient for large sections of the Salvadoran population. The level of social spending has also increased in the past decade, although investments in education and health care are still relatively low, both in a historical perspective and with respect to other Central American countries (Rivera Campos 2000: 221). Furthermore, economic concentration has not diminished and the distribution of income is still extremely skewed (Pleitez Rodríguez 2001: 121).

Hence, the critique of the reforms of the ARENA government is that they have not been able to lay the basis for sustainable growth, nor for equity, and that a new strategy is needed that goes behind orthodox neoliberal recipes. Some key elements of these critiques are that there should be more space for sectoral policies at the micro and meso level, that particular attention to the agricultural sector is needed (especially for small producers), that more investments are needed in health care and education, that the taxto-GDP ratio should be raised (and be made more progressive), and that more attention should be given to issues of poverty and equity ${ }^{14} \mathrm{~A}$ recurring element in these critiques is that current economic policies are the exclusive domain of the ARENA government, whose policies in particular benefit a few elites with interests in the financial sectors, while the govern- 
ment has been unwilling to consult other sectors in the formulation of policies. Some reporters have stated that ARENA acts as if it is 'owning the country'. 15

The position of this new financial elite has been the result of structural changes in the Salvadoran economy, which has become highly dependant upon the remittances of Salvadorans living in the United States. Their disbursements are now by far the most important source of foreign currency, while the export of coffee (the backbone of the Salvadoran economy for nearly a century) has further declined. The inflow of remittances- in a liberalised economy - has made for a boost of consumption based on imported articles (amongst others a tremendous increase in the import of cars), which was by no means matched by growth in the export sector. As already mentioned, the contrary was true: the export sector lagged behind. These developments have given rise to new economic elites with interests in banking and trade, who have been highly influential in defining economic policies in El Salvador and who amongst others supported the dollarisation of the economy. Here, the political economy of structural adjustment becomes manifest. While there has been economic reform and growth, the economic policies have remained the strict domain of both old and new Salvadoran elites, which dominate the ARENA party. If peace building is about tackling 'the roots' of a conflict, these are certainly roots that have been largely untouched. The flaw in the Salvadoran peace process is that decision making in the economic policy was not democratised (the main opportunity to do so in the economic forum never succeeded). It remained a case of business as usual: economic growth combined with migration and social exclusion.

\section{Conclusion}

In this chapter I have explored the achievements of the triple transition in El Salvador. I would argue that the case of El Salvador is a success story of ending a civil war and creating political structures that can avoid a relapse into civil war. The shift from civil war to civil strife in El Salvador is an important achievement and is a rather successful example of peace building as politics. Despite these successes, the three transitions that took place in the 1990s have their limits and have in some respects not been complementary.

The transition from war to peace was successful in stopping political violence, though it was unable to curtail new forms of violence. This new violence, I have argued, cannot only be explained by the weakness of the new institutions (like the police force) but should also be explained by problems of social exclusion and migration. Hence, there appears to be a relationship between the emergence of new violence and the social, economic and political changes in Salvadoran society. Our understanding of these connections is, however, limited. 


\section{Chris van der Borgh}

Political democratisation has been a core element of the peace process. This process had already started before the peace accords, leading to a kind of 'authoritarian democracy' in which the military still played an important role. The demilitarisation of political life in combination with some judicial reforms triggered the process of democratisation. Despite these reforms, important problems exist in several areas, such as the police force, the judicial system and the modernisation of institutions. In particular the low level of consensus building, both between political parties and between state and society, shows that political culture in El Salvador has retained many of its authoritarian features.

Finally, the process of economic reform was not negotiated in the peace talks and (apart from a few measures) was not included in the peace accords. The process was therefore not fine tuned with the objectives stated in these accords. Just like everywhere else, the contents of structural adjustment policies have been contested in El Salvador. There has been hardly any space to discuss these policies, however, as the formulation of economic policy has been the exclusive domain of the ARENA government that has been in power since 1989 and that represents the interests of both old and new economic elites. The mechanism that was described in the peace accords to initiate such a dialogue (the socio-economic forum consisting of government officials and representatives of employers' and employees' organisations) did not succeed because of a lack of political will from the government, and the social partners not really understanding its meaning. One of the flaws of the triple transition in El Salvador is the lack of democratisation of the policymaking process and the dominant influence of (new) economic elites in the formulation of economic policies. One can argue, indeed, that the Salvadorans have voted for this policy during three consecutive presidential elections. On the other hand, the international community (in particular the IFIs) could have pushed harder for such a dialogue to occur, through mechanisms like the socio-economic forum, making aid conditional upon achievement of the measures in the peace accords.

The Salvadoran triple transition shows that the three transitions do take place, but do not always support each other, and may even be contradictory. In fact, the transitions have their own dynamics that are often difficult to manage by outside actors. The scope of action of the international community has its limits; reforms can easily be planned and initiated but may get stuck in the process, as happened with the reforms of the police force and the judicial sector. It is true that in the beginning of the 1990s some developments were difficult to predict, as was the case with the tremendous increase in remittances and its effects on the Salvadoran economy, and with the emergence of new violence. So it is fair to say that the agendas that were established in this period - the peace accord of 1992 that stipulated the democratic reform and demilitarisation, and the programme of structural adjustment that was defined in 1989 - were not able to confront in a satisfactory manner the old and new problems that emerged in Salvadoran society. 
Although the peace accord and the structural adjustment programme were supposed to be complementary, they were by no means fine-tuned. This was also due to the fact that - despite the political democratisation they had to allow for in the peace talks - the economic elites organised in the ARENA party were able to safeguard their interests through an economic reform programme. This programme was rather exclusive and can hardly be seen as supportive or to provide a basis for a sustainable peace.

The idea that recovery after conflict will involve some kind of a triple transition remains valid, however. Changes in the security regime, the political system and the economic sphere are necessary and interrelated. What can be learned from the case of El Salvador is that these transitions are not linear, and that while some roots of the conflict may be addressed, others may not. What is more, there are opposing interpretations of what these roots are and what should be done, structural adjustment and its relation to peace building being a case in point. For that reason, what is needed is not blueprints about policies but political space to seriously discuss policy alternatives. In this respect, consensus building between state actors and civil society in El Salvador has remained extremely limited.

\section{Notes}

1 For example, the Stability Pact for South Eastern Europe (a political framework agreement on international cooperation between donor agencies, international organisations, civil societies and governments) emphasises that 'only if there is progress in all three sectors can a self-sustaining process of peace be achieved' (see www.stabilitypact.org).

2 Carothers (1999: 93, 101) emphasises that institutional reform is not merely a technical process and that it should not be separated from 'the messy political world around them'.

3 For an overview of the peace agreements, see Estudios Centroamericanos 1992.

4 US pressure was important, for instance, when the Salvadoran government was not willing to comply with the recommendation of the Ad-Hoc Commission to dismiss 102 highly-placed members of the military that had committed serious human rights violations.

5 According to data quoted by Bourgois (2001: 19) the number of people who died during the $1980 \mathrm{~s}$ as a result of the war $(6,500$ per year) is less than the number of people who died in the $1990 \mathrm{~s}$ as a result of criminal violence $(8,700-11,000$ per year).

6 In its report of 28 July 1994, the Joint Group paid particular attention to the death squads, partly using data from the CIA and the US State Department.

7 The issue of consensus building is closely related to the nature of the political culture, as well as the depth of the process of democratisation. Authoritarian practices have persisted in government institutions, political parties and civil society organisations (cf. Pleitez Rodríguez 2001: ch. 3).

8 ARENA (in particular the main board, COENA) has been controlled by the new elites, which has led to internal fights within the ARENA party (see Zamora 1998).

9 This happened in combination with a simplification of the tax structure and a modernisation of the state apparatus (privatisation). For an overview of the economic reforms, see Rivera Campos (2000). 


\section{Chris van der Borgh}

10 It should be emphasised that the Salvadoran government was itself convinced of the need for such a strategy and was according to Del Castillo (2001) even 'more royalist than the king'.

11 According to Del Castillo (2001) this was implemented through a mix of increased external resources, higher domestic revenue, expenditure switching and increased bond financing and money creation. Low-priority projects of the reconstruction plan (such as poverty alleviation) were, however, postponed. The fiscal targets were not questioned, while there might have been some limited scope to do so, according to Boyce (1995: 2109). The reconstruction programme amounted to 7.3 per cent of government expenditure, of which 40 per cent was financed by grants and 30 per cent by long-term loans.

12 Some have explained this as the result of a lack of political will (cf. Wood and Segovia 1995). Del Castillo (2001) emphasises that the Salvadoran government spent more on transfers to local governments for expenditure on health care, education and reintegration of ex-combatants. This may point to a certain reluctance to invest in the groups that were most affected by the war, as a part of this group was the constituency of the FMLN.

13 These households counted for 47.5 per cent of the entire population. The data are from the Ministry of Economy and authors question the ways they are calculated. Furthermore, it is not clear in what way the remittances sent home by Salvadorans in the United States have influenced the (improvements in) data on poverty.

14 See Saprin (2000), Acevedo (1995) and Paus (1995).

15 Hector Dada in Candell Salazar (2002).

\section{Bibliography}

Acevedo, C. (1995) 'Structural Adjustment, the Agricultural Sector, and the Peace Process', World Development 23 (12): 2153-72.

Ball, N. (2000) 'The Challenge of Rebuilding War-Torn Societies', in C.A. Crocker and F.O. Hampson with P. Aall, Managing Global Chaos. Sources of and Responses to International Conflict, Washington DC: United States Institute of Peace.

Binford, L. (2002) 'Violence in El Salvador. A Rejoinder to Philippe Bourgois's "The Power of Violence in War and Peace" ', Ethnography, 3 (2): 201-19.

Bourgois, P. (2001) 'The power of violence in war and peace. Post-Cold War lessons from El Salvador', Ethnography 2 (1): 5-34.

Bourtel, K. (2002), 'Quand l'ex guérilla gouverne la capitale du Salvador', Le Monde Diplomatique, March: 16-17.

Boyce, J. (1995) 'External Assistance and the Peace Process in El Salvador', World Development, 23 (12): 2101-16.

Burgerman, S. (2000) 'Building the Peace by Mandating Reform. United NationsMediated Human Rights Agreements in El Salvador and Guatemala', Latin American Perspectives, 27 (3): 63-87.

Candell Salazar, R. (2002) 'El Salvador: 10 años de "Paz" ... Y el país celebra, lamenta u olvida?', Estudios Centroamericanos, 639-40, San Salvador Universidad Centroamericana.

Carothers, T. (1999), Aiding Democracy Abroad: The Learning Curve, Washington, D.C.: Carnegie Endowment for International Peace.

(2002) 'The End of the Transition Paradigm', Journal of Democracy, 13 (1): $5-21$.

Costa, G. (1999) La Policía Nacional de El Salvador (1990-1997), San Salvador: UCA Editores. 
Cousens, E.M. (2001) 'Introduction', in E.M. Cousens and C. Kumar with K. Wertmeister (eds), Peacebuilding as Politics. Cultivating Peace in Fragile Societies, Boulder: Lynne Rienner.

Cousens, E.M. and C. Kumar with K. Wertmester (eds) (2001) Peacebuilding as Politics. Cultivating Peace in Fragile Societies, Boulder: Lynne Rienner.

De Soto, A. and G. del Castillo (1994) 'Obstacles to peacebuilding', Foreign Policy, 94: 69.

Del Castillo, G. (2001), 'Post-Conflict Reconstruction and the Challenge to International Organizations: The Case of El Salvador', World Development, 29 (12): $1967-85$.

Estudios Centroamericanos (1992) 'Acuerdos de Paz', ECA 519-20: 103-52, San Salvador: UCA.

Forman, S. and S. Patrick (2000) Good Intentions. Pledges of Aid for Postconflict Recovery, Boulder: Lynne Rienner.

Goodhand, J. and D. Hulme (1999) 'From wars to complex political emergencies: understanding conflict and peace building in the new world disorder', Third World Quarterly, 20 (1): 13-26.

Kumar, K. (ed.) (1997) The Nature and Focus of International Assistance for Rebuilding War-Torn Societies, Boulder: Lynne Rienner.

Miall, H., O. Ramsbotham and T. Woodhouse (1999) Contemporary Conflict Resolution, Cambridge: Polity Press.

Paris, R. (2001) 'Whilson's Ghost: The Faulty Assumptions of Postconflict Peacebuilding', in C.A. Crocker, F.O. Hampson and P. Aall (eds), Turbulent Peace. The Challenges of Managing International Conflict, Washington, DC: United States Institute of Peace Press.

Paus, E. (1995) 'Exports, Economic Growth and Consolidation of Peace in El Salvador', World Development, 23 (12): 2173-93.

Pleitez Rodríguez, A. (ed.) (2001) Informe sobre Desarrollo Humano El Salvador 2001, San Salvador: PNUD.

Popkin, M.L. (2000) Peace without Justice: obtsacles to building the rule of law in El Salvador, University Park, PA: Penn State University Press.

Rivera Campos, R. (2000) La Economía Salvadoreña al Final del Siglo: Desafios para el Futuro, San Salvador: Flacso.

Rosa, H. (1993) AID y las Transformaciones Globales en El Salvador, Managua: CRIES.

Saprin/El Salvador (2000), The Impact of Economic Stabilization and Structural Adjustment Programs in El Salvador. Available online at http://www.saprin.org/elsalvador/research/els_exec_summ.pdf.

Spence, J., M. Lanchin and G. Thale (2001) From Elections to Earthquakes. Reform and Participation in Post-War El Salvador, Cambridge: Hemisphere Initiatives.

UN (1995) The United Nations and El Salvador 1990-1995, New York: United Nations.

Wood, E. and A. Segovia (1995) 'Macroeconomic Policy and the Salvadoran Peace Accords', World Development, 23 (12): 2079-99.

Zamora R.R. (1998) El Salvador: Heridas que no cierran. Los Partidos Políticos en la Post-Guerra, San Salvador: Flacso.

(2001) La Encrucijada de la Economía Salvadoreña, Collección Aportes No. 11, San Salvador: Flacso. 


\title{
6 Playing Russian roulette Putin in search of good governance
}

\author{
André Mommen
}

In his state-of-the-union address on 8 July 2000, Russia's president Vladimir Putin touched on several governance themes, including the need to strengthen central authority. He said that 'an era is beginning in Russia where the authorities are gaining the moral right to demand that established state norms should be observed' and that 'strict observance of laws must become a need for all people in Russia by their own choice'. He pointed out that 'competition for power' between the centre and regional powers has been 'destructive', and that 'we have to admit that [Russia] is not yet a full blown federal state'. Instead, according to Putin, Russians have 'created a decentralized state'. He listed Russia's 'economic weakness' as one of its most serious problems.

Putin mentioned fraudulent connections between politicians and private persons that were at the origin of Russia's governance problem. Several conditions contributed to this governance problem: an abdication of legitimate government power; excessive bureaucratic power; the potential of illegal (international) markets; and facilities for international money laundering (Blasi, Kroumova and Kruse 1997: 114-21). Therefore Putin called for strengthening Russia's civil society, preserving essential freedoms such as that of the press and ownership rights, ensuring equal conditions for competition in the economy, distancing the state from excessive interference in business operations, etc. According to Putin, Russia had to reform herself in order to overcome several handicaps created during a decade of weak governance $(R F E / R L$ Newsline, 10 July 2000). On 18 April 2002 Putin reiterated this when stressing that 'the Russian economy should grow more quickly, because we would otherwise lose time and again, curtailing our global and economic potentialities in the process' (Pravda, 18 April 2002).

Is Russia on her way back to recovery? In this article the problems listed by Putin will be analysed by referring to the constraints of a changing international environment and to Russia's inability to cope with governance problems inherited from the past. 


\section{Russia's changing international governance environment}

In international relations theory the issues of accountability and democratisation have become related concepts now that good governance has been married to legal issues and international law. Accountability refers to the process of holding another responsible for performance in the sense of political, moral or legal liability for the results of behaviour or event. Thus, for proper observance of rules and regulations, those administering the rules must be held responsible and accountable for their actions (U Myint 2000: 35-6). The neoliberal world order created the concept of good governance as one of the critical issues in politics and business of today. For companies, good governance means securing access to broader-based, cheaper capital, and for investors it means enhanced shareholder value. Self-regulatory organisations (SROs) and mechanisms are acclaimed as the instruments guaranteeing good governance. SROs should write trading rules, set sanctions against dishonest traders and ensure contract compliance without relying on an external agent for enforcement (Frye 1999: 5). Not the state, but a highly transparent market has to regulate preferences and direct investment. Even in world politics self-regulatory mechanisms and agencies are promoted as countervailing powers neutralising the impact of state interventionism. Together with the rediscovery of Alexis de Tocqueville's (1951) civil society, SROs predicted the coming of a new golden age.

The term 'good governance' stresses the political, administrative and economic values of efficiency and capitalism and marries the new public management to the advocacy of liberal democracy. Good governance became an export product of the Western international institutions to the former communist countries and the developing world. The passage of the Foreign Corrupt Practices Act (FCPA) by the US government in 1977 was a watershed event in the fight against corruption. It was argued in Senate hearings that US companies had to pay bribes to compete with foreign multinationals. But since European corporations could deduct bribes as business expenses for tax purposes, competitive pressures may well have encouraged them to escalate the level of bribery to win business away from US competitors (Cragg and Woof 2001: 182).

Many organisations became involved in combating fraud and corruption. The International Anti-Corruption Conference (IACC) that was held for the first time in 1983, in Washington D.C., and subsequently every two years (New York 1985, Hong Kong 1987, Sydney 1989, Amsterdam 1992, Cancún 1993, Beijing 1995, Lima 1997, Durban 1999 and Prague 2001), put forward the idea of law enforcement issues and the development of successful strategies and tactics for deterring and investigating official corruption. Later the scope of the conference grew to include the entire spectrum of stakeholders in the effort to combat corruption and fraud throughout the world. The IACC became the premier global player for networking against corruption and for bringing together an international 
cross-section of those responsible for containing corruption in their own societies and those with a stake in the success of their efforts. The Organisation for Economic Cooperation and Development (OECD) signed in December 1997 the Convention on Combating Bribery of Foreign Public Officials in International Business Transactions and founded a Best Practices Institute gathering cross-national information and analysis in areas such as public management, business-government relations and social policy. Law enforcement institutions are crucial for the struggle against public and private corruption. International instruments such as a United Nations Convention Against Corruption are important for bridging the gaps between national legal systems.

However, many corporations have been paying bribes around the world for decades. The International Telephone and Telegraph Corporation (ITT) offered the US Central Intelligence Agency (CIA) \$1 million in 1970 to block the election of presidential candidate Salvador Allende in Chile. Corporate financing of the established political parties had become a tradition. In Germany the Flick Corporation scandal of 1982 showed how a widely condoned practice increased the temptation to acquire resources by illegal methods. Flick 'cultivated' the political scene by a wide variety of direct or indirect interventions aimed at sponsoring the careers of handpicked political talents and at promoting them to suitable positions. In fact, Flick manipulated the balance of inner-party forces by intervening in favour of pro-market factions and by making and unmaking party alliances and government coalitions (Girling 1997: 17). Nowadays, multinational companies are becoming increasingly sensitive to the corruption question and they have been giving support to the anti-corruption forums. The International Chamber of Commerce adopted anti-bribery standards. Governments are called to enact legislation to criminalise foreign bribery (Tanzi 2000: 11).

The use of the term of corporate governance (Hirst 2000: 17) would in this context not be entirely superfluous. Corporate governance is supposed to improve the accountability and transparency of the actions of the large companies and the behaviour of their managers, and to sustain Russia's transition from socialism to capitalism. Transparency in all actions of government is estimated being essential to promote integrity and to fight corruption. Transparency is important for maximising the disclosure of relevant financial information for stockholders. In the United States the Securities and Exchange Commission (SEC) and most New Deal legislation were intended to maximise transparency of corporate conduct and to enhance the reporting of relevant financial information to investors and securities enforcement agencies. After the Watergate crisis the SEC launched a Voluntary Disclosure Programme, placing the onus on US corporations governed by federal securities law to identify payments of a questionable nature. The final outcome was the FCPA that became law in 1977 (Cragg and Woof 2001: 185).

Financing election activities and political parties should be transparent so as to prevent corruption. Therefore the adoption of a private-sector 
integrity policy is necessary. The second Global Forum on Fighting Corruption and Safeguarding Integrity (held at The Hague on 28-31 May 2001) also stressed the necessity of citizens' involvement and independent media in order to obtain the rule of law in administrations. The Conference acknowledged the catastrophic effect that corruption is having on societies and the necessity of taking immediate and effective measures to curb corruption in all its forms. National anti-corruption strategies should be monitored in accord with the demands of civil society organisations, the anti-corruption organisation Transparency International (a non-governmental organisation acting as a watchdog on international corruption), and a number of Southern anti-corruption organisations.

The concept of good governance is also promoted by the World Trade Organisation (WTO) and multinational companies representing the selfimage of triumphant international capitalism, and it belongs to the rhetoric and ideology of the Washington Consensus which make believe that good governance is the key to sustained development, a low degree of criminality and the extinction of corruptive behaviour of both rulers and special interest groups. Since the early 1990 s the international institutions have launched an offensive against international money laundering, which is regarded as a handmaiden of global corruption. The International Monetary Fund (IMF) and the World Bank are pressing for innovative regulatory initiatives to strengthen the detection of money laundering and to improve supervision of financial institutions to limit the scope of this activity (U Myint 2000: 44). Good governance belongs to the so-called second generation reforms promoting sound and sustainable growth and efficient government with an effective civil society and a highly performing private sector. Good governance ideology is based on participatory and democratic traditions, promotion of equity, gender balance and the rule of law. Economic and institutional good governance reforms are always translated into changing governance rules and legal constructions supporting a regime's legitimacy. They have to refer to procedures of decision-making and legality or criteria of justice.

In international relations theory the meaning of the concept of good governance was transformed into a form of international governance referring to the possibility of governing without government (Rosenau and Czempiel 1992), in the form of international governance or even global governance (Prakash and Hart 1999) and global democracy (Held 1995; Holden 2000; Sassen 2000). Economic reforms and democratisation should go hand in hand and cooperation between nations should be based upon competing and interdependent states. Meanwhile new patterns of international cooperation and new actors or non-governmental institutions and agencies are occupying the international terrain. The decay of the sovereign state has to be considered as an outcome of these global processes transforming institutions and modes of capital accumulation (Ruggie 1993). Economic and institutional reforms tend to increase the speed of the globalisation process now that the nation-state is 
digging its own grave. Strong pressures coming from outside obliged them to open up their economies to foreign capital and to democratise their internal political structures. States were obliged to meet the newly established international governance standards of accountability and democratisation. Manuel Castells $(1996,1998)$ has argued that global capitalism no longer operates on the basis of expansion and incorporation, but on a new logic of consolidation and exclusion. According to Castells a dual process of capitalist inclusion and exclusion is working its way through the capitalist world system. In reaction to this process a renewed nationalism is being fuelled in all countries, not only in Russia.

\section{Russia's governance problems}

According to Joseph Stiglitz (2000: 5), all the calamities Russia has experienced during the long transition period were caused by external pressures exercised by the IMF and US Treasury Department economists whose faith in the market was unmatched by an appreciation of the subtleties of its underpinnings, that is, 'of the conditions required for it to work effectively'. The neo-liberal reformers failed to move Russia towards a real market economy at all by paying insufficient attention to the institutional infrastructure that would allow a market economy to flourish. The rapid privatisation urged upon Moscow by the IMF had allowed a small group of oligarchs to gain control of state assets (Stiglitz 2000: 5). Russian radical reformers monitored by the IMF believed that markets are 'natural' and 'spontaneous' social orders, which supposedly can flourish and develop best in the absence of any intervention. Reformers like Grigory Yavlinsky emphasised the importance of institutions monitoring the rules of the game and enforcing basic rules upon market parties (McFaul 2001: 140-6). Fixing property rights, backing up contracts, protecting competition, reducing asymmetries and frictions were seen as the state's core mission in economics. Emphasis was put on economic transparency and low transaction costs. The IMF did not back these social-democratic reformers. So the ultra-liberals headed by prime minister Yegor Gaidar could envisage a 'big bang' based on liberalisation, privatisation and stabilisation as the pillars of their radical reform strategy. The shock therapists not only believed in their quick reforms, but also speculated on the creation of a large group of people with vested interests in capitalism in order to prevent a reversion to communism.

Spontaneous privatisations were followed by a voucher-based mass privatisation (Boycko, Shleifer and Vishny 1996: 69-95). Chief privatiser Anatoly Chubais believed that Russian enterprises had to sever their links with the state and the political machinery. Therefore on 11 June 1992 the Russian Parliament passed a law on privatisation. Vouchers worth 10,000 roubles each to every Russian citizen were issued. The vouchers could be exchanged for shares in enterprises. However, a quarter of the shares were directly given to the employees and these employees could purchase another 
15 per cent at a discounted price. But the mighty lobby of industrialists pressed for a second option whereby 51 per cent of the shares were sold to the workers and 49 per cent were auctioned. Finally, a third option allowed a management buyout by a group that promised to restructure the firm. The voucher privatisation was a source of mass corruption, because political compromises, regional deviations and corrupt practices permitted special deals with the government. Vouchers were tradeable and managers discovered opportunities to buy vouchers and shares with funds borrowed from their company. Auctions were manipulated. Managers were better informed than outsiders and tried to get control over the best enterprises with the help of organised crime. Millions of extra vouchers were printed and used vouchers circulated freely. Meanwhile unlicensed 'investment companies' collected money from the public.

Not all firms, however, were privatised with the help of vouchers and auctions. Most oil, gas, diamond, gold and other metal producers were privatised 'privately' because they were hard-currency earners and competitive on the world market. In the case of Gazprom only individual investors were admitted, excluding foreign and professional buyers. This form of insider privatisation inspired former Finance Minister Boris Fyodorov in 1995 to qualify Gazprom's privatisation as 'the biggest robbery of the century, perhaps of human history' (Rousso 2001: 8).

At the time of the voucher privatisation, commercial and capital markets law did not exist and basic institutions enforcing good governance had not yet founded (Gustafson 1999: 58-76). In 1994 a Securities Commission was created in name, but accountants did not exist in Russia. Government authorities showed that they had no interest in taking steps to ensure effective corporate governance by transferring control rights from managers to outside shareholders, while managers learned that they could plunder their firms with little risk of persecution. According to Russia's senior prosecutor, the privatisation process has been undermined by bid-rigging by banks (Rose-Ackermann 1999: 36). After the privatisation drive, no financial information was available for the outsiders and most companies refused external audits. Outsiders were denied a seat at the board of directors although they owned a minority in the firm's capital. Managers issued new shares in order to dilute the holdings of the other shareowners at a low price. At the regional level, governments protected insiders and they allowed tax breaks, too, in an attempt to protect local employment and to prevent takeovers (Rousso 2001: 9). Finally, privatisation set a premium on perpetuating inefficiency and corruption and it undermined confidence in government, in democracy, and in reform' (Stiglitz 2002: 159).

In 1995, with president Boris Yeltsin's popularity low and presidential elections in the offing, the Russian state was nearly bankrupt due to heavy subsidies to failing industries and poor tax collection. Oligarch Vladimir Potanin (of Uneksimbank) proposed to the government that a group of bankers should loan funds to the cash-strapped government, with repayment 
secured by the government's majority stake in key strategic and lucrative metals, oil, and other industries excluded from voucher privatisation. According to Boris Fyodorov, this loans-for-shares privatisation gave shares as security to the Moscow-based banks of the oligarchs 'splitting up companies among old friends' (Rousso 2001: 9). The right to manage the auctions was parcelled out among the major banks, who succeeded in acquiring the firms with bids at or just above the minimum. The biddings were rigged by having affiliates of the banks organising the auctions and by excluding for 'technical reasons' competing bids. 'Auction' became a euphemism for a selling off at knockdown prices. Loans-for-shares was a deal Yeltsin could use in 1996 when he was in need of financial and political support from the oligarchs controlling the media and the banks in order to bar the communist Gennadi Zyuganov the path to the Kremlin.

What had been envisioned as a short transition period with a mild recession turned into a slump. In the period 1990-1999, Russian industrial production fell by almost 60 per cent, even greater than the fall in Gross Domestic Product (GDP) of 54 per cent. Investment in manufacturing almost came to a stop and farm livestock numbers decreased by half. Russia was able to attract some foreign investment in natural resources because the government priced its natural resources low. Economic growth did not recover, because investment was halted, capital was used up and savings had been vaporised by inflation. Privatisation led to asset stripping rather than to enhanced efficiency, and fuelled capital flight as long as the recession deepened and the American stock market kept on booming (Stiglitz 2002: 144). The IMF had told Russia to privatise as fast as possible, but in the absence of a corporate governance infrastructure privatisations incited corruption and the theft of assets from the minority shareholders. Privatisation turned over enterprises to their old managers (insiders) focusing on asset stripping and the tunnelling of profits. It diminished the role of the central government, but that devolution left the local and regional authorities with far wider discretionary power and enabled them to extort 'rents' or 'taxes' from privatised firms.

More than a decade after the big bang, Russian capitalism is clearly still different from Anglo-Saxon shareholder capitalism trusting self-regulatory organisations to endorse general standards ${ }^{1}$ for board practices. Russia's big problem is that its legal system is not well fitted for fighting corruption. Fighting corruption requires poverty-reducing strategies in addition to cooperation and commitment at all levels, from global to local, and at all levels of government and from non-governmental organisations (NGOs). In addition, NGOs have also to be more transparent about their goals and aims and about their sources of income and expenditure. In the case of Russia, corruption is not an entirely new phenomenon as it accompanied the transition from socialism to capitalism and gave birth to a form of corruptive crony capitalism, Russian- or 'Kremlin'-style. Russia's governance problems were discussed at many international forums and often cited as a 
key factor behind Russia's economic problems (Roaf 2000). The US Congress even organised a hearing on corruption in Russia and the activities

of Russian criminal émigrés in the area of white-collar fraud. As a part of its overseas expansion programme, the Federal Bureau of Investigation (FBI) opened in 1994 Legal Attaché offices in Moscow, Kiev and Tallinn.

Many governance problems in Russia are due to contradictions and antagonisms characterising regional and/or centre-periphery problems. Several aspects of the poised relationship between the Russian state and its society have to be analysed in the light of these contradictions. That the Kremlin's authoritarian solutions to successive crises undermining the country's stability and security met much 'structural' resistance from the outside world, is a consequence of the impact the globalisation process has on Russia's policy issues. Changes in the forms and mechanisms of governance were accompanied by shifts in the location of governance and governing capabilities. Therefore the rule of law could become a key feature of the transition process now that international actors and trend watchers were pressing the Russian government for more thoroughgoing judicial reforms, a better protection of human rights and more transparency. These reforms occurred in many spheres of public life. Sometimes they had serious effects at local, regional and national levels, and finally they obliged the Kremlin to find some kind of modus vivendi with foreign critics by engaging a dialogue with them. There are some signs announcing a more stable dialogue with the outside world and the modernising forces in Russian civil society.

\section{Corruption: a Russian style of governance?}

When the Soviet Union collapsed, the class of 'New Russians' (Brady 1999: 44-62) organised into shadowy syndicates controlling banks, casinos, stock exchanges, hotels, restaurants and commercial firms in most Russian cities. The perception of Russian citizens was that criminal structures determined the course of violent events (Handelman 1995: 21-3). However, violence is only used in a situation of emergency. Soon the Russian criminal elite formed a class of income recipients living on the 'real economy'. The consequences were that bribery of government officials, the police, and even the courts could become prevalent and that the criminal class could receive government funds by embezzlement. Meanwhile, the rates of capital flight were growing fastest for criminal gains and unreported profits (and therefore Russia was put on a blacklist by the G-7 in June 2000). But when, after the financial crisis of 1998, Russia had to adopt a new policy with clear goals and objectives providing a basis for accountability and integrity, the dominant forces in the Kremlin complied to the pressure from the IMF and international capital markets for more financial transparency. The effect was that, after his election in March 2000, president Putin immediately announced plans to drastically increase spending on law enforcement and 


\section{André Mommen}

the national court system. A new procedural code for Russia's criminal law was introduced. According to Interior Minister Boris Gryzlov, all organised crime-combating efforts would be deployed within a single vertical chain of command, including the Interior Ministry, directorates in federal districts, and territorial agencies. Each of the seven federal districts would receive operative investigative bureaus (Moscow News, 15-21 August 2001). Then, Economic Development and Trade minister German Gref announced a set of measures 'making Russia free of corruption' by simplifying the tax and customs systems, by consolidating off-budget funds, by abolishing excise, tax on the use of resources in situ, and tax on the reproduction of the mineral raw materials base, which were established at will by officials (Moscow News, 8-14 August 2001).

These actions against corruption and organised crime met the opinion of the population. In a poll conducted at the end of November 2000 among 650 people who could be considered part of Russia's opinion-making elite, ROMIR-Gallup International found that 27.8 per cent considered corruption the greatest threat to Russia's security. Interviewed by Rossiiskaya Gazeta ( 7 August 2002), Georgy Satarov of the INDEM (Foundation for Information and Democracy) think tank and a former adviser to Yeltsin highlighted the role of corrupt law enforcement. Noting that the country had reached a stage of 'developed corruption networks', he stated that corruption was so widespread in part because of the unfair and often illegal ways that state property was privatised in the 1990 s, leaving many hidden secrets and vulnerable officials and businessmen. He added that increasing state salaries would not immediately affect the corruption problem, since many officials have bought or been placed in their positions specifically to practice corruption. Referring to a previous report (INDEM 1998; Levin and Satarov 2000), Satarov found political parties to be the most corrupt organisations in Russia, followed by the traffic police, the State Duma, and prosecutors' offices.

In Russia, corruption has become a key mechanism through which political interests have built the electoral support necessary to ensure access to the state's resources (Makarychev 2002a, 2002b). In turn corruption has shaped a politics of factional competition over power and resources and, as a virus capable of crippling the Russian governance structure, bribing is discrediting public institutions and private life. Moreover, corruption is having a devastating impact on human rights, and thus undermining civil society and its development. Hence, combating corruption requires that the government should ensure the integrity of its officials by political parties in promoting transparency in their financing and by the private sector in applying high standards of accountability. This is not only a matter of enacting correct laws and establishing an independent, effective and efficient judiciary committed to upholding the rule of law, but may also require changes in attitudes and in long-standing practices.

The control of corruption is an essential element in the promotion of Russia's world-market integration and the accumulation of wealth and prop- 
erty. As Putin stated in his state-of-the-nation address in 2000, transparency and impartial forms of public control as well as cooperation by the private sector are considered to be of the utmost importance, and independent and investigative media should play a vital role in public life. Corruption, however, is virtually a near-universal governance problem. Weberian bureaucracy was meant to have abolished particularism, nepotism and gift-taking because officials were salaried and trained to impartiality. But in Russia, low pay and cultural patterns encouraged civil servants to accept 'speed money'. As capitalism globalised, corruption acquired an international dimension. A few decades ago criminals corrupting politicians and bureaucrats did not necessarily develop into full-fledged international mafias. Nowadays they are imitating the international arms traders who traditionally pay bribes for having their weaponry sold to corrupt government officials. Government positions may be a means of giving favoured people (cronies) access to a share of the spoils (bureaucratic mercantilism) (Girling 1997: 42-85). In the case of Russia, corruption may help overcome the rigidities of an overregulated economy and influence the bureaucratic system. In the Soviet Union the command economy criminalised a wide range of market exchange. Hence, substantial illegal market activities involving bribes could expand at many levels of the ruling hierarchy during the last decades of the communist regime. Soon legal authorities overlooking illegal activities started taking bribes to permit law enforcement.

As a whole, Russian society and politics resisted market-based economic relations (McIntyre 1996) because of national or local networks of patrons and clients. Relations between most firms and the state were not characterised by market relations, but by networking entrepreneurs and political power brokers. The privatisation process that was launched in 1992 contributed to the serious corruption problem. Although privatisation was one of the many reforms introduced that were designed to provide sustained growth, privatisation badly damaged the state's structure. The rising trend in the use of corruption as a tool to discredit political opponents had brought scandalous cases of corruption in the media. In Russia prominent political figures, including president Yeltsin and his ministers and high officials, have been accused of corruption and, as a consequence, some of them resigned or were forced out of office. ${ }^{2}$ Corruption in Russia is often blamed on behavioural norms inherited from the Soviet era and its authoritarian political structures. Though in this period corruption existed at all levels of society and was closely related to the command economy (Holmes 1993: 198), the phenomenon was rather marginal.

The World Bank thinks that corruption is the flat abuse of official power for private gain. One can simply define it as deriving some advantage for oneself or for related individuals by any abuse of authority by an appointed or elected agent for private gain, or any attempt to cause such abuse (Johnston 2001: 11; Vannucci 2000: 1). Following the World Bank definition, corrupt behaviour includes bribery, extortion, fraud, embezzlement, nepotism, 
cronyism, appropriation of public assets and property for private use and influence peddling (cf. Girling 1997; Miller, Grødeland and Koshechkina 2001; Jain 2001). Nevertheless a problem exists because Russian society differs in many aspects from Western individualistic capitalism. Many parts of Russia's civil society can be characterised as traditionally organised communities with close social relationship where the frequency of corruption is likely to be greater, its identification much more difficult, and its punishment more problematic (Tanzi 1995: 164). ${ }^{3}$

Transparency is seen as a major instrument for fighting corruption and mafia activities. Immunity and privilege should not prevent corrupt public servants and politicians from being held accountable under the criminal law, and transparency in all aspects of national and governments should ensure international official activity, including the legally guaranteed rights of citizens to access to information. Respect of freedom of opinion and expression, full and complete disclosure of funding sources of political parties, and private-sector activities untainted by corruption are considered by the Second Global Forum on Fighting Corruption as important preconditions for a successful campaign against corruption. However, this highly moralistic appeal makes abstraction of the social and economic backgrounds of the phenomenon called corruption. Corruption breaks a moral or social code of conduct or an administrative rule. Of course, this requires that the rule or the code is precise and transparent. Another aspect is that the corrupt official who breaks the rule wants to derive some recognisable benefit for himself or his relatives, his friends, his tribe or political party. The benefit derived must be seen as a direct quid pro quo from the specific corrupt act. At any rate, there must be evidence that a precise rule is broken. The problem is that in many cases the rules are not precise or transparent. In post-communist societies the Weberian governance type of ideal bureaucracy will prove very difficult to install (Miller, Grødeland and Koshechkina 2001: 39-60; Punch 1993). In these societies the cost of the corrective role of the government is likely to rise and to affect economic relationships within the private sector as well. In that social environment the establishment of a true market economy will prove to be very difficult, because traditionally organised societies resist transparent markets.

In Russia, with its clientelistic networks, transparency is mostly unknown. Instruments that make corruption possible and attractive include regulations of various kinds such as the issue of licences and permits, fines for violations of existing legal norms, control over the procurement of contracts and public investment, tax incentives, subsidies, credit, overvalued foreign exchange, hiring and promotion, tax administration decisions, etc. Control over these instruments can give state employees great power to extract large rents for themselves and their families. Many factors have influenced emerging corruption and criminality in Russia. In the absence of a strong and developed civil society the mafia functions as a voluntary organisation regulating economic and welfare transactions with the state. Summing up, in 
Russia corruption distorts the redistributive role of the government and it is likely to have negative implications for the stabilisation role of the government. Corruption will raise the costs of running the government, while reducing government revenues and introducing payoffs. Corruption has a negative impact on growth and productivity too (Rose-Ackermann 1999: 3; INDEM 1998).

\section{Some basic governance problems}

Under Putin's rule the government is trying to modernise its governance structures. A lack of funds is hindering that modernisation process in areas such as infrastructures, nuclear energy plants, research and development, social welfare, pensions, ${ }^{4}$ public health, education and the armed forces. In search of sustained economic growth the Putin administration wants to exercise better control over natural resources and commodity exports and to attract Foreign Direct Investment (FDI) by creating "a Russia that is free of corruption, where protection of the individual and business will be a top priority' (German Gref, Minister of Economic Development and Trade, in Moscow News, 8-14 August 2001). As a 'perfect Russian nationalist ruler', Putin is struggling with his own image now that the forces of globalisation are pressing his government to meet the new international standards of the rule of law in order to create - in connivance with foreign capital and international agencies - a business-friendly environment, which implies promoting social stability and military security, creating a stable fiscal system of regular tax collection, and establishing the rule of law in all subjects of the Federation as preconditions for the creation of sustained economic growth.

\section{Creating a favourable environment for FDI}

Though Russia's Institute of Direct Investment Foundation regularly organises in the presence of leading businessmen like Anatoly Chubais (Unified Energy Systems) or Mikhail Khodorkovsky (YUKOS) Russian Investment Symposia in all major capitalist countries, Western investments in Russia over the last ten years have been less than in Poland, the Czech Republic and Hungary, and less than one-tenth of those in China. As multinational capital only wants to settle in peaceful countries with a good governance structure, crisis-ridden and land-locked Russia was not a first-choice location for investment. The inappropriate way the Russian government reacted to conflicts between civility and incivility, conformity and nonconformity, morality and legality, majorities and minorities, may explain why foreign capital preferred to invest in other countries. Chechnya is but the most obvious case in point. Russian casualties due to alcohol abuse, street crime and drug use are extremely high and indicate that Russian society is in crisis. The issue is whether the crisis can be contained within tolerable levels. 
Foreign investors are still afraid of Russia's security system. There are residual concerns over the possible mishandling of the major nuclear arms inventories in the remnants of the Soviet Union. The focus of concern has now shifted to the proliferation of nuclear weapons throughout the lessdeveloped world. In addition, there is certain to be increasing international concern for environmental transgressions, most of which are indifferent to arbitrary national boundaries. A two-track policy can offer some advantages: a reinforcement of Russian civil society, and a better application of the rule of law. The big problem is that Russia's civil society is still keeping a low profile and that most NGOs have remained weak because they are small and dependent on foreign resources and funds. Foreign NGOs are interested in investing their resources in important urban centres like Moscow or St Petersburg, not in Russia's crisis-ridden provincial towns.

International actors argue that Russia, just like the rest of the world, must pursue universal human interests guided by universal human values. Now that there is a growing and inescapable demand to enforce globally adopted codes of individual and group conduct and behaviour, Russia will have to comply. First of all, human rights have to be protected. During the Yeltsin administration legislators were already aware of the necessity of a modern legal structure. Article 2 of the Constitution of the Russian Federation (1993) mentions that 'man, his rights and freedoms shall be the supreme value. It shall be a duty of the state to recognise, respect and protect the rights and liberties of man as citizen'. So the use of excessive force (brutality) against persons and property must be avoided. Responding to foreign criticism on the events in Chechnya, Putin emphasised that the Constitutional Court should play a role in developing European human rights standards. Second, civil and criminal codes have to establish legal frameworks protecting the rights of man. A step forward was the adoption of new Civil and Criminal Codes. The new Civil Code of January 1995 eliminates the restrictions of the former Soviet Code designed to protect and regulate socialist ownership. The new Criminal Code of 1997 is a big step forward too. Its most valuable contribution is that it covers several types of economic crimes and fraud that the Soviet Criminal Code of 1960 failed to define. The new Criminal Code establishes criminal liability for securities fraud, for false bankruptcy, money laundering, illegal disclosure of confidential banking or commercial information, operating an unregistered business or bank, and tax evasion. It defines as criminal certain acts of state officials, such as corruption and bribe-taking, abuse of authority, and unjust denial of registration or issuance of licences.

The court system is struggling with powerful competitors: state officials and businessmen bypassing the judicial system. Although the judges became independent in 1992 and cannot be hired and fired by the Minister of Justice, the presidential administration still interferes in these matters. Local or district judges are frequently told by higher judges what sentences to impose. Many judges and prosecutors are often not impartial, some are 
corrupt or involved in politics, and most of them are working in very poor conditions. However, Putin soon obtained a vested interest in reforming the system of justice, when World Bank President James Wolfensohn ${ }^{5}$ started pressing for substantial reforms. Putin's legislative package included a substantial curtailment of prosecutors' powers leading to a polemic between the government and the judiciary, which was not inclined to accept unconditionally a change of court presidents and an age limit for judges or a modification of their existing forms of immunity.

\section{The fiscal crisis of the Russian state}

The government's inability to balance its budget and its resort to massive short-term borrowing had led in 1998 inevitably to default and devaluation in effect, bankruptcy on a nationwide scale. The problem was that, during the transition period under Yeltsin, the federal system remained too centralised regarding taxation, and there was a lack of transparency in the fiscal policies of the regions who carried out their own fiscal policies (Bikalova 2001: 2). The federal government tried to get rid of some obligations and therefore delegated a wide variety of responsibilities (child care and military pensions) to the regions without granting them opportunities to collect additional revenues.

The big problem in the 1990s was that about 40 per cent of Russia's GDP was generated by a steadily growing 'informal sector' (which has 'exempted' itself from paying taxes). Until recently, the state's revenue at all levels consisted not of actual 'live' money but of barter and various write-offs and quasi-moneys, resulting from the massive practice of tax-evasion. So Russia's permanent fiscal crisis increased the decay of the state, explaining the failure of state-society relations and the growth of criminal or forbidden activities. Response with more and more repression in order to combat these forbidden activities and to collect taxes contained the danger that the population would respond by ever-more determined tax evasion and a growing informal sector fuelling criminal transactions. Moreover, the ideology of a market-based democracy promoted tax-evasion by a pressing need for more private investment and consumption now that the state as a provider of free collective goods was approaching bankruptcy. At that moment the Russian state was unable to collect more than two-thirds of the taxes called for in the official budget. The worst offenders were the privatised companies. Many businesses avoided registration and thus escaped paying taxes. Tax evasion and dissimulation of profits by big companies became a widespread evil. To lower their profits, enterprises charged one another low prices, which they offset under the table with black money or bartered goods. They created subsidiaries in remote regions or areas with weaker tax offices, or exported their profits to foreign countries. Big oil companies created subsidiaries in the United States or opened bank accounts in Switzerland, Cyprus or other tax havens. The government experimented with amnesties and deferrals and 
forced bankruptcies, none of which brought much result. Large earners of undeclared income came under scrutiny by tax inspectors, but to little avail. If tax leakage is a universal fact, the measure of a good tax system is the extent to which it keeps the problem in bounds. But in Russia the problem is still out of control.

The Russian state was the source of all tax-collecting problems. The tax administration was operating in an unfair way and was unable to bring in adequate state revenues while not stifling or distorting the economy. The system was jerry-built from bits and pieces left over from the communist era. Because it tended to tax gross revenues rather than profits, and corporations rather than individuals, the Tax Code focused on the 'visible' businesses inherited from the soviet era. But as the Russian economy shifted from production to consumption, services, and small business, the tax system failed to follow. This incited businessmen to stay underground. A general tax reform became necessary after the first reforms in 1994. A new Tax Code was drafted defining the relationship of the taxpayer to the state, establishing who must pay, and setting deadlines and other obligations. A special tax court has to protect taxpayers against the widely spread practices of levying fines and penalties. Finally, new taxes should only be introduced by legislation, not by edict (Robinson 1997). On the 1 January 1999 the new Tax Code became effective (Ministry of Taxation of the Russian Federation 1998, 2000). ${ }^{6}$ At the beginning of 2001, the regressive Unified Social Tax replacing previous payments to the four social insurance funds was introduced. This new tax, as part of an overall tax reform, focuses on improvement of tax collection, the abolition of the black market and an overall increase in central governance capability (Nies 2002).

However, as before the tax reforms, much of the pressure from the tax collector falls on large enterprises. The industrial and building sectors especially bear most of the tax burden, while the oil and pipeline sector generates 25 per cent of total taxes. State-controlled stakes are not contributing dividends to the budget. According to former prime minister Sergei Stepashin:

The state appears to have no means of influencing an organization. The country is losing 200 billion roubles a year as a result. It is ridiculous that Russia gets normal dividends from just one organization: Vietsovpetro. On the whole, the yield on state controlled stakes is under 1 per cent a year [...] Isn't it paradoxical that we get three-quarters of all dividends from six joint-stock companies while the remaining quarter comes from almost 4,000 companies where the state has a stake? It is imperative to audit all state property, including our largest companies

(Moscow News, 28 November-4 December 2001)

Finally, Russia collects only a small share of its revenues from individual income taxes. Corporate tax rate was cut from 35 to 24 per cent and the 13 
per cent flat income tax has boosted tax revenues. ${ }^{7}$ (Since 1 January 2001, Russians have enjoyed a 13 per cent flat tax.) This low flat tax for individuals was instituted because the Russian tax collector is only interested in the big visible targets, mainly the large commodity exporters. They can be intimidated through pressure and the threat of restructuring and foreclosure. Dealing with the small and unofficial businesses is very difficult and requires a long-term strategy and more tax agents. In Moscow alone, the inspectors are responsible for patrolling over 400,000 registered businesses. In order to protect the tax collectors, president Yeltsin created a Tax Police (Italianmodelled, and quickly growing to over 20,000 policemen), which has become the most cost-effective operation in Russian history, returning 50 roubles of clear 'profit' for every rouble spent on it. However, the courts are still reluctant to convict tax evaders. Moreover, if the Russian government shifts from its present focus on corporate taxes to taxes on individuals, as is the practice in all civilised countries, the Russian tax service will have to patrol millions of returns.

Recent laws have bolstered taxpayers' rights and the Tax Office is no longer allowed to demand immediate payments of fines. But these reforms are unlikely to change the basic situation, because the government needs money, and the powers of the courts are weak. The tradition of government agencies legislating through regulations is still too strong. This incites taxpayers to defend themselves by any means available (bribery, political clientelism, dissimulation, violence, evasion). To be sure, the unofficial economy is everywhere, because inside every officially registered enterprise there are unregistered private businesses, 'tunnelling' profits out the back door. The unofficial economy is a cash economy, which leaves no paper trail and creates leakages of recorded bank accounts into unrecorded cash and dual salaries. As the Russian economy becomes more open to the outside world, the sources of tax leakage, contraband, shuttle trade and money laundering multiply. Insurance companies are instruments for tax evasion, and banks transfer black money to foreign countries.

During 1994-1997 Russian capital flight was estimated at $\$ 300$ billion in net outflow. The classic way to export capital is to understate the quoted price of exported goods or to inflate the price of imported products and services. 'Importing air' (fictitious services) from a Russian offshore partner is a variant on that theme. Therefore offshore subsidiaries have become a highly developed art form among Russian businessmen. Because the complete Russian private sector has moved offshore and most large deals and transactions automatically carry a large foreign component, only a fraction of the transaction value will be paid and declared inside of Russia, while the rest will be settled from one offshore account to another (Abalkin and Whalley 1999: 421-44). In 1998, after the August crash, the Primakov government advised the Central Bank to raise obligatory sales of hard currency by exporters up to 75 per cent of their hard currency receipts (Abalkin 2002: 871), which was conducive to increasing the Bank's hard 
currency reserves, even though it did not limit the capital flight from Russia. Getting control over export earnings has remained an important policy target of the 'centrists' in the State Duma. In an interview, their spokesman Yevgeny Primakov formulated three priorities guiding Russia's economic policy:

First, the country's natural resources [...] It is through royalties, through rent for the extraction of natural resources that a substantial part of revenues is generated, which are then given to society through the national budget. Second, modernization of basic assets [...] To succeed, a modernization programme should include revision of customs, tax, and credit policies. Third, the state needs to carry out fundamental R\&D programs in some breakthrough areas on a selective basis [...]

(Moscow News, 23-29 May 2001)

\section{Defunct regional governance structures}

For more than a decade the centre-periphery struggle was an ongoing bargaining game over the ultimate distribution of powers in the Russian Federation. The 'regions' gained more power at the local level at the expense of the federal authorities. Ethnic republics were even striving for full independence, while 'krais' and autonomous 'okrugs' were building their own chartered nation-state, or, at least, pleading for an upgraded statute with elected governors and the right to sign treaties (Petersson 2001: 45-8; McAuley 1997: 42-81). The oblasts wanted to obtain the same status as the ethnic republics. Meanwhile, the political centre was doomed to bargain with each of the federation subjects simultaneously about substantive policy decisions (taxes, personnel, status). In most cases the centre-periphery antagonisms were observed by the players as being beneficial to their mutual interests. The political centre could preserve its predominance and authority as the voice of the Russian Nation, while the subjects of the federation in their 'contradictory resistance to globalization' (Makarychev 2000) tried to obtain a larger share of governmental subsidies or to attract foreign investment (Moscow News, 8-14 August 2001). During the centre-periphery bargaining process, some kind of hierarchy was established among the subjects of the Russian Federation and enabled the periphery to determine its contribution to the centre when discussing jurisdictional and distributional issues and establishing intra-regional agreements. A critical element in this process was that sub-national actors tried to obtain special treatment from the centre by virtue of unilateral changes in strategy or behaviour. When president Yeltsin met his regional representatives in Petrozavodsk in 1993 he could propose to them the creation of the Federation Council, which would be staffed by representatives of the eighty-nine provincial governments and would serve as the Upper House of the Russian Republic. 
They were not of great help to Yeltsin when he went into battle against his Parliament in September 1993.

The local rulers preferred unity in diversity. The leaders of the ethnic republics refused equal treatment of all Federation subjects, which would have left them badly outnumbered by the predominantly Russian oblasts. Then, the centre could reinforce its predominance over the regions. The new constitution ratified on 12 December 1993 treated republics and regions essentially as equals and dropped most references to sovereignty. In 1994, only two republics (Chechnya and Tatarstan) refused to acknowledge the legitimacy of the new constitution. Moscow reacted by signing a treaty with Kazan. Yeltsin offered similar bilateral treaties to the other republics and oblasts when he was looking for re-election in 1996. Efforts were made to promote regional associations as intermediary governance structures able to bargain with Moscow on a foot of equality. But few of these clubs could amount to much more than regional trade associations or meeting points for regional leaders discussing some minor economic problem of initiatives. For a while, the so-called Siberian Agreement had served as a regional opposition centre to Yeltsin (Valliant 1997: 12-13). But the capacity of most regional agreements to deal collectively with Moscow was undermined because of inter-regional economic differences, interests and rivalries.

In the early transition years Yeltsin had appointed most governors in the oblasts. Many of them were supporters of the Democratic Movement. Exceptions were found in some oblasts, where elections were held in April 1993, and in a few other districts. In the republics the situation was quite different. By the end of 1993 sixteen of the republics had used their right to form their own governments, to create presidential systems and to elect their presidents. Five republics retained a soviet-style political system in which the parliamentary body (soviet) elected an executive. When Yeltsin strengthened the executives in the republics at the time he abolished the remaining soviets, he also strengthened his local opponents. Because all leaders of the republics were popularly elected, their position was much stronger than the governors of the oblasts who were not (at least until 1996). Meanwhile many republics had become fiefs of local bosses. These excesses did not occur in most oblasts, but all regional leaders showed authoritarian styles of government, and many municipal authorities complained about governors not respecting municipal autonomy.

These authoritarian tendencies in the regions complicated centre-periphery relations. Though by 1995 the president gained the executive right to appoint, punish and dismiss governors whether they were elected or not (presidential decrees of 3 October and 22 November 1995), Yeltsin soon became reluctant to use this right as popular support for elected local executives had grown. Many regions adopted charters in 1994-1995, specifying rules for selecting executives, and pressure on Yeltsin grew to hold such elections. Yeltsin even delayed the elections of governors. 


\section{André Mommen}

During the transition period the regions split into new rich and new poor. In 1995, the top fifth of Russian regions had nearly five times the per capita GDP of the bottom fifth. Discussions of the Russian regions often mention that only a dozen 'rich regions' contribute more to the federal budget than they receive in return. ${ }^{8}$ On the eve of the August 1998 crash, Moscow had by far and away the highest per capita income in Russia, over three times the national average, due to the growth of the financial sector. Much of the inequality between regions is a product of differences in natural endowment, but uneven economic development in the regions was a major consequence of transitory policies and the globalisation process. Thanks to the oil and gas bonanza, some Siberian regions acquired a high per capita GDP. However, according to sociologist Olga Kryzhtanovskaya, the federal government manages to keep economically powerful regions, such as Khanty-Mansi and Yamal-Nenets autonomous okrugs, 'politically weak' by promoting mediocre regional politicians (Literaturnaya Gazeta, 11 November 1998). In contrast, regions previously specialising in military goods and heavy equipment lost ground, while the southern agricultural regions were severely depressed because of the free inflow of imported food. All these poor and crisisridden regions, among them many ethnic ones, reacted by opposing price reforms for a long period. ${ }^{9}$

Fiscal reallocation is a constant and contentious issue in centre-periphery relations and disputes. Regions depending on subsidies from Moscow are experiencing deficits, which in some cases are equal to the entire annual budget. Therefore rich regions may embark on the path of economic separatism or form their own gold and hard-currency reserves in violation of federal law and halt the transfer of tax payments to the centre. The have-not regions are too well entrenched in the political system to be ignored. The principle of 'taking from the rich' remains a constant temptation for populist politicians or generals bidding for power in Moscow. Opponents of the political centre pretend that Moscow determines subsidies on the basis of political criteria. Communist regions even pretend that they are heading the 'black list' and that they receive few subsidies. Defenders of centralisation usually think that the regions are centres of mismanagement and that regional governors fail to pass on federal monies transferred to them for wages. In the 1990s governors often blamed the federal government for mounting arrears (Vremya $M N$, 16 November 1998). However, wage arrears in 2001, due to underfinancing from the federal budget, totalled 610 million roubles, and they are still growing. Public-sector workers often have their wages paid in vodka or flour (Moscow News, 19 December 2001). Therefore, governors still can make speeches blaming Moscow for poor local living conditions, meanwhile often using their own branches or insurance companies to gain access to revenue streams that they generate or to control the interest generated by state funds. 


\section{The Putin reforms}

The first thing that newly-elected president Putin had to do was to bring order to the provinces (Mommen 2000). Russian decentralisation is fiscally unsustainable and contributes greatly to insidership and corruption. During the Yeltsin decade, attempts to bring order to the provinces quickly became bogged down. Under pressure from local leaders paying lip-service to the Kremlin, Yeltsin had to give up his attempts to re-centralise the state. The presidential representatives appointed by Yeltsin in order to reestablish his authority in the regions were degraded to figureheads without any power or influence, distrusted by local authorities and power structures. For many years some republics ignored Moscow's authority or federal laws by putting their own laws on an equal footing with Russia's.

Moreover, according to Prosecutor-General Yury Skuratov, 70 per cent of regional legislation did not correspond to federal law (RFE/RL Newsline, 27 January 1999). Justice Minister Pavel Krashenninikov told the State Duma on 5 March 1999 that approximately 20 per cent of all legal acts contradict the federal constitution. A new register of regional normative acts should ensure their conformity with constitutional standards ( $R F E / R L$ Newsline, 9 March 1999).

In June 1999 Yeltsin signed a law on the principle of dividing power between the Russian Federation and the regions (Rossiyskaya Gazeta, 30 June 1999). All new federal and regional laws must be adopted in accordance with this law. The law institutionalised the process of signing power-sharing treaties between the centre and the regions, including the procedure of their preparation and responsibility of both sides (Article 3). On 11 April 2000 the Constitutional Court ruled that lower courts could stop the implementation of regional laws if they violated federal legislation. Previously, the Constitutional Court had ruled that it had sole responsibility for examining regional laws. Since the Constitutional Court lacked the resources to review the numerous laws passed by the regions that violated federal norms, the federal government could not react to them (Kommersant Daily, 7 April 2000).

The newly-elected State Duma of December 1999 did not constitute an obstacle to Putin's centralisation attempts. Though Putin had never before been an independent decision-maker, his large electoral victory in March 2000 silenced his contenders and the Yeltsin family clan. He began to form a new team by strengthening the power structures against the regional bosses. Finally, he ended their automatic right to a seat in Russia's upper house. Federal subjects had to get rid of all the inconsistencies between the republican and the federal constitution (Makarychev 2001; Makarychev \& Valuev 2002). Putin even tried (without success) to pass a bill that would give the president the right to appoint governors. Instead of implementing a former plan drafted by Georgy Satarov which foresaw about 60 regions, he parcelled out Russia's 89 component republics and regions into seven new 
districts, each overseen by a presidential appointee in order to curtail local autonomy. In these districts Putin is represented by a 'governor-general' who manages the local operations of the power ministries (defence, interior, security and justice) and deals with constitutional irregularity problems. $\mathrm{He}$ connected these governors-general to the old defence territories. ${ }^{10}$

When appointing former Minister of Finance Mikhail Kasyanov to be his prime minister, Putin opted for a powerful Kremlin handing down instructions. Under Yeltsin, economic policy had been shaped by the Kremlin staff, including such conspicuous figures as Anatoly Chubais, Aleksander Livshits and Aleksei Kudrin. Conversely, under Putin the key decision-makers on economic matters are the government staff composed of professionals who drafted a ten-year socio-economic plan as well as an 18month economic programme. This neoliberal programme called for tight control over government spending and ensured the passage of tax reform legislation in the State Duma, among other things, and for a new social contract between state and citizen, with the former guaranteeing stable roubles for business interactions, a normal tax system, and the decriminalisation of the economy. The programme also aims for ensuring minimum annual GDP growth of 5 per cent. Putin abandoned the idea of forming a 'system' of political parties in the State Duma. He preferred to accept Luzhkov's and Primakov's Fatherland-All Russia (OVR) merger with the Unity Party, forming a new 'centrist' party called Unified Russia that dominates the State Duma (Moscow News, 18-24 April 2001). It allowed him to isolate the Communist Party.

Putin's war in Chechnya still makes a bad impression on many Western human rights' watchers, but in the foreign capitals nobody worries about what happens in this remote area of Russia's territory. The Western powers have no interest in having Russia's central authority weakened and challenged by ethnically-defined nations espousing Islamic fundamentalism. This dirty war enabled Putin to reinforce state authority over the media owned by the oligarchs. Yury Luzhkov, the mayor of Moscow, who was connected with Gusinsky's MOST Bank in 1999-2000 and was Putin's strongest challenger to the Kremlin's grip on power and money in Russia, was attacked in the state-run media, which gave him a pounding before the general Duma elections in December 1999, alleging murder, corruption, fraud, links to Scientology and so on. Luzhkov had to recognise that he lost the battle, but he retrieved enough favour to reappear in the Kremlin.

Though the oligarchs had contributed to the election of Putin, their position was less powerful than in 1996 when they managed to have Yeltsin re-elected. Echoing Stalin, Putin said he would eliminate the oligarchs-as-aclass (The Economist, 13 May 2000). He warned Russia's tycoons that their days of running the country were over. This popular warning concealed him with both the populists of the right and the left. Later on, Putin reiterated. In January 2001 when meeting the business elite, he denied the oligarchs' right to conduct the country in their own interests (Fruchtmann 2002: 358). 
Putin's war on the oligarchs was highly selective. Berezovsky who was not allowed to add the aluminium industry to his empire, resigned from the State Duma on 19 July 2000 and fled to the West. Vladimir Gusinsky (Media-MOST) was forced to sell his shares in Gazprom and to cede his television station NTV to his enemies. Putin replaced Rem Viakhirev of Gazprom, the natural gas monopolist and principal shareholder of Gusinsky's Media-MOST, by his collaborator Aleksei Miller.

How should Putin's move against the oligarchs be interpreted? The oligarchs-as-a-class only had to realign themselves with their president, who soon pronounced the vital words that he would not review the results of privatisation (Kagarlitsky 2002: 207). Putin's coming to power only meant the decline of some oligarchs and the elevation of others. Putin only attacked those oligarchs exercising excessive political influence through their banks handling accounts of various government agencies. There is less and less evidence of bankers directly and defiantly pushing the authorities around. Oligarchs like Mikhail Khodorkovsky, Chukotka Governor Roman Abramovich, LUKoil president Vagit Alekperov and aluminium magnate Oleg Derispasko managed to maintain their wealth and influence. The Kasyanov government in August 2000 established a council for entrepreneurial activities and an investment commission headed by the Prime Minister (RFE/RL Newsline, 8 August 2000).

For sure, Putin is not anti-business. In an interview with Izvestiya on 14 July 2000 he defended the actions of the tax police and the federal prosecutor-general against several companies. According to Putin, 'the state has the right to expect entrepreneurs to observe the rules of the game'. $\mathrm{He}$ explained that the 'state announced that it would act more vigorously towards the environment in which business operates. I am referring first and foremost to the tax sphere and the restoration of order in the economy'. Noting that the defence budget totalled only 140 billion roubles ( $\$ 5$ billion), Putin charged that in 1999 more than 80 billion roubles ( $\$ 2.7$ billion) evaded the state coffers through zones with special tax privileges called ZATOs (closed autonomous territorial districts).

\section{Conclusions}

After the March 2000 election of president Vladimir Putin the Russian Federation has regained its political and economic stability and is responding more adequately to global pressures. Financial stability and economic growth are a source of optimism. Moreover, Putin seems to have his financial household under control. Russian leaders believe that under globalisation no nation will be able to develop successfully in isolation. Therefore Putin is changing his governance structure now that Russia is currently being pushed to accept thoroughgoing institutional reforms. Putin wants to show his strength, too. According to some Kremlin watchers, Putin is modelling himself upon Tsar Nicolas I, who ruled from 1825 to 1855 with 
draconian discipline (RFE/RL Newsline, 11 January 2002). However, Russia's governance structures remain weak in the area of basic law and order - to protect citizens' lives and property rights, and to enforce contracts. Laws and judicial systems are deficient.

Although the Russian state is weak, it is still ever-present (McFaul 2001: 326-8). As long as the economy stays afloat, thanks to Russia's oil and gas export and the weak rouble, Putin's authority will remain unshaken. Therefore Putin's top economic priorities will be the maintenance of macroeconomic stability, the regulation and indexation of tariffs for Russia's natural monopolies, and the reorganisation of the banking sector $(R F L / R L$ Newsline, 17 January 2002). Though high oil and metal prices in combination with devaluation of the rouble in 1998 have helped Russia regain some international footing, the country's economic future is uncertain (US Congress 2001). A return to strong executive authority is congruent with Putin dominating the State Duma (Sutela 2000) and with mainstream liberals, now posting up as his advisors.

\section{Notes}

1 In the United Kingdom these rules were defined in 1993 by the Cadbury Committee in the 'Combined Code', and in Canada in the Dey Report. In these countries stock exchanges require disclosure of conformity to certain recommended practices. In the aftermath of the Enron bankruptcy in the United States, the House Committee on Energy and Commerce believed that the New York Stock Exchange, the American Stock Exchange, and the Nasdaq should endorse similar rules for board practices.

2 There is a growing concern over corruption in Russia now that economists in connivance with the Washington Consensus have discovered that corruption is detrimental to sustained development. An EBRD/World Bank survey reported that Russian firms paid an average of 4.1 per cent of their revenues in bribes. High levels of corruption are likely to have been an important factor behind Russia's extremely low level of FDI (Roaf 2000: 2, 5).

3 This also implies that models of criminal or illegal behaviour of the type pioneered by Gary Becker and by Allingham and Sandmo will be of limited applicability to Russian situations (Tullock 1980: 71).

4 On 3 July 2001 the State Duma passed on first reading a package of pension reform bills giving a new status to the Russian Pension Fund and introducing a three-stage state pension security model with basic pension, insurance pension, and accrued pension.

5 At the World Bank's Second World Conference on Perfecting the System of Justice at St Petersburg in July 2001, Wolfensohn said 'there is a direct link between poverty and corruption levels in all countries'. As for Russia, he thought 'its leaders are taking a constructive approach to that issue, denouncing corruption' (Moscow News, 11-17 July 2001).

6 The main federal taxes include not only enterprise profit tax, value-added tax (VAT), excises on specific goods and raw materials, personal income tax (in 2001, 99 per cent of the proceeds of this tax will go to regional budgets), but also the well-known tax on extraction of minerals and raw mineral ores, customs and state duties, and contributions to state extra-budgetary funds ('the consolidated social tax'). This tax replaces previously separate taxes for pensions, social insurance, medical insurance and unemployment. 
7 The 13 per cent flat tax Putin signed into law on 6 August 2000 replaces a previous three-bracket system with a top rate of 30 per cent. This flat rate would reduce corruption, remove subsidies from favoured constituents, raise the money to pay for badly-needed services, and establish the credibility to push for further reforms (Berman and Rabushka 2000). In 1999 tax revenue equaled 9-10 per cent of Russian GDP, but by November 2001 revenue had grown to 16 per cent. However, these increases in fiscal earnings are also influenced by the economic upswing after the devaluation of 1998 and high international oil prices. They are certainly not due to the presumed effects of the Laffer Curve (lower marginal tax rates produce higher revenues) (Murdock 2002).

8 Usually discussions of the 'donor regions' do not define exactly which regions are involved. The Ministry of Finance reported that there are thirteen donor regions: St Petersburg, Moscow City, Moscow Oblast, Lipetsk, Samara, Tatarstan, Perm, Sverdlovsk, Bashkortostan, Khanty-Mansi, Yamal-Nenets, Krasnoyarsk and Irkutsk (RFE/RL Russian Regional Report, 27 May 1999).

9 Finally, price controls disappeared almost everywhere (McIntyre 1996). They reappeared after the August 1998 crash (RFE/RL Russian Regional Report, 10 September 1998).

10 Putin named his seven governors-general in May 2000. Apart from Sergei Kirienko (Volga district), Leonid Drachevsky (Siberia), and Pyotr Latyshev (Urals district), the other functionaries came from the security sector: FSB director Viktor Cherkesov (Northwest district), army general Viktor Kazantsev (North Caucasus), former KGB officer Georgy Poltavchenko (Central district), and army lieutenant-general Konstantin Pulikovsky (Far East).

\section{Bibliography}

Abalkin, Leonid (2002) 'Some notes on current problems of foreign economic relations of Russia', The World Economy, 25 (6): 869-74.

Abalkin, L. and J. Whalley (eds) (1999) 'The problems of capital flight from Russia', The World Economy, 22 (3): 421-44.

Berman, Michael S. and Alvin Rabushka (2000) 'Russia adopts 13 per cent flat tax', The Russian Economy, Hoover Institutions Public Policy Inquiry, July 26.

Bikalova, Nadezhda (2001) 'Intergovernmental fiscal relations in Russia', Finance \& Development, 38 (3): 36-9.

Blasi, Joseph R., Maya Kroumova and Douglas Kruse (1997) Kremlin Capitalism. Privatizing the Russian Economy, Ithaca: Cornell University Press.

Boycko, Maxim, Andrei Shleifer and Robert Vishny (1996) Privatizing Russia, Cambridge, Mass.: The MIT Press.

Brady, Rose (1999) Kapitalizm. Russia's Struggle to Free Its Economy, New Haven: Yale University Press.

Castells, Manuel (1996) The Information Age: Economy, Society and Culture, Oxford: Blackwell.

(1998) End of Millennium, Oxford: Blackwell.

Cragg, Wesley and William Woof (2001) 'Legislating against corruption in international markets. The story of the US Foreign Corrupt Practices Act', in Arvind K. Jain (ed.), The Political Economy of Corruption, London: Routledge.

Fruchtmann, Jakob (2002) 'Steuern durch Macht - Macht durch Steuern. Die russische Steuerpolitik unter Putin', Osteuropa, 52 (3): 346-61.

Frye, Timothy (1999) Brokers and Bureaucrats. Building Market Institutions in Russia, Ann Arbor: The University of Michigan Press. 
Girling, John (1997) Corruption, Capitalism and Democracy, London: Routledge. Gustafson, Thane (1999) Capitalism Russian-Style, Cambridge: Cambridge University Press.

Handelman, Stephen (1995) Comrade Criminal. Russia's New Mafia, New Haven: Yale University Press.

Held, David (1995) Democracy and the Global Order: From the Modern State to Cosmopolitan Governance, Cambridge: Polity Press.

Hirst, Paul (2000), 'Democracy and governance', in Jon Pierre (ed.), Debating Governance. Authority, Steering, and Democracy, Oxford: Oxford University Press.

Holden, Barry (ed.) (2000) Global Democracy Key Debates, London: Routledge.

Holmes, Leslie (1993) The End of Communist Power. Anti-Corruption Campaigns and Legitimation Crisis, Oxford: Polity Press.

INDEM (1998) Russia vs. Corruption: Who Wins? Analytic Report, Moscow (www.indem.ru).

Jain, Arvind K. (ed.) (2001) The Political Economy of Corruption, London: Routledge.

Johnston, Michael (2001) 'The definitions debate. Old conflicts in new guises', in Arvind K. Jain (ed.), The Political Economy of Corruption, London: Routledge.

Kagarlitsky, Boris (2002) Russia Under Yeltsin and Putin. Neo-liberal Autocracy, London: Pluto Press.

Levin, Mark and Georgy Satarov (2000) 'Corruption and institutions in Russia', European Journal of Political Economy, 16 (1): 113-32

McAuley, Mary (1997) Russia's Politics of Uncertainty, Cambridge: Cambridge University Press.

McFaul, Michael (2001) Russia's Unfinished Revolution. Political Change from Gorbachev to Putin, Ithaca: Cornell University Press.

McIntyre, Robert (1996) 'Regional Variations on Russian Chaos: Price Controls, Regional Trade Barriers, and Other Neo-classical Abominations', Communist and Post-Communist Studies, 29 (1): 95-102.

Makarychev, Andrei S. (2000) 'Islands of globalization: Regional Russia and the outside world' (Working Paper No. 2), Eidgenössische Technische Hochschule, Zürich, August.

- _. (2001) 'In search of international roles: Volga Federal District' (Discussion Papers, No. 21, Local Government and Public Service Reform Initiative), Open Society Institute, Budapest.

(ed.) (2002a) Politiko-administrativnye aspekty korruptsii v refionakh Privolzhskogo Federalnogo Okruga (Political and administrative aspects of corruption in the regions of the Volga Federal District), Nizhny Novgorod: Centre for Social \& Economic Expertise, Eurasia Foundation (Moscow Office) and Centre for Strategic and International Studies.

(ed.) (2002b) Tenevaya politika: Korruptsiya $i$ prestupnost $v$ Rossii $i$ mire (Shadow politics: Corruption and crime in Russia and worldwide), Nizhny Novgorod: Centre for Social \& Economic Expertise, Eurasia Foundation (Moscow Office) and Centre for Strategic and International Studies.

Makarychev, Andrei S. and Vasilii Valuev (2002) 'External relations of Tatarstan: Neither inside, nor outside, but alongside Russia' (Working Paper, No. 23), Eidgenössische Technische Hochschule, Zürich, March. 
Miller, William L., Åse B. Grødeland and Tatyana Y. Koshechkina (2001) A Culture of Corruption? Coping with Government in Post-Communist Europe, Budapest: Central European University Press.

Ministry of Taxation of the Russian Federation (1998) Tax Code of the Russian Federation. Part One of the Tax Code of the Russian Federation, No. 146-FZ of July 31 .

- (2000) Tax Code of the Russian Federation. Part Two of the Tax Code of the Russian Federation, No. 117-FZ of August 5.

Mommen, A. (2000) 'Zayavka V. Putina na vlast: konets rossiyskogo dlya regionalnoy Rossii' (Putin's bid for power: the end of Russia's federalism?), Polis. Politicheskie Issledovaniya (Polis. Political Studies), 10 (5): 70-80.

Murdock, Deroy (2002) 'Even Russia realized the wisdom of a flat tax', Dallas Morning News, 4 March.

Nies, Susanne (2002) 'Die Einheitliche ozialsteuer und die Reform des russischen Sozialversicherungssystems', Osteuropa-Wirtschaft, 47 (1): 60-83.

Petersson, Bo (2001) National Self-Images and Regional Identities in Russia, Aldershot: Ashgate.

Ponton, Geoffrey (1994) The Soviet Era. Soviet Politics from Lenin to Yeltsin, Oxford: Blackwell.

Prakash, Aseem and Jeffrey A. Hart (1999) Globalization and Governance, London: Routledge.

Punch, Maurice (1993) 'Key issues', in Maurice Punch et al. (eds), Coping With Corruption in a Borderless World. Proceedings of the Fifth International AntiCorruption Conference, Deventer: Kluwer Law and Taxation Publishers.

Roaf, James (2000) 'Corruption in Russia', Conference on Post-Election Strategy, Moscow, 5-7 April.

Robinson, Judith (1997) 'Russia amending tax laws', BISNIS - Business Information Service for the Newly Independent States, March (http://permanent.access.gpo.gov.htm).

Rose-Ackermann, Susan (1999) Corruption and Government. Causes, Consequences, and Reform, Cambridge: Cambridge University Press.

Rosenau, James N. and Ernst-Otto Czempiel (eds) (1992) Governance without Government: Order and Change in World Politics, Cambridge: Cambridge University Press.

Rousso, Alan (2001) 'Privatisation and corruption in Russia', Paper delivered at the 10th International Ant-Corruption Conference, Prague 2001.

Ruggie, John G. (1993) 'Territoriality and beyond. Problematising modernity in international relations', International Organization, 47 (1): 139-174.

Sassen, Saskia (2000) 'Territory and territoriality in the global economy', International Sociology, 15 (2): 372-93.

Stiglitz, Joseph (2000) 'The insider: what I learned at the world economic crisis', The New Republic, 17 April (The Brookings Institution, Washington DC).

- (2002) Globalization and Its Discontents, London: Allen Lane/Penguin Books.

Sutela, Pekka (2000) 'Russia's economy: present-day and prospects.' Talk at the School for Slavonic and East European Studies, University College London, May.

Tanzi, Vito (1995) 'Corruption: Arm's-length relationships and markets', in G. Fiorentini and S. Peltzman (eds), The Economics of Organised Crime, Cambridge: Cambridge University Press. 


\section{André Mommen}

- (2000) 'The role of the state and the quality of the public sector', Cepal Review, 71 (August): 7-22.

Tocqueville, Alexis de (1951) De la démocratie en Amérique, Paris: Librairie de Médicis.

Tullock, G. (1980: 71) Trials on Trial: The Pure Theory of Legal Procedure, New York: Columbia University Press

U Myint (2000) 'Corruption: causes, consequence and cures', Asia-Pacific Development Journal, 7 (2): 33-58.

US Congress (2001) Russia's Uncertain Economic Future, Joint Economic Committee, 107th Congress, 1st Session, Washington: Government Printing Office (GPO).

Valliant, Robert (1997) 'The political dimension', in Tsuneo Akaha (ed.), Politics and Economics in the Russian Far East. Changing Ties With Asia-Pacific, London: Routledge.

Vannucci, Alberto (2000) 'Corruption, Political Parties, and Political Protection', EUI Working Paper RSC No. 62, Badia Fiesolana, San Domenico. 


\title{
7 'Good governance' can make bad government
}

\author{
A study of international \\ anti-corruption initiatives in \\ Bosnia-Herzegovina
}

\section{David Chandler}

In November 1995 the Dayton Peace Agreement ended the Bosnian war and established the framework of the new Bosnian state. This involved several levels of representative government, including central state institutions, the two entity-level bodies, the Muslim-Croat Federation and Republika Srpska, district cantons within the Federation and municipal bodies across Bosnia. As well as elected bodies, Dayton established a framework of international political regulation to ensure that the principles of good governance were enforced in the divided state. Although initially designed to be temporary, in 1997 international regulation was extended on an indefinite basis. The key international body responsible for overseeing the Dayton framework is the Peace Implementation Council (PIC), an ad hoc institution established by the fifty-five governments and international organisations which sponsor and direct the Dayton process. The policies of the PIC are implemented in Bosnia by the Office of the High Representative (OHR), which can impose legislation and dismiss elected politicians (Chandler 2000). Over the last seven years the mandate of the OHR has expanded and assumed a key role in maintaining the legislative and institutional framework of the state.

At its Brussels meeting in May 2000 the PIC produced a programme for the next phase of the peace process in Bosnia, marking a significant shift in priorities, focusing on strengthening the governance capacities of the legal and administrative institutions of the Bosnian state. ${ }^{1}$ To enable Bosnia to meet the EU entry requirement of having an integral and independent state, Bosnian representatives were to begin to assume ownership of the day-to-day running of the state from international community officials. Lord Paddy Ashdown, who assumed the post of High Representative in May 2002, and his predecessor, Wolfgang Petritsch, have both regularly stressed the key importance of Bosnian ownership of the political process. $^{2}$ Heads of other international institutions involved in the democratisation process, such as the Organisation for Security and Cooperation in Europe (OSCE), have argued that now is the time for 'the elected officials to take ownership of the peace process' and for Bosnian citizens to 'take ownership of their own future'. ${ }^{3}$ 


\section{David Chandler}

The Office of the High Representative has highlighted political corruption as one of the most important areas in which the external provision and enforcement of good governance regulation is required to help Bosnia meet EU requirements (OHR 1999: 5). In 1999 and 2000, high-profile statements from the US State Department asserted that 'the problem of corruption was undeniably one of the prime obstacles to achieving the goals set forth at Dayton' and that the US was to make 'fighting corruption a central focus of Dayton implementation' and the 'highest priority' for the international community in Bosnia (Dlouhy 1999; Pardew 2000). While the problem of corruption is not unique to Bosnia, many policy-advisers argued that the problem in Bosnia was more severe due to the unique circumstances of the war and the resulting fragmented nature of the Bosnian polity. David Dlouhy, Director of the US State Department's Office of Bosnia Implementation, informed the House of Representatives Foreign Relations Committee in September 1999 that:

[D]uring the war, the nationalist warring parties took advantage of the breakdown in government structures to gain control of large parts of the Bosnian economy. This economic power enabled, and continues to enable, the large mono-ethnic parties to sustain their party apparatus and exert their influence at all levels of society.

(Dlouhy 1999)

For Dlouhy and the US State Department, anti-corruption initiatives were an essential aspect of international good governance strategy, crucial for the development of 'true democracy where rule of law and not rule of nationalist party politics reigns' (Dlouhy 1999). The OHR stated that 'corruption ... undermines the very legitimacy of government and public confidence in democracy' (OHR 1999). The highlighting of corruption as a barrier to good governance and the internationally managed democratisation process in Bosnia reflects the growing international consensus that corruption undermines political institutions by weakening their legitimacy and accountability (Heywood 1997). Political corruption substitutes private interests for public interests, and in so doing damages democracy by undermining trust in public institutions which depends on both the equal treatment of citizens and the openness of decision-making.

Both the development of anti-corruption strategies and their use as a component part of international programmes for good governance are fairly recent developments. Corruption hardly figured in international discourse prior to the 1990s. During the last decade major world powers and international agencies, such as the International Monetary Fund, World Bank, United Nations, Organisation for Economic Co-operation and Development, the G7 group of industrialised nations and the European Union, have increasingly focused on both good governance and the problem of corruption (Doig and Theobald 2000; Robinson 1998; Szeftel 2000). For many 
commentators there is an assumption that anti-corruption strategies fit closely with the aims of good governance and can be effective in increasing the accountability of state institutions and revitalising networks of trust in civil society (Theobald 2000: 149). ${ }^{4}$

Over the last five years a high international profile has been given to the development and implementation of an internationally coordinated anticorruption strategy in Bosnia. This experience allows the anti-corruption strategy, and the good governance agenda informing it, to be assessed and for some lessons to be drawn regarding the external management of good governance programmes designed to facilitate self-government and to strengthen collective state institutions in post-war states such as Bosnia. The following sections consider the problem of corruption, international community responses, especially in relation to public awareness and institution building, and the questions arising from this experience.

\section{Corruption}

The question of corruption in relation to good governance in Bosnia was first highlighted in July 1997 when UK Foreign Secretary Robin Cook accused nationalist politicians on all sides of a failure to tackle customs irregularities and the black market. ${ }^{5}$ The problems of customs collection were explicitly linked to the political institutional framework, as Cook suggested that this was a political manipulation designed to undermine 'the ordinary peoples of Bosnia's right to accountability'. ${ }^{6}$ Within a month the corruption issue was transformed, as policy NGOs such as the International Crisis Group called for the OHR to take action in this otherwise neglected area. ${ }^{7}$ In response to this pressure, the High Representative's Office proposed to establish an Anti-Fraud Unit; this was endorsed at the December 1997 Peace Implementation Council forum in Bonn and the Unit was established within the OHR Economics Department in April 1998.

The anti-corruption NGO Transparency International's Bosnia survey of March 1998 reported that the creation of criminal centres of power and the political framework inherited from the communist regime had meant that the "style of government is essentially top-down, with "rule of party" rather than "rule of law", and an absence of accountability and transparency, let alone a culture of consultation and consensus building' (Dlouhy 1999). The 'rule of party' was held to undermine the new institutional structures established by Dayton and necessary for self-government. Corruption was not only blamed for the lack of democratisation but also for the international community's failure to entice foreign investment, necessary to free Bosnia from international assistance. ${ }^{8}$ The New York Times alleged in August 1999 that: 'As much as a billion dollars has disappeared from public funds or been stolen from international aid projects through fraud carried out by Muslim, Croat and Serbian leaders who keep Bosnia rigidly partitioned into three ethnic enclaves.' According to Peter Singer, writing in the World Policy 
Journal, 'the true power brokers [in Bosnia] are an ultra-rich elite at the helm of combined political/economic/criminal networks' who dominated 'a veiled structure of domestic control which hinders international efforts at reform in all areas and at all levels'; Singer concluded that 'the result is that the rule of party comes before rule of law' (Singer 2000).

In July 2000, the US Congress General Accounting Office (GAO) report into corruption in Bosnia concurred that the root cause of corruption was Bosnia's political leadership (Pardew 2000). Harold Johnson, GAO's Associate Director, responsible for preparing the report, argued in Congress that there was little evidence that US strategy adequately addressed 'the underlying causes of corruption and lack of reform, namely the continued obstructionist behaviour of hard-line nationalist political leaders' (Johnson 2000). Jacques Klein, the UN's Special Representative to Bosnia, viewed that: 'Dayton stopped the violence, but it did not end the war, and the war is still being fought bureaucratically through obfuscation, delay and avoidance by a group of leaders who do not want to lose power' ${ }^{10} \mathrm{He}$ was supported by Richard Holbrooke, US ambassador to the UN and architect of the Dayton Agreement, who spoke out on the eve of the November 2000 elections accusing Bosnia's leading politicians of being 'crooks pretending to be nationalists'. ${ }^{11}$

From the beginning, the discussion of corruption in Bosnia has been highlighted as a political question of good governance, through the assertion of a link between the nationalist political leaderships and criminal elements involved in tax and customs evasion. However, where corruption claims have been investigated there has been relatively little evidence of the involvement of leading political parties. In fact, surprisingly, the OHR and other international bodies have at no point produced a comprehensive report documenting the extent of corruption and fraud in Bosnia and Herzegovina. ${ }^{12}$ As Sam Gejdenson argued at the House of Representatives International Relations Committee in September 1999, one of the problems with addressing the issue has been "exaggerated guesstimates of corruption figures and misidentified reports'. ${ }^{13}$ Gejdenson, the top Democrat on the Committee, argued that the problems had been 'grossly overstated' and that Bosnia was facing the same troubles as other emerging democracies. ${ }^{14}$

The US Government's General Accounting Office's July 2000 report found no evidence to support the New York Times's claim that American or international aid was 'being lost to large-scale fraud or corruption'. One of the main examples of losses was the US Embassy's loss of $\$ 900,000$ in operating funds due to the failure of the bank holding these assets. Out of the total of $\$ 1,000$ million spent on Bosnia since 1995 by the US government, this was a very small proportion, less than 0.1 per cent, and it was believed that the full amount could be recovered. ${ }^{15}$ Nevertheless the GAO report also suggested that crime and corruption were 'endemic at all levels of Bosnian society'. ${ }^{16}$ This was not based on hard evidence of endemic corruption but 
'a near consensus opinion among officials we interviewed' that endemic crime and corruption threatened Dayton implementation (Johnson 2000). Similar subjective anecdotal evidence is produced regularly, along the lines of Transparency International interviews, which operate on the basis of general 'perceptions' of corruption (Heywood 1997). The OSCE Citizen Outreach Campaign Anti-Corruption Opinion Poll in 2000 asked questions like 'Do you believe that corruption exists in Bosnia and Herzegovina?' and 'Is corruption affecting the continuing development of Bosnia?', and asked people to gauge the level of corruption from 'endemic' to 'insignificant'. ${ }^{17}$ Earlier subjective opinion poll evidence of corruption, such as that conducted in December 1999 by the US State Department, indicated that over 50 per cent of Bosnian citizens believed corruption was prevalent in government and business. However, this is consistent with similar polls in Central and Eastern Europe. ${ }^{18}$

The main evidence of political collusion seems to be the claim that 'Bosnian authorities may be using the foreign donations to make up for income the government has lost to crime'. According to the GAO this could be 'hundreds of millions of dollars'. ${ }^{19}$ The IMF estimates that the bulk of this is due to the black-marketing of cigarettes, with an estimated $\$ 230$ million lost annually. ${ }^{20}$ More often figures for corruption are not even 'guesstimates' of the level of tax and customs evasion but are established simply on the basis of the budget deficit made up by the international administration. The Dutch ambassador to the UN therefore puts the annual figure at $\$ 500$ million. $^{21}$ Of course, tax or customs evasion is hardly unique to Bosnia. In Britain the estimated loss to the taxpayer from cigarette smuggling alone is estimated at far more than in Bosnia, at $£ 4$ billion annually; however, no commentators have considered this to be 'corruption'. 22 However, even at this level the facts are not clear concerning a lack of local commitment on the issue. Allan Wilson, General Manager of the International Customs and Fiscal Aid Organisation Office in Banja Luka, stated that the international monitors were impressed with the achievements of the Sector for Customs Frauds of the [Srpska] Republic Customs Administration, obtained in spite of the shortage of personnel', ${ }^{23}$ while Bosnian Federal police in Tuzla Canton developed a compendium of case files running to 5,500 pages. $^{24}$

From the available evidence the political ties to corruption, assumed by the international community policy-makers developing good governance regulations, are yet to be conclusively established. In September 1999 the Federation Government established a Commission of International Legal Experts to investigate international press allegations of political corruption, consider the cause and extent of corruption, and recommend measures to improve anti-corruption efforts. The Commission reported in February 2000 , concluding that 'the nature of corruption in Bosnia is not ... systematic corruption organised by all three sets of "nationalist leaders", ${ }^{25}$ The International Commission stated: 
The types of corruption and organized crime afflicting Bosnia are similar to those that afflict other Central and East European states and states of the former Soviet Union, where they are endemic at the domestic level. They relate primarily to tax evasion, customs evasion, and misappropriation of domestic public funds. In Bosnia, they are augmented by the fact that a significant volume of illicit and contraband goods passes through the country on their way to Western Europe ... The Commission found no reliable, quantitative estimate of the total level of corruption in the Federation. It may be, however, that the level and type of corruption in Bosnia differs from their Central and Eastern European neighbours in a number of important ways. According to some NGO workers familiar with the problem in these countries, corruption in Bosnia is 'bush league' by comparison, and neither as highly organized nor as sophisticated. ${ }^{26}$

From the evidence assessed by the International Commission, it would appear that the most effective strategy for tackling the problems of budgetary deficits through tax and customs evasion would be through assisting Bosnian police, prosecutors and judges with the resources to investigate cases with the support of the United Nations Mission in Bosnia-Herzegovina International Police Task Force (IPTF) and the European Commission's Customs and Fiscal Assistance Office (CAFAO) programme. However, subsuming international anti-corruption strategy under the mechanisms of good governance has meant that the international focus of resources has not been centred on dealing with corruption as part of the drive against major crime. International institutions working in Bosnia have used anti-corruption initiatives primarily to introduce mechanisms of good governance. These governance mechanisms include: regulative measures to increase government transparency; initiatives to strengthen the workings of Bosnian government institutions; and public awareness campaigns to inform and encourage the public to see corruption as a major political issue. It is these aspects of 'systemic' anti-corruption strategy, rather than international support for criminal 'case' work, that this chapter seeks to examine.

\section{International Strategy}

The Luxembourg Peace Implementation Council Steering Board, meeting in June 1998, encouraged the OHR to coordinate the international community in implementing a comprehensive anti-corruption strategy. The Madrid PIC meeting in December 1998 reiterated concerns regarding a comprehensive anti-corruption strategy:

The Council expresses deep concern about continuing corruption and evasion of public funds. It welcomes the High Representative's development of a comprehensive anti-corruption strategy which will ... provide 
the framework necessary to identify, develop and implement changes in the structure and procedures of government, to significantly reduce corrupt activities and to establish a public awareness program ... The High Representative will take the lead in co-ordinating International Community efforts aimed at eliminating opportunities for corruption, tax evasion and diversion of public revenue; ensuring transparency in all phases of governmental operations; strengthening the legal system and the judiciary; and implementing control mechanisms and appropriate penalties to ensure compliance. A key component of the strategy will be to develop a public awareness campaign to educate citizens about the deleterious effects of corruption on their lives and on society.

(OHR 1999: 11)

In February 1999 the Unit launched its 'Comprehensive Anti-Corruption Strategy', defining corruption - using the World Bank's definition - as 'the abuse of public office for private gain' (OHR 1999: 5). The OHR's 'Comprehensive Anti-Corruption Strategy' was approved by the Peace Implementation Steering Council and closely involved the United Nations, European Commission, the World Bank, US Treasury, US Justice Department and US Agency for International Development. There was a two-track approach to deal with systemic political corruption, in addition to the individual case approach, providing assistance to the investigation and prosecution of major criminal cases. This emphasis on the systemic approach sought to address the 'confluence of factors' outlined by David Dlouhy at the end of 1999 , in particular the influence of 'nationalist party structures that took root during the war' and 'Bosnian mindsets formed by years of autocratic and communist rule' (Dlouhy 1999).

The Comprehensive Anti-Corruption Strategy sought to address 'Bosnian mindsets' through education and public awareness campaigning. According to the OHR: 'An informed citizenry is crucial for the success of any anti-corruption program. If the public is apathetic towards corruption and accepts it as an inevitable presence, efforts to alleviate corruption will be futile' (OHR 1999: 11). The problem of nationalist party dominance was to be approached by establishing mechanisms to safeguard governing structures from the influence of nationalist parties, ensuring transparent financial management with strict control and monitoring of public revenue, tax and customs regulation. The work of government itself was to be closely monitored by parliamentary commissions, audit institutions and transparency offices.

\section{Public awareness}

The systemic anti-corruption strategy involves a high level of international involvement in public education and political awareness to facilitate greater public involvement in the political process. As James Pardew states: 
Our strong preference would be that the Bosnians undertake the changes themselves because it is clearly in their long-term, collective self-interest to do so. To promote that kind of thinking, we set a high priority on promotion of independent media, support of open and transparent elections, and encouragement of pro-reform and proDayton leaders and political candidates, regardless of ethnic background or party (Pardew 2000).

Christopher Bennett and Gerald Knaus argue: 'Most Bosnians are aware how corrupt their leaders are and secretly support international efforts to restructure their country. But given their dependency on the current system, they are not yet ready to demand reforms, transparency and accountability. ${ }^{27}$ According to David Dlouhy: 'democratic concepts of accountability to the public and transparency are not yet second nature to most Bosnians' (Dlouhy 1999). The Commission of International Legal Experts assert that institutional change has 'outpaced the salutary but slower progress made in individual and collective assimilation of the panoply of habits of character and values that liberal democratic and free market institutions entail'. ${ }^{28}$

The public education campaign is premised on the assumption that the people of Bosnia are unaware of their real interests in this area and therefore in need of education by their international administrators. This need for increased awareness about the issue of corruption is seen to fit in with broader governance aims of replacing the political salience of ethnicity with themes which cut across ethnic lines. In fact, the two questions have become increasingly interlinked, with electoral support for the leading nationalist parties seen as an indicator of public attitude towards corruption. For this reason the international institutions involved in the Bosnian political process have heavily emphasised the question of political corruption in the run-up to recent elections. As the OHR states: "only when citizens recognize corruption and are aware of its effects, will they be able to make the correct choices at the ballot box' (OHR 1999: 38). It would appear that the anti-corruption strategy is a highly politicised one. According to Peter Singer, the anti-corruption issue has a central role to play in the democratisation process and is the strongest card the international community has in encouraging political opposition to the leading nationalist parties:

[T] he one issue that has consistently motivated Bosnian voters to turn against the ethnic-nationalist parties is graft - when it is fully exposed. Voting for reconciliation with 'the enemy' is one thing, but it is a lot easier to abandon party allegiances in order 'to get rid of those thieves'. In fact, one of the major achievements of the West was engineering the removal of the hard-line SDS (Serb Democratic Party) from power in Republika Srpska. This came not because of public disgust with the party's nationalist program but because its overwhelming corruption 
was revealed and publicized. Exposing, condemning, and removing corrupt officials from power is one of the few points of leverage against the nationalists that is popular with the typical Bosnian on the street. Anti-corruption is the best multiethnic issue of all. ${ }^{29}$

The OHR asserts that: 'The ultimate success of the battle against corruption will be determined by the political will of the citizens of Bosnia and Herzegovina and the expression of that will in the election of their leaders. ${ }^{30}$ To this end the OHR makes 'public awareness' a central pillar of its anti-corruption strategy, stating: 'All segments of society, from children in primary school to the business community and government officials, must be made aware of both the nature and consequences of corruption' (OHR 1999: 11). The second phase of its public anti-corruption awareness campaign was timed to coincide with the November 2000 general elections. Comprising five TV episodes, 10 radio spots, 60 jumbo poster and 80,000 comic books and an animated video clip the message is to inform citizens about how they can become involved in the fight against corruption, by insisting on their right to a responsible, accountable government' ${ }^{31}$ To encourage informed awareness, the central campaign slogan is 'Gdje idu nase pare?' 'Where is our money going? 32

The role of encouraging non-nationalist parties has fallen largely to the OSCE, responsible for organising elections in Bosnia. In the run-up to the November 2000 general elections the OSCE went into full swing to attempt to 'raise citizens' awareness of corruption, thus allowing voters to make an informed choice at the polls' ${ }^{33}$ In order to facilitate 'an informed choice', on 15 September the OSCE launched its own anti-corruption campaign, scheduled to run until the eve of polling on 10 November. ${ }^{34}$ However, raising public awareness did not involve specific allegations of corruption. According to the OSCE's 'Anti-Corruption Campaign Frequently Asked Questions' information sheet, the OSCE focuses on speaking out against corruption in general by voting for 'anti-corruption' candidates. ${ }^{35}$ The Civil Society Anti-Corruption Public Outreach Programme organised by local internationally funded NGOs and OSCE 'Community Facilitators' set up radio shows, public tribunes, round-table discussions and public meetings covering the whole territory. The OSCE's campaign was clearly targeted at providing support for opposition parties who were seen as likely to gain through 'raising awareness' about government corruption. OSCE Head of Mission, Robert Barry, felt little need to involve the main political parties, who were expected to lose out through this work: 'We do not expect much support from the authorities playing a major role in all this, but we do expect they will no longer exist after November 11. ${ }^{36}$

The fact that Barry expected little support from the main parties was not surprising. While all Bosnian parties condemned corruption, the international education and public awareness campaign has created opposition from leading Bosnian politicians. It was in the context of publicising political 
corruption, both internally and internationally, that Chris Hedges from the New York Times was invited to a briefing by the OHR Anti-Fraud Unit to highlight its work (Dlouhy 1999). The result was a catalogue of misrepresentations which increased international pressure on Bosnian institutions and brought an angry response from the Bosnian President Alija Izetbegovic that its goal was to slander the Bosnian government. ${ }^{37}$

Despite the extensive publicity given to anti-corruption themes by the OHR and the OSCE, the November 2000 general elections resulted in the nationalist parties doing better than the international administration had expected. ${ }^{38}$ The regular press features on international findings that 'corruption is commonplace in all aspects of life' had not led to a change in voter preferences. ${ }^{39}$ In the Muslim-Croat Federation the Croatian Democratic Union (HDZ) won the majority of Croat votes, and the main Muslim party, the Party of Democratic Action (SDA), was a close second to the more moderate Social Democratic Party (SDP). In Republika Srpska the leading nationalist party, the Serbian Democratic Party (SDS), won the majority of Serb votes for the presidency and were the largest party in the National Assembly with 36 per cent of the vote. This would appear to indicate limitations with the strategy of making political corruption the central political issue at elections.

It seems that the anti-corruption campaigns have promoted political cynicism rather than a hope in political change, and have backfired on the international community. Voting returns indicate that the public awareness aspects of international anti-corruption strategy have not had a beneficial influence on levels of public political participation and have had little positive impact on levels of trust and cooperation, either within or between ethnic groups. It seems that the conclusion Bosnian voters have drawn from the institutionalisation of anti-corruption into every walk of life has been that no politicians can be trusted. While the international community promoted the corruption issue as a way of undermining support for the nationalist parties, the impact has been a wider one. The good showing of the SDS in the November 2000 elections was probably helped by widespread allegations of corruption against the former Western-backed prime minister, Milorad Dodik, while the poorer than expected showing for the moderate SDP in the Federation may be due to the long-running allegations of corruption in Tuzla. ${ }^{40}$ If all politicians are corrupt then voters are less likely to see change and progress as possible through the ballot box.

Evidence indicates that, far from anti-corruption being a vehicle for broadening support for multi-ethnic parties, the issue seems to be one that favours the nationalists. The less trust people have in the broader political process, the more likely it is that parochial and local links will come to the forefront. This is supported by literature on the importance of high levels of generalised trust for establishing inter-communal bonds, 'bridging' social capital as opposed to 'bonding' social capital, in the terminology of Robert Putnam's recent work (Putnam 2000; see also Fukuyama 1995). If elected 
representatives are just out to line their own pockets then they cannot be trusted to prioritise the interests of their voters. Concern over representation can only lead to a higher level of insecurity and atomisation. Political pessimism and insecurity are more likely to lead to support for nationalist parties or to non-participation than to support for parties which promise political change. It is little surprise that, in the run-up to elections in October 2002 , the key concern of the OHR was that voters would not vote at all. ${ }^{41}$

\section{Institution-building}

According to leading international statesmen and policy-makers, the popular nationalist parties are putting the personal interests of the political elites above those of the Bosnian public: 'politicians play the nationalist card to mask their lack of commitment to develop state institutions. For them, public accountability and personal responsibility are notoriously absent' ${ }^{4}{ }^{4}$ The High Representative, Wolfgang Petritsch, argued that the political elites have the wrong approach to the political process: 'The government is there to work for the citizen, and not the other way around' ${ }^{43}$ For Petritsch: 'the corruption of public institutions is one of the most serious and major obstacles' preventing Bosnia becoming integrated in European institutions. ${ }^{44}$ Because the problem of corruption is seen to lie with the Bosnian government, Bosnian politicians are caught in a no-win situation. They have been criticised for failing to do more than create committees and commissions that have not 'measurably' reduced crime and corruption (Johnson 2000). Yet, when they do form anti-corruption teams headed by the entity prime ministers and involving key ministers such as the Minister of the Interior and Justice and members of the Intelligence and Security Services and Customs, they are accused of attempting to hamper anti-corruption initiatives or of seeking to whitewash the situation. ${ }^{45}$

The response from international policy-advisors has been to call for more regulation of the actions and power of Bosnian politicians. One approach has been to call for the decentralised powers at entity, canton and municipal level to be weakened. For some commentators the problem is that there is 'too much' government in Bosnia, with the division of responsibilities between the state and entity governments making it difficult to clearly allocate responsibility. ${ }^{46} \mathrm{~A}$ similar complaint is expressed by advisors who argue that all levels of political authority need to be restricted: 'The basic difference between the two entities of Bosnia is the fact that there are three levels of corruption in the Federation (municipalities, cantons and the Federal authorities) [while] there are "only" two in the Republika Srpska (no cantons). ${ }^{97}$ International analysts argue that: 'Without dismantling Bosnia's existing domestic power structures, there is no way out of the current quagmire' (Bennett and Knaus 1999).

The only solution to corruption appears to be greater external regulation. Steve Hanke, Johns Hopkins professor and advisor on economic issues to the 


\section{David Chandler}

Bosnian government, suggests the solution lies in 'shrink[ing] the size of the government down to almost zero ... That is the only way to get rid of corruption. Have no aid, no government officials, minimum state. ${ }^{38}$ Professor Hanke argues that the monetary system set up by the US and the IMF is 'the only non-corrupt institution in Bosnia ... because it is run by a foreigner' ${ }^{49}$ Rather than strengthening Bosnian political institutions, the OHR has targeted them as the central problem, stating that there is no evidence of corruption regarding internationally-administered funds, but that: 'Corruption and fraud, which are undoubtedly a serious problem in the country, primarily centre on the misuse of local public funds and budgets' ${ }^{50}$ International policy, informed by good governance principles, starts from the assumption that elected government is an opportunity for corruption and inevitably leads to the conclusion that 'corruption-busting is therefore a task for the West' (Bennet and Knaus 1999).

The Bosnian political institutions are increasingly restricted or bypassed by current international policy. They are restricted through external pressure on policy-making. As James Pardew states, the US government is working with the IMF, World Bank and EBRD to strengthen conditionality 'to apply as much leverage as possible to overcome resistance by the Bosnian leadership to implement the changes necessary to undercut corruption' (Pardew 2000). They are bypassed by the creation of new regulatory mechanisms that include little Bosnian representation. For example, in September 1999 the OHR announced the formation of an Anti-Corruption and Transparency Group (ACT) with the objective of strengthening international efforts. The Group's chair is the Principal Deputy High Representative, Ralph Johnson, and the membership is comprised of about a dozen international organisations, as well as the US government's newly formed Anti-Corruption Task Force. ACT does not, however, include any participation by Bosnian officials or independent experts. ${ }^{51}$ This trend to bypass or restrict the political institutions is supported by the European Stability Initiative (ESI) Bosnia Project that warns that transferring responsibility for governance and overseeing the operation of public institutions to Bosnian political leaders would be a mistake. Far from giving elected representatives increased authority, the ESI suggests that more control should be given to Bosnian civil servants backed by the international community. ${ }^{52}$

The new regimes of budgetary transparency and government audit requirements are designed for international financial institutional control rather than Bosnian ownership of decision-making. The systemic anticorruption approach has tended to strengthen the regulatory powers of the Office of the High Representative: This has meant that international regulation over the political sphere has been extended. This was highlighted following the success of the nationalist parties in the November 2000 elections. The issue of political corruption was high on the agenda as international representatives discussed the options of dealing with the political impasse (Chandler 2001). As the Chairman of the US Senate Foreign Relations Committee, Senator Joseph Biden, stated in January 2001: 
If there isn't some significant attempt to deal with the stranglehold the nationalists have on the country on the part of these leaders ... we'll start to wash our hands of it [because] you have a position where the three major parties have just decided to split up the country and split up the booty and the spoils. ${ }^{53}$

Due to international pressure, OSCE Head of Mission Robert Barry's wish that the leading nationalist authorities would be out of power after the November elections has to some extent been fulfilled. Despite the expressed wishes of Bosnian voters, the international administration was able to push through the creation of non-nationalist administrations at both entity and state levels. On the basis that international action was necessary to put the public interest above corrupt sectional national interests, there was a high level of international involvement in the make-up of the post-election government in Republika Srpska. The US ambassador to Bosnia, Thomas Miller, warned in December 2000 that Washington would no longer provide funds to the entity if the SDS was allowed to form a government or if SDS representatives were included in a coalition. ${ }^{54}$ Luke Zahner, deputy spokesman for the OSCE, stated that if the Republika Srpska government wanted international donor support, it must forego the election process and instead install a government of experts. ${ }^{55}$ Under international pressure the Prime Minister of the Republika Srpska Assembly, Mladen Ivanic, is from the Party of Democratic Progress (PDP), which came second in the elections with 13 per cent of the vote. After consulting with High Representative Petritsch, Ivanic presented a new government of technocrats and professionals with little or no political involvement. ${ }^{56}$ Ivanic's government included only one openly-declared SDS member, Goran Popovic, the Minister for Trade and Tourism. Under international pressure of withdrawal of funding, Popovic was later replaced, which meant that the new Republika Srpska government was led by an internationally vetted group of technocrats and excluded any representatives of the dominant political party. ${ }^{57}$

A similar level of interference ensured that a Western-backed coalition of parties took power in the Muslim-Croat Federation. Immediately following the elections, ten leading $\mathrm{HDZ}$ representatives were removed from the cantonal assemblies in the Federation for breaches of OSCE election rules, and in March 2001 the High Representative dismissed the Croatian Presidential representative, HDZ leader Ante Jelavic, and three other leading Croatian representatives. The basis for these dismissals was the allegation that Jelavic and others were 'not concerned about the wellbeing and position of the Croats' but 'criminal elements', and that the HDZ was seeking greater decision-making autonomy 'to allow them to continue to pursue their personal interests and to further enrich themselves'. ${ }^{58}$ Despite the fact that the HDZ received the support of the majority of Bosnian Croats, the UN Mission in Bosnia argued that the leadership of the party was only concerned with their own narrow 
personal interests. ${ }^{59}$ This move was supported by leading Western states and the international community institutions. ${ }^{60}$ James Lyon, the Balkan Director of the International Crisis Group, stated: 'I would not like to mention names of individuals or companies, but corruption is in the essence of the HDZ. It exists in the name and in the interest of corruption', adding that 'the party leadership does not really care about the interests of the Croat people, but only about its own pockets' ${ }^{61}$

The incoming High Representative, Paddy Ashdown, also used the corruption issue to impose his will on the political process, controversially arguing that the principles of good governance enabled him to sack ministers he regarded as not fulfilling their responsibilities, including among others the Deputy Prime Minister of the Federation, Nikola Grabovac. ${ }^{62}$ The implications of the current systemic anti-corruption approach for the establishment of strong self-governing institutions are not promising. The creation of a modern state framework requires that Bosnian political institutions are strengthened, rather than just the administrative and legal ones. There is an inherent danger that international anti-corruption initiatives will do little to empower Bosnian representatives. In fact, the desire to restrict and regulate the Bosnian political elites can only weaken accountable political institutions. The strategy would seem to be developing away from, rather than towards, self-government with democratic institutions increasingly marginalised and the powers of external international bodies extended.

\section{Conclusion}

The international community's systemic anti-corruption strategy aimed at developing mechanisms of good governance has been successful in Bosnia, but only in so far as it has acted to marginalise the sphere of politics. The process of imposing decisions that the international community feels are in the public interest has strengthened external mechanisms of international governance but undermined domestic Bosnian institutions of government, weakening political institutions and discouraging public participation in the political sphere. If the international community is deciding which parties represent the public interest and which policies they should be implementing, then there is little room for political contestation or for democratic involvement. The current policies for promoting good governance in Bosnia, such as the international anti-corruption campaign, beg the question of whether the international administrators see the sphere of internal Bosnian politics as necessary at all.

The narrow view of legitimate politics, apparently held by the international institutions implementing mechanisms of good governance, would reduce Bosnian political institutions to the role of administrators of international policy decrees. From the point of view of the international community, leading nationalist political parties appear to be corrupt precisely because they are engaged in representing and negotiating on behalf 
of the particular interests of an ethnic constituency, interests which are defined as conflicting with the public interest. However, there is nothing innately corrupt about politicians supporting the aims of a particular political constituency. The reflection of particular interests is the essence of representational democracy; all political parties historically reflect particular social, sectional or regional interests. In a highly segmented society such as Bosnia, it is inevitable that elected representatives will reflect this social division. The international community is, in fact, calling for a Bosnian political class that is apolitical, which does not reflect these particular concerns and therefore is disconnected from Bosnian society.

As commentators have noted in relation to other good governance initiatives, there is a clash between the demands of these programmes, such as anti-corruption campaigns, and the demands of politics, because the "public interest' demands impartiality while 'the stock in trade of party politicians is partiality' (Williams 2000). Politics would indeed not be necessary if all questions could be decided by the technicians of good governance developing the 'correct law' or ideal method of administration. As with all techniques of good governance, anti-corruption campaigns can easily neglect the political realities of coalition- and consensus-building necessary to political life, seeking in effect to remove politics from government. The reason representational politics is necessary is because individuals, in Bosnia or anywhere else, do not subjectively see the world through some automatic and agreed understanding of what the public interest is.

It is by the political engagement of individuals - for example, through voting for competing political parties - that public interests emerge through a process of political consensus-building, both in political parties and also between parties in representative assemblies or parliaments. The public interest is shaped through the democratic process and is not something that can be decided or defined by an international administrator of good governance, no matter how well intentioned. The process of externally imposing policy on political representatives, through economic sanctions and the dismissal of 'non-cooperative' elected leaders, ensures that there is no possibility of an emergent public interest, as there is no negotiation between representatives and the public are alienated from the political process.

The political sphere in Bosnia may reflect political cleavages in society but it also remains a necessary mechanism in the reconciliation of these conflicting interests. Particularly in circumstances of social and political division, representational democracy is central to overcoming the fears and concerns of citizens through the transparent and accountable process of consensus-building and decision-making in political assemblies. The artificial institutional settlement in Bosnia, where the international community assumes executive and legislative powers, makes the development of trust impossible as this process lacks transparency or accountability. The manipulation of pliant political elites, isolated from any electoral base in society, may make it easy for international legislators 
to impose good governance decrees, but it can only institutionalise societal divisions rather than overcoming them. Politicians that have little representational legitimacy are unlikely to be able to build bridges within society and lack the capacity to resolve conflicts. The weak position of the new elites highlights the artificial nature of this internationally enforced process, in which decisions arrived at are dependent on international supervision. This increases insecurity on all sides, as there is little local control or ownership of the political process, necessary for the settlement to be self-sustaining after international withdrawal.

The experience of Bosnia suggests that good governance is problematic, to the extent that it attempts to take politics out of government. This highly reductionist view of politics fails to recognise the dynamic role of the democratic process in building consensus within society and in overcoming conflict. High-handed international good governance intervention in the political sphere has done little to help overcome insecurities and divisions, while undermining collective political bodies in which Serb, Croat and Muslim representatives can negotiate accountable solutions. An anti-corruption agenda, which provided the necessary resources for the Bosnian government institutions to raise tax and custom revenue, could make a positive contribution to Bosnian political life. However, the evidence indicates that the imposition of a good governance agenda has not contributed to resolving the problem of corruption, while it has had a deleterious impact on government through restricting the political sphere and institutionalising political segmentation along ethnic lines.

\section{Notes}

1 European Commission, 'Support to the Common Institutions of the State of Bosnia and Herzegovina'. Tender No. EC/BIH/00/043. November 2000.

2 Paddy Ashdown, 'The High Representative Paddy Ashdown's Television Address to the Citizens of Bosnia and Herzegovina', Sarajevo, 31 May, 2002. Available online: http://www.ohr.int/ohr-dept/presso/presssp/default.asp?content_id=8554; Wolfgang Petritsch, 'Address of the High Representative for Bosnia-Herzegovina to the Peace Implementation Council', Brussels, Office of the High Representative, 23 May 2000. Available online: http://ohr.int/speeches/s20000523a.htm.

3 Robert Barry, 'Report by the Head of Mission Robert Barry to the Permanent Council of the OSCE', Sarajevo, OSCE, 9 December 1999. Available online: http://oscebih.org/events/barry_report-10-12-99.htm; Robert Barry, 'Presentation by OSCE BiH Head of Mission, Ambassador Barry, to the Permanent Council of the OSCE', Sarajevo, OSCE, 2 March 2000. Available online: http://www.oscebih.org/events/barry-2-3-2000.htm.

4 'Final Report', A Global Forum on Fighting Corruption: Safeguarding Integrity Among Justice and Security Officials, Washington DC, 24-26 February 1999. Available online: http://www.state.gov/www/global/narcotics_law/global_forum/global_forum_report. pdf; Robin Theobald, 'Conclusion: Prospects for Reform in a Globalised Economy', in Doig and Theobald 2000: pp. 149-59. 
5 Michael Binyon, 'Cook Warns Bosnia Aid May Be Cut Off', The Times, 30 July 1997.

6 Office of the High Representative Bulletin, No. 56, 31 July 1997. Available online: www.ohr.int/bulletins/b970731.htm.

7 Office of the High Representative Bulletin, No. 59, 5 September 1997. Available online: www.ohr.int/bulletins/b970905.htm.

8 Tracey Wilkinson, 'Bureaucracy, Corruption Plague Foreign Investment in Bosnia', Los Angeles Times, 29 March 1998.

9 Chris Hedges, 'Leaders in Bosnia are Said to Steal up to \$1 Billion', New York Times, 17 August 1999.

10 Hedges, op. cit.

11 'Bosnian Nationalists Strong but Short of Majority', Reuters, 22 November 2000.

12 'Corruption and Anti-Corruption Measures in the Federation of Bosnia and Herzegovina', Final Report of the Commission of International Legal Experts, 25 February 2000, p. 14.

13 Sam Gejdenson, 'Gejdenson on Corruption in Bosnia', International Relations Committee Democratic Staff Press Release, 15 September 1999.

14 Paula Wolfson, 'Bosnia Corruption', Voice of America, 15 September 1999.

15 Andrew F. Tully, 'Bosnia: Clinton Administration Sees Hope in Fighting Corruption', Radio Free Europe/Radio Liberty, July 2000. Available online: http://www.rferl.org.

16 Christopher Marquis and Carlotta Gall, 'Congressional Report Says Corruption is Stifling Bosnia', New York Times, 7 July 2000.

17 OSCE, 'Citizen Outreach Campaign Anti-Corruption Opinion Poll', OSCE Mission to Bosnia and Herzegovina, 2000. Available online: http://www.oscebih.org.

18 OSCE, 'Facts About Corruption', OSCE Mission to Bosnia and Herzegovina Public Information Office, 2000.

19 Marquis and Gall, op. cit.

20 Mladen Mirosavljevic, 'Corruption in Republika Srpska', AIM Banja Luka, 29 September 2000.

21 Ibid.

22 BBC, 'Cigarette Smuggling "Costs £4bn”', BBC News, 27 November 2000. Available online: http://news.bbc.co.uk.

23 Mirosavljevic, op. cit.

24 Final Report of the Commission of International Legal Experts, p. 14.

25 Ibid., p. 21.

26 Ibid., pp. 21-2.

27 Bennett and Knaus (1999).

28 Final Report of the Commission of International Legal Experts, p. 7.

29 Singer (2000).

30 Ibid., p. 41.

31 OHR, 'OHR Launches 2nd Phase of Anti-Corruption Campaign', OHR Press Release, 7 September, 2000. Available online: http://www.ohr.int/press/p20000907a.html.

32 Ibid.

33 OSCE, 'Civil Society Takes Part in Anti-Corruption Campaign in Bosnia and Herzegovina', OSCE Mission to Bosnia and Herzegovina Press Release, 12 October 2000.

34 OSCE, 'Anti-Corruption Campaign Launched', OSCE Mission to Bosnia and Herzegovina Press Release, 15 September, 2000.

35 OSCE, 'Anti-Corruption Campaign FAQs', OSCE Mission to Bosnia and Herzegovina Press Information, 2000. 


\section{David Chandler}

36 Mirosavljevic, op. cit.

37 Alija Izetbegovic, 'The Goal of Article in The New York Times is to Slander what Chris Hedges calls Bosnian Government', Dnevni Avaz, Sarajevo, 18 August 1999; Bakir Izetbegovic, 'Bakir Izetbegvic will Sue OHR', Dnevni Avaz, Sarajevo, 19 August 1999.

38 'General Elections 2000 in Bosnia and Herzegovina: Final Results', OSCE. Available online: http://www.oscebih.org/pre_results/scripts/finalresults $2000 . \mathrm{htm}$.

39 'Protection, Promotion and Monitoring of Human Rights in the Republika Srpska, 1 October-31 December 2000', NED Grant Project. Posted to Tribunal Watch 23 January 2001. Available online: http://listserve.acsu.buffalo.edu/archives/twatch-l.htm.

40 Nick Thorpe, 'Bosnians Turn a Deaf Ear to West's Plea for Change', Guardian, 16 November 2000; Nermina Durmic-Kahrovic, 'Tuzla Officials Face Corruption Inquiry', IWPR's Balkan Crisis Report, No. 227, 16 March 2001.

41 Paddy Ashdown, 'Inaugural Speech by Paddy Ashdown, the new High Representative for Bosnia \& Herzegovina', BiH State Parliament, 27 May 2002. Available online: http://www.ohr.int/ohr-dept/presso/presssp/default.asp?content_id=8417.

42 Final Report of the Commission of International Legal Experts, p. 6.

43 OHR, 'Speech by the High Representative, Wolfgang Petritsch', BiH AntiCorruption and Transparency Conference, Sarajevo, 14 February 2000. Available online: http://www.ohr.int/speeches/s20000214.html.

44 Final Report of the Commission of International Legal Experts, p. 26.

45 Mirosavljevic, op. cit.

46 Susan Taylor Martin, 'Corruption Marrs Bosnia Mission', St. Petersburg Times, 19 August 1999; Wilkinson, op. cit.

47 Boris Divjak, 'Corruption in Bosnia and Herzegovina - The Iron Fist Channelled'. 2000. Available online: http://vrhinka.com/vrhinka/anti-corruption $\% 20$ forum/clanek_3.htm.

48 Barry Wood, 'Bosnia Corruption', Voice of America, 20 August 1999.

49 Ibid.

50 Ibid., p. 13.

51 Final Report of the Commission of International Legal Experts, p. 39.

52 'International Efforts to Combat Corruption in Bosnia and Herzegovina', Background Paper 4, October 1999, European Stability Initiative Bosnia Project.

53 'Bosnia "Must Oust Nationalists to Keep US Help"', Reuters, Sarajevo, 14 January 2001.

54 'US Warns Bosnian Serbs on Karadzic Party', RFE/RL Newsline, Vol. 4, No. 240, Part II, 13 December 2000.

55 Ibid.

56 Zeljko Cvijanovic, 'Ivanic Bows to Western Pressure', IWPR's Balkan Crisis Report, No. 211, 22 January 2001.

57 Janez Kovac, 'Bosnian Moderates Oust Nationalists', IWPR's Balkan Crisis Report, No. 211, 22 January 2001.

58 Wolfgang Petritsch, 'The High Representative's TV Address on Dismissal of $\mathrm{Mr}$ Jelavic and Three Other HDZ Officials', Office of the High Representative Press Statement, 8 March 2001. Available online: http://www.ohr.int/press/p20010307a.htm.

59 'Bosnia and Herzegovina Media Round-Up', Office of the High Representative, 26 March 2001.

60 'UN Security Council Supports High Representative, Condemns Attempt to Establish Croat Self-Rule in Bosnia', Office of the High Representative Press Release, 26 March 2001. 
61 'Bosnia and Herzegovina Media Round-Up', Office of the High Representative, 26 March 2001.

62 David Chandler, 'The King of Bosnia', Spectator, 8 June 2002. Available online: http://www.spectator.co.uk/article.php3?table $=$ old \&section $=$ back\&issue $=2002-0$ 6-08\&id $=1980 \&$ search Text $=$ chandler.

\section{Bibliography}

Bennett, Christopher and Gerald Knaus (1999) 'Battling Corruption in the Balkans', Global Beat Syndicate, 27 August 1999.

Chandler, David (2000) Bosnia: Faking Democracy After Dayton, 2nd edn, London: Pluto Press.

__ (2001) 'Bosnia: The Democracy Paradox', Current History (2001), 100 (644): 114-19.

Dlouhy, David B. (1999) 'On Corruption in Bosnia-Herzegovina', Statement to the House International Relations Committee, 15 September 1999, Bosnia Report, New Series No. 11/12, August-November 1999, Bosnian Institute.

Doig, Alan and Robin Theobald (2000) 'Introduction: Why Corruption?', in Alan Doig and Robin Theobald (eds), Corruption and Democratisation, London: Frank Cass: 149-59, 1-12.

Fukuyama, Francis (1995) Trust, New York: Free Press.

Heywood, Paul (1997) 'Political Corruption: Problems and Perspectives', Political Studies (1997), XLV: 417-35.

Johnson, Harold J. (2000) 'Crime and Corruption Threaten Successful Implementation of the Dayton Peace Agreement', Statement of Harold J. Johnson, Associate Director, International Relations and Trade Issues, National Security and International Affairs Division, before the House of Representatives Committee on International Relations, 19 July 2000.

OHR (1999) A Comprehensive Anti-Corruption Strategy for Bosnia and Herzegovina, Anti-Fraud Unit, Economics Department, Office of the High Representative, Sarajevo, February 1999.

Pardew, James W. (2000) 'The Impact of Corruption in Bosnia, Statement before the House International Relations Committee, by James W. Pardew, Principal Deputy Special Advisor to the President and the Secretary of State for Democracy in the Balkans, 19 July 2000.

Putnam, Robert (2000) Bowling Alone: The Collapse and Revival of American Community, New York: Simon \& Schuster: 13447.

Robinson, Mark (1998) 'Corruption and Development: An Introduction', European Journal of Development Research, 10 (1): 1-14, 1-2.

Singer, Peter W. (2000) 'Bosnia 2000: Phoenix or Flames?', World Policy Journal, New York, Spring: 31-7.

Szeftel, Morris (2000) 'Between Governance and Underdevelopment: Accumulation and Africa's "Catastrophic Corruption", Review of African Political Economy, 27 (84): 287-307.

Theobald, Robin (2000) 'Conclusion: Prospects for Reform in a Globalised Economy', in Doig and Theobald (eds), Corruption and Democratisation, London: Frank Cass: 149-59.

Williams, Robert (2000) 'Democracy, Development and Anti-Corruption Strategies: Learning from the Australian Experience', in Alan Doig and Robin Theobald (eds), Corruption and Democratisation, London: Frank Cass: 135-48. 


\title{
8 Clanism and predatory capitalism

\author{
The rise of a neoliberal \\ nomenklatura in Ukraine
}

\author{
Hans van Zon
}

After the fall of the Berlin Wall, communism in Central and Eastern Europe fell apart like a house of cards and it seemed that almost everywhere in the region a transition towards parliamentary democracy and market economy was taking place. Many saw it as a democratic revolution. International financial institutions moved in and were ready to lend while giving advice according to the prescriptions of the Washington Consensus. Progress in the so-called transition economies was measured in transition indicators that showed a quite differentiated progress in transition towards market economy. But, apart from a few 'laggards', capital accounts and foreign trade were liberalised everywhere, the economy was deregulated and state enterprises privatised.

A closer look reveals that the above account is not accurate and only represents part of the story. 'Transition' brought about in Central and Eastern Europe socio-economic systems that are very diverse and that cannot be captured under the label 'transition economies'. The state-run and bureaucratised economy of Belarus is hardly comparable to the market economy of Slovenia or even the robber-baron capitalism of Russia, while the oriental despotism that emerged in countries like Azerbaidzjan and Uzbekistan is very different from the fragile market economies of Latvia and Lithuania.

Despite the variety in Eastern Europe, in all countries east and south-east of the future EU border of $2004^{1}$ the former nomenklatura took over power while perpetuating authoritarian rule, often under the façade of a parliamentary democracy. Everywhere they managed to get hold of the major assets of the nation, mostly by privatising them. Everywhere east and southeast of the EU border of 2004 neo-patrimonial societies emerged with powerful state bureaucracies. In none of these countries did a genuine market economy emerge. ${ }^{2}$ This contrasts with the widespread optimism during the early 1990 s about the prospects for market economy and parliamentary democracy. Also, institutions such as the IMF, OECD, World Bank and EBRD assumed that capitalism could be introduced by decree. They stated in 1990 about the Soviet economy that 'A recovery from the reduced level of output should be able to get underway within two years or so ... 
further, strong growth of output and rising living standards could be expected for the remainder of the decade and beyond' (IMF et al. 1990: 18-19).

Conspicuous in Russia was the role of the International Financial Institutions that aligned with a Russian kleptocratic elite in its efforts to plunder the country. For example, it was thanks to an IMF loan in 1996 that president Yeltsin could finance his election campaign against the communist Zyuganov. Part of this money, i.e. \$4 billion, was channelled to private accounts. The burden of paying back the loans, that gave the IMF additional leverage, was shifted to the Russian taxpayer. Behind the IMF and World Bank stood the USA that put all its cards on the clan of so-called reformers around Chubais that organised the sell-out of Russia's wealth to a small clique of oligarchs. The liberalisation of capital accounts, on the advice of the IMF, allowed Russian oligarchs to channel on average $\$ 2$ billion a month during the 1990s into their accounts abroad. According to a World Bank publication 'Russia's privatisation led to a small number of individuals, who mostly achieved initial wealth through favourable deals with or outright theft from the government, [having] control of most of Russia's major firms' (Transition Newsletter, January-February 2002). In the words of Joseph Stiglitz, former chief economist of the World Bank, 'privatization [in Russia HvZ] has gone ahead without a sufficient legal framework. As a result, rather than providing incentives for wealth creation, there have been incentives for asset stripping' (International Herald Tribune, 27 January 2000). According to Stiglitz, Western donor organisations willingly allowed Russian oligarchs to strip Russia's industrial assets (The Observer, 29 April 2001). 'How was it that a few oligarchs could bleed Russia of billions of dollars through state give-away of assets under privatization schemes encouraged by the IMF, but there was not enough money to pay miserly pensions to the aged?' (The Day, 12 June 2001).

It is in this light that we explore the development of the state-society nexus in Ukraine, after Russia the second largest successor state of the Soviet Union, from the perspective of management of socio-economic conflict potential. Also, we will address the question to what extent the activities of international financial institutions and the way Ukraine has been inserted into the world economy have influenced socio-economic conflict in Ukraine.

\section{Ukraine: general social and economic development}

Although secretary-general Gorbachev came to power in 1985 and soon afterwards announced Perestroika, Ukraine remained until 1989 under a Brezhnevist leadership and was shielded from Perestroika. Until independence (1991), Ukraine was isolated and therefore few within the elite or the population at large were aware of the magnitude of the economic and political crisis. As a result the Ukrainian elite was unprepared for reforms and 


\section{Hans van Zon}

was unwilling to implement them. When in 1991 a pro-reform Yeltsin emerged as the president of Russia the communist elite of Ukraine was not interested in a renewal of the Union. Independence was for them a means to cut themselves off from the reform process in Moscow. Ukrainian politics was hardly affected by the dissolution of the Soviet Union and the emergence of an independent Ukraine. No parliamentary elections were announced and prime minister and government did not change.

In a meeting of Ukrainian, Russian and Belarussian party leaders in December 1991 it was decided that the Soviet Union should be abolished. This was not the result of a democratic process but of a backroom deal. Nevertheless, 90 per cent of the population voted for independence in a referendum held in December 1991. Many, among them many ethnic Russians, thought that Ukraine would gain economically from independence.

Immediately after gaining independence the new Ukrainian government was preoccupied with consolidating independence and only to a minor extent with social and economic development. The reign of President Kravchuk (1991-1994), the former party functionary responsible for ideology, was characterised by massive mismanagement, and there were no signs that the government wanted to introduce a market economy. Privatisation remained limited to the sphere of trade. Hyperinflation took away savings of the population but allowed speculators to amass fortunes.

The deep economic crisis in which Ukraine was plunged (industrial production declined by about 75 per cent during the 1990s) was related to the fact that markets in the area of the former Soviet Union shrank and supply chains were disrupted. Also, a large part of industrial production was linked to the military industrial complex that was relatively very important in Ukraine and that was integrated into the Soviet military industrial complex. Military orders almost disappeared overnight. Other important contributing factors to the economic crisis were the lack of energy resources, the gigantic task of building up a new state apparatus and the total lack of experience with economic systems other than the centrally planned economy. But the most important reason was mismanagement and the squeezing of enterprises by directors, managers and bureaucrats.

In 1994, President Kuchma came to power under a programme of closer relations with Russia and more rights for the Russian-speaking majority. However, he announced a reform programme, supported by international financial institutions. But reforms were very slow and only partially implemented. Only those reforms were implemented that did not threaten the interests of a kleptocratic ruling elite. This all had the result of continuing economic decline. Ukraine was the only transition economy with a decade of uninterrupted economic decline. For the overwhelming majority of the population, the defining moment of the 1990s was not independence or democracy but a plunge into poverty. Whereas under communism the population was sure of employment, a social security system, free health care 
and free education, this whole social safety net unravelled in a matter of several years.

Only with the government of Viktor Yushchenko (December 1999-April 2001), the former director of the Central Bank, were substantial reforms implemented and the economy started to grow. The conservative government of Kinakh (from April 2001) slowed down reform and some of the reforms initiated by the previous government were stalled.

From 1999 living standards increased and poverty levels diminished. Nevertheless, a survey held in early 2002 found that that only 1 per cent of the people were well off, 32 per cent said their incomes were medium, 53 per cent considered themselves poor and 13 per cent destitute. In 1991 only 8 per cent and 0.5 per cent had considered themselves poor and destitute (Zerkalo Nedieli, 5-18 January 2002). This means that in 2002 about two-thirds of the Ukrainian population considered themselves poor or destitute. Another survey found that, in December 2001, 32 per cent of the population did not have enough money for food ( 36 per cent in 1996), and another 48 per cent did not have enough money to buy clothes and shoes (52 per cent in 1996). ${ }^{3}$

In 2001 , the official unemployment rate was 4.5 per cent. However, many unemployed are not registered as such due to high severance payments for enterprises in case of forced redundancies. Instead of firing people, they prefer to send redundant personnel on unpaid leave (16.1 per cent of all employees in 2000) and long-term maternity leave ( 8.3 per cent of all women in 2000). Acording to the standards of the International Labour Organisation, Ukraine had about 11.5 per cent unemployed in 2002. At first sight, there seems to be a rigid labour market with so few people being officially fired. In reality, there is an excessively flexible labour market without any protection against workers being sent on unpaid leave. Also, salaries are often not paid.

As a result of the deteriorating socio-economic situation, birth rates dropped and mortality rates increased. The population of Ukraine started to decline from the early 1990s onwards, from 52.25 million inhabitants in 1993 to about 49.25 million in 2001, and the population age structure deteriorated. Not taken into account are the millions of Ukrainians who went abroad for prolonged stays without informing the Ukrainian authorities. According to a recent poll, half of young people want to emigrate (Zerkalo Nedieli, 6-13 July 2002). This indicates the magnitude of the emigration problem.

Ukrainian society also became polarised. The gap between the small group of extreme rich and the larger section of the population that became impoverished increased. The Gini coefficient, based on official figures, stood at 22 for Soviet Ukraine at the end of the 1980s. By 1997, it had increased to 38, almost to the level of the United States (40). (Since then it started to decrease somewhat, at least according to official figures.) However, as the new rich usually do not report most of their income, a Gini coefficient that is based on real income differences must be much higher. 


\section{Hans van Zon}

Many expected that the Ukrainian middle class would gradually expand during the transition process. However, the middle class continuously contracted. Economic decline meant for most Ukrainian citizens a downward social mobility. In Kharkiv, Eastern Ukraine, respondents were asked in an opinion poll: 'In your opinion, what is your place in society now, which step on the social staircase do you occupy?' While in 1986, 85 per cent of respondents reckoned themselves to belong to the middle class, this declined in 1996 to 39 per cent. While 6 per cent of respondents reckoned themselves in 1986 to be in the lower class, this percentage rose to 49 per cent in 1996 (TACIS EDUK 1996). This means that, in terms of selfascribed social status, the social stratification of the population of Kharkiv deteriorated enormously. The authors of the report noticed that values that had at one time determined the respondents' social status, such as level of education and moral and human qualities, dropped considerably in their view, whereas such factors as level of income, personal connections and business qualities become more and more important.

Given the fact that so many were plunged into poverty and despair, and that so many were socially declassified, it is striking that a relative social peace has been preserved in Ukraine. Few mass protests and strikes took place. According to a SOCIS-Gallup poll (2002), over half of respondents believed that mass protest action would be impossible in their respective regions under any circumstance, be it a deepening economic crisis or the violation of constitutional rights and freedoms (The Day, 28 October 2002). This raises questions about the mechanisms of conflict mediation and interest representation in Ukrainian society.

Conflict-resolving mechanisms existent in Ukraine are typical for a patrimonial society faced with social disintegration and the breakdown of hierarchy. The abolishment of communist rule brought to the fore a society that was pseudo-modern or even anti-modern. Ukrainian society shows a lack of accountability on all levels, a lack of organisational transparency, an aversion to the Western 'book-keeper mentality' and a preference for informal dealings. Ukraine misses the institutional encapsulation of agency that is so typical of Western developed capitalism. According to Elster et al. (1998: 27), 'The core symptom of failed institutionalisation is violence. The essence of violence is the absence of legitimating rules to which actors can refer'. Ukraine is a prime example of a badly institutionalised social order. Once again according to Elster et al., 'a well institutionalised social order is one in which the (contingent, "non-natural") rules according to which political and distributional conflicts are carried out are relatively immune from becoming themselves the object of such conflict ... In such a social order, even the temptation of actors to embark upon a dangerous regressus ad infinitum (in the course of which controversies over rules spill over to controversies over the rules of rule making and further to the question of the ultimate authority - or rather the factual power! - to settle such issues) is a rare occurrence. There is, in other words, a solid hiatus between rules and decisions' (1998: 27). 
There is no rule of law in Ukraine. There is hardly a horizontal institutional differentiation. Therefore, in the Weberian sense, Ukrainian society can be considered to be anti-modern. Anti-modern social practices explain to a certain extent the economic decline of Ukraine. Social capital in Ukraine has a pre-modern character and holds back the development of organisational capital. Like in any pre-modern society impersonal norms of social integration are very weak and there is a sharp distinction between ingroup and out-group.

With the collapse of communism a particularisation of society took place that implied the emergence of an archipelago of social networks. A division between inside and outside morals, typical for pre-modern societies, became more pronounced. Also as in pre-modern societies, universal and impersonal mechanisms of social integration are very weak. Against this background of social disintegration the 'war of all against all' developed, a Hobbesian nightmare in which only the brute power of the strongest counts.

Ukraine became an experimental ground for those who were inclined to take risks, and gave numerous opportunities to those who were reckless. Rather than developing into a modern society with citizens, Ukraine remained a society with subjects to an unaccountable regime. Development of civil society stagnated (Nanivska 2002). A survey in 2002 found that only 4.7 per cent of the population said that they participated in social life (Interfax Ukraine, 26 September 2002). Although the situation of the population deteriorated during the $1990 \mathrm{~s}$, civil disobedience got less support. One can speak about intensifying political alienation in Ukraine. It seems that relative social peace is primarily related to the fact that Ukraine is not only a patrimonial society but also a blocked society that is deeply criminalised and where people are in many ways discouraged to change anything in power relations. Also, intermediate institutions are not developed or have been dismantled.

In Soviet times, the communist party was an instrument of repression but also an instrument of social cohesion. It not only mobilised the population, although this mobilisation function became less pronounced under the rule of Leonid Brezhnev, but it also functioned as an instrument for the party leadership to find out what was happening at the micro-level. The party was often responsive to non-political complaints. If someone was maltreated by an enterprise or a housing estate, he/she could go to the local party committee and complain. The party committee had the means to do something about it.

Especially in Ukraine, the most communist among the Soviet republics, the party bosses at the lower level often took the complaints of the population seriously. Since the late 1970s anonymous complaints were also looked at, on the grounds that people often did not dare to complain from fear of reprisal. The communist party functioned as a kind of ombudsman. Also, there were in the party communists in higher positions who took communist ideology seriously. For instance there were 'red directors' who really cared 
for their employees. Admittedly, cynicism and corruption spread under Brezhnev's rule. But, especially in the industrial east of Ukraine, the communist party was also a kind of protective mechanism for the population. The party was a mover and a shaker and, to a certain extent, it kept society together.

The disappearance of the party-state axis caused an institutional vacuum and released a predatory ruling elite from its last restraints. Actually, key figures in the party and Komsomol already prepared themselves for the new era while positioning themselves for the appropriation of the assets of the nation during the late 1980s. This process of commercialisation and hidden privatisation had been sanctioned and even organised by the central committee, starting in $1988 .{ }^{4}$ After independence, the red directors and those other communists who did not want to collaborate with the plunder of state assets were gradually pushed aside. Clan-networking, combined with capturing the state on all levels, characterised the coordination mechanisms of the new 'virtual economy'. Mafia gangs colluded with state officials in their battles to control the assets of the nation. Mafias often replaced state institutions, offering 'protection' where state institutions failed to do so.

It was not the ability to compete in a free market that was decisive for economic survival, but having the right connections in the state apparatus decided about the numerous privileges granted to insiders. In Ukrainian business, relations are not governed by formal rules or norms but by a code of honour, loyalty and friendship. Loss-making enterprises managed to survive, using state subsidies, while profitable enterprises often could not survive.

The most crucial development in 1991 was the falling-away of the communist party as the last obstacle protecting the population against the predatory behaviour of the nomenklatura and associated criminal elements. After 1991, the population lacked any institution to protect itself against a parasitic elite and state. Conflict-regulating mechanisms were not developed. Moreover, Ukrainian society is not law governed and what laws there are are often contradictory. A labyrinth of laws and presidential decrees provides bureaucrats with high discretionary power. No enterprise can follow all laws and pay all taxes, and it is therefore dependent upon the goodwill of officials. Common practice is that formal rules and laws are disregarded. This exposes citizens and enterprises to arbitrary rule.

Although the population was offered parliamentary democracy and civil liberties, at least in the constitution, the overwhelming majority of the population did not make use of these rights and did not begin to organise themselves. Political parties emerged but they mainly served as vehicles for the interests of influential businessmen, lacking any political programme or sizeable membership, apart from the communist party that acted as a ritualistic opposition. ${ }^{5}$ The official trade unions continued to play their traditional role, that is, primarily serving as a transmission belt for enterprise management and providing a range of services for their membership, such 
as providing places in their holiday resorts, helping enterprise management with the distribution of housing and goods etc. In Soviet times, virtually everyone had been a member of a trade union, but after independence membership of trade unions fell drastically. According to one survey, in 2002 only 21 per cent of the adult population were members of a trade union, while another survey in the same year pointed to a 4 per cent trade union membership (Zerkalo Nedieli, 26 October-2 November 2002, and The Day, 28 October 2002).

The population remained inactive because they were too preoccupied with sheer survival, they were withheld from action by repression, or they believed the authorities would not respond to protests. ${ }^{6}$ The historical experience of oppression also played a role. This is exemplified in the fact that in Western Ukraine, part of which had been incorporated in the Soviet Union as recently as the Second World War, 11.8 per cent of the population participated in protest actions, while only 7.0 per cent did so in Eastern Ukraine (Zerkalo Nedieli, 26 October-2 November 2002).

The assets of enterprises were appropriated by enterprise management often under their eyes. For example the 20,000 employees of the Avtozaz car factory in Zaporizhzhye were not paid their salaries for several months in 1993, and then after the period of non-payment, the factory's management suddenly founded the Avtozaz bank. The employees concluded that the start-up capital for this bank must have been financed by their unpaid salaries. No employee action followed. Employees are often in many ways dependent on their employer. Apart from a salary, the employer provides housing and access to enterprise shops, enterprise clinics, holiday resorts and many other facilities. It is very easy for management to punish militant workers. This is part of the explanation why, apart from independent miners' trade unions ${ }^{7}$ and an independent trade union of journalists (founded in October 2002), no independent trade unions emerged in Ukraine. Usually, when faced with injustice in the workplace, the reaction is escapism (for example, finding a job elsewhere), shirking, alcoholism and suicide. Job rotation is at a very high level, as are the suicide rate and diseases related to alcohol abuse.

Public authorities usually side with enterprise directors. They are part of one and the same cohesive system. Executive, legislative and judiciary powers are also merged (that is, there is no separation of powers) and this apparatus hangs over Ukrainian society. State structures are effectively used against critical journalists and opposition parties. Free media hardly exist, and state control over the media has even strengthened under the rule of president Kuchma. Some legitimacy is retained by often allowing nonpayment of utility bills, and there is a system of tiny privileges by which many profit. ${ }^{8}$ The population does not trust the institutions of the state. Corruption is omnipresent and state institutions do not deliver. In most institutes of higher education corruption has become ingrained, and in health care under-the-counter payments have become common practice. The 
state, as a predator and parasite, suffocates society and the economy, and does not adequately fulfil the developmental role played by the state in developed economies. The state has weakened, but has remained at the same time over-powerful because it is able to control and block everywhere initiatives in society and economy. Enterprises cannot do anything without the support of bureaucrats. In summary, a situation has emerged in Ukraine in which the superstructure has become almost disconnected from the population at large.

\section{The case of Donetsk}

In order to analyse the state-society nexus in more detail, it is expedient to look at the regional and local level. We take the case of Donetsk province because this is a key region in Ukraine, and trends in Donetsk, the major centre of the East Ukrainian industrial heartlands where large numbers of Ukrainians live, are representative of Ukraine as a whole. The central problems of the Ukrainian economy and society are most visible in Donetsk.

The province of Donetsk, in the centre of Donbass, has 4.865 million inhabitants (1 July 2001) and with 10 per cent of the total population of Ukraine is its most populous province. It accounts for 19.3 per cent of Ukraine's industrial production (2001) and for approximately a fifth of Ukraine's exports. A fifth of all employed work is in coal mining. Heavy industry accounts for more than half of industrial production. Since 1991, Donetsk - like Ukraine as a whole - faced a drastic decline in production. Since 1992 the number of employed fell in Donetsk by approximately a third.

The end of Soviet rule saw the emergence of clan networks that operated partly legally and partly in the shadow. The reforms of Mikhail Gorbachev provided opportunities for the upper echelons of the party-state, especially the Komsomol leaders, to enrich themselves. ${ }^{9}$ They established construction companies and real-estate businesses, and became active in show business. Satellite companies were formed around big state enterprises, while at the same time trading with them. This was very profitable and already before the collapse of the Soviet Union and communism, fortunes were made by squeezing state-owned companies. State structures always stood behind these mostly young businessmen. In Donetsk the myriad of commercial firms that emerged around big state enterprises were linked to these enterprises through close personal links. Often, the commercial enterprises providing services to these state-owned companies, or purchasing their products, were headed by close relatives of the directors of these companies, and sometimes the directors themselves headed the commercial companies. This squeezing of state-owned enterprises was overseen by the local and regional public authorities. They were complicit in this state-managed economy and profited directly from the plunder of state-owned companies. Often state functionaries were involved in the commercial firms. Without the approval 
of state functionaries, the squeezing of state-owned enterprises would not have been possible. Therefore, the primary accumulation of capital in Donetsk was based on the plunder of state-owned companies with the complicity of public authorities.

After independence, the commercial structures grew bigger as prices were freed and opportunities for speculation widened with the hyper-inflation that struck Ukraine in the early 1990s. Especially with energy trade and steel exports, huge fortunes were made. In Donetsk the origins of many fortunes lay in coalmining. A very popular business was supplying steel, equipment, conveyor belts and other materials to coalmines in exchange for coal (especially coking coal) with its further supply to coke-chemical plants, metallurgical enterprises and power plants. Although coal mining was a loss-making sector and dependent upon big state subsidies, commercial structures were price setters and created big profit margins in the buying and selling of coal. Through their influence upon public authorities in Donetsk they arranged that they were imposed upon enterprises as sole suppliers. Part of the profits of these commercial structures disappeared into offshore accounts. Part was used to expand the empires of these structures. In the waves of privatisation, commercial structures acquired a range of enterprises. First it was not productive enterprises but rather, for example, local football clubs, hotels, cafés and restaurants. Privatisation in Ukraine was very slow, and the big strategic enterprises that now dominate the economy of Donetsk were privatised only from the late 1990s onwards.

The first sign that commercial structures had established themselves politically was with the appointment of Vladimir Shcherban as head of the provincial council in July 1994. He represented these commercial structures. In 1993 and 1994 the power of the Donetsk clan was at its height, shortly after the big miners' strike of 1993 that brought a leader of the Donetsk clan, Efim Zvjagilski, to the top of the government in Kiev (September 1991-June 1994) ${ }^{10}$ Miners' strikes were used by local politicians to their advantage in their negotiations with Kiev. The debts of mines, that were state-owned, were cancelled and fines for overspending on wages were abolished. In the mid-1990s, clashes between competing clans about control of energy supplies were very violent. As a result of clashes over resources, Vladimir Shcherban was removed in 1996. Akhmet Bragin, at that time owner of the football club Shakhtyer and mentor of Rinat Akhmetov, the most powerful tycoon in Donetsk, was blown up along with six of his bodyguards during a football match. In November Yevgeniy Shcherban, a member of parliament from Donetsk, was gunned down. In spring of 1996 two other leading Donetsk businessmen were assassinated. Outsiders, that is, individuals from other regions, were involved. Prime Minister Pavel Lazarenko (1996-1997), from a clan based in Dnepropretovsk (to which president Kuchma also belonged), amassed a fortune by buying and selling natural gas from Russia. ${ }^{11}$ He wanted to expand his empire by imposing himself upon steel enterprises in Donetsk. He wanted his United Energy 
Systems to control the emerging chain gas-metal-gas pipes (Lyakh 2001: 9). To this end, according to the general prosecutor of Ukraine, he ordered the killing of several leaders of the Donetsk clan. The Industrial Union of Donbass lost the conflict and concentrated afterwards on seizing control over steel enterprises in Donetsk.

During 1995-1997 the unification of fragmented elite groups began under the banner of regional autonomy. Politicians from Donetsk wanted regional autonomy in order to get hold of local energy resources and to maintain the freedom to develop economic relations with Russia. Also, groups that had previously been involved in the shadow economy became active in legal business. This period was also marked by the criminalisation of the political sphere. In May 1997 the governor of Donetsk, Sergey Polyakov, a Lazarenko protégée, was replaced by Viktor Yanukovich. His appointment was a compromise between Donetsk and Kiev. He had business interests in Donetsk but was at the same time a supporter of president Kuchma. Since 1997, after the violent clashes, the Donetsk clans built up their empires in silence, without openly challenging the state power in Kiev. A silent compromise emerged between Kiev and Donetsk: Donetsk organised support for the president, guaranteeing a majority for him in Donbass, while Kiev would let the Donetsk clan manage its own affairs. This meant that the Donetsk clan could constitute its own fiefdom, with its own rules that are different from those of Kiev, on condition of their loyalty to president Kuchma.

After the coalmines and cokes factories, the commercial structures gained control over the steel enterprises, most of which were privatised from 1998 onwards. In 2000, the privatisation of machine-building enterprises started and local financial industrial groupings took controlling stakes in most of these enterprises. The Industrial Union of Donbass (IUD) and the related grouping ARS created Ukruglemash, unifying six local enterprises producing equipment for mining and steel manufacturing (Salon Dona $i$ Basa, 31 May 2001). In 2001, Donbassenergo, the largest energy distributor in Ukraine and owner of several thermal power generating stations, came under the control of IUD after a shadow privatisation. The electricitygenerating sector has become more interesting lately since payment discipline has improved: 19 per cent of electricity was paid for in 1999, 38 per cent in 2000 and 61 per cent in 2001 (Zerkalo Nedieli, 2-9 February 2002). This means that nowadays, the whole of the energy sector, all the basic industries and the larger part of machine-building in Donetsk have come under the control of the Donetsk clan. The clan now controls the three most important production chains in Donetsk: coking coal-cokemetal; energy coal-electricity-steel, and gas-steel-gas pipes.

The Donetsk clan has become the most influential clan in Ukraine and the Industrial Union of Donbass the most influential single business grouping. One can see an ongoing integration of the major financial industrial groupings in informal holding companies and cross-shareholdings. 
Financial industrial groupings are integrating production in Donetsk in both vertical and horizontal ways. Initially, the fortunes amassed by the financial industrial groups could not be invested in big enterprises because these were only privatised since the late 1990s. Once this privatisation started, the commercial structures were so powerful, financially and politically, and so well organised, having eliminated thousands of small commercial competitors while forging unity among the few remaining holding companies, that the takeover of the big enterprises in Donetsk was an easy task. Privatisation was meant to create more efficient economic structures and competition. Instead, privatisation created in Donetsk a monopoly that controlled the whole regional economy. Even before the strategic industries were privatised, the public authorities in Donetsk were 'privatised' by financial-industrial groupings.

Gradually politics in Donetsk came to resemble politics in communist times. The political culture is still very much as it was in communist times and communist sentiments are very much alive. Political opposition is almost absent, although the communist party is very strong, attracting 35 per cent of the votes during the parliamentary elections of 1998. But the communist party does not pose a challenge for local authorities. Leading figures in the communist party, like many other politicians, have stakes in big enterprises and are interested in preserving the status quo. When the position of president Kuchma was threatened, he could, until mid-2002, reckon on the support of the communist party. Nor do the local trade unions pose a challenge for the local elite.

There is no media freedom. Regularly critical journalists are harassed and in July 2001 Ihor Oleksandrov, a critical journalist, was killed after exposing a local politician. As usual in Ukraine, the assassination was covered up by the public authorities. Although there is widespread dissatisfaction among the population, this is not expressed in political unrest or instability, although strikes occur in Donetsk more often than in Ukraine as a whole. In 1998, of all strikers in Ukraine, 35 per cent were in Donbass (the provinces of Donetsk and Luhansk). Nevertheless, given the scale of deprivation and social injustice, strike activity is at a remarkably low level. In 1999, according to official statistics, 94 per cent of all industrial strikes (counted in lost man-hours) occurred in coalmining. This is related to the fact that industrial relations in mining are fundamentally different to those in other industrial branches. For miners, payment in money form has always been the most important part of a miner's remuneration package, and the range of services offered by mines was always much more meagre compared to other branches of industry. Therefore the decline in wages hit miners much harder than it did other workers. Another factor is that the nature of the work in mines, being heavily dependent on the help of colleagues, furthers mutual support and solidarity.

The mining industry has several relatively small independent unions that are militant but are not able to constitute an effective countervailing force 


\section{Hans van Zon}

for mine directors, as they are uable to unite and instead spend a lot of energy quarrelling amongst themselves. Simon (2000: 149) noticed that 'workers can display great social cohesion and power when mobilised but lack independent leadership and are frequently vulnerable within the enterprise'. Strikes were not directed against the mine directors but against the government, because almost all of the 170 mines in the region, most of which are loss-making, are state-owned, although they are de facto controlled by the Donetsk clan. State ownership makes it easier to claim subsidies from government and to channel miners' dissatisfaction towards the state. This is the reason that few in Donetsk favoured the mine privatisation that was planned to start in 2002 but was blocked by the Ministry of Fuel and Energy (headed by a representative from Donetsk).

The coal industry, with respect to mine safety, is one of the most dangerous in the world. A staggering 59 per cent of all industrial injuries in Ukraine occurred in Donbass (1998), while only 15 per cent of industrial employees work there. This figure is related to the highly injury-prone industries that are located there, such as mining and the steel industry. The extremely high injury rate in the mining industry is not so much related to lack of funding but rather to a configuration of interests that produces neglect. Most accidents are caused by ignoring safety rules. For example, oxygen equipment is made in such a way that, if miners carry it in the prescribed way, their movements are severely impaired. As a result, they do not carry it when going underground. However, the equipment could be easily redesigned so that miners' movements would not be impeded. Also, miners' families get big compensation in case of death or injury. In addition, smoking in dangerous places often occurs. Work often continues when the methane content in mines surpasses critical levels. This is due to the fact that miners' pay is linked to the amount of coal produced. The result is a death rate of between 300 and 350 a year over the past five years. It is telling that the Ukrainian mine with the most modern equipment (Setka) has a gas explosion every five years on average, and six fatalities each year. One of the most profitable mines, Zasiadka in Donetsk, has one of the highest casualty levels. The assistant director told me that lack of mine safety is related to high methane content and lack of funds.

One would assume that mine safety would be one of the most urgent issues for miners and their trade unions. However, improvement of mine safety does not figure high on the list of priorities of trade unions, unlike employment and wage issues.

The strategy of the Donetsk clans, after their violent clashes and defeat in the mid-1990s, has been to build up a solid base in Donetsk, without interference from politicians in Kiev. In exchange for the support of the Donetsk clan in the presidential elections, Kuchma would not interfere in Donetsk, leaving Donetsk to the Donetsk clan. Indeed, the Donetsk authorities delivered a victory for president Kuchma in November 1999 by rigging the elections. OSCE observers reported extreme electoral infringements in 
Donetsk. The first round of the elections showed that an overwhelming majority supported the left parties, and the communist Simonenko had a clear lead over all other candidates. However, Kuchma won the elections with a difference of 21 per cent over Simonenko. In most other provinces Simonenko won the second round where he had a lead in the first round. Only Kharkiv, Sumi and Donetsk were exceptions (Kovaleva 2001). Nowhere in Ukraine was Kuchma so successful as in Donetsk during the March 2002 parliamentary elections. Donetsk was the only province where Kuchma's party (For a United Ukraine) finished first. Regional authorities used absentee ballots on a massive scale, employing huge administrative pressure and the use of local thugs to intimidate opposition politicians and election observers. Donetsk authorities also provided full support for president Kuchma in the scandal around the murder of journalist Gongadze in which president Kuchma was accused of ordering his killing. Everybody who wanted to change things in Donetsk was made aware that this is not possible. For example, the National Energy Regulation Commission and the State Commission for Securities and Stock Market, which keep a register of owners, refused to grant licences to the new owners of Donbassenergo (linked to the Industrial Union of Donbass). As the Kyiv Post noticed: 'The ritualistic murder of Oleksey Romashko, member of that commission, had a psychological effect strong enough to make these agencies take a softer stand' (The Day, 5 January 2001).

Donetsk enterprises have become the most powerful in Ukraine. Six out of the fifteen biggest enterprises in Ukraine, in terms of revenues, are from Donetsk (2000). Of the ten biggest intermediary companies, five are from Donetsk; of the fifteen biggest Ukrainian exporters, seven are from Donetsk. Given the relative weakness of other clans, the Donetsk clan recently became more influential in Kiev, especially given the fact that the Donetsk clan is expanding its influence beyond the borders of Donetsk. It already controls Luhansk, and has made important inroads in the rich provinces of Zaporizhzhya and Dnipropretovsk. Donetsk's financial industrial groupings are also getting stakes in the raw material base of the Crimea (Lyakh 2001: 10).

Conspicuous in Donetsk is the extremely low level of foreign direct investment, despite efforts to attract foreign direct investment through Free Economic Zones. Foreign investment amounted to only 0.7 per cent of all investment in Donetsk in 1995, 3.2 per cent in 1997 and 10.6 per cent in 2000 (Lyakh 2001: 17). In 2000, accumulated foreign investment was $\$ 155$ million, that is $\$ 63$ per capita. The origin of foreign capital is not that clear. By far the greatest investments came in 2000 from the Virgin Islands $(\$ 54.7$ million, i.e. 32.4 per cent), pointing to the return of local capital flight. The most important foreign investors in Donetsk are Russians. Among others, they acquired the successful chemical company Stirol (Kyiv Post, 11 October 2001). However, Russia does not figure among the main investors in regional statistics because they often channel their investment through non-Russian enterprises. (Makogon and Khadzhinov 2001: 219). 


\section{Hans van Zon}

The share of foreign trade with Russia is far higher than the Ukrainian average, and many enterprises are dependent on inputs from Russia and Russian markets. Russians feel themselves at home in Donetsk; less so Western investors, who are faced with many obstacles. It seems that Donetsk wants foreign capital but not foreign investors, especially Western investors. Initiatives to attract foreign direct investment, such as the Free Economic Zones and the Technopark, were disguised attempts to organise tax exemptions for enterprises linked to the Donetsk clan. The integration of Donetsk in the world economy has been very shallow. Deep integration, which means integration in transnational production chains, has been very limited. Exports consist mainly of steel, while steel producers are faced with increasing costs, related to more expensive energy supplies and transport costs, and decreasing profits. While total profits of the Ukrainian steel enterprises were $\$ 2$ billion in 2000 , it was $\$ 1.3$ billion in 2001 . The prognosis is $\$ 700$ million for 2002 (Zerkalo Nedieli, 2-9 February 2002).

The conventional wisdom in explaining the economic decline of Donetsk is that this is related to the falling apart of the SU and COMECON, and therewith the disappearance of important markets and supply chains as well as the transition to a new economic system. Given the account above, one important factor explaining the decline can be added: the squeezing of industrial enterprises by commercial groupings. Enterprises were deliberately deprived of the means to survive and resources were redistributed to commercial enterprises. The 1990s saw a massive redistribution of resources away from productive activities and the population, thereby undermining effective demand. Strategically located officials were persuaded, with some financial help, to 'defect' and participate in rent-seeking activities. In this process, the governance capacities of local and regional authorities were undermined, as was their relative autonomy. As Ganev (2001: 21) argued for Bulgaria, "Post-communist redistribution is rarely "mediated" by the visible parts of the institutional edifice - government or parliament; rather it unfolds in the impenetrable universe of administrative agencies, ministerial departments and custom offices'. The question emerges with recent economic growth and increased investment whether rent seeking has become less interesting for the tycoons? After all, it does not seem to be in their long-term interest to sit on their capital and let their productive assets be worn away. However, investment in Donetsk remained at a rather low level.

There is also a problem with dominant belief systems that are strongly rooted in the communist past. All major players in Donetsk, including the larger part of the population, share the belief that value subtracting sectors, like the larger part of the steel and coal industries, are actually value producers. All major players think that the organisation of the production process is just a technical problem, not an economic one, in the same way that economic problems were ignored in communist times.

The key to understanding the regional economy of Donetsk is to understand the working of clan politics. The Donetsk clan, a coherent amalgam 
of holding companies with strong internal bonds, controls the regional economy and regional politics. Although there is not a clear organisational structure in the clan, the Industrial Union of Donbass is dominating the Donetsk clan. The clan has captured control over the three most important production chains: coking coal-coke factories-steel; gas-steel-pipes and coal-electricity-steel. Investments are at a very low level and directed towards the basic industries. There are no signs that big enterprises are restructuring. Small and medium-sized companies are weakly developed and their access to markets is prevented by monopolistic structures.

Recent economic growth does not point to a sustainable recovery because profits in the main economic sectors on which growth has been based are dwindling. Nevertheless, the Donetsk clan developed into the most powerful clan in Ukraine and growing influence in government will help to emulate the Donetsk model in other regions of Ukraine.

Donetsk is atypical because, among others, it has a long history of miners' militancy, and because more than most other regions in Ukraine it was faced with brutal repression. This has had an impact upon the mentality of the population that has been more subject to the pressures of sovietisation than most other industrial regions. At the same time Donetsk felt privileged in Soviet times because of the high wages in the mining and steel industries. Donetsk was also one of the showcase regions of Soviet communism. But after independence, the status of Donetsk changed from that of a major industrial centre in a superpower towards a marginal region in a newly independent and impoverished state at the periphery of Europe.

Despite some atypical features, the predicament of Donetsk epitomises the weaknesses of Ukraine as a whole, with respect to the economy, politics and the state-society nexus. Ukraine as a whole is faced with a distorted economic structure, but Donetsk even more so. Ukraine as a whole is faced with a patrimonial society and state, but Donetsk even more so. Ukraine as a whole is not very receptive for foreign enterprises, but Donetsk even less so. More than in Ukraine at large, the power of oligarchs spread in Donetsk. More than in Ukraine as a whole, the economy in Donetsk is state dominated. Even more than in Ukraine, the regional economy of Donetsk is monopolised. Even more than in Ukraine, the media in Donetsk province are state-dominated.

\section{The role of international financial institutions}

In the above account, the international financial institutions did not figure. Their direct role in developments in Donetsk have been marginal and their impact was mainly indirect, through the influence of these institutions on the macroeconomic policies of the Ukrainian government.

Shortly after declaring independence in 1991, the government of Ukraine began the process of integrating itself into the world economy and its attendant financial institutions. Within a short period of time Ukraine became a 
member of the IMF, the EBRD, IBRD and an observer at the GATT (later World Trade Organisation). Ukraine joined the IMF on 3 September 1992. However, economic mismanagement and failure to implement economic reforms prevented the development of any significant financial assistance from the IMF in the period 1991-1994. Also other donor institutions stayed aloof. The Ukrainian government ran large government budget deficits that were financed by printing money, causing hyperinflation. Only since July 1994, with the coming to the fore of Leonid Kuchma as president and the announcement of economic reforms, did international financial institutions like the IMF become involved in policy preparation. With the support of IMF, World Bank, EBRD, European Commission and fourteen donor nations, Ukraine embarked in October 1994 on an economic reform programme that brought about unification of the exchange rate, the liberalisation of many features of the exchange rate, the abolition of price controls on many products, and the increase of interest rates to positive levels in real terms. IMF proposals were above all destined to attain financial stabilisation.

Reform efforts of the Ukrainian government were closely monitored by donors, headed by the IMF, and loans were made dependent on progress in reforms, at least according to the IMF. However, prime minister Vitaly Masol, an old-style communist, stayed in power until March 1995, when Yevhen Marchuk, a former KGB man, took over. In April 1995 there was a sudden shift in the government's position, with Kuchma insisting that 'rapid market transformation of the economy must address the social needs of the population and provide a strong safety net' (Hare et al. 1998). It meant a return to former president Kravchuk's economic strategy: gradualism, characterised by a large role for the state. It meant, de facto, no reform at all. Nevertheless, the IMF promised in April 1995 a credit line of $\$ 1.96$ billion to support the government's 1995 economic reform programme. In 1995 the Ukrainian GDP continued to contract, by 12.2 per cent. Consumer goods industries especially suffered under the flood of imported consumer goods.

Under its 1996 economic reform programme, aimed at macroeconomic and structural adjustment, and again supported by IMF, World Bank, EBRD, European Commission and fourteen donor nations, Ukraine made substantial progress in reducing inflation and introducing a new currency (the hryvna). The donors, who met in December 1996, promised $\$ 3.5$ billion, of which $\$ 1.1$ billion was in IMF loans, linked to a wide-ranging package of macroeconomic and structural reforms that Ukraine intended to implement in 1997. ${ }^{12}$ However, there were big problems with the implementation of major aspects of these programmes. Despite some improvement in financial stabilisation, the general economic situation continued to deteriorate and GDP continued to decline. ${ }^{13}$ The originally-planned three-year IMF programme supported by an Extended Fund Facility had to be replaced with a more modest one-year Stand-By Arrangement in August 1997, as the government and parliament were not ready to undertake the structural reform as required by the IMF. 
The IMF broadened its recommendations to improve governance by deregulation, privatisation, de-monopolisation, more flexible labour markets, land reform and energy sector privatisation and restructuring. Short-term capital inflows and borrowing from domestic banks made it easier for the government to postpone restructuring and to finance a budget deficit that was not sustainable, also given the very high interest rates. ${ }^{14}$ By the end of 1997 Ukraine had received $\$ 4.6$ billion of loans from Western donor countries and institutions. Under prime minister Pustovoytenko (July 1997--December 1999) reforms were hardly implemented. Nevertheless, IMF disbursements continued to flow. In 1998, IMF support was crucial to avoid contagion due to the Russian financial crisis. Indebtedness attained unaffordable levels and in 2000, under the reform-minded prime minister Yushchenko, the foreign debt had to be restructured. Since late 1999, IMF disbursements dropped sharply, despite the fact that economic reforms were implemented, especially in the crucial energy sector. Also payment discipline in the energy sector improved dramatically. Energy tariffs were increased, under pressure from the IMF. ${ }^{15}$

In the case of Ukraine there seems to be a negative correlation between speed of economic reforms and IMF disbursements. It seems as if the IMF has had a hidden agenda. It might have been that IMF support during 1994-1999 was a reward for a foreign policy that was more aligned with that of the West. The decision of the IMF to support Ukraine in 1994 was on the initiative of the USA, worried about the stability of Ukraine with its large Russian minority and Russian-speaking majority. The involvement of the IMF was preceded by an agreement between Russia, Ukraine and the USA that included Russian recognition of Ukrainian eastern borders, dismantlement of Ukrainian nuclear warheads and the delivery of Russian nuclear fuel for Ukrainian nuclear power stations. Of course, IMF support was not part of the official deal because formally the IMF is a multilateral institution, independent of the USA.

The IMF did not raise its voice during the reign of prime minister Pavel Lazarenko (1996-1997), who squeezed the country of its scarce resources. He was a main player in the Ukrainian gas business. Russian gas was sold by Russian Itera to United Energy Systems of Ukraine, in which Lazarenko had stakes, for about $\$ 80$ per thousand cubic metres while the real price was considered to be $\$ 40-45$. Itera and the Ukrainian gas importers split about $\$ 4$ billion a year between them (Aslund 2001: 318). Ukrainian gas oligarchs also earned fortunes from the gas transit business. Also, mechanisms were created that generated debts at a fast pace. Often, the state gave sovereign guarantees for loans granted to enterprises. Once the enterprises failed to repay the loans, the state took over the obligation to service the loans. According to $\mathrm{O}$. Sukoniako, president of the Ukrainian Banking Association, 90 per cent of loans from foreign international organisations, obtained by industrial enterprises under government guarantees, have been paid out of the state budget (The Day, 31 October 2002). Also, the state 


\section{Hans van Zon}

budget paid for the debts accrued by Ukrainian companies that imported gas from Russia and Turkmenistan but failed to pay for it. However, the IMF did not raise the issue of sovereign guarantees from the side of the state that perpetuated soft budget constraints upon those enterprises that managed to attract loans. On the other hand, commercial loans became unattainable for enterprises due to the crowding-out effects of the treasury bill market.

The liberalisation of foreign exchange, as required by the IMF, facilitated capital flight from Ukraine that was far greater in size than foreign direct investment. ${ }^{16}$ Liberalisation of foreign trade created international competition for the unreformed Ukrainian enterprises, which were often out-competed by foreign enterprises. Many foreign loans were used to finance the budget deficit and not used for productive purposes. ${ }^{17}$ The IMF allowed Ukraine to live above its means. A major IMF requirement was administrative reform, reducing the large number of ministries and state committees, creating transparency and reducing the number of civil servants to 300,000 by the end of 1998 . However, the IMF failed to check the implementation and no reductions in the size of ministries took place. Later, the prime minister stated in an interview that no reduction in the number of staff had taken place and that no significant change had resulted from the presidential decree on administrative reform (Finance Week, Nr 13, 1999).

The positive impact of IMF policies was mainly in the sphere of monetary policy and financial infrastructure. A stable hryvna and better-managed state finances certainly helped the Ukrainian economy. Recently, reforms in agriculture showed a beneficial impact, while more transparency in the energy sector reduced the ability of oligarchs for asset stripping in this sector. Also the banking sector became healthier, although enterprises still hardly benefit from bank lending.

IMF influence was at its height late 1999, when president Kuchma was reelected and Ukraine was faced with the need to restructure its foreign debt, for which IMF assistance was required. It was under IMF and US pressure that Viktor Yushchenko, the director of the Central Bank, was appointed as prime minister. Yushchenko became the most popular prime minister of independent Ukraine, reflected in the fact that his party got most votes in the parliamentary elections of 2002 , primarily because he brought order to the chaotic state finances and started to pay the pensions and salaries of public institutions regularly.

Since 2000 , when indebtedness started to diminish from unaffordable levels, Ukraine became less dependent upon the IMF. Also, the strategic importance of Ukraine for the West diminished compared to the 1990s and the US-Ukraine relationship cooled down, especially after it appeared that president Kuchma gave his consent to the sale of radar equipment to Iraq in violation of the UN sanctions regime. Deteriorating relations with the USA had an impact on support for Ukraine from the international finan-

cial institutions, whose policies became increasingly a function of US 
foreign policy. Ukraine prefers nowadays to borrow on the international capital markets, with higher interest rates, than to accept cheaper IMF loans given under strict conditions. Therefore, we may not expect significant leverage of the international financial institutions upon Ukraine in the short and medium term.

The only direct impact International Financial Institutions had on Donetsk province was through the coal programme of the World Bank, aimed at softening the environmental and social impact of coalmine restructuring. This bank forwarded $\$ 320$ million in loans to the Ukrainian government to finance a coal restructuring plan. Also EU (TACIS) and UK (DFID) money was used for coalmine restructuring. The miners' trade union of Donetsk complained that none of the money had reached the region. The World Bank complained that almost no restructuring took place and too few mines have been closed. Non-governmental organisations observed corruption with the institution overseeing the closure of mines and the Ukrainian accounting chamber admitted that $\$ 14$ million, destined for compensation for ex-miners, simply disappeared. Also, the mine closures were mismanaged and often resulted in subsidence and the pollution of drinking water. The World Bank failed to demand consultations with nongovernmental organisations. ${ }^{18}$ Several times the World Bank interrupted lending for the coal-restructuring programme.

\section{Conclusion}

The case of Ukraine shows a country that has opened up to the world economy only to a limited extent. The case of Donetsk province shows an example of a region actually shielding itself from any outside interference, including that of foreign investors and the government in Kiev. Donetsk shows an economy monopolised by a coherent clan that harasses any opposition. The case of Donetsk is relevant because the region is a key one in Ukraine and the Donetsk clan increased its influence in Kiev. Donetsk is an example to follow for many within the economic and political elite of Ukraine.

The international financial institutions had only a very limited impact on socio-economic policies in Ukraine, unlike in Russia under president Yeltsin where the neoliberal experiment was fully supported by the government. There are in Ukraine some superficial parallels with developments in states with neoliberal policies, such as flexibilisation of the labour market, privatisation, (limited) deregulation and liberalisation of foreign economic relations. Ukraine remained, however, a bureaucratically controlled economy that hardly opened up to foreign capital. As in many countries of the south, de-regulation and liberalisation were functional in the ascendancy of rent seeking. Whereas in many countries of the south intermediate institutions were marginalised, these could not develop at all in Ukraine. In Ukraine, not a neoliberal lean state but a neo-patrimonial and over-powerful 


\section{Hans van Zon}

state emerged that is dominated by a conglomerate of clans headed by the country's president.

This chapter has raised some questions about the future cohesion and stability of Ukrainian society. One of the observations is that the Ukrainian elite and state are not responsive towards the demands and needs of the population while intermediate institutions hardly developed. There is also inadequate information about what is happening in society at large. This raises the spectre of future instability. This could occur if the interests of the population are disregarded even further, for instance in case of widespread eviction of tenants related to non-payment of rent or in case of widespread cut-off of electricity and gas in case of non-payment of the utility bill. International financial institutions are pressurising the Ukrainian government to enforce payment discipline, to raise energy tariffs and to privatise energy distributors. A recent survey (2002) showed that twice as many people from the younger generation feel dissatisfied with their current way of life than the older generation, despite the fact that the living standard of the younger generation is substantially higher (The Day, 28 October 2002). This points to turbulent times ahead.

\section{Notes}

1 In 2004 the Baltic States, Poland, Czech Republic, Slovakia, Hungary and Slovenia will become members of the European Union.

2 As Polyani (1957) noticed, 'The step which makes isolated markets into a market economy, regulated markets into a self-regulating market, is indeed crucial' (p. 57) and 'a self-regulating market demands nothing less than the institutional separation of society into an economic and political sphere' (p. 71).

3 The calorie intake per capita per day dropped in Ukraine from 3,597 kilocalories in 1990 to 2,567 kilocalories in 1997, while the protein consumption fell in the same period from 105.3 grams to 75.4 grams.

4 There is evidence that by 1988 elements within the ruling elite in Moscow were already preparing for the demise of the centrally planned economy and to safeguard their interests (Knabe 1998).

5 Only 3.6 per cent of respondents in a survey said that they were members of a political party. Of these, 54 per cent did not materially support their party and only 16 per cent made regular contributions (Zerkalo Nedieli, 26 October-2 November 2002).

6 Ibid. Although a lot of respondents in a survey (August 2002; 39-45 per cent) are in principle ready to take part in protest actions, actually few participated in reality. The main reason is that they thought the public authorities would ignore these actions ( 41.7 per cent).

7 The Independent Union of Ukrainian Miners claimed to represent 52,000 of the then 350,000 Ukrainian miners (Kyiv Post, 26 September 2001)

873.7 per cent of households receive at least one benefit. The average value of total benefits per household is 89.35 hryvna (about $\$ 17$ ) per month (Whitefield 2002: 77).

9 Between 1987 and 1992 in the area of the former Soviet Union the ratio of exfunctionaries in the business elite grew from 38 per cent to 61 per cent.

10 Zvjagilski was later accused of stealing \$22 million from state coffers (Kyiv Post, 17 June 1999). 
11 Former prime minister Pavel Lazarenko is awaiting trial in the United States for the embezzlement of $\$ 180$ million.

12 Of this $\$ 3.5$ billion package $\$ 1.1$ billion were World Bank loans and the remainder would be supplied by other multilateral donor institutions.

13 Inflation went down. Consumer prices increased by 891 per cent in 1994, 377 per cent in 1995, 80 per cent in 1996, 16 per cent in 1997 and 11 per cent in 1998. Real GDP declined in 1995 by 7 per cent, in 1996 by 6.3 per cent, in 1997 by 0.5 per cent, in 1998 by 3.3 per cent and in 1999 by 0.7 per cent (Ukrainian Economic Trends, September 1999, for the year 1999: Ukrainian Central Bank)

14 The government budget deficit was 3.2 per cent of GDP in 1996, 5.6 per cent in 1997 and 2.7 per cent in 1998 (on a cash basis). In these official figures transactions from non-budget funds to support enterprises are not taken into account.

15 This meant a very heavy burden for an impoverished population which has to spend on average 60 per cent of its income on food.

16 It has been estimated that capital flight up to the end 1999 amounted to three times the gross foreign debt.

17 The main problem in Ukraine was not lack of investment funds. With approximately 20 per cent of GDP available for investment, this should have been enough to support economic growth. However, investment funds were channelled towards the wrong sectors. Much money was also channelled towards private bank accounts abroad. Also, government lending pushed interest rates up, crowding out private enterprises.

18 See CEE Bankwatch Network (2002).

\section{Bibliography}

Aslund, A. (2001), 'Ukraine's Return to Economic Growth', Post-Soviet Geography and Economics. 42 (5): 312-28.

CEE Bankwatch Network (2002) World Bank involvement in the restructuring of Ukraine's coal sector has not brought the benefits that were expected. Available online: http://www.bankwatch.org/press/2002/press91.html.

Elster, J., Offe, C.; Preuss, U.K. (1998) Institutional Design in Post-communist Societies: Rebuilding the Ship at Sea, Cambridge: Cambridge University Press.

IMF, World Bank, OECD, EBRD (1990) The Economy of the USSR, Washington, D.C.: World Bank.

Ganev, V.I. (2001) 'The Dorian Gray Effect: winners as state breakers in postcommunism', Communist and Postcommunist Studies, 34: 1-25.

Hare, P.M., Ishaq, M and Estrin, S. (1998) 'Ukraine: The Legacies of Central Planning and the Transition to Market Economy', in T. Kuzio (ed.) Contemporary Ukraine: Dynamics of Post-Soviet Transformation, Armonk, NY: M.E. Sharpe.

Knabe, B. (1998) 'Die System-Mafia als Faktor der sowjetisch-russischen Transformation, Teil 1: Vorbereitung und Durchfuhrung des Systemwechsels', Berichte des Bundesinstituts fur ostwissenschaftliche und internationale Studien, nr. 47.

Kovaleva, E. (2001) 'Regional politics in Ukraine's transition: Donetsk elites'. Contribution to the conference 'Confronting Change: North East England and East European Coalfields', Newcastle, 12-13 November.

Kuzio, T. (ed.) (1998) Contemporary Ukraine: Dynamics of Post-Soviet Transformation. Armonk, NY: M.E. Sharpe.

Lewis, Ann (2002) The European Union and Ukraine, London: The Federal Trust. 


\section{Hans van Zon}

Lyakh, A. and Pankow, W. (eds) (1998) The Future of Old Industrial Regions in Europe - the case of Donetsk region in Ukraine, Warsaw: Foundation for Economic Education.

Lyakh, A. (2001) 'Economic Restructuring and Investing in the Donetsk Region: Internal Factors and an International Perspective'. Contribution to the conference 'Confronting Change: North East England and East European Coalfields', Newcastle, 12-13 November.

Makogon, Y. and I. Khadzhinov (2001) 'About the problems in the coal mining industry of Donetsk Oblast'. Contribution to the conference 'Confronting Change: North East England and East European Coalfields', Newcastle, 12-13 November.

Nanivska, Vira (2002), 'Civil Society', in Ann Lewis The European Union and Ukraine, London: The Federal Trust.

Polyani, K. (1957) The Great Transformation. The Political and Economic Origins of Our Time, Boston: Beacon Press

Simon, R. (2000) Labour and Political Transformation in Russia and Ukraine, Aldershot: Ashgate.

Standing, G. and L. Zsoldos (2001) Worker Insecurities in Ukrainian Industry: The 2000 ULFS, ILO, Geneve.

TACIS EDUK (1996) Addressing the Social Impact of Restructuring Enterprises in Ukraine, Socio-Economic Public Opinion Poll, October 1996.

Ukraina u tsifrach u 1999 rotsi (2000), Kyiv: State Statistical Committee.

Whitefield, Stephen (2002) 'Welfare Reform and Poverty Alleviation in Ukraine', Post-Soviet Affairs, 18 (1): 71-90.

Zon, H. van (2000), The Political Economy of Independent Ukraine, London and New York: Macmillan. 


\title{
9 Between globalisation and sub-national politics
}

\author{
Russian think tanks and liberalism
}

\author{
Andrey S. Makarychev
}

More than ten years after the dissolution of the Soviet Union, Russia is still in search of her political and cultural identities, and is still in the process of rediscovering her role in the world. ${ }^{1}$ The post-Soviet transition she has endured was complicated by the fact that Russia went through a 'double disappointment' - in both socialism and liberalism. Indeed, on the one hand, most Russians comprehend (willingly or reluctantly) that there is no way to make a comeback to the communist past. Yet on the other hand, it is believed that 'the liberal project in contemporary Russia has no prospects'. Some Russian theorists call Russian reforms of the 1990s 'pseudo-liberal experimenting', making the strong point that it was criminal groups who mainly managed to take advantage of it. The belief that market forces will set up themselves the most effective forms of economic activities failed to become widely accepted in Russian intellectual circles. ${ }^{3}$

Yet Russia's debate on post-Soviet transition was not exclusively focused on the application of liberal principles for the sake of the country's modernisation. Two simultaneous processes - the unfolding of a regionalist drive and creating the basis for federalism, on the one hand, and the country's inclusion into the global milieu, on the other - all throughout the 1990s were key factors shaping Russia's choices. Studying Russia's case is politically important and academically relevant since the country's transformation keeps open multiple options. In the sphere of sub-national politics, they range from further fragmentation (for example, on the basis of seven federal districts created by president Putin in 2000) to re-centralisation under the ideological umbrella of 'strengthening the vertical of power'. In global affairs, the choices might switch from isolationism, as being advocated by 'national patriots', to the espousal of post-modernist versions of the 'borderless world' and the 'end of geography'. The future landmarks are therefore still unclear and open to different interpretations.

This chapter sets out to analyse the global-local nexus in Russia as seen from the perspective of the evolution of (neo)liberal ideology. My initial assumption is that there is a clear correlation and even conflation between the concepts of globalisation and regionalisation. Indeed, analysing Russian domestic political, economic and social trends, one may easily come to the 
conclusion that almost all of them could be framed by and understood with the concepts traditionally applicable to the phenomenon of globalisation: the diminishing role of administrative borders (between the constituent parts of the federation); the growing mobility of financial capital that tends to spill over from one territory to another, thus challenging the local authorities; the appearance of networks of non-governmental and non-territorial actors (trans-localisation of policy exchanges); the territorial reshuffle (creation of federal districts, multiple projects of enlarging the subjects of federation through mergers, etc.); and mass-scale migration (basically from the southern periphery to the large cities).

Methodologically I am adhering to one of the constructivist ideas that institutions are based on products of human consciousness that tend to take the form of collective understandings of reality. The ability to generate ideas is a subtle yet most effective form of power ('soft authority'). Yet constructivist approaches are regularly criticised for insufficient proofs of their theory of the primordial influence of ideas upon institutions and the policy-making process (Milliken 1999: 227). There is a long Russian tradition of treating intellectuals as pure theorists who tend to turn society into experimental ground for testing their ideas. ${ }^{4}$ In a similar way, it is said in the West that

... much of today's scholarship is either irrelevant or inaccessible to policymakers ... Academicians often appear caught up in an elite culture in which labels, categories, and even the humour have meaning for 'members only'. Their writings are filled with references to other scholars' writings; they speak to each other rather than to a wider public ... Much of what is produced is intended to gain the kind of academic identification with a theory or equation that will lead to professional advancement. Little evidence exists of a direct effort to influence public policy through scholarly writing.

(Newsom 1995-96: 62-3)

My task in this chapter is to show that there is a sphere at the intersection of Russia's domestic and transnational politics where the translation of the intellectual products into policies does take place. My intention is to show the ways in which the widely spread concepts of knowledge management, epistemic communities, forward thinking and intellectual capital are projected onto Russia's discourses on globalisation and regionalisation. Of course, the discussions being held are not deprived of normative context, since they by and large focus on the issues of Russia's identity. What is Russia and how is it supposed to meet the West? Is there any peculiar mission Russia is destined to carry out? Is there a single 'globalisation design', or are we facing spontaneous and self-driven global-scale developments? Is globalisation underpinned by ideological pre-given platforms, or are these pragmatic interests that promote it? Shall the international 
community' be allowed to impose its decisions upon sovereign nations? Is the notion of fundamentalism applicable to the East or to the West as well? Are 'humanitarian interventions' about human rights only, or about interests as well? These and other normative questions are asked in tackling both global and regional issues in Russia.

\section{Russia's globalisation debate}

Some of the arguments of Russia's supporters of globalisation are formulated in neoliberal terms. It is, for instance, argued that the Western-based economic system has spread all over the world, and meets no viable alternative; that globalisation increases the set of options that are open for each country; and that global openness is the only way of enhancing domestic competition and getting rid of Soviet-style industrial and financial practices and institutions. However, some other arguments of Russian 'globalisers' have nothing to do with neoliberalism. It is a widely shared opinion that it is in Russia's national interest to weigh all the pros and cons of future WTO membership, ${ }^{5}$ and then use access to global markets to enhance Russian competitive advantages, basically in export-oriented industries. Perhaps the most telling example of this attitude is the report 'On National Economic Strategy in Global Competition', published by High Scientific and Consultative Council, the East-West Institute, the European Business Club, and the authoritative magazine Expert. ${ }^{6}$ The report's main message is that Russia needs temporarily to pursue 'the policy of self-reliance' which might take as long as between ten and fifteen years. At this time, Russia has to give clear priority to developing its domestic market, taking advantage of its export industries as donors for some other - most prospect potentially sectors of the economy. During that time, strategically important and potentially competitive industries have to be protected by the state. Meanwhile, those market niches in which Russia has no chance to compete internationally even in the remote future ought to be opened for foreign capital. The state also has to stimulate the import of capital and technologies, instead of commodities. Only after the completion of the transitional period should access by foreign producers and service providers be liberalised.

Yet the resistance to globalisation is on the rise in Russia's academic circles, although a good deal of the alarmist invectives are rather misleading. For example, some Russian anti-globalists think that globalisation leads to a decreasing variety of commodities available at national markets, ${ }^{7}$ ignoring the differentiation of goods and services that does take place. Other protesters claim that the majority of people on the planet have no idea what globalisation is. This certainly may be true, but by the same token, if a majority of the Russian population is ignorant of what federalism is, this fact should not imply that federalism is bad, irrelevant or non-existent. ${ }^{8}$

However, four arguments of the anti-global 'camp' find their sympathisers in Russian academia and the expert community. The first argument is that 
globalisation increases the vulnerability of security structures. The more domestic actors open up to the world, the more sensitive they become to outside pressures. Many of these (new) actors, such as NGOs, media, business communities and ethnic groups, being parts of transnational networks, project onto Russia foreign influences. Significant resistance to these actors has come from the traditional military elite, which does not welcome the inroads into the national security sphere. There is much reason for debate on this issue. Globalisation indeed has prompted a far-reaching and profound review of security relations. According to the traditional view, power is at the core of national security and therefore security is almost synonymous with military strength. New moderate alternatives, however, started to erode the assumptions embedded in Realpolitik and/or neo-realist logic. The security discourse in Russia has shifted to focus on culture, civilisation and identity, as well as on the role of ideas, norms and values. In addition to the military dimension, the new concept of security encompasses economic, political, socio-cultural and, potentially, ecological aspects. Security policy cannot be limited to issues directly linked to the threat and/or the use of military force by state actors. The successful prevention and resolution of conflicts depends less on inter-state action than on local conditions, concerning, for example, minority and human rights, environmental hazards, drug trafficking and organised crime. In essence, the changing nature of conflict demands that greater emphasis be placed on the societal underpinnings of security.

Second, part of Russian academia is also interested in the idea of globalisation implying mass-scale technologies aimed at shaping and reshaping people's minds, their attitudes and world views. Public discourses might well serve as tools for creating an artificial, illusory milieu of meanings, which could mislead ordinary people. Ideas might turn into labels, myths or stereotypical symbols of somebody's political will. The function of this type of discourse is to make the right impression by emphasising certain traits and hiding others. Instead of a real picture, one might achieve a deceptive imitation of reality - like in the theatre. The cognitive structure of public discourse is shifting towards propaganda, rumours, information wars, etc. ${ }^{9}$ Third, there is the idea that globalisation creates 'parallel political spaces'. For instance, in Moscow mayor Yurii Luzhkov's interpretation, globalisation has led to the emergence of the 'shadow world' of business and politics, which is nontransparent and almost invisible, both internationally and domestically. Meanwhile, this 'second' world obtains strength and challenges the 'first' world of open rules and controllable policy-making procedures. ${ }^{10}$ Fourth is the idea of globalisation turning out to be a new edition of colonialism. Liberalism is in a position to sustain itself in Western countries because, according to Alexander Panarin's reading, "the entropy of all "illiberal" restrictions, poverty, authoritarian and criminal practices, ecological degradation - is thrown away, to the peripheral spaces'. ${ }^{11}$ Alexander Neklessa, a Russian political economist, treats the proliferation of neoliberal globalisation as 'de-modernisation', civilisational regress, anthropological catastrophe 
and 'the night of history'. ${ }^{12}$ At this point one can see the interconnectedness of anti-liberal and anti-globalist discourses in Russia.

Hence, we see many fears and harsh criticism of globalisation from both anti-neoliberal and nationalist platforms that are rather strong in Russian academic circles. Yet what is offered as an alternative to what is called 'Western-style' or neoliberal globalisation? First, the usage of the Russian word 'vsemirnost' is proposed by some political linguists (Reviakin 2001). Unlike 'globalisation', 'vsemirnost' skips technical and material characteristics, putting an accent on ethical background. 'Vsemirnost' is a kind of 'warm' globalisation, 'globalisation with a human face', sensitive to the needs of ordinary people and conducive to the emergence of the worldwide community spirit. Second, closer dialogue between Western and nonWestern cultures and civilisations is called for. Russian policy analysts Panarin and Pastukhov speak about the prospects of 'orientalisation of the West', having in mind that Russia might serve as a meeting place, or a bridge between the West and the East (Pastukhov 2001). Third, Russia's application for WTO membership is under question. And finally, an alternative to neoliberal globalisation is the concept of the 'Russian World' advocated by Piotr Schedrovitskii and some of his associates. The concept is based on the assumption that there are as many Russian speakers living worldwide as those residing inside Russia. All of them have to be treated as most valuable assets, both culturally and geopolitically. ${ }^{13}$ A number of Russian think tanks have meaningfully contributed to the globalisation debate.

\section{The Council on Foreign and Defence Policy (SVOP)}

In organisational terms, the SVOP is a clear example of an establishmentdriven think tank. It is aimed not only at providing policy-makers with political analyses, but also at facilitating contacts between non-governmental elites of Russia and the Western countries. Ideologically, the SVOP is an example of a transitory think tank: in tackling globalisation issues, it moves from state-centric to more or less transnational approaches. This kind of evolution perhaps was facilitated by the fact that from the very beginning the SVOP was designed as a 'forum think tank' offering opportunities of direct communication between liberal Westernisers and 'Russian patriots', communists and 'oligarchs', former government officers and independent analysts. ${ }^{14}$ On the one hand, in its publications the Council adheres to the idea that Russia has to strengthen her statehood under the pressures of globalisation. Among those industries that have to be patronised by the central government are nuclear energy, the space industry, information technologies, gas extraction and reprocessing, the aviation industry, and the military-industrial complex. One of the SVOP's recommendations is that Russian authorities have to start seriously promoting the attractive image of Russia overseas. On the other hand, the SVOP shares the opinion that Russia needs both an effective state apparatus and a strong civil society as a 
counterweight to corruptive bureaucracy. To find its niche in the global world, Russia needs to fight corruption more aggressively and defend private property rights more consistently. The SVOP has criticised the 'Doctrine of Information Security' passed by the Russian Security Council for taking the discussion too far away from the opportunities opened by the spread of new information technologies to secrecy and state control over information flows. Accession to the WTO is strongly supported by the SVOP, and application for NATO membership is said to be considered as well. ${ }^{15}$

\section{The Moscow School of Cultural Policies (MSCP)}

Like the SVOP, the MSCP also serves as an example of an evolving think tank, yet it moves in the opposite direction: from the 'romantic' neoliberalism of the early 1990s to more accentuated state-centric assumptions of the beginning of the current decade. In his earlier works, Piotr Schedrovitskii, the intellectual guru of MSCP, has argued that the best Russian reaction to globalisation would be to switch to the concept of a 'post-national', 'post-industrial' and 'cosmopolitan' state, since the centuries-long sovereignty has lost its importance. This new type of state should be based on professional networks of a 'new elite', comprising toplevel managerial and creative actors investing in 'humanitarian technologies' and a knowledge-based economy. ${ }^{16}$ The nation-state, in his reading, ceases to be the centre for economic and technological innovations. In order to survive in an increasingly demanding world, the 'territorial state' adheres to the exploitation of resources and sticks to a 'manageable democracy' concept, implying the usage of coercion and violence. As a result, financial capital rebels and challenges the oppressive state. In a typically neoliberal way, Schedrovitskii (2000) asserts that globalisation 'erases traditional divides based on ethnic and religious identities ${ }^{17}$ - a thesis which runs against the Russian experience of the 1990s. However, the neoliberal views of Schedrovitskii have significantly changed. In his indicative words, we should stop thinking about national interests in purely corporate or regional terms. To survive in the increasingly competitive world, the central state has to be drastically strengthened.

\section{The Institute for Globalisation Problems}

This institute is led by the young economist Mikhail Deliaguin, who in the summer of 2002 was appointed advisor to the Russian government. Deliaguin is known as the most consistent Russian critic of the Western model of globalisation, and as a supporter of greater state interference in economic affairs. His main political message is that Russian liberalism has to mature and eventually accept a greater role of state regulation. IGP's narrative, however, is based on a number of questionable assumptions, such as that the United States is the architect of globalisation. ${ }^{18}$ Yet the facts 
destroy the certainty of that view - the United States is, for instance, very sceptical about the United Nations and reluctant to admit the legitimacy of the International Criminal Court. In reality, the thesis of a single 'founding father' of globalisation is rather shaky. Equally questionable, especially in the aftermath of the September 11 tragedy, is Deliaguin's thesis that globalisation brings new advantages to the United States. Another assumption of the IGP is that greater transparency (as demanded by international financial institutions) makes Russia more vulnerable and less competitive. ${ }^{19}$ Again, this sounds like an invitation to debate. The corporate elite would respond that it is in Russia's interest to allow companies to design and follow global corporate strategies and profit from international openness. The IGP also claims that global integration endangers cultural identities. This is hardly correct, since we are witnessing the rise of ethnic, religious and regional identities in the last decade. To a certain extent, the formulation of the problem has to be reversed: the self-assertion of identities challenges the domestic stability of certain states, including Russia.

\section{Spiritual Heritage Foundation}

This foundation is headed by Alexei Podberiozkin, who in the mid-1990s broke with the communist party and is one of the few Russian left-wing intellectuals combining political analysis with public policy participation. Podberiozkin seems to understand that Russian neoliberals lose their ground in the globalisation debate because they have missed a very important argument: instead of saying that global integration is better for the state, they adhere to an anti-state platform. Unlike the neoliberals, Podberiozkin argues that Russia's problem is not how to get rid of the state but how to make it more legitimate and effective. In his words, socialist ideas are in no way inimical to the information society, corporate planning and other pivots of the global society concept. ${ }^{20}$

In short, the globalisation debate in Russia touches upon a number of important issues, having both domestic and international relevance. It means that the globalisation issue is moving from diplomatic and defence policy spheres to become a part of Russia's domestic debate on political and economic reforms. However, there are two major misfortunes in Russia's globalisation debate. First, the opponents tend to ignore each other and prefer to avoid engaging in direct discussion with each other, thereby speaking mainly to their own audience. Second, Russia's globalisation debate tends to neglect comparisons with other transitional countries, which might be rather useful both academically and politically.

\section{Russia's sub-national politics debate}

Some of the political and administrative leaders in Russia's regions used to be well-known protagonists of liberal ideas (for example, Boris Nemtsov 
and Sergei Kirienko in Nizhny Novgorod, Anatolii Sobchak in St Petersburg, Gavriil Popov in Moscow city, Yurii Matochkin in Kaliningrad). Yet liberal policies in the regions went through a period of 'ebb and flow' and 'rise and fall', and have met a number of structural challenges that have transformed the initial design of Russia's 'liberal project' as applicable to the regions. The sub-national liberals of the early 1990s had to either step down or adjust to the much more conservative and corporatist/paternalistic structures that were on the rise all across the country. In particular, the unfolding of protectionist and anti-globalist attitudes is a good illustration of the fact that many Russian provinces feel threatened and insecure as to trade liberalisation policies, future WTO membership, and opening the Russian domestic markets to foreign competitors.

Reshaping Russia's federalism was a high-profile issue for the Russian expert community in the 1990s. There were many assessments of what the sub-national institutions had to look like. Beginning in the mid-1990s, the basic idea was to enlarge the provinces through a re-division. Some experts have suggested implicit acceptance of the division of Russia into three semiautonomous 'world regions' - by analogy with Braudel's world economies (Kirian 2001). President Putin's administrative and territorial reform of 2000 was partly inspired by this enlargement philosophy. However, the seven new federal districts, the first creation of Vladimir Putin in his capacity as Russia's president, are assessed very differently. One way of thinking is well described by Irina Busygina, an expert of the Moscow-based Institute of Europe, who reasons that the meaning of the federal districts extends far beyond pure technological rationalisation aimed to increase the effectiveness of the territorial management. 'Federal districts are probably too large in scale to produce within their borders one definitive regional identity, but at least they present a better framework for such attempts than the huge national one' (Busygina 2002: 302).

On the other hand, the eventual militarisation of Russian politics is of great concern to democratically-minded analysts. The Russian policy expert Nikolai Petrov (2002), for example, has forecast that Putin's goal is to introduce a semi-military system in Russia, implying less public control over local authorities, a return to traditional methods of political appointment (based on patronage), an almost total severing of ties between the state and the country's nascent civil society, and the demise of all elements of federalism in Russia. The paradox, however, is that military governors might actually foster liberal reforms in the regions. Vladimir Egorov, a former admiral who was elected governor of Kaliningrad oblast, contracted Yegor Gaidar's neoliberal Institute of Economy in Transition to draft a strategic programme for regional development. Speaking about the involvement of Lebed in Russian politics, political analyst Alexei Bogaturov acknowledges his tremendous contribution to the emergence of a new type of political leadership in Russia, 'disciplined but intrinsically free; ambitious but capable of self-restraint; tough but possessing a flexible mind'. ${ }^{21}$ Most important, 
though, is that Bogaturov's assessment leads one to conclude that generals in public life are able, by and large, to maintain democratic principles. They have to be sensitive to societal demands and have to learn to communicate and interact with the media, NGOs and other non-traditional policy actors.

\section{The Centre for Strategic Research of the Volga Federal District (CSR-VFD)}

This Centre was constituted on the basis of the Moscow School of Cultural Politics discussed in the previous section. The liberal roots of CSR-VFD thinking are manifested in its praise for trans-territorial actors that are supposedly not tied to specific geographical boundaries, in particular financial-industrial groups (along with the semi-independent media, non-governmental organisations, and other information actors). The greatest assets of these groups are mobility and networking potential, and their operational space is defined not by territorial landmarks but by economic and financial rationale. In Schedrovitskii's words, the economic operators are not interested in where the president has drawn the borders of the districts, for they have their own logic based on the fact that economic, financial and business resources are highly diversified and dispersed all across Russia and the world. ${ }^{22}$ Financial flows and intellectual capital are examples of spheres of networking that are beyond the reach of the government. The widespread practice of locking out flows of goods and information within the regional borders hurts the interests of new economic actors, who support the free circulation of capital, technology and information. The most active business and information actors have become the 'agents of globalisation' and restructure the territorial, administrative and informational space of Russia.

A report issued by the CSR-VFD in the fall of 2000 accuses the regional governors of forming an economic climate suitable for a rather limited number of 'proxies' (especially those enterprises with the largest portion of export revenues), granting special immunities and privileges to them, establishing red-tape hierarchies, erecting barriers for the free movement of goods, giving budget subsidies to insolvent and inefficient enterprises, and introducing other protection measures incompatible with integration into the global economy. Strategies of survival of the regions chiefly related either to the arms trade (which is based on maintaining international conflicts and arms races) or raw material export. Traditionally, Russia was ruled by institutions 'glued' to geographic segments of its vast territory. Yet the creeping logic of globalisation tends to restrict the autonomy of individual territories because it is based on deconstructing the hard linkage between administrative and economic borders.

This think tank argues that very few regional governments have proven capable of turning into organisational, intellectual or managerial leaders, and that the regions have failed to react to the global challenges. As a result, 


\section{Andrey S. Makarychev}

capital was quick to protest against troublesome administrative restrictions and tough regulations by running away from the regional governments ('the revolt of capital'). Since the financial crisis of August 1998, the number of depressed regions has increased while the aggregate role of the regions in elaborating the nation's strategic priorities has decreased. This is basically due to the fact that the regional governments have neglected the new 'spatial design' of the global world - in which the shapes of market forces do not coincide with the official borders - and have failed to react adequately to the most essential modernisation challenges. Actors inclined to think in terms of a particular territory are becoming increasingly disadvantaged in cases where they are directly challenged by mobile trans-territorial actors.

The logic of economic processes (mergers, purchase of shares, property transfers) has given much of the economic power in the regions to 'newcomers' ('challengers') - people and institutions from outside not incorporated into political and administrative hierarchies existing in the regions. The regional political elites sooner or later have had to discover that the development strategies of basic economic actors are being decided not locally but either in a different region (which may be the headquarters of an oil, gas, metallurgical or aluminium company) or even abroad. Very much as in the West, enterprises owned by large corporations start playing decisive roles in Russia's regional development. Thanks to their economic, technical and financial dominance, large firms can, by the combined effect of their industrial and location policies, transform themselves into 'poles' for development and profoundly influence local and regional development. Needless to say, this kind of development naturally provokes conflicts of interest between the regional authorities and big business

To survive politically, according to the CSR-VFD report, the regional administrations have to invest more resources into networking and horizontal communication. To increase their adaptive and transformative capacity, the regions have to be in motion, incorporating and accommodating both economic and institutional demands. The regions need to reorder and reshape their operations in order to remove the territorial compartmentalisation and fixation. The future landscape of regional Russia should resemble the network of mega- and technopoles and offshore zones, otherwise the regions will be either marginalised or forced to imitate the development patterns of others. ${ }^{23} \mathrm{~A}$ theory of regional governance as a type of corporate management has appeared, which is partly based on the fact that regional governments are major shareholders of the most profitable industrial enterprises.

However, in a 2002 report the CSR-VFD shows some early signs of dissatisfaction with the liberal paradigm of the regional policy which it adhered to before. Schedrovitskii and his colleagues try to distance themselves from the neoliberal conception of regionalism exposed above. The regions, as the CSR-VFD suggested in 2002, were quick to usurp many federal powers and manipulate them, and were prone to the expansion of 
their newly acquired powers at the expense of the federal centre. Meanwhile many problems have arisen because the regions fail to cooperate with each other horizontally, and the CSR-VFD's experts have expressed their growing concerns about dramatic inequalities between the subjects of federation. ${ }^{24}$ The new CSR-VDF agenda is therefore formulated quite clearly: restoring the unity of the country that was torn apart by both regional and corporate elites. Consequently, in order to iron out the disproportions between the regions, an exclusive reliance upon the 'invisible hand of the market' is of no avail. What is needed is the compensatory policy of the central state, that might level out imbalances and keep common economic and political space within Russia. Big business is also portrayed as a troublemaker for Russian federalism, and the large corporations are treated not as the only sources of progress and modernisation, but actually as contenders and rivals of the state. Contrasting with the 2000 report, big business is found guilty of 'perforating' the state and capturing the most lucrative economic and political platforms, in the meanwhile bearing no social responsibility for their operations. ${ }^{25}$

Thus, under these circumstances, the state has to rediscover its 'points of responsibility' in the provincial Russia. For example, CSR-VFD insists that the federal laws have to be given priority while deciding on power-sharing between central and non-central governments. The logic of strengthening the central state power also stems from the fact that it is not unusual that one subject of federation might be separated from another by lack of transport communication. Its underdevelopment leads to the stark fragmentation of Russian spatial infrastructure. Nobody except for the state is able to knit all the spatial segments of Russian territory together. Should the state fail to do so, it will definitely lose its control over its vast periphery, and the centres which decide upon the usage of Russian resources will move overseas. Another possibility is that, due to decay of the central power, the large Russian corporations will take over political development in the regions and divide them into 'zones of influence'. ${ }^{26}$

The CSR-VFD's attitude to municipal self-government has also drastically changed. Instead of praising local (city-level) elites for professionalism and the sense of mission, as was the case in the late 1990s, the Centre's 2002 report advocates deeper federal interference in the sphere of local politics. The basic message of this report is that the federal authorities must restore the unified controlling system supervising all sub-national institutions, including the municipal ones. In particular, the idea of applying the procedure of the bankruptcy of municipal units which default on their financial obligations was announced and given full support. This spirit of 'dirigisme' leads CSR-VFD to a controversial and highly contested idea of 'extended federalism', implying the inclusion of the cities and the religious and professional communities into the subjects of federative relations. ${ }^{27}$ Another very debatable idea of the Centre's new approach is that, in the aftermath of the September 11 terrorist attack, Russia's sub-national regions have to transfer 


\section{Andrey S. Makarychev}

the bulk of their security functions to the federal and supra-national authorities. In the United States, on the contrary, the deeper involvement of the state governors and city mayors in providing homeland security is at the top of the political agenda. So there is some duality in the CSR-VFD's position: it still advocates concentration of resources in prioritised regions, but at the same time it thinks that the federal government has to possess some compensatory resources for other, less fortunate territories. ${ }^{28}$ In fact, the CSR-VFD's drift towards state-centric approaches is so drastic that it has been accused by some regional commentators of ignoring the democratic potential of federalism. ${ }^{29}$

\section{The Centre for Strategic Research 'North-West' (CSR-NW)}

This Centre was established by its Moscow-based 'big brother' - also named the Centre for Strategic Research - and patronised by German Gref, the Minister of Economic Development and Trade. The purpose of the CSR$\mathrm{NW}$ is to serve as an expert unit for the administration of the presidential representative, inexperienced in regional issues. Conceptually, the CSRNW's doctrine portrays each of the federal districts as an 'assembly terrain' which might constitute in the future the new centres of economic crystallisation for Russia. According to this think tank, the creation of seven 'large regions' (federal districts) was a direct reaction to Russia's security challenges (that is, the war in Chechnya) and sharpened global economic competition. It claims that Russia's regional policy has to be outwardoriented, since one of the main features of globalisation is 'the erosion of administrative borders' which makes state-centric approaches obsolete and inadequate. The Centre states that non-administrative tools of regionbuilding should be given priority. Territorially and administratively fixed resources yield to mobile ones, driven by the spirit of innovation and what is called humanitarian communications (human-capital-based and knowledgedriven). That is why the CSR-NW asserts that the confines of Russia's federal districts are still being shaped, and this process is far from being over. The doctrine of the CSR-NW posits for example that 'the boundaries of the North-West will be drawn where we deem it proper, or should be kept low profile, where others will draw them for us'. ${ }^{30}$

\section{The Expert Institute of the Russian Union of Industrialists and Entrepreneurs}

This think tank's analysis resonates quite well with some of the liberal approaches developed by the CSR-NW, and by the CSR-VFD prior to 2002. It argues that, by the end of the $1990 \mathrm{~s}$, capital - regardless of its regional affiliation - had rushed to 'new economic platforms', that is, those territories where business conditions were the most favourable. The shape of these territories resembles 'archipelagos' and does not necessarily coincide with 
the boundaries of the federation subjects. ${ }^{31}$ The new Russian business elite (which emerged in the aftermath of the crisis of August 1998) came up with the idea of defending their property from the arbitrary and incompetent decisions of regional higher-ups and of making business structures transregionally integrated. Financial and industrial groups took advantage of both the managerial weakness of the regional elites and their temporary disorientation in the transition period from Yeltsin to Putin. Inevitably the creation of huge transregional corporations makes the regional authorities rethink many of their old-fashioned strategies of industrial development. There is no longer much room for Soviet-style orders to industrial actors, who are motivated by making money and expanding their markets. Should the business climate in a region go sour, major investors might leave as fast as they have appeared, the Expert Institute predicts.

\section{Centre for Political Technologies (CPT)}

The analysis of the CPT is very much in tune with the Expert Institute. It is based on the theory that in a relatively small federation with subjects heavily dependent on a single enterprise, the most typical pattern could be described as oligarchic monopolism. The term, coined by Rostislav Turovskii of the CPT, means that there is a dominating economic actor eager to convert its financial and managerial potential into a political one (as in the case of Taimyr). In larger regions, the governors have to consider different strategies for different economic actors. This can be called oligarchic pluralism, a more complicated model of relations between political rulers and economic agents based on a balance of interests and a search for compromises (examples are the Khanty-Mansy Autonomous Okrug and Sverdlovsk, Yaroslavl', Tomsk, and Murmansk oblasts). If the regional political structures are insufficiently inclusive and adaptive, the region faces the prospect of oligarchic wars, with each of the competing economic groupings trying to undermine the rivals. ${ }^{32}$

\section{Council on Foreign and Defence Policy (SVOP)}

Unlike the Expert Institute and the CPT, the SVOP criticises sub-national governments not for ineffectiveness, but rather for autarchy and interference into some of the federal competences. In particular, the Council is rather critical of the restrictive measures introduced by regional administrations that have impeded the free circulation of commodities between different provinces of the federation, creation of regional 'quasi-customs' and armed units reporting to the local authorities. In SVOP's analysis, the country, at least prior to Putin's accession to the Kremlin, was steadily moving towards confederalisation. ${ }^{33}$ Some of ethnically non-Russian republics within Russia have started calling themselves 'states' (Bashkotrostan, Buriatia, Yakutia, Chuvashia) and speaking of 'economic sovereignty' (Komi and Karelia). Some other territories have claimed their right to establish their own regulations concerning military 
service and the dislocation of Russian troops, signing agreements with other countries or foreign regions, and disobeying federal legislation. All these developments were conducive, according to SVOP's analysis, to a corrosion of statehood and greater instability.

In the meantime, the SVOP has tried to incite the regions to contribute positively to solving the nationwide issues. In particular, the SVOP proposes the conclusion and implementation of the inter-regional agreements stipulating that refugees and asylum-seekers have to be redistributed across Russia, provided that regional administrations take care of their employment and social issues. This might help avoid 'dangerous concentrations' of immigrants in a limited number of border regions. At the same time, the paradox is that the SVOP does not rule out in principle the cessation of some territories. Separation from Russia, a SVOP working paper suggests, has to be put into a wider security context but should only come as a result of a lengthy negotiating process. ${ }^{34}$ Yet another SVOP report adheres to a much more conservative approach, calling for a moratorium on all alterations of administrative borders in Russia, and an inclusion of the municipalities into the vertical system of executive power. In fact, the SVOP is among the first Russian think tanks to raise the issue of institutionalising the practice of federal interference into the affairs of subjects of the federation. ${ }^{35}$

\section{The Foundation for Effective Politics (FEP)}

The Foundation's director, the reputed political consultant Gleb Pavlovskii, is one of the outspoken advocates of Putin's territorial reform. Ideologically, he presents himself as a 'republican'. Putin, in Pavlovskii's reading, has inherited from Yeltsin a 'non-sovereign Russia', a loose de facto confederation without effective nationwide power. The regional barons have managed to create a 'parallel' structure (a 'shadow state') of semi-autonomous oligarchs, paying scarce attention to the Russian Constitution and insisting on having their own parallel 'sovereignties'. Some of the regional regimes are autarchies that ideologically were based on a mix of ideas borrowed from the Soviet era, 'perestroika' and some ethnocratic prejudices. The Council of Federation, the upper chamber of the Federal Assembly, was throughout the 1990s a meeting place of regional barons that used to blackmail the federal centre. ${ }^{36}$

In this situation the most important challenge for Putin was to restore the 'domains of the federal competence'. In Pavlovskii's opinion, the process of standardisation of regional political and legal spaces, initiated by Putin, is indispensable for Russia's survival. ${ }^{37}$ The creation of the system of seven districts, in this logic, is a tool for better tying up the centre and the periphery. The federal centre might be an instrument to contain the governors, and to promote civic liberties in the regions. In Pavlovskii's interpretation, it is in the federal centre's interest to have an independent 
judiciary in the regions in order to seriously restrict the governors' ambitions and power. Although the governors would of course fiercely resist such changes, Pavlovskii believes that their obstruction is doomed to failure. Simultaneously, he admits that the geographic shape of the federal district is far from being optimal. Pavlovskii also assesses the limitations of the presidential envoys, people with 'apparatus thinking'38 who have grown up politically in state-like hierarchies, and whose functions are not sufficiently clear. The federal centre is reluctant to give them a free hand in regional affairs, fearing that some of the district heads might eventually opt for playing the confederal card. ${ }^{39}$

\section{Russian Public Political Centre (RPPC)}

Alexei Salmin, the RPPC's director and founder, is an authoritative Russian policy analyst. Being close to the mild version of the 'Euro-Asian' school of political thought, he is an advocate of strengthening the centre's control over the regional elites. Blaming the Russian constitution of 1993 for multiple uncertainties in centre-periphery relations, he calls the Yeltsin system of centre-regional relations a 'feudalism' rather than a 'federalism'. The result is a growing lack of solidarity of the regional units, degradation of the feedback between Moscow and the provinces, and an overall crisis of legitimacy of Moscow vis-à-vis the regions. In Salmin's opinion, the first moves in tightening the oversight over the regions were made before Putin came to power, namely in 1996, with increasing pressure from Moscow upon those regions that failed to comply with the federal regulations in finances, foreign policy and other issues. Salmin does not applaud the prospect of an unfolding of multiple trans-regional networks of global scale on Russian territory. To counter this tendency, he advocates a reasonable standardisation of regional Russia. ${ }^{40}$

\section{'Politika' Foundation}

The Moscow-based 'Politika' Foundation is known for its leader, Viacheslav Nikonov, one of the most reputed Russian policy analysts, who ideologically portrays himself as 'conservative'. In terms of regional policies, Nikonov, like Salmin and Pavlovskii, is an overt opponent of non-democratic regimes being established in many of the Russian provinces. Two basic problems of Yeltsin's model of federalism are that the regional elites have obtained de facto control over the federal agencies located in the regions, and that the regional chief executives became legitimate parts of the federal legislature, having their seats in the upper chamber of the parliament. ${ }^{41}$ In Nikonov's reading, Putin's regional policy resonates well with the principles of Russian conservatism since it contains no traces of liberalism, unlike Putin's economic strategy. Putin, in Nikonov's prediction, will keep pursuing the policy of re-centralisation by strengthening the powers of his envoys in the 


\section{Andrey S. Makarychev}

federal districts ${ }^{42}$ and eradicating the separatist legislation in some republics such as Tyva and Tatarstan (this goal is in fact already achieved). As for the federal districts, Nikonov on behalf of the 'Politika' Foundation has suggested abstaining from legally fixing the limits of competency for regional heads, on account of the danger of the tacit division of Russia into seven potentially self-sustained large regions. ${ }^{43}$

\section{Gorbachov Foundation}

Unlike the think tanks discussed above, the experts of the Gorbachov Foundation are by and large rather reserved with regard to the federal districts. They state that Putin's territorial reform was conducive to the appearance of excessive bureaucratic layers, tending to interfere into the affairs of the constituent units of the federation. The district authority is not duly framed in legal terms. Another negative result of Putin's reform is the weakening of the upper chamber of parliament - the Council of Federation - where the regional chief executives lost their seats. Yet the power of the governors did not vanish at all - the regional 'bosses' managed to readjust to their new situation and find new supporters (such as large corporations, for example) in their continuing tug-of-war with Moscow. The procedure of federal intervention is weak or, in some fields, non-existent. In sum, in the view of the Gorbachov Foundation, Putin's innovations did not improve the quality of political management in the country. ${ }^{44}$

\section{Conclusion}

This analysis of Russian think tanks in the debates on globalisation and subnational politics confirms that ideas incite innovations and thus require a special kind of 'cognitive actor' whose role is to select the most viable pieces of thought and then give them publicity (Laffey and Weldes 1997). To influence political agendas, think tanks have to become 'policy entrepreneurs' and find their niches in the policy milieu. The major challenge they face is perhaps the politicisation of knowledge (Stone and Garnett 1998), since all of them are eager to gain political influence. A transnational diffusion of information, ideas, interpretations and experiences is an important part of Russia's rediscovery of her identity. The cognitive actors analysed in this chapter contribute to the instrumentalisation of an identity search, that is, a construction of legitimacy of policy judgements (Stone 2001). We have seen that a situation of multiple uncertainties produces the demand for alternative sources of advice. Cognitive actors not only inform but also alert political elites. There is both a political and a normative competition between the different institutions and approaches they advocate. Table 9.1 illustrates the roles of think tanks in democracy building. ${ }^{45}$

Intellectually, the Russian expert community is very divided on both global and regional issues, and therefore does not speak with a single voice. 
Table 9.1: The roles and functions of Russian think tanks

\begin{tabular}{lll}
\hline Roles of think tanks & Think tank functions & Examples in Russia \\
\hline $\begin{array}{l}\text { Political } \\
\text { infrastructure } \\
\text { builders }\end{array}$ & $\begin{array}{l}\text { Provide their resources } \\
\text { for negotiating with key } \\
\text { decision makers }\end{array}$ & CSR-NW, CSR-VFD \\
$\begin{array}{l}\text { Technical advisers } \\
\text { Providing contract } \\
\text { services to authorities }\end{array}$ & FEP \\
$\begin{array}{l}\text { Agenda setters } \\
\text { Generating ideas and } \\
\text { applying pressure for } \\
\text { change of policy }\end{array}$ & All \\
$\begin{array}{l}\text { Facilitators of } \\
\text { interactions between } \\
\text { political groups }\end{array}$ & $\begin{array}{l}\text { Multiplying the voices } \\
\text { that are brought to bear } \\
\text { on an issue and offering } \\
\text { alternative routes }\end{array}$ & \\
\hline
\end{tabular}

It is split on a number of normative issues, but it seems that the split between globalists and anti-globalists in Russia by and large corresponds to the liberal-conservative divide in Russian domestic politics. Often globalisation is rejected on the same grounds as liberalisation: because it is about deregulation, competition and privatisation. The global North-South alarms Russian anti-globalists for the same reasons as the disparity between the locomotive and insolvent regions in Russia.

There is a strong feeling among Russian intellectuals that the liberal ideology as was being adopted at the beginning of 1990 s is going through a painful and profound transformation. Most experts accept that the preconditions for the 'liberal project' in post-communist Russia were rather modest. Boris Nemtsov, the leader of the Union of Right Wing Forces, has recognised that there are too few adherents of the liberal idea in Russia. Yegor Gaidar, the liberal prime minister of 1991-1992, has publicly admitted ten years after leaving office that he himself and his like-minded colleagues in the government lacked a clear apprehension of what had to be achieved as a result of liberal reforms. What the first liberals in the government had were merely working hypotheses. The permanent tug-of-war between dispersed liberal groups, and the lack of coherence within the liberal movement, have led to its degradation. Boris Kapustin, an expert at the Moscow-based Foundation for Social and Political Studies, claims that in today's Russia there is no economic, social or political ground for the 
appearance of a strong liberal platform. ${ }^{46}$ Vladimir Mau, one of leading pro-market reformists and the rector of the Public Industry Academy, suggests that the current version of Russian liberalism has to be reshaped, and that the new cycle of more socially-democratic policies might appear soon. ${ }^{47}$ In stark contrast to the neoliberal discourse of the 1990 s, Mau believes that the liberal economy will not be able to function without an effective judiciary system, a strong police apparatus, and a transparent state apparatus. ${ }^{48}$ Yegor Gaidar and Sergei Kirienko, the pioneers of Russia's liberalisation, agree that classical capitalism is not actually feasible in today's Russia.

Finally, Russian traditionalist thinkers, in their turn, move towards accepting the basic political values that were formed in Russia during the 1990s. Vladimir Aksiuchits, the chairman of the Russian Christian Democratic Movement, was perhaps the first 'liberal conservative', with his adherence to both Russian traditions and the newly acquired freedoms of human rights, local self-government, etc. ${ }^{49}$ What could result from this encounter of different and evolving worldviews is a 'new Russian ideology'. Alexei Kara-Murza, an intellectual leader of the Union of Right Wing Forces, has assumed that the liberals must start communicating with the socialists and together build the nation-state. ${ }^{50}$ One of the first political incarnations of the 'new Russian ideology' is perhaps Evgenii Primakov, but such a new ideology received much more articulation in Vladimir Putin's accession to power in $2000 .^{51}$ Putin's ideological platform, born out of political necessity, is characterised by such metaphors as 'centrism', 'consolidation', 'practicality' and 'system approach' (Tuzov 2002). The question, however, remains open whether this platform may be called an ideology at all.

\section{Notes}

1 The author expresses his gratitude to the International Policy Fellows Program (Open Society Institute, Budapest) for supporting this research.

2 Alexander Dugin, 'Postliberalnaya era' (Post-liberal era). Available online at http://arctogaia.com/public/dug2.htm.

3 'Modernizatsionniy vyzov sovremennosti in rossiiskie alternativy' (Modernisation challenge of modernity and Russian alternatives), Universe of Russia, X(4), 2001: 28.

4 See 'Intelligentsia i vlast' (Intellectuals and Power), round table at the journal Polis. Available online at http://www.politstudies.ru/fulltext/1992/3/12.htm.

5 See Vasily Auzan and Ekaterina Shokhina, 'Mozgovoi shturm' (Brain Storm). Available online at http://www.expert.ru/expert/current/data/tishkl.shtml

6 'O natsional'noi ekonomicheskoi strategii v usloviakh mirovoi konkurentsii' (On National Economic Strategy in Global Competition). Available online at http://www.expert.ru/conference/details/13jun.shtml.

7 See http://www.russ.ru/politics/20011015-zna-pr.html.

8 'Globalizatsia i neravnomernost mirovogo razvitia' (Globalisation and unevenness of the world development), Mirovaya ekonomika $i$ mezhdunarodnie otnoshenia, No. 3, 2001.

9 See http://www.strana.ru/print/134527.html. 
10 Yurii Luzhkov, 'Otkrytaia perspektiva' (Open Perspective). Available online at http://www.mk.ru/Sunday.asp?artid=48759.

11 Alexander Panarin, 'Agenty globalizma' (Agents of Globalism). Available online at http://www.archipelag.ru/text/234.htm.

12 See http://www.archipelag.ru/text/019.htm.

13 'Russkii mir: vosstanovlenie konteksta' (Russian World: Restoring the Context). Available online at http://www.archipelag.ru/text194.htm.

14 Viacheslav Nikonov, 'Sovety raznie nuzhny' (All kind of councils are needed). Available online at http://www.polity.ru/newpage3.htm.

15 'Rossia i protsessy globalizatsii: chto delat?' (Russia and Globalisation Process: What Is to Be Done?). Available online at http://www.svop.ru/yuka/1100.shtml.

16 Piotr Schedrovitskii, 'Bunt kapitalov' (The revolt of the capital). Available online at http://www.nns.ru/Elect-99/analit/scanar/scen343.html.

17 Schedrovitskii, Piotr. 'Gosudarstvo v epokhu gumanitarnykh tekhnologii' (The state in the epoch of humanitarian technologies). Available online at http://www.russ.ru/politics/meta/20000721_sch.html

18 See http://www.russ.ru/politics/20020212-stol-pr.html.

19 See http://www.russiananalitica.com/russian/interview/0700/008.shtml.

20 See http://www.russ.ru/politics/20020128-stol-pr.html.

21 Alexei Bogaturov, 'Generalami my otboleli' (We have ceased to fear the generals). Available online at http://www.obraforum.ru/bogaturov4.htm.

22 See http://www.regionforum.ru.

23 Piotr Schedrovitskii, ' $\mathrm{Na}$ puti $\mathrm{k}$ novoi ekonomike' (On the way to new economics). Available online at http://www.csr-nw.ru/text.php?item=publications\&code $=11$.

24 Ilia Kochetkov, 'Est tselostnost, no net edinstva' (There is an integrity, but not unity). Available online at http://www.birzhaplus.sandy.ru/birzha/bn210215.htm.

25 Piotr Schedrovitskii, 'Samare neobkhodimo vtoroe dykhanie' (Samara needs the second breath). Available online at http://www.shkp.ru/articles/0501_SamaraII .htm.

26 O.B. Alekseev et al., 'Povestka dnia sovremennoi regionalnoi politiki' (The Agenda for Today's Regional Policy). Available online at http://www.regionforum.ru/library/?nn=9.

27 Piotr Schedrovitskii, 'Cherez 5 let v strane ne budet dotatsionnykh regionov' (In five years there will be no subsidised regions in the country). Available online at http://www.shkp.ru/articles/300502_Mordov.htm.

28 D.I. Sheiman and P.G. Schedrovitskii, 'Tekhnologii regionalinogo planirovania: ot industrialnoi $\mathrm{k}$ innovatsionnoi modeli' (Technologies of regional planning: from industrial to innovation models). Available online at http://www.regionforum.ru/library/?nn=10.

29 See 'Minutes of Discussion in Yoshkar-Ola', 23 May 2002. Available online at http://www.prometa.ru.

30 See http://www.csr-nw.ru/strategy.php and http://www.csr-nw.ru/text.php?code= 9\&item=stgram.

31 'Rossia kotoruiu pora uvidet' (The Russia which has to be identified). Available online at http://www.exin.ru/test/doc7.html.

32 Rostislav Turovskii, 'Gubernatory i oligarkhy: istoria vzaimootnoshenii' (The governors and the oligarchs: History of relations). Available online at http://www.politcom.ru/c_b.html.

33 'Perspektivy razvitia federalizma $v$ Rossii' (Perspectives of Federalism Development in Russia). Available online at http://www.svop.ru/yuka/852.shtml.

34 'Dezintegratsia Rossii' (Russia's Disintegration?). Available online at http://www.svop.ru/yuka/697.shtml. 


\section{Andrey S. Makarychev}

35 A.N. Domrin, 'Federalnoe vmeshatelstvo v dela subiektov federatsii' (Federal interference into the affairs of the subjects of federation). Available online at http://www.svop.ru/yuka/713.shtml.

36 See http://www.fep.ru/publications/management/zel0blizka.html.

37 See http://www.fep.ru/publications/management/21-05-2002-rosgaz.html.

38 See http://www.fep.ru/publications/management/12-05-2001-str.html.

39 As a dangerous symptom, Pavlovskii refers to the fact that each of the presidential envoys is eager to have under his control the media resources. See http://www.fep.ru/publications/management/08-06-2002-rosgaz.html.

40 Alexei Salmin, 'Rossiiskaia federatsia i federatsia v Rossii' (Russian Federation and federation in Russia). Available online at http://www.politcom.ru/print.php?fname.

41 Viacheslav Nikonov, 'Federativnaia revoliutsia' (Federal revolution). Available online at http://www.polity.ru/revol.htm.

42 Federal News Service, 19 April 2002. Available online at http://www.polity.ru /comment01.htm.

43 Viacheslav Nikonov, 'Oko gosudarevo' (The eyes of the chief of state). Available online at http://www.polity.ru/oko.htm.

44 'Dva goda reform federativnykh otnoshenii: itogi i perspektivy' (Two years of the federal reform: outcomes and perspectives). Available online at http://www. gorby.ru/fond/conf.asp?ID=31

45 Some of the table's wording is borrowed from Scott (1999).

46 Boris Kapustin, 'Krizis tsennostei i shansy rossiiskogo liberalizma' (The Crisis of Values and the Chances of Russian Liberalism), Polis. Available online at http://www.politstudies.ru/fulltext/1992/6/5.html.

47 Vladimir Mau, 'Liberalizmu byt' (Liberalism Will Persist). Available online at http://www.iet.ru/personal/mau/itogi225.html.

48 Vladimir Mau, 'Kto reformiruet politicheskie instituty' (Who is to reform the political institutions?). Available online at http://www.expert.ru/expertcurrent/data/mnenie.shtml.

49 Viktor Aksiuchits, ' $\mathrm{My}$ - liberalnie konservatory' (We are liberal conservatives). Available online at http://www.russ.ru/antolog/vek/1991/06/aksuch.htm

50 A.F. Kara-Murza, 'Russkie - stikhiinye liberaly?' (Are Russians unorganized liberals?). Available online at http://www.sps.ru/sps/040701karamursa1.

51 'Konets kontsa ideologii? Linii politicheskogo razmezhevania' (The end of the end of ideology? The lines of political delineation). Available online at http://www.politeia.ru/politeia/bulletins/25-04-02.html.

\section{Bibliography}

Busygina, Irina (2002) 'Russia's Regions in Search of Identity', Acta Slavica Iaponica, Slavic Research Centre, University of Hokkaido, Sapporo.

Kirian, Piotr (2001) 'Miry-regiony Rossii' (Russia's World Regions). Available online at http://www.russ.ru/politics/econom/20010227_kir-pr.html.

Laffey, Mark and Jutta Weldes (1997) 'Beyond Belief. Ideas and Symbolic Technologies in the Study of International Relations', European Journal of International Relations, 3 (2): 193-238.

Milliken, Jennifer (1999) 'The Study of Discourse in International Relations: A Critique of Research and Methods', European Journal of International Relations, 5 (2): $225-54$.

Newsom, David (1995-96) 'Foreign Policy and Academia', Foreign Policy, No. 101: 52-67. 
Pastukhov, Boris (2001) 'Konets russkoi ideologii' (The End of Russian Ideology), Polis. Available online at http://www.politstudies.ru/fulltext/2001/1/5.htm.

Petrov, Nikolai (2002) 'Seven Faces of Putin's Russia: Federal Districts as the New Level of State-Territorial Composition', Security Dialogue, 33 (1): 73-91.

Reviakin, Andrei (2001) 'Vsemirnost' i globalizatsia'. Available online at http://ekg.metod.ru/pub/inoe-2001-revyakin.html.

Schedrovitskii, Piotr (2000) 'Gosudarstvo v epokhu gumanitarnykh tekhnologii' (The state in the epoch of humanitarian technologies). Available online at http://www.russ.ru/politics/meta/20000721_sch.html.

Scott, James M. (1999) 'Transnationalizing Democracy Promotion: the Role of Western Political Foundations and Think Tanks', Democratization, 6 (3): 157-66.

Stone, Diane (2001) 'Think Global, Act Local or Think Local, Act Global? Knowledge Production in the Global Agora'. Paper prepared for 'Reshaping Globalization: Multilateral Dialogues and New Policy Initiatives', Central European University Conference, Budapest, 17 October.

Stone, Diane and Mark Garnett (1998) 'Think tanks, policy advice and governance', in Diane Stone and Mark Garnett (eds), Think tanks across nations. A comparative approach, Manchester: Manchester University Press.

Tuzov, Nikolai (2002) 'Gosudarstvu trebuetsa ideologicheskaia programma' (The state needs ideological program). Available online at http://www.ng.ru/printed/politics/2002-07-18/2_program.html. 


\title{
10 'Bad governance' under democratic rule in Taiwan
}

\author{
Tak-Wing Ngo
}

Development is commonly seen to be contingent upon good governance while good governance is the product of liberal democracy. The assumption is that development planning represents an exercise of instrumental rationality. A state that is plagued by corruption, rent seeking, or cronyism is incapable of asserting its rational agency. And where the ruling regime is thought to be unpredictable, inefficient and politically volatile, long-term investment is deemed unlikely. A stable, transparent and efficient government is thus seen to be providing the necessary environment for development. Such good governance is often assumed to be congruent with liberal democracy and the rule of law. It is often said that free elections, public opinion and a strong civil society are the common ingredients of liberal democracy that keep governmental power in check.

Authoritarian rule is viewed as capable of facilitating development under very specific circumstances, as exemplified by the so-called developmental states in East Asia. The East Asian states are characterised by their developmental capacity that allows them to extract and allocate social resources for the goal of promoting industrial development. In essence, state intervention creates rents by granting subsidies to targeted industries, extending preferential loans to individual businesses, creating monopolistic enterprises to pick and protect winners, or even engaging directly in production to develop new markets. These rents, according to the developmental state theory, are channelled into productive purposes rather than personal gains because of the presence of institutional safeguards such as state autonomy, technocratic insulation, embeddedness and collaborative government-business relations. None the less, the long-term sustainability of such developmental authoritarian states has become questionable in the advent of the Asian financial crisis during the late 1990s. The crisis exposed the prevalence of state predation, official corruption and rent seeking. These are thought to be derived from inadequate institutional supervision. Calls for governance reform, particularly democratic and legal reforms, became widespread in the Asian region.

Ironically, one of the exemplary cases in East Asia - Taiwan - appears to contradict the logic of the triplet: liberal democracy - good governance development. The island had been put under martial law rule by the 
Kuomintang regime for almost 40 years. During this period, despite the strong suppression of civil liberties, the island underwent substantial economic development. Martial law was subsequently lifted in 1987, followed by a peaceful process of democratisation. Constitutional reforms were undertaken, and free elections to the parliamentary bodies and presidency were institutionalised. Eventually, regime change took place in 2000 when the Kuomintang lost the presidential election. The once-outlawed Democratic Progressive Party took office. None the less, political liberalisation and democratisation have been accompanied by widespread and intensified corruption, rent seeking and gangster involvement in politics. Bad loans in public financial institutions increase exponentially in the wake of democratic reforms. Financial scandals occur one after the other during electioneering. Gold and goons have become the rules of the game. In short, democratic transformation in Taiwan has given rise to 'bad governance'.

This chapter aims to account for such a peculiar relationship between democratisation and bad governance in Taiwan. It argues that the reasons are to be found in the political logic and state structure that were institutionalised under Kuomintang rule. To do so the chapter examines developmental and spoliatory activities sanctioned by the state in Taiwan during the past five decades. Instead of adopting a binary distinction between developmentalism and spoliation, our discussion highlights various kinds of activities deriving from state intervention: rent creation and allocation, official corruption, state predation and rent seeking. The chapter argues that (i) despite the common perception of Taiwan as an exemplar of the developmental state, spoliatory activities abounded; (ii) these spoliatory activities were not just sporadic irregularities in the course of state-led development but were in fact sanctioned or even institutionalised by state actions; (iii) these activities did not arise in isolation but were closely related to one another; (iv) spoliatory as well as developmental policies originated from and were constrained by the same political logic concerning regime maintenance; and (v) political liberalisation and democratisation removed political censorship but at the same time also removed the constraints on spoliation.

\section{Governance and development under authoritarian rule}

Let us begin by examining the enigmatic relationship between authoritarian rule and active state involvement in promoting economic development. When the Kuomintang retreated to Taiwan in 1949, it encountered a hostile indigenous population whose hatred of the Kuomintang regime was buttressed by the massacre in 1947. Thanks to the outbreak of the Korean War, the United States decided to defend Taiwan against communist takeover and take part in helping the Kuomintang consolidate its rule in the island. Shattered by the threat of complete demise, the Kuomintang regime wasted no time in re-erecting the political institutions of the state to anchor its power and resources. 
The fall of the mainland to the communists created the circumstances under which political exclusion became a justifiable course. A state of national emergency and martial law was declared since China was under communist insurgency. Taiwan became the temporary capital city of China after the central government as well as the parliamentary bodies retreated to the island. The parliamentary bodies were composed of delegates elected from all parts of China and were supposed to represent the interests of the whole of China. But as long as the mainland was under communist control general re-elections were not possible. The representative institutions therefore enjoyed an indefinite term, which lasted for over 40 years. The majority of the population in Taiwan (officially merely a province) was excluded from participating in state affairs that supposedly represented national rather than provincial interests. Paradoxically, its legitimacy was based on its unrepresentativeness. As long as China was divided by civil war and the recovery of the mainland was a national goal, the state enjoyed political seclusion from the local population. It justified its existence in terms of an imaginary community of which the local community was only a marginal part (Ngo 1993).

Paradoxically, this authoritarian regime was also the driving force behind developmental projects. It promoted capital accumulation, prioritised strategic investments, nurtured market competitors and shaped industrial restructuring. Development projects ranged from agriculture, industry, export, banking, to R\&D. It has become a conventional wisdom to regard these state projects as evidence of the developmental state (see, for instance, the oft-quoted study of Haggard 1990). In particular, the Kuomintang government promoted industrialisation by giving direct subsidy to targeted industries, offering market protection against foreign competition, and granting preferential credits to specific enterprises. For instance, specific loans were allocated through designated banks to import machines; medium- and long-term credit special funds were created to finance basic construction and long-term investment; special interest rates were granted to provide capital for raw material imports and pre-shipment production (Shea and Yang 1994).

Besides setting up new industries and directing capital investment, the Kuomintang government also regulated market entry to enhance the competitiveness of domestic industries. Under the so-called import substitution' policy of the 1950s, import restraint, tariff and foreign exchange control were implemented to protect infant industries. The textile and the automobile industries were among the beneficiaries. Later on, market protection was lifted in a number of sectors to promote export competitiveness. These included simplifying the multiple foreign exchange rates into a single rate, relaxing import restraint, simplifying export procedures, rebate of customs duties for exports, tax exemptions for exports and providing export credit. These were entailed in the nineteen-point fiscal and economic reform announced in 1960 . The reform was subsequently enacted as the 
Statute for the Encouragement of Investment, which was implemented in three phases: $1960-70,1971-80$ and 1981-90.

In the area of $R \& D$, the Kuomintang state also undertook a major lead. An outstanding example was the semiconductor industry that ultimately turned Taiwan into the biggest producer of computer chips in the world. The industry began as a pilot IC project undertaken by the government in the 1970s, with the aim of upgrading Taiwan's industrial structure. Research institutes, laboratories and science parks were set up to establish state-ofthe-art R\&D capacities. In addition, the government set up pioneering joint ventures with the private sector and foreign investors, most notably United Microelectronics and later Taiwan Semiconductor (Meaney 1994).

What was the basis of such a developmental imperative? Why did the Kuomintang regime undertake such a painstaking effort to promote economic development? The answer lies in one factor: revenue accumulation. Economic development was hailed as the means for revenue (Council for U.S. Aid, Archive no. 31-00.49.02). Stable fiscal accumulation was deemed essential for regime survival for the Kuomintang. The Kuomintang regime who lost the mainland to the communists during the civil war had one overwhelming political imperative: to recover the mainland and, in the immediate future, to prevent Taiwan, its last foothold, from being taken over by the communists. This survival imperative was translated into two central missions for all economic institutions: maintaining economic stability and promoting accumulation. Stability in terms of price level and the stable supply of basic necessities were needed for maintaining internal security. Accumulation for military expenditure was prioritised for the sake of external security. Both internal and external security concerns required the saving of foreign exchange - for the purchase of necessities and weapons that was in grave shortage. The limited foreign exchange coming from US aid had to be rationed and used effectively, hence the need for central planning. All economic planning works began with such a concern.

Since 1949 Taiwan had never been relieved from the external threat of a military takeover. As a result, the survival imperative (and hence the striving for revenue) remained strong. When US aid stopped in the 1960s, the only way to earn foreign exchange was by promoting industrial export. Since then, continuous economic growth became the only source of foreign exchange and state revenue. The prime purpose of accumulation for regime survival is evident in public expenditure. Over 75 per cent of the total expenditure was spent on defence during the 1950s. Another 10 per cent was spent on government administration. The two expenditures constituted nearly 80 per cent of the budget in the 1960 s and some 56 per cent in the 1970s. Furthermore, part of the export revenues was tucked away by the state as foreign exchange reserve and gold reserve. Over the years, a huge reserve was built up for national security's sake in case of a military conflict with the Chinese communist regime. Foreign exchange reserve increased from US\$2 million in 1950 to US\$76 million in 1960 , US\$600 million in 
1970 , US $\$ 5,400$ million in 1980 , and over US\$80,000 million in 1990 . Gold reserve increased from one million liang to over 13 million during the same period. To support such a huge accumulation scheme, rapid and continuous growth was needed. This formed the political basis of development planning in Taiwan (Ngo 2001).

\section{The creation of spoils and rents}

State actions undertaken to promote development (such as granting subsidies to targeted industries, extending preferential loans to enterprises and sanctioning monopolies) create rents. The preferential distribution of rents by state officials to a privileged few creates ample opportunities for corruption. A common phenomenon in developing economies is the transfer of useful resources for private gain during the process of creating and allocating rents. I refer here to official corruption for individual, private gains. Bureaucratic intervention in the market creates rents that can be given out in exchange for bribes. In the case of Taiwan, the problem had been a big concern, especially when the Kuomintang had a notorious history of being corrupt during its mainland rule, and when the extent of state intervention was so pervasive in creating vast opportunities for corruption.

A glance here is sufficient to reveal the situation. During the import substitution period, a company had to apply for fourteen different licenses to export a product, to negotiate for some twenty months to set up a new production line, and to apply for eight licenses to run a new shop (Chu Peilien 1992: 199-200). Every step during the process was prone to corruption as bribes were paid to smooth out the application procedure.

Textile production offers another example (see Minutes of Council for U.S. Aid, various years). Raw cotton was procured by the Textile Subcommittee of the Council for U.S. Aid. It was then allocated to designated spinners at a pre-determined price. The Sub-committee then bought back the yarn, and allocated it to weavers. Yarn and cloth supply was calculated by the Taiwan Production Board according to the simple arithmetic of daily needs. Factories were inspected regularly by Police Inspection Groups to ensure that allocated yarn was not sold in the black market and that mills did not give fraudulent production figures. Finished garments were distributed through officially designated dealers. The number of spindles and looms was controlled by the Sub-committee. Power supply to factories was also rationed. A vast amount of textile produce was transacted between government departments. The complicated process created numerous loopholes prone to corrupt practices. Later on, when exports were promoted, the policy of tax rebate for exports was plagued with allegations of corrupt practices (The Reminiscences of Mr. Wei Yung-ning 1994: 51-2). Government archives reveal vast number of corruption allegations against officials and managers of state enterprises (Taiwan Production Board Archive, no. 4737). 
An extreme example can be found in the case of the Central Trust of China. The Trust was originally set up for the procurement of military weapons. It subsequently extended its operation to handle all overseas trade for the government. These included military and civilian procurement, export sales of sugar, rice and salt, and imports of fertiliser. In connection with its trade operations, the Trust ran warehouses, cargo insurance and reinsurance. It also operated bank credits and life insurance for all military and civil servants. Later on, the Trust was also used by state officials as a policy instrument for extending preferential loans to selected industries and enterprises (Shen 1972). The Trust was also entrusted with the power to give out textile production contracts to spinners (Council for U.S. Aid Archive, Textile Sub-committee, Minutes of Meetings 1952). Since domestic demand for textiles was great but the numbers of spinners and weavers were severely restricted, producers remarked that 'spinning yarn was like spinning gold thread, printing cloth was like printing bank notes' (The Reminiscences of Mr. Wu Hsiu-chi 1992). The Central Trust gradually assumed a special status by virtue of its control over huge bank credits, gold reserve, foreign exchange, civilian and military supplies and business contracts. Eventually, the Trust grew into a mammoth agency. The headquarters alone had more than 1,500 staff. Every county and municipality had branch offices. Overseas divisions were set up in San Francisco, New York, Chicago, Miami, Panama, Bonn, Vienna, Paris and elsewhere. This huge establishment, together with the Trust's control over trade, bank credits, gold reserve, foreign exchange and civilian and military supplies, made the Trust the operational heart of the state machinery. In its lifespan of operation, allegations of corrupt practices never stopped (see Shen 1972).

Ironically, corruption, although abundant, was restrained by the nature of the regime. First and foremost among these constraints was the Kuomintang's defeat in mainland China. There was a tacit consensus within the Kuomintang that corruption, power struggle and the predatory practices of the party during the Republican period were some of the main reasons for its defeat. On its retreat to Taiwan, the Kuomintang admitted past errors and moved to purge those factions that paralysed party functioning. It became very sensitive to the corrupt practices of party and government officials that might repeat the experience of the Republic era. Allegation of corrupt practices could bring down even highly influential government and party officials. This is certainly the case of K.Y. Yin, who is commonly regarded as the mastermind behind Taiwan's modernisation. Yin was accused of corruption in 1955 during his term as Head of the Central Trust of China. He stepped down because of the charges, and did not return to office after he was cleared of the allegation (Shen 1972: 264 463). Similar cases abound. High-ranking officials including Liu Harng-chen, Li Kuo-ting and Hsu Peh-yuan were at once removed from their office by charges of corruption and abuse of power.

A related check and balance against official corruption is concerned with power conflicts within the ruling regime. From the outset, the Kuomintang 
regime was never a unified political party. Even after the party reform in the early 1950s, factional strife continued (Winckler 1988). The state was an amalgamation of multifarious bases including bureaucratic sectionalism, factional interests, oligopolistic networks and personal connections (Ngo 2002b). In such circumstances, allegation of corruption became a way of attacking political rivals. A well-known case is the downfall of Wu KuoChen, chairman of the Taiwan Province. He was seen as a member of the 'political study faction'. During his visit to the United States, Wu was removed from office in his absence because of accusations of corrupt and illegal practices. Another cadre fell victim in 1969, when veteran party financial specialist Hsu Po-Yuan was removed from office as president of the Central Bank. Being a member of the 'Madame Chiang faction', Hsu was accused of having been involved in a scandal. In sum, the rival factions within the Kuomintang regime served as watchdogs for one another, preventing widespread corruption among the top leaders.

Added to the above constraints was an external monitor: the United States. Some US\$1.5 billion in non-military aid was extended to Taiwan between 1951 and 1965 as part of America's containment policy (see Jacoby 1966). The US government was thus keen to see to it that its aid money was spent properly by the Kuomintang government. This was done through a number of supra-ministerial committees and councils established to implement economic projects associated with the aid programme. The Council for U.S. Aid was established in 1948 and resumed operation in 1951 to administer aid, select aid projects and oversee local currencies. It gradually assumed the responsibility of development planning, aid utilisation, fiscal control, agricultural development and price control. Others included the Joint Committee on Rural Reconstruction and the Foreign Exchange and Trade Commission. In all these supra-ministerial agencies, American aid officials sat in the meetings and controlled de facto veto power through their control of US aid. They thus served as a check on any abuse or misuse of public finance.

In sum, the past defeat of the Kuomintang, the internal power competition of the ruling factions, and the presence of an external monitor helped prevent corruption by individual power holders that might undermine the collective survival of the regime. Although bureaucratic intervention in the market created ample opportunities for exchanging bribes with rents, a certain degree of 'good governance' was guaranteed when corruption was kept within checks.

\section{Extraction by predatory state agencies}

Although corruption at the individual level was restricted by the political logic of collective regime survival, the same logic had given rise to predatory activities of the state as a corporate actor. The overwhelming emphasis on revenue mentioned earlier meant that state extraction of societal surplus was 
severe. The extracted surplus was used to support the war machine and a large public sector staffed by Kuomintang followers.

Let us begin with land reform again. Shortly after the implementation of the Land to the Tiller Act, agricultural surplus was appropriated by the state in the form of land tax and the compulsory sale of rice to the government at low price. Furthermore, a rice-fertiliser barter system was set up, under which farmers had to exchange rice for state monopolised chemical fertiliser at official rates. It is estimated that the 'hidden rice tax' involved in the barter system constituted two to three times the average annual rice tax in the 1950s and the early 1960s, and more than the total tax income of the government during the same period (Kuo 1983: 36). Meanwhile, agricultural products appropriated by the state, especially sugar and rice, were exported to earn foreign exchange. They constituted 83 per cent of Taiwan's total export value in 1950, 73 per cent in 1955 and 47 per cent in 1960 . These were official figures based on multiple foreign exchange rates. Under a single exchange rate, the percentage would be even higher (Shiau 1989: 62).

Part of the exacted agricultural surplus, together with US aid, was used to establish monopolies or semi-monopolistic enterprises in a vast number of manufacturing and servicing sectors, including defence, energy, steel, shipbuilding, heavy machinery, construction, fertiliser, sugar refining, tobacco and wine, public utilities and transportation, shipping, banking and financial services. The control of such 'upstream industries', which lasted until the 1990s, gave a stable source of revenue for the Kuomintang.

The huge public sector characterised by state monopolies was staffed with Kuomintang followers. When the Kuomintang government retreated to Taiwan after its defeat by the Chinese Communist Party in mainland China, it took with it three million military staff and public service personnel. These mainland Chinese stood in contrast with the six million Taiwan Chinese who, despite being ethnically the same, had been residing in the island for several generations. Open confrontation between the two groups took place on 28 February 1947, when riots broke out and spread over the island. In response to the Taiwanese attack, the mainlander regime launched a massacre. An estimated 18,000 to 28,000 people were killed; more were arrested and executed later. Taiwanese intellectuals, social elite, government critics and journalists were the primary subjects of the massacre (Lai et al. 1991). Since then the ethnic cleavage between the Taiwanese and the mainlanders became the central tension in the body politic. Most local Taiwanese were excluded from jobs in the public sector, which offered prestigious employment welfare and job security. High positions in state enterprises were often used by the Kuomintang as rewards for veterans.

We mentioned earlier the internal rivalry of the ruling regime in keeping individual corruption in check. The same logic of political rivalry, however, not only drove the state into becoming a collective predatory actor but also turned it into a network of bureaucratic and political factions mutually competing for influence and resources. The fact that under martial law there 


\section{Tak-Wing Ngo}

was no institutionalised mechanism to decide who took what positions and resources meant that not only bureaucratic offices but also their functions and jurisdictions were fought over. Furthermore, since the Kuomintang was an émigré regime without an indigenous social basis, whoever could establish its political support and mobilise social resources would survive in the internal struggle. Bureaucratic offices thus provided the institutional means for sponsoring oligopolistic networks, extending political favouritism and extracting spoils. The latter in return helped expand the institutional infrastructure that sheltered sectionalism.

The state became a major contender with conflicting self-interests in the polity. There are endless examples of intra-state fights. In general, different power clusters tried to undermine their rivalries by: (i) impeding others' institutional resources and jurisdiction; (ii) imposing taxes and rents or transferring costs onto others; (iii) securing stable revenue basis by creating monopolistic businesses; and (iv) picking supporters by offering favourable policies or preferential treatments.

Contentions among economic ministries, the armed forces, planning commissions, state enterprises and various levels of governments over the control of land, roads, tax, licenses, rents, etc. were overwhelming (Ngo 2002b). The armed forces were in particular very effective in extracting resources from and transferring costs to other state agencies. From the outset, the military refused to submit to any budgetary constraints. The Ministry of Finance had no control over the expenditure of the military. Because of that, until the 1960s the government totally gave up any budgetary plan for the entire administration. Deficit was covered mainly by selling gold reserves or printing money (Li Kuo-ting Archive, B59-22.1). To make budgetary planning possible the government introduced a special tax to cover military expenditure: Special Contributions to National Defence. Even after that, military requests for fuel, rice, flour, clothing, cement, steel, and communication, transportation and hygienic equipment were frequently made to the government. Government ministries had to comply, albeit very reluctantly (Taiwan Production Board Archives, no. 033/1961/1.1; no. 034/1962/1.1). Further than that, the Garrison Command set up an economic police force and placed it in every factory and company. The official stated purpose was to maintain economic order and to conduct inspections to ensure that production was carried out according to government regulations (Council for U.S. Aid Archive, Textile Sub-committee, Minutes of Meetings, 23 July 1952). In practice, factories had to take care of the salaries of their police. The financial burden was shared by the provincial government, which controlled many state enterprises.

Over the years various power clusters competed over revenue extraction via the state agencies they controlled. In addition to taxes and various sorts of levies, rents derived from monopolies became the major form of extraction. As a result, the number of state enterprises grew. Bureaucratic offices which had state enterprises directly under their control included Ministries 
of Economic Affairs (10), Finance (9), Transportation (5), Veterans Commission (28), the provincial government (33), Taipei and Kaohsiung city governments (7) and country governments (8). As mentioned earlier, these enterprises essentially covered strategic industries and monopolies in sugar, salt, fertiliser, steel, shipbuilding, machinery, construction, petrochemicals, electricity, banking, insurance, tobacco and liquor, telecommunication, shipping, mining, forestry, transportation, port facilities, media, etc.

The above-mentioned enterprises all appeared in state accounting. They constituted a small part of the actual size of the state sector, the main bulk of which was hidden. This included enterprises that were either controlled by government-funded legal entities, jointly owned by government-funded legal entities and private companies, subsidiaries of state enterprises, or controlled by subsidiaries of state enterprises (Chen et al. 1991). These state enterprises were hidden because, according to the law, they were considered private. In fact, they were firmly controlled by the state, but were free from government auditing and parliamentary monitoring. By the $1990 \mathrm{~s}$, the total number of state enterprises, public and hidden, was estimated to be several hundred. These included firms controlled by national enterprises under ministries of the Executive Yuan; some 60 firms owned by national enterprises under the Veterans Commission; some 70-80 firms under the Bank of Communications; numerous firms controlled by provincial, city and country enterprises; and the vast number of private firms jointly owned by state enterprises, various levels of government, government-funded legal entities and the Kuomintang party (Chen et al. 1991: Tables 2.1-2.5).

These legions of open and hidden monopolies conferred stable income in terms of rents to individual bureaucratic offices. Furthermore, state agencies' competition to embezzle rents was accompanied by the battle to confiscate the embezzlement of others. As a result, a lot of effort was spent not in 'governing the market' but in governing the state: that is, negotiating compromise between various intra-state kingdoms and in mediating the transactions among them.

Under US pressure, the central government announced the policy of privatising as many state enterprises as possible, with the exception of national public utilities and those strategic monopolies that directly affected defence and daily living. A privatisation law was enacted as early as 1953 . The policy was a complete failure, since no state agency was willing to privatise enterprises under its control. For example, suggestions to privatise province-owned banks were strongly opposed by the Finance Office of the provincial government. The Finance Office argued that privatising the banks would lower the capacity of the government to control credit flow, deprive the government of the policy instrument of preferential loans, reduce the revenue of the provincial government, and create the possibility of confrontation among local factions who wanted to gain control of local banks (Chen et al. 1991: 412). Likewise, central ministries reacted in the 
same way. Although the Ministry of Economic Affairs was responsible for implementing the privatisation law, it refused to sell any of its companies. Other state agencies reiterated the anachronistic idea that there should not be any strict distinction between state-owned and privately-owned enterprises. That all enterprises should be developed by the government and the people together, with the exception of those enterprises concerning defence and natural monopolies which should be run by the government ('Outline of Industrial Policies and Post-war Five Year Construction Plan'. Chiang Kaishek Archive, Special Documents, Economy, vols 10-13).

The public sector remained dominant in the economy until the 1980s. Since then the role of the state increasingly became the subject of criticism. State domination in the economy was criticised as being the major obstacle for industries to develop forward and backward linkages and upgrading. The business sector even threatened to launch an investment strike if the government did not retreat from its dirigiste role (Ngo 1995). Eventually the Kuomintang regime agreed to 'privatise' state and party monopolies, liberalise the financial sector and reduce market regulation. In reality, however, many of those privatised enterprises remained under indirect state or party control (Chen et al. 1991).

\section{Rent allocation}

Besides official corruption and state predation, spoliation arising from state intervention also occurred in the form of rents allocated to private sector players in exchange for political support. Economists have pointed out that the state creates and gives out rents as a means of purchasing political support. Political incumbents do this by either distributing resources directly to supporters in terms of subsidies, loans, or contracts; or creating rents for favoured groups by restricting market entry. In the case of Taiwan, the logic extends further than that. It hinges upon the imperative of political survival for the émigré Kuomintang regime.

Before we explain the political logic behind rent allocation, let us first look at the economic implications. The developmental state literature portrays the rent allocation exercise as one of 'picking winners'. It has been suggested that rent is used by the state to groom individual market players and to reward successful market competitors. In other words, rent is tied to performance: enterprises are rewarded with rents when they earn profit.

This winner-picking process has been well documented in Taiwan. But a closer look at some of the cases reveals that the notion of 'winners' requires careful qualification. The most well known case of picking winners can be found in the automobile industry. The first automobile manufacturing company, Yue Loong Motor, was established in 1953 by a former Shanghai textile industrialist, T.L. Yan, who retreated to Taiwan in 1949. The company had the blessing of the government, and received over US $\$ 3$ million from the US aid administered by the government. In cooperation 
with Japan's Nissan it assembled passenger cars for the local market in 1960. To protect the company, the government prohibited further investment in automobile assembly and imposed high tariffs on imported passenger cars. A proposal to produce automobiles for the Southeast Asian market by Teng-Eng Iron was hence rejected by the government. Teng-Eng proposed to form a joint venture with America's Ford, who agreed to transfer 100 per cent of the technology to Taiwan in five years (Forging the Future: An Oral history of the Teng-Eng Iron Co. 1993: 174-5). The industry remained highly protected until the mid-1970s. Only four new firms were allowed to enter the market. They formed joint ventures with General Motors, Fuji, Toyota and Willy's.

Another eye-catching example is the export sector. It is estimated that some 70 per cent of Taiwan's foreign trade was handled in the 1970s by foreign companies such as Japan's sogo shosha and American buyers (Fields 1995: 211). The colonial heritage enabled many producers, large and small, to establish ties with sogo shosha. To capture the huge profit in this trading business, the state promulgated a plan in 1978 to promote local large trading companies. Seven companies, including Pan Overseas, Collins, Nanlien International, Great International, E-Hsin, Taipoly and Peacock, were picked by the government as the market leaders qualified for privileged measures.

At the end, a handful of enterprises emerged to become oligopolies in the economy under the protection of the government. Although being winners in the domestic market - thanks to the rents given by the state - these oligopolies were not necessarily successful competitors in the world market. For instance, Yue Loong Motor failed to manufacture cars that could compete in the export market. In fact, the entire automobile industry, due largely to government protection, was inefficient and uneconomical, confined mainly to the simple assembly of imported parts and components with minimal transfer of technology (Arnold 1989: 184). Similarly, those measures implemented to promote large trading companies turned out to be obstacles rather than facilitation, because they limited the market share of large trading companies in the export business. The limitations were upheld by state agencies, having hitherto monopolised the import and export of various commodities, who feared that they would be driven out of the market by the trading companies (Fields 1995). At the end, the large trading companies failed to thrive; the export sector continued to rely on its own export networks.

The inefficiency connected with rent allocation can be further illustrated in the case of the export processing zone. The idea of establishing an export processing zone was put forward in 1956 as an antidote to the severely protected domestic market. The goal was to attract domestic and foreign investors to use Taiwan's cheap labour force for manufactured exports, by offering privileges such as freedom of management, tax exemption, low customs duties and less foreign exchange controls. The project encountered 
substantial opposition within the government, in fear of the zone becoming a threat to firms operating outside the zone. A compromise was reached requiring firms in the zone to have established their overseas market outlets before they invested in the zone ( $\mathrm{Li}$ 1995: 162-3). The first zone in Kaohsiung was established in 1966, after some ten years of deliberation. During the early years of its operation, state-trading agencies prohibited firms in the zone from supplying made-up parts to other firms within the zone. These firms had to ship their products first to Hong Kong; they were then shipped back to Taiwan to be used by the firms next door (Li 1997: 5).

Our question thus remains why the Kuomintang government did not allow the market to determine winners and losers when the outcome of rent allocation was far from efficient in certain areas. Or even if the government insisted on creating and granting rent by fiat, why it did it not replace the inefficient players with more enterprising ones. The answer, as we have just mentioned, lies in the politics.

\section{The political logic behind rent allocation}

From the outset, the Kuomintang faced a hostile and alien society which saw the regime as a coloniser, especially after the 28 February massacre. The Kuomintang regime declared a state of national emergency and martial law, justified on the ground that China was under communist insurrection. Under martial law, major constitutional rights were denied, including the freedoms of the press and association. General elections to the National Assembly and other representative bodies were suspended, thereby allowing the mainlander incumbents who retreated to Taiwan to continue their office indefinitely. Chambers of commerce, industrial associations, labour unions and professional societies were created by Kuomintang initiatives. Other civic organisations not sanctioned by the regime were banned. All in all, the mainlanders monopolised all public sector positions, leaving the private sector to the Taiwanese.

Here lies the reason why the Kuomintang government had to create and distribute rents by fiat rather than allowing private enterprises to compete freely for normal returns under market conditions. The ethnic cleavage contributed to a deep distrust on the part of the mainlander regime towards the Taiwanese-dominated private sector. The state restricted private capital growth, and entrusted the task of accumulation to the public sector, even at the expense of economic efficiency.

Under market regulation, the main beneficiaries of protective rents went to state- and party-owned enterprises and a few oligopolies closely associated with the Kuomintang. State monopoly in the strategic sectors (energy, steel, banking, etc.) not only ensured a stable source of revenue for the Kuomintang government, but also allowed the state to control the supply of necessary inputs in other economic sectors, hence ensuring the state's command over private business. 
The Kuomintang regime's arm's-length relationship with the private sector, and its concern over political control, are best illustrated in the way preferential loans were given by state-owned banks. Bank credits were seldom rationed according to industrial policy goals but to the size and ownership of enterprises - state-owned enterprises first, then big enterprises, and then small and medium enterprises - although the efficiency of capital use ran in precisely the opposite direction. Most of the loans made to the private sector were in the form of short-term credit used for export financing. Such a lending practice and the state policy of forbidding private participation in banking was resented by private business, big and small. But the Kuomintang government refused any financial liberalisation for fear that it might give rise to powerful Taiwanese financial empires. To meet the growing need for financial services, the Kuomintang regime would rather allow the entry of foreign banks and overseas Chinese banks than that of domestic private banks (Cheng 1993).

The political imperative of regime maintenance also explains why certain players were picked as winners despite their poor performance. These were players whose political support the state had to purchase by means of rents. For instance, in the automobile case, one wonders why the government did not pick Teng-Eng as a targeted company for protection. Teng-Eng was the largest steel and machinery producer at that time, employing more than 4,000 workers. Not only did it possess machine-producing experience, but it also promised to acquire the technology from Ford within five years. The main reason was that T.L. Yan of Yue Loong was a mainlander and a loyal follower of the Kuomintang regime, who allegedly had very close ties to the president. In contrast, the founder of Teng-Eng was a local Taiwanese who was well known for his distrust of mainlanders who retreated to Taiwan.

The story of Teng-Eng went further than that. Alerted by the size of the company, the distrust of mainlanders by the company owner, and the allegation that the owner supported a rival faction against president Chiang Kai-shek and his son, the government forced Teng-Eng to go bankrupt in 1960. The provincial government then took over ownership from the Teng family and turned Teng-Eng into a government-owned enterprise (Ngo 1998). After the takeover, the market share of the company diminished, leaving its former competitor, Tatung, to become the largest machinery producer. In retrospect, the market leader in the machinery industry and one of the largest enterprises in the economy was virtually eliminated by the government out of political considerations.

Similar considerations can be found in other cases. For instance, in the highly protected textile market during the import substitution period, the main beneficiaries who captured the rent were either state-owned textile mills, or those set up by people close to the Kuomintang. When the government decided to allow the setting up of 20,000 new spindles in 1953, local producers lobbied hard for the right to enter the market. Eventually, 10,000 of the spindles went to state-owned operation, the rest were captured by 
Tainan Spinning. Tainan Spinning won the bid by having a legislator serving as its chairman, and by successfully lobbying the county and municipal assemblies to throw their support behind the application (The Reminiscences of Mr. Wu Hsiu-chi 1992: 192-3).

All in all, privilege, in the form of rents, was allocated to state-owned enterprises, to party-owned enterprises, to mainlander firms that were politically well connected, and to a few Taiwanese families who gave political allegiance to the regime in exchange for the oligopolistic rent (Chu 1994: 116). In the last two categories, firms like Yue Loong Motor, Tatung and Tainan Spinning, together with other picked winners such as Formosa Plastics and Far Eastern Textiles, have maintained their positions among the largest private enterprises in Taiwan until now.

\section{Rent seeking in the oligopolistic sector and local economies}

The creation of rents by state intervention and the allocation of rents to political supporters invite other social players to engage in rent seeking. In other words, artificially contrived rents are subject to competition. Economists have theorised that competition of this kind generates 'social waste'. In contrast to profit seeking where value maximisation efforts produces social surplus, rent seeking results in social waste because resources that could otherwise be devoted to value-producing activity are engaged in competitive effort for nothing other than distributive results. 'Rent seeking, as such,' argues Buchanan (1980: 360), 'is totally without allocative value.'

Incidentally, the political factor that led to rent creation and predation by the state also restricted rent seeking by social players. It restricted rent seeking in the national economy in a number of ways. First, the wide range of monopolistic enterprises controlled by the Kuomintang meant that the regime had its own stable source of financial resources. It did not depend on business donation for funding.

Second, the authoritarian nature of the regime also prevented extensive rent seeking among collective actors in different economic sectors. As part of the regime-building exercise, the Kuomintang set up various state-sponsored business associations to penetrate, organise and demobilise economic interests. A tightly controlled, hierarchical system of business representation was established. In such a system, every business association was the single, compulsory, non-competitive, state-sponsored organisation within a specific sector, and enjoyed exclusive representation of the sector as well as the exclusive recognition by the government. At the top of the hierarchy were three peak organisations: The Federation of Industry, the Federation of Commerce and the National Council of Industry and Commerce. The entire system served as an executive arm of the Kuomintang regime rather than as collective actors of sectoral interests. Elections for office-bearers of these associations were supervised by the Kuomintang; and leaders of the peak 
associations were handpicked by party leaders (Chu 1994: 118-19). In such a system, interest representation across sectors gave way to hierarchical control, thus restricted collective actions of bargaining and rent seeking.

Third, ethnic cleavages prevented rent seeking in the oligopolistic sector. This requires some elaboration. One way to reduce rent seeking, according to Tullock (1980: 109), is to introduce bias into the selection process. By picking only those players who possess certain traits, it discourages those who do not possess those traits to invest in rent seeking because it does not pay. The mainlander-Taiwanese divide functions as such a kind of bias in the process.

The Kuomintang's arm's-length relationship with the private sector restricted the extent of individual rent seeking. It did not pay for individual Taiwanese enterprise to engage in rent seeking because (i) they were Taiwanese; (ii) they had very limited access to power networks within the party and the state due to the political exclusion of Taiwanese in the polity; (iii) they were not big enough or their business were not strategically important enough to warrant the political attention of the ruling regime. Because of that, only a small group of well-connected mainlander and Taiwanese enterprises were entitled to the state-sanctioned rents given in exchange for their political allegiance to the regime.

With profits guaranteed by monopolistic rents in the domestic market, most of the oligopolies were not interested in the export market. The export market was left to the bulk of small and medium Taiwanese manufacturers. The growth of the export sector began in the early 1960s, when the government turned to export industries for foreign exchange and income to compensate for the loss of US aid when it ceased in the mid-1960s. The private sector expanded rapidly to produce exports for the overseas market. The private sector's share of the total value of manufactured production increased from 56.2 per cent in 1960 to 63.2 in $1965,79.4$ in $1970,85.8$ in 1975 and 85.5 in 1980. The value of exports of the small and medium enterprises that dominated the sector constituted 55.7 per cent of their total sales in 1972,53 per cent in $1975,66.7$ in 1980 and 71.1 in 1985 . Over 70 per cent of Taiwan total manufactured export value in 1981 came from the small and medium enterprises (Chou 1992: 117-18). These enterprises received hardly any assistance from the state and had little incentive to engage in rent seeking due to the reasons mentioned above. But since they had to compete on their own in the world market, they became the real adaptive and efficient sector in the Taiwan economy and the major exporter and foreign exchange earner.

In sum, although state intervention created and allocated huge amount of rents, these rents were captured by a small group of oligopolies without invoking widespread rent seeking among Taiwanese businesses in the private sector. As a result, a dual economic structure emerged, with a highly protected, rent-consuming domestic sector and an unprotected, profitseeking export sector competing on the world market. 
Limited rent seeking in the oligopolistic sector contrasted sharply with widespread rent seeking in the local economies. This took the form of competition between organised local factions. The bases of factional ties varied from locality to locality, ranging from familial, regional, dialectal, to sub-ethnic groupings (Chai and Chang 1994). Many had already existed since the Japanese period. The most significant feature about these local factions is that their rent seeking was sanctioned by the Kuomintang regime.

Although barred from participating in national politics, factions gained access to local politics through elections. Local-level elections were introduced in 1950 for county and city assemblies, as well as for mayors and magistrates, in sixteen counties and five cities. The Taiwan Provincial Assembly also had its first election in 1951. Since then local elections had been held regularly. Competition was fierce, and the voter turnout rate was high. By becoming mayors, magistrates, or county assembly members, representatives of local factions gained access to the local policy-making process or became policy makers themselves.

Once in power, local factions gained control of various types of advantages. The first type was control over local monopolistic enterprises such as local banks, credit cooperatives, agricultural and fishery cooperatives, and transportation companies. The second type was the privileged access to loans in the provincial treasury, which were accessible to local factions with elected provincial councillors. The third concerned profit derived from local construction work or from supplying materials to local purchasing authorities. The fourth involved the abuse of public power or corruption, including the manipulation of urban development plans, construction schemes, or land prices, and the operation of vice dens, underground money markets, etc. under the cover of public authorities (Chu 1992: 151-2).

Again, the existence of widespread rent seeking in local economies derived from the same political imperative of regime survival. Local politics served as a kind of selective compensation for exclusion in national politics. Extraction by national monopolies was compensated for by gaining access to local monopolies. What is even more intriguing in this process is that local appendages of the Kuomintang formed part of the distributional coalition that created and allocated rents in the local economy. Over the years, the Kuomintang deliberately avoided nominating party candidates for a certain proportion of seats to allow for non-partisan competition in local elections. To avoid some factions turning their grievances towards the regime due to persistent losses during elections, the Kuomintang supported different factions in turn to allow everyone to get a share of the rent. This rent-sharing strategy helped secure stable support for the regime from the grass-roots level.

Rent seeking at the local level did not spill over to the national level because local factions were not allowed to form territory-wide coalitions or to establish relationships with central-level politicians. Since the majority of the local factions were Taiwanese, their attempt to form broad coalitions 
would threaten the mainlander regime and was thus harshly repressed. This restriction was upheld for over 40 years until the end of martial law in 1987.

\section{Gold and goons in democratic Taiwan}

From the above, we can see that the Kuomintang regime's accumulation imperative was not much affected by spoliatory practices when military confrontation with the mainland was still a real threat. Until martial law was lifted in 1987, although bureaucratic rivalry and factional contention were fierce, corruption and rent seeking were constrained by the logic of regime survival. Likewise, local factions were not allowed to form territory-wide coalitions or to establish relationships with central-level politicians for fear that such a development would threaten the Kuomintang regime. This began to change with the end of martial law. The opening up of the authoritarian system unravelled a process in which old and new interests sought ways of constituting or reconstituting themselves in the emerging system. In particular, this occurred at a time when strongman Chiang Ching-kuo died unexpectedly, leaving a power vacuum in the ruling Kuomintang for bitter political struggle.

In his attempt to consolidate power, president Lee Teng-hui, an indigenous Taiwanese without strong political backing within the party, allied with Taiwanese business and local factions to combat his mainlander rivals in the Kuomintang leadership. He also sped up democratic reform to empower the elected legislature. In such a process, the authoritarian regime was opened up, but bureaucratic sectionalism and the local power structure remained intact and was even strengthened. It merely ended the arm's length relationship between government and business, as well as the confinement of spoliatory politics at the local level. Taking advantage of the anarchic interim, business groups, political factions and local interests strove to institutionalise themselves in the new regime. Locked in an internal power struggle, the Kuomintang lost its authority in disciplining party members. Incumbent parliamentary members sought local and business patronage to meet electoral competitions. It has become an era of spoliatory politics where 'gold and goons' dominated (Ngo 2002b).

When electoral competition became keener than ever, so did rent seeking. Election campaigns often involved huge expenditure for advertising, lavish banquets and, most important of all, vote buying. A coalition between local factions, national political parties and business conglomerates gradually emerged, with the former providing organisational power and the latter financial resources. During the 1989 legislature election, the first election after the lifting of martial law, about 40 per cent of the newly elected legislators received financial contributions from stock exchange houses, land developers and other businesses. The proportion of elected legislators with strong business backing rose sharply to two-thirds in the following election in 1992 (Shiau 1996). Lawmakers with business backing shunned their other 


\section{Tak-Wing Ngo}

legislative duties and focused almost exclusively on bills and budgets affecting the interests of their business patrons. They chose to participate in committees such as Economics and Finance that dealt with tax, land development and stock market issues. Factional leaders gained new access to government procurement and construction projects, benefited from 'porkbarrel' bills, and obtained easy loans from state-owned banks (Kuo and Tsai 1998: 174).

Recent studies show that corporate governance has worsened in financial institutions as a result of democratisation (Sato 2002). Bad loans increased sharply. This happened because democratisation loosened Kuomintang control over grassroots financial institutions such as farmers' associations and credit cooperatives. Local factions and business groups gained more control and influence over these public credit facilities. They increasingly turned these financial institutions into their own electioneering instruments. Management of credit facilities in these grassroots cooperatives became more arbitrary. At the same time, they also pressured the government to relax the criteria of setting up new banks. Newly set-up banks could then be used as a means to channel money to factional interests and to fund campaigns and vote buying during elections. Lending became more competitive which, together with the arbitrary management, resulted in the sharp increase in the number of bad loans.

As politics became a lucrative business, elections became more expensive, so spoils became bigger in compensation for the election costs. This had invited increasing criticism but it was the Asian financial crisis and the subsequent recession that directed popular grievances towards spoliatory politics. Taiwan suffered from relatively mild setback during the foreign exchange turmoil. Although the New Taiwan Dollar depreciated by about 20 per cent and the stock market lost one-fourth of its value, there was no economic crisis per se. However, it was the subsequent economic recession, rise in unemployment, and politicians' preoccupation with rent-seeking politics rather than economic recovery policies that raised popular discontent. The Kuomintang was increasingly being seen as closely associated with spoliation. Combating gold and goons became a major political issue during the 2000 presidential election. Eventually the Kuomintang lost the election and stepped down after half a century's rule in Taiwan.

The change of government did not bring about a substantial modification to the rules of the game. Although Chan Shui-bian won the presidency in the 2000 election, his Democratic Progressive Party held less than onethird of the seats in the legislature. Even with the electoral gain during the 2001 legislature election, the Democratic Progressive Party still could not command a majority in the chamber. The minority government failed to get enough parliamentary support to carry out radical reforms that might change the nature of spoliatory politics. Instead, the ruling party competed with the Kuomintang over business and factional resources in order to widen its own cronies and support bases. In doing so the Democratic 
Progressive Party increasingly dived into the same game that it used to criticise. Gold-and-goon politics was strengthened under the democratic process.

\section{Conclusion}

In retrospect, the opening-up of the authoritarian system in Taiwan did not automatically result in a liberal politico-economic order. Instead, a new type of oligarchic politics adapted to the electoral game emerged. The old oligarchic interests merely reconstituted and enmeshed themselves in the new system. As a result, spoliatory activities intensified. However, under the rules of the game, spoliation was exchanged for short-term support in running political office rather than for support in the pursuit of longer-term developmental goals.

While Taiwan has been hailed first as a successful case of the East Asian developmental state and then as an exemplar in democratisation, its trajectory of change shows that there is no direct and simplistic relationship between the triplet 'liberal democracy - good governance - development'. The structural logic that shapes the form of governance, developmental objectives and regime change derives from historically specific circumstances. This reminds us that good governance is far from merely a technocratic process involving nothing more than political transparency, electoral fairness, or rational coordination. Likewise, development is more than just the outcome of technocratic insulation, embedded autonomy and getting the policies 'right'. The Taiwan case starkly illustrates the capability of predatory politics to adapt to market liberalisation and political democratisation. It warns us against taking the face value of market reforms and democratisation too readily. The idea of the liberal triplet is a highly stylised and post hoc rationalisation of the historical outcome of advanced Western countries. It will be a gross misinterpretation of the complexity of reality if we treat the triplet uncritically as a universal yardstick of modernity.

\section{Bibliography}

Arnold, Walter (1989) 'Bureaucratic Politics, State Capacity, and Taiwan's Automobile Industrial Policy', Modern China 15, 2 (April): 178-214.

Buchanan, James M. (1980) 'Reform in the Rent-Seeking Society', in James M. Buchanan, Robert D. Tollison and Gordon Tullock (eds) Toward a Theory of the Rent-Seeking Society, Texas: A\&M University Press.

Chai, Ming-hui and Chang Mau-kuei (1994) 'The formation and transformation of local factions', Journal of the Institute of Ethnology, Academia Sinica 77 (Spring): 125-56.

Chen, Shin-ming S. et al. (1991) Disintegrating KMT-State Capitalism: A Closer Look at Privatizing Taiwan's State- and Party-Owned Enterprises, Taipei: Chenshe.

Cheng, Tun-jen (1993) 'Guarding the Commanding Heights: The State as Banker in Taiwan', in Stephan Haggard, Chung H. Lee and Sylvia Maxfield (eds) The Politics of Finance in Developing Countries, Ithaca: Cornell University Press. 


\section{Tak-Wing Ngo}

Chiang Kai-shek Archive, Special Documents, Economy, vols 10-13.

Chou, Tien-chen (1992) 'Small and Medium Enterprises in the Power Periphery', in Michael H.H. Hsiao et al. (eds) Dissecting the Taiwan Economy: Monopoly and Exploitation under the Authoritarian Regime, Taipei: Taiwan Research Fund.

Chu, Yun-han (1992) 'Oligopolistic economy and authoritarian regime', in Michael H.H. Hsiao et al. (eds) Dissecting the Taiwan Economy: Monopoly and Exploitation under the Authoritarian Regime, Taipei: Taiwan Research Fund.

(1994) 'The realignment of business-government relations and regime transition in Taiwan', in Andrew MacIntyre (ed.) Business and Government in Industrialising Asia, Sydney: Allen \& Unwin.

Chu, Pei-lien (1992) A Chronological Biography of Su Yun-Chang, Taipei: Institute of Modern History, Academia Sinica.

Council for U.S. Aid Archive, no. 31-00.49.02.

Minutes of the Council for U.S. Aid, various years.

Textile Sub-committee, Minutes of Meetings, various years.

Fields, Karl J. (1995) Enterprise and the State in Korea and Taiwan, Ithaca: Cornell University Press.

Forging the Future: An Oral history of the Teng-Eng Iron Co., 1940-1962 (1993) Oral History Series No. 49, Taipei: Institute of Modern History, Academia Sinica.

Haggard, Stephan (1990) Pathways from the Periphery: The Politics of Growth in the Newly Industrializing Countries, Ithaca: Cornell University Press.

Jacoby, Neil (1966) U.S. Aid to Taiwan: A Study of Foreign Aid, Self-Help, and Development, New York: Praeger.

Kuo, Cheng-tan and Tsai Tzeng-jia (1998) 'Differential Impact of the Foreign Exchange Crisis on Taiwan, Japan, and South Korea: A Politico-Institutional Explanation', Issues \& Studies 34, 11/12 (Novermber/December): 144-80.

Kuo, Shirley W.Y. (1983) The Taiwan Economy in Transition, Colorado: Westview Press.

Lai, Tse-han; Ramon H. Myers and Wei Wou (1991) A Tragic Beginning: The Taiwan Uprising of February 28, 1947, Stanford: Stanford University Press.

Li, Kuo-ting (1995) The Evolution of Policy Behind Taiwan's Development Success, 2nd edn, Singapore: World Scientific.

(1997) 'Reminiscences in the Thirtieth Anniversary of the Setting Up of Export Processing Zone by the Ministry of Economic Affairs', Industry of Free China 87, 3 (March): 144-80.

Li Kuo-ting Archive, B59-22.1.

Meaney, Constance Squires (1994) 'State Policy and the Development of Taiwan's Semiconductor Industry', in Joel D. Aberbach, David Dollar and Kenneth L. Sokoloff (eds) The Role of the State in Taiwan's Development, Armonk NY: M.E. Sharpe.

Ngo, Tak-Wing (1993) 'Civil Society and Political Liberalization in Taiwan,' Bulletin of Concerned Asian Scholars 25, 1 (January-March): 3-15.

- (1995) 'Business Encirclement of Politics: Government-Business Relations Across the Taiwan Strait,' China Information 10, 2 (Autumn): 1-18.

- (1998) 'Economic Intervention and Non-Intervention: The Ruling Strategies of Hong Kong and Taiwan Compared', Hong Kong Journal of Social Sciences 12 (Autumn): 1-16.

- (2001) 'State-led Development and State-sanctioned Rent Seeking in Taiwan', paper presented to the AAS Annual Conference, 22-25 March 2001, Chicago. 
(2002a) 'Characterising the State in Taiwan: Amorphous Politics and Functional Mutations in Episodic Agency'. Paper presented to the Conference 'Revisiting the Asian State', 28-30 June 2002, Leiden.

(2002b) 'Developmental Imperative and Spoliatory Politics: A Comparative Study of Mainland China, Taiwan and Hong Kong', in Luigi Tomba (ed.) East Asian Capitalism: Conflicts, Growth and Crisis', Milan: Feltrinelli Editore: 193-220.

The Reminiscences of Mr. Wei Yung-ning (1994) Oral History Series No. 3, Taipei: Academic Historica.

The Reminiscences of Mr. Wu Hsiu-chi (1992) Oral History Series No. 41, Taipei: Institute of Modern History, Academia Sinica.

Sato, Yukihito (2002) 'Democratization and Financial Reform in Taiwan: The Political Economy of Bad-Loan Creation', The Developing Economies XL, 3 (September): 226-51.

Shea, Jia-dong and Yang Ya-hwei (1994) 'Taiwan's Financial System and the Allocation of Investment Funds', in Joel D. Aberbach, David Dollar and Kenneth L. Sokoloff (eds) The Role of the State in Taiwan's Development, Armonk NY: M.E. Sharpe.

Shen, Yun-loong (1972) Draft Life Chronicle of Mr. K.Y. Yin, Taipei: Chun-chih Wen-Hsieh.

Shiau, Chyuan-Jeng (1989) The Neo-Mercantilism in Taiwan, Taipei: Institute of National Policy Research.

- (1996) 'Elections and the changing state-business relationship', in Hung-Mao Tien (ed.) Taiwan's Electoral Politics and Democratic Transition, Armonk NY: M.E. Sharpe.

Taiwan Production Board Archive, no. 4737.

- no. 033/1961/1.1.

no. 034/1962/1.1.

Tullock, Gordon (1980) 'Efficient Rent Seeking', in James M. Buchanan, Robert D. Tollison and Gordon Tullock (eds) Toward a Theory of the Rent-Seeking Society, Texas: A\&M University Press.

Winckler, Edwin A. (1988) 'Elite Political Struggler 1945-1985', in Edwin A. Winckler and Susan Greenhalgh (eds) Contending Approaches to the Political Economy of Taiwan, Armonk NY: M.E. Sharpe. 


\title{
11 The political economy of recovery in Indonesia
}

\author{
J. Thomas Lindblad
}

'Corruption in Indonesia has already become a habit and a culture of society. Therefore, apart from upholding the law, combating corruption must begin with changing cultural concepts' (Kompas, 5 September 2000). This observation, made by an expert on public administration at the Airlangga University in Surabaya, sounds simple enough and is likely to meet with approval from almost anybody who has ever done business in Indonesia. But to change cultural traits in a society is far more difficult than to reformulate economic policies. The present Indonesian government under President Megawati Soekarnoputri has embarked upon a relatively expansive macroeconomic policy accompanied by substantial budget deficits which as such already represents a radical turnabout compared to the restrictive balanced-budget policies recommended or imposed by the World Bank and the IMF only a couple of years ago. Economic policy-making has changed dramatically in a short span of time but are the roots of the problem being addressed? That is the underlying concern of this contribution about economics and politics in Indonesia both before and during the severe crisis that hit Indonesia in the late 1990s.

Two specific questions are of particular importance. The first one concerns the very fact that virtually all observers of the Indonesian economy, whether at home or abroad, were taken by surprise when the crisis hit Indonesia. How come the crisis was not foreseen? What does it tell us about our perception and understanding of a society experiencing sustained rapid economic growth - as Indonesia indeed did until the second half of 1997 ?

The second question refers to the management of the crisis situation and prospects for recovery. According to the latest statistics, both Thailand and South Korea, the other two severely hit countries, are staging a return to rapid growth and a remarkable recovery (Far Eastern Economic Review, 21 November 2002). Why is Indonesia lagging behind? Can it be attributed to the fact that the economic crisis developed into a social and political crisis in Indonesia but not in Thailand or South Korea? Or does the slow recovery imply that non-economic factors played, and still play, a more important role in Indonesia than in the other two countries? 
This chapter is divided into two parts. The first one offers a historical perspective by reviewing the prelude to the crisis, whereas the second one deals with the crisis years. However, the analysis presented here does not pretend to duplicate existing surveys of how the economic and political crisis unfolded in Indonesia (see, for example, Hill 1999; Simandjuntak 1999; van Dijk 2001; Booth 2002; Thee in Dick et al. 2002: 231-41). It is an account that does not focus exclusively on either economics or politics but explores precisely the relationship between the two. 'Good governance' is an important guiding concept. It is defined as consisting of three elements: rule of law, transparency and accountability. Its main purpose is "to build confidence and trust in the government, with the community, the business sector, and the investors' (Ananta 2001: 128). It is demonstrated below that good governance is a scarce and urgently needed commodity in Indonesia today.

\section{The long road to crisis}

In 1993 Indonesia was included among the eight Asian economies designated by the World Bank as 'highly performing'. The average annual rate of economic growth during the early 1990s exceeded 7 per cent, impressive enough although lower than the 9 per cent recorded for the late 1980s (World Bank 1993: 1; World Bank 1997: 2). In 1995, the manufacturing sector accounted for almost 25 per cent of the gross domestic product (GDP), up from 13 per cent in 1983, whereas the share of total employment found in agriculture had dropped from 55 per cent in 1982 to 44 per cent in 1995 (World Bank 1997: 153-5). Such statistics convey that a major structural transformation was taking place in the fast-growing Indonesian economy, a change away not only from agriculture but also from the traditional excessive dependency on unprocessed raw materials in favour of an increasingly important industrial sector producing for both the growing domestic market and foreign consumers. Observers generally agreed that the economic record of the Suharto administration was impressive, but conceded that social achievements were less substantial (Hill 1996: 191).

High annual growth rates at around 8 per cent were again reached in 1995 and 1996 and were forecast for 1997 as well. Meanwhile the yearly population growth rate had slackened to 1.7 per cent, down from 2.3 per cent in the 1970 s, so that a growth in per capita income of almost 6.5 per cent per year appeared within reach. Yet discontent was rising and ever more loudly voiced. Riots erupted in the streets of Jakarta in July 1996 following the Suharto administration's removal of Megawati Soekarnoputri from the chair of the democratic party, PDI (Partai Demokrasi Indonesia), in favour of a more docile leader. The political system evoked disillusionment and contempt more than anything else. Tales of corruption proliferated, especially when the children of the ageing president were involved. Nevertheless, as late as in May 1997, the World Bank still expressed its full confidence in the 'sound' macroeconomic policies of the Suharto administration and in a 
future perspective of continued rapid economic growth. Only in passing and in cautious wording did the World Bank economists refer to "the importance of good governance' (World Bank 1997: 131-2). Widespread political alienation and pervasive corruption were acknowledged but did not appear important in terms of determining the country's economic prospects. The World Bank report was released less than six weeks before the devaluation of the Thai baht and only four months prior to the first agreement between the Indonesian government and the IMF on a huge rescue package.

What went wrong? How come supposedly well-informed observers of the Indonesian economy were unable to predict the sudden and dramatic collapse which occurred in the second half of 1997 and the first half of 1998? During the crisis, a search for an explanation was undertaken by Lloyd Kenward, who had in fact served as a task manager for the World Bank team in 1997. Kenward argues that no warning signals emanated from the conventional macroeconomic or financial market indicators but that there were indications 'just below the surface' which could and should have been picked up. Structural or institutional weaknesses were exposed by successive policy slippages, scandals and personnel changes. Examples from the final year prior to the crisis included the national car scandal, a proposal for a national motorcycle, use of reforestation funds by Habibie's aircraft industry, the privatisation of excise tax collection in Bali, a gold mine scandal in Kalimantan, the bail-out of ailing banks by the central bank, and even monopoly practices in the printing of stickers for the Southeast Asian Games held at Jakarta in 1997 (Kenward 1999: 81-2). None of these incidents warranted much attention as such, but taken together they represented massive evidence that something was fundamentally wrong in the Indonesian economy even before the crisis hit.

Kenward's explanation in retrospect is interesting also from the point of view of methodology. Wrong conclusions were drawn not because the available evidence was wrong but because evidence of a different kind was overlooked. Observers were conditioned to concentrate on conventional macroeconomic indicators and structural developments rather than scattered microeconomic events on the level of individual firms and projects. There was much attention to statistics and economic trends but far less to persons and their mutual connections. A scarce exception was the work of the Australian political scientist Richard Robison. Already in 1986 he drew attention to the concentration of economic power in the hands of a small group of large business conglomerates that were more often than not controlled by well-connected Indonesians of Chinese descent (Robison 1986: 276-320).

There has been strikingly little research on the business conglomerates in Indonesia. Around 1990 a couple of surveys by private business firms identified the largest conglomerates in operation (CISI 1990; Data Consult 1991; Widyahartono 1993). Combined sales of the top 200 at the end of the $1980 \mathrm{~s}$ amounted to Rp.66 trillion (where 1 trillion $=1$ thousand billion) which 
corresponded to $\$ 28$ billion or slightly above one quarter of GDP. The top forty conglomerates were good for Rp.37 trillion or almost $\$ 16$ billion, whereas the top ten accounted for Rp. 21 trillion and the top five for Rp.16 trillion (see also Booth 1998: 320-1). Twenty-two conglomerates cited a turnover in excess of Rp.1,000 billion; of these, all but four were controlled by Indonesians of Chinese descent (Data Consult 1991: 26, 31). Between them, the 200 top conglomerates controlled almost 45,000 individual companies. The five largest business groups at the time were:

1 Salim or Waringin Kencana (annual turnover reported at Rp.8100 billion), controlled by Liem Sioe Liong, reputedly the richest man in Southeast Asia and a long-time associate of Suharto;

2 Astra International (Rp.2200 billion), founded and built up by William Soeryadjaya (Tjia Kian Liong);

3 Bank of Central Asia (Rp.1960 billion), actually a subgroup of the Salim concern;

4 Lippo (Rp.1800 billion), run by Mochtar Riady (Lie Mo Tie);

5 Sinar Mas (Rp.1800 billion), managed by Eka Tjipta Widjaja (Oei Ek Tjhong).

The scarce statistics on the top 200 conglomerates testify to an extreme degree of concentration of private business capital in the Indonesian economy. Under such circumstances, personal connections between leading businessmen and political power holders become all the more important. This suggests a systemic vulnerability to collusion and corruption that could, and indeed did, prove fatal in a crisis situation.

Kenward admits that more attention should have been paid to signs of structural weaknesses. Such signs often referred to cases of collusion between big business and the Suharto government. It is instructive to extend his line of argument beyond the few years immediately preceding the crisis. It then becomes clear that evidence of that kind was already in place around 1990. This is illustrated by several seemingly isolated incidents.

In early 1991 it became known that Bank Duta, a private bank with large deposits of foundations under Suharto's direct control, had lost $\$ 416$ million in the preceding year in foreign exchange speculations. A former vice president director went to jail but the bank was rescued by, amongst others, the business tycoon Panjogo Pangestu (Phang Djoen Poen), owner of the Barito Pacific conglomerate and a long-time associate of the president (Jakarta Post, 27 June 1991). This highlighted both the inadequate supervision by the central bank and the benefits to be reaped from an immediate access to the president.

A similar case, albeit with a very different outcome, followed in 1992 when Bank Summa, a subsidiary of Astra International, was liquidated. Losses over 1991 were cited at \$207 million, including a \$103 million loan from the Indonesian central bank, Bank Indonesia. Nevertheless, in July 
1992 Bank Summa was still eligible for new state-guaranteed loans at low interest rates. Only a couple of months later trading was ceased by the order of Bank Indonesia. There was no bailout as in the case of Bank Duta, but instead depositors were paid with money earned from the sale of the Soeryadjaya family's vast equity holdings in Astra International. It was rumoured that the non-political and non-corrupt public image of William Soeryadjaya precluded a bailout by the Indonesian government. The government's refusal to bail out Bank Summa effectively paved the way for a takeover of Astra International by Suharto cronies such as Liem Sioe Liong, Prajogo Pangestu and Henry Pribadi (Asian Wall Street Journal, 18 January 1993; MacIntyre and Sjahrir 1993: 12-16; Fane 1994: 30; Cole and Slade 1996: 136-7).

The liberalisation of the financial sector had begun in the late 1980s and soon gained momentum, but government supervision was lagging behind. In 1991, one stock brokerage firm, Wira Unggul Sekuritas, was even charged with swindling other brokers by using bad cheques (Business News, 24 January 1991). A major structural problem was the tendency among state banks in particular to extend very large loans to well-connected businessmen against low interest rates and with a minimum of collateral. In 1993 six out of seven state banks were found to have lent more than they were entitled to do. Such lending practices inflated the share of bad debts in total outstanding loan capital. Non-performing loans, a euphemism for failures to pay, were then estimated at 15 per cent of the total (Jakarta Post, 10 December 1993). One year later the proportion of 'problem loans', another euphemism for not paying, had risen to 18 per cent for state banks while the average for the entire banking sector amounted to 12 per cent (James 1995: 9).

The massive influx of foreign loan capital, both to state enterprises and to private firms, facilitated huge investments, especially in infrastructure and real estate. Even apart from the doubts about their profitability, there were two latent problems. One was the financing of long-term projects with shortrun loans, the other that revenues were likely to materialise in rupiahs whereas debts had to be repaid in foreign currencies. There was a built-in vulnerability to external disturbances in the foreign exchange market in the sense that a devaluation of the rupiah would have disastrous effects on capacities to honour obligations to foreign creditors.

In 1991 the Indonesian government published a list of 'mega projects' at a total cost of a staggering $\$ 79$ billion, most of which had to be taken up as loans abroad. The list met with severe criticism and the majority of the envisaged projects were labeled 'unaffordable' by Sumitro Djojohadikusumo, cabinet minister under both Sukarno and Suharto and doyen among Indonesia's economists (Muir 1991: 19). His warnings fell on deaf ears, and foreign creditors also failed to fully realise the potential risks of such commitments.

Suharto's six children came of age around 1990, and they all went into private business, often forging alliances with leading conglomerates. The 
Suharto children provided direct access to the president and the reins of political power in return for a substantial slice in the profits from the subsequent business ventures. A case in point is the petrochemical plant of Chandra Asri in Cilegon in West Java, a huge investment of $\$ 900$ million made by a Japanese consortium, acting in concert with Prajogo Pangestu and Bambang Trihatmodjo Bimantara, Suharto's second son. The investment project was controversial from its very start in 1992, not only because of the direct involvement of both the son and a close friend of the president, but also because the Japanese owner was permitted to hold 100 per cent of the equity in its Indonesian subsidiary in undisguised violation of the foreign investment regulations at the time (a relaxation of these rules occurred only in June 1994). In addition, the Indonesian government rendered direct support by furnishing $\$ 500$ million of the required investment funds through a credit from the state-owned Bank Bumi Daya (Hill 1992: 17).

Chandra Asri was designed to produce ethylene and propylene, used in hard plastics and cables. Shortly before production got underway in 1995 the firm requested protection from imports of ethylene and propylene into Indonesia. The request was turned down but resubmitted, and in January 1996 Suharto ordered a steep increase in import tariffs for precisely these two goods, an order that was contrary to simultaneous measures to liberalise Indonesia's foreign trade. Chandra Asri thus began producing under a protective umbrella that would have been unthinkable in the absence of powerful vested interests (Hobohm 1995: 29-30; James 1995: 32-4).

Suharto's youngest son, Hutomo Mandala Putra (Tommy), had already gained notoriety in January 1991 when his agency BPPC (Badan Penyangga dan Pemasaran Cengkeh, Body for Buffer Stock and Marketing of Cloves) was granted monopoly rights to purchase and distribute the cloves needed by Indonesia's cigarette industry. There was a public outcry since this favour was in obvious contradiction to the deregulation and liberalisation policies to which the Suharto government had committed itself in the late 1980s. Critics included the speaker of the Parliament and the secretary-general of the ruling Golkar party. Two years later, in 1993, BPPC obtained large credits from state banks at low interest rates despite an outstanding huge debt to Bank Indonesia (MacIntyre and Sjahrir 1993: 13).

Even more infamous was Tommy Suharto's involvement in the national car industry, one example of favouritism cited by Kenward. In 1993 an agreement was reached between the Humpuss group, controlled by Tommy, and the Korean car manufacturer Kia about the assembly of Kia cars in Cikampek in West Java. But the construction of the new factory in Cikampek met with long delays, whereas the Suharto government was eager to introduce the so-called national car, called Timor, in the Indonesian market. In 1996, the firm set up for this purpose, TPN (Timor Putra Nasional, National Son Timor), with Tommy Suharto in command, got permission to import 'national' cars assembled at the Kia plant in 


\section{J. Thomas Lindblad}

Korea without having to pay the mandatory 35 per cent luxury tax on motor cars produced by a foreign manufacturer using primarily foreign inputs. This flagrant violation of its own rules by the Suharto government set a 'very bad precedent'. Protests from Japanese, European and American car manufacturers in Indonesia translated into a case that was brought before the World Trade Organisation (WTO) in March 1997, which Indonesia predictably lost.

The story of the Busang gold mine was arguably the most dramatic incident of collusion between the Suharto family and private business interests. In late 1996, a small Canadian gold mining firm, Bre-X, claimed to have found gold reservoirs in Busang in Kalimantan. A controversy about possible foreign and domestic partners ensued, as Bre-X lacked sufficient means for a future exploitation. Two of the Suharto children, his eldest son Sigit Harjojudanto and eldest daughter Siti Hardijanti Rukmana (Tutut), were involved, together with Suharto's longtime associate Bob Hasan (The Kian Seng), whose business firm had benefited greatly from privileges in the logging industry in Kalimantan. There was a public outcry of indignation as many commentators failed to see why precisely these individuals should be entitled to share in the gains from the exploitation of the country's riches (McLeod 1997: 29-31). In the event, the geologist in question died under mysterious circumstances, the sample was proved to be a fake, and no gold was ever found. Financial losses were incurred by the Canadian investors but the loss of prestige was for the Indonesian government and the president.

Other examples could also be cited of business deals where members of the Suharto family secured unique and highly profitable privileges. In 1992 Bambang was given the monopoly for marketing oranges from Kalimantan, and in 1996 Suharto's young grandson Ari Sigit was entrusted with the exclusive right to collect excise taxes on beer in Bali. Others in the family were involved, too: for instance, Suharto's half-brother Probosutedjo, controlling the Mercubuana conglomerate, as well as his cousin Sudwikatmono of the Subentra group, known to sit on the boards of a very large number of private firms. With some exaggeration, Indonesia watcher Adam Schwartz claims that there was participation by members of the Suharto clan in almost every major infrastructure project in Indonesia (Schwartz 1994: 136). Soon after the fall of Suharto in May 1998, several accounts have been published about the extensive business interests of his family members (Tempo, 16 November 1998; Backman 1999: 260-86; Elson 2001: 278-80). In 1999 the total wealth of the Suharto family was estimated at $\$ 15$ billion (Time, 24 May 1999).

Perhaps the most cynical expression of the link between political power and private business interests was Suharto's initiative in early 1996 to set up a foundation, Yayasan Dana Sejahtera Mandiri (Autonomous Welfare Fund Foundation), ostensibly in order to skim off excessive profits in leading firms for distribution among millions of poor families. Board members 
included Suharto himself, Sudwikatmono, Bambang, Liem Sioe Liong and his son Anthony Salim, all - in the words of the critical press - 'known for their concern for the poor' (Jakarta Post, 23 December 1996).

The rise of the conglomerates, increasing collusion with the ruling elite and mounting foreign indebtedness are all sides of the same coin. The conglomerates could expand at breakneck speed because of their political connections and their access to cheap credit, in particular from the state banks. The expectation of government protection and guarantees, in the literature often referred to as 'moral hazard', added fuel to quick expansion and reckless lending abroad. This also came to the fore in the case of Bapindo, the state bank set up specifically for financing industrial projects. Already in 1995, Bapindo was considered technically bankrupt, although still functioning. The later deputy director of Bank Indonesia, Anwar Nasution, saw this as an indication 'that state-owned firms have been the milk-cows for corrupt high-ranking officials' (Nasution 1995: 6). Two episodes illustrate the path to disaster in Bapindo.

The first episode was the Golden Key scandal in early 1994. The Golden Key chain of department stores was counted among the top 200 conglomerates, and was controlled by Eddy Tonsil (Tan Tjoe Hong). Bapindo issued letters of credit for imports of goods that were never delivered and gave Golden Key a huge investment loan without collateral. When enormous losses were subsequently reported at Bapindo there was a public outcry. Several high-ranking Bapindo officials were arrested, an action unprecedented in the history of Indonesian state banks. In early 1995, Bapindo joined forces with Bank Bumi Daya in financing the takeover of Konindotex, a bankrupt cluster of textile factories. Beneficiaries included Bambang and the son of a former chief of central intelligence, who were able to settle the Konindotex debts of Rp.763 billion (\$355 million) with loans offered at extremely low interest rates (Fane 1994: 31; Nasution 1995: 19).

Even the central bank was not above suspicion. In May 1995, officials at Bank Indonesia were investigated on charges of collusion with troubled banks under their supervision. They had allegedly received a substantial amount of money from the debt-ridden Bank Perniagaan (Far Eastern Economic Review, 22 May 1995).

All these examples testify to an appalling lack of good governance in Indonesia during a relatively long period preceding the crisis of the late 1990s. Although it was a continuous long-term process, there seems to have been a change for the worse around 1993. Several indicators point in the same direction, including some conventional macroeconomic variables. Foreign indebtedness climbed from $\$ 81$ billion in 1993 to $\$ 136$ billion in 1997, an increase of 68 per cent in only four years. Meanwhile average corporate returns on assets dropped from 5.5 to 4.1 per cent whereas the excess of debts above equity in private firms rose from 100 per cent (i.e. twice as much debt as equity) to 130 per cent. The deficit on the current 


\section{J. Thomas Lindblad}

account of balance of payments, expressed as a proportion of GDP, increased from an average of 2.4 per cent over the years 1991-1995 to 3.3 per cent in 1996, which is the same as saying that Indonesian demand for foreign currency was rising faster than foreign demand for rupiahs (Hill $1999 ; 24,63,66)$. Corruption scandals proliferated and criticism of the prerogatives enjoyed by the Suharto family stiffened. External factors, such as the accelerated globalisation of financial transactions, clearly played a part, but the main explanation should probably be traced in the domestic arena.

The general elections in 1992 had been uneventful, despite persistent public criticism of corruption and manipulation. A new cabinet took office in March 1993, and here we find a number of significant personnel changes, again a factor, which Kenward mentioned in his retrospection in the midst of the crisis. An older generation of liberal economists, the so-called technocrats under the leadership of the highly respected Widjojo Nitisastro, was replaced by a younger generation, the so-called technologists, who strongly preferred selective state intervention in the name of a growth spurt above letting market forces decide. Significantly, the latter group was headed by B.J. Habibie, the ambitious minister for research and technology who enjoyed Suharto's special protection and almost unconditional support. There was almost immediate criticism on the part of the World Bank of the new cabinet's disregard of market-oriented liberalism, as evident in the tariff protection of the petrochemical industry, including the Chandra Asri case, and the strong emphasis on hi-tech projects in Habibie's own department. The former was in contradiction with the Indonesian government's commitment to liberalisation and deregulation, whereas the hi-tech projects were to be realised through use of financial resources outside the budget and parliamentary control.

Domestic criticism was harsh. Anwar Nasution spoke of an 'erosion of the soundness of Indonesia's macro- and micro economic management' (Nasution 1995: 5). Another critic was more elaborate, referring to an 'erosion of financial discipline, inertia, government, bureaucracy, monopolistic competition, high-cost economy, a negative impact of conglomerates on income distribution and domestic competition (Kompas, 6 May 1995). Meanwhile off-budget expenditures were rising at an alarming rate. New national priorities included a domestic aircraft industry, a bridge between Surabaya and Madura, and facilities for the generation of nuclear power. In August 1995, the maiden flight of the N-250 prototype produced by Habibie's IPTN (Industri Pesawat Terbang Nusantara, National Aircraft Industry) took place with much media coverage, but the whole matter was widely criticised as a huge waste of the taxpayers' money.

Looking back with the benefit of hindsight on the seven or eight years preceding the crisis, it becomes clear that the pattern of rapid economic growth in Indonesia was far less robust than what one might infer from conventional macroeconomic statistics. The evidence was not only in the 
realm of political economy. Statistics on social progress also point in a similar direction. It is well documented that the distribution of income, as expressed by the Gini coefficient, remained more or less constant in the long run in Indonesia, that is, gains from growth were distributed across income groups in even proportions (Hill 1996: 192). While often seen as a positive result, such an observation can equally well be interpreted as a failure of economic gains to generate relatively larger benefits for those most in need. In addition, more recent statistics convey that the distribution of income in fact deteriorated during the mid-1990s. The share of the poorest fifth of the population in total income dropped from 8.7 per cent in 1993 to 8.0 per cent in 1996, whereas the share of the richest fifth increased from 40.7 per cent to 44.9 per cent in the same years. The share of the richest 10 per cent rose especially fast and the top ten families in Indonesia were said to account for more than one-half of all corporate assets in the country (Smith 2001: 3). Just before the crisis, there was a widespread feeling that rapid economic growth really only benefited those who were well connected. A social crisis was pending.

This account of the road leading up to the crisis of the late 1990s in Indonesia has in particular demonstrated the fragility of a pattern of rapid economic growth characterised by institutional weaknesses and a want of good governance. It is appropriate to quote what two keen observers of Indonesian society and economy had written in mid-1996: 'With a very open capital account, Indonesia can be vulnerable to destabilising capital movements by sudden changes in investor confidence, the result of actual or potential (or even imaginary!) political crises' (Manning and Jayasuriya 1996: 11). These words were more prophetic than the authors could have imagined.

\section{How to manage a crisis}

The rupiah was floated on 14 August 1997 but economists, both at home and abroad, were still by and large convinced that Indonesia would not be as badly affected as Thailand. A cautious optimism prevailed throughout September and October 1997 when the government thought it was sufficient to call off a few mega-projects and initiate some reforms in the financial sector. The first agreement with the IMF, concluded on 31 October, offered a huge standby facility in return for promises to reform economic institutions, in particular in banking. The sixteen 'worst' banks were closed on the next day, including Bank Andromeda controlled by Bambang. But contrary to intentions and expectations, the bank closures triggered off a massive capital flight. Confidence in the Suharto government's capability to handle the crisis was further eroded when Bank Andromeda reappeared in the guise of Bank Alfa. Suharto's intention actually to implement the reforms imposed by the IMF was clearly at best half-hearted.

Then came the free-fall of the rupiah, to one-third of its pre-crisis value by December 1997 and for a moment even less than one-fourth in January 


\section{J. Thomas Lindblad}

1998. Rioting broke out, often with ugly anti-Chinese undertones. The IMF expressed grave dissatisfaction with the progress of reforms and the highly unrealistic new budget presented by the Suharto administration. A second agreement with the IMF was deemed necessary to force compliance upon the Indonesian government. The agreement was signed by a visibly apprehensive president on 15 January 1998. The Indonesian government was anew committed to further deregulation, including dismantling monopoly constructions such as the BPPC's for cloves and that held by the national logistics agency, Bulog (Badan Urusan Logistik), for the distribution of vital foodstuffs.

By early 1998 there was a growing awareness that the severity of the crisis in Indonesia could not be attributed only to contagion, that is to the spillover effects of the financial crisis in the wider region of East Asia. Other explanations were required as well. The macroeconomic fundamentals were far less sound than what most observers had believed and there was something wrong with the political fundamentals, especially governance (Soesastro and Basri 1998: 5-6). When comparing Indonesia to neighbouring countries, it became tempting to establish a direct correlation between the extent to which good governance prevailed and the severity of the crisis (Backman 1999: 4).

The financial crisis in Indonesia deteriorated into a general economic crisis and again a warning signal was sounded by Sumitro Djojohadikusumo. He wrote: 'if the government is reluctant to fully implement the reform, the economic recession may turn into a depression from which it would take a long, painful period of time to recover' (Jakarta Post, 12 January 1998). These words too were to prove true.

Matters soon went from bad to worse in early 1998. Suharto deliberately defied international opposition and distrust with his choice of Habibie as vice president and the installation of a new controversial cabinet including both his own daughter Tutut and his crony Bob Hasan. There was a breakdown in effective macroeconomic policy while student protests and food riots gathered momentum. Reforms were slow in forthcoming or took place only on the surface. The BPPC monopoly, for instance, disappeared as scheduled but reappeared in the form of a new partnership between cloveproducing cooperatives that in turn were under the control of Tommy Suharto (Jakarta Post, 24 February 1998). The IBRA (Indonesian Bank Reform Agency) had been created in late January 1998 but not until April 1998 were seven of the most troubled banks closed, whereas 54 other banks were placed under supervision. Again, the measure backfired. Depositors withdrew their capital and transferred it abroad. A banking reform would clearly only work in a conducive general economic and political climate.

The lack of confidence about the capability of the Suharto administration to guide Indonesia out of the severe crisis prompted yet another agreement with the IMF. As a matter of fact, more than five months of IMF dissatisfaction had led to a continuous deferral of the actual disbursement 
of promised rescue funds. The third agreement was concluded on 10 April 1998 reiterating the urgent need for structural reform as well as the necessity of restrictive, austere fiscal and monetary policies. It was widely seen as Indonesia's last chance to come to terms with the IMF. Abolition of monopolies such as the one enjoyed by the BPPC was reaffirmed but, again, Tommy Suharto found a shrewd way of circumventing the reform (Jakarta Post, 25 April 1998). In a similar fashion he was formally dissociated from the management of TPN, but was said to continue exercising control over the national car programme behind the scenes.

Politics overtook economics with the dramatic events in May 1998 that left an unknown number of victims of the rioting and looting in the streets of Jakarta and forced Suharto to step down (see, further, Forrester and May 1999; Mietzner 1999; van Dijk 2001: 185-216; Elson 2001: 289-93). A run on the country's largest private bank, BCA, brought the bank to a nearcollapse and aggravated the capital flight from Indonesia. On 25 June 1998, Habibie, the new president, reached an accord with the IMF and the fourth agreement was signed a few weeks afterwards. Bank restructuring was reaffirmed and a separate body, INDRA (Indonesian Debt Restructuring Agency), was established. The IMF now finally allowed for a more expansive fiscal policy causing a large deficit on the government budget. It was then almost a year after the crisis had begun and much precious time had been lost.

The year 1998 was the worst peacetime year in terms of economic performance in modern Indonesian history. GDP growth became negative. National income actually fell by 13.7 per cent, a decline within one year of the same magnitude as the decline in national income during the entire depression in the 1930s. Open unemployment increased and millions of families shifted from just above to below the official poverty line (Simandjuntak 2000: 58-65; Thee in Dick et al. 2002: 237-9). Investment came to a virtual standstill and the exchange rate of the rupiah stabilised at about one-third of its pre-crisis level.

Reviewing the first year of crisis, from August 1997 to July 1998, it is clear that the policies adopted failed to turn the tide. Some commentators, especially in Indonesia, have tended to blame the IMF. Hal Hill's examination of IMF recommendations, however, demonstrates that the IMF may have given unguided advice and also paid undue attention to institutional weaknesses, but that it would be a mistake to make the IMF shoulder the main responsibility for the severity of the crisis (Hill 1999: 78-80). It is likely that the slow disbursement of rescue funds did more harm to the prospects for recovery than any policy action recommended by the IMF.

In an authoritarian system of highly centralised political power as existed in Suharto's Indonesia, the personality of the president becomes crucial, especially in times of crisis. Two quotations from Indonesian observers in early 1998 are illuminating. The first one is from a businessman: 'The problem is he doesn't seem to listen to anyone any more. A feeling of helplessness prevails. 
You can't do anything any more.' The second one is from a political commentator: 'There has been a real change in his political behaviour' (Far Eastern Economic Review, 22 January and 26 February 1998; see also Elson 2001: 293-4). The ultimate proof that Suharto had lost touch with reality was his flirtation, in February 1998, with the idea of a currency board system that would guarantee a fixed exchange rate at the cost of an enormous drain on the country's reserves but that might remain in force just long enough for the assets of the Suharto clan to be converted into foreign currencies at an attractive rate of exchange (Hill 1999: 112-13).

Policies for crisis management were from the very start accompanied by conflicting signals from Suharto. The closure of the sixteen banks in compliance with the first IMF agreement was followed by the discrete rescue of several investment projects controlled by family members and associates of the president. The agreement with the IMF in January 1998 was similarly followed by controversial appointments and an overt defiance of IMF recommendations. Such behaviour had devastating effects on investor confidence, both among cronies, who did not know if they would continue to enjoy preferential treatment, and among those who had not been favoured in the first place (Haggard and MacIntyre 1999: 16-19). This became a vicious circle. Loss of investor confidence meant capital flight, which pushed the value of the rupiah down and which in turn was seen as a sign of failure in government policies. It became obvious that there would be no recovery in Indonesia as long as Suharto remained in power. The president himself had become part of the problem.

Dealing with the huge foreign debt was one of the most urgent concerns of the Habibie administration. By September 1998, total foreign indebtedness exceeded $\$ 140$ billion, almost the same amount as in December 1997 (Soesastro and Basri 1998: 37; Hill 1999: 57). Restructuring was complicated due to the large numbers of persons and enterprises involved, about 800 individual borrowers and 400 foreign creditors. Aided by an agreement with major Western creditors in early June 1998, the newly established INDRA attempted to convert short-run loans into loans that would only mature after eight or more years. But INDRA met with vehement opposition from owners of banks in trouble. There was also much confusion since the debt restructuring was intimately connected with an accelerated privatisation of state-owned enterprises such as Telkom, Indosat, the Gresik cement factory, Krakatau steel, various mining establishments and the management of toll roads, port facilities and airports (Evans 1998: 13-14). In November 1998 the failure of INDRA prompted the so-called Jakarta Initiative that facilitated direct negotiations and settlements between domestic debtors and foreign creditors. By mid-1999 the Jakarta Initiative covered 330 debt-ridden Indonesian firms, but these firms accounted for less than one-third of total foreign private debt (Fane 2000: 37; van Dijk 2001: 297).

The second crisis year, 1998/99, was the year of reformasi, when even president Habibie and his cabinet ministers adopted the reformist zeal. 
Despite much confusion and recurrent criticism about slow progress, the workings of IBRA and INDRA did considerably enhance transparency in corporate Indonesia. A badly-needed new bankruptcy law, to replace the existing one inherited from the Dutch colonial period, was approved in August 1998, but by November of the same year only three bankruptcies had been declared. Numbers were to increase substantially in late 1998 and throughout 1999, but only one-fifth of the cases were won by the creditors. The judiciary was said to suffer from 'governance problems', a euphemism for blunt corruption (Fane 2000: 35-6). What really mattered when introducing good governance in the Indonesian economy was not so much new laws and regulations but the way in which they were enforced and implemented.

The dismantling of monopoly positions in the economy was often retarded by vested interests. One notorious example was the logistics agency BULOG, where the reform of distribution networks was complicated by rumours that the very officials entrusted with implementing reform were themselves exporters of food who would benefit from the higher international prices in a liberalised market. There seemed to be a real danger of merely shifting collusion from one network to another when trying to reform the system. A similar discussion also applied to the new legislation on decentralisation that transferred substantial authority from the central government in Jakarta to the provinces. New practices of collusion, corruption and nepotism, known by the Indonesian acronym KKN, were feared at the regional or local level that would result in a reappearance of the familiar problem of the 'high-cost economy', a euphemism used by the World Bank (David Ray in Ramstetter 2000: 22).

By the time of the special session of the Indonesian legislative assembly MPR (Majelis Permusyawaratan Rakyat) in November 1998, disillusionment with the Habibie administration was already widespread and the deliberations were accompanied by violent riots and casualties among demonstrating students. The MPR passed several general decrees to combat KKN (korupsi, kolusi, nepotism) and promote good governance. It also called for an investigation of Suharto and his family on corruption charges that in the event came to focus on Tommy Suharto, whereas Suharto himself was considered too feeble for interrogation. Habibie, who literally owed his ascendancy to power and prominence to Suharto, was little inclined to push forward with the investigation of the former president. This merely reaffirmed that Habibie was too strongly associated with the preceding administration to become an effective reformer. He was above all seen as a transitional figure whose main task it was to pave the way for a new president and a new type of government in Indonesia.

The first half of 1999 brought some positive signals, although overall prospects deteriorated due to increasing regional violence. The budget released in January 1999 was a far cry from the one presented one year before in its realistic assessment of the arduous road to recovery. Meanwhile 
the number of banks operating in Indonesia had shrunk from 237 to 179, of which 35 were in the process of rehabilitation. IBRA estimates of the funds needed for a full recapitalisation amounted to a staggering $\$ 44$ billion. This was a steep increase from the original estimate at about $\$ 25$ billion and total estimates were to rise even further (Pardede 1999: 25-6; Adiningsih 2001: 181). The most powerful indication of change, however, was the peaceful and democratic elections held on 7 June 1999 when Megawati Soekarnoputri's opposition party, renamed PDI-P (Partai Demokrasi Indonesia Perjuangan, Indonesian Democratic Party for Struggle), gained the upper hand over Habibie's ruling Golkar party.

Habibie's prospects of clinging on to the presidency vanished altogether in September and October 1999 in the wake of the bloodshed in East Timor and the Bank Bali scandal. Auditing by an international bank brought to light that payments amounting to Rp.546 billion ( $\$ 80$ million) had been made by Bank Bali to individuals connected with the Golkar party. Both IBRA and Habibie were seriously implicated, and the whole incident was widely seen as yet another proof that the Habibie administration was not equipped to undertake reform and improve governance in Indonesia's public institutions (Booth 1999: 5--6; Simandjuntak 2000: 67-9; van Dijk 2001: 417-30).

In a most extraordinary sequence of events, the nearly blind Abdurrahman Wahid was elected Indonesia's fourth president during the MPR session of October 1999, thereby bypassing Megawati Soekarnoputri who had to content herself with the vice presidency (see, further, Mietzner 2000; van Dijk 2001: 461-8). There was great optimism, both at home and abroad, instilled by Wahid's impeccable reputation as a Muslim leader and intellectual and the very fact that he had been no part of Suharto's ruling elite. Signs of a cautious recovery included a modest economic growth in real terms and less inflation, but the optimism was dampened by the slow progress in debt and bank restructuring. Bank Mandiri had been formed by a merger between four state banks (Bapindo, Bank Exim, Bank Dagang Negara and Bank Bumi Daya), but the value of its assets remained doubtful (Jakarta Post, 26 January 2000). Criticism was levied at the recapitalisation programme, as it only appeared to favour rich banks (van Dijk 2001: 406). Returns from the sale of appropriated assets were often disappointing, as, for instance, in the case of the government's 30 per cent equity share in BCA (McLeod 2000: 24-6).

Economic policies under Wahid during 2000 and the first half of 2001 were fragmented and increasingly erratic. One obvious explanation is that the Wahid cabinet represented a very broad spectrum of political parties that all had to be appeased. Another refers to frequent personnel changes. By June 2000, scarcely more than half a year after the new cabinet had been formed, five cabinet ministers had already been dismissed and even one of the replacements was no longer in function. In addition, policy-making was hampered by a drawn-out conflict between president Wahid and Sjahril 
Sabirin, governor of Bank Indonesia, which eventually led to the latter's detention. The relationship between Wahid and parliament deteriorated successively, especially after August 2000 when the president was warned that he would be impeached if he did not improve his behaviour. The disappointing economic performance over the year 2000 was widely ascribed to political uncertainties.

Wahid's credibility as a reformer received a serious blow in mid-2000 by a scandal about payments made from Bulog's staff pension funds to private individuals. Compared to similar cases in the Suharto period, the amount of money was small, only Rp.35 billion ( $\$ 4$ million), but the president was personally involved through his masseur, who had allegedly acted as an intermediary (McLeod 2000: 7). Whatever the truth of the matter may be, the episode illustrates an important heritage from the Suharto regime, that is that proximity to the president alone could render authority to irregular payments. Wahid was quickly losing support, even among his most militant followers (van Dijk 2001: 493-520). In July 2001 he was removed without much further ado by the MPR and replaced by Megawati Soekarnoputri, the fourth person to serve as Indonesia's president in little more than three years. Political stability has since been restored and there is much confidence in the economists entrusted with the country's recovery from crisis. Yet it is too early to assess the accomplishments of her administration, especially with regard to institutional reform and governance.

This account of crisis and attempts at recovery has above all demonstrated how factors in the sphere of political economy hampered crisis management and made recovery policies largely ineffective. The fall of Suharto in May 1998 was a watershed in modern Indonesian history, not because Indonesian institutional culture changed overnight but because Indonesia finally embarked upon the long and difficult road of reforming its institutions. The reformasi movement as such has not changed the system, but it did at least identify the criminality of public institutions and make clear that change was necessary (Tim Lindsey in Ramstetter 2000: 9). So far the process of institutional change has been chaotic and haunted by bottlenecks, including the possible creation of new forms of collusion, corruption and nepotism as the power-holding elite changed shape and relations between centre and periphery were altered as well. Warnings were already being sounded within months after the Wahid administration took office (Jakarta Post, 5 January 2000).

\section{Conclusion}

Why was the crisis in Indonesia unforeseen? Why has Indonesia lagged behind in recovering? There is a simple common answer to both questions: a lack of good governance. The foundation of rapid economic growth in Suharto's Indonesia was less robust than it seemed. Supposedly sound macroeconomic fundamentals drew attention away from institutions that 


\section{$262 J$. Thomas Lindblad}

had been weakened by sustained corruption, collusion and nepotism. That is why observers failed to foresee the crisis and also why the crisis hit Indonesia more severely than it did any other country in East Asia.

But political economy also played a prominent part in the Indonesian government's effort to handle the crisis and steer the economy out of the deep recession. Almost a full year of precious time was lost by a crisis management that became ineffective because of the prevailing lack of good governance. Reform and recovery since May 1998 have presented exceedingly difficult challenges to three consecutive post-Suharto administrations, again because of the heritage from an essentially corrupt regime. The weakness of institutions has proven highly resilient in both good and bad times, but by consistently focusing on reform, Indonesia at long last appears to be on the right track.

\section{Bibliography}

Adiningsih, S. (2001) 'Restructuring the banking system: Indonesia's challenge', in A.L. Smith (ed.), Gus Dur and the Indonesian Economy, Singapore: Institute of Southeast Asian Studies: 174-83.

Ananta, A. (2001) 'Policies for sustainable economic development in Indonesia', in A.L. Smith (ed.), Gus Dur and the Indonesian Economy, Singapore: Institute of Southeast Asian Studies: 116-37.

Backman, M. (1999) Asian Eclipse: Exposing the Dark Side of Business in Asia, Singapore: Wiley.

Booth, A. (1998) The Indonesian Economy in the Nineteenth and Twentieth Centuries: A History of Missed Opportunities, London: Macmillan.

- (1999) 'Survey of recent developments', Bulletin of Indonesian Economic Studies $35(3): 3-38$.

_ (2002) 'Growth collapses in Indonesia: A comparison of the 1930s and the 1990s.' Paper presented at the XIIIth International Economic History Congress, Buenos Aires, 22-26 July.

CISI (1990) A Study of Top-200 National Private Business Groups in Indonesia, 1989, Jakarta: CISI Raya Utama.

Cole, D.C. and B.F. Slade (1996) Building a Modern Financial System: The Indonesian Experience, Cambridge: Cambridge University Press.

Data Consult (1991) Anatomy of Indonesian Conglomerates, Jakarta: Data Consult.

Dick, H.W. et al. (2002) The Emergence of a National Economy: An Economic History of Indonesia, 1800-2000, Crows Nest, NSW: Allen \& Unwin.

Dijk, K. van (2001) A Country in Despair: Indonesia between 1997 and 2000, Leiden: KITLV Press.

Elson, R.E. (2001) Suharto: A Political Biography, Cambridge: Cambridge University Press.

Evans, K. (1998) 'Survey of recent developments', Bulletin of Indonesian Economic Studies 34 (3): 5-36.

Fane, G. (1994) 'Survey of recent developments', Bulletin of Indonesian Economic Studies 30 (1): 3-39.

(2000) 'Survey of recent developments', Bulletin of Indonesian Economic Studies $36(1): 13-45$. 
Forrester, G. and R.J. May (eds) (1999) The Fall of Soeharto, Singapore: Select Books.

Haggard, S. and A. MacIntyre (1999) 'The politics of moral hazard: The origins of financial crisis in Indonesia, Korea and Thailand', ICSEAD Working Paper Series 99-14, Kitakyushu: International Centre for the Study of East Asian Development.

Hill, H. (1992) 'Survey of recent developments', Bulletin of Indonesian Economic Studies 28 (2): 3-41.

— (1996) The Indonesian Economy since 1966: Southeast Asia's Emerging Giant, Cambridge: Cambridge University Press.

- (1999) The Indonesian Economy in Crisis: Consequences and Lessons, Singapore: Institute of Southeast Asian Studies.

Hobohm, S. (1995) 'Survey of recent developments', Bulletin of Indonesian Economic Studies 31 (1): 3-40.

James, W.E. (1995) 'Survey of recent developments', Bulletin of Indonesian Economic Studies 31 (3): 3-38.

Kenward, L.R. (1999) 'Assessing vulnerability to financial crisis: Evidence from Indonesia', Bulletin of Indonesian Economic Studies 35 (3): 71-95.

MacIntyre, A. and Sjahrir (1993) 'Survey of recent developments', Bulletin of Indonesian Economic Studies 29 (1): 5-33.

McLeod, R.H. (1997) 'Survey of recent developments', Bulletin of Indonesian Economic Studies 33 (1): 3-43.

- (2000) 'Survey of recent developments', Bulletin of Indonesian Economic Studies 36 (2): $5-41$.

Manning, C. and S. Jayasuriya (1996) 'Survey of Recent Developments', Bulletin of Indonesian Economic Studies 32 (2): 3-43.

Mietzner, M. (1999) 'From Soeharto to Habibie: The Indonesian armed forces and political Islam during the transition', in G. Forrester (ed. ), Post-Soeharto Indonesia: Renewal or Chaos?, Singapore: Institute of Southeast Asian Studies: 65-102.

- (2000) 'The 1999 general session: Wahid, Megawati and the fight for the presidency', in C. Manning and P. van Diermen (eds), Indonesia in Transition: Social Aspects of Reformasi and Crisis, Singapore: Institute of Southeast Asian Studies: $39-57$.

Muir, R. (1991) 'Survey of recent developments', Bulletin of Indonesian Economic Studies 27 (3): 3-27.

Nasution, A. (1995) 'Survey of recent developments', Bulletin of Indonesian Economic Studies 31 (2): 3-40.

Pardede, R. (1999) 'Survey of recent developments', Bulletin of Indonesian Economic Studies 35 (2): 3-40.

Ramstetter, E.D. (2000) 'Survey of recent developments', Bulletin of Indonesian Economic Studies 36 (3): 3-47.

Robison, R. (1986) Indonesia: The Rise of Capital, North Sydney: Allen \& Unwin.

Schwartz, A. (1994) A Nation in Waiting: Indonesia in the 1990s, Sydney: Allen \& Unwin.

Simandjuntak, Dj.S. (1999) 'An inquiry into the nature, causes and consequences of the Indonesian crisis', Journal of the Asia-Pacific Economy 4: 171-92.

(2000) 'The Indonesian economy in 1999: Another year of delayed reform', in C. Manning and P. van Diermen (eds), Indonesia in Transition: Social Aspects of Reformasi and Crisis, Singapore: Institute of Southeast Asian Studies: 58-76. 


\section{J. Thomas Lindblad}

Smith, A.L. (2001) 'Abdurrahman Wahid's economic agenda: The views of leading decision-makers and commentators', in A.L. Smith (ed.) Gus Dur and the Indonesian Economy, Singapore: Institute of Southeast Asian Studies: 1-24.

Soesastro, H. and M. Chatib Basri (1998) 'Survey of recent developments', Bulletin of Indonesian Economic Studies 34 (1): 3-54.

Widyahartono, B. (1993) 'Konglomerat: Antara teori dan realitas', in Kwik Kian Gie (ed.), Konglomerat Indonesia: Permasalahan dan Sepak Terjangnya, Jakarta: Sinar Harapan.

World Bank (1993) The East Asian Miracle: Economic Growth and Public Policy, Washington, DC: World Bank.

(1997) Indonesia: Sustaining High Growth with Equity, Washington, DC: World Bank. 


\title{
12 China's transition to industrial capitalism

\author{
Tracking institutional reform
}

\author{
Henk Houweling
}

In 1976 three prominent leaders of the Maoist revolution passed away, well pampered and peacefully. The departure of Zhou Enlai, of veteran Marshall Zhu and of Mao opened the gate for reformers to step in. Who were the new leaders that entered through that door? What have been their policies? And what has been achieved in terms of institutional change?

This chapter studies the reform era in the People's Republic of China (PRC). Why did China enter into the era of reform, and why in 1978? To explain the catching-up by Japanese enterprises in the ability to design, produce and sell worldwide branded manufactured products with those in countries that industrialised first, scholars have invented the notions of a 'developmental state' and of a 'governed market'. After having achieved victory in 1949, the newly-proclaimed PRC moved into a different track of development, probably best known for its communal system of agriculture, which was introduced in 1957-1958. However, in the Maoist era, China was transformed from an impoverished and war ravaged peasant society into an industrial economy.

Since the beginning of the Deng reforms in 1978, the rate of growth of GDP increased from an annual average of 3.6 per cent in the 1970 s to 8.2 per cent between 1980 and 1990 and to 11.4 per cent between 1990 and 1994. The savings ratio in that latter year is reported to be 42 per cent. In 1998, the contribution of agriculture to GDP had fallen to 21 per cent. Foreign markets are penetrated with textiles, shoes, toys, furniture and electronic products such as DVD players, even though in 1998 China's share in world exports of goods and services was just 3 per cent.

Is reforming China re-inventing the developmental state, imitating Japan, South Korea, the Taiwan province of China and Singapore in this respect? To anticipate the argument: that is not the case. In 1998, the PRC is in terms of value-added created by industry the most industrialised country of the world. Despite its high level of industrialisation, the PRC is classified by the World Bank as a 'low income economy'. Ranked on the basis of GNP per capita, China in 1999 takes position 149 out of 181.

A note of caution applies throughout this chapter. The complexity and diversity of the topics under study, the enormous size and diversity of the 
country, the inequality between the coastal areas and the interior, the sheer speed of change and its multivariate nature, pose just so many threats to the reliability and validity of one's judgments. What do averages say in a country as unequal in development as China? China's Far West is as large as Australia, though with a population of about 370 million. These people subsist on average on a third of the per capita income of coastal China. Extreme poverty is the rule in landlocked provinces like Guizhou and Gansu, where per capita income is estimated at about 8 per cent of Chinese living in Shanghai. In addition, Chinese terminology about reform is ambiguous, suggesting continuity by hiding radical change. Steinfield (1998: 10) asserts:

One of the geniuses of Chinese economic reform has always been the tendency to blur semantic distinctions and sidestep inflammatory labels. China is a socialist nation, yet one with a vast non-state sector. It is a nation with few 'private firms', but millions of 'non-state' firms. The country maintains 'public ownership' over industrial assets, but not necessarily 'state ownership'. State firms are owned by 'the people', yet in many cases sell shares to individuals in Shanghai, Szenzhen, New York and Hong Kong.

This chapter is organised as follows. The following section highlights social leftovers from previous history. Social transformations are not written on a blank sheet, and the hand that writes has a memory. New forces released in society that produce institutional change, interact with 'givens' from the past. The next section is an effort to explain transitions, using political theory and facts about social change in the PRC. Finally, institutional change in China is analysed, using property rights as a criterion.

\section{Historical leftovers and their impact on China's transition}

The Chinese people have the longest history in sharing an uninterrupted political community. In Agrarian Aristocratic Empires, such as Imperial China, the political elite around the emperor offers protection to peasants against less developed nomadic tribesmen, against the hazards of nature and against the wrath of heaven. In external politics, agrarian empires do not border on equals. Empires are therefore not integrated into a system of inter-state relations.

The history of Western political thought has a tradition in which social scientists compare the European inter-state system with Agrarian Aristocratic Empires and the potentials for autonomous development of both systems of authority. The institutional pattern of Imperial China has been characterised by Marx as an example of the 'Asiatic mode of production'. Marx argued why societies in which that mode of production prevailed were incapable of development. Without the stimulus of an external force from capitalist societies, 
empires get stuck at a rather low level of the development of forces of production. The function of colonialism is therefore to destroy imperial institutions and to introduce industrial capitalism from the outside. Weber considers Imperial China as 'prebendalist', which is a decentralised form of empire. In such systems functionaries of the court have a legitimate right to intervene in society as well as a title to a stipend levied on peasants. Weber sees Asian Empires to be richer than the feudal society of early modern Europe.

The legacy left behind by vanished empires is very different from the social foundations created in the era of mercantile capitalism in the West. China did not experience the institutional transformation of state and society induced in Europe's mercantile era by trade and overseas expansion. In China, the legacy of empire did go on nationwide display in the summer of 1988. A mass audience viewed on television several instalments of the documentary 'Lamentation of the Yellow River'. Created by young Chinese academicians, millions of Chinese compared Imperial history with the history of expanding Western society. They could see images of Smith, Hegel, Marx and many others, hearing their comments on why Imperial China had fallen behind the West and become victimised by it. The implication was clear to them: the Chinese Communist Party is the successor to the Imperial Throne. The following year, some of the people who had watched this television series were crushed on Tian'anmen Square. The nationwide attention evidences the great awakening underway among the Chinese people. In the short history of China's national consciousness, the series may be compared with the 4 May Movement.

\section{The legacy of the commune}

After having defeated Japan and the Kuo Min Tang (KMT), the Maoist leadership faced the task of transforming a war-ravaged and impoverished peasant society into an internationally capable and prosperous entity. The question to be answered was how to catch up in wealth and power with countries that industrialised before China did. The revolutionary leadership agreed that survival required industrialisation: 'We first carried out the land revolution, then the socialist transformation. These two revolutions are only means, the ultimate goal is to pave the way for China's industrialisation' ${ }^{1}$ Its consensus, however, did not imply agreement on how to achieve that aim.

Using party archives, Qing (1999) pictures two very different understandings in the party leadership of the economic organisation required for industrialising China. She connects the assumptions of these understandings to two cultural traditions of the Chinese Empire. The first tradition is summarised as one of mutual benefit and of 'complementarity', while the other one is characterised as one of 'antagonistic contradiction'. The first one would give rise to a mixed economy concept of a 'private economy with public guidance'. The other one relies exclusively on conflict, which should be resolved by public sector dominance. 


\section{Henk Houweling}

Between 1949 and 1955, the economic policy of the Chinese Communist Party (CCP) operated upon the 'mixed economy' concept. The mixed economy is somewhat comparable with Bukharin's New Economic Policy in the Soviet Union before Stalin took over in 1928, although in China, instead of an improvisation, the mixed economy was the leadership's choice. In the countryside the mixed economy built on pre-war reality, as the CCP did not inherit a 'feudal' agriculture. On the eve of World War Two ' $t$ there were no large domains managed by a landed nobility and no serfdom. [...] Holdings larger than 67 ha. were only 2 per cent of the land. Land could be bought and sold freely.' However, in the 1930s rent took away 43 per cent of the crop of tenants (Maddison 1998: 69). Such a share leaves little residual for the tenant farmer and points to conflict. Reflecting on both traditions, Qing (1999: 28-9) quotes the Chinese Deputy Premier and Minister for Agriculture, who commented in February 1953: 'We must protect two different kinds of rural initiatives and enthusiasm'; one was 'poor peasants' enthusiasm for mutual aid and cooperatives', the other being 'individual farmers' enthusiasm for individual farming and private land ownership'. She reviews the challenge by poor peasant activists to the mixed economy and refers to Mao's fear of rural instability due to a rising gap in income between rich and poor in the countryside.

After Mao gradually turned away from the mixed economy approach, the drastic step was taken in 1958 towards the formation of 26,000 giant communes out of 123 million peasant households. This radical change builds on the conflict tradition in China's rural life and its culture, but the formation of communes was not uncontested in the leadership. The intense debate in the party in the late 1950s basically comes down to making a

choice between favouring an approach to development either on the basis of providing all a free but equally meagre meal prepared in communal kitchens, or reliance on private entrepreneurs whose efforts translate into different people enjoying unequally sized dinners, prepared in private households and restaurants. Preferences in that choice hide the more important debate about how to connect agriculture and its peasants in the countryside to urban-industrial development in such a way as to promote the best rate of growth in both sectors. It took till the Eighth Party Congress of May 1958 to 'overturn the gradualist economic blueprint (of the mixed economy)', replacing it with 'the radical economic blueprint (of socialism with class struggle)' (Qing 1999: 24). At its second session, the Eighth Party Congress initiated the transformation towards socialism based on the notion of 'class warfare'.

Implementing the radical economic experiment resulted in an unprecedented demographic disaster. Becker (1996) estimates the number of famine deaths at 30 million, with peasants being the chief victims. That disastrous outcome could not have but a disenchanting, secularising impact on the state of mind in Chinese society and its ruling elite. The policy disaster induced by the Great Leap experiment destroyed the CCP's utopian justifi- 
cation of rule (cf. Yang 1996). In addition to starving peasants, the gospel of liberating society from the capitalist yoke also found its natural death. 'Learning from experience' became the slogan reformers brought to bear in their battle against the utopists. In the reform era of the PRC, reformers like Deng changed politics from serving a political religion of liberation into a tool of imposing market reform. His black cat/white cat analogy reflects the turn to pragmatism in China. Instead of liberating 'forces of production' by communising social relations of production, the Great Leap era ushered in liberating market forces. The reform decision of December 1978 to institute the household responsibility system will be further studied later in this chapter. The point for raising it here is that the restoration of household farming equally brought a return to farming on plots too small to mechanise as China enters the free trade era.

\section{The legacy of industrial planning}

Until 1958, the mixed economy discussed above included the state industrial sector. In the Great Leap period, private ownership in industry was eliminated (Maddison 1998: 81-2). Japanese-owned enterprises were expropriated right after the war. At the outbreak of the Korean War, most other foreignowned assets were seized as retaliation for the trade embargo Western powers had imposed upon the country to punish the regime for defending its border with North Korea in the face of MacArthur's decision to cross the demarcation line.

In the interval up to the reform era, the CCP did succeed in transforming peasant society into an industrial economy, its top priority. There can be no doubt that under Maoist institutions, an industrial revolution involving the urbanisation and factoryisation of hundreds of millions of peasants had taken off. The living standards of hundreds of millions of people improved, and their ways of life were changed forever. Between 1952 and 1978, life expectancy increased from a dismal 38 to 64 years. In that period the years of primary education of a person of 15 years and older jumped from 5.33 to 8.93 .

In terms of the industrial transformation, the CCP's policy has been an enormous success. In 1952, the sectors of industry and construction together accounted for 10.6 per cent of GDP, while agriculture, farming and fishing contributed 58.6 per cent of output. At the eve of reform in 1978, the sectors of industry and construction had expanded their contribution to 38.0 per cent of GDP, whereas the share of farming, fishing and forestry was reduced to 33.7 per cent (Maddison 1998: 56). Comparing India with China over the post-war period, Maddison finds that, except for the 1958-1964 period, industrial growth in China outpaced that of India. The PRC increased its advantage after 1978. In 1995, the PRC has proportionally turned into the most industrialised economy of the world, with industry accounting for 41 per cent of GDP (India: 25 per cent; the UK and US: 22 per cent; Japan and Germany: 28 per cent). 


\section{Henk Houweling}

\section{Institutional residues and political authority}

The Maoist party-state imported class identity from the West and tried to stamp it on Chinese society and its international relations. That identity, and its institutional foundation, leaves another historical layer on which the institutions of industrial capitalism have to be erected. Since Weber, social scientists have studied the potential for development of a society from the point of view of its form of authority. 'Development' as used here stands for the emergence of a pattern of institutions sometimes summarised as 'modernity' or 'progress', but I prefer the notion of 'development'. 'Sequential development', meaning the international spreading of industrial capitalism into the major power system and beyond, takes time. Such transformations, wherever they have occurred so far, left a trail of violence without precedent in their wake (Houweling 1996).

The political science of growth generating institutions, founded by Marx, Schumpeter and Weber, tried to rank political institutions from the perspective of facilitating or obstructing economic growth. The concept of the 'developmental state' is on one side of the continuum on the scale of the political potential of a society to develop. 'Developmental states' do have an internal existence. The system of rule of a 'developmental state' facilitates the growth of domestic enterprise in both the capital and consumer goods sectors. Their governments are capable of preventing foreign entrepreneurs, and their governments, from pre-empting the rise of a system of capital accumulation controlled by a national entrepreneurial class. Governments of developmental states have maintained interdependence sovereignty. On the other side of the continuum is the state whose government has little or no domestic sovereignty. Being weak at home, such a government depends on outside resources to stave off domestic challengers. The price of that dependence is a loss of its capacity to manage interdependence between domestic society and more developed actors that wait at its borders to get access, so that transnational forces move in or out at will. Bayart describes the policy of a government of a legally sovereign state that has little or no control over domestic society as the 'politics of the belly' of a 'neo-patrimonial' system of political authority. In these systems, 'the state' is an empty shell; the façade of a clientelist network. In a market economy, prices are independent of the names of those who engage in transactions. In neo-patrimonial economics, prices are personalised. ${ }^{2}$

Where do communist institutions stand on this scale? Students of growth-generating institutions consider communist systems as a half-way step between the procedural institutions of industrial capitalism, including its political expression in representative democracy, and the personalised, quasi-religious foundation of Sultanist political authority in empires. Communist party-states do have an internal institutional existence, even too much of one. However, there is tension in the foundation of the existence of these states. Think about the party as a 'collective hero'; an expression that 
unites the dominance of procedures ('collective') over great war leaders such as Mao, Deng and Zhu (individual war heroes). Charisma is the highly personalised quality of the leader to create a mass following of true believers. That quality cannot be easily routinised in party regulations. Some find in the notion of 'comradeship' the contradiction of intimacy of life in a peasant village and the bringing together of millions of people in a single organisation, which requires bureaucratic routine and thus the formalisation of relations. In the CCP, these contradictions worked themselves out in the mixture of leadership dominance by probably as few as ten people at the top, in Mao's position in that group as the number one charismatic leader, and the routinisation of party work in implementing policy according to established norms. The composition of that mixture changed over time. Teiwes (2000: 105) quotes central-level bureaucrats on the causes of the reform (from his interviews in March 1993):

When Mao did not personally intervene, the system functioned more or less by standard procedures. The government dealt with issues, there were local discussion and feedback to the Centre. But when Mao intervened this could no longer be sustained, the waters were muddled, and in 1958 there was not planning.

The growth potential of such a system depends on the ability of the collective leadership to restrain the charismatic man at the top. Dependence is mutual: the party comes into power due to the mobilising potential of the great leader, but the great leader depends on the party for implementing his policy. The party needs to restrain the great leader by routinising his charisma in the procedural regulation of party work, for the party of course has to survive the individual leader. Victory for the CCP removed from the scene powerful enemies that had compelled Mao into a compromise policy in provinces under party control. In two disastrous adventures, the Great Leap and the Cultural Revolution, personal charisma destroyed party routine (cf. Teiwes 2000 ).

What is the future of the communist government in a capitalist society? Is the CCP satisfied to bridge two very different institutional designs for Chinese society? Will it close the shop as soon as that bridge has been crossed? Will that organisation split apart into two different parties, a progressive and a more conservative one, and move to a system of representative government? Or will its fate be decided by upheavals of war and revolution of the sort that in the first half of the nineteenth and in the midtwentieth century brought down the old regimes in the industrialising major powers of Europe?

Growth-generating institutions are part of reality. The wealth-generating and disciplining institutions of industrial capitalism allowed countries that industrialised first to conquer the temperate climatic zone of the planet and to populate these areas. The impact of these institutions on performance 


\section{Henk Houweling}

may be exemplified in the worlds of the Chinese. In the early 1990s, after a decade of reform, the population of the PRC of over one billion is estimated to produce a value-added of about US\$500 billion, while the 50 million overseas Chinese living in Southeast Asia are estimated to produce at the same time a value-added of about US $\$ 450$ billion (East Asia Analytic Unit, 1995: 1). While they share the same ethnic culture with mainlanders, the overseas Chinese in Southeast Asia have set up very large, family-controlled conglomerates, which have diversified in their host economies without a limit. The reason for this lies in the preferential access to economic opportunities for these Chinese entrepreneurs, created by neo-patrimonial political leaders in exchange for their political support.

Taiwan, province of China, further illustrates how policies and institutions can impose a certain growth-promoting system of social relations of production and distribution. The KMT government learned from its failures, and from Mao's success among peasants, not to rely on the support of the land-owning elite. After having settled on Taiwan, it implemented land reform and imposed commercialised agriculture. The 'commanding heights' of heavy industry were constructed by political entrepreneurs of the KMT. When the KMT government faced a crisis of domestic and international survival (after the Nixon shock of the US entering into relations with the PRC, and the oil price rise crisis in the 1970s), it sought for support among the people of Taiwan by creating a powerful layer of small entrepreneurs. At present times, small and medium family enterprises absorb about 80 per cent of the labour force in the Taiwanese economy, which generates a yearly per capita income of about US $\$ 18,000$. In the Chinese worlds, we thus find contemporary evidence of the differences in the potential for development of three different forms of political authority, namely the Maoist system in the mainland before the reform era, the KMT rule in Taiwan, and the crony capitalist systems in overseas Southeast Asia.

Finally, in the case of China, population growth has likely been a background force that pushed the communist leadership into a reform role. After the mass starvation during the Great Leap, total rural fertility veered back to more than the 1950 rate of about 6 to between 7 and 8 in 1964, only to decrease to 3 in 1979. The rural population between 1960 and 1978 increased from $531,340,000$ to $790,140,000$ (Maddison 1998: 77). Due to population increase, rural villages had to produce more grain for the cities at the expense of cash crops for local markets. To impose the state monopoly of purchase (and sale) of foodstuffs, markets and crops for local sale had to be suppressed in order for cities to be fed cheaply. Population growth in the countryside may have caused the build-up of pressure to breach the wall of the CCP's control over rural-to-urban migration (cf. Zhou 1996). In 1949, China counted 57.65 million urban residents; in 1976 that number had increased to 163.41 million (Gao 1999: 318). At present times, about 120 million Chinese have left the countryside to work in coastal urban-industrial sites. People escaping the controls of mobility by superior authority bring 
about a labour market without which private capital accumulation cannot be achieved.

\section{Political realism and the study of 'transition'}

What has political realism to say about why political elites recast society and adopt industrial capitalism? In this section I highlight three domains in which I think political realism contributes to explaining why societies adopt industrial capitalism. The first domain is called here 'entrepreneurial politics'. Entrepreneurial realism explains choices made by top leaders about reform policy. The second domain is structural realism. Structural realists focus on the international context of reform and its impact on national level societies. They properly consider the international expansion of countries that developed first as a deadly danger to the survival of societies that are organised according to other codes of social existence. In the third domain, political realism, political realists focus on inequality as a source of (dis)satisfaction. Societies adopting industrial capitalism experience rising inequality during the initial stage of the transition.

\section{Entrepreneurial politics}

The CCP leadership has in one way or another to reach agreement about the course and pace of change in China, for the CCP decides on reform policy and the party-state is the domain of action for reformers. However, the communist party-state is ravaged by intra-elite battles. The CCP is therefore not a unitary actor, although it has not fallen apart like the communist party of the Soviet Union. Between consensus and falling apart, we have infighting by individuals in the top echelon of the CCP. Accordingly, the curving road of reform policy is the outcome of the pulls and pushes among top leaders who, among other things, have to take into account expected responses from their adversaries and supporters in the bureaucracy in the capital, in the provinces and in the counties.

Such strategic decision-making, or rational choice, by individual leaders is studied in international relations in the theory of political entrepreneurship (cf. Bueno de Mesquita 2000). The entrepreneurial version of political realism locates the cause of China's entering into the reform era in leadership struggles about the proper course of policy. In this approach, individual leaders, not states, are the rational actors. Individual leaders take decisions from the prospect of staying in office, respectively to improve their station relative to their competitors. In entrepreneurial realism, such a thing as the 'national interest' does not exist independently of the personal interest of the entrepreneur. Political entrepreneurs may therefore prosper by setting a country onto the path of self-inflicted damage in cases where it is profitable to do so. ${ }^{3}$ Accordingly, decisions about reform are contested and result from a winning coalition within the political-military elite of the country. This 


\section{Henk Houweling}

brings the field of transition into the domain studied by game theorists and expected utility theorists.

Decisions by the CCP to transform the planned economy into a market economy with Chinese characteristics (or, a socialist market economy) are indeed severely contested within the leadership. The rise, fall and come-back of reformer Deng Xiaoping, the violent death of Marshall Lin Biao in late 1971 and the fate of the 'gang of four', all highlight the contested nature of party politics in reforming China. In the reform era policy, contests at the top translate into headlines. ${ }^{4}$ In the Soviet Union, entrepreneurial politics left the country without a political framework for decision-making on reform and for implementing it. Consequently, reformers could not build a constituency within the communist party supporting reform. In China, reform policy has been set within the CCP. ${ }^{5}$

\section{Structural realism: the domestic level}

Domestic reform occurs in a global context. The impact of international contexts on policy and society is the field studied by structural realists. Structural realism, founded by Hobbes, considers inter-state relations as being played out in the state of war and being determined by that state. Chinese history in the nineteenth and twentieth centuries proves him right. In its assumptions, structural realism is collectivist, whereas entrepreneurial realism is individualist. Consequently these sub-theories of political realism are alternatives. Problems coming out of their incompatibility wait for solution. For the purpose of this chapter it is sufficient to observe that the impact of the evolving international context on national societies and their policies runs through the door guarded by national-level politicians.

In structural realism, rational actors at the domestic level establish property rights, ending the state of war among them by appointing a guardian over them, which compels each member to equality in submission to the potential force of the state. 'Leviathan' brings peace, which is consensually preferred over the state of war. ${ }^{6}$ It is a facilitator of economic growth in the sense of making peace sustainable between rational actors intent on improving their status, but preferring peace above the state of war in the pursuit of that interest.

The notion of citizenship comes historically from the construct of all contractors being equally subjected to the powers of state. 'Equally subjected' implies 'no exceptions for cronies' or for established wealth owners claiming a natural right to property. The equality created by 'Leviathan' is embodied in the procedural equality of the institutions of industrial capitalism. However, the pursuit of equality does not extend beyond these institutions. Individuals living in these institutions pursue private gain, conceived as a tool to create status differentials in terms of wealth. Their motivation is distinctly non-egalitarian. Therefore, 'Leviathan' also denotes the set of private relations among citizens formalised in the 
legal system protecting inequality in wealth. Consequently, egalitarian institutions have effects which are distinctly unequal in terms of wealth. Such a system of private relations regulated by the law is called 'civil society'. Property rights exist in a legally incorporated civil society. ${ }^{\text {? }}$

In China in transition we find, therefore, the following situation. The institutions of the Maoist system had no place for 'class enemies'. In that sense, the state created a status division in society between party and nonparty members. However, these institutions promised to create substantive equality in living conditions for proletarians. The communal dining hall comes to mind. The social outcome of these institutions was indeed, more or less, substantive equality, except of course for the party elite. In their experimentation during the Great Leap, these people did not even notice that the plates in the communal dining hall were empty, leading to starvation (leaders dine somewhere else). The members of that elite pursued status differentials by non-economic means, for example by surpassing each other in ideological correctness or in competition in honouring the great leader.

In industrial capitalism, we have egalitarian institutions. These institutions, however, protect inequality. Why do transitions from one to the other occur? In structural realism the cause of the transition is that aggregate of wealth - and thus the potential for power - generated by the latter surpasses the level of the former. This observation implies that the poor in capitalist societies are usually richer than the poor in substantive egalitarian, but institutionally inegalitarian, societies. That observation certainly fits the Chinese case. Therefore, wherever these institutions clash in international life, using state power as a tool, institutions required for the building of industrial capitalism replace those of Leninist-Maoist systems.

In societies in transition, civil society is weakly developed and people are vulnerable to the government in the capital (they see their property stolen or removed, have to pay prices dependent upon their relation with the rulers, see economic opportunities open to others that remain closed to them). They may be arrested at night for activities considered 'private', that is, unregulated by law in 'Leviathan' states, such as religion. In 'Leviathan' political systems, political entrepreneurs have to operate within limits set by law. In these societies, the problem of 'power transition' between governments has been solved, giving 'the state' an independent existence from 'the government' of the day. Such governments have a legal handle to transform the social relations of production, viz. the force of the law. The trouble is that 'Leviathan' states emerge interactively with the transition to industrial capitalism; such states do not precede such transitions. In structural realism, violent competition in the international realm compels such transitions. This brings us back again to entrepreneurial realism. In entrepreneurial realism, the introduction of market forces, and the limits to their operation, are the outcome of an internal political struggle which does not translate into the law. That is why a great leader may be honoured one day, and be crucified as a traitor the next day. Lin Biao, Deng and the 'gang of four', to name only recent cases, met that fate. 


\section{Henk Houweling}

\section{Structural realism: the international level}

Structural realism applied to inter-state relations implies that property rights are established by rivals in conquest and are protected by the hegemonic power winning such a contest. The distribution of international property rights is at stake in international wars. In the era of colonialist imperialism, which coincides in time with the second industrial revolution in Western Europe, all laggards in development met military defeat, Czarist Russia and Imperial China being the largest and last ones. At that time, their capitalist rivals had obtained access to the military fruits of modern industry. Not free trade but military power allowed Europeans to overrun China, as well as the rest of the planet, in the search for labour and raw material inputs for industry. Apparently, the power of the market mechanism alone is not enough to dissolve pre-capitalist societies. At the international level, property rights are set by the sequence in which major powers industrialise and by the outcomes of the wars they fight. Industrial prowess and access to military capability are two sides of the same coin.

Historically, the capability to extract energy and matter from nature is correlated with establishing control over and protection of trade, raw material and market assets beyond borders. What will be the impact on regional stability when China begins to project military power around its borders? What will be the impact on the natural environment in China and worldwide, when over a billion people extract inputs for industry and exit waste to nature on the same per capita basis as the so called developed countries do today? ${ }^{8}$ Although the latter created the international order of formal equality in sovereign status in which China is integrating, they were the first ones to roam around the globe for natural resources and treasures.

Origin and consequences at the international level of China's transformation are within the theoretical domain of structural realism. Indeed, in 1969 , the year in which the end of the Cultural Revolution was officially proclaimed by the Ninth Party Congress, China faced war with its former ally, the Soviet Union. The domestic leadership struggle ended with the arrest of the Gang of Four on 6 October 1976, a few weeks after these people had played such prominent roles in the funeral ceremony of Mao on September 18. Accordingly, the decision to transform China to the market-led mobilisation of productive forces is the outcome of international threats. Domestic institutions governing relations of production and distribution are thus tested in the international domain for their capacity to mobilise and allocate labour, capital and military power. The more prosperous society is, the larger the resources flow in the tax link between society and government, increasing government capacity to promote growth and social contentment. The more technologically advanced its economy is in relation to the others, the greater is its potential for building military capacity. In the PRC's case, these institutions were found defective. 


\section{Status and status inequality}

Political realists consider status, or relative standing, and efforts to improve it relative to others, to be a determinant of behaviour. Why is 'status' seen as an important variable in understanding why societies adopt industrial capitalism? Consider the following question: 'Is the change to an industrial market economy the expression of a "natural" longing for a materially abundant ways of life and associated freedoms?' In case of an affirmative answer, such an economy and society would have been invented a great number of centuries ago. However, the history of the industrial era counts at best for 200 years. Mass consumption thus is an ex-post facto phenomenon of industrial capitalism and therefore cannot have been an original motive in society transiting to its institutions. Research into linkages between income wealth and self-reported happiness confirms what Hobbes revealed in a blunt way about people: improving relative standing, or status, is a source of happiness.

International status competition implies that the rulers of late-industrialising countries have to explain at home why the first industrialising countries have such materially abundant lifestyles. The PRC, due to its origin, is a stark example of a regime facing the challenge of rising domestic inequality during transition. The PRC government originated in response to Western class-based societies. These countries had humiliated the realm. The PRC government thus was induced to organise resistance against the Western invasion in the name of abolishing the class order at home and overcoming it abroad. Chinese people were promised they would catch up with and then overtake their external enemies. The legacy of that promise is in its failure and in the transformative impact of that failure in the reform era.

The absolute size of the difference between Chinese regions has increased since 1978. In Imperial times, people in the coastal south had opportunities for trade and experienced commercialisation of relations (cf. Seagrave 1985). It is unlikely that the short period of communist rule eradicated this advantage. In rich Shanghai, affluent urbanites are not really waiting for peasant migrant workers making camp at night on the street's overpasses. Back home, the latter have a story to tell. The rise in inequality is inevitable when the workforce shifts from low-productivity agriculture to higher rewarding industrial activity. It should be noted that the support base of the Party, the urban-industrial proletariat employed in State Owned Enterprises (SOEs), has to bear the brunt of the cost of transition. These people are not just dismissed, they are expelled from the protected SOEs' shells in urban areas, their houses demolished. ${ }^{9}$ The conclusion therefore is that Maoist ideology is no longer particularly functional in the reform era to obtain legitimacy for the government. While that ideology rejects status competition in consumption, functionaries looking out of their window see Chinese driving Mercedes, wearing watches of glittering gold, etc. Their passing-by leaves migrants in the dust. The problem is that migrants see that too. 


\section{Henk Houweling}

Economic growth and technological progress require an uninterrupted stream of buyers. So consumption has to be enhanced in the coastal areas before it can be extended nationwide. The trick that governments of redistributing social systems in transit to industrial capitalism have to perform is to tie greed to virtue. The pre-war and post-war Japanese elite, as well as the post-war Korean Park regime, proved to be masters in performing that trick. Linking individual acquisitiveness and demonstrated wealth to glory proved to be the work of nationalists. However, these governments also narrowed income inequality as industrialisation proceeded. Japan became known for competitive success on the work floor of the 'Toyota family' and its blue-collar managers. All were (and most still are) employed by Japan Inc. Will China move that way as well? Is the present government capable of explicitly setting aside Maoist rhetoric without casting aside its developmental role?

\section{Tracking institutional reform in China}

Policies set in intra-elite battles, in the international and domestic contexts in which they are played out, modify domestic institutions of governance, production and distribution. In this final section, the process of transition towards a market economy is measured by tracking over time the changing shares different forms of property ownership contribute to China's GDP, to labour absorption and to capital formation. ${ }^{10}$

The state Deng left is no longer autarkic and inward-looking in its development strategy. The share of the individually-owned industrial sector in total industrial production expanded. In 1978 it hardly existed, contributing 1.85 per cent to total industrial output and employing less than 25 million people, while in 1996, the share of individually-owned enterprises in industrial output had expanded to 15.48 per cent, employing about 40 million people. The foreign-invested sector's share in industrial production expanded from 1.21 per cent in 1985 to 16.65 per cent of industrial output in 1996. And in the 1990s, enterprises in the communal sector (see below) are run as privately-owned enterprises. The share of Central state investment in total investment is down to 3 per cent (yet the party-state is still the world's largest borrower from the World Bank). Foreign investors sent in 1998 US $\$ 42$ billion in direct investment. The export sector is another source of foreign currency flowing into the economy.

\section{Agriculture}

The Great Leap disaster, says Yang (1996: 96-7), destroyed the political and mental basis of communal farming underlying the radical streak in Maoism and peasant culture: 
The Central leadership, headed by Mao, had to retreat [...] party unity had eroded. More fundamentally, the famine disabused the peasants of any illusion they might have harbored about communes [...] peasants and basic level cadres took advantage of the political relaxation and widely adopted household based farming [...] Mao could for now mobilize enough political resources to suppress household contracting, he was incapable of erasing the horror of the famine. The Great Leap Famine [...] fundamentally reshaped the motivations and beliefs of the people it affected and removed the political base that Mao had tapped.

De-collectivisation brought the transfer of ownership rights in agriculture from the brigade to household producers. It reinstated the farmer's right to the residual over cost and taxes. At the same time, the government raised prices of the amount of grain farmers had to sell to the state. The household responsibility system thus changed the unit accountable for production from the commune to the household. Some claim that dismemberment of the communes has been the work of spontaneous peasant responses to the Great Leap famine. Whatever may have happened, the collapse of the urban permit system is the real beginning of capitalist reform: peasant mobility created a primitive labour market, which is a necessary requirement for private capital accumulation. Industrialisation can begin when peasants leave the land, when are expelled from it.

However, to call the right to sell output and to get access to the residual 'household responsibility' is not very helpful. Where do peasants get their inputs from? They cannot buy seed, fertiliser and pesticide on a market. The prices Chinese farmers pay are political prices. In October 1983, the Central Committee of the CCP and the State Council issued the 'Directive on Implementing the Separation of Party and Government and on Building Township Government'. Its implementation brought the withdrawal of the party from the daily management at the county and village levels. However, instead of reducing bureaucracy, it expanded. Local functionaries were given the power to tax and to supply inputs to peasants. Consequently, the power to price inputs gives control over the size of the residual. Or, in other words, the institutional separation of 'politics' and 'economics' is far from complete. The recent turn to local elections could be an instrument to bring that separation one step ahead.

The Household Responsibility system did greatly improve productivity in the agro-sector. The economic dynamo moved in the early 1980s from the State Owned Enterprises to the partially privatised agricultural sector. Farming, forestry and fishing in 1978 accounted for 72 per cent of the workforce and 33 per cent of GDP; in 1995 the sector produced 23 per cent GDP with 53 per cent of the workforce. At present times, China has a surplus of grain and its farmers face cheaper imports, leading to declining prices. At the other end of the squeeze, the government is phasing out farm subsidies. Accordingly, China is entering into the WTO with an agricultural sector 
which is over-taxed and over-staffed, and in which 5-15 per cent of its food basket in richer Central China (the Henan, Hubei and Hunan provinces) is now lying uneaten. Tiny plots leased to families are too small to improve productivity, but to consolidate family plots into larger holdings suitable for mechanisation requires a market in land. ${ }^{11}$ It would be no surprise if such a step is taken in the near future. In 1994, the central government decided to extend the land contracts for another 30 years. The ruling also 'permit(s) the compensated transfer of the right to land use according to law'. This transfer permit is the beginning of a contract system in property transfer.

Pressure in this direction is indeed building up. Farmers now protest that, after paying local taxes, no residual remains, land is abandoned and young family members move to the cities for work in order for farming households to pay land-lease and other taxes. Local and central governments are in a bind here. In order to pay for public works, local authorities levy taxes on land leased to families and may even invent new taxes to stay afloat as revenue declines. Bernstein (2000: 95) states that '(a)dditional "above-quota" fees, fines and apportionments imposed by local officials' are a powerful source of rural instability. He reports, among others, a wave of unrest in the autumn of 1995 in Shanxi, Henan and Hunan provinces involving 100,000 peasants, which took 100 lives including those of 30 officials. Hubei, Jiangxi and Anhui also had mass peasant protests against officials appropriating produce above the 5 per cent permitted level. One may now observe in the countryside scenes of farmers chasing privatising tax collectors out of the village with clubs.

For the central government, the family plot guarantees household subsistence. Farming is a social safety net of sorts for millions of very poor people in non-coastal China. In poor provinces, such as Gansu and further west, millions of peasants are too poor to leave. These people are trapped on the land and consume what they produce. The formation of a land market has a price: the eviction of people who work for subsistence.

\section{The State Owned Enterprises ${ }^{12}$}

The makers of steel, machinery, cement, petro-chemical products and military equipment were once the industrial base of China's planned economy. In 1978, the industrial sector was dominated by large State Owned Enterprises, providing employment for the urban elite workforce. SOEs are towns within cities, and in these towns one finds schools, hospitals and restaurants, recreational facilities and the living quarters of workers. The worker's life is integrated into the organisational unit of the enterprise. In 1978, the state sector contributed 78 per cent to industrial output; in 1996, its share had declined to 28 per cent. The share of SOEs total value-added decreased from 56 per cent in 1978 to 37 per cent in $2000 .{ }^{13}$ However, in absolute terms the number of SOEs and the people employed there expanded (Maddison 1998: 81), and presently there are 118,000 SOEs. 
Politics at each level is involved in the SOEs' control system. In terms of control, not all SOEs are regulated by bodies of the central state; even counties may have SOEs assigned to them. The urban bias of the pre-reform era is reflected in the concentration of SOE employment in cities: in 1996 the SOE sector accounted for 57 per cent of urban employment. Maddison (1998) finds for the pre-reform era huge investment outlays allocated to industrial giant enterprises. The enterprises also produced the military hardware for the country's armed forces. Over time, work became more productive. Maddison reports a substantial rise in annual labour productivity of 3.1 per cent. However, labour productivity increased due to the annual growth in capital stock of 13.3 per cent. Communist party-states are systems for mobilising people and capital, whereas capitalist systems generate profit by technological and organisational innovation. Accordingly, annual increase in total factory productivity had been slight, implying wasteful resource allocation by the planning authorities.

The major innovation in the SOE sector in the reform era has been their financing. SOEs have turned into corporations, and the burden of financing SOEs has been shifted away from state banks to the public investors in the Shanghai and Shenzen stock market who buy and sell shares in these companies. ${ }^{14}$ The very large domestic savings did create a potential to finance a private-sector boom. However, private savings are now diverted to SOEs. While experiments with shareholding companies began in 1982, since the early 1990s the number of shareholding companies in the urban-industrial sector began to grow fast. At the end of 1995, China had 5,873 formally registered shareholding companies.

As provincial governments receive quota from China's stock market regulators, who are party officials, companies are competing for the right to list their shares by lobbying provincial governments. Accordingly, power over who obtains capital resides in party politics at different levels. SOEs are the main provider of employment in cities. Logically, therefore, provincial governments give priority to SOEs that provide jobs in their home province. At present times, the state has a controlling majority in 90 per cent of the stockexchange-registered companies. Consequently, the regulatory environment of these enterprises is very different from the one in which capitalist enterprises operate. Bankruptcy is a politically sensitive matter. The allocation of capital to SOEs by giving these enterprises the right to issue and register stock is reported to encourage bribery. For example, the Kangsa Group (textiles) obtained its market listing by giving free shares to government officials who ruled on its access to the stock exchange. Therefore, the capital market is saddled with lower-quality SOEs that would otherwise not be able to list shares. While employment in the sector expanded, the change to private individuals helping to finance SOEs did not imply improved resource allocation. The political cost of marketisation thus increased in these years.

In Spring 1998, the newly appointed premier Zhu Rongji announced sweeping reforms of the banking system, to remove local party control over 


\section{Henk Houweling}

banks, and end subsidised credits to SOEs. If implemented, these drastic measures would give the country's private entrepreneurs access to the capital market on equal footing with SOEs. Tens of millions of people in cities working in SOEs are expected to lose their jobs. Under new rules private companies are allowed access to capital markets, and Chinese security firms are to decide which enterprises may tap private savings. However, security firms in China are still all state-owned and could be subjected to political pressure in selecting clients. For example, the underwriters still have the potential to price initial offerings at very low prices, which ensures that share prices surge in early trading and allows substandard companies to raise capital. A new Nasdaq-style securities market in Shenzhen will have less strict listing requirements. The objective is to finance younger and smaller companies. In any way, private companies begin to compete with the state for capital.

Summing up, in the reform era the inefficient SOEs have become a threefold threat to stability. First, a substantial proportion of the urban proletarian elite has to be laid off as a condition for improving efficiency. Second, in order to keep these enterprises afloat, private-sector savings are diverted via the banking system to SOEs. Third, the debt overhang of these companies threatens financial stability as that sector turns into a financial market and the Yuan becomes convertible.

\section{The collectively-owned sector}

The final important economic sector to be discussed here is the collectivelyowned sector. In fact, this sector is properly considered to be the most dynamic one in China's economy. If there is a thesis to defend about China's industrial success, it is has to be found at the local level, in Township and Village Enterprises (TVEs). According to government statistics, there are at present times 1,475,000 collectively-owned enterprises. A subset of these comprise 'rural industry', consisting of 228,000 Township Enterprises and 689,000 Village Enterprises. These enterprises are the core capital accumulation and most of them are under the control of Chinese people and contribute to exports.

In the communal sector, property rights are more clearly established than in the SOE sector. Township and village governments implement ownership rights in the communal sector. The communal enterprises carry no responsibility for welfare provision of the workforce they employ. These enterprises behave more like textbook producers in the sense of operating on market prices: they survive on the difference between revenues from sales and cost of inputs, implying that there is the possibility of bankruptcy. These enterprises have no access to preferential credits.

For these reasons alone, some authors see the TVEs as privately owned businesses under another name. Usually, these authors have difficulty in seeing any opportunity for growth in a non-privatised world. Oi (1999), using 
agent-principal theory, explains the paradox of how township and village governments, who exercise ownership rights, operate in some respects as real businessmen do. Political decentralisation created an incentive structure for these people, transforming them from party agents into principals. From the structural realist point of view, the external context of a collective actor shapes its internal operations, whoever may be in charge. Indeed, depending on incentives, constraints and opportunities provided by external context, communist party functionaries may operate as capitalist businessmen as well as authoritarian central planners who induce famine in the countryside - a key insight of entrepreneurial realism.

TVEs are active in light industries. The origin of rural industrialisation is the agro-commune discussed earlier. At that time, the rural industry sector operated outside the planning systems, producing inputs for communes that were not provided by the planning sector. The existence of this rural industry sector testifies to the high level of urban bias in the planning system. In terms of input provision, the countryside was left to its own devices. Consequently, the rural industry sector could not function as agent of monetarisation in the countryside, which is required for sales of manufactures produced in cities. In the pre-reform era, consumer society simply did not exist in the countryside. Due to the reforms, the TVE sector is forging a national economy out of the previously urban-industrial economy and its subservient food supplier. Again, we thus meet political factors shaping business organisation.

Political acceptance of the rural industry sector by central authorities comes late. In the planning period, rural industry operated in the margins of the planning system, producing in 1971 about 3 per cent of industrial output. Political instinct at the central level is (still is?) to favour the SOEs and to discriminate against rural industries in case of difficulties in centrallevel politics. The Autumn 1989 austerity programme, initiated by Premier Li Peng, turned its back upon rural industries. However, for understandable reasons, that proved to be short-lived. In 1993, TVEs produced 29 per cent of China's total industrial output and over 40 per cent of the exports, and employed about 40 per cent of its industrial workforce (Bowles and Dong 1999).

Paul Bowles and Xiao-Yuan Dong (1999) provide interview material from the TVEs in China's three northern provinces from which they conclude that property rights in TVEs do not hamper efficiency. They do, however, affect spending the residual. Local governments pursue the objectives that private property owners leave to governments: a high level of employment and spending residual in public works, including education and road improvement, from which local residents profit. The authors find that their provisions solve worker's incentive problems which private owners tackle by dismissal threats. These findings give some substance to the assertion that a 'market economy with Chinese characteristics' does exist in some parts of that huge economy in transition. 


\section{Henk Houweling}

\section{Notes}

1 Mao Zedong at the Meeting of National Industrialists' and Merchants' Representatives, 8 December 1956 (quoted in Qing 1999: 1).

2 Some authors consider 'crony capitalism' to be an expression of political culture. This is incorrect. Eighteenth-century France and England are excellent examples of the economics of crony capitalism, and Weber even doubted - on very good grounds - that it disappeared in the West. In case a network of personalized dominance falls apart, as in contemporary Indonesia, the state collapses. Weberians thus find that rulers easily destroy incentives for economic growth of their subjects.

3 The Cultural Revolution is, from this perspective, a method of domestic leadership struggle.

4 Premier Zhu Rongi proclaims 'Adjust to embrace the world' (headline of China Daily, 15 June 2000); China's Chief WTO negotiator Long Yongtu leaves no doubt that China is moving to WTO capitalism, not to Deng's 'market economy with socialist characteristics': 'The important thing is to let our enterprising people free in the market. If we hold them in our arms, they will never grow up. I think this is a bitter lesson in China's past' (International Herald Tribune 17 November 2000: 21); Vice President of China's Academy of Sciences, and son of Jiang Zemin, Jiang Mianheng fears that China runs the risk of becoming 'a vassal of the capitalistic, neo-imperialist Western alliance' (South China Morning Post 14 June 2000: 18).

5 A lot is known about the entrepreneurial politics of transition in China (cf. Silk 1993), but information hidden in party archives is required for reconstructing intra-elite coalitioning from a rational-choice perspective. Chinese-speaking political scientists will no doubt enlighten the politics of transition from this angle.

6 'Leviathan' is sometimes misunderstood. It does not stand for an armed gang, calling itself 'government' and arresting people at night. Prior individual consent is the basis of its founding act. However, a Leviathan government is authoritarian in the sense of not being a party to the consensus that created it.

7 In societies in which industrial capitalism is hegemonic, one meets the state, in the sense of the "legally regulated relation between private individuals pursuing private interests' everywhere. No guns are visible in such an encounter. In civil society, guns are pushed so far back in the background that in some conceptions civil society is believed to exist outside the state. That is no less incorrect in the present stage of globalisation as in previous phases.

8 Vaclav Smil (1992) gives a summary of the devastating impact of China's industrialsation on the natural environment. The power vacuum in the countryside has turned party agents into principals, cutting forests once planted to stop deserts. With respect to energy needs, the International Energy Agency estimates that Chinese oil imports, largely from the Middle East, will have increased to over 8 million barrels a day in 2020, increasing the country's net import dependence from 25 per cent to 76 per cent.

9 'No work, no future', says a report about the rust belt of the three northern provinces in the South China Morning Post (20 June 2000: 17). And 'China's urban poor population, made up mostly of laid-off workers, will probably keep growing because of the problems plaguing SOEs' (China Daily Hong Kong, 21 June 2000).

10 Political reform will not be covered in this section. See for the post-Mao communist state, David Shambaugh (2000).

11 Every person in farming has access to a third of a hectare of cultivated land, compared with 99 ha in the United States. 
12 Here I borrow liberally from Edward Steinfield (1998). Classification of Chinese enterprises is not standardised across the literature. A much more optimistic assessment of the performance of the state sector is given in Dic Lo (1999), but his contribution raises issues that cannot be discussed here.

13 This information is based on a data sheet provided to me by David Xiue of the Institute of European Studies, Chinese Academy of Social Sciences, Beijing.

14 A large proportion of SOEs made substantial losses, accounting for about US $\$ 270$ billion non-performing loans in state banks.

\section{Bibliography}

Becker, Jasper (1996) Hungry ghosts. China's secret famine, London: John Murray.

Bernstein, Thomas, P.(2000) 'Instability in rural China', in David Shambaugh (ed.) Is China unstable?, New York: Sharpe.

Bueno de Mesquita, Bruce (2000) Principles of world politics. People's power, preferences and perceptions, Washington: CQ Press.

Bowles, Paul and Xiao-Yuan Dong (1999) 'Enterprise ownership, enterprise organization, and worker attitudes in Chinese rural industry: some new evidence', Cambridge Journal of Economics 23: 1-20.

East Asia Analytic Unit (1995) Overseas Chinese business networks in Asia, Department of Foreign Affairs and Trade, Commonwealth of Australia.

Gao, Mobo (1999) 'Manufacturing truth and culture of the elite', Journal of Contemporary Asia 29 (3): 309-27.

Houweling, Henk W. (1996) 'Destabilizing consequences of sequential development', in Luc van de Goor, Kumar Rupesinghe and Paul Sciarone (eds) Between development and destruction. An inquiry into the causes of conflict in post-colonial states, London: Macmillan.

Lo, Dic (1999) 'Reappraising the performance of China's state-owned industrial enterprises, 1980-1996', Cambridge Journal of Economics 23: 693-718.

Maddison, Angus (1998) Chinese economic performance in the long run, Paris: OECD.

Oi, Jean C. (1999) Rural China takes off. Institutional foundations of economic reform, Berkeley: University of California Press.

Qing, Simei (1999) 'Conflicting CCP visions of China's economic development, the 1950s'. Paper presented at the Conference 'China at 50', Lund University, October 18-20.

Seagrave, Sterling (1985) The Soong dynasty, London: Corgi Books.

Shambaugh, David (2000) 'The Chinese state in the post-Mao era', in David Shambaugh (ed.) The modern Chinese state, Cambridge: Cambridge University Press.

Silk, Suzan (1993) The political logic of economic reform in China, Berkeley: University of California Press.

Smil, Vaclav (1992) China's environmental crisis. An inquiry into the limits of national development, Armonk NY: Sharpe.

Steinfield, Edward S. (1998) Forging reform in China. The fate of state-owned enterprises, Cambridge: Cambridge University Press.

Teiwes, Frederick C. (2000) 'The Chinese state during the Maoist era', in David Shambaugh (ed.) The modern Chinese state, Cambridge: Cambridge University Press. 


\section{Henk Houweling}

Yang, Dali (1996) Calamity and reform in China. State, rural society and institutional change since the Great Leap famine, Stanford: Stanford University Press.

Zhou, Kate Xio (1996) How the farmers changed China. Power of the people, Boulder: Westview Press. 


\title{
13 From new order to new world order \\ Good governance and violence in Indonesia
}

\author{
Judith Large and Nick Mawdsley
}

Indonesia is an extreme example of neoliberal globalisation, exhibiting prominent roles for the market and private sector, accelerated opening of global markets, breakdown of national borders, increased role of international (financial and political) institutions, the reduction of subsidies, and social welfare protection programmes for the poor. There remains a state apparatus that attempts to perform its duties of law enforcement, market regulation and service delivery, while prioritising the maintenance of national unity at all costs in an increasingly nationalist and fractured political context. Critics observe that the neoliberal good governance project can be counter-productive (Moore 2001; MacEwan 1999; Duffield 2001), the latest version of the goal of linear development or modernisation, which 'similarly entitles the North to develop and democratise the South in its image' (Abrahamsen 2000). The international is present in the domestic, and increasingly local constituencies experience and engage with direct lines of control by global actors.

Despite widespread interest in 'ethical globalisation' and promoting the 'global values' of respect for life, liberty, justice, equity, mutual respect, caring, integrity, and respect for human rights, a normative agenda that 'must be the cornerstone of global governance' (Maxwell 1999), it is difficult to find evidence of such applied principles in the current enormity of the Indonesian experience, a society in rapid transition, political upheaval, and in some cases violent fragmentation. Critics such as Wade (2002) argue that encroaching US/World Bank hegemonic relations undermine such intent and exhibit a growing gulf between finance ministry agendas and civil society proponents, such that the market consistently overrules questions of rights. This chapter takes a similar position and will argue that the political stability of Indonesia is a primary concern for the international community, which works through and reinforces residual dominant national power structures to protect and promote its interests (global corporate investment and regional geo-political concerns). The priority given to governance in the economic sector, including adjustment policy, debt management, business environment, commercial court, bankruptcy laws, corporate governance, linking inward investment and economic recovery to governance, implies 
that 'good governance' is primarily a tool to enhance these interests and the neoliberal agenda.

This chapter will argue that neoliberal reforms in Indonesia, from the late 1960 s onwards, were imposed through direct alliances between northern actors and Indonesian elites in the form of the New Order, and subsequently formalised and extended to encroach on basic parameters of development and human security. Dominant power structures in Indonesia were and still remain firmly based on patronage and corruption. President Suharto balanced political and economic power through a core of crony and nationalist businessmen, who were given preferential access to contracts, natural resources and various rent-seeking schemes in return for providing financial contributions and political patronage to Suharto. Only during crisis periods when Indonesia's economy was under severe strain were neoliberal reforms successfully introduced, but these did not have the backing of a system of governance that could effectively regulate the financial or corporate sectors. The combination of the liberalisation of Indonesia's finance sector, the structure of its private sector, its political uncertainty and system of governance set the scene for the economic and political crisis that the country has now endured for the last five years. Politicians, the government and military continue to be involved in business with no sense of a conflict of interests, and de facto governance is based on individuals and organisations acting to maintain positional, interest-based power. Popular resistance is met by collusion between military, business and political actors who will resort to state (military) and civil violence to protect these interests.

Reform agendas intersect specific contexts, and currently the rapid combination of democratisation and decentralisation is proving volatile. The sections that follow show how hopes for Reformasi in post-Suharto Indonesia are severely compromised through the legacy of New Order politics and structures, and economic crisis. Key factors include structural adjustment, debt and poverty; the instability and insecurity connected with mismanaged decentralisation; multi-level nationalist and localised forms of identity politics; and the impact of global corporate governance on the 'good governance' project and local populations.

\section{Background to new order politics}

The reform process did not change the underlying structure and culture of the political elite

Nursyahbani Katyasungkana, 2000

General Suharto came to power amidst a violent backlash aimed at the Indonesian Communist Party, a key component of the popular support for the previous president Sukarno and a counterbalance to the powerful military.

Official Indonesian history claims that this was the result of the involvement 
of officials of the communist party in an attempted coup that led to the murders of leading generals in the Indonesian military. But it is now accepted that the events of 1965-1966 involved the CIA, the Indonesian military, and influential elites, as a result of the communist party's challenge and popular campaign for land reform that had a strong following amongst the rural poor. This campaign and popular support challenged the Cold War interests of the US and the varied interests of the Indonesian military, national and local elites and landowners, which advanced the establishment of a strategic alliance between Washington, figures in the Indonesian military and landowners. Popular sentiments for reform that challenged international and national political and economic interests were crushed by widespread violence orchestrated by the military, providing General Suharto with the opportunity to take power as president and bring Indonesia into the global economic order.

Indonesia under the nationalist president Sukarno was prominent in leading the policy of non-alignment during the Cold War. Despite the economic crisis of the late 1950s and early 1960s, Sukarno rejected the World Bank's offer of 'substantial loans to Indonesia conditional upon the implementation of severe austerity measures and the denationalisation of the previously foreign-owned sector of the economy' (DTE 2000). In stark contrast, Suharto quickly appointed a team of US-trained economists to develop the New Order's economic policy and patch up relations with the US and IFIs. As early as 1966, Suharto accepted IMF assistance in developing a stabilisation plan for the economy, and in 1967 laws on foreign investment, forestry and mining emphasising economic development by the private sector were passed. These laws were particularly significant through their negative impacts on both local elites and rural communities, especially outside of Java. Foreign investment in mining, oil and gas was particularly intense in Sumatra, Kalimantan and West Papua/Irian Jaya, with both Exxon Mobil in Aceh and the gold mining giant Freeport in West Papua beginning operations in 1967.

At the same time, the 1967 Forestry Law paved the way for the appropriation of the nation's forests by the private sector, through forest concessions rewarded to political and business associates of Suharto, regardless of the pre-existing claims of local communities over the land. By the 1990s, more than 60 million ha of forest land (roughly a third of Indonesia's total land area), mostly outside of Java, was controlled by major business conglomerates, military and other elite figures with support from foreign forestry interests. The control of resources by elites and Jakarta-based domestic and foreign private companies has directly contributed to the emergence of separatist movements in Aceh and Papua, and violence by local communities due to the appropriation of their natural resources through commercial largescale forestry and other natural resource extraction operations.

With no real political space for opposition voices and a strong military presence down to village level (the babinsa) which included routine state 
surveillance procedures, the New Order government entrenched a culture of governance and business practice resting on 'corruption, collusion and nepotism', popularly known as 'KKN'. Political exclusion, repression and abuse of human rights represented the consolidation of power in the name of national development. Once economic liberalisation accelerated following the fall in the price of oil in the 1980s and 1990s (Aspinall and Berger 2001), foreign interests in Indonesia revolved around doing business and keeping Indonesia an ally in terms of regional politics and an ever-growing China. Although human rights abuses, especially in East Timor, were later raised by the international community, political and economic interests as the primary determinants of foreign policy required cooperation and engagement with the New Order power structures and doing business the New Order way. This involved dependency on both the network of Suharto-linked cronies and the military, and although the corrupt judiciary meant that there was no legal certainty, a beneficial outcome for foreign investors could generally be assumed through the networks of patronage mediated by Suharto and his inner circle.

Political control was delivered through the sole ruling party Golkar (all civil servants were obliged to be members of Golkar, which was the only political party allowed to be active at village level) and its associated organisations. Security and control of internal dissent was ensured through the army's territorial command system and intelligence agencies; and control of the economy was assured through government issuance of licences and contracts coupled with the cronyism between Suharto and the twenty dominant business families that controlled 75 per cent of the Indonesian economy. Throughout the New Order, Suharto remained in control of all three - Golkar, the military and government policy - and employment in each was seen as a means to personal enrichment rather than public service. State power was exercised through both patronage and repression. Uhlin (1997: 42) documents how foreign and cukong ${ }^{1}$ capital was distributed to military bureaucrats and rural elites, and also used to buy the loyalty of potential dissidents such as Muslim groups, for instance, by buying mosques. Other dissidents were often violently repressed.

Through the centrality of Golkar, the mandatory reorganisation and simplification of various political parties and Muslim factions within Indonesian society, previously representative actors became passive coplayers in a new and more rigid interpretation of the ideals behind the original Pancasila ${ }^{2}$ ideology from 1945. This submissiveness became politically and ideologically systemised in the concept of 'floating masses', which in reality meant that all kinds of political activity became monopolised by the New Order State (Vatikiotis 1993). This resulted in an almost complete de-politicisation of the Indonesian society and the introduction of a neopaternal form of government in which Suharto figured as the dominating father figure. It is the legitimacy of this political and ideological construction that is currently being questioned during the ongoing restructuring of 
the Indonesian State and society. Indonesia may thus present an exception to neoliberal depolitisation linkages argued in this volume. Close examination of Indonesian society today reveals political mobilisation of such actors as the urban poor, Islamicist parties, secular NGOs, nationalist groups and even ministers, in response to IMF reforms, multinational corporate presence, and international influence in the economy and politics.

\section{Economic crisis and structural adjustment - debt, privatisation and poverty reduction}

As a result of the sudden economic crisis, the inability to defend the rupiah and restore business confidence, Indonesia was compelled to request support from the IMF in October 1997. The IMF programme covered fiscal, monetary and banking policy, bank restructuring, foreign trade, investment and deregulation, privatisation and public enterprise, social safety net provision, environmental and forestry policy and corporate debt restructuring. This massive programme of structural change included, amongst reductions of tariff and non-tariff barriers on a range of goods, opening up of specific sectors for foreign investment including oil palm plantations, retail and wholesale trade, the identification of state-owned enterprises for privatisation, and the establishment of the Indonesian Bank Restructuring Agency (IBRA).

Overall, the structural adjustment programme contained well over 100 significant measures covering a range of sectors with a strong emphasis on the establishment of good governance and neoliberal policy reform, which aimed to secure the Indonesian economy and recover outstanding private sector debts to international creditors. However, the very nature of the Indonesian economy and the concentration of capital within a few large conglomerates means that, in return for structural adjustment and without an effective bankruptcy process, IMF funds have been used to subsidise the debts incurred by businesses that dominated the New Order economy. More disturbing is that a number of these businesses have been accused of financing human rights abuses in Indonesia.

\section{Private and public sector debt}

As of 2001, domestic and external debt-service expenditure made up 41 per cent of expenditures and 61 per cent of tax revenues. Indonesia, alongside Angola, Ethiopia, Pakistan and Nigeria, is now classified as a severely indebted and low-income country (INFID 2002). Before 1997, the Indonesian government had no domestic debts and manageable external debt of roughly 25 per cent of GDP. By 2001, the government's external debt was US\$70 billion, with more than two-thirds owed to multilateral institutions, and a similar level of domestic debt, the more problematic according to the World Bank, the bulk of which represents the $\$ 65$ billion 


\section{Judith Large and Nick Mawdsley}

used to cover the bank recapitalisation programme. Many trace these problems directly to the 1997 crisis when the IMF stepped in with instructions to close 16 banks (Harianto 2002). Rather than improve confidence in the banking system, the bank reconstruction programme is estimated to cost the state between 60 and 100 per cent of GDP (spread out over several years), leaving few resources for inter-regional income transfers.

In 2002 the debt-servicing obligation was Rp.130 trillion ( $\$ 13$ billion) for domestic and external debt. This is equivalent to three times the total public sector wage bill, including the military, and it is eight times the education budget. The International NGO Forum for Indonesian Development argues that comprehensive reform is needed, both of the Consultative Group on Indonesia (CGI) as a forum, and of the terms of Indonesia's debt. In particular, debt repayment should be seen as secondary to human development and welfare needs, the government and creditors should really consider debt relief, public funds should not be used to subsidise private debt, 'and the legality of part of Indonesia's potentially criminal debt should be considered' (INFID 2002).

\section{Privatisation}

In Indonesia, privatisation has been ongoing since the Suharto era, on the pretext of involving the private sector in the economic development and the provision of infrastructure, goods and services for the public interest. In fact, the purpose of privatisation was to facilitate economic power in conglomerates owned by Suharto cronies and in companies owned by the Suharto family (Schwarz 1994: 144-61). In the 1980s, several acts, government regulations and presidential decrees were issued, including: Act No. 15 of 1985 on Electrical Energy; Presidential Decrees on toll roads; Act No. 3 of 1989 on Telecommunications; Act No. 13 of 1992 on Railways; Act No. 14 of 1992 on Road Traffic and Transportation; Acts on aviation and shipping. The essence of these regulations was to allow private companies to get involved in providing various services. Independent power producers (IPPs) like US CalEnergy or UK PowerGen have been doing business since obtaining Power Purchase Agreements from the Suharto regime, and will rely on US and UK pressure on the IMF to see that investments are ensured.

The role of foreign companies was further encouraged in 1994 with the adoption of foreign direct investment regulations to facilitate privatisation. Since that time several strategic state-owned enterprises have been taken over by foreign companies. These privatisations (including the granting of sub-contracts and concessions for government services; licensing agreements; management contracts; operating, equipment or asset leasing agreements; joint ventures; and BOT, Build-Operate-Transfer schemes) were the cause of many cases of conflict between the government and workers' unions in the state enterprises on the one hand, and foreign investors on the other (INFID 2001). 
Wahid, and Megawati after him, inherited the foreign debts incurred by Suharto, who was 'lent at least $\$ 100$ bn by the West as a reward for his anticommunism during the Cold War' (Pettifor 2001). The World Bank, as the Chair of the CGI, and the IMF have proposed a strategy for managing Indonesia's public debt that relies on fiscal consolidation, IBRA asset recovery, privatisation and improved macroeconomic performance. The IMF recommended classic monetary measures, including the removal of subsidies on kerosene and other fuels. Reaction to this measure of a 30 per cent price hike on fuel included mass demonstrations in major cities and further loss of confidence in president Wahid, contributing to his downfall in late $2001 .{ }^{3} \mathrm{~A}$ year later Bill Guerin (2002) observed that a projected hefty 39 per cent further reduction of subsidies on oil-based fuel and electricity, married to a 20 per cent increase in tax revenues, would bring down the public debt level. Total public and private sector debt was at a staggering \$210 billion. Targets for gross domestic product (GDP) growth of 5 per cent and inflation easing off to 8 per cent seemed a tad cosy given current business sentiment. 'Extra revenue will come from slapping value-added tax (VAT) on electricity and highway toll charges, and from higher property taxes, the usual suspects as it were. The subsidy cuts will further restrain the weak spending power of the average consumer ... The head of the Indonesian National Front for Labour Struggle, Dita Indah Sari, has said the government was placing more priority on pleasing the IMF by withdrawing fuel subsidies than on attending to the people's needs' (Guerin 2002).

The removal of subsidies must be seen against the backdrop of economic realities for the majority of the population where, even accounting for six million people being absorbed back into agriculture (six million more now than four years ago, but with no increased agricultural production), an estimated 30 per cent of the labour force is without employment. Converted to foreign currency, the average weekly wage fell from US\$22 in 1997 to $\$ 10$ three years later. The government-regulated minimum wage increased in 1998 by 15 per cent while inflation hit 80 per cent (Kristiansen 2001). UNICEF documented attempts and problems with 'social safety net' provision but concluded that current national health budgets have shrunk by 20 per cent and education by 40 per cent. Their report takes the view that the financial crisis has 'had severe social consequences. Community and government action, with the help of international donors, may have absorbed some of the sharpest blows. But millions more people have plunged into poverty. The health service is deteriorating, and millions of children are malnourished' (Stalker 2001).

The combination of grievance over forestry, logging and mineral concessions to foreign corporations, continued profit holdings by the Suharto family and acute unemployment and lack of opportunity is a potent mix contributing to structural strain and increased violence. This is further aggravated by the current experience of decentralisation as first attempts are made to implement local autonomy laws. 


\section{Mismanaged decentralisation policy as a source of instability and insecurity}

The Indonesian economy has been driven by the use of natural resources principally oil and gas, minerals and timber - but increasingly through manufacturing - principally textiles, wood-based products and machinery. But centralised control was absolute. For example, the 1967 Forestry Law allowed the Ministry of Forestry to claim land that was not under individual property title as state land to be used for the benefit of the people. The result was that approximately 75 per cent of the land area of Indonesia came under the control of the state, even though much of it, especially outside of Java, had been held under traditional communal land title, recognised under both the Constitution and the 1960 Agrarian Law. This land-grab then was used to promote the development of forest-based industries.

The New Order government claimed legitimacy through its modernisation drive and a national development project based on booming oil exports during the 1970s and 1980s. Indonesia was among Southeast Asian success stories for high literacy rates and self-sufficiency in rice. Resource extraction projects, agricultural development, education and infrastructure projects reached outward from Jakarta to all the regions of Indonesia. Aspinall and Berger (2001: 1007) observe that these economic changes were combined with 'an increasingly pervasive and intrusive civilian and military apparatus, which oversaw the standardisation and centralisation of administration, education, and other government services'. Moreover local governance was itself standardised into a mould based on the Javanese model of desa, disregarding and overriding a multiplicity of local forms based on traditional adat law, custom and practice. Ambitious social engineering projects included mass 'transmigration' to relieve population pressures on Java and Madura, leading to new, distorted demographic balances in the regions.

In 1999 under president Habibie, the Indonesian parliament (DPR) voted in favour of two laws, Nos 22 and 25, which promised to leave a significant share of state revenues in the hands of the regional governments. Strongly supported by the IMF and the World Bank, the two laws were envisaged within Indonesia as a necessary step towards diminishing centralised control of New Order patrimonialism, and as a way of curbing separatism and demands for autonomy by giving the regional governments the constitutional and financial wherewithal to maintain a considerable degree of self-determination. Decentralisation is in other words touted as the antidote to communal violence and separatist tendencies - an antidote administered or at least prescribed by multinational development agencies in most conflict-prone areas of the world. The World Bank (2002) survey on 'Evaluating Governance and Decentralisation in Indonesia' refers to 2001 as the 'Big Bang', a take-off or launching period.

In fact warnings had already been signalled that rapid change was not viable. Kim Hak-Su of the UN Economic and Social Commission for Asia 
and the Pacific (ESCAP) went on record in August 2000 stating that most of Indonesia's 26 provinces were not ready for a sudden power shift (Murray 2000) and recommended staged transitions beginning with administrative duties to be followed by financial powers. There has been little consensus or clarity as to the aims and speed of decentralisation. Separate and highly sensitive extended negotiations between the centre and the regions, especially Aceh and West Papua, were needed. In actuality, regional autonomy laws were passed without such dialogue, and in Aceh and West Papua, where separatist sentiments are strong, special autonomy laws were passed in 2001 without effective political negotiation.

In most of the period since the enactment of the law, there has been a parliamentary crisis. Megawati openly criticised the regional autonomy law, ${ }^{4}$ taking a different stand on the issue than Wahid. Already before these laws were scheduled for implementation in the State Budget for 2001, expectations towards the changes that these laws would bring ran high, in parliament, in the media, and in the regions (Bubandt 2001). The outbreak of violence in Ambon in late 1998 and January 1999 was in part due to underlying tension about changed demographic balance between transmigrants and Ambonese (unfortunately also reflected in Muslim/Christian identities) and concern over how this would be reflected in local government jobs, and the provision of services. ${ }^{5}$

Grievances had accumulated in Ambon since the inception of the New Order. After defeating the rebellion in South Maluku in 1950, Sukarno sought support and courted favour by locating prestige projects in Ambon and Seram, notably the Wayame shipyard, an Oceanography Research Institute and a huge sugar mill. Incredibly all were either re-sited or moved to Java by Suharto, with the exception of the Institute, which was reduced to a substation of a Jakarta centre. The Banda Sea was leased out to a Japanese fishing cooperative, but eight years of protests by local fisherfolk, environmentalists and students brought about a reversal. Suharto-linked conglomerates relied on the army to arrest local villagers attempting to protect their land or fishing rights.

In North Halmahara the reorganisation of Kao district boundaries under a new Makian administration contributed to political disputes and rivalries culminating in protracted violence during 2000 and 2001. In Central Kalimantan, wide-spread riots, causing the deaths of between 300 and 600 people, erupted on 18 February 2001, after two Dayak officials reportedly paid local preman a sum of Rp.20 million to orchestrate anti-Madurese attacks in the town of Sampit (Kearney 2001).

Struggles over local posts in the expected wake of decentralisation were also associated with the outbreak of violence in Poso, central Sulawesi in May 2000 (Arragon 2001). Violent clashes in Sampit, Kalminatan, Poso, central Sulawesi, Ambon and North Maluku reveal how intimately the real and perceived changes to the local balance of power associated with decentralisation intertwine with communal violence after 1999. The processes of 


\section{Judith Large and Nick Mawdsley}

democratisation and decentralisation, touted by modernist, 'good governance' discourse of the World Bank and the IMF as the best way to ensure both economic progress and national integrity (World Bank 2000), can in some cases promote socially combustible identity politics as regional actors struggle to adapt to a changing political landscape. Decentralisation and democratisation do not inevitably initiate violent identity politics. It is, however, necessary to identify conditions under which decentralisation contributes directly to latent conflicts emerging as violent or radical identity politics. Ancient traditional land claims and unspoken grievances regarding subordinated authority and the misuse of central power, against a backdrop of mistrust and no experience of genuine representation in decision making, are prime conditions present in each geographical flashpoint mentioned above.

Despite gains in development under the New Order, one issue of perennial concern in Indonesia is the degree of discrepancy between regions. The Indonesia Human Development Report, which compares per capita income, educational attainment and life expectancy across provinces and districts, demonstrates wide disparities in poverty, health and education indicators. Infant mortality rates, for example, range from 24 per cent in Jakarta to 52 per cent in West Papua to 81 per cent in West Nusa Tenggara. It is wide disparities such as these that, when combined with ethnic and other differences in locations like West Papua, which ranks 25 th out of 26 provinces in the provincial human development index (BPS-Statistics 2001), that have contributed to the ongoing potential for social conflicts. If successfully implemented, decentralisation reform could benefit a few resource-rich provinces, mainly East Alimental, Papua, Aceh and Riau. However, each of these has exhibited extreme fragmentation and uneven transition, and both Papua and Aceh are sites of full-scale rebellion and independence movements. Java is likely to benefit, since tax revenues are concentrated in Java in general ( 85 per cent of total tax revenues) and Jakarta in particular.

\section{Global corporate governance over local populations}

Freeport Indonesia, a subsidiary of Freeport McMoRan Copper and Gold, runs one of the largest mines in the world at Grasberg Mountain in West Papua, with legendary operations that have included the provision of a physical infrastructure (roads, power, housing, airfield) and latterly clinics, vocational training and anti-malaria campaigns. Freeport is said to 'rule' or govern with the help of the Indonesian military. The company has frequently resorted to military assistance to put down resistance or protest from local people (ICG 2002), but is currently working with its partner Rio Tinto on 'sustainable development' policies and community outreach, particularly to the Amungme and Kamoro peoples. In early 2000 an Amungme leader brought a suit against Freeport in its parent home state of Louisiana, accusing the company of taking sacred land, polluting water and being party to military abuses. The case was dismissed by the court. 
The following year a lawsuit was filed by the International Labour Rights Fund on behalf of eleven villagers in the Indonesian province of Aceh (Alden 2002). They claimed Exxon Mobil, which operates a natural gas field in the province, paid and directed Indonesian security forces that carried out murder, torture and rape in the course of protecting the company's operations in the 1990s. In both cases civilians from opposite ends of Indonesia's islands were holding TNCs accountable for abuses by the armed forces of Indonesia, bypassing the Indonesian justice system and government.

Exxon Mobil denied the allegations. In an intervention, which drew international attention, the US State Department warned that the action alleging complicity in human rights abuses by the oil group could have a 'potentially serious adverse impact' on US interests. In a letter to the US district court in Washington, the State Department's legal adviser said a decision against Exxon 'would risk a potentially serious adverse impact on significant interests of the United States, including interests directly related to the on-going struggle against international terrorism'. It was claimed that the lawsuit could discourage foreign investment in Indonesia, particularly in the energy and mining industries. That would in turn hurt government revenues and further weaken a key US ally. ${ }^{6}$

Aceh is the site of an ongoing armed struggle, but also hosts huge Arun gas fields and plant facilities in the north at Lhokseumawe, which produce one third of the country's liquefied natural gas exports. The conflict has disrupted production on several occasions. Field interviews and related studies (Sjamsuddin 1984) indicate that the rise of the independence movement in the mid-1970s is directly related to the growth of the beginning of exploitation of the oil and gas reserves near Lhokseumawe, the lack of legitimacy in land requisition, perceived plunder of revenues by Jakarta, and a consistent experience of Exxon Mobil, PT Arun and related facilities offering little employment, no training opportunities or returns to local Acehnese. The plant is surrounded by an estimated 3,000 Indonesian soldiers. ${ }^{7}$

Corporate positioning in Indonesia is intrinsically entwined with government oil and gas interests and the military. PN Pertamina is the state oil and gas company, formed in 1968, formally accountable to the Ministry of Mines and Energy but with its leadership chosen from the army, who also benefited directly from its finances. The company's first president director from 1968 until 1976 was an army colonel who had served as a commander of South Sumatra's Sriwijaya Division, which during the war of independence established a reputation as an income earner for the Indonesian army. They sold vast quantities of rubber, pepper, tea and coffee to Singapore to buy weapons and supplies. The trade continued long after its wartime justification had ended. In 1957, when the army took over the former Shell fields in North Sumatra, the same individual was appointed to establish a limited liability company, PT Pertamina, to rehabilitate the oil industry and to start exporting. 
Oil and gas are minerals with strategic importance, hence the military see it as their prerogative to be involved. The military has traditionally been involved in all aspects, from signing concession agreements, to controlling oil-related transportation, to providing security for companies and industries, which is part of the army's role in all forms of economic enterprise in Indonesia. Mobil Oil Indonesia, Inc. entered a production sharing contract with Pertamina in 1968, which allowed Mobil to explore in Aceh province in northern Sumatra. For Mobil there were advantages to the deal with Pertamina. There was less haggling over financial returns and, since Pertamina took over many of the ordinarily time-consuming administrative tasks such as visas and work-permits, they were provided smooth systems for dealing with the bureaucracy. Crucially, Mobil could also rely on Pertamina to provide for the overall security in the places where oil operations were taking place.

Under Habibie reform was brought in to break the oil company monopoly. World Bank recommendations for Pertamina include: a separation of government and commercial functions by introducing greater competition into downstream activities, and a more level playing field for upstream investments in oil and gas. But structurally at field level the business activities of the military continue. Similarly, military financing has become one of the key components of the reform discourse. The 17th IMF letter of intent dated 17 August 2001 reported that the State Audit Agency (BPK) under president Wahid 'completed audits of eight military foundations (two from the Ministry of Defence, three from the Army, and one each from the TNI headquarters, the Navy, and the Air Force), as well as one State Police foundation, and states that 'The implementation of corrective actions in all cases will be publicised on a regular basis'. The results, however, do not appear to have ever been publicised.

Given unknown amounts of off-budget financing ${ }^{8}$ arrangements, notoriously poor pay for recruits and soldiers, and the need for a force capable of guarding 'stability', it seems that the military business complex will be left largely on the periphery of the reform agenda. The armed forces continue to rely in part on the off-budget funds that business activities provide.

As in Aceh, the Indonesian province of West Papua has been the site of a longstanding separatist struggle, with roots in resistance to the incorporation of West Papua into Indonesia in 1963, a political affair that was orchestrated by Jakarta. Since West Papua did not achieve independence with the rest of the country, nor was it part of the Indonesian nationalist movement, it has weak ideological linkages with Indonesia as a whole. Like Aceh, West Papua is host to valuable natural resources (particularly gas, copper, gold and timber), but most of the revenue from these has gone to the national government and foreign contractors. These resources have also attracted waves of migration from other parts of Indonesia for decades, resulting in demographic changes, but also in land and resources being lost to outside investors and immigrants, with little or no compensation. 
Migrants have also had greater access to services such as health and education, and have come to dominate positions of authority in the province, with comparably few Papuans being represented in positions of authority in major enterprises or local government. For example, until recently the majority of the police force was Javanese, an issue currently under review and reform.

British Petroleum has been developing a new natural gas project, Tangguh LNG, in Papua that will test whether resource companies can operate without defensive stances and the generation of conflict. Under a production-sharing contract with Pertamina, it will extract gas from BerauBintuni Bay in West Papua, mostly from offshore fields, and pipe it to an onshore plant to be liquefied and loaded onto tankers for export. Tangguh LNG will take up about 3,000 ha of land, a small area compared to a mine like Freeport or a large-scale logging operation. However, its economic, social and political impact will be significant. BP plans to invest US $\$ 2$ billion, which could create revenues of US $\$ 32$ billion between 2006, when exports are due to begin, and 2030. It is estimated that the central government will earn nearly US\$9 billion from the project during this period, with some US $\$ 3.6$ billion going to Papua. The exact division between the various levels of government will not become clear until secondary legislation is passed to interpret the special autonomy law.

BP is thus dealing nationally and locally, and was due to sign an agreement in mid-2002 with local government and villagers when tensions flared, partly over land compensation and partly over status questions. These were subsequently resolved. To win local support, BP intends to offer community development not only to the seven villages directly affected but to people all around Bintuni Bay. There are also plans for an 'adat heritage fund'. These initiatives, like Freeport's relatively recent concern with its 'ethical policy' towards employees, reflect new lines of influence and responsibility. They also reflect traditional 'national interest', and BP will use many embassy channels in Jakarta for good offices and influence. Effectively Freeport and BP relate far closer to local governance than central government. This irony aside, corporate responsibility is still more the exception than the rule.

Currently in West Papua the Moi people are resisting PT Intimpura (an Indonesian logging firm) which was granted 339,000 ha of forest concessions in the midst of ancestral lands. WALHI (Wahana Lingkungsan Hidup Indonesia), the Indonesian Forum for the Environment, sees the free trade agenda as the commodification of humans, publicly-owned natural resources and the Earth. Environmental activists in their network cite 'Business as Usual' in the Mehtawais, site of a proclaimed (1981) UNESCO Biosphere Reserve, where in spite of claimed preservation and heritage status an all too familiar cycle of extractive plunder is again firmly in place - private logging which paves the way for oil palm plantations goes hand in hand with the destruction of coral reef habitats. The Indonesian Forestry Ministry claims no ability or means to protect 
national parks since the loss of its reforestation fund to the Finance Minister as part of IMF-imposed reforms. ${ }^{9}$

\section{Conclusion}

On 1 June 2002 the Jakarta Post reported Indonesia's minister of national development planning Kwik Kian Gie's call on the government to sever contact with the IMF once their mutual contract expired in November. One month earlier prominent politician Amien Rais said selling all state-owned companies was unpatriotic, un-nationalistic and completely wrong (Antara News Agency 30 April 2002). Kwik likened the IMF to a colonial power and claimed that, in return for loans, the lender has bound Indonesia to rules and regulations that have caused the country to descend further into bankruptcy and disorder. As a member of president Megawati Sukarnoputri's cabinet and of the Democratic Party of Struggle, Kwik understood Jakarta's need for relations with the IMF. Analysts point to political rather than economic considerations for his statement, namely maintaining support among the country's majority Muslims and countering challenges from more fundamentalist parties.

The US 'war against terrorism', the re-positioning of US troops in the neighbouring Philippines, and the focus on Southeast Asia as a potential haven for militant elements has angered many Indonesians who see Washington's campaign as an anti-Muslim movement. Wishing to maintain majority support, the government initially did not arrest suspected militants, provoking criticism from regional governments and the US. Particularly since the shock of losing East Timor - which many perceived as Western Christian interests pulling away a Catholic part of Indonesia - the subject of Indonesian national integrity is extremely sensitive. The Indonesian military, although heavily involved in legal and illegal business ventures, sees its role as the guardian of national unity and the stabilising force from international and domestic political interests.

As the American Congress approved \$4 million for "counter-terrorism fellowships' to Indonesia, the Director of the Indonesian Legal Aid Foundation stated that 'Before giving the aid, the US should calculate the impact. No matter how small it is for the military they could use it to justify past repression' (Purdum 2002). Advocates of political reform are worried that the post-2002 Bali bombing focus on security, by the Megawati administration and foreign governments alike, will divert attention from the urgent need to strengthen civilian institutions, reform the armed forces (particularly in terms of financial transparency), build an accountable justice system, and end corruption.

To date good governance issues in Indonesia were primarily driven by the World Bank's economic policy agenda. This chapter has argued that socalled good governance reform and adjustment mechanisms are influenced by specific context, including the legacy of New Order politics and struc- 
tures, the sharp increase in overall poverty and social strain in Indonesian society, and the impact of TNC administrative and development arrangements in the region. In particular the rapid combination of democratisation and decentralisation is proving volatile. The result is that the international community is overstretched in its support for governance and neoliberal reform in Indonesia, and compromised by competing agendas such as the need for regional stability and simply 'doing business' which requires cooperation with the very power structures that represent the impediment to reform. Conditionalities have been ineffective in achieving desired reforms, in effect ignoring domestic politics and historical complexity.

Suharto's fall came amid popular cries for genuine representative democracy, a multi-party system and social justice and human rights. Since the 1997 Asian crisis the IMF has led attempts to reform and revive the Indonesian economy, while the international community, principally through the United Nations, IMF, World Bank and USAID, have placed good governance at the centre of their developmental assistance programmes. The strategic alliances in Indonesia today, just as did those that led to the birth of the New Order in the 1960s, involve local, national and international actors and increasingly reflect interests which subsume social and human rights to strategic concerns. Buru Island, notorious as a prison camp site for thousands of tapol or political prisoners captured and transported after the purges of the $1960 \mathrm{~s}^{10}$ today hosts former Javanese prisoners who later became farmers or craftsmen on release. Many fled the recent violence in southern Maluku, and are now housed in camps for IDPs (internally displaced persons). Observing the arrival of UNDP to works on Buru in relief and reconstruction, an Indonesian commented wryly: 'From New Order to New World Order'.

Given that the IMF and taxpayers of IMF-contributing countries are providing the capital for the loans to Indonesia and that the Indonesian people are paying the price of these loans, it is completely within reason that the IMF becomes more accountable to both these groups. Indonesia to date represents a failure of the neoliberal package as promoted by the IFIs. A new approach is required to effectively support reform from within Indonesia, not imposed from outside. This demands focus and commitment to building democratic legitimacy, accountability and political dialogue.

Current policy perpetuates old power structures and contributes to national instability and insecurity. Despite growing 'anti-IMF' sentiment among some Indonesian politicians, the draft budget for 2003 was crafted to appease the International Monetary Fund and ensure that the country continues to receive the remaining tranches of a long-drawn-out US\$5 billion rescue programme. This was the seventh letter of intent (LoI) between the IMF and the Indonesian government. Targeted spending for development for 2003 accounts for only 2.8 per cent of GDP, compared with 3.1 per cent this year. Guerin (2002) states that the central government actually gets in more money than it pays out and in the 2002 budget this surplus 


\section{Judith Large and Nick Mawdsley}

is almost $\$ 5.3$ billion. But the reality is a deficit equivalent to 2.5 per cent of GDP. Internal interest payments of Rp59.6 trillion ( $\$ 6.5$ billion) and external interest payments of $\$ 3$ billion turn the surplus into a deficit of $\$ 4.2$ billion: 'This is the crux of what the IMF-Indonesia relationship is all about. The interest on foreign and domestic debt is a stranglehold that forces Indonesia to seek new loans in a vicious circle that traps the government within a master-servant relationship with the IMF and other international donors' (Guerin 2002). Meanwhile many in the population feel trapped in a master-servant relationship with their government.

The central challenge for Indonesia is transforming these power relationships to create a society and system of governance that addresses people's needs and builds on the opportunities presented by a liberalised economy by effectively distributing assets and proceeds of economic growth. Approaches to reform in Southeast Asia must take seriously the issue of development defined as equity and social justice in addition to economic growth.

\section{Notes}

1 'Cukong' refers to Indonesian Chinese capitalists often in close alliance with the political and military elite.

2 Introduced by Sukarno in 1945 as a unifying ideological focus for creating the new Indonesian nationality, Pancasila was meant as five umbrella principles for the population: faith in God (to be conceived as chosen, as Allah, Visnu, Buddha or Christ) Humanity, Nationalism, Representative government based on consensual marfakat traditions, and Social justice.

3 'Fuel Price Hike Effective Today', Jakarta Post, 16 June 2001

4 See 'VP criticizes regional autonomy law', Jakarta Post, 17 May 2001

5 Interviews by the authors with residents in Ambon, spring 1999 and 2000.

6 The letter in question was from William Taft, Legal Adviser to the Dept. of State, and included an enclosure indicating the view that adjudication in the US would compromise the ability of the Indonesian government to guarantee the safety of foreign investment. See Steven Kretzmann, 'Exxon in Aceh: America's double standard', in Asia Times, 22 August 2002, and Kenneth Roth, 'US hypocrisy in Indonesia', International Herald Tribune, 14 August 2002.

7 Don Greenlees, 'The China Gas Deal: the Gas 'n' Guerilla Grind', The Australian, 22 August 2002 via Joyo Indonesia News. Greenlees notes investors get squeezed from both sides (bribes to police, protection dues etc.): 'This is the reality of doing business in the midst of East Asia's most brutal guerilla conflict.'

8 At the national level the military's economic interests include natural resource extraction, service sectors including finance, real estate, manufacturing and construction. In localised conflicts such as Ambon, anecdotal evidence is strong on entrepreneurial initiatives such as parrot and other rare bird export. In Aceh stories in a similar vein abound, with drugs, weapons and prostitution as small enterprises. McCulloch (2001) classifies the level and type of involvement in criminal opportunism by the military and police as dependent on several variables: location; local commanders; availability of 'lootable' commodities; level of professionalism in a particular unit; and local civil-military relations.

On the traditional dual function of the military, see Ian MacFarling, The Dual Function of the Indonesian Armed Forces, Canberra: Australia Defence Studies Centre, 1999. 
9 In Malinau, East Kalimantan, the amount of timber cut from newly formed small concessions is greater than that from large concessions. IMF reforms that withdrew the ban on export of sawn logs have stimulated the local timber market as local prices have risen towards regional markets prices. The huge overcapacity in the timber processing industry (roughly 2-3 times the sustainable cut from Indonesia's forests) has also fuelled expansion of small scale as well as rampant illegal logging in the district. See Down To Earth fact sheet NO50 August 2001. Available online: http:www.dte.gn.apc.org.

10 Also immortalised by the literary masterpiece of Pramoedya Ananta Toer, the Buru Quartet, originally recited by the author to his cellmates in the camp.

\section{Bibliography}

Abrahamsen, Rita (2000) Disciplining Democracy, London: Zed Books.

Alden, Edward (2002) 'US tries to halt rights suit against Exxon', Financial Times (UK) 6 August.

Antlöv, H. (1999), 'Decentralization, Public Administration Reforms and Local Democracy in Indonesia.' Paper presented at the conference 'Social and Economic Structures and the Origin of the Asian Crisis', Lund, Sweden, November.

Arragon, L.V. (2001) 'Communal Violence in Poso, Central Sulawesi: Where People Eat Fish and Fish Eat People', Indonesia, 72: 45-79.

Aspinall, Edward and Marker Berger (2001) 'The break-up of Indonesia? Nationalisms after decolonialisation and the limits of the nation state in post-cold war Southeast Asia Third World Quarterly, 22 (6): 1003-24.

BPS-Statistics Indonesia, BAPPENAS, UNDP (2001) 'Towards a New Consensus: Democracy and Human Development in Indonesia', Indonesia Human Development Report, 2001.

Bubandt, Nils (2001) 'Decentralisation, Conflict, and the New Politics of Tradition in North Maluku.' Draft paper presented at the workshop 'Governance, Identity and Conflict. Assessing the Impact of Democratization, Decentralization, and Regional Autonomy on Stability in Post-Suharto Indonesia' at the Nordic Institute of Asian Studies (NIAS) in Copenhagen, 31 August - 1 September.

Buentjen, C. (1998), 'Fiscal Decentralization in Indonesia', Report P4D 1998-11, Support for Decentralization Measures, GTZ-Jakarta.

DTE (2000) 'A Brief History of the IFIs in Indonesia. Down to Earth', Factsheet No 5. Available online: http://dte.gn.apc.org/Af5.htm

Duffield, Mark (2001) 'Governing the Borderlands: Decoding the Power of Aid', Disasters, 25 (4): 216-29.

Galvan, D. (2001) 'Market liberalisation as a catalyst for ethnic conflict in Senegal and Central Java, Indonesia.' Paper presented at the 97th Annual Meeting of the American Political Science Association, San Francisco, September.

Guerin, Bill (2002) 'Indonesia's cycle of subservience to the IMF', Asia Times, 10 September.

Harianto, F. (2002) 'A Skeleton of Bank Restructuring in Indonesia.' Paper presented at the conference 'Forum on Indonesia - The First 100 Days of President Abdurrahman Wahid: An Economic Agenda', Singapore, January.

Hefner, Robert W. (1999) 'Islam and the Nation in the Post-Suharto Era' in Adam Schwarz and Johnathan Paris The Politics of Post-Suharto Indonesia, Singapore: Council on Foreign Relations, SNP Editions Pte Ltd. 


\section{Judith Large and Nick Mawdsley}

Higgott, R. and H. Nesadurai (2002) 'Re-thinking the Southeast Asian development model (SEADM): bringing ethical and governance questions in', CSGR Working Paper No 92/02. Centre for the Study of Globalisation and Regionalisation, University of Warwick.

INFID (2001) 'INFID Lobby on CGI' (Consultative Group on Indonesia) Meeting, Jakarta, November.

- (2002) 'Comprehensive strategies needed for Indonesia's recovery', INFID position paper on the CGI.

International Crisis Group (2001) Bad Debt: the Politics of Financial Reform in Indonesia, Asia Report No. 15, Jakarta and Brussels.

- (2002) Indonesia: Resources and Conflict in Papua, Asia Report No. 39, Jakarta and Brussels.

Kaiser, Jurgen (2002) 'Doing without the IMF: Figuring out where the money comes from', Jakarta Post, 6 August.

Kaiser, Kai (2002) 'Evaluating Governance and Decentralisation in Indonesia', in The 2002 Governance and Decentralisation Survey (GDS), World Bank Office Jakarta. Available online: http://www.worldbank.or.id/decentralization

Katyasungkana, Nursyahbani (2000) 'The Problem of Creating Democratic Institutions', in Chris Manning and Peter Van Dierman, Indonesia In Transition, London: Zed Books.

Kearney, Marianne (2001) ' "Irate Officials” behind clashes in Central Kalimantan', The States Times, 23 February.

Kristiansen, Stein (2001) 'Unemployment, Identity and Business: Violent Youth Groups in Yogyakarta and Nusa Tenggara Barat.' Paper presented at the NIAS Workshop on Governance, Identity and Conflict, Copenhagen, 31 August - 1 September.

McCulloch, Lesley (2001) 'The role of the Indonesian Military in Business.' Paper prepared as a chapter in forthcoming edited volume on military in business, London: Palgrave.

MacEwan, Arthur (1999) Neoliberalism or Democracy? Economic Strategy, Markets, and Alternatives for the 21st Century, London and New York: Zed Books.

Manning, Chris and Peter Van Dierman (2000) Indonesia In Transition, London: Zed Books.

Maxwell, Simon, (1999) 'Global Governance: An Agenda for the Renewal of the United Nations?' London: Overseas Development Institute Briefing Paper 2/July.

Miguel, E., P. Gertler and D.I. Levine (2001) 'Did industrialisation destroy social capital in Indonesia?' Berkeley: University of California Press.

Moore, David (2001) 'Neoliberal Globalisation and the Triple Crisis of 'Modernisation' in Africa', Third World Quarterly, 22 (6): 909-29.

Murray, Leigh (2000) 'Indonesia Warned Don't Rush Regional Autonomy', Dow Jones Newswires. 3 August.

Nathan Associates (2001) 'The Gains from Open International Trade and Investment in the Deregulation Era: Implications for Indonesia's International Economic Policy in the 21st Century', USAID Partnership for Economic Growth, Jakarta.

Pettifor, Ann (2001) 'Indonesia Pays the Price of IMF blunder', Guardian, 9 July.

Purdum, Tod S. (2002) 'US to Resume Aid to Train Indonesia's Military Forces', New York Times, 2 August.

Schmidt, J.D. (1998) 'Southeast Asia between global neoliberal discipline and local quests for welfare.' Working Paper No 84, Asia Research Centre, Murdoch University, Australia. 
Schwarz, Adam (1994) A Nation in Waiting: Indonesia in the 1990s, St Leonards, Australia: Allen \& Unwin.

Schwarz, Adam and Johnathan Paris (1999) The Politics of Post-Suharto Indonesia, Singapore: Council on Foreign Relations, SNP Editions Pte Ltd.

Sidel, John (1999) 'Indonesia Update: Trends toward Consolidation, Threats of Disintegration', WriteNet Paper No. 18.

Sjamsuddin, S. (1984) 'Issues and politics of regionalism in Indonesia: Evaluating the Acehnese experience', in Lim Joo-Jack and S. Van (eds), Armed Separatism in Southeast Asia, Singapore: ISEAS.

Stalker, Peter (2001) 'Beyond Krismon: The Social Legacy of the Indonesian Financial Crisis'. Available online: http://www.unicef-idc.org

Strategic Forecasting (2002) 'Indonesia: Anti-IMF Rhetoric Tailored for Muslims'. Available online:

http://www.globalpolicy.org/wtc/analysis/2002/0605indonesia.htm

Tempo (2002) 'Party time for the rich', Tempo Magazine, 23-29 July.

Uhlin, Anders (1997) Indonesia and the Third Wave of Democratisation, Richmond: Curzon.

UN (2000) 'U.N. Guidelines: Cooperation between the United Nations and the Business Community', issued by the Secretary General, 17 July.

Vatikiotis, Michael (1993) Indonesian Politics under Suharto, London: Routledge.

Wade, Robert Hunter (2002) 'US hegemony and the World Bank: the fight over People and Ideas', Review of International Political Economy, 9 (2), Summer: $215-43$.

William, James (2001) 'Globalization and Decentralization: The Gains from Open Domestic and International Trade.' Keynote speech at Conference on Domestic Trade, Decentralisation and Globalization, Jakarta, 3 April.

World Bank (1992) Governance and Development, Washington, D.C.: World Bank.

World Bank (2000) World Bank Development Report 1999/2000: Entering the 21st Century, Washington, D.C.: World Bank.

World Bank (2001) Indonesia: private sector development strategy, Washington, D.C.: World Bank.

World Bank (2002) Evaluating Governance and Decentralisation in Indonesia, Washington, D.C.: World Bank. 


\title{
14 Good governance, privatisation and ethno-regional conflict in Cameroon
}

\author{
Piet Konings
}

By proclaiming that a 'crisis of governance' underlies 'the litany of Africa's development problems', the World Bank's 1989 report Sub-Saharan Africa: From Crisis to Sustainable Growth placed the concept of good governance at the heart of the donor agenda for Africa (World Bank 1989: 60). Painfully confronted at the time with the relative failure of its structural adjustment programmes (SAPs), the World Bank was inclined in this report to blame the weak, predatory and neo-patrimonial African states for the poor performance of structural adjustment rather than to question its own neo-liberal reform package. It therefore stressed the need not only for less but also for better government in African states.

But what is good governance and how is it to be promoted? The term remains rather vague. The World Bank (1992: 1) defines it in managerial terms as 'the manner in which power is exercised in the management of a country's economic and social resources for development'. Good governance was to flow from enhanced accountability within the public sector, transparency and openness in decision-making, the rule of law, and more efficient public management. World Bank officials also added the issue of capacity building to enable technocrats to initiate and implement market-based economic reforms as an essential element for good governance (Sandbrook 2000: 10-13).

Whereas the World Bank couched its interventions in the affairs of African countries in governance terms that enabled it to claim not to have preferences for particular types of regime, bilateral aid donors felt less inhibited in linking democracy to good governance. The latter sought to promote a liberal-democratic system through a combination of political conditionalities and financial support for democratisation initiatives and capacity building, such as the introduction of international election observation and the empowerment of non-government organisations. Although bilateral donors continuously stressed that democratisation had its intrinsic merits, it is beyond any doubt that they saw it primarily as a vehicle for promoting the more efficient implementation of structural adjustment measures. Democratisation was said to empower the electorate by providing it with mechanisms of a parliamentary and extra-parliamentary nature to check 
upon the ruling regime's neo-patrimonial practices and to participate in the decision-making process about necessary structural adjustment measures. This would contribute to the legitimisation of unpopular neo-liberal reforms among the population.

Clearly, the good governance discourse, propagated by the donor community generally and the World Bank in particular, represents an instrumentalist, managerial and technocratic approach to development. It aims at promoting the emergence of a more conducive and, in their view, more legitimate political environment, backed by the requisite administrative capacity, for the successful implementation of orthodox structural adjustment (Olukoshi 1998: 35). This approach entails an essentially depoliticised notion of governance. It narrates the proposed restructuring of African societies simply as a managerial and technical problem rather than as being contested and political. Disagreements and conflicts over the design and implementation of neo-liberal reforms are usually absent from any analysis, and development emerges as a neutral project guided by 'technical considerations of economy and efficiency, rather than ideological and political considerations' (Abrahamsen 2000: 143). When the World Bank and governance theorists do acknowledge conflict, they are usually in the habit of treating it solely, or primarily, as the result of the 'selfish' and 'illegitimate' machinations of vested interests that are steeped in a variety of neo-patrimonial relations. In the end, this approach tends to insulate governance from the actual political process: persistent struggles for power, control over resources, as well as access to the decision-making process about the contested neo-liberal reforms. It tends in particular to gloss over the weak and dependent position of African states in the world capitalist system. The continent's strategic and economic marginalisation in the new world order, and its dependence on foreign assistance, have facilitated intervention and governance by international institutions and organisations to the extent that more and more decisions that determine the well-being of Africa's peoples are today being made outside the continent in the Washington offices of the Bretton Woods institutions. Power, in other words, is increasingly located outside the political community as conventionally defined by democratic theory, and beyond the reach of the democratic control of Africa's citizens (Abrahamsen 2000: 146-7).

While elected African governments have frequently tried to avoid, postpone, manipulate and dilute the imposed neo-liberal reforms, which tend to further undermine the patronage networks on which their power continues to rest and the limited legitimacy they still enjoy among the electorate, their dependence on continued financial assistance has generally led them to fall into line with the demands of their external constituency. Civil-society organisations that have either emerged or obtained a large measure of autonomy during political liberalisation are usually completely excluded from the decision-making process about neo-liberal reforms and have often displayed strong opposition to austere structural adjustment measures. Interestingly, in 


\section{Piet Konings}

the absence of any powerful opposition parties in the African democratic transition, newly created ethno-regional associations have come to serve as the new intermediaries between the state and the electorate in a number of African states, including Cameroon (Kasfir 1998; Nyamnjoh and Rowlands 1998). Their leadership is determined to represent and defend ethno-regional interests during structural adjustment and often strives for a larger degree of ethno-regional autonomy and self-determination.

In this chapter I want to demonstrate these arguments with an extended case study of privatisation in Cameroon. Privatisation has become one of the cornerstones of the public-sector reforms imposed by the Bretton Woods institutions on Cameroon. In the first part of this study, I highlight the linkage between good governance and privatisation and its embeddedness in particular relations of power. In the second part, I focus on the vehement resistance of ethno-regional associations and other civil-society associations, in particular the trade unions, to the government announcement on 15 July 1994 of the privatisation of the Cameroon Development Corporation (CDC), a huge agro-industrial parastatal located in the coastal area of Anglophone Cameroon. These organisations perceived the announced privatisation of this important regional parastatal as a further step towards ethno-regional marginalisation and a severe threat to their workers' welfare.

\section{Governance and privatisation in Cameroon}

Privatisation has become a key instrument in the structural adjustment programme and the good governance agenda imposed on Cameroon by the Bretton Woods institutions and bilateral donors. It is an essential part of the overall neo-liberal reform package aimed at creating transparency and accountability in the management of national affairs as well as a favourable environment for opening up the Cameroonian economy to market forces and private-sector development.

As in most other African countries (Grosh and Makandala 1994; Tangri 1999), the parastatal sector in Cameroon has grown rapidly since independence (Tedga 1990; Van de Walle 1994; Walker 1998). From a handful of public enterprises inherited from the British and French Trust Authorities at independence and reunification in 1961, the Cameroonian parastatal sector grew to 219 enterprises in the mid-1980s, employing approximately 100,000 people. Growth in public-sector ownership was the result of a series of economic and political factors, in particular statist conceptions of development, economic nationalism, and the need for political patronage (Tangri 1999: 19-22).

The 1960s was a period when 'statism' was a key feature of development thinking and strategy on the continent. The view that the state should be the prime motor of development was widely shared, and ownership and intervention by the state was accepted as the dominant development paradigm. State entrepreneurship was also strongly supported by Western donors. For 
example, the enormous expansion of the Cameroonian agro-industrial parastatal in the post-colonial period was largely financed by the World Bank and other international financial institutions (Konings 1993a: 26).

Public-sector expansion was also encouraged by the fact that, at independence, Africa's economies were characterised by a weak and subordinate indigenous private sector and foreign control. Most post-colonial governments tried to forestall the development of a national bourgeoisie, which they regarded as a potential political threat, and to reduce foreign dominance. Attaining greater ownership and control of the "commanding heights of the economy' would enable them to influence the broad direction of national development. Subsequently, the parastatal sector came to be viewed as 'national patrimony' and its sale to foreigners was regarded negatively.

And, last but not least, state expansion afforded prebendal and patronage possibilities and was therefore seen by the African political elite as a valuable mechanism in the consolidation and maintenance of political power. According to Nicolas van de Walle (1994: 155-6), public enterprises in Cameroon 'proved to be an ideal instrument to distribute state resources in the form of jobs, rents, power and prestige', enabling the president to reward allies and co-opt opponents, and thus 'secure his own power base'. A 'patrimonial logic' existed in many African post-colonial states (Chabal and Daloz 1999), but was particularly forceful in Cameroon, a country with stark ethno-regional cleavages (Ngayap 1983; Kofele-Kale 1986; Gabriel 1999). State resources could be used to forge the ethno-regional alliances necessary for national unity and political stability and to obviate the need for coercion. The political importance of state-owned enterprises is evident from the fact that the Cameroonian government used to subsidise parastatal-sector losses to the tune of some 150 billion CFA francs a year prior to the start of the economic crisis in the mid-1980s. Though many of Cameroon's oil revenues were initially kept in secret bank accounts abroad, their primary function soon became the covering of parastatal deficits.

By virtually any measure of economic performance, the record of stateowned concerns has proved disappointing. Although by no means uniformly negative in their performance, public enterprises have been judged inefficient and unprofitable. The Cameroonian government itself has regularly recognised the operating ineffectiveness of its parastatals but little noticeable improvement in public enterprises has occurred (Konings 1993a: 27). Remarkably, the international financiers who made a major contribution to parastatal expansion failed to raise any serious alarm about the dismal performance of Cameroonian public enterprises for a long time. This may be explained by the fact that they, like others, were impressed by the general performance of the Cameroonian economy which was viewed as one of the rare success stories in Africa, registering a phenomenal growth rate of 6-7 per cent between 1970 and 1986 (Konings 1996). It was not until the crisis in the Cameroonian economy in 1987 that the World Bank began to express its 


\section{Piet Konings}

disillusionment with the performance of state enterprises, attributing their poor performance to the following factors:

The causes of the bad results of the 60 enterprises, in which the state participates to a greater or less extent, are ... the excessive size of the initial investments and the low earning capacity of the projects, overemployment, a too heavy administrative structure, the absence of clearly defined objectives and concomitant criteria of performance, and incentives for the management. These enterprises also suffer from the usual ills of public enterprises: the pursuit of social objectives without any direct financial compensation from the state, the politicisation of management and the interference of supervising ministries in the management, the slow reaction to developments in the market and the poor financial structure.

(World Bank 1987: 5)

Subsequently, in 1988/89, the Bretton Woods institutions forced the reluctant Biya government to adopt an SAP, making privatisation a cornerstone of their lending conditions. Privatisation intended to achieve at least three things.

1 It would contribute to solving the problem of rising budgetary deficits and in the process also generate revenue that could be used to pay off government debts. With few exceptions, state-owned enterprises had been operating at a loss. In 1984, they had operating losses of FCFA65 billion, representing 1.5 per cent of GDP; the following year losses increased to FCFA121 billion or 3 per cent of GDP. The situation continued to deteriorate. Between 1989 and 1994, state-owned enterprises accumulated debts of an additional FCFA352 billion, bringing their total to over FCFA750 billion or 22 per cent of GDP (Walker 1998: 263).

2 It would contribute to the depoliticisation of the economy through the dismantlement of state redistributive and welfare activities, which were lumped together as 'neo-patrimonial' or rent-seeking practices. These practices were held responsible for the various shortcomings of stateowned enterprises, in particular widespread corruption, political interference, political appointments, weak monitoring and overstaffing. Privatisation was thought to lead to greater transparency and accountability, to increase efficiency in the allocation of resources and to stimulate more economic competitiveness, all of which were expected to promote greater total factor productivity in the national economy.

3 It would contribute to the promotion of private enterprise and attract badly needed foreign capital. Generally speaking, privatisation could produce a desirable change in the balance of power between the state and the private sector. 
Public enterprise reform and private sector development have been designed in the offices of the Bretton Woods institutions. Like other structural adjustment measures, they have been accepted by virtually all bilateral donors and presented to African governments as the only way to development and economic growth. Ever since the Biya government was compelled in 1990 to introduce a certain measure of political liberalisation, including a multi-party system and a limited degree of freedom of press and association, there has been little local participation in the actual formulation of privatisation schemes. The degree of control exerted by donors and creditors, especially the Bretton Woods institutions, on these new democracies poses a challenge to key features of liberal democracy as commonly conceived in political theory in that it threatens to erode the right to national self-determination and self-government. This is a form of democracy characterised by local political emasculation, where the fine-tuning of externally directed policies is the best that can be hoped for and where voices of dissent are persistently overruled by the government's accountability to its financial sponsors (Abrahamsen 2000: 145). The result is what Mkandawire (1999) has termed 'choiceless democracies', democracies in which pronouncements in favour of economic liberalisation are the only political route available.

Strikingly, the donor community has been keen to resist any accusation of undue influence over domestic policy choices, and has eagerly promoted the notion of national ownership of SAPs. 'Ownership' implies that the Bretton Woods institutions no longer impose policies on African countries but merely put their superior economic knowledge and planning skills at the disposal of governments, which then make an autonomous decision as to whether to adopt the suggested policy measures. Clearly, such a discourse denies the fact that public enterprise reforms and private-sector development programmes have been subjected to little local debate and have usually not required legislative debate. These programmes are normally simply imposed after secret consultations with a few top national technocrats representing the government.

There is obviously a serious contradiction between the donors' ardent quest for the insulation of technocracy and their calls for greater accountability and transparency in economic affairs. There appear to be two main reasons for their preference to deal with insulated technocrats. First, they rightly assume that Africa's 'old guard' neo-patrimonial leaders are less inclined to faithfully implement structural adjustment because of its potential for undermining the clientelist networks on which their power rests. Technocrats, in contrast, are thought to be driven purely by considerations of competence and professionalism required for the effective design and implementation of economic reforms. Second, donors seem to feel that, since adjustment requires unpopular sacrifices, in-camera negotiations with technocrats are preferable to a participatory decision-making process by which popular demands can derail 'necessary' reforms. Most newly elected African governments also appear to eschew popular input into adjustment 


\section{Piet Konings}

programmes. Not only do they have limited room for manoeuvre in negotiations with the IMF, the World Bank and other lenders but they are also expected to implement any agreements as negotiated. Knowing that they will therefore be unable to satisfy some demands, presidents and their lieutenants avoid consultations they cannot control and ignore or undermine articulations of dissent and protest, such as opposition by civil-society organisations and independent newspapers.

Remarkably, although the donors are able to design and impose structural adjustment measures upon African governments, they appear to have less control over their actual implementation. There is considerable research and empirical evidence to suggest that African governments may sign documents initiating a privatisation programme without intending ever to execute it (Bennell 1997; Tangri 1999). For these government leaders, the need to continue financial assistance flows demands acquiescence to donor demands but the realities of the domestic political economy limit what is politically feasible. Under these circumstances, a strategy of initial acceptance followed by delay and obstruction may be the most effective.

Privatisation, in fact, represented a severe challenge to (i) the neopatrimonial logic of the Cameroonian regime which laid a solid foundation for co-opting the various ethno-regional elite factions into the 'hegemonic alliance' (Bayart 1979) and thus secured a considerable measure of political stability in the post-colonial state; (ii) the post-colonial state's welfare concerns manifest, among others, in the creation of employment and relatively good conditions of service in the public sector; and (iii) the existing national sentiments, looking upon the parastatal sector as part of the 'national patrimony' (Campbell 2001).

One of the defensive tactics of Cameroonian government leaders has been the attempt to privatise state corporations and put them in their cronies' hands (Hibou 1999). Similar to other African countries (cf. Tangri and Mwenda 2001), the privatisation process in Cameroon thus reinforced patterns of patron-client relations that the exercise itself was supposed to eliminate. Little wonder then that the donors, including the World Bank, have recently expressed concerns about the politicisation of economic reforms (World Bank 1997, 2000).

Another tactic has been what Van de Walle (1993) has called 'the politics of non-reform'. In 1991 a World Bank mission provided an overview of the disappointing state of the Cameroonian government's efforts to reform and sell off state-owned enterprises: the delay in establishing government agencies to oversee the process, the government's reluctance to sell off anything but bankrupt or inconsequential enterprises, the in-fighting over which firms would be first to be sold or liquidated, and the foot-dragging over issuing tenders and establishing the criteria by which bids would be evaluated (Walker 1998: 4). Again, in its 1994 report Adjustment in Africa: Reforms, Results, and the Road Ahead, the World Bank asserted that in the area of privatisation, little progress had been made in Cameroon. The report 
constantly rated Cameroon on the bottom rungs of economic policy and adjustment performance, and it pointed out that the IMF had signed and cancelled three successive stand-by agreements because of the government's failure to achieve negotiated targets (World Bank 1994).

The slow progress of the privatisation programme is clearly manifest in the actual number of privatisations that were executed between 1989 and 1996. To fulfil the terms of the structural adjustment loan negotiated between the Cameroonian government and the World Bank in 1989, the Cameroonian government completed an initial review of the parastatal sector over the following year that culminated in a presidential decree in October 1990 designating an initial set of 15 enterprises ( 7 per cent of the total of 219) that were to be sold off. In July 1994, a second presidential decree added an additional 15 enterprises to the group destined for divestiture, most of them in the agro-industrial and transport sectors. However, as of mid-1996 only 10 of the 30 enterprises on the divestiture list had actually been sold.

While African governments have often tried to postpone or dilute the imposed privatisation programmes, civil-society organisations have frequently opposed their implementation as being harmful to their members' interests and have demanded a voice in the decision-making process (Olukoshi 1998; Konings 2002). One of the privatisations in Cameroon that sparked off virulent opposition from ethno-regional associations and pressure groups was that of the Cameroon Development Corporation (CDC). The CDC was the most prominent of the 15 enterprises selected for privatisation in July 1994, being the largest agro-industrial parastatal in the country. Its estates are located in the coastal area of Anglophone Cameroon and its operation has been of great importance to regional development.

\section{Privatisation of the CDC and ethno-regional opposition}

The CDC is the most important agro-industrial parastatal in the country with more than 100,000 hectares of land. It is one of the few agro-industrial enterprises in the world that specialises in a variety of crops - the four major ones being rubber, palm oil, tea and bananas. With the help of huge loans from several well-known financial institutions, including the World Bank, the International Development Association (IDA), the European Development Fund (EDF), the Commonwealth Development Corporation (Comdev) and the French Caisse Centrale de Coopération économique (CCCE), it expanded its area under cultivation from 20,000 to 42,000 hectares following the achievement of independence and reunification in 1961. It is the country's second largest employer, surpassed only by the government, and formerly employed 25,000 workers. At present, it still employs about 12,500 permanent workers and a few thousand seasonal and casual workers (Konings 2001). 


\section{Piet Konings}

The CDC is, furthermore, one of the country's oldest enterprises. Its history is closely linked with the political and economic history of Anglophone Cameroon. It was founded in 1946 but its roots can be traced back to the German colonial period (1884-1916) when many large-scale private plantations were created on the fertile, volcanic soils around Mount Cameroon in the present South West Province of Anglophone Cameroon. The establishment of a plantation economy in the region led to the expulsion of the original occupants of the land, notably the Bakweri, into prescribed native reserves (Matute 1990; Ardener 1996). With the British occupation in 1914/15, the property of German planters was confiscated and turned over to the Custodian of Enemy Property. When the British took over the administration of the area shortly afterwards, the plantations were merged and a government department was formed to manage them. By 1922, however, the British Mandate Authority had already decided to get rid of them, as the administrative costs of maintaining them was said to be prohibitive. It then seriously considered returning the plantation lands to the original owners but dropped the idea in the end. Instead, it came to the conclusion that it would be in the best interests of the territory and its inhabitants to put the plantations back in the hands of foreign private enterprise. At an auction held in London in November 1924, almost all the estates were bought back by their former German owners.

At the start of the Second World War, the German estates were again expropriated by the Custodian of Enemy Property. After the war, a decision had to be reached, once again, on how to dispose of the properties. The Bakweri chiefs and educated elite, organised in the so-called Bakweri Land Committee (BLC), immediately began agitating for the return of their ancestral lands. The BLC sent several petitions, first to the British Crown and subsequently to the United Nations, as Britain had assumed responsibility for the territory, the so-called Southern Cameroons, under United Nations Trusteeship after the war. However, after considerable deliberations, the British Trusteeship Authority declined once again to surrender the exGerman plantation lands to their original owners (Molua 1985; Konings 1993a). Instead, it announced in November 1946 that they would be leased to a newly established statutory corporation, the Cameroon Development Corporation (CDC).

The corporation came into being with the passage of two ordinances in December 1946. The first ordinance, the Ex-Enemy Lands (Cameroons) Ordinance no. 38 (1946), provided for the acquisition of the ex-German plantation lands which had been vested in the Custodian of Enemy Property for the duration of the Second World War. Under the terms of this ordinance, the governor of Nigeria, who was responsible for the administration of the Southern Cameroons, was to declare them 'native lands' and hold them in trust for the common benefit of all the inhabitants of the territory. The second ordinance, the Cameroons Development Corporation Ordinance no. 39 (1946), provided for the setting up of the 
corporation. All the lands acquired by the governor under the first ordinance were to be leased to this corporation for a period of sixty years. Significantly, the corporation was charged with a double responsibility: it was to develop and manage the approximately 104,000 hectares of estate lands in the interests of the people of the Trust Territory, and it was to provide for the spiritual, educational and social welfare of its employees. After fulfilling all its obligations, the corporation was to pay direct taxes to the government of Nigeria and all profits were to be used for the benefit of the people of the Trust Territory.

The CDC has been significant in the development of the Anglophone region. Students of plantation agriculture, such as Beckford (1972), have blamed the persistent poverty and underdevelopment of plantation economies on this mode of production. In the case of the CDC, however, this thesis finds little support. The corporation has been a major instrument of modernisation and is largely credited with whatever socio-economic development has occurred in Anglophone Cameroon. It has created employment for both men and women, has constructed numerous roads, supplied water and electricity, built and staffed schools, awarded a substantial number of scholarships, provided medical care for a large proportion of the local population, and has stimulated the supply of goods and services to itself and its workers. It played a key role in the commercialisation and modernisation of peasant production in the 1950s and in the establishment of regional smallholders' oil palm and rubber schemes since the early 1960s (Ardener 1958; Konings 1993b). Of late, it has handed over a substantial part of its oil-palm plantations to local contractors. As a result, the CDC has been called the economic lifeline of Anglophone Cameroon.

The government announcement on 15 July 1994 of the privatisation of this important agro-industrial enterprise was all the more shocking to the Anglophone population since the CDC (i) had been one of the very few public enterprises in Cameroon to perform relatively well until the economic crisis; (ii) had been able to survive this crisis mainly because the management and workers had agreed to adopt a series of drastic adjustment measures aimed at reducing costs and increasing productivity; and (iii) was on the way to economic recovery following the 50 per cent devaluation of the CFA franc in early 1994 that made CDC products more competitive on the world market (Konings 1995).

The announced privatisation of the CDC prompted vehement protest actions in Anglophone Cameroon from various ethno-regional associations and pressure groups that had been either created or granted a large measure of autonomy in the wake of political liberalisation in December 1990. The following ethno-regional organisations have been the most active.

First, there are the various Anglophone associations that since 1993 have been operating under an umbrella organisation, the Southern Cameroons National Council (SCNC). The emergence of these movements can only be understood in the context of what has been called the Anglophone 


\section{Piet Konings}

problem' (Konings and Nyamnjoh 1997, 2000; Eyoh 1998a). Several factors need to be taken into consideration in explaining the emergence and development of this problem. Its roots may be traced back as far as the partitioning, after the First World War, of the erstwhile German Cameroon Protectorate between the French and British victors, first as mandates under the League of Nations and later as trusts under the United Nations. The subsequent creation of territorial differences in language and cultural legacy laid the historical foundation for the construction of Anglophone and Francophone identities. An even more important factor was the form of state that the Francophone majority more or less imposed upon the Anglophone minority during the constitutional negotiations for a reunified Cameroon in 1961. The Anglophone political elite had proposed a loose form of federation, which they thought would be a safe guarantee of the equal partnership of both parties and of the preservation of the cultural heritage and identity of each. The Francophone political elite instead opted for a highly centralised form of federation that they considered merely a transitory phase in the establishment of a unitary state. By 1972, they had already succeeded in transforming the federal state into a unitary state. The most decisive factor, however, was the nation-state project after reunification. For the Anglophone population, nation building has been driven by the firm determination of the Francophone political elite to dominate the Anglophone minority in the post-colonial state and to erase the cultural and institutional foundations of Anglophone identity. Gradually, this created an Anglophone consciousness: the feeling of being recolonised and marginalised in all spheres of public life and thus becoming second-class citizens in their own country. Anglophone grievances are numerous in the political, economic and cultural domains.

In the political domain, Anglophones complain of their exclusion from key positions in the government and public sector and their inferior role in the decision-making councils and organs. A general Anglophone complaint is that they are assumed to be fit only to play 'deputy' or 'assistant' to Francophones. In the economic domain, Anglophones complain of the Francophone-dominated state's exploitation of their region manifest in a dismantlement of its enterprises, neglect of infrastructure, lack of public investment, and the rape and drain of economic resources. They claim in particular that their region has failed to benefit from its rich oil resources, the revenues of which are allegedly being used by the post-colonial state to 'feed the bellies' of its allies (Bayart 1989). In the cultural domain, Anglophones complain of the continuous attempts at 'Frenchification' or what Kofele-Kale (1986) has called 'the Gallicising of public life', that is the pre-eminence of French as the dominant language, and of inherited French institutions and bureaucratic practices in all aspects of state administration and public life, not least in Anglophone areas.

The co-opting of the Anglophone elite into the 'hegemonic alliance' and the autocratic nature of the post-colonial regimes prevented Anglophones 
from openly organising in defence of their interests until the political liberalisation process in the early 1990s. The newly created associations and pressure groups were able to place the Anglophone problem on the national and even international agenda, laying claims to self-determination and autonomy. While most of the Anglophone associations initially demanded a return to a two-state (Anglophone and Francophone) federation, the Biya government's persistent refusal to enter into any meaningful negotiation forced them to consider secession and the creation of an independent Southern Cameroons state.

The government announcement of the CDC privatisation was seen by these Anglophone associations as a further step in the dismantling of the Anglophone colonial legacy by the Francophone-dominated state. As a consequence, they called upon Anglophones to forget about any internal differences and form a united front against attempts to sell the CDC to Francophone or French interests.

Besides the Anglophone associations, there were also the associations of the elite and chiefs in the South West Province of Anglophone Cameroon where most of the CDC estates are located. The most prominent South West associations were the South West Elite Association (SWELA) and the South West Chiefs' Conference (SWECC). There is some overlap between these organisations, with some important South West chiefs also being members of SWELA (Konings 1997; Nyamnjoh and Rowlands 1998; Eyoh 1998b). Both associations claim to be non-political pressure groups, with their main aims being to promote the South West Province's socio-economic and cultural revival. The South West was to be restored to its former glory after having been marginalised by the Francophonedominated state and subjected to the 'imperialism' of the other Anglophone province, the North West Province. Although both organisations supported most of the Anglophone grievances about Francophone domination, they equally claimed that the South West had been more disadvantaged than the North West in the post-colonial state in terms of distribution of strategic posts in the federation and the unitary state. Moreover, they stressed that the South West plantation economy had been massively invaded by North West migrants who had come to form the majority of the workers and managers on the plantations and even of the urban population in South West towns. They accused the North West 'settlers' of dominating and exploiting their province by 'grabbing the best land' and controlling the regional administration, business and trade (Konings 2001). This situation has often given rise to rivalry and conflict between the South West and North West elites. The South West elite and chiefs particularly feared that the newly created Anglophone movements' pursuit of either a return to a two-state federation or outright secession would lead to renewed South West domination by the entrepreneurial North West majority. They were therefore inclined to champion a ten-state federal system based on the existing ten provinces in Cameroon, which 


\section{Piet Konings}

would retain the present separation between the South West and the North West Provinces, thus safeguarding the former's autonomy.

Despite such internal rivalries and conflicts within the Anglophone community, the South West elite and chiefs favoured a (temporary) alliance with the leadership of the Anglophone movements when the privatisation of the CDC was announced. This alliance was justified on the grounds of the corporation's immense contribution to the welfare and development of the Anglophone community as a whole.

And finally there was the Bakweri Land Committee (BLC), the organisation of the Bakweri chiefs and elite in Fako Division of the South West Province, whose main goal has continued to be the retrieval of their ancestral lands that were expropriated under German colonial rule for the purpose of plantation production and later, in 1946, leased by the British Trusteeship Authority to the CDC. The BLC felt particularly aggrieved by the announced privatisation of the CDC. It felt betrayed at not having been previously consulted about the corporation's privatisation and it warned the government that the CDC lands were Bakweri lands and thus could not be sold to non-natives without Bakweri consent and compensation. The BLC is being supported in its current struggles by both the South West and Anglophone associations.

In addition to the ethno-regional associations, there were other civilsociety organisations in the region that resisted the privatisation of the CDC. The most important was the Fako Agricultural Workers' Union (FAWU) that is responsible for the representation and defence of the CDC workers' interests (Konings 1993a, 1995). Its president, Mr C.P.N. Vewessee, is one of the most prominent trade-union leaders in Cameroon, having played a significant role in the achievement of a large measure of tradeunion autonomy in 1992. He insisted that the CDC could not be privatised without the FAWU being consulted, arguing that the workers had made personal sacrifices during the economic crisis to assist the corporation's recovery by accepting drastic cuts in salaries and fringe benefits and contributing to a compulsory savings scheme. Moreover, the union, he said, would resist any mass lay-offs and/or deterioration in the workers' conditions of service as a result of privatisation (Konings 1995).

And, finally, the Anglophone press has strongly condemned the announced privatisation. It has continued to defend the Anglophone cause and to inform the Anglophone population of the issues at stake.

\section{Ethno-regional protest actions against CDC privatisation}

During the economic crisis, starting in 1986/87, there were frequent rumours in Anglophone Cameroon that the Biya government was hoping to privatise the CDC and sell it to Francophone or French interests. The government strongly denied such rumours but Anglophones remained on the alert, ready to act if their regional patrimony was threatened. 
In June 1992, for instance, it was rumoured that the French were interested in taking over the corporation after the Biya government, highly dependent on French support and aid, had managed to obtain a FCFA7 billion low-interest loan for the ailing company from the French CCCE. Although this loan provided much-needed capital for investment purposes, the increased control over the corporation by France was highly resented by $\mathrm{CDC}$ workers and managers, as well as by the general public in Anglophone Cameroon. It was then reported in Anglophone newspapers that the CCCE wanted to take over the CDC oil-palm estates, which again resulted in widespread protests in Anglophone Cameroon. In July 1992, SWELA began to collect signatures for a petition against this alleged takeover. ${ }^{1}$

This outcry against expanded French control over the corporation contrasted sharply with Anglophone sentiments regarding previous and later transfers of the management of two major CDC crops to AngloAmerican companies. Few protests were voiced in Anglophone Cameroon when the corporation entrusted the management of the banana sector to the American multinational Del Monte in 1987. And Anglophone newspapers even lauded the agreement between the CDC and (the British) Comdev in late 1992 which stipulated that management of the corporation's three tea estates be transferred to Comdev for a period of ten years. Anglophones argued that these two Anglo-American companies had wide experience in plantation management. Comdev had even had experience in Anglophone Cameroon, having satisfactorily managed the CDC from 1960 to 1974 (Konings 1993a: 41-5). Above all, Anglophones strongly believed that Anglo-American companies would be less inclined than French ones to dominate and exploit an Anglophone region and that their business culture fitted in well in Anglophone Cameroon.

When the government finally did announce the privatisation of the CDC on 15 July 1994, Anglophones were deeply incensed. All existing ethnoregional associations and opposition parties formed a united front to resist the government's decision. One Anglophone columnist, Mr Jing Thomas, captured the essence of Anglophone sentiments:

The CDC is unlike any other corporation. It means native lands, especially those of the Bakweri. It means jobs for Cameroonians, especially the Anglophones. It is a symbol of Anglophone survival against all odds ... If the CDC falls ... the last act of internal colonisation would have been completed. ${ }^{2}$

Anglophones once again alleged that privatisation of the CDC was 'an illdisguised plot to hand over the corporation to the French and the Francophones' or 'a plan by Biya to compensate his "tribesmen" and allies with a slice of the parastatal cake'. ${ }^{3}$ There were protest marches in Anglophone towns organised by SWELA and the Anglophone associations. Protesters carried banners with slogans such as 'France: Hands off 
Anglophones' and 'Hands off or we will burn the plantations'. The National Executive of the Cameroon Anglophone Movement (CAM), the most important Anglophone association, met on 30-31 July 1994 and condemned the CDC privatisation as a declaration of war against the people of Southern Cameroon and called upon Anglophones to observe 16 August as a day of protest and solidarity with the CDC. ${ }^{4}$ SWELA thereupon declared 12 August as another day of solidarity with the CDC. Despite a ban on demonstrations on its solidarity day and a heavy police presence, a determined group of SWELA members led by Secretary-General Martin Nkemngu marched successfully to the governor's office where they presented a protest memorandum for the attention of the head of state. ${ }^{5}$ At a press conference in Limbe (Victoria) on 20 August, the FAWU president, $\mathrm{Mr}$ C.P.N. Vewessee, declared that the union and the workers were totally against the dubious privatisation of the CDC. Since the workers had a joint financial stake in the corporation amounting to FCFA5.5 billion, the privatisation could only be enforced on terms acceptable to the majority of the workers. ${ }^{6}$ In August, the Biya government sent a delegation of highranking Anglophone allies to the capitals of the two Anglophone provinces to try to calm the population. They were jeered and asked whether they would 'benefit from the spoils'.

Unsurprisingly, the most vehement opposition in Anglophone Cameroon came from landowners. As soon as the privatisation of the CDC was announced, the Bakweri chiefs and elite mobilised to revive the moribund BLC and to adopt a common position with regard to the privatisation, which had been planned without any consideration having been given to the Bakweri land problem. Soon thereafter the BLC was renamed the Bakweri Land Claims Committee (BLCC).

On 23 July 1994, the Bakweri chiefs and elite met in Buea under the chairmanship of Paramount Chief S.M.L. Endeley of Buea and Paramount Chief F. Bille Manga Williams of Victoria (Limbe) to discuss the implications of the government's decision. They agreed to voice strong opposition to the announced privatisation on the grounds that the CDC lands were Bakweri lands and thus could not be sold to non-natives without Bakweri consent. After lengthy and passionate discussions, an ad hoc committee was elected by acclamation to assist the BLCC in preparing a detailed memorandum on the Bakweri position to be presented to the government and all other interested parties. ${ }^{7}$

Over 500 Bakweri chiefs, notables and elite gathered at the Buea Youth Cultural and Animation Centre on 4 August 1994 and approved the memorandum drawn up by the ad hoc committee. In the memorandum, the Bakweri agreed that, if privatisation had to take place at all, it should be on the basis of 'a creative and enlightened partnership between the owners of the land on which the corporation operates and the providers of finance capital without which it would not be possible to run a modern, technologically sophisticated agro-industrial complex like the CDC'. They insisted that 
any privatisation plan be based on 'terms which recognise the ownership of land as a distinct variable which together with the cash make plantation agriculture possible; consequently, landowners deserve ground rent compensation in much the same way as the CDC was liable to pay ground rents for the use of the land' ${ }^{8}$ The memorandum was later presented to the provincial governor for onward transmission to President Biya. At the end of this historic meeting, the eminent Bakweri scholar and secretary of the ad hoc committee, Professor Ndiva Kofele-Kale, was designated counsel for the Bakweri people with instructions to present their case before the United Nations and other international fora.

The Bakweri case was strongly supported by the Anglophone movements. A powerfully worded petition to the head of state, co-signed by the Anglophone movements and the Bakweri chiefs, reiterated that the Bakweri had never relinquished ownership of the CDC lands and that the corporation could not be sold without Bakweri consent. It pointed out that the Bakweri had never been paid royalties for the use of their lands since the creation of the CDC in 1946 and also stressed that the Bakweri were not inclined to renew the 60 -year CDC lease, thus reclaiming the $\mathrm{CDC}$ lands after its expiry in 2007.

Concerned about the mounting anger in the Anglophone region in general and the Bakweri community in particular, the Biya government decided to send a delegation of high-ranking Anglophone allies to the South West Province to appease the population. The delegation was led by Chief Ephraim Inoni, the Deputy Secretary-General at the Presidency, and the Chief of Bakingili, a village located on the territory of a Bakweri subgroup. The delegation met a number of Bakweri representatives in Buea to discuss the land problem. Though speaking on behalf of the government, Chief Inoni appealed to the Bakweri representatives not to forget that he was one of them. He acknowledged that there should have been prior contact between the government and the Bakweri before the announcement of the corporation's privatisation but he denied the widespread rumours in Anglophone Cameroon that the French and some high-ranking Francophones had masterminded the whole operation. While admitting that the financial situation of the corporation had improved after the 1994 devaluation of the CFA franc, he argued that privatisation would enable the corporation to obtain new capital for necessary investments in production and processing. The Bakweri Paramount Chief S.M.L. Endeley, who had always been a staunch supporter of the regime until the Bakweri land issue arose,${ }^{9}$ then took the floor. Amid thunderous applause he declared that he as the custodian of the ancestral lands and the Bakweri population as a whole were against the privatisation of the CDC. He requested that Chief Inoni report this to President Biya:

We are in a country where we like to cheat ourselves, where government hands decisions through dictatorship ... We say no, no [to privatisation], 


\section{Piet Konings}

go and tell Mr Biya that he cannot afford to go down in history as the man who sold the CDC. ${ }^{10}$

After the government delegation returned to Yaoundé, no further government action took place concerning CDC privatisation, but this apparent victory for Anglophone resistance turned out to be short-lived. In 1997 rumours of an imminent privatisation of the CDC became more and more persistent. In conformity with the agreement concluded with the IMF and the World Bank within the framework of the Enhanced Structural Adjustment Programme (ESAP) in 1997, the privatisation of the CDC was expected to be launched soon. That the government, under severe pressure from the Bretton Woods institutions, was preparing the ground for the privatisation of the CDC could be seen from the speeches and interviews of leading government and CDC officials at the opening ceremony of the corporation's golden-jubilee celebration in Bota-Victoria on 1 December 1997. In his speech on that occasion, the newly appointed Prime Minister Peter Mafany Musonge, a Bakwerian himself who had been the CDC's general manager from 1988 to 1997, said:

Since the traditional international funding agencies no longer finance corporations like CDC, the establishment should be prepared ... to foster new business relationships to raise new money while the state plays the role of facilitator ... Traditional rulers within CDC's areas of operation, workers and other Cameroonians must understand perfectly well and make sure that peace reigns for conclusive investment. ${ }^{11}$

The CDC chairman, Mr N.N. Mbile, added that 'privatisation should not scare us as we are confident that government will protect the interests of the Cameroonian people, the original landowners, the workers, new investors and the state itself'. Moreover, the CDC deputy general manager, $\mathrm{Mr}$ Richard Grey, then revealed that the highly reputable international consultancy firm Coopers and Lybrand had already been selected by the World Bank and the government to carry out a study into the privatisation of the CDC that would be completed by 30 June 1998. The Bakweri chiefs who attended the ceremony, notably Chief S.M.L. Endeley of Buea, were frustrated by these statements and revelations and condemned any future privatisation. ${ }^{12}$

The CDC was finally put up for sale in January 1999. Few protests were heard from the now almost dormant Anglophone movements (Konings and Nyamnjoh 2000). Their leadership's only activity was to make a strongly worded statement on 10 April 1999 warning prospective CDC buyers to desist from investing in the purchase of the CDC. Bakweri chiefs and elite, however, quickly rallied again. In a meeting with South Western members of parliament and government, they denounced the privatisation of the CDC saying that the latter's acceptance of the CDC sale 'was tantamount to a 
betrayal of their people'. ${ }^{13}$ The BLCC officially wrote to President Biya on behalf of the Bakweri people on 3 March 1999 requesting that it be included in the privatisation negotiations and that compensation be paid for the use of Bakweri lands. When rumours spread that various multinational companies like Fruitiers/Dole, Chiquita and Del Monte were already negotiating with individual government officials about the purchase of the whole or parts of the CDC at throwaway prices, the Bakweri in the diaspora once again addressed the head of state on 1 October 1999 in support of the BLCC position. ${ }^{14}$

Since no reply was forthcoming from the presidency, the BLCC, strongly supported by South West associations like SWELA and SWECC, decided to raise national and international awareness by starting a high-profile publicrelations campaign through the writing of open letters, petitions and newspaper articles and the use of the Internet. For this purpose, an interim bureau of the BLCC was set up in the United States in May 2000 to establish an effective, active and visible BLCC presence within the Bakweri and Cameroonian diaspora community and to open permanent lines of communication with all potential buyers of the CDC, donor agencies, NGOs and foreign governments directly or indirectly involved in the sale of the CDC. The BLCC-USA became very vocal, creating its own website on the Internet. ${ }^{15}$ Its first action was to send a memorandum to the managing director of the IMF, Mr Horst Köhler, on 16 June 2000. In this memorandum, it warned him about the growing unrest among the Bakweri and threatened legal action should the privatisation of the CDC be pursued without BLCC involvement:

As the current impasse in Zimbabwe and Kenya demonstrates, land expropriated from African natives by European colonialists a century ago is the source of much contemporary unrest and instability. All Cameroonians of goodwill bear witness that the Bakweri people have over the years opted for a peaceful resolution of the CDC Bakweri land problem. However, should the privatisation of the CDC go ahead without the input of the Bakweri on whose land most of the corporation's agro-industrial activities are located, we preserve the right to seek legal redress against the government of the Republic of Cameroon, the IMF, the World Bank as well as all lessees who derive title to the land by whatever means, in any country of the world where such bodies are located. ${ }^{16}$

This was followed by massive pro-BLCC demonstrations in New York and Washington during the September 2000 United Nations Millennium Summit that was attended by a huge Cameroonian delegation led by President Paul Biya. As a result of these demonstrations and a flurry of other pro-BLCC activities on this occasion, the embarrassed Cameroonian delegation, along with leading donor agencies, were able to gauge the high 
levels of support for the BLCC within the entire Cameroonian diaspora community in the United States.

In a press release on 5 August 2000, the BLCC revealed that it was going to take its campaign for land restitution and compensation 'a notch higher' by seeking consultative status within the United Nations Economic and Social Council (ECOSOC). It believed that the granting of consultative status would provide it with a global platform to proclaim its struggle for land rights, "bringing it into contact with other NGOs which claim to represent the interests of indigenous groups from around the world as well as with sympathetic UN members who have championed the cause of dispossessed people on the floor of the General Assembly and at the numerous ECOSOC meetings over the years'. ${ }^{17}$ Soon afterwards, on 21 August 2000, the BLCC counsel, Professor Ndiva Kofele-Kale, was invited by the United Nations to make a representation on the Bakweri lands issue to the United Nations Human Rights Commission in Geneva.

Following the government's renewed call for tenders for the sale of the CDC in September 2000, the BLCC cautioned prospective buyers in an open letter as follows:

It is our duty to advise you to think twice before you commit the resources of your shareholders in a venture that is still mired in controversy and whose promised financial and economic rewards may prove to be illusory in the long run. ${ }^{18}$

It became increasingly evident that the BLCC was finding it hard to defend Bakweri interests at the national level after 'their own son', Peter Mafany Musonge, was appointed prime minister in 1996. Without doubt, one of the main reasons for his appointment to this position was that President Biya regarded him, being an ex-CDC general manager and a Bakweri, as the most suitable candidate to handle the delicate issue of CDC privatisation.

The appointment of Musonge initially raised high expectations among the Bakweri. They were convinced that their son would pay particular attention to the land question and take Bakweri interests into consideration during any eventual sale of the CDC. Their expectations appeared to have a solid foundation because, in his former capacity as CDC general manager, Musonge had publicly declared during a 1994 radio interview that any privatisation of the CDC should be 'not only economically effective but also socially equitable'. For that reason, indigenous landowners, workers and investors would be directly involved in this endeavour. ${ }^{19}$ Once appointed prime minister, however, he came under immense pressure from the IMF and his master, Paul Biya, to champion the economic advantages of CDC privatisation and to forget about the payment of compensation to Bakweri landowners. Unable to convince his ethnic group to give up its claim to what could possibly amount to tens of billions of CFA francs after more than 
fifty years of CDC existence, he is reported to have resorted to intimidation, using the Buea sub-prefect and the Fako prefect to that end.

In March 2000, the Buea sub-prefect, Mr Aboubakar Njikam, banned a BLCC general assembly meeting for which he had earlier given his approval. The prime minister appears quickly to have ordered a halt to the meeting when he learnt that compensation was high on the agenda, but he failed to intimidate the committee, which eventually met on 15 April 2000. In June 2000 , the Fako prefect, Jean-Robert Mengue Meka, accused it of being an illegal organisation and the committee was ordered to cease its activities. Two of the newly elected BLCC executives, Chief Peter Moky Efange (president) and Mola Njoh Litumbe (secretary-general), responded by telling Mengue Meka that he was acting illegally himself by claiming that the BLCC, which was founded as early as 1946, was an unlawful association. The prefect was reminded that the BLCC was a duly incorporated organisation that had been registered in accordance with the laws of the country and had been received by the South West governor in 1994 and could thus not now have its legality questioned. ${ }^{20}$

With the high profile publicity given to the BLCC both at home and abroad, the prime minister could no longer ignore the committee and its demands. He invited it to a working session in his Yaoundé office and, on 4 October 2000, the BLCC leadership met with Musonge, Chief Ephraim Inoni, the Bakweri deputy general secretary at the Presidency and a number of other government officials. During this meeting Musonge conceded that the issues of land ownership and the payment of ground rents were legitimate demands but urged that these demands be pursued separately from the issue of privatisation. He argued that a hostile environment was being created by the BLCC protest campaign, which was scaring off potential investors. ${ }^{21}$

The BLCC delegation agreed with the prime minister that privatisation would be successful only in a peaceful atmosphere, but it pointed out that the Bakweri protest actions, such as the UN Millennium Summit demonstrations, stemmed from a lack of government response to their pleas and representations. It stressed that Bakweri protest actions would inevitably continue until 'justice, equity, and legitimate rights of the Bakweri were met'. The delegation then reiterated the main BLCC demands, namely:

- that the government recognise that the lands occupied by the CDC were private property as defined by Part II of the 1974 Land Law and that the Bakweri were the legitimate owners of these lands;

- that the Bakweri be fully involved in the CDC privatisation negotiations to ensure that their interests were effectively protected;

- that ground rents be paid to a Bakweri land trust fund; and

- that the Bakweri, acting jointly or individually, be allocated a specific percentage of shares in each of the privatised sectors of the corporation. $^{22}$ 


\section{Piet Konings}

While the BLCC was trying to embark on a dialogue with local and national authorities, it continued to caution potential CDC buyers and the Bretton Woods institutions against any privatisation of the corporation without the involvement of the landowners. The latter, in turn, brought strong pressure to bear upon the Cameroonian government to settle the privatisation imbroglio. In the wake of the reluctance of foreign companies to invest in the CDC, primarily because of the unresolved land issue, the government was compelled to reissue the CDC bid for tenders first on 1 January 2001 and then again on 1 January 2002. The government now appears to have accepted a privatisation construction that closely resembles the original proposal launched by Musonge when he was still CDC general manager, involving the landowners, the workers and the investors. It intends to sell a majority stake in each CDC sector (rubber, oil-palm, tea and bananas) to foreign companies. However, the CDC lands will not be sold but offered on a long-lease basis to soothe the Bakweri landowners who fear the loss of their lands in the process. Other shares will be sold to the workers and Cameroonian interests, with the state maintaining a 10 per cent stake in each sector. ${ }^{23}$

\section{Conclusion}

In this chapter I have attempted to show that privatisation has become a cornerstone in the good governance-structural adjustment linkage formulated by Western donors and creditors and imposed upon African states. It is, in essence, an attempt to free state enterprises from 'politics', in particular from the government's neo-patrimonial logic which is seen as the basic cause of their malfunctioning, to introduce transparency, accountability and the rule of law in policy-making and implementation needed for the efficient operation of market forces, and to redirect the state away from being an entrepreneur to being a promoter of private enterprise. Privatisation is also said to have a potentially liberating effect on civil society: it will empower the people by creating opportunities for private initiative and entrepreneurship.

My case study of the privatisation of the CDC in Anglophone Cameroon has provided sufficient evidence to substantiate our main thesis that the good governance-structural adjustment linkage, though largely framed in managerial and technical terms, is actually highly political, being embedded in particular relations of power, and ironically it often contradicts the liberal-democratic principles prescribed by the bilateral donors. In this respect, it has clearly demonstrated that:

- Privatisation schemes imposed by the Bretton Woods institutions tend to erode national sovereignty over basic economic policy decisionmaking despite the fact that these institutions usually try to depoliticise their interventions in African states by referring to their superior economic knowledge and technocratic skills. Moreover, the installation 
of a technocracy to implement 'correct' policies is an encouragement of authoritarian forms of governance: accounting to external agencies takes the place of accountability to legislatures and the electorate, democratic decision-making processes are circumvented, and a resulting 'cult of secrecy' discourages political debate and dialogue (Mkandawire 1999).

- Government leaders have constantly attempted to postpone and manipulate the implementation of privatisation schemes, which challenge the patronage system that forms a stabilising and uniting factor in the weak nation-state, undermine their limited popular legitimacy, and create ethno-regional opposition. Nevertheless, they have been eventually forced to comply so as not to forfeit any needed financial assistance.

- The government announcement of the privatisation of the CDC in Anglophone Cameroon has been particularly contested by various ethno-regional associations that have emerged during political liberalisation. Having been excluded from the decision-making process, they have strongly protested against their loss of control over ancestral lands and regional parastatals, which they considered as a renewed onslaught by the Francophone-dominated post-colonial state on the Anglophone cultural and economic heritage.

\section{Notes}

1 The Oracle, vol. 1, no. 3, 1992, p. 2.

2 Fako International, vol. 1, no. 2 (January), 1995, p. 18.

3 New African, no. 326 (January), 1995, p. 25; and Africa International, nos 279/280 (January-February), 1995, p. 39.

4 CAM, 'Communiqué of the Enlarged Ex-Bureau Meeting, 30-31 July 1994 (mimeo); and CAM, 'CAM Resolution on the Privatisation of the CDC', 30-31 July 1994 (mimeo).

5 The Herald, 18-21 August 1994, p. 7.

6 Cameroon Post, 6-19 September 1994, p. 9.

7 Fako International, vol. 1, no. 2 (January 1995), pp. 14-16.

8 Memorandum of the Bakweri People on the Presidential Decree to Privatise or Sell the Cameroon Development Corporation, Buea, 27 July 1994.

9 Chief S.M.L. Endeley is a brother of Dr E.M.L. Endeley and Mr D.M.L. Endeley, who were leading figures in the BLC. He is a retired Chief Justice who acted, among others, as chairman of the ruling party, the Cameroon People's Democratic Movement (CPDM), in Fako Division and chairman of the CDC before being appointed Paramount Chief of Buea in 1992. For his career, see Gwellem, J.F. (1985) Cameroon Year Book 1985/86, Limbe: Gwellem Publications: 113-14.

10 Cited in Fako International, vol. 1, no. 2 (January 1995), p. 16.

11 The Post, 5 December 1997, pp. 1-2.

12 Ibid.

13 Isaha'a Boh Cameroon, Bulletin no. 405.

14 See 'Letter from the Bakweri around the World to President Paul Biya of Cameroon', dated 1 October 1999.

15 See online at http://www.bakwerilands.org. Most of the documents quoted in this study can be found on this website. 


\section{Piet Konings}

16 Letter from Dr Lyombe Eko, Executive Director of BLCC-USA, to Mr Horst Köhler, Managing Director of the IMF, dated 16 June 2000.

17 Press Release no. blc/us/05/08/00, 'The BLCC to seek consultative status at the UN Economic and Social Council' (ECOSOC).

18 BLCC, 'Open Letter to All Prospective Buyers of CDC Plantations', Buea, 12 October 2000.

19 See Cameroon Post, 26 July-2 August 1994, pp. 12-13.

$20 \mathrm{BLCC}$, 'The BLCC refuses to stand down in the face of threats from Fako administrative authorities', Buea, 15 June 2000.

21 Through such manoeuvres, Musonge succeeded, albeit temporarily, in dividing the BLCC into two camps: on the one hand, a majority faction led by its president, Chief Efange, which stood its ground, and, on the other, a minority faction led by the Bakweri Paramount Chief, Sam Endeley, which was more sensitive to Musonge's arguments. The latter accused the new BLCC executive of being too 'radical' and opposed its ongoing Internet campaign on the CDC's privatisation compensation.

22 See Report of the Meeting of Prime Minister Mafany Musonge with BLCC Delegation, Yaoundé, 4 October 2000.

23 See Privatisation of the Cameroon Development Corporation (CDC): International Call for Tenders, Yaoundé: Ministry of Economy and Finance, 1 January 2001.

\section{Bibliography}

Abrahamsen, R. (2000) Disciplining Democracy: Development Discourse and Good Governance in Africa, London/New York: Zed Books.

Ardener, E. (ed.) (1996) Kingdom on Mount Cameroon: Studies in the History of the Cameroon Coast 1500-1970, Cameroon Studies, vol. 1, Providence/Oxford: Berghahn Books.

Ardener, S.G. (1958) 'Banana Co-operatives in Southern Cameroons', in Conference Proceedings, Ibadan: Nigerian Institute of Social and Economic Research: 10-25.

Bayart, J.-F. (1979) L'État au Cameroun, Paris: Presses de la Fondation Nationale des Sciences Politiques.

- (1989) L'État en Afrique, Paris: Fayard.

Beckford, G.L. (1972) Persistent Poverty: Underdevelopment in Plantation Economies of the Third World, New York/London: Oxford University Press.

Bennell, P. (1997) 'Privatization in Sub-Saharan Africa: Progress and Prospects during the 1990s', World Development 25 (11): 1785-1803.

Campbell, B. (2001) 'Governance, Institutional Reform and the State: International Financial Institutions and Political Transition in Africa', Review of African Political Economy 88: 155-76.

Chabal, P. and J.-P. Daloz (1999) Africa Works: Disorder as Political Instrument, Oxford: James Currey.

Eyoh, D. (1998a) 'Conflicting Narratives of Anglophone Protest and the Politics of Identity in Cameroon', Journal of Contemporary African Studies 16 (2): 249-76. - (1998b) 'Through the Prism of a Local Tragedy: Political Liberalisation, Regionalism and Elite Struggles for Power in Cameroon', Africa 68 (3): 338-59.

Gabriel, J.M. (1999) 'Cameroon's Neopatrimonial Dilemma', Journal of Contemporary African Studies 17 (2): 173-96.

Grosh, B. and R.S. Makandala (eds) (1994) State-Owned Enterprises in Africa, Boulder/London: Lynne Rienner. 
Hibou, B. (1999) 'The "Social Capital" of the State as an Agent of Deception', in J.-F. Bayart, S. Ellis and B. Hibou (eds) The Criminalization of the State in Africa, Oxford: James Currey: 69-113.

Kasfir, N. (1998) 'The Conventional Notion of Civil Society: A Critique', in N. Kasfir (ed.) Civil Society and Democracy in Africa: Critical Perspectives, London: Frank Cass: 1-20.

Kofele-Kale, N. (1986) 'Ethnicity, Regionalism and Political Power: A Post-Mortem of Ahidjo's Cameroon', in M.G. Schatzberg and I.W. Zartman (eds) The Political Economy of Cameroon, New York: Praeger: 53-82.

Konings, P. (1993a) Labour Resistance in Cameroon: Managerial Strategies and Labour Resistance in the Agro-Industrial Plantations of the Cameroon Development Corporation, London: James Currey.

(1993b) 'Contract Farming and Capital Accumulation in Cameroon: The Case of the CDC Smallholder Schemes', in P. Geschiere and P. Konings (eds) Itinéraires d'Accumulation au Cameroun, Paris: Karthala: 217-39.

- (1995) 'Plantation Labour and Economic Crisis in Cameroon', Development and Change 26 (3): 525-49.

- (1996) 'The Post-Colonial State and Economic and Political Reforms in Cameroon', in A.E. Fernández Jilberto and A. Mommen (eds) Liberalization in the Developing World: Institutional and Economic Changes in Latin America, Africa and Asia, London/New York: Routledge: 244-65.

- (1997) 'Agro-Industry and Regionalism in the South West Province of Cameroon during the National Economic and Political Crisis', in P.N. Nkwi and F.B. Nyamnjoh (eds) Regional Balance and National Integration in Cameroon: Lessons Learned and the Uncertain Future, Yaoundé/Leiden: ASC/ICASSRT: 289-305.

(2001) 'Mobility and Exclusion: Conflicts between Autochthons and Allochthons during Political Liberalization in Cameroon', in M. de Bruijn, R. van Dijk and D. Foeken (eds) Mobile Africa: Changing Patterns of Movement in Africa and Beyond, Leiden: Brill: 169-94.

- (2002) 'Structural Adjustment and Trade Unions in Africa: The Case of Ghana', in A.E. Fernández Jilberto and M. Riethof (eds) Labour Relations in Development, London/New York: Routledge: 311-36.

Konings, P. and F.B. Nyamnjoh (1997) 'The Anglophone Problem in Cameroon', The Journal of Modern African Studies 35 (2): 207-29.

- (2000) 'Construction and Deconstruction: Anglophones or Autochtones?', The African Anthropologist 7 (1): 207-29.

Matute, D.L. (1990) Facing Mount Fako: An Ethnographic Study of the Bakweri of Cameroon, Milwaukee: Omni Press.

Mkandawire, T. (1994) 'The Political Economy of Privatisation in Africa', in G.A. Cornia and G.K. Helleiner (eds) From Adjustment to Development in Africa: Conflict, Controversy, Convergence, Consensus?, New York: St. Martin's Press: 192-213.

- (1999) 'Crisis Management and the Making of "Choiceless Democracies"', in R. Joseph (ed.) State, Conflict, and Democracy in Africa, Boulder/London: Lynne Rienner: 119-35.

Molua, H.N. (1985) 'The Bakweri Land Problem, 1884-1961: A Case Study.' Unpublished MA thesis, University of Ibadan.

Ngayap, P.F. (1983) Cameroun: Qui Gouverne?, Paris: L'Harmattan. 


\section{Piet Konings}

Nyamnjoh, F.B. (1999) 'Cameroon: A Country United by Ethnic Ambition and Difference', African Affairs 98 (390): 101-18.

Nyamnjoh, F.B. and Rowlands, M. (1998) 'Elite Associations and the Politics of Belonging in Cameroon', Africa 68 (3): 320-37.

Olukoshi, A. (1998) The Elusive Prince of Denmark: Structural Adjustment and the Crisis of Governance in Africa, Uppsala: Nordiska Afrikainstitutet, Research Report no. 104.

Sandbrook, R. (2000) Closing the Circle: Democratization and Development in Africa, Toronto: Between the Lines.

Tangri, R. (1999) The Politics of Patronage in Africa: Parastatals, Privatisation and Private Enterprise, Oxford: James Currey.

Tangri, R. and Mwenda, A. (2001) 'Corruption and Cronyism in Uganda's Privatization in the 1990s', African Affairs 100 (398): 117-33.

Tedga, P.J.M. (1990) Enterprises Publiques, État et Crise au Cameroun, Paris: L'Harmattan.

Walker, S.T. (1998) 'Both Pretense and Promise: The Political Economy of Privatization in Africa'. Unpublished PhD thesis, Indiana University.

Walle, N. van de (1993) 'The Politics of Nonreform in Cameroon', in T.M. Callaghy and J. Ravenhill (eds) Hemmed In: Responses to Africa's Economic Decline, New York: Columbia University Press: 357-97.

- (1994) 'The Politics of Public Enterprise Reform in Cameroon', in B. Grosh and R.S. Makandala (eds) State-Owned Enterprises in Africa, Boulder/London: Lynne Rienner: 151-74.

World Bank (1987) Cameroon Country Economic Memorandum, Washington, DC: World Bank.

(1989) Sub-Saharan Africa: From Crisis to Sustainable Growth, Washington, DC: World Bank.

-(1992) Governance and Development, Washington, DC: World Bank.

_ (1994) Adjustment in Africa: Reforms, Results and the Road Ahead, New York: Oxford University Press.

- (1997) The State in a Changing World, New York: Oxford University Press.

_ (2000) Can Africa Claim the 21st Century?, Washington, DC: World Bank. 


\title{
15 Global neoliberalisation and violent conflict
}

\author{
Some concluding thoughts
}

\author{
Jolle Demmers
}

Since the late twentieth century, Western aid policy and development thinking has been dominated by the doctrine of global neoliberalism. The policy of global neoliberalism is presented as the main recipe for development. The final chapter of this book explores the link between this global policy and the rise of new patterns of violent conflict (the so-called 'internal', 'intra-state' or simply 'contemporary' conflicts). The main question addressed in this chapter is if, and if so, how processes of global neoliberalisation connect with the recent rise of new patterns of violent conflict.

As is shown in this volume, since the 1980s most countries in the developing world have traded their state interventionist economic policies for neoliberal ones. Apart from enormous wealth and economic growth, global neoliberalisation also went with increased income inequality, poverty and the massive deprivation of human needs. This process of global neoliberalisation coincided with the rise of a new pattern of conflict. Although there is debate on the characterisation of these conflicts, scholars tend to agree that they are 'new' in the sense that they bear little resemblance to the European wars in the era of the dynastic state or to the 'total wars' of the first half of the twentieth century. If anything, they are seen to resemble earlier medieval wars in their lack of differentiation between state and society, soldier and civilian, internal and external transactions across frontiers, or war and organised crime (Miall et al. 1999: 69). In addition, it seems to be the identity group - however defined - and not the nation-state that is at the core of most contemporary conflicts: sources of these new wars lay predominantly within rather than between states (Azar 1990). The connection between these two phenomena, global neoliberalisation and 'new wars', will be scrutinised in this chapter. This endeavour is somewhat complicated by the fact that most approaches to contemporary conflict have little to say in relation to the effects of globalisation and liberalisation. As Miall et al. (1999: 80) claim: 'Grandiose global-level conflict theories [...] are difficult to substantiate in particular cases'. Although this is certainly the case, the country studies in this volume show how, in the encounter with national and local contexts, the forces of global neoliberalism have produced unexpected and 


\section{Jolle Demmers}

often unwanted outcomes, including violent conflict. This chapter therefore underlines the importance of incorporating the effects of global neoliberalisation in conflict analysis.

This chapter will look into general approaches to conflict and development, and will discuss the connection between global neoliberalisation and conflict by looking at the changing role of the state, the rise of identity conflicts and the phenomena of 'post-nation-state conflicts'.

\section{Contemporary conflict: developmental and local origins}

Within both policy and academic circles, the view that contemporary conflicts are complex and multi-causal is largely uncontested. In conflict theory there is ample eye for a levels-of-analysis approach, including individual, group, state, regional and global levels as sources of conflict. However, in practice, the mainstream views largely focus on local origins of conflict, often combining ideas on scarcity, the deprivation of human needs and weak institutions as best explaining conflict. As Duffield (1999: 7) stresses: '[w]ithin mainstream thinking conflict is understood in terms of multiple causes that stem from a developmental malaise often compounded by ignorance and sectarian manipulation. It is essentially irrational, backward looking and associated with various forms of scarcity or breakdown'. In this discussion the global level is hardly seriously considered. This is also reflected in what is perhaps the key debate in contemporary conflict theory, that is, the 'greed' versus 'grievance' controversy. Advocates of the 'greed' argument stress the importance of economic factors in causing and sustaining conflict. Paul Collier, for instance, claims that 'conflicts are far more likely to be caused by economic opportunities than by grievance' (2000: 91). Conversely, proponents of the 'grievance' argument see political factors, and in particular the deprivation of human needs, as the most important factors in contemporary conflicts (e.g. Azar 1990). Both views, however, tend to share a local, intra-state focus and hardly include the effects of globalisation or neoliberalisation within their analysis. Issues such as the link between local war economies (e.g. those based on illegal mining and the trading of diamonds and coltan, and the production of poppies and coca) and the global economy, or the effects of Structural Adjustment programmes and unfair trade on local producers, are not addressed.

Within global governance circles, the 'global component' is mentioned more often. However, here global neoliberalisation is largely seen to have a positive effect. Rather than questioning global neoliberalisation, ideas are put forward how free market reforms and good governance can contribute to conflict resolution and political stability through the promotion of economic growth (see Chapter 1). From this point of view globalisation and market deregulation are seen to furnish the basis of stability. This volume shows an opposite view. In the various country studies we have touched upon the adverse effects of global neoliberalisation. In many cases neoliber- 
alisation either fuelled or triggered violent conflict. Rather than promoting stability, neoliberal reforms and good governance policies supported the rise of identity conflicts and the parallel economy. A key aspect of the analysis of this process is the changing competence of the state and the shift from 'government' to 'governance'.

\section{From government to governance: the changing role of the state}

Contemporary development thinking is characterised by a controversy between the 'hyperglobalisation' and the 'durable disorder' analyses (Held et al. 1997; Cerny 1997; Duffield 2000). The proponents of the 'hyperglobalist' or neoliberal view, such as the international financial institutions (IFIs) and free market economists, largely rely on the ordering hand of the market and assume that market reform will promote worldwide growth and order. This view is contradicted by an interpretation stemming from political economy. This 'durable disorder' interpretation claims that global neoliberalisation tends to encourage new and durable forms of division, inequality and instability (Duffield 1999; Kanbur 2001). The case studies in this book all largely support the latter interpretation by showing evidence of the complexity of market liberalisation. The rise of predatory capitalism in Eastern Europe, the emerge of (ethnic) conflicts over land privatisation in Indonesia and Cameroon, the overall rise of parallel economies, the severe financial crises in Latin America, all show that neoliberalisation is not unproblematic. The response of the international financial institutions to these serial market failures and setbacks is elaborately discussed in the introductory chapter of this book. The World Bank, for instance, claimed that it was not the neoliberal model that was to blame for the lack of progress, but rather the immature, corrupt and inefficient state administrations of developing countries and transition economies themselves. It was stressed that global neoliberalism could only successfully proceed in a 'sound' governance environment. As a consequence, the idea of good governance became a key aspect of global governance and a condition for development assistance. This World Bank argument, however, can be turned upside down: the chapters in this book show evidence of how the prescribed recipe of good governance and neoliberalisation can be the means through which separatist movements and illiberal economies are emerging. A key aspect of this analysis is the changing competence of the state.

Most authors in this book do not oppose so much the idea of good governance in itself, but rather the tendency of the World Bank recipe of neoliberal good governance to 'take politics out of government' (Chandler, this volume). Or, as Duffield (1999) claims, the shift from government to governance. 'Regarding the location of power, the changing competence of the nation state is reflected in the shift from hierarchical patterns of government to the wider and more polyarchical networks, contracts and partnerships of governance' (1999: 2). The erosion of state authority takes 


\section{Jolle Demmers}

place from 'below' as well as from 'above'. The power of supra-national and international 'global governance' actors such as the IFIs, MNCs and international NGOs vis-à-vis the nation-state has increased. As Konings pointed out in his study of Cameroon (this volume), the neoliberal good governance approach entails an essentially depoliticised notion of governance, insulating governance from the actual political process: the struggles for power, control over resources, as well as access to the decision-making process. Paradoxically, he claims, the emphasis on the technocratic aspects of governance has the overall effect of undermining the institutionalisation of the liberal-democratic system demanded by the international donors.

Earlier, Leftwich (1993) argued that the general but simplistic appeal for a better 'governance' as a condition of development is naïve. He claims that developing countries need both a strong and an active state. What is required is not necessarily a democratic state (though it would be highly desirable if it could also be that) but a developmental state. By this he means a state whose political and bureaucratic elite has the genuine developmental determination and autonomous capacity to define, pursue and implement developmental goals. He stresses that economic development should not be seen as a 'managerial' question as the World Bank's literature on good governance asserts, but as a political question. 'For all processes of development express crucially the central core of politics: conflict, negotiation and cooperation over the use, production and distribution of resources' (Leftwich 1993: 617).

In practice, the elevation of governance above government and of economics above politics is clearly visible in many developing countries. This shift greatly influenced the state- and nation-building capacities of developing countries. This is problematic since, as Moore claims, 'strong nation-states have been historical prerequisites for development' (2001: 924) Whereas states in Europe went through a process of nation-building based on the idea of the national economy and the state territory as a viable economic unit (the so called 'threshold principle'), developing countries are confronted with a very different economic reality. The economy today revolves around global market shares much more than the national economy. This makes it much more difficult for developing countries to transform into stable nation-states.

Apart from the loss of economic decision-making power, developing states cope with a number of additional problems. First of all, they often have to deal with the consequences of the Cold War, during which superpower rivalry was fought out in their countries: including the policies of pouring arms into their often fragmented societies and the sudden cessation of financial support after 1989. Many countries in Africa and Central America (but also, for instance, Afghanistan) now cope with heavily armed societies and weak regimes. As a consequence, warring parties began to develop their own means of economic sustainability. In addition, developing countries are confronted with contemporary international norms. They have 
to cope with the paradox of the 'sacredness' of state borders in international law on the one hand and the principle of human rights, including the right to ethno-national self-determination, on the other hand. This often poses a great threat to the territorial integrity of Third World states (Ayoob 1996). The incapacity of governments to monopolise national territories or control economic dynamics has resulted in the proliferation of all types of 'new' coalitions between shadow state rulers, local warlords or armed factions and foreign multinational companies (Douma 2002: 50).

In summary, by taking politics out of government and proclaiming a shift from government to governance, the neoliberal-good governance project erodes the competence of the state in many post-authoritarian, postcommunist and post-colonial states and undermines the process of nation-state building. The effects of this are twofold: the rise of identity conflicts, and post-nation-state conflicts.

\section{Free market reforms and identity conflicts}

Most studies of contemporary conflict do not incorporate the effect of globalisation or market reforms into their analyses. Kaldor (1999) is an exception to that rule. She clearly argues that the new wars have to be understood in the context of the process known as globalisation' (1999: 3). She signals the rise of a new 'identity politics' that emerged out of the disintegration or erosion of modern state structures, especially centralised authoritarian states. 'The collapse of communist states after 1989, the loss of legitimacy of post-colonial states in Africa or South Asia, or even the decline of welfare states in more advanced industrial countries provide the environment in which the new forms of identity politics are nurtured' (1999: 78). In a context where the neoliberal framework has been more or less fixed by external IFI and donor government agencies, and where transnational activities abound, political classes suffer from growing impotence and declining legitimacy. As a consequence, they play the ethnic or nationalist card. In this sense, identity politics can be seen as a form of political mobilisation, a survival tactic, for politicians active in national politics either at the level of the state or at the level of nationally defined regions, as in the case of the republics of the former Yugoslavia or the former Soviet Union (Kaldor 1999: 78).

Although the specific case studies in this volume do not show evidence to support this thesis, the link between free market reforms, declining state legitimacy and identity conflicts comes to the fore repeatedly. In particular the cases of Cameroon, Indonesia and Taiwan in this book show how free market reforms, and especially privatisation, can be a trigger for identity (ethnic) conflict. As Large and Mawdsley (Chapter 13) show for Indonesia, the control of resources by elites and Jakarta-based domestic and foreign private companies has directly contributed to the emergence of separatist movements in Aceh and Papua. They highlight the increased use of 
violence by local communities due to the appropriation of their natural resources through commercial large-scale forestry and other natural resource extraction operations, all heavily supported by IFI programmes. During the past decade, the combination of grievance over forestry, logging and mineral concessions to foreign corporations, continued profit holdings by the Suharto family and acute unemployment and lack of opportunity, proved to be a potent mix that contributed to structural strain and increased violence. In the case of Cameroon, Konings (Chapter 14) notices the emergence of newly created ethno-regional associations that have come to serve as the new intermediaries between the state and the electorate. Their leadership is determined to represent and defend ethno-regional interests during structural adjustment and often strives for a larger degree of ethno-regional autonomy and self-determination. Konings shows how privatisation presented a severe challenge to the neo-patrimonial logic of the Cameroon regime, which laid a solid foundation for co-opting the various ethno-regional elite factions into its 'hegemonic alliance'. Neopatrimonialism, although clearly corrupt and clientelistic, thus secured a considerable measure of political stability and inclusion. With the introduction of market reforms the 'hegemonic alliance' fell apart, as did the nation-building capacity of the state. Likewise, the case of Taiwan shows how the opening up of the authoritarian system did not automatically result in a liberal political economic order and that there is no direct and simplistic relationship between the triplet 'liberal democracy - good governance - development'. Here, too, the durable disorder interpretation is applicable. In the encounter with local histories and specificities, privatisation produced unwanted outcomes, such as the rise of ethnic tensions between the Kuomintang and local Taiwanese and, ironically, the rise of 'bad governance' (Ngo, this volume).

\section{Post-nation-state conflicts}

Contemporary conflicts have often been portrayed as medieval, irrational and backward-looking. Recent attention to the political economy of internal war, however, points out that contemporary warfare is often a highly rational, calculated affair (Douma 2002; Richani 2002; Keen 2000; Collier 2000; Berdal and Malone 2000). The war economies that emerged after the Cold War, revolving around the illegal trade of diamonds, arms, drugs and coltan in Africa, Eastern Europe and Central Asia, and production of poppies (e.g. in Pakistan) and coca (e.g. in Colombia and Bolivia) are understood to be deliberately perpetuated by networks of warlords and subordinate groups. This gave impetus to the idea that contemporary conflicts are to an important extent caused by 'greed' and economic motivations. Keen (1998), for instance, with a wink at Von Clausewitz, concluded that internal forms of war are now better understood as the continuation of economics by other means. 
The IFIs view the increase of war economies in developing countries with concern (World Bank 1997). In fact, the reaction of the international community to the rise of the 'new wars' was twofold. First, during the 1990s, conflict management was incorporated into mainstream development thinking and policy. This went with the introduction of the concept of 'human security' and the emerging of an international 'Security Community' (see Thomas 2001). Second, there was a continued stress on the need for good governance and support for the idea that market deregulation and liberalisation in combination with strict anti-corruption measures can help to overcome scarcity and promote growth, and therefore contribute to conflict resolution. In this view war economies are seen as largely local affairs, stemming from 'bad governance'. Duffield (1999), however, claims that market deregulation and privatisation can also be the means by which illiberal political economies are emerging. He links the contemporary rise of war economies in many developing countries to the worldwide trend of globalisation and liberalisation and the decline of state formation as a political project. In a world where actors move beyond the state in the pursuit of economic power, war economies are on the rise. The result of this are the socalled 'post-nation-state conflicts'. These are often internal forms of war in which actors (warlords) find it no longer necessary to project power through the juridical or bureaucratic control of a relatively fixed territory. While globalisation and liberalisation have perhaps not caused these new forms of war, market deregulation has made it easier for warring parties to develop the parallel or grey international linkages necessary for survival (Duffield 1999).

Recent research on the linkage between local economies of war and international markets shows the importance of multinational corporations to warring parties and how the prevailing free market ideology creates an enabling environment for their transactions. In Columbia, for instance, with the growth of oil concessions, foreign companies developed a complex strategy engaging the state, rebel forces and para-military (see Richani 2002). The effects of the unfair global trade system are another case in point. The World Bank and the IMF preach economic integration of all societies, but only enforce trade liberalisation in poor countries. This double standard of pushing poor countries to open markets and allowing rich countries to protect their markets is greatest in sectors such as textiles and agriculture. As Douma (2002: 50) points out, the continuing protectionist measures, such as massive subsidies to farmers in the North and the existence of tariff barriers and import quotas, have had a detrimental impact on the prospects of poor countries to gain access to important consumer markets. This unfair trade system can be easily connected to processes of criminalisation and even conflict. In situations where there are few sources of livelihood, joining military groups, or shifting to coca or poppy growing, or coltan or diamond mining, may be essential survival strategies. The LTTE in Jaffna, for instance, provided Tamil youths with an alternative career path 
when the economic mainstream had little to offer them. In the case of Colombia, peasants are known to shift from growing bananas (earning \$16 a month) to illegal coca production (earning $\$ 100$ a month). In Congo, a group of illegal coltan miners can earn up to $\$ 30$ a day. All these processes have an important impact on the existence and perseverance of war-related economic systems.

Although not in the form of 'wars', parallel economic activities, transborder trade and illiberal economic transactions take place in most of the countries under study in this volume. The case of Russia, for instance, shows how in the neoliberal era corruption acquired an international dimension. Whereas a few decades ago criminals corrupting politicians and bureaucrats did not necessarily develop full-fledged international mafias, nowadays they are imitating the techniques of international arms traders (Mommen, this volume). In addition, the various case studies show how rapid free market reforms, particularly privatisation, fuelled corruption and the rise of criminal networks. However, as is clearly highlighted in the cases of Ukraine, Russia, Taiwan, Indonesia and Argentina, these networks often involved the state bureaucracy, giving cause to the rise of 'neoliberal nomenklaturas' (e.g. in Ukraine).

\section{The linkages between neoliberalisation and violent conflict}

This chapter argues that there are indeed connections between processes of global neoliberalisation and the so-called 'new wars'. The strong focus of the dominant development recipe on rapid free market reforms and good governance fuelled identity and post-nation-state conflicts. By elevating governance above government, and economics above politics, this global policy undermined nation- and state-building capacities in many developing countries. The decline of state formation as a political project resulted in a loss of legitimacy of political classes and nurtured new forms of identity politics. In addition, economic groups, both legal and illegal, increasingly operated 'around the state'. Market deregulation made it easier for these groups to develop the (parallel) linkages necessary for survival.

The changing competence of the state resulted in other apparently contradictory processes as well. Paradoxically, the shrinkage of the state often coincided with the strengthening of its repressive core (Pereira and Davis 2000). What we have indeed seen in many of the country studies in this book is that, despite the demise of authoritarian rule and formal military control of the state, the power and influence of militaries and police have not diminished. As Pereira and Davis (2000: 3) noted for Latin America: 'the enduring power of the militaries and the police has been reinforced by the dismantling of other parts of the state apparatus by policies of market-oriented reform. Indeed, as economic safety nets for the relatively disadvantaged have disappeared, poverty and income inequality have been 
on the rise, and crime has started to soar in many countries in the region. As disorder in civil society increases, political challengers with control over the means of violence have strengthened their position, with groups as diverse as veterans, guerrillas, paramilitary forces, drug traffickers, and the police acting with increasing impunity'.

So, apart from identity conflict and post-nation-state conflict, global neoliberalisation fuelled other forms of conflict and violence as well. In all case studies in this volume, market reforms went with the increase of income inequality, and in some cases, with a sharp rise in poverty. In some cases, this triggered violent civil protests and new forms of popular movement and rebellion. Although research points out that in general poverty is not the initial trigger for violent conflict, it often sustains violent conflict (Goodhand 2001). In addition, it is generally groups who suffer sudden changes in wealth and status that are most likely to engage in conflict. During the late 1990s, many developing countries went through sudden and profound financial crises. As we have seen in the cases of Argentina and Indonesia (and to a much lesser extent, China), the violent protest movements that emerged in reaction to these crises were severely repressed by the government. Other cases highlight the rise of new violence ('everyday violence') that seemed to accompany market reforms (e.g. in El Salvador). In contrast, countries such as Chile and Mexico (although the Zapatistas form an important exception) went through relatively stable and successful processes of neoliberalisation. In both cases, a large part of this stability can be attributed to the political system of restricted democracy, where the military and corporate powers controlled the framework of economic management and civil society.

Despite the discourse of good governance, including the protection of human rights and the 'empowerment' of civil society, the IFIs often supported the repressive measures of free market economies. The cases of Ukraine and Indonesia show how the various goals encompassed by the good governance project are at times highly contradictory. The IFIs are overstretched in their support for anti-corruption and poverty reduction on the one hand and 'doing business' on the other. In addition, they are compromised by competing agendas such as accountable public administration and the protection of human rights versus geopolitical security, particularly after 11 September 2001. Not surprisingly, in both cases, economic and security issues were privileged above the 'softer' good governance agendas. The result of this was continued IMF support for the clearly corrupt and repressive governments of Ukraine and Indonesia.

In summary, the past decade shows convincing evidence for the inability of the neoliberal good governance recipe embraced by the IFIs and many donor countries to solve many pending social, political and economic problems. The various goals encompassed by the good governance project turned out to be highly contradictory, undermining development and at times enhancing new forms of violence and warfare. 


\section{Jolle Demmers}

\section{Bibliography}

Ayoob, Mohammed (1996) 'State Making, State Breaking, and State Failure', in C.A. Crocker, F. Osler Hampson and P. Aall (eds) Managing Global Chaos, Sources of and Responses to International Conflict, Washington D.C.: Institute of Peace Press: $37-51$.

Azar, Edward (1990) The Management of Protracted Social Conflict: Theory and Cases, Aldershot: Dartmouth.

Berdal, Mats and David M. Malone (eds) (2000) Greed and Grievance: Economic Agendas in Civil Wars, Boulder: Lynne Rienner.

Cerny, Philip G. (1997) 'Globalisation, Fragmentation and the Governance Gap: Towards a New Medievalism in World Politics?' Paper presented at Workshop on Globalisation: Critical Perspectives, University of Birmingham, Department of Politics, 14-16 March.

Collier, Paul (2000) 'Doing Well out of War: An Economic Perspective', in Mats Berdal and David M. Malone (eds), Greed and Grievance: Economic Agendas in Civil Wars, Boulder: Lynne Rienner: 91-112.

Douma, Pyt S. (2002) The Political Economy of Internal Conflicts: A Comparative Analysis of the Economics Underlying Internal Conflicts in Angola, Colombia, Sierra Leone and Sri Lanka, The Hague: Netherlands Institute of International Relations Clingendael.

Duffield, Mark (1999) 'Globalisation \& Market Economies.' Paper prepared for the Fletcher Forum of World Affairs issue on the Geography of Confidence: Environments, Populations, Boundaries, 26 March, South Bank University, London.

- (2000) 'Globalization, Transborder Trade, and War Economies', in Mats Berdal and David M. Malone (eds.), Greed and Grievance: Economic Agendas in Civil Wars, Boulder: Lynne Rienner: 69-90.

Goodhand, J. (2001) Violent Conflict, Poverty and Chronic Poverty, Chronic Poverty Research Centre, Working paper 6.

Held, David, David Goldblatt, Anthony McGrew and Jonathan Perraton (1997) 'The Globalisation of Economic Activity', New Political Economy 2 (2): 257-77.

Kaldor, Mary (1999) New and Old Wars: organized violence in an global era, Cambridge: Polity Press.

Kanbur, Ravi (2001) 'Economic Policy, Distribution and Poverty: The Nature of Disagreements.' Available online at http://www.ifad.org/poverty/lecture.pdf.

Keen, David (1998) 'The Economic Functions of Violence in Civil Wars, Adelphi Paper 320, London: International Institute of Strategic Studies: 1-88.

- (2000) 'Incentives and Disincentives for Violence', in Mats Berdal and David M. Malone (eds), Greed and Grievance: Economic Agendas in Civil Wars, Boulder: Lynne Rienner: 19-42.

Leftwich, Adrian (1993) 'Governance, Democracy and Development in the Third World', Third World Quarterly 14 (3): 605-26.

Miall, Hugh, Oliver Ramsbotham and Tom Woodhouse (1999) Contemporary Conflict Solution: the prevention, management and transformation of deadly conflicts, Cambridge: Polity Press.

Moore, David (2001) 'Neoliberal globalisation and the triple crisis of "modernisation" in Africa: Zimbabwe, the Democratic Republic of the Congo and South Africa', Third World Quarterly 22 (6): 909-29. 
Pereira, Anthony W. and Diane E. Davis (2000) 'New Patterns of Militarized Violence and Coercion in the Americas', Latin American Perspectives 111, 27 (2) March: 3-17.

Richani, Nazih (2002) The interface between domestic and international factors in Colombia's War System, New York: Kean University.

Thomas, Caroline (2001) 'Global Governance, Development and Human security: exploring the links', Third World Quarterly 22 (2): 159-75.

World Bank (1997) A Framework for World Bank Involvement in Post-Conflict Reconstruction, Washington, D.C.: World Bank. 


\section{Index}

Abdurrahman Wahid, President of Indonesia (1999-2001) 260-1, 293, 298

accountability 5, 135, 171; in BosniaHerzegovia 168; effectiveness and 9; in Latin America 93; in Ukraine 184 Aceh 289, 295, 296, 297

Africa: African Recovery Programme 26-7; average growth 25 ; conflicts $334-5$; criminal activity 26 ; financial sector markets 25; Marxist military regimes 19; statism 308-9; Structural Adjustment Programmes (SAPs) 4, 24-7, 306-8, 310-11; trade 25-6; war economies 336

Agency for International Development (AID) 7

Agrarian Aristocratic Empires 266-7 agriculture, EU subsidies 26

Aksiuchits, Vladimir 220

Alfonsin, Raul, President of Argentina (1983-89) 47

Algeria, African Recovery Programme 26

Allende, Salvador President of Chile (1970-73) 136

Ambon 295

Amien Rais 300

Amnesty International Reports 31, 106 anti-corruption campaigns: AntiCorruption and Transparency Group (ACT) 172; Anti-Corruption Opinion Poll (2000) 165; Civil Society AntiCorruption Public Outreach Programme 169; Comprehensive Anti-Corruption Strategy 167-9, 172; conflicts and 337; International AntiCorruption Conferences (IACCs) 135-6; politics and 175

anti-globalisation debates $30-3,184-5$, 205-7
Anwar Nasution 253, 254

APEC (Asia Pacific Economic Coperation) 96

Argentina: Alianza government (1999-2001) 82-3; asambleas populares $84-5,86,88,89 \mathrm{n} .5$; banking system 74-5, 78; cacerolazos 83,84 ; cereal production 78 ; conflicts $79,80,81,82,339,88$ n. 2 ;

Convertibility Plan 45, 46, 47, 66,

69-71, 72, 74; corralito measure 66-7, 75, 82, 88n.3; crisis (2001-2) 76-9; crisis of neoliberalism 68-75; deindustrialisation 72-3; deregulation 71, 81-2; devaluation 46; economic indicators 43 ; foreign debts $46-7,66$, 70, 87, 88n.1; GDP 73, 74, 76; human rights 79 ; international crises 73 ; kleptocracy 45-6; labour conflicts 79-81; looting 83; MTD

(Movimiento de Trabajadores Desocupados) 85-6; participatory democracy 68; Peronism 41; piquetero movement 79, 85-6, 88, 89n.5; political participation $83-5$; poverty and indigence 77-8; privatisation $70-1,72-3$; protests $66-8,79-83$, $88 \mathrm{n} .4$; regime change 39 ; regime of accumulation 71 ; social structure 87 ; Structural Adjustment Programmes (SAPs) 22, 41, 45-50, 66, 69-75; Supreme Court 84, 87; trade unions 79; unemployment 76, 79, 85-6

Ashdown, Paddy 161, 174, 176n.2, $178 \mathrm{n} .41$

Asia: 'Asian miracle' 27-8; financial crises $(1997,1998)$ 14-16, 27-8, 50, 224; NICs 27-8; war economies 336 Aspinall, Edward 294

Astra International 249, 250 
authoritarianism 93-4, 224, 225-8

Avotaz 187

Avritzer, Leonardo 103

Aylwin, Patricio, President of Chile (1990-4) 55

Azerbaidzjan 180

Bali 248

Ball, N. 117

Baltic countries, democratisation 21

Bank Bali 260

Bank Duta 249

Bank Indonesia 253, 261

Bank of Central Asia 249

Bank Summa 249-50

Bapindo Bank 253

Barry, Robert 169, 173, 176n.3

Becker, Jasper 268

Beckford, G.L. 315

Belarus 180

Belize, Puebla-Panama Plan (PPP) 108

Bennett, Christopher 168

Berger, Marker 294

Bernstein, Thomas, P. 280

Biden, Joseph 172-3

Binford, L. 124

Biya, Paul, President of Cameroon (1982-) 322, 323, 324

Blair, Tony, Prime Minister of Great Britain (1997-) 19-20

board practices $140,156 \mathrm{n} .1$

Boguratov, Alexei 210

Borja, Rodrigo, President of Ecuador (1988-92) 43

Borón, Atilio 93

Bosnia-Herzegovia: accountability 168 ;

Civil Society Anti-Corruption Public Outreach Programme 169; corruption 162-6, 171; decentralisation 171 ; elections (2000) 170-1, 172-3; electoral reforms $168-71$; EU requirements 161, 162; European Stability Initiative (ESI) 172; institution-building 171-4; international strategy 166-7; interventionism 119; Legal Experts Commission 165-6, 168; peace process 161; political parties 169-70, 173-4; public awareness 167-71; transparency 168; see also MuslimCroat Federation; Office of the High Representative (OHR); Republika Srpska

Bourgois, P. 124, 131n.5
Boutros-Ghali, Boutros 119

Bové, José 31

Bowles, Paul 283

BPPC (Badan Penyangga dan Pemasaran Cengkeh) 251, 256

Brady Plan 70, 97

Bragin, Akhmet 189

Brazil 15, 23

Bre-X 252

British Petroleum 299

Bucaram, Abdala, President of Ecuador (1996-7) 43

Buenos Aires 67, 79, 83

BULOG 259, 261

Bumi Daya 251

bureaucratic mercantilism 143

Burnside, Craig 34n.7

Buru Island 301

Busang gold mine 252

Busygina, Irina 210

Cameroon: Anglophone problem 315-18; Bakweri Land Committee (BLC) 314, 318, 323-6, 328n.21; Cameroon Anglophone Movement (CAM) 320; conflicts 336; Enhanced Structural Adjustment Programme 322; privatisation 308-13, 336; State Owned Enterprises (SOEs) 309-10; Structural Adjustment Programmes (SAPs) 310, 322; trade unions 318

Cameroon Development Corporation (CDC) 313-18; protests against privatisation $318-26$

Canada, board practices 156n.1

capital, flow of 17

capitalism 28-9, 138

capitalist models 16

Cárdenas, Cauthémoc 100, 101, 103, 104

Cardoso, Fernando Henrique (Brazilian President) (1994-2002) 23, 52

Caribbean, economic indicators 48

Carothers, T. 119, 126, 131n.2

Castells, Manuel 138

Cavallo, Domingo 46, 47, 66, 67, 69-70, 71,74

Centeno, Miguel Angel 102

Central America 108-9, 334-5

Central Europe, democratisation 21

Central Salawesi 295

Cerny, Phil 11

Chandra Asri 251, 254

charisma 271 


\section{Index}

Chávez, Hugo, President of Venezuela (1998-) 23

Chechnya 145, 146, 154

Chile: Amnesty Law (1978) 55; Asian crisis and 52-4; authoritarian enclaves 52; Christian Democrats 57, 63n.6; 'Concertación' governments $52,54,56-7,58,61,62$; consolidation 58,60 ; corruption 136 ; democratisation 57-60; economic indicators 59; factual powers 58,60 ; foreign debts 53; Framework Accord 60 ; GDP 52-3; growth rates 39; human rights 54-5, 63n.5; Labour Reform 61; National Security Council 54; neoliberal crises 50-1; poverty reduction $52,60-1$; social policies 60-1; Socialist Party 41, 60; stability 339; Structural Adjustment Programmes (SAPs) 22, 41, 61-2; success of 51-2; Tributary Reform 61; Truth and Reconciliation Commission 55

China: agricultural reform 278-80; Central Trust of China 229; collectively-owned sector 282-3; communes 267-9; competition 28; Cultural Revolution 276; economic indicators 265; economic reform 266; entrepreneurial politics 273-4; environmental issues 284n.8; famine 268-9; Gang of Four 274, 275, 276; GDP 28, 269; Great Leap era 268-9; Household Responsibility system 279; industrial planning 269; industrialisation 267; inequality 277-8; institutional residues 270-3; joins WTO 28; liberalisation and 18; overseas Chinese 272; population growth $272-3$; poverty 266 ; poverty reduction 269; social history 266-73; State Owned Enterprises (SOEs) 277, 280-2; structural realism at domestic level 274-5; structural realism at international level 276-8; Taiwan and 225-6

Chinese Communist Party (CCP) 268, $271,273-4$

Chomsky, Noam 31

Chubais, Anatoly 138, 154

citizenship 11-13, 51, 274

civil society 135,275

Clinton, Bill, US President (1993-2001) 19-20
Collier, Paul 332

Colombia 337, 338

colonialism 267, 276

Comdev 319

communism 18, 21-2, 270-1; see also transition economies

competition, effectiveness and 9-10

conflict theories 331-2

conflicts: conflict resolution 332; market reforms and 335-6; neoliberalisation and $338-9$; origins of $332-3$; postnation-state $336-8$

Congo 26, 338

constructivism 204

consultation, effectiveness and 9

contemporary conflicts: see conflicts

Cook, Robin 163

Cordero, Febres, President of Ecuador (1984-8) 43-4

corporate governance 136

corporate power, citizens versus consumers 11-13

corporatism 52

corruption: definition of 167 ; democratisation and 168-9; development and 156n.2; Foreign Corrupt Practices Act (FCPA) (1997) 135; international 143, 338; International Anti-Corruption Conferences (IACCs) 135-6; multinational companies 135-7; transparency and 144

cosmopolitan democracy 32

Costa Rica, Puebla-Panama Plan (PPP) 108

Cotonou Agreement (2000) 26, 33n.3

Council on Foreign and Defence Policy (SVOP) 207-9

Cousens, E.M. 117-18

Cristiani, Alfredo, President of El Salvador (1989-94) 121-2

Croatian Democratic Union (HDZ) 170, 173-4

crony capitalism $284 \mathrm{n} .2$

Customs and Fiscal Assistance Office (CAFAO) 166

Davis, Diane E. 338

Dayton Peace Agreement (1995) 161, 164

De Soto, A. 120

debt crises (1982), sovereignty and 16-17 debt relief 5

decentralisation 8,11 ; monitored 9 
Del Castillo, G. 120, 132n.11

Del Monte 319, 323

Deliaguin, Mikhail 208-9

Demmers, Jolle 29, 30

democracy 3,93 ; cosmopolitan democracy 32 ; definition of 32-3; market democracy 92, 118; National Endowment for Democracy (NED) 7, 33n.4; participatory democracy 68 democratic consolidation 58, 60 democratisation: electoralism 121 ; emphasis of 7-16; empowerment and 306-7; exclusiveness and 118; global 32; gradual process of 118 ; impact of 18-19; motivations for 13

Deng Xiaoping 274

depolitisation 58, 333-4; national arena 11-13; neo-imperialist 7-16; World

Bank view 8-11

deterritorialisation 13

developing countries 26, 92-3, 334

development: approaches to 2-3; authority forms and 270 ; rational agency and 224

Development Assistance Committee (DAC), Good Governance 33n.2

developmental states 270, 334

Dita Indah Sari 293

Dlouhy, David 162, 167, 168

Dodik, Milorad, Prime Minister of Republika Srpska (1998-) 170

Dollar, David 34n.7

domestic reform $274-5$

Donetsk 188-95; assassinations 189-90, 191, 193; clan networks 188-91, 194-5; foreign debts 199 ; foreign direct investment 193-4; imports/exports 194; industries 188, 189, 190, 192; media 191; privatisation 189, 190-1, 192; strikes 191; trade unions 191-2

Douma, Pyt S. 337

Duffield, Mark 332, 333, 337

Duhalde, Eduardo, President of Argentina (2001-03) 45-6, 67, 87

'durable disorder' analysis 333

Duran-Ballen, Sixto, President of Ecuador (1992-96) 43

East Asia, developmental capacity 224

East Asia financial crisis 14, 27

East Timor 260, 290, 300

Eastern Europe: democratisation 21-2; fundamental changes 18 ; industries
22; market economies and 180-1; war economies 336

economic growth 332

Ecuador: Andean Thatcherism 43-4; economic indicators 43 ; regime change 39

EFTA (European Free Trade Association), trading partners 21

El Salvador: ARENA 120, 121, 123, 125, 127-8, 130, 131, 131n.8;

Christian Democrats 121; civil strife $116,129,131 \mathrm{n} .5$; civil war $116,120-2$, 131n.5; democratisation 125-6; economic liberalisation 126-8, 130, 131n.9; FMLN guerrilleros 120, 122, 125; GDP 128; imports/exports 129; nationalisations 121 ; peace process 119-22, 130, 131; Plan for National Reconstruction (PRN) 120, 132n.11; police force (PNC) 122, 123, 130; poverty reduction 128-9, 132n.13; Puebla-Panama Plan (PPP) 108; security $122-5$; Structural Adjustment Programmes (SAPs) 120, 126-7, 129, 131; tarrifs 127; UN mission $119,122-3$

elections, effectiveness and 9

electoralism 121

Elster, J. 184

Endeley, S.M.L. 320, 321-2, 328n.21

Enlightenment project 14

entrepreneurial politics 273-4

environmental protection, nation-states and $34 \mathrm{n} .12$

ethical globalisation 287

EU (European Union): Africa and 26; agricultural subsidies 26; corruption 162; employment rates 20 ; financial crisis (1992/93) 15; former colonies 33n.3; human rights 33n.3; preferential trade agreements 26 ; trading partners 21

European Stability Initiative (ESI), Bosnia Project 172

Exxon Mobil 297

factual powers 58

Falk, Richard 12, 28, 32-3, 34n.9

Fault Lines of Democracy (Stark) 93

FBI (Federal Bureau of Investigation) 141

FDI (foreign direct investment) 145-7, $193-4,292,156 \mathrm{n} .2$

financial markets 13-16, 17 


\section{Index}

Flick Corporation 136

Flores, Francisco, President of El Salvador (1999-) 125

Foreign Corrupt Practices Act (FCPA) (1997) 135

Forman, S. 117, 122

Foundation for Effective Politics (FEP) 216-17

Fox, Vicente, President of Mexico (2000-) 91, 103, 106, 107; presidentialism 103-4

France 4, 318-20

free markets $9-10,17$

Freeport Indonesia 296

Frei Ruiz-Tagle, Eduardo, President of Chile (1994-2000) 53-4, 55

Fujimori, Alberto, President of Peru (1990-2000) 23, 24, 39, 44-5, 62n.2

Fydorov, Boris 139, 140

Gaidar, Yegor, Prime Minister of Russia (1991-2) 138, 219, 220

Garcia, Alan, President of Peru (1985-90) 45

GATT (General Agreement on Tariffs and Trade) 96

Gazprom 139, 155

Gejdenson, Sam 164

Germany 136

Giddens, Anthony 14, 29

Gill, Stephen 31

global competition 205

Global Forum on Fighting Corruption $137,144,176$ n. 4

global governance 137

globalisation 205-6, 209; destructive globalisation 31

Golkar 290

Good Governance: 'attractions' of 6-7; definition of 306 ; history of $4-5$

goods, flow of 17

Gorbachov, Mikhail, President of Soviet Union (1988-91) 181

Gorbachov Foundation 218

government to governance 333-5

Grabovac, Nikola 174

Gray, John 10, 11, 14, 29

Gref, German 142

Grosso, Carlos 83

Gryzlov, Boris 142

G7 group 17, 162

Guatemala, Puebla-Panama Plan (PPP) 108

Guerin, Bill 293

Guinea Equatorial, African Recovery Programme 26

Guzman, Abimael 45

Habibie, B.J, President of Indonesia (1998-9) 248, 254, 256-60, 294, 298

Hanke, Steve 171-2

HDZ (Croatian Democratic Union) 170 , 173-4

Hedges, Chris 170

Held, David 32

High Scientific and Consultative Council 205

Hill, Hal 257

HIPC (highly indebted poor countries) initiative 5

Hogenboom, Barbara 23

Holbrooke, Richard 164

Honduras, Puebla-Panama Plan (PPP) 108

Hong Kong, investment 27

human development index (HDI) 34n.11

human rights: Argentina 79; Chile 54-5, 63n.5; development and 3; EU 33n.3; Indonesia 289-90; Mexico 106; nation-states and 34n.12; Russia 146

Hutomo Mandal Putra: see Suharto, Tommy

Hutton, Will 14, 29

'hyperglobalisation' analysis 333

IBRA (Indonesian Bank Reform Agency) 256, 260, 291, 293

identity politics $335-6$

ILO (International Labour Office) 14

IMF (International Monetary Fund): balance of payments crises $27-8$; Bosnia-Herzegovia and 165; Cameroon and 313; corruption 137, 162; double standards 337; economic subversion 78; El Salvador and 127; financial markets 17 ; Indonesia and 255-7, 289, 291, 300, 301-2; national sovereignty and 29; Partnership for Sustainable Global Growth 5; Russia and 138, 141, 181; technocratic approach to development 5; Ukraine and 196-8; US influence 14

imperialism 266-7

import-substitution policies 18-19

income distribution, perspectives on 51

INDEM (Foundation for Information and Democracy) 142 
India 28,269

Indonesia: aircraft industry 254; assassinations 289; business conglomerates 248-53; car industry 251-2, 257; cigarette industry 251 , 256 ; conflicts 339 ; corporate governance 296-300; corruption 246, 259, 261, 290; crisis 247-55; crisis management 255-61; decentralisation 294-6; economic indicators 247 , 253-4, 255, 257; financial sector 250-1, 253, 255, 256, 257, 260; foreign debts $250,258,291-2,293$; foreign direct investment 289-90, 292; gold mining 252; human rights 289-90; IBRA (Indonesian Bank Reform Agency) 256, 260, 291, 293; INDRA (Indonesian Debt Restructuring Agency) 257, 258; investment 27 ; military business involvement 298, 302n.8; natural resources 289, 294, 296-9; New Order 289-91; Pancasila 290, 302n.2; political parties 260,290 ; poverty 293; poverty reduction $252-3$; privatisation 258, 292-3; reformasi 258-9, 261, 288; riots 256, 259; Structural Adjustment Programmes (SAPs) 291-3; transmigration 294; violence 289, 295-6, 335-6

Indonesian Development Forum 292

INDRA (Indonesian Debt

Restructuring Agency) 257, 258

inequality $28-9,277-8$

information 5

Inoni, Ephraim 321, 325

Institiute for Globalisation Problems (IGP) 208-9

institutions: constructivism and 204; growth generating 270-1; quality 92-3; reform 131n.2; social order 184

Interamerican Development Bank (IDB) 109

International Anti-Corruption Conferences (IACCs) 135-6

International Chamber of Commerce 136

International Criminal Court 209

International Crisis Group 163, 174

International Customs and Fiscal Aid Organisation 165

international financial institutions (IFIs) 333,339

international governance 137 international organisations: destructive globalisation 31 ; government networks $34 \mathrm{n} .8$

International Police Task Force (IPTF) 166

international recession (2001) 50

International Telephone and Telegraph Corporation (ITT) 136

internationalism, adaptation of 118-19

Ivanic, Mladen, Prime Minister of Republika Srpska (2000-) 173

Izetbegovic, Alija, President of Bosnia (1990-2000) 170

Jaffna $337-8$

Jakarta 247

Jakarta Initiative 258

Japan 27, 28

Java 295

Johnson, Harold 164

Johnson, Ralph 172

Jones, Claudio 106

Kabila, Laurent, Congo President (1997-2001) 25

Kaldor, Mary 335

Kalimantan 248, 252, 295

Kapustin, Boris 219

Kara-Murza, Alexei 220

Kasyanov, Mikhail 154

Kazan 151

Keen, David 336

Kenward, Lloyd 248, 249

Keohane, Robert O. 32

Keynesianism 16, 18, 19, 22-3, 61

Kharkiv (Eastern Ukraine) 184

Kia cars 251-2

Kiev (Ukraine) 189

Kim Hak-Su 294

Kinakh, Anatoliy, Prime Minister of Ukraine (2001-02) 183

Kirchner, Nestor, President of Argentina (2003-) 88

Kirienko, Sergei 220

Klein, Jacques 164

Klein, Naomi 31

Knaus, Gerald 168

Kofele-Kale, Ndiva 316, 321, 324

Konings, Piet 334, 336

Krashenninikov, Pavel 153

Kravchuk, Leonid, President of Ukraine (1991-94) 182

Krugman, Paul 10, 14 


\section{Index}

Kryzhtanovskaya, Olga 152

Kuchma, Leonid, President of Ukraine (1994-99) 182, 187, 191, 192-3, 196

Kudrin, Aleksei 154

Kwik Kian Gie 300

Lagos, Ricardo, President of Chile (2000-) 52, 53, 56

Large, Judith 335

Latin America: accountability 93; capital flows 47; conflicts 338-9; debt crises (1980s) 38; democratisation 39-51; economic indicators 48 ; financial crises 41-3, 50; GDP 41; importsubstitution policies 18-19; income distribution 39-40; inflation 50-1; institutionalised violence $63 \mathrm{n} .5$; international recession (2001) 50; ISI development 38,40 ; kleptocracy 41-3; liberalisation and 17; Lost Decade 39, 41; neoliberal regimes 22-4; political parties 41; populist governance $38-9,40$; poverty $41-3$, 49; poverty reduction $50-1$; social exclusion 50-1; sovereignty and 93; Structural Adjustment Programmes (SAPs) 39, 40

Lavagna, Roberto 87

Lavín, Joaquin 56

Lazarenko, Pavel, Prime Minister of Ukraine (1996-7) 189, 197, 201n.11

League of Nations 32

Least Developed Countries (LDCs) 26

Lechner, Norbert 93

Lee Teng-hui, President of Taiwan (1988-2000) 241

Leftwich, Adrian 3, 334

Legal Experts Commission 165-6, 168

legal framework 5

'Leviathan' states 274-5, 284n.6

Lin Biao 274

Lippo 249

Livshits, Aleksander 154

Loaeza, Soledad 105

Lomé Agreement 26

Lozano, Claudio 77

Luzhkov, Yury 154, 206

Lyon, James 174

Machinea, José Luis 66, 73

Maddison, Angus 269

Madrid (Hurtado), Miguel de la, President of Mexico (1982-8) 91, 95, 96, 104
Mafia, transnational networks 22

Mahuad, Jamil, President of Ecuador (1998-2000) 43

Malaysia, investment 27

Mandela, Nelson, President of South Africa (1994-9) 25

Manuel Rodriguez Patriotic Front 54

Mao Zedong, Chairman of PRC (1949-59) 265, 268, 271, 276

market democracy 92,118

market economies 200n.2

market reforms 335-6

Marx, Karl 266, 270

Mau, Vladimir 219-20

Mauritius 25, 26

Mawdsley, Nick 335

Megawati Soekarnoputri, President of Indonesia (2001-) 246, 247, 260, 261, 295

Melo, Fernando Collor de (Brazilian President) (1990-92) 23

Menem, Carlos, President of Argentina (1989-99) 24, 46, 47, 70

Mexico: agricultural sector 97, 101, 107; assassinations 97, 103; authoritarianism 93-4; banking sector 98, 112n.3; Commission for Financing and Consolidation of Resources 101; corporatism 100-2, 112n.5; corruption 105; debt payments moratorium (1982) 16 ; decentralisation 104-5; democratisation $92-5,100-6$; devaluation 50; elections 91 ; electoral reforms 102, 103, 111; Federal Institute for Elections (IFE) 102, 103; foreign debts $96,97,112 \mathrm{n} .2$; foreign investments 96; GDP 98; human rights 106; joins GATT 96; maquiladora programme 94, 99, 109; market democracy 92; Mexican Network Against Free Trade (RMALC) 109; NAFTA and 23, 94; National Plan for Development 106; National Programme for Solidarity (PRONASOL) 102, 107, 112n.6, 112n.8; North-South divide 94-5, 107-10, 111; Oportunidades 108; Pact for Stability 96; Pact of Economic Solidarity 96; paramilitary groups 106, 108; peso crisis (1994/95) 14-15, 73, 97-9; Plan Puebla-Panama (PPP) 92, 112n.10; political parties 91, 94, 100-5, 106, 111; poverty 
reduction 102, 106-10; presidentialism 103-4, 112n.7; privatisation 96-7, 101-2; Progressa 107-8; Puebla-Panama Plan (PPP) 108-10; re-regulation 105 ; social development 106-10; stability 339; Structural Adjustment Programmes (SAPs) 91, 95-100; trade unions 94; trading partners $96,113 \mathrm{n} .11$; US influence 97, 99; violence 106; World Bank and 91-2, 95-6, 112n.1; Zapatistas 91, 97, 102, 109, 113n.13

Mexico City 103

Miall, H. 117, 331

Miller, Robert 173

Mkandawire, T. 310

Mobil Oil Indonesia 298

Mommen, André 22

money laundering 137

Montesinos, Vladimiro 44

Moore, David 334

Moscow 152, 154

Moscow School of Cultural Policies (MSCP) 208

Mozambique 25, 26

multinational companies: Argentine debts 47 ; board practices $140,156 \mathrm{n} .1$; corruption 135-6; good governance and 135; war economies and 337

Muslim-Croat Federation 161, 170, 173-4

Musonge, Peter Mafany, Prime Minister of Cameroon (1996-) 322, 324-5, $328 \mathrm{n} .21$

Nader, Ralph 31

NAFTA (North American Free Trade Association) 23, 94

National Endowment for Democracy (NED) 7, 33n.4

nation-states, end of $137-8$

Neklessa, Alexander 206

Nemstov, Boris 219

neoliberal regimes 16-28

neoliberalisation, problems of 333

NGOs, relevance of 31-3, 33n.4, 34n.12

Nicaragua, Puebla-Panama Plan (PPP) 108

Nicholas I, Tsar of Russia (1825-55) 155

Nigeria 25, 26

Nikonov, Viacheslav 217-18

Noboa, Gustavo, President of Ecuador (2000-) 43 nomenklatura 180

North Halmahara 295

North Maluku 295

nuclear weapons 146

Nursyahbani Katyasungkana 288

Nye, Joseph S. 32

OECD (Organisation for Economic Cooperation and Development) 13,96 , $136,33 n .2$

Offe, C. 184

Office of the High Representative (OHR): Anti-Corruption and

Transparency Group (ACT) 172; Anti-Fraud Unit 163, 170; Comprehensive Anti-Corruption Strategy 167-9, 172; corruption 162; role of 161

Oi, Jean C. 283

oligarchic monopolism 215

'National Economic Strategy in Global Competition' 205

ONUSAL (UN in El Salvador) 119

Organisation for Economic Cooperation and Development (OECD), corruption 162

Organisation for Security and Cooperation in Europe (OSCE) 161, 165,169

Panama, Puebla-Panama Plan (PPP) 108 Panarin, Alexander 206, 207

Papua 289, 296

parallel economies 333, 337--8

parallel political spaces 206, 216

Pardew, James 167-8, 172

Paris, R. 118-19

participation 9, 83-5

Participatory Development and Good Governance (PDGG) 13

Partido de Acción Nacional (PAN) 91, 102,104

Partido de la Revolución Democrática (PRD) 100, 104, 106

Partido Revolucionario Institucional (PRI) 91, 94, 100-5, 111

Partnership for Sustainable Global Growth (IMF) 5

Party of Democratic Action (SDA) 170

Pastukhov, Boris 207

Patomaki, Heikki 12-13

Patrick, S. 117, 122

Pavlovskii, Gleb 216 


\section{Index}

peace building 117-19, 127

Peace Implementation Council (PIC) $161,163,166-7$

Pemex 105

Pereira, Anthony W. 338

Perestroika 181

Pertamina 298

Peru: Andean Thatcherism 44-5; economic crisis 45; economic indicators 43; regime change 23, 39; Shining Path 45

Peters, Dussel 107

Petritsch, Wolfgang 161, 171, 178n.43, 178 n. 58

Petrov, Nikolai 210

Pinochet Ugarte, Augusto (President of Chile) (1973-1990) 41, 51, 58, 63n.5; arrest of 53, 54-5, 56, 57

Plan Puebla-Panama (PPP) 92, 112n.10

plantation economies 315

Podberiozkin, Alexei 209

political approach to development 3,5

'Politika' Foundation 217-18

populism 23-4

post-communist countries, human development index (HDI) 34n.11

Potanin, Vladimir 139

Pou, Pedro 74

poverty alleviation approach 3,5

poverty reduction: Chile $52,60-1$; China 269; corruption and 156n.5; El Salvador 128-9, 132n.13; Indonesia 252-3; Latin America 50-1; Mexico $102,106-10$

Poverty Reduction Strategy Papers (PRSPs) 5, 9, 10

preferential trade agreements 26

Preuss, U.K. 184

Primakov, Yevgeny 149-50, 220

private sector $9-10$

privatisation 17, 326-7, 335-6;

Argentina 72-3; Cameroon 308-13, 318-26, 336; Donetsk 189, 190-1, 192; Indonesia 258, 292-3; Mexico 96-7, 101-2; Russia 138-40, 143, 181-2; Taiwan 233-4; Ukraine 182, 186

property rights 275,276

public discourses 206

public sector management 5

Putin, Vladimir, President of Russia (2000-): on authority 134; corruption 141; human rights 146; problems facing 145; reforms 153-6, 210, 216, 218

Putnam, Robert 170

Qing, Simei 267-8

Quito 43

Ramsbotham, O. 117

Reagan, Ronald President of US (1980-8) 17

realism $273-8$

regionalisation, definition of 18

Republika Srpska 161, 168, 170, 171, 173

Rivera Campos, R. 128

Robinson, Richard 248

Robinson, William I. 13

Rodríguez, Victoria 104

Rodríguez Saa, Adolfo, President of Argentina (2001) 67, 83

Rodrik, Dani 10,92-3

Rúa, Fernando de la, President of Argentina (1999-2001) 46, 52, 66, 67, 83

Russia: capital flight 149-50; central state power 213; Centre for Political Technologies (CPT) 215; Centre for Strategic Research 'North-West' (CSR-NW) 214; Centre for Strategic Research of the Volga Federal District (CSR-VFD) 211-14; Civil Code 146; corporations 213; corporatism 139; corruption 140-5, 208, 337--8; Council on Foreign and Defence Policy (SVOP) 207-9, 215-16; Criminal Code 146; devaluation 50; donor regions 152, 157n.8; Expert Institute of the Russian Union of Industrialists and Entrpreneurs 214-15; FDI

(foreign direct investment) 145-7, 156n.2; federalism 210, 217; Federation Council 150-1; financial crisis (1998) 15; Foundation for Effective Politics (FEP) 216-17; fraud 134; GDP 140, 147, 152, 154; globalisation debate 205-9;

Gorbachov Foundation 218; govenors 216-17; govenors-general 154, 157n.10; governance problems $138-41$; human rights 146; IMF and 138, 181; Institiute for Globalisation Problems (IGP) 208-9; International Finance Institutions 181 ; kleptocracy $181-2$; 
legal system 146-7, 153; liberal ideology 219-20; Loans for Shares 140; loans-for-shares 139-40; Mafia 22; militarisation 210-11; moratorium (1998) 50; Moscow School of Cultural Policies (MSCP) 208; neoliberalism 205; oligarchs 154-5; parallel political spaces 216; pensions $156 \mathrm{n} .4$; political parties 154; 'Politika' Foundation 217-18; price controls 152, 157n.9; private sector $149-50$; privatisation 138-40, 143, 181-2; reforms 153-5; regional governance $150-2,153$, 209-18, 157n.8; regionalisation 203; Russian Public Political Centre (RPPC) 217; 'Russian World' 207; Securities Commission 139; Spiritual Heritage Foundation 209; status of 22; taxation 147-50, 152, 156n.6, 157n.7; territorial reform 203, 210, 215-16, 218; think tanks' roles 218; transition 203; transparency 144; WTO and 208

Rwanda 26

Salim (Waringin Kencana) 249

Salinas de Gortari, Carlos, President of Mexico (1988-94) 95; election of 100-2; populism 24; reforms 91,96 , $97-8,104,110 ;$ violence and 106

Salmin, Alexei 217

Sané, Pierre 31

Sassen, Saskia 11

Satarov, Georgy 142, 153

Schedrovistskii, Piotr 207, 208, 211, 212

Scherban, Vladimir 189

Schumpeter, Joseph A. 270

Schwartz, Adam 252

SDA (Party of Democratic Action) 170

Seattle summit (1999) 30

Seattle summit (1999), anti-globalisation demonstrations 31

security $22,161,165,169$; antiglobalisation debates 205-6

Security Community 337

self-regulatory organisations (SROs) 135 Senegal 26

services, flow of 17

Shanghai 277

Siberia 152

Sierra Leone 26

Simai, Mihály 21

Simon, R. 192

Sinar Mas 249
Singapore 27

Singer, Peter 163, 168-9

Skuratov, Yury 153

Slaughter, Anne-Marie 34n.8

Snyder, Richard 105

social cohesion 10

social exclusion $50-1$

socialist models 16

socio-economic approach to development 3

Soeryadjaya, William 249, 250

South Africa 25, 26

South Korea 27, 246

Soviet Union, fall of $18,21-2,182$

Spain 47, 62n.1

Spiritual Heritage Foundation 209

SROs (self-regulatory organisations) 135

stability 96, 172, 332-3, 334, 339

Stark, Jeffrey 93

state, changing role of 333-5

state effectiveness $2-7$; poverty and 9

status 277-8

Steinfield, Edward S. 266

Stephashin, Sergei 148

Stiglitz, Joseph 138, 181

strategic liberalisation 118

Structural Adjustment Programmes

(SAPs): in Africa 4, 24-7, 306-8,

310-11; in Argentina 22, 41, 45-50, $66,69-75$; in Brazil 23; in Cameroon 310,322 ; in Chile 22, 41, 61-2; efficiency of 4; in El Salvador 120, 126-7, 129, 131; in Indonesia 291-3; in Latin America 39, 40; in Mexico 91, 95-100; Sub-Saharan Africa 25; in Taiwan 226-7, 272; in Ukraine 196-7

structural realism $274-8$

Suharto, President of Indonesia (1968-98): comes to power 288-9; corruption 249 ; fall of 301 ; family dealings 250-2, 257, 258, 259; reforms 255-7; success of 247

Suharto, Tommy 251-2, 257, 259

Sukarno, Achmad, President of Indonesia (1945-68) 289, 295, 302n.2

Sumitro Djojohadikusumo 250, 256

Sustainable Development 4

Taiwan: agricultural sector 231; authoritarianism 225-8; automobile industry $234-5,237$; conflicts 336 ; corruption 228-30; Democratic Progressive Party 225; developmental 


\section{Index}

projects 226; elections 240, 241-2; exports 235-6, 239; gold and goons 241-3; import substitution policy 226,228 ; industries 233; investment 27; Kuomintang regime $225-8$, 229-30, 231, 240, 241, 272; loans 237; local factions 240-1; martial law 224-5, 226, 236; massacres 231; military expenditure 232 ; peak organisations 238-9; privatisation 233-4; recession 242; rent allocation, logic behind 236-8; rent seeking 238-41; rents 228-30, 232-3, 234-6; security $227-8$; state agency extraction 230-4; strategic sectors 236; Structural Adjustment Programmes (SAPs) 226-7, 272; technology 227 ; textile industry 228-9, 237-8; US Aid 230

Tamil 337-8

taxes, collection 10

technocratic approach to development $2-3,4,307,34 \mathrm{n} .7$

technology, mass-scale 206

Teichman, Judith 95

Teiwes, Frederick C. 271

Thailand 27, 246, 255

Thatcher, Margaret, UK Prime Minister (1979-90) 17

Third Way 52

Thomas, Jing 319

Toqueville, Alexis de 135

Township and Village Enterprises 282-3 transition 273-6

transition economies $180-1$

transnational corporations 31

transnational organisations 31

transparency 5, 8, 136, 144, 206

Transparency International 163, 165

Trejo, Guillermo 106

Trilateral Commission 17

triple transition 117-19, 130-1

Tullock, Gordon 239

Turovskii, Rostislav 215

Uganda 25,26

Uhlin, Anders 290

Ukraine: accountability 184 ; antimodernism 185; capital flight 198 , 201n.16; civil strife 184-5, 200n.6; corruption 186, 187, 198-9; criminal activity 186 ; economic crisis 182 ; economic develoment 181-8; elections (1999) 192-3; foreign debts
195-8; GDP 196, 201n.13, 201n.14; international financial institutions 195-9; media 187; political parties 186, 200n.5; poverty $182-4,200$ n. 3 , 201n.15; privatisation 182,186 ;

Russia-US deal 197; social development 181-8; stabilisation and 200; Structural Adjustment Programmes (SAPs) 196-7; trade unions 186-7, 200n.7; transparency 184; unemployment 183; see also Donetsk

UN (United Nations): in BosniaHerzegovia 164, 166, 173-4; Convention against Corruption 136; corruption 162; Development Programme 5, 33n.1; Economic Commission for Latin America 41; NGOs and 32; ONUSAL 119, 122-3; transnational parliament 32

United Kingdom 19-20, 314, 156n.1

USA: Bosnia-Herzegovia and 162, 164-5; corruption 135,141 ; depolitisation and 13-16; El Salvador and 121, 123, 131n.4; Foreign Corrupt Practices Act (FCPA) (1997) 136; foreign policy changes 7-8; free trade 20; General Accounting Office (GAO) 164; Indonesia and 300; middle-class alliance 19-20; Russia and 141; Taiwan and 225, 230, 235; transparency 136; Washington Consensus 14

USAID 119, 126

Uzbekistan 180

Vargas Llosa, Mario 62n.2

Venezuela 23

Videla, Jorge Rafaél, President of Argentina (1976-81) 41, 46

violent conflicts 338-9

'voice', effectiveness and 9

'vsemirost' 207

Wade, Robert Hunter 287

Walle, Nicholas van de 309, 312

war economies 336-8

Waringin Kencana (Salim) 249

Washington Consensus 14, 15, 137, 156n.2

Weber, Max 267

Weldon, Jeffrey 103-4

West Java 251

West Papua 295, 296, 298-300 
Weyland, Kurt 24

Wilson, Allan 165

Wolfensohn, James D. 8, 147, 156n.5

Woodhouse, T. 117

Woods, Ngaire 9

World Bank: Africa and 306-8; Cameroon and 309-10, 312; conditions for assistance 333; corruption 137, 143, 162; democratisation 8-11; developing countries 34 n. 10 ; double standards 337; 'Evaluating Governance and Decentralisation in Indonesia' 294; Indonesia and 247-8, 293, 298; Mexico and 91-2, 112n.1; national sovereignty and 29; policy changes 4-5, 34n.5; Structural Adjustment Programmes (SAPs) 25; technocratic approach to development 4-5; US influence 14, 17

World Bank Reports: Adjustment in Africa 312-13; Attacking Poverty (2000-2001) 8-9, 10; Building Institutions for Markets (2002) 8-9, 10 ; Relations with Mexico (1994) 95-6; Social Cohesion (2003) 10; The State in a Changing World (1997) 5, 8-9, 34n.6; Sub-Saharan Africa (1989) 4, 306

World Economic Forum (Davos) (2001) 17,26
WTO (World Trade Organisation) 28, 29,30

Wu Kuo-Chen 230

Xiao-Yuan Dong 283

Yang, Dali 278-9

Yavlinsky, Grigory 138

Yeltsin, Boris, President of Russia (1990-2000): corruption 143; election campaign 181; Loans for Shares 140; popularity of 139 ; re-elected 154 ; regional governance 150-1, 153, 182

Yin, K.Y. 229

Yushchenko, Viktor, President of Ukraine (1999-2001) 183, 198

Zahner, Luke 173

Zamora, R.R. 126

Zapatistas 91, 97, 102, 109, 113n.13

Zedillo de Ponce León, Ernesto, President of Mexico (1994-2000) 91, 95, 98, 103, 104, 107, 110

Zhu Rongji, Premier of China (1998-) $282,284 \mathrm{n} .4$

Zvjagilski, Efim 189, 200n.10 
